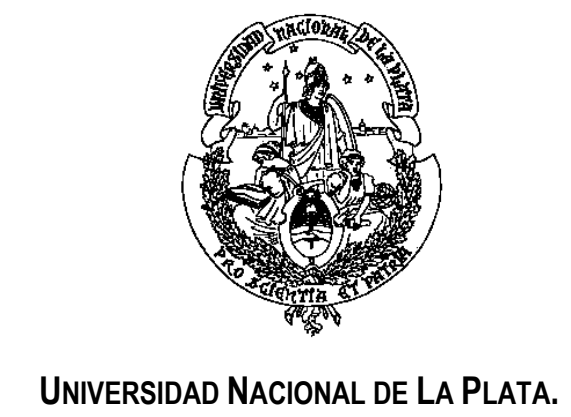

FACULTAD DE HUMANIDADES Y CIENCIAS dE LA EdUCACIÓN.

SeCRETARÍA de Posgrado.

\title{
"Perros en las fábricas: La política sindical del PRT-ERP, sus prácticas y la experiencia de sus militantes en fábricas del Gran Buenos Aires, 1973-1976."
}

Santiago Stavale

Tesis para optar por el grado de Doctor en Ciencias Sociales.

Directora de Tesis: Tortti, María Cristina (IdIHCS).

Co-director de Tesis: Celentano, Adrián (IdIHCS).

Fecha de presentación: Martes 05 de febrero de 2019. 


\section{RESUMEN}

Esta tesis estudia la línea político-sindical del "Partido Revolucionario de los Trabajadores-Ejército Revolucionario del Pueblo" (PRT-ERP) y la experiencia de sus militantes en dos casos: las fábricas Talleres Electrometalúrgicos Norte Sociedad Anónima (TENSA) y Mercedes Benz Argentina (MBA), ubicadas en el Gran Buenos Aires, entre los años 1973-1976.

El año 1973 inició un período que modificó profundamente las condiciones en las que se venía desenvolviendo la conflictividad obrera y el movimiento de protesta en los años previos. La salida democrática del régimen dictatorial instaurado en 1966 y el retorno del peronismo al gobierno, significaron un desafío para la nueva izquierda, especialmente para una organización como el PRT-ERP que decidió continuar la lucha armada y mantener una posición crítica frente al gobierno peronista. No obstante se trató del período de mayor crecimiento de la organización en general y en el movimiento obrero en particular.

En ese sentido, esta investigación busca analizar cómo fue que la organización enfrentó el desafío que supuso el nuevo escenario político y, especialmente, cuáles fueron las orientaciones con las que intervino en el movimiento obrero y como fue la experiencia de sus militantes en las fábricas. Para ello, aborda el objeto de estudio desde un doble registro: el de la perspectiva de la organización, su concepción, su estrategia y las herramientas que desarrollo en el movimiento obrero; y el de la experiencia de base concreta de sus militantes fabriles, específicamente la forma en que buscaron traducir la línea político-sindical de la organización en las fábricas.

\section{Palabras Clave:}

PRT-ERP, Movimiento Obrero, militancia fabril perretista, experiencia de clase, lucha sindical, lucha armada. 


\begin{abstract}
This thesis studies the political-labour union line of the "Worker's Revolutionary PartyPeople's Revolutionary Army" (PRT-ERP) and its activists' experience in two cases: the factories North Electrometallurgical Workshops Stock Company (TENSA) and Mercedes Benz Argentina (MBA) which were located in the outskirts of Buenos Aires, between the years 1973 and 1976.

Year 1973 started a period that deeply modified the conditions in which workers' disputes and the protest movements were developing throughout the previous years. The democratic way out of the dictatorial regime established in 1966 and the peronism's return to the government meant a challenge to the "new left", especially to an organization like PRT-ERP which was determined to keep on the armed conflict and a critical position towards the peronist government. Nevertheless, the organization's greatest expansion has been dealt with in general, as well as the workers' movement in particular.

In this sense, this research work tries to analyse on one hand, the way in which the organization faced the challenge that the new political scenery entailed. And, on the other hand it especially analyses what were the orientations with which the organization intervened in the workers' movement and how was its militants' experience in the factories. For this reason, the research approaches the object of study from a double search: the one of the organization's perspective, its conception, strategy, and the tools it developed into the workers' movement; and the one the concrete base experience of its militants in factories, specifically the way in which they tried to translate the political-workers' union line of the organization into the factories.
\end{abstract}

\title{
Key Words:
}

PRT-ERP, worker's movement, PRT labour militancy, class experience, labour unions fight, armed conflict. 


\section{ÍNDICE}

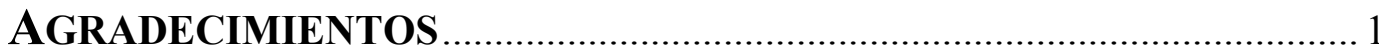

\section{Presentación de la Tesis}

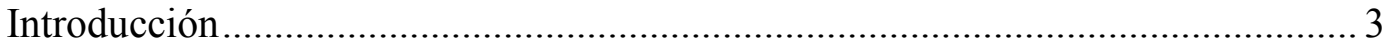

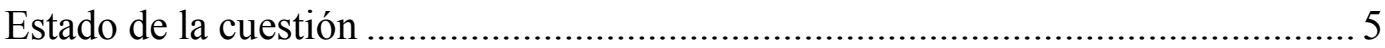

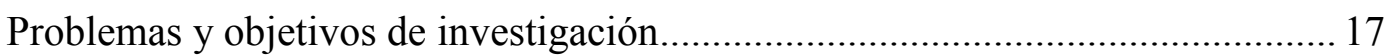

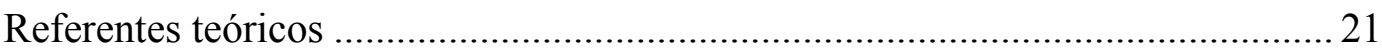

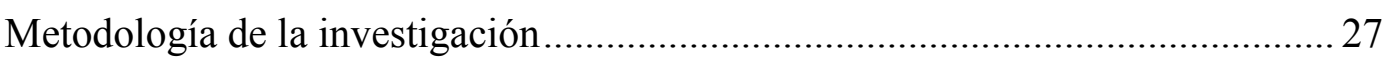

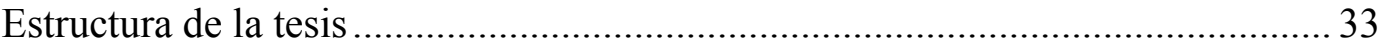

PRIMERA PARTE

“Construir el partido en la fábrica. La política sindical perretista (1973-1976)"

CAPÍTUlO 1. Orígenes y definiciones fundamentales de la línea político sindical perretista (1965-1973)

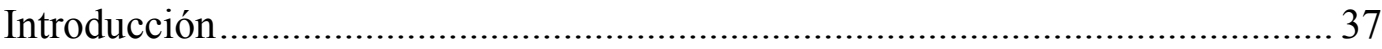

1.1. Debates de origen que dejaron huella............................................................. 38

1.2. La ruptura como cimiento de la línea sindical perretista................................... 42

1.3. Los fuegos del "Cordobazo": La CGT-A y los "Azos" en el balance perretista

1.4. El Gran Acuerdo Nacional y la polémica con el peronismo revolucionario .. 58

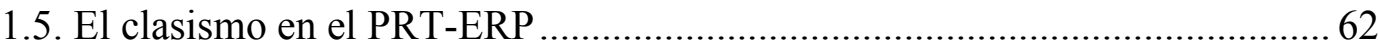

1.6. Algunas notas sobre la línea político-sindical perretista ..................................... 68

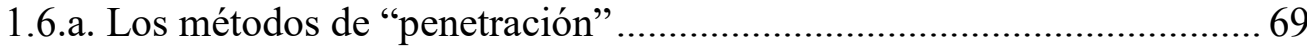

1.6.b. "Inserción” y "dirección política” ............................................................. 75

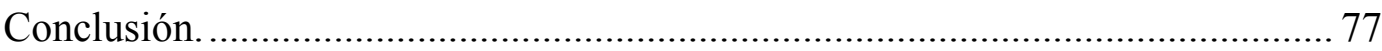

CAPÍTUlO 2. Definiciones ante la encrucijada democrática (1973) 
Introducción 78

2.1. Un partido armado ante el dilema de las elecciones. 78

2.2.La "oleada" de conflictos y las definiciones perretistas: del triunfo de Cámpora al retorno de Perón 87

2.2.a. La lucha contra el "Pacto Social" 92

2.2.b. Luchar contra la "burocracia sindical" en momentos de contraofensiva gubernamental: Definiciones y polémicas fundamentales. 98

2.3. Construir "el partido en la fábrica". 106

2.3.a. Las células: el esqueleto (el modelo ideal) 109

2.3.b. Las agrupaciones sindicales. 118 Conclusión 125

\section{Capítulo 3. El Movimiento Sindical de Base y la Tendencia Obrera} Revolucionaria 22-de Agosto, ¿dos propuestas complementarias? (1973-1975)

Introducción

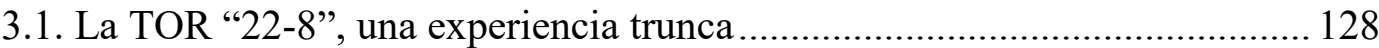

3.2. El MSB, organizador del trabajo sindical.................................................. 135

3.2.a. El MSB: génesis, definiciones y estructura....................................... 136

3.2.b. El II Plenario Nacional y la intervención de la Regional Buenos Aires. .

3.2.c. El MSB deviene en brazo sindical del PRT-ERP ............................ 149

Conclusión 158

\section{CAPítulo 4. Años de luchas decisivas (1974-1975)}

Introducción

4.1. Los bandos se definen (1974)

4.1.a. Hacia un "nuevo enfoque estratégico".

4.1.b En búsqueda del Frente Nacional Antiburocrático. 165

4.1.c. El "Estado policial" y la "situación revolucionaria"

4.2. La Regional Buenos Aires y su penetración en las fábricas 176

4.3. La lucha sindical en el centro de la política perretista (1975) 181

4.3.a. Las paritarias: el PRT-ERP ante la batalla por los aumentos 181

4.3.b. El Rodrigazo y las Coordinadoras en la política perretista 185 
4.3.c. Unir todas las luchas y todos los sectores contra el "enemigo principal"

4.4. El camino hacia el golpe 197

Conclusión 203

\section{SEGUNDA PARTE}

"Perros en las fábricas: los casos de TENSA y Mercedes Benz Argentina"

\section{CAPÍTUlO 5. TENSA "globo de ensayo" del ERP}

Introducción 205

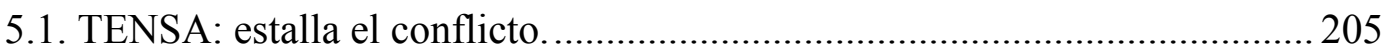

5.2. Ninguna tregua a TENSA: el ERP en la fábrica........................................209

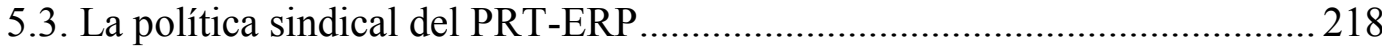

5.4. Tensa “globo de ensayo" de López Rega ...................................................... 223

5.5. La huelga: un punto de inflexión............................................................... 230

5.6. 1975: la agrupación, las coordinadoras y el golpe final. ........................... 233

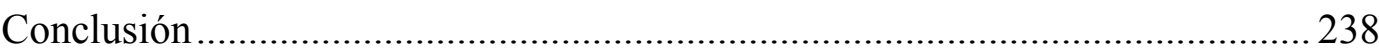

\section{CAPÍTUlO 6. Perros en "La Mercedes"}

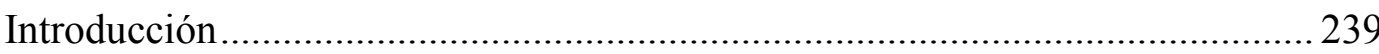

6.1. Orígenes del PRT-ERP y del movimiento de base en MBA ......................... 240

6.1.a. Mercedes Benz, la gigante de la Matanza ........................................ 240

6.1.b. La conflictividad detrás de la aparente calma. Luchas obreras previas

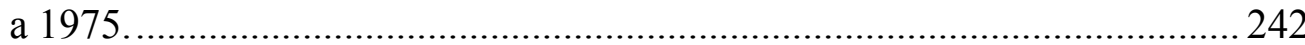

6.2. El CROEMBA y la política sindical perretista.......................................... 246

6.3. La huelga de 22 días y el papel de los perretistas en el conflicto................. 253

6.4. El "grupo de los 9": entre las conquistas obreras y la lucha contra la "burocracia"

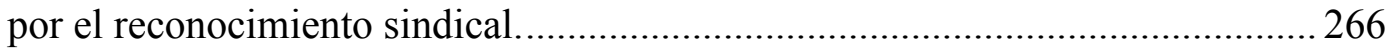

6.5. MBA y los perretistas ante el Plan Mondelli y los comienzos de la dictadura .. 


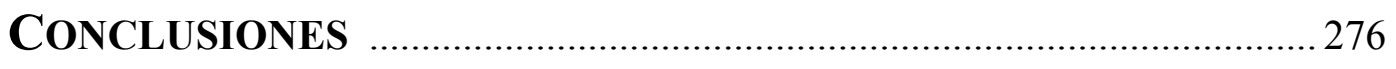

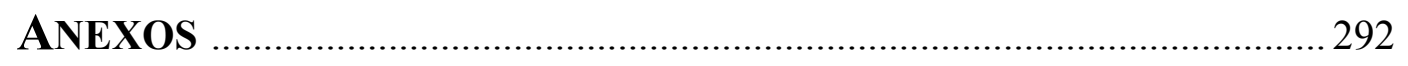

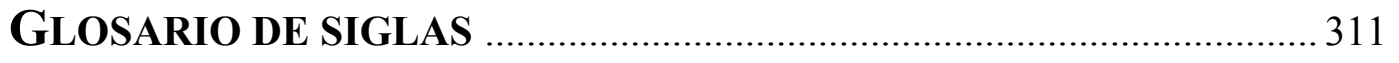

BIBLIOGRAFÍA Y FUENTES .............................................................. 313 


\section{AgRAdecimientos}

Agradecer a todas y todos aquellos que me apoyaron en la realización de esta tesis sería imposible. Es que detrás de todo trabajo de investigación existe una red amplísima de afectos, colegas, compañeras, compañeros y familiares, que ya sea por una palmada o una reflexión sesuda permiten a quien investiga sentirse acompañado en una actividad que, por momentos, se torna insoportablemente solitaria. No obstante aquí dedicaré unas líneas a quienes de alguna u otra forma, tuvieron un lugar especial en mi trabajo.

En principio quiero agradecerles a mi directora y mi codirector por el apoyo que me brindaron. Especialmente quiero destacar la tarea de Cristina Tortti, quien dedico todo su tiempo y más para ayudarme a terminar esta tesis. Sus correcciones línea por línea, sus agudos comentarios, su lectura analítica y su amplitud para escuchar, reflexionar y debatir mis ideas, respetándolas pero exigiéndoles rigurosidad historiográfica, fueron fundamentales tanto para este trabajo como para mi formación como investigador.

En ese tren es imposible dejar de agradecer a mis colegas del Equipo de Investigación "Las formas y los sentidos de la política y la militancia: la nueva izquierda argentina en los años '60 y '70', espacio de reflexión, discusión e intercambio que ha inspirado muchas de las ideas que aquí se plasman.

Esta tesis, además, ha sido posible gracias a un conjunto de instituciones: la Facultad de Humanidades y Ciencias de la Educación de la UNLP, donde cursé mis estudios de grado y de posgrado; el Doctorado en Ciencias Sociales; y el CONICET, institución que financió mi trabajo como investigador (porque investigar es trabajar). Además fueron fundamentales la Comisión Provincial por la Memoria y su Archivo de la ex Dirección de Inteligencia de la Policía de la Provincia de Buenos Aires (DIPBA), el Centro de Documentación e Investigación de la Cultura de Izquierdas en la Argentina (CeDInCI), el Archivo Oral de Memoria Abierta, las hemerotecas de la UNLP y del Congreso de la Nación, los archivos digitales Fundación Pluma, Ruinas Digitales y, muy especialmente, El Topo Blindado, sin el cual no hubiese podido acceder a muchas de las fuentes que aquí encontrarán.

En la frontera difusa entre lo académico y afectivo, quiero agradecerle a Héctor Löbbe, quien sin tener ningún compromiso formal que lo vinculara a mi investigación, colaboró conmigo en todo lo que pudo: leyendo, pasándome materiales, dándome ánimo y valorando mi investigación. Personas como el no son fáciles de encontrar. Vaya 
entonces mi reconocimiento a un intelectual comprometido con la historia de la clase obrera y con quienes buscamos reconstruir el pasado para transformar el presente.

En esa misma frontera también entra Mariela, mi hermana, compañera, colega y confidente, sin duda la mejor de los Stavale. Sin sus lecturas, sus comentarios, sus correcciones, mates y jornadas de trabajo esto no hubiera sido posible.

Pasando al terreno de los afectos no puedo dejar de mencionar a mis padres, Horacio y Viviana, quienes me apoyaron siempre más allá de sus diferencias políticas. A mi sobrinos Pedro y Clarita - pronta a nacer- por recordarme día a día que si el presente es de lucha el futuro será de ellos. A mis amigos. A mis compañeras y compañeros de militancia sin los cuales nada de esto tendría sentido y la historia sería solo para los museos.

A mi compañera Sabrina, por estar, por quererme, por acompañarme, por escucharme, por aguantarme, por transformarme. Sus abrazos y sonrisas fueron mi principal refugio. Por último quiero agradecerle a todos los trabajadores que brindaron su testimonio para esta investigación y a los que no también. Especialmente quiero destacar a Julio D'alessandro, por proporcionarme muchísimos contactos, a Roberto Mereta quien tuvo una invaluable generosidad, a Mario Massolini, Lalo Piñon y Ricardo Hoffman por su predisposición constante. En fin, a todos, porque fueron los protagonistas de un sueño que tarde o temprano se hará realidad. Sus voces son los puentes que la dictadura no pudo quebrar. A ellos va dedicado este trabajo. 


\section{PRESENTACIÓN DE LA TESIS}

\section{Introducción}

El interés por el estudio de los años 70 en Argentina, radica en la complejidad de una etapa signada por un proceso de radicalización política que fue protagonizado por la clase obrera y un conjunto de organizaciones sociales y políticas que venían estructurándose desde los años 60, y que formarán el campo de la nueva izquierda ${ }^{1}$. Especialmente estimuladas por la revolución cubana y por la creciente protesta social ligada a la crisis de legitimidad que vivía el sistema político argentino, resultado, principalmente, de la proscripción del peronismo, aquellas organizaciones se caracterizaron por intentar resolver dicha crisis a través de la transformación revolucionaria de la sociedad, orientada hacia objetivos socialistas.

Para ello les era fundamental entablar un vínculo dinámico con amplios sectores de la clase obrera argentina. Ganarse el apoyo de esta última se transformó en una meta primordial para estas organizaciones que buscaron: penetrar en las principales fábricas del país, intervenir en las luchas sindicales, disputar la primacía de la dirigencia peronista tradicional y promover el papel revolucionario de la clase obrera.

Ahora bien, la identificación de esta última con el peronismo se transformó en un desafío especial para las nuevas organizaciones de izquierda en la búsqueda por lograr ese vínculo. Alejadas de las interpretaciones de la izquierda tradicional, este conjunto de organizaciones dieron respuestas disímiles y hasta opuestas a este desafío: mientras que algunas de ellas entendieron como posible la articulación entre socialismo y peronismo, otras se decidieron a construir un "verdadero partido de clase" siendo críticos del fenómeno peronista, al cual consideraban como un movimiento populista que limitaba a los obreros a los márgenes de la "ideología burguesa" (Tortti; 2014).

El caso del Partido Revolucionario de los Trabajadores-El Combatiente (PRT-EC), será paradigmático en ese último sentido. Surgido en 1968 de la ruptura PRT $^{2}$, conservó de esta última organización su orientación práctica y política hacia la clase obrera, a la que

\footnotetext{
${ }^{1}$ Dentro de ese campo, las organizaciones más importantes fueron: Montoneros, Peronismo de Base, Partido Revolucionario de los Trabajadores, Partido Comunista Revolucionario, Vanguardia Comunista, entre otros.

${ }^{2}$ Es de destacar que el PRT fue fundado en 1965 como el resultado de la fusión de dos organizaciones (Frente Revolucionario Indoamericano Popular, y Palabra Obrera) que tenían militancia entre los trabajadores azucareros y forestales de Tucumán y Santiago del Estero, e industriales del Gran Buenos Aires y el Litoral (Pozzi, 2001). Además, desde sus inicios, adhirió y fue miembro de la IV Internacional definiéndose como parte de la corriente trotskista (Weiz, 2006; Mangiantini, 2016)
} 
buscó organizar en un partido revolucionario de tipo marxista-leninista. Su desarrollo en un contexto de auge revolucionario y de represión dictatorial, y la influencia de las concepciones guevaristas ${ }^{3}$, lo llevaron a plantearse una línea de guerra revolucionaria por el socialismo, lanzando en 1970 su Ejército Revolucionario del Pueblo (ERP). A través de esta línea, se dispuso a penetrar en las principales fábricas de la argentina, disputar la conciencia de los obreros dando una "lucha ideológica" contra la "ideología burguesa" infundida por el peronismo, e incorporar a los obreros a la guerra revolucionaria.

Ahora bien, el año 1973 inició un período que modificó profundamente las condiciones en las que se venía desenvolviendo la conflictividad obrera en los años previos. La salida democrática del régimen dictatorial instaurado en 1966 y el retorno del peronismo al gobierno, son hechos claves que le dan especificidad al período y que significaron un desafío para aquellas organizaciones que, como el PRT-ERP, decidieron continuar la lucha armada y mantener una posición crítica frente al gobierno peronista por considerar que este último era parte de una "maniobra contrarrevolucionaria" que buscaba dividir al movimiento revolucionario y frenar la movilización popular.

Esta tesis se propone reconstruir históricamente la línea político-sindical del PRT-ERP, las herramientas que construyó para penetrar en el movimiento obrero, y algunas de sus experiencias en fábricas del Gran Buenos Aires, entre los años 1973 y 1976. Para ello, nuestra estrategia de trabajo consistirá en abordar el objeto de estudio desde un doble registro: Por un lado, analizamos la perspectiva de la organización, su concepción y su estrategia de desarrollo en el movimiento obrero durante el período abordado, caracterizado, a grandes rasgos, por una reorientación del trabajo político hacia las fábricas y una ponderación distinta y destacada de las luchas sindicales. Como parte de ese cuadro, prestaremos principal atención al estudio del Movimiento Sindical de Base (MSB), espacio impulsado por el PRT-ERP en 1973, que se transformó en la viga maestra de su trabajo sindical a lo largo de todo el período. Por otro lado, estudiamos la experiencia de base concreta de sus militantes en dos fábricas del Gran Buenos Aires, territorio de mayor concentración industrial del país: Mercedes Benz Argentina (automotriz ubicada en Gonzales Catán) y Talleres Electromecánicos Norte S.A.

\footnotetext{
${ }^{3}$ Consideramos que los principios fundamentales del guevarismo que influyeron en la organización fueron: 1- que la única vía para el triunfo de una revolución socialista en América Latina era la lucha armada; 2- que en aquel proceso las burguesías nacionales no jugaban un papel revolucionario sino que formaban el "furgón de cola del imperialismo"; 3- que, en el proceso revolucionario, era necesario construir una nueva moral revolucionaria que debía ser la base para la construcción de un "hombre nuevo". (Guevara, 1965, 1968)
} 
(metalúrgica ubicada en Vicente López).

Para llevar adelante este trabajo utilizamos fuentes documentales, testimonios y fuentes orales. Para el análisis de fuentes documentales escritas utilizamos por un lado documentos y publicaciones de la organización (documentos oficiales, boletines internos, prensa orgánica, revistas orgánicas, volantes y boletines fabriles), el archivo de la Dirección de Inteligencia de la Policía de la Provincia de Buenos Aires (DIPBA), así como también diarios y revistas comerciales de la época. En cuanto a las fuentes orales, trabajamos con entrevistas editas $\mathrm{y}$, fundamentalmente, realizamos entrevistas en profundidad a quienes fueron militantes y simpatizantes de la organización $\mathrm{y}$ participaron como testigos clave o integrantes de las agrupaciones por ella impulsadas, así como a trabajadores que formaban parte de otras organizaciones o que, aun sin integrarlas, tenían contacto con militantes o simpatizantes del PRT-ERP al interior de la fábrica.

\section{Estado de la cuestión}

\section{Los años setenta}

Estudiar la década del 70 en Argentina supone estudiar un período histórico atravesado por un proceso de politización y radicalización política en el que la lucha de clases canalizada en las rebeliones populares, manifestaciones de masas y las organizaciones revolucionarias, fueron las protagonistas. Este período tuvo como una de sus características la consolidación de una relación dinámica y dialéctica entre las organizaciones de izquierda y la clase obrera (Pozzi y Schneider 2000), relación que desde el surgimiento del peronismo había quedado trunca. (Camarero, 2007) Los niveles de movilización obrera y popular registrados a partir del golpe de estado de 1955, frustraron sucesivamente los intentos de "normalización” del sistema político y económico que pretendían imponer las clases dominantes, conduciendo a una notable deslegitimación de las instituciones estatales y del régimen político (Portantiero, 1977; O' Donnell, 1982; Cavarozzi, 1983; Pucciarelli, 1997). A lo largo de este proceso los sindicatos se fueron transformando en actores decisivos de la arena política $\left(\mathrm{O}^{\prime}\right.$ Donnell, 1982; Torre, 2004), a la vez que se fueron consolidando conducciones sindicales fuertemente verticalistas y burocratizadas, con la que todo aspirante al poder político se vio obligado a negociar (James, 1990).

Al mismo tiempo, a lo largo de la década del '60, se produjo una transformación de todas las identidades políticas (Altamirano: 2001): mientras que parte de la militancia 
peronista transitó un proceso de radicalización que comenzó a acercarlo a la izquierda revolucionaria (Brennan, 1996; James, 1990; Gordillo: 2003; Bozza; 2014; Celentano 2015), sectores de esa misma izquierda rompieron con los partidos tradicionales a partir de nuevas definiciones: la necesidad de un acercamiento con el movimiento popular que llevará a la reinterpretación del peronismo y la convicción de que la lucha armada era la única vía al socialismo (Tortti; 1999). Este contexto de progresiva radicalización tomó un nuevo impulso tras el golpe de estado de la autodenominada Revolución Argentina en 1966, que lejos de lograr su pretendido objetivo de suspender la política, la puso en un estado de permanente ebullición (De Riz, 2000). El nuevo escenario fue caldo de cultivo para el crecimiento de esa nueva izquierda emergente (Tortti, 2014) y de una nueva oposición sindical antiburocrática, condensada en un primer momento en la experiencia de la CGT de los Argentinos (James, 1990; Bozza, 2009), que cuestionó profundamente a la "burocracia sindical" que se veía fuertemente desprestigiada por sus compromisos con la dictadura. Este proceso asumió un nuevo giro hacia 1969 (Brennan, 1996; Castillo y Raimundo, 2012) con las manifestaciones conocidas como RosariazoCordobazo-Rosariazo que dan inicio a una nueva etapa en la lucha de clases (Balvé; Balvé, 2005) abriendo paso a lo que Juan Carlos Portantiero (1977) caracterizó como una crisis de hegemonía.

Como remarcan la mayoría de los autores, a partir allí se potenciaron y surgieron nuevas experiencias obreras que comenzaron a cuestionar desde las bases, en los propios espacios de trabajo, la hegemonía de las conducciones sindicales, buscando enfrentar la política económica de la dictadura, así como las arbitrariedades patronales. Experiencias como las del clasismo cordobés de Sitrac-Sitram o el Sindicalismo de Liberación encarnado por Agustín Tosco fueron las expresiones más acabadas de este nuevo proceso que tuvo epicentro en Córdoba, y que se fue expandiendo al resto de las provincias con distintos niveles de intensidad (Brennan, 1996; James, 1999; Schneider, 2005; Brennan y Gordillo, 2008; Iñigo Carrera, Grau y Martí, 2014). La rebelión de las bases del interior parecía anunciar el advenimiento de una vanguardia proletaria capaz de lanzar un ataque tanto económico como político contra el capitalismo (James, 1999). Esta realidad estuvo atravesada y acompañada por el surgimiento de un nuevo movimiento revolucionario en el que coexistieron diferentes vertientes de la nueva izquierda que, a grandes rasgos, se dividieron entre quienes optaron por una estrategia insurreccionalista y quienes lo hicieron por vía guerrillera (Tortti, 1999 y 2014). Entre estas últimas se destacó el Partido Revolucionario de los Trabajadores-Ejército 
Revolucionario del Pueblo (PRT-ERP) (Santucho, 1988; Blixen, 1988; Mattini,1996; Seoane, 1992; Pozzi, 2001, 2012; Gorriarán Merlo, 2003; De Santis, 2005, 2010; Flores, 2006; Weiz, 2006; Caviasca, 2006; Leiva Flores; 2007; Pasquali, 2007; Diez, 2010; Carnovale, 2011; Centurión, 2013; Scoppetta y Torres, 2014; Getselteris, 2015). Si bien la organización política PRT encuentra sus orígenes en 1965, es al calor de éste proceso de radicalización en crecimiento, que consolida su brazo armado ERP en 1970 (De Santis 2010; Getselteris, 2015), aspirando a dirigir y representar al movimiento obrero y al pueblo argentino en la lucha armada y revolucionaria por el socialismo.

Este proceso de radicalización política que comenzaba a trastocar los cimientos de la dominación social y que encontró un nuevo punto de auge hacia 1971 con la respuesta insurreccional conocida como el Viborazo empujó a las clases dominantes y la cúpula militar a buscar una salida política que le permitiera absorber el descontento, preservando el imperio de las clases dominantes (Schneider, 2005). En ese marco, la convocatoria a elecciones, el regreso a las instituciones democráticas y la legalización del peronismo se sintetizaron en la propuesta del Gran Acuerdo Nacional (GAN) que se erigió como el único camino posible para salir de la crisis social y política. La audacia de la estrategia radicó en proyectar la reinserción del peronismo al sistema político con el objetivo de aislar a los elementos más radicalizados, devolverle legitimidad a la acción estatal y encauzar la conflictividad en el marco de la democracia parlamentaria, frustrando la confluencia entre la izquierda social y la izquierda política (Tortti, 1999). A nuestro entender, y como reconoce gran parte de la bibliografía, Perón aparecía como el único capaz de detener el proceso de radicalización política. Más allá de la disputa entre el viejo líder y la cúpula militar, ambos coincidían en un diagnóstico común acerca de la naturaleza de la crisis en la sociedad argentina y compartían un mismo objetivo: la institucionalización de la lucha de clases y la represión de los sectores revolucionarios (De Riz, 2000). El retorno del peronismo al poder se transformó en un hecho y el año 1973 inauguró una nueva etapa política marcada por un cambio de las condiciones en las que se iba a desenvolver la conflictividad obrera, ya no en un contexto dictatorial sino bajo un régimen democrático (Lenci, 1998).

Como remarca Juan Carlos Torre (2004), el retorno de Perón venía de la mano de una reconstrucción política, y con un llamado a la conciliación y al "orden social" que tenía una acogida más feliz entre sus adversarios políticos que entre sus propios seguidores quienes asistían con la esperanza de que había llegado la hora de la esperada reparación histórica. Este plan se encontraba con un primer obstáculo: el hiato existente entre la 
formula de conciliación propuesta por el líder y el espíritu de movilización generalizada que alcanzaba, incluso, a un sector importante de su propio movimiento.

Por su parte, Werner y Aguirre (2007) remarcan que el proyecto de Perón se resumía en el Pacto Social como "política de pacificación y unidad nacional contra la realización de las expectativas de la clase obrera”. En esta misma línea, Bonavena, Mañon, Nievas, Piva y Pascual (1998) plantean que el eje principal de dicho proyecto era la subordinación de esta última a los intereses del empresariado nacional.

Ahora bien, la existencia de un gobierno consagrado por el voto popular, con gran participación de los trabajadores, había tenido por consecuencia la creación de un nuevo espacio político para transformar el descontento en protesta. La nueva atmósfera política no ayudó a congelar la conflictividad obrera, sino que por el contrario esta se expandió. La movilización obrera traía consigo una fuente adicional de radicalización de los conflictos, yendo más allá de las causas inmediatas de los mismos y llegando a cuestionar las relaciones de autoridad en la fábrica. Como remarca Torre (2004) las fábricas vivieron durante esos años en un estado de rebeldía.

A su vez, lo que en un principio fue el desmantelamiento inicial del aparato represivo por parte del gobierno de Cámpora rápidamente se transformó en violencia que, a través de una nueva legislación represiva y, sobre todo, a partir de la formación de las fuerzas para-estatales, golpearán tempranamente a la militancia revolucionaria (Franco, 2012; Schneider, 2015).

Con la muerte de Perón el 1 de julio de 1974 se rompió el "dique de contención" que había podido contener parcialmente los efectos de los enfrentamientos sociales, aumentando la inestabilidad política e institucional y propiciando el derrumbe definitivo del proyecto concertación económica que resumía el Pacto Social (De Riz, 2000; Torre, 2004). El nuevo gobierno, al mando de María Estela Martínez de Perón, asumió con el expreso objetivo de "acabar con la subversión" a través de la represión legal e ilegal y abandonar el programa económico reformista imponiendo planes de ajuste de corte "ortodoxo" (Rugier y Fiszbein, 2006). La intervención de distintas provincias, universidades y sindicatos se combinaron con medidas como el estado de sitio y la incorporación de las FF.AA en la represión interna (Franco, 2012). No obstante los planes de gobierno se encontraron con una resistencia obrera que, expresada en una multiplicidad de conflictos, encontró su pico en las jornadas de lucha de junio y julio de 1975 contra el Plan Rodrigo y en la conformación de las Coordinadoras Interfabriles en el Gran Buenos Aires (Cotarelo y Fernandez, 1997; Colom y Salomone, 1998; Torre, 
2004; James, 2005; Löbbe, 2006; Brunetto, 2007; Werner y Aguirre, 2009; Slatman, Rodríguez y Lascano, 2009). Estas movilizaciones, que propiciaron la renuncia de las figuras más importantes del gobierno, fueron el campanazo definitivo que llevó a las clases dominantes a cerrar el ciclo de radicalización política e ideológica a través de la represión sistemática y planificada mediante el golpe de Estado instaurado el 24 de marzo de 1976.

Democracia, estrategia revolucionaria y movimiento obrero en los estudios sobre el PRT-ERP

Efectivamente, el escenario de apertura democrática significó un desafío profundo para el conjunto de la nueva izquierda (incluida la Tendencia Revolucionaria del peronismo) y en especial para el PRT-ERP, que decidió continuar desarrollando su "guerra revolucionaria", con el retorno de Perón y la instauración de un gobierno constitucional de amplia base popular como telón de fondo. Las expectativas de gran parte de la población, sobre todo de la clase obrera, el nuevo marco de libertades democráticas y el protagonismo de los sectores revolucionarios del peronismo en el nuevo gobierno, fueron condiciones que en principio se presentaban desfavorables y adversas para el desarrollo de una organización que optaba por continuar con la lucha armada. Sin embargo, durante dicho período, la organización estuvo signada por un significativo crecimiento que la transformó en una de las organizaciones revolucionarias más numerosas e influyentes de la época, al mismo tiempo que complejizó el desarrollo de su línea política y la práctica de sus militantes (Pozzi, 2001).

El hecho de que la organización se asumiera como un partido revolucionario de los trabajadores, y reafirmara su concepción político ideológica como marxista-leninista, suponía una búsqueda incesante por penetrar en el movimiento obrero, incorporando a los "elementos más destacados de la clase" para elevarla en su conjunto a nuevos niveles de organización (De Santis; 2010). En ese marco, la intervención sindical debía conjugar la consolidación de conducciones clasistas en los sindicatos con la propuesta estratégica de la "guerra revolucionaria por el socialismo". Pero ésta debía desarrollarse en el seno de una clase obrera con una fuerte raigambre identitaria ligada al peronismo (James; 1990), lo cual significaba un verdadero desafío para el PRT-ERP, desafío que merece ser estudiado.

Sin embargo, un repaso sobre la literatura historiográfica referida al PRT-ERP, muestra la escasez de estudios referidos a su intervención sindical y a las experiencias prácticas 
de sus militantes en el espacio fabril; ellos más bien se concentran en las cuestiones referidas a los problemas estratégico-organizativos y de la lucha armada. De este modo, por ejemplo, las referencias al Movimiento Sindical de Base (MSB), viga maestra del trabajo sindical del PRT-ERP (Leiva Flores; 2007), son de una gran generalidad, quedando pendiente un análisis crítico y profundo de sus características en las diferentes provincias o regionales, así como de las razones de su desigual desarrollo (Pozzi; 2001). Entre los estudios principales sobre el PRT-ERP encontramos tres tipos de producciones: las académicas, los aportes periodísticos y las memorias, reflexiones y producciones de ex militantes y dirigentes de la organización, además de las compilaciones documentales -siendo la de Daniel De Santis (2005) la más importante hasta el momento, por su sistematicidad y organización y por ser la más completa.

Los tres tipos de abordajes mencionados se concentran en la discusión sobre los posicionamientos políticos e ideológicos, las características y prácticas organizativas y la lucha armada, discusión a través de la cual intentan dar una explicación del éxito parcial de la organización, o de su derrota.

Entre las principales producciones de ex militantes encontramos visiones y balances profundamente distintos sobre la experiencia de la organización, sus aciertos y sus errores. Entre quienes enfatizan en sus errores o deficiencias, encontramos, por una parte, los trabajos de Gorriarán Merlo (2003) y Julio Santucho (1988), que más allá de sus diferencias coinciden en que uno de los graves errores en los que incurrió el PRTERP fue la posición política y la actitud tomada frente al gobierno de Héctor Cámpora. Mientras el primero hace eje en que el PRT-ERP no aprovechó el escenario de apertura democrática manteniendo una actitud ofensiva en todo momento, Julio Santucho halla el problema en la pervivencia de "lastres ideológicos" que habrían llevado a la organización a un militarismo extremo y a no valorizar la democracia.

Por otra parte se encuentra el trabajo de Luis Mattini (1996), ex dirigente perretista, quien sostiene que el PRT-ERP nunca logro conformarse como el partido proletario que pretendió ser, ya que no representó a la clase obrera argentina que en su mayoría era peronista. Para el autor, aunque el PRT-ERP se autoproclamase la vanguardia de esta última, no lo era ni podía serlo ya que lejos de ser la expresión de una clase era la expresión de una coyuntura de radicalización política. En ese sentido, lo que hubiese necesitado la clase obrera no era una mayor dosis de violencia revolucionaria sino una sabia orientación política, algo que el PRT-ERP nunca comprendió, por lo que cayó en el militarismo. 
Por último, y en discusión con estas perspectivas, encontramos las producciones de Daniel De Santis (2009 y 2010). Para este último el PRT-ERP fue el intento más importante en la construcción de un partido revolucionario de la clase obrera en Argentina, logrando influir decisivamente en una gran parte de la vanguardia obrera de las principales fábricas y dirigiendo a una importante fracción de ella. Para De Santis el crecimiento del PRT-ERP en el período 1973-1976 se debió a que caracterizó correctamente la situación política del período como de "situación revolucionaria" y, en consecuencia, la derrota no se explicaría por un error de análisis ni por una "desviación militarista" sino como parte de un cuadro más general caracterizado por: la falta de unidad entre las organizaciones revolucionarias; la división del pueblo entre una numerosa vanguardia social que se identificaba con las organizaciones revolucionarias y el resto de la población que mantenía expectativas en el gobierno peronista y en Perón lo que no habría permitido el tránsito a una situación de "crisis revolucionaria"-; y, en última instancia, por la derrota militar.

Por otro lado, en el campo de las producciones académicas, hallamos una serie de trabajos que sostienen que la política de lucha armada del PRT-ERP llevo a esta organización a un "aislamiento político" (Anzorena; 1998). En este registro se destaca el trabajo de Vera Carnovale, quien rechaza la teoría de la "desviación militarista" para hallar en la propia construcción identitaria perretista y la fidelidad de sus militantes a la línea partidaria, las consecuencias del aislamiento (Carnovale; 2011). Para la autora la concepción vanguardista, propia del legado guevarista, combinada con la fe ciega en el poder de la lucha armada y en el triunfo de la revolución, y la disposición sacrificial ante la lucha, son los elementos que explican lo que para otros son errores o desviaciones.

En este grupo de producciones también se encuentra el trabajo de Eduardo Weisz (2006). Si bien el autor rescata la tesis de Carnovale para explicar el militarismo del PRT-ERP, halla las causas del "aislamiento" en problemas organizativos e ideológicos. Para Weiz el PRT-ERP contaba con una lógica organizativa fuertemente centralizada y basada en la idea de la infalibilidad de la dirección, lo cual habría blindado a ésta última de las críticas, no permitiéndole acceder al diagnóstico de las bases. El aislamiento también se explicaría por una aplicación dogmatica, teleológica y pragmática del marxismo, y sobre todo por un menosprecio de la dimensión subjetiva y de la cultura política argentina, lo cual habría producido una subestimación de la capacidad del peronismo e impedido ver las verdaderas demandas de los trabajadores. 
Por otro lado, y desde una perspectiva diferente, encontramos como aporte central el trabajo de Pablo Pozzi (2001), quien efectúa un análisis completo sobre la composición del partido, su estrategia integral de poder, la identidad organizacional y militante, y su concepción de la democracia. Pozzi se posiciona contra quienes analizan al PRT-ERP como un fenómeno externo y alejado de las masas, y busca demostrar, a partir de una exhaustiva reconstrucción, que surgió estrechamente ligado al movimiento social (Pozzi; 2001). A la hora de explicar la derrota, el autor entiende que ésta se debió a la combinación de una fuerte represión, destinada a quebrar los nexos entre el PRT-ERP (y el resto de las organizaciones revolucionarias) y la base obrera, con un conjunto de debilidades propias de la organización. Entre estas últimas destaca la insuficiencia en la comprensión del marxismo, lo cual habría llevado a la organización a sobreestimar las posibilidades de triunfo, a tener una visión idealizada de la clase obrera y, como consecuencia de ello, a confundir combatividad con conciencia de clase. Por otro lado el autor plantea que lo militar tendió a autonomizarse y aunque no haya guiado a la totalidad de la política del PRT-ERP, por momentos fue contradictorio con su trabajo de masas y, por otros, complementario. Además considera que, en última instancia, ello condujo a la organización a una escalada militar para la cual no estaba preparada. En cuanto al tema de nuestro interés, plantea una vía interesante para explorar cuando sostiene que uno de los problemas que la organización no pudo solucionar fue el de la distancia que separaba su propuesta estratégica de guerra revolucionaria de las reivindicaciones gremiales o sindicales básicas.

En esta misma sintonía, entre otros, se halla el trabajo de Guillermo Caviasca (2006) quien al igual que Pozzi entiende que uno de los problemas más importantes que sufrió el PRT-ERP fue el de la ausencia de una propuesta política que se ubicara entre lo reivindicativo y lo estratégico. De este modo, si bien el PRT-ERP tenía claramente definido el objetivo de desarrollar el clasismo en la lucha económica y la guerra revolucionaria en términos estratégicos, en el medio había una "laguna". En lo que refiere a nuestro tema, el trabajo de Caviasca logra delimitar las concepciones desde las cuales el PRT-ERP abordaba su militancia en el movimiento obrero e identifica los niveles de inserción que éste logró. Desde allí plantea que la militarización y el aislamiento no deben pensarse uno como causa de lo otro, sino a la inversa. Para Caviasca el aislamiento fue producido por la represión efectiva y selectiva a las organizaciones revolucionarias y a las fracciones de vanguardia de la clase obrera que venían protagonizando importantes batallas, aunque sin lograr traccionar al conjunto del 
movimiento popular que, mayormente, no rompió con el peronismo gobernante. Habría sido ese aislamiento político el que generó el proceso de militarización en el PRT-ERP y en el resto de las organizaciones político-militares.

Por último es de destacar que en los últimos años han proliferado investigaciones que se han dedicado al estudio de dimensiones no exploradas de la experiencia política perretista, como son el trabajo de Marcelo Maggio (2012) dedicado al estudio de la experiencia del diario El Mundo, vespertino adquirido por la organización en 1973; el libro de Paola Martínez (2015) dedicado al estudio de género, más específicamente sobre la experiencia de las mujeres del PRT-ERP; y el reciente trabajo de Silva Mariños (2017) dedicado al análisis del Frente Antiimperialista y por el Socialismo, espacio político impulsado por la organización durante el período 1973-1976.

\section{La política sindical perretista y la experiencia obrera: una vacancia}

Como vemos en este rápido recorrido, el conjunto de estos trabajos no se preocupa específicamente por la relación que entabló la organización con el movimiento obrero en sus múltiples dimensiones. Si bien los últimos trabajos repasados problematizan la inserción de masas y analizan lateralmente el trabajo político del partido en el movimiento obrero, y si bien existen trabajos como los de Gregorio Flores (2013) y Daniel De Santis (2009) en los que se recrean sus experiencias de militancia obrera, los análisis sobre la intervención sindical del PRT-ERP y la práctica de sus militantes en sus espacios de trabajo - atendiendo las particularidades de la experiencia de clase (Thompson, 1989) que se vivió en ellos- son escasos. En ese último camino, se hallan una serie de trabajos y de artículos interesantes que demuestran esta preocupación y que son un puntapié inicial importante para el análisis de esta dimensión tan poco explorada. Por un lado, nos encontramos con el trabajo de Laura Scoppetta y Pablo Torres (2014, 2018), quienes han investigado la política sindical del PRT-ERP en Rosario. La hipótesis general del trabajo es que la organización logró una importante inserción en ciertos ámbitos fabriles de aquella ciudad y sus alrededores, convirtiéndose en uno de los actores políticos más relevantes de la zona. En el trabajo, los autores buscan reconstruir las particularidades de dicha inserción haciendo especial énfasis en el entrecruzamiento de la lucha sindical con las luchas político-militares. En cuanto a la actividad estrictamente sindical, buscan analizar si existió una distancia entre la teoría y la práctica en el desarrollo de la organización. Partiendo de esta preocupación, observan que si bien el PRT-ERP, en sus formulaciones teóricas, entendía a la actividad sindical 
como una actividad insuficiente y no como una forma cotidiana de construcción de poder en la fábrica, en la práctica militante esa línea fue sufriendo modificaciones sustanciales en tanto que fue reapropiada y recreada por sus militantes sindicales que ajustaron la línea partidaria a las condiciones particulares de cada espacio fabril, e hicieron posible que la organización se transformase en una opción a nivel de base dentro de las fábricas. Al mismo tiempo, como dijimos, la investigación está atravesada por la pregunta sobre el impacto de la lucha armada al interior de las fábricas. Para responder a dicha preocupación los autores realizan un interesante análisis de diferentes casos, entre los que se destaca el del frigorífico Swift. Este caso les permite mostrar que las acciones armadas ligadas a conflictos sindicales no solo no fueron rechazadas por los trabajadores, sino que además permitieron la expansión del trabajo político de la organización entre los trabajadores, abriendo puertas a nuevos establecimientos. En ese sentido, para los autores, la voluntad de fundir lo sindical y lo militar habría sido uno de los aportes más novedosos realizados por el PRT-ERP a las formas de la militancia de la época. Sin embargo, Scoppetta y Torres remarcan que los principales límites que tuvo dicho desarrollo estuvieron en la incapacidad de la organización para recuperar sindicatos o estructuras gremiales que le permitieran transformarse y visibilizarse como una alternativa real frente a la burocracia sindical. Finalmente los autores señalan como una de las principales dificultades del PRT-ERP la traducción de su trabajo de base en formas políticas que trascendieran los marcos estrictos de la fábrica.

Por otro lado nos encontramos con una tesis doctoral y dos artículos que, con objetivos distintos, también son interesantes aportes al análisis de esta dimensión. La primera, de Laura Pasqualli (2007), si bien esta apuntada al estudio del conjunto de organizaciones guerrilleras que intervinieron en el Gran Rosario, dedica un importante espacio al análisis del PRT-ERP, el estudio de su inserción en la zona y su relación con la clase obrera. En cuanto a los artículos, nos referimos a un trabajo de Barbara Noelia Centurión (2013) y a otro de Rafael Farace y Gabriela Jäkel (2016). El primero de ellos analiza la experiencia del PRT-ERP en la fábrica de Cristales Rigolleau de la ciudad de Berazategui, intentando demostrar los estrechos lazos que forjó con sus trabajadores. En él, la autora reconstruye los niveles de inserción de la organización y su línea en el marco de la conflictividad de la fábrica, llegando a la conclusión de que las decisiones que tomaron los trabajadores estuvieron fuertemente influenciadas por los planteos políticos perretistas. Por otro lado, el segundo de los artículos, se propone estudiar y comparar las nociones de burocracia sindical y democracia obrera en el PRT-ERP, en 
Montoneros y en el Peronismo de Base. En él, los autores destacan que, si bien en las tres organizaciones el concepto de "burocracia" es utilizado despectivamente para caracterizar al mismo sector del sindicalismo, existían importantes matices a la hora de explicar el origen y la naturaleza de aquel fenómeno; lo que no sucedería en el caso de la "democracia obrera" concepto que era significado de la misma manera.

Después de esta revisión, y aun teniendo en cuenta estos avances, resulta evidente la existencia de un doble vacío historiográfico en los estudios del PRT-ERP: por un lado aquel relativo a su política sindical, su línea de intervención en el movimiento obrero, el grado de inserción logrado por sus militantes en el ámbito gremial y el nivel de dirección alcanzado por no pocos obreros prerretistas; y por otro el que refiere a la experiencia concreta de sus militantes en las fábricas. De modo que queda planteada la necesidad de un estudio sistemático de estos dos aspectos en el que: 1- se reconstruya la perspectiva político-ideológica, la estrategia, las formas de organización, las líneas de intervención que se dio la organización para insertarse e intentar dirigir al movimiento obrero argentino y el mapa de inserción fabril; 2- al mismo tiempo se reconstruyan y analicen experiencias concretas de sus militantes obreros y sus organizaciones de base, en nuestro caso, en dos fábricas del Gran Buenos Aires.

En tal sentido, nos proponemos indagar tanto en los testimonios de los protagonistas como en el material documental (panfletos, volantes y boletines), recurriendo a las herramientas que brinda la historia social (James 2004; Winn, 2004; Lorenz, 2007), para intentar dar cuenta de la manera en que los militantes buscaron resolver una orientación y una línea política pretendidamente universal en una realidad particular, recuperando de este modo el pasado que fue hecho pero no escrito por ellos (Hoggart,1957; Thompson, 1984; Hobsbawm, 1984).

Para este propósito, dos trabajos como A la conquista de la clase obrera (...) de Hernán Camarero (2007) y Algo parecido a la felicidad (...) de Federico Lorenz (2013) se tornan complementarios y referencia metodológica obligada.

Por un lado el trabajo de Camarero, destinado a estudiar los modos a través de los cuales el Partido Comunista Argentino (PCA) logró ser una corriente de peso en el movimiento obrero durante el período de entreguerras, nos da un ejemplo serio y sistemático de cómo reconstruir y estudiar el desarrollo de una organización de pretensiones revolucionarias en el seno de la clase obrera. El trabajo asume especial importancia para nuestro proyecto, en tanto que su análisis hace foco en las formas y los métodos en que un partido que se reconocía oficialmente como marxista-leninista, 
penetró en las principales fábricas del país, y logró una gran inserción en el movimiento obrero, influenciándolo y organizándolo a través de múltiples herramientas. Es de destacar que el estudio no solo nos interesa en tanto referencia para el análisis de una organización marxista en el seno del movimiento obrero, sino también porque muchos de los modos, herramientas e instrumentos utilizados por el PCA para insertarse en el mundo obrero (estructura celular de organización, boletines fabriles, etc.) fueron reapropiados por organizaciones de la nueva izquierda, entre ellas el PRT-ERP.

Por otro lado, el interés específico en la obra de Federico Lorenz se torna más evidente ya que el autor se propone pensar la relación entre una organización armada (Montoneros) y su frente sindical a través de un estudio de caso para el período 19731978. En su trabajo, Lorenz hace eje en la articulación de experiencias y prácticas de la lucha política, sindical y armada en un grupo de trabajadores que organizados en una agrupación sindical decidieron vincularse a una organización político-militar a través de su frente sindical (Juventud Trabajadora Peronista -JTP-). La riqueza del trabajo reside en la búsqueda por conocer el lugar que tuvo, y las formas que adoptó la violencia política dentro de las luchas sindicales de la época a partir del relato de los trabajadores y no desde la voz oficial de las organizaciones, lo cual lo transforma en lectura ineludible para quien se proponga investigar sobre la relación entre organizaciones de la nueva izquierda y la clase obrera argentina.

Es de destacar que el rol pionero que ha tenido este trabajo motivó, en el último tiempo, a la proliferación de una serie de estudios de casos que se proponen abordar los años setenta desde los trabajadores (Soul, 2011; Ducid, 2014; Dawyd (ed.) 2017; Della Savia, 2017, 2018), analizando las formas organizativas de base de diferentes fábricas e identificando sus particulares estrategias políticas ${ }^{4}$.

En esa dirección, cobra especial importancia para nuestra investigación los estudios sobre la experiencia de lucha de los obreros de Mercedes Benz Argentina (Rodríguez, 2011; Harari, Casco Peeble, Guevara, 2014; Casco Peeble y Lenuda, 2016; Casco

\footnotetext{
${ }^{4}$ El libro de reciente producción editado por Darío Dawyd y motorizado por la Universidad de La Matanza, incluye estudios de tres fábricas metalúrgicas de aquella localidad (INSUD, Martín Amato y Santa Rosa), por su parte los artículos de Guillermo Della Savia (2017 y 2018) versan sobre la experiencia en las fábricas Del Carlo (metalúrgica) y Matarazzo (fideera), ubicadas en la Zona Norte del Gran Buenos Aires. Interesados por la historia local, los trabajos realizan una reconstrucción de las experiencias en base a diversas fuentes y, si bien no se ocupa de analizar la intervención de una organización política en particular, reconstruyen el mapa de organizaciones que intervinieron en las mismas y la forma en que aportaron a la politización de los conflictos. Por otro lado la tesina de licenciatura de Ducid se dedica a estudiar la experiencia de la JTP en la fábrica Propulsora Siderúrgica de Ensenada.
} 
Peeble, 2016). Entre ellos sobresale la tesis de maestría de Mariano Casco Peeble (2016) ya que se dedica al estudio de la "radicalización sindical" vivida en la planta en el período que ocupa nuestro trabajo. Allí el autor realiza un análisis histórico general de la empresa y particular del proceso de organización obrera, resaltando la forma en que la participación de organizaciones revolucionarias operó como un factor clave en esa radicalización. En ese sentido resulta un trabajo fundamental que recuperaremos porque proporciona una exhaustiva reconstrucción de la conflictividad obrera que nos permite ubicar la intervención perretista y analizarla en su especificidad.

Como ha podido observarse a partir de este estado de la cuestión, los estudios sobre la actividad política del PRT-ERP en el movimiento obrero no abundan, y menos aún los referidos a su actividad sindical. Por su parte, aquellos trabajos que han intentado recuperar y reconstruir esta dimensión de análisis, serán para nosotros una puerta de entrada a un campo por explorar.

Abordar el vínculo entre una organización revolucionaria de la nueva izquierda y la clase obrera, así como la trayectoria y la experiencia de sus militantes en el espacio fabril, se presenta como un desafío que empieza a ser enfrentado por nuevas investigaciones como la presente.

\section{Problema y objetivos de investigación}

\section{El problema de investigación}

La reflexión sobre la violencia política y su vínculo con el movimiento social, ha sido parte constitutiva de los debates que atraviesan a la historia reciente argentina. En ese marco, como observa Omar Acha (2010), una parte de la bibliografía ha sosteniendo que las organizaciones armadas se constituyeron y actuaron desde un vanguardismo externo, representando la expresión más delirante y extraviada de la época (Ollier, 1986; Romero, 2003; Vezzeti, 2002, 2009). Coincidimos con Tortti (2006; 2015) en que este tipo de bibliografía ha tendido a realizar un "doble recorte" al centrar el análisis de estos procesos en uno solo de los tramos de esa historia (el que se abrió con el Cordobazo en 1969) y concentrándose sólo en los "partidos armados", sin poder ver que esas organizaciones fueron parte de un proceso de activación social y político más amplio que se venía gestando desde la caída del peronismo en 1955.

Este estudio, que intenta dilucidar cómo fue la relación entre una de esas organizaciones armadas -el PRT-ERP-y (una parte de) la clase obrera argentina, parte teóricamente de la idea de que la violencia política es un elemento constitutivo de la lucha de clases, y 
que en el caso argentino formó parte de la experiencia de los trabajadores. En ese sentido, compartimos con Federico Lorenz la idea de que en el estudio del vínculo entre las organizaciones armadas y el movimiento obrero, la división taxativa entre "lucha armada" y "lucha sindical" resulta al menos insuficiente para analizar un espacio de acción mucho más complejo en el que ambos términos por momentos, lejos de ser antagónicos, se tornaron intercambiables (2013:14).

Desde ese punto de partida, nos dedicaremos a reconstruir las estrategias y herramientas que se dio la organización para penetrar en las principales fábricas y las distintas políticas que ensayó para incorporar obreros a sus filas y transformarse en la dirección política al interior de los establecimientos entre los años 1973-1976. A su vez analizaremos, a través del estudio de casos, los vínculos forjados con los obreros de dos fábricas del Gran Buenos Aires, las formas de su activismo político y sindical, sus organizaciones de base y sus organismos gremiales. En esa dirección, buscaremos reconstruir la experiencia fabril perretista atendiendo tanto a la influencia que sus militantes lograron ejercer, y los niveles de politización y organización que pudieron construir en el mundo obrero, como los límites que tuvieron en esa tarea.

Como vimos, un repaso sobre la literatura historiográfica referida al PRT-ERP nos arroja una escasez importante de estudios sobre su intervención sindical y las experiencias prácticas de sus militantes en el espacio fabril, concentrándose la mayoría de las producciones fundamentalmente en las cuestiones referidas a los problemas estratégico-organizativos y de la lucha armada. Esto resulta llamativo si atendemos al hecho de que el PRT-ERP, habiendo definido a la clase obrera como el sujeto de la revolución socialista, concentró gran parte de sus esfuerzos en penetrar y desarrollarse en el movimiento obrero e intervino activamente en las luchas sindicales de la época. Todo ello, a su vez, enmarcado en una estrategia de "guerra revolucionaria" que generó y habilitó nuevas formas de resolver los conflictos que rompieron con los métodos clásicos del sindicalismo tradicional.

En ese marco el PRT-ERP elaboró una concepción del sindicalismo y sus tareas, que desarrolló desde sus orígenes a través de sus células partidarias de fábrica y agrupaciones sindicales, y desde 1973, también a través del "Movimiento Sindical de Base" y la "Tendencia Obrera Revolucionaria 22 de Agosto". En la práctica modeló un tipo de militante clasista cuya acción organizada incidió significativamente en el movimiento obrero de las grandes ciudades (Pozzi; 2004).

Como dijimos, la tesis se plantea el análisis de su objeto en un doble registro partiendo 
de la certeza de que no puede comprenderse cabalmente una experiencia políticosindical si no se tiene en cuenta tanto la perspectiva y las aspiraciones de la organización estudiada como la experiencia de quienes la encarnaron y tradujeron su línea a la realidad concreta. Desde esta perspectiva consideramos que se trata de dos dimensiones mutuamente necesarias y complementarias para alcanzar nuestros objetivos, que permiten iluminar un mismo problema desde dos ángulos distintos. De este modo la investigación busca: por un lado, reconstruir la línea de intervención político-sindical del PRT-ERP, la influencia y los límites de su acción; y por otro, analizar las experiencias desarrolladas por los militantes obreros perretistas en dos fábricas de la región del Gran Buenos Aires, entre los años 1973 y 1976, rastreando en su práctica, los resultados de la política de la organización, así como también las tensiones y dificultades a las que se enfrentó. En relación a esta última dimensión, se indagará, principalmente, sobre tres tensiones a las que se enfrentaba el obrero perretista en sus espacios de militancia: 1- las propias de toda organización política revolucionaria cuando actúa en el ámbito sindical-reivindicativo e intenta dar el salto al plano político. 2- las generadas al intentar construir una organización marxista leninista en el seno de una clase obrera fuertemente identificada con el peronismo; y 3-aquellas que suponían implementar y combinar una línea de lucha armada al interior de la fábrica con el desarrollo de la actividad sindical. De este modo, se buscará identificar y analizar las diversas vías ensayadas para resolver estas tensiones durante el período señalado.

Por su parte, el recorte temporal propuesto para el estudio agrega una nueva dimensión problemática y una nueva tensión que atravesará todo el período 1973-1976, producto de que la apertura democrática y el retorno del peronismo al poder, generaron expectativas en una gran parte del movimiento de protesta. El nuevo contexto estuvo caracterizado por el intento, de parte del nuevo gobierno, de encauzar por canales institucionales la conflictividad social, transformando profundamente las condiciones de la lucha que venían impulsando las organizaciones de la nueva izquierda, y las que venía protagonizando la clase obrera en los marcos de la dictadura militar. Bajo esas nuevas condiciones, el PRT-ERP debió: 1- definir su posición ante la coyuntura electoral, el gobierno de Cámpora, y luego el del mismo Perón; 2- definir si continuaría o no con la actividad militar; 3- adaptarse al nuevo contexto democrático-legal; y 4- en relación directa con este último punto, reorientar su trabajo en el movimiento obrero.

En este último plano, la organización debió hacer frente a dos políticas de gobierno que marcaron la nueva conflictividad obrera: por un lado al Pacto Social, estrategia 
económica gubernamental que suponía el congelamiento de la libre negociación colectiva de trabajo, y por el otro, al fortalecimiento de la burocracia sindical, favorecida a través de la Ley de Asociaciones Profesionales.

La organización encaró esta etapa bajo la consigna de aprovechar al máximo las condiciones de legalidad política, aunque sin abandonar la lucha armada. En ese sentido, se dispuso a lanzar herramientas político-organizativas que permitieran nuclear en su seno a amplios sectores del pueblo, disputando la dirección del movimiento obrero y popular. Ejemplo de ello fueron el Frente Antiimperialista y por el Socialismo (FAS), frente político ideado para la lucha democrática, y el MSB, para el ámbito sindical.

La combinación y la tensión del trabajo legal con el ilegal será, entonces, una de las características fundamentales de la política perretista para la nueva etapa, que se manifestó de manera peculiar al interior de las fábricas. Ahora bien, la particularidad de este período nos arroja a un escenario paradójico que motiva y forma parte del problema de investigación: este cambio en la situación política, en principio desfavorable para el desarrollo de la lucha armada, se transformó en el período de mayor actividad militar de la organización (y de las organizaciones armadas en general), y en el período de mayor crecimiento del PRT-ERP en el movimiento obrero (Pozzi; 2004).

En síntesis, nuestro problema se articula en base a dos dimensiones de análisis: la dimensión político-organizacional, en el que buscaremos analizar el lugar que le asignaba el PRT-ERP al trabajo político en el movimiento obrero y en especial al trabajo sindical en su estrategia revolucionaria -para lo cual estudiaremos el conjunto de herramientas organizativas que ensayó para lograr sus objetivos, entre las que se destaca el Movimiento Sindical de Base-; y la dimensión militante en la que investigaremos cuáles fueron las características y las limitaciones de la experiencia de sus militantes obreros en las fábricas Mercedes Benz y TENSA, ubicadas ambas en el Gran Buenos Aires. A su vez, ambas dimensiones de análisis estarán atravesadas por la particularidad del periodo 1973-1976 anteriormente expuesta.

\section{Objetivos de la tesis}

Esta tesis doctoral se ubica en el campo de estudios del movimiento obrero y la izquierda y busca contribuir al conocimiento del vínculo desarrollado entre política revolucionaria y lucha sindical durante los años setenta. En función de ello se propone como objetivo general reconstruir y analizar las prácticas político-sindicales del PRT- 
ERP, las herramientas que ensayó para lograr sus objetivos (entre las que se destaca el Movimiento Sindical de Base) y la experiencia de sus militantes en dos fábricas del Gran Buenos Aires en el periodo de 1973-1976, buscando aportar al mencionado campo de estudio construyendo una visión más completa y compleja de su trayectoria.

En esa dirección este trabajo se propone los siguientes objetivos específicos:

- Reconstruir la perspectiva político-ideológica del PRT-ERP, su concepción del poder y su estrategia revolucionaria, haciendo hincapié en las líneas de intervención sindical desarrolladas en el período 1973-1976.

- Indagar sobre las características que asumió el vínculo entre lucha armada y lucha sindical en la propuesta del PRT-ERP, en la experiencia de sus militantes y en la recepción de los obreros al interior de las fábricas.

- Reconstruir y analizar el lugar que ocupó el Movimiento Sindical de Base en la estrategia sindical del PRT-ERP, sus perspectivas y limitaciones, y la forma en que fue llevado adelante por sus militantes.

- Analizar la práctica cotidiana de los militantes fabriles perretistas y las características que asumió la construcción sindical en dos fábricas del Gran Buenos Aires; delinear las formas organizativas adoptadas en cada caso, e identificar perfiles militantes resultantes de las propias experiencias.

- Reconstruir y analizar las formas en que la organización y sus militantes problematizaron y afrontaron la presencia de la identidad peronista al interior de las fábricas.

\section{Referentes Teóricos}

A continuación plantearemos algunos referentes teóricos que, entendemos, son pertinentes para nuestra investigación. Para ello presentaremos tres ejes conceptuales: 1Un conjunto de conceptos históricos que nos servirán para caracterizar la época y el período a estudiar, 2- algunos conceptos teóricos que definirán la perspectiva y el marco teórico desde el que parte esta investigación, y 3- una serie de categorías que nos servirán para el estudio específico de la dimensión militante al interior de las fábricas.

Para el primer eje conceptual, entendemos fundamental el concepto de nueva izquierda (Tortti; 2014), al que definimos junto a María Cristina Tortti como el conjunto de fuerzas sociales y políticas que durante los años 60 y 70 protagonizaron un proceso de movilización y radicalización política que "incluyó desde el estallido social espontáneo 
y la revuelta cultural hasta el accionar guerrillero, y desde la eclosión de movimientos urbanos de tipo insurreccional al surgimiento de direcciones clasistas en el movimiento obrero" (Tortti; 2014: 17) .

La experiencia de lucha que la clase obrera realizó en el marco de la resistencia al golpe de estado de 1955, así como el triunfo de la Revolución Cubana, generaron las condiciones para un profundo debate en el seno de las organizaciones de izquierda. El nuevo escenario dio pie para una discusión renovada sobre las vías para la revolución y para una revisión del fenómeno peronista que llevó a un copioso sector de la intelectualidad y de la militancia izquierdista a romper con las interpretaciones clásicas de la izquierda tradicional. Por un lado se puso en discusión la estrategia armada como camino para el triunfo de la revolución y por otro lado se dejo de ver al peronismo como una mera forma de "totalitarismo", "demagogia" o "manipulación" buscando nuevas interpretaciones que dieran explicación a las razones por las cuales los trabajadores asumían el peronismo como su propia identidad de clase. (Tortti; 2014)

Ahora bien estas discusiones estuvieron lejos de ser homogéneas en las organizaciones que formaron la nueva izquierda: hubo organizaciones que adoptaron el peronismo como identidad e ideología, así como hubieron las que mantuvieron una visión crítica del mismo; en el mismo sentido, las aguas se dividieron entre quienes optaron por la lucha armada y quienes siguieron defendiendo una estrategia insurreccionalista.

Es por eso que advertimos junto a la autora que el concepto de nueva izquierda funciona como una "puerta de entrada a ese multifacético mundo socio-cultural-político"(Tortti; 2014: 17) que busca nominar a un complejo y expansivo conglomerado de fuerzas sociales y políticas que no se articularon como un actor político único, que contuvo en su seno diferentes expresiones y tradiciones políticas e ideológicas, pero que compartían una misma confianza en las virtualidades revolucionarias del pueblo, y en algunos casos, mismos métodos y objetivos.

Creemos que dicho concepto nos permite estudiar una de sus organizaciones, el PRTERP, entendiéndola en un marco más amplio, como parte de un movimiento de oposición social y política que no solo incluye a las organizaciones que practicaron la lucha armada, y evitar así las visiones que explican el surgimiento y desarrollo de este tipo de organizaciones como un fenómeno de exclusiva radicalización política juvenil exterior al movimiento social y específicamente al movimiento obrero.

En efecto, el surgimiento de las organizaciones armadas fue parte de un proceso de radicalización política que incluyó a importantes sectores sociales, que se potenció tras 
el Cordobazo en 1969, y que abrió un período de crisis de hegemonía (Portantiero, 1977). Éste estuvo marcado por la incapacidad de las clases dominantes argentinas para proyectar un orden y alguna forma de dominación legítima sobre el conjunto de la sociedad, obligándolas a ensayar una salida política por fuera del régimen dictatorial. Entendemos junto a Tortti (1999) que el objetivo último de la apertura democrática y la legalización del peronismo, ideado por Lanusse, fue el de frustrar la confluencia entre la izquierda social y la izquierda política que se venía dando en base al enfrentamiento a la dictadura y al convencimiento de que no había salida posible por fuera de una revolución.

En ese sentido el concepto de nueva izquierda cobra particular importancia para el estudio del período 1973-1976, ya que la salida democrática de la dictadura y el retorno del peronismo al gobierno acentuó las diferencias de sus actores al suspender el eje que en la práctica los unificaba, la lucha antidictatorial, poniendo en primer plano, y como ordenador de la nueva racionalidad política, aquel que los dividía: el peronismo. Este escenario renovó los debates entre las organizaciones revolucionarias, sobre todo por el papel que cada una consideraba que iba a jugar este último en el gobierno y, en consecuencia, por la decisión de continuar o suspender la actividad armada. Aunque en sentidos diferentes, un gobierno peronista, popular y democrático, significaba un cambio profundo de las condiciones en las que venían desarrollándose tanto las organizaciones revolucionarias del peronismo como el PRT-ERP y otras organizaciones de izquierda. En el caso del PRT-ERP, específicamente, porque se trataba de una organización que, manteniendo una posición crítica hacia el nuevo gobierno, se proponía ganar la dirección de una clase obrera mayormente peronista al tiempo que desarrollar una estrategia de guerra revolucionaria.

Los conflictos sociales y las luchas en las fábricas se multiplicaron a lo largo del período. La experiencia vivida por la clase obrera desde 1969, el surgimiento de corrientes clasistas en su seno (Brennan; 1996) y el crecimiento de las organizaciones revolucionarias en las fábricas hicieron imposible la concreción del proyecto de “democracia integrada" ideado por Perón (De Riz; 2000; Svampa, 2003). El plan de reconstrucción política ensayado por éste último se encontraba, así, frente a un obstáculo: el hiato existente entre su fórmula de conciliación y el espíritu dominante en la movilización que lo devolvía al gobierno. Las fábricas vivían un estado de rebeldía (Torre; 2004). Poco después, la muerte del viejo líder y el recrudecimiento de la lucha de clases llevo a lo que Liliana De Riz (2000) denomina la "descomposición de la 
sociedad populista" que las clases dominantes terminaron resolviendo finalmente a través del golpe de estado de 1976.

Ahora bien, como nuestra investigación está centrada en el estudio de una expresión específica de esa nueva izquierda, el PRT-ERP, y su vínculo con el movimiento obrero, se reveló necesario precisar algunas categorías que son fundamentales en nuestro análisis y que forman parte de nuestro segundo eje conceptual.

En principio debemos tener en cuenta que el PRT-ERP se definía como un partido marxista-leninista, lo que supone una forma y un criterio organizativo especifico. Como remarca Pablo Pozzi (2004) los criterios de cantidad y calidad en un partido clandestino de cuadros y militantes, como lo era el PRT-ERP, son diferentes a los de un partido de afiliados o a los de una organización movimientista. Ello significó, para el PRT-ERP, una forma particular de realizar el trabajo político y sindical entre la clase obrera que hacía eje en la "educación” y "concientización" de los trabajadores, y que intentaremos desentrañar a lo largo de la investigación.

Ahora bien, siendo que estudiaremos la política que se dio la organización para la clase obrera argentina y los vínculos que forjó su militancia con una parte de ella, es necesario aclarar que entendemos por los conceptos de clase y experiencia de clase.

Para definir a la clase nos ubicamos en el debate de la corriente conocida como "marxismo británico" (Stedman Jones; 1983; Hosbawm, 1987; Anderson, 1985; Thompson, 1989; Hoggart, 1990). En el identificamos dos posiciones centrales en la definición de la clase: aquellos que le dan un peso central a la dimensión cultural (Thompson; 1989) y aquellos que buscan dar una explicación desde un punto de vista más estructural (Anderson; 1985). Sin intentar resolver esta discusión, podemos decir que recuperamos de la concepción thompsoniana de clase la idea de que no se la puede entender y pensar sin la dimensión de la lucha, aunque, al mismo tiempo, coincidimos con Pozzi, Schneider y Camarero (2001) en que "la existencia del capitalismo como tal define la existencia de la clase obrera" y que, por ende, no puede dejar de tenerse en cuenta que aquella se define por su relación con los medios de producción aunque dicho vínculo no sea estático sino dinámico.

Partiendo de estas consideraciones entendemos a la experiencia de clase (Thompson; 1989) como una mediación entre la clase y la conciencia de clase, es decir, como la vivencia de quienes ya forman parte de ella. Cuando hablamos de experiencia, entonces, hacemos referencia a la forma en que son vividas las relaciones de producción, la 
explotación y la lucha, esto es, la forma en que es vivida la situación de clase por los hombres y mujeres que las componen.

Esta definición de experiencia nos permitirá entender y estudiar el proceso de radicalización política que vivió la clase obrera argentina, así como las razones por las cuales parte de esa clase decidió organizarse en un partido como el PRT-ERP que se proponía la revolución socialista como meta, optaba por la vía armada para lograrla y cuestionaba al peronismo, combatiendo a sus expresiones ortodoxas y polemizando con sus versiones revolucionarias.

Ahora bien, también aplicaremos el concepto de experiencia en otro sentido y lo ajustaremos al estudio de la dimensión militante, abriendo paso al tercer y último eje conceptual. De este modo también hablaremos de "experiencia militante", como un concepto que busque captar las lógicas, características, tensiones y significados que adquieren las vivencias del militante fabril de una organización revolucionaria, que se halla en una posición de mediación entre la línea partidaria y la práctica concreta. Mediación no entendida como mero brazo ejecutor de una línea prefabricada, sino como expresión del arte de resolver una orientación y proyecto político de corte universal en una realidad particular.

Esta experiencia militante adquirió una impronta particular al interior de las fábricas durante los años 70. La búsqueda constante por parte de las organizaciones revolucionarias de insertarse en los establecimientos industriales, llevó a construir diferentes herramientas para lograr dicho objetivo, siendo la proletarización de sus militantes una de las más destacadas (Linhart, 1997; Carnovale, 2006; Celentano, 2009; Águila y Viano 2009). Esta práctica consistía en la incorporación intencional de los militantes a los establecimientos fabriles desde la cual se buscaba una inserción en los lugares de trabajo que apuntara a aumentar constantemente la porción de obreros a sus filas, garantizar la unidad entre la teoría y la práctica y activar políticamente dentro de la clase. Como subraya Héctor Löbbe (2006) esta política a su vez configuró dos tipos de militantes al interior de la fábrica que caracterizaron a la militancia fabril de dichas organizaciones y que consideramos pertinente recuperar para nuestra investigación: por un lado el militante obrero, que el autor define como aquel que bajaba a la fábrica (se proletarizaba), y que respondía de manera mucho más disciplinada y vertical a la orientación general que le daba su organización; y por otro lado, el obrero militante, definido como aquel obrero de una fábrica que se incorporaba por propia voluntad y convencimiento a una organización política. Era un obrero de vanguardia, esto es, que 
por su politización no reflejaba el nivel promedio alcanzado por el resto de sus compañeros, y que, por ende, se encontraba tensionado entre sus aspiraciones (y las de su organización) y la realidad que le imponía el día a día de la fábrica.

Esta militancia fabril, que apostaba a promover el papel revolucionario de la clase obrera (Brennan; 1996), apuntaba a fortalecer los organismos de base al interior de los establecimientos, esto es, los instrumentos organizativos de la clase obrera que limitaban el poder efectivo del capital en la primera línea del conflicto de clases (Cuerpo de Delegados, Comisiones Internas, Comités de Reclamo, etc.). Estos organismos se transformaron en herramientas fundamentales para las organizaciones de la nueva izquierda que lucharon por construir un modelo de democracia sindical que confrontara directamente con el de la "burocracia sindical" (Löbbe, 2010; Raimundo, 2010; Pérez Álvarez, 2010).

En el marco del concepto de "experiencia militante" haremos referencia a una categoría especifica que denominaremos militancia fabril perretista. Con ello nos referimos a una práctica militante encarnada por hombres y mujeres que formaron parte del movimiento obrero argentino y que desde su espacio de trabajo (la fábrica) buscaron construir y desarrollar la propuesta política del PRT-ERP, en algunos casos a través del Movimiento Sindical de Base. Esto supone reconstruir un tipo de práctica, un conjunto de tareas y una impronta militante específica y analizar en que aspecto y hasta qué medida se logró una síntesis entre el proyecto político de la organización y la experiencia concreta de los militantes obreros perretistas. En ese sentido será posible identificar "estilos" de construcción e intervención político sindical que variaron, a grandes rasgos, según las herramientas organizativas construidas (las planteadas por la organización o las creadas por los propios obreros). Ello dependió tanto de las características y condiciones políticas de cada planta (tamaño, presencia de otras organizaciones, fortaleza de la "burocracia sindical", etc.) como del perfil de los militantes que lo encarnaron (obreros militantes, militantes obreros, simpatizantes, colaboradores, etc.).

De esta manera, el concepto de experiencia nos servirá para el abordaje de dos niveles de análisis con diferente alcance: por un lado una nivel general de clase, que nos permitirá analizar las vivencias y la experiencia de los obreros de las fábricas a estudiar, hayan sido o no activistas, y las características de la relación que construyeron con una de las organizaciones revolucionarias de la época: con el PRT-ERP. Y por otro lado, un nivel militante que nos permitirá observar y analizar las exigencias de la práctica, las 
realidades y particularidades de cada uno de los espacios fabriles, las prioridades políticas y las vivencias de los militantes perretistas, teniendo en cuenta que cada uno de los casos conforman un conjunto de variables y factores que reflejan las vicisitudes, dificultades, y contradicciones de una práctica que no siempre tuvo la impronta que se pretendió, y que en muchos casos aparece oculta detrás del relato tanto de la organización como de las voces de autoridad dentro de la militancia partidaria.

\section{Metodología de la investigación:}

De acuerdo a los objetivos de esta tesis, y a las dos dimensiones desde las cuales se aborda el objeto, hemos implementado un diseño de investigación flexible, centrado en una estrategia metodológica de tipo cualitativo. Para el análisis de ambas dimensiones político-organizativa y experiencial- se utilizaron diversas técnicas para la construcción de datos, desde el análisis de fuentes documentales escritas (Valles, 1997) hasta la entrevista en profundidad (Ruiz Olabuénaga, 1999; Piovani, 2007).

Respecto de la primera, acudimos a fuentes secundarias escritas de distinto tipo: volantes y boletines de fábrica del PRT-ERP y materiales de agrupaciones sindicales impulsadas por la organización; informes de inteligencia de la policía bonaerense; diarios nacionales como La Nación, La Prensa, La Opinión, Clarín, Noticias y El Mundo, con el fin de estimar el grado de relevancia pública de la organización. A su vez analizamos documentos internos y públicos. Las distintas publicaciones orgánicas del PRT, como El Combatiente, Estrella Roja, revista Nuevo Hombre, así como publicaciones del MSB, el Frente Antiimperialista por el Socialismo. Para ello contamos con el corpus de todas las colecciones documentales de dichas publicaciones, lo que nos permitió un estudio exhaustivo y sistemático de las mismas. Debemos entender, como señalan Pollak y Heinch (2006), que todas las fuentes deben ser sometidas a un análisis sociológico que integre en la reflexión el contenido con su contexto social de producción.

A la documentación accedimos gracias al acervo documental de varios archivos históricos: aquel digitalizado y complementado por el grupo Construir Proyectar Identidad del Archivo Biográfico Familiar de Abuelas de Plaza de Mayo y compilado por Daniel De Santis (2010); el repositorio digital El Topo Blindado; el Centro de Documentación e Investigación de la Cultura de Izquierdas (CeDInCI); el archivo de la DIPBA y el Centro de Documentación de la Comisión Provincial por la Memoria; la 
Hemeroteca de la Biblioteca Nacional, de la Legislatura de la Plata y de la UNLP; y el Centro de Documentación y Archivos de Memoria Abierta.

Como técnica de recolección de datos primarios, utilizamos la entrevista en profundidad. Aquella herramienta incorpora un enfoque "comprensivo" capaz de aproximarse al sentido que los actores le atribuyeron a sus prácticas y discursos, además de permitirnos reconstruir los procesos y acontecimientos de los que fueron protagonistas y que no quedaron registrados en otros documentos. Optamos por un tipo de entrevista semi-estructurada. A través de dimensiones analíticas predefinidas, buscamos abordar los ejes relevantes de nuestra investigación: la identificación y la reconstrucción de la trayectoria particular de las principales herramientas de intervención sindical que se dio el PRT-ERP en el Gran buenos Aires, por un lado, y las problemáticas y contradicciones principales con las que se encontraron los militantes del partido en la práctica cotidiana de la militancia en las fábricas, por otro. En cuanto al criterio de elección de los entrevistados, se utilizó un "muestreo intencional” entre quienes fueron militantes y simpatizantes que participaron como testigos claves o integrantes de las agrupaciones impulsadas por el PRT-ERP, militantes y dirigentes de aquella organización que ocuparon rangos de responsabilidad en materia sindical y obreros y activistas de otras corrientes políticas que compartieron experiencias comunes con los militantes perretistas. También aplicamos el "muestreo bola de nieve", accediendo a los entrevistados a través de las redes personales de contactos iniciales. Respecto a la cantidad de entrevistas, se avanzó hasta alcanzar la "saturación" en la información obtenida, entrevistando a un total de 39 personas, consiguiendo distintos tipos de testimonios que permitieron realizar un análisis desde distintos ángulos y punto de vista: así hemos podido entrevistar a dirigentes político y sindicales nacionales y regionales de la organización, algunos de ellos como Luis Mattini, Rafael Peralta y Daniel De Santis, que fueron parte de la Mesa Nacional Sindical, a militantes que fueron responsables políticos y sindicales al interior de las fábricas, así como a militantes fabriles de base de la organización y obreros simpatizantes de la misma; también pudimos entrevistar a militantes fabriles o simpatizantes de otras corrientes políticas (Partido Socialista de los Trabajadores, Vanguardia Comunista, Juventud Trabajadora Peronista, Peronismo de Base) y a dirigentes como Armando Jaime (Frente Revolucionario Peronista); y por último obreros activistas independientes que fueron compañeros de trabajo de los militantes perretistas. Además se acudió a entrevistas editadas, disponibles en bibliografía de carácter testimonial o documental (Pozzi, 2001; 
Pozzi, 2012; De Santis, 2000, 2006, 2010; Anguita y Caparrós, 2010a, 2010b, 2010c; Blixen, 1987, Flores, 2006 entre otros), en las cuales se encuentran diálogos y experiencias de participantes claves del proceso histórico abordado.

Es de destacar que el trabajo con testimonios supone algunos recaudos metodológicos que es necesario tener en cuenta. Como indica Vera Carnovale (2007) se trata de una fuente sustentada sobre la memoria, que lejos de funcionar como un receptáculo de eventos, hechos históricos o experiencias vividas, contiene procesos de significación activa en la que intervienen tanto el contexto político y cultural en el que se emite el testimonio como la trayectoria posterior del testimoniante. Por tales razones es imprescindible que el investigador tome distancia sometiendo a análisis crítico el contenido de ese material. En el mismo sentido, Pablo Pozzi, refiriéndose al historiador oral, advierte que éste además de utilizar las técnicas propias del entrevistador debe incorporar las del historiador, vale decir, tomar "todos los recaudos necesarios tanto al interrogar la fuente como al construir una explicación a partir de ella” (2011: 6).

En tal sentido esta investigación acude a la "triangulación" del material oral con el resto de las fuentes disponibles, así como a la contrastación de los testimonios entre sí, con el fin de reducir al máximo las imprecisiones o posibles "distorsiones" de los recuerdos. Aun así, como sugiere Carnovale, ello no resuelve el problema de la "representatividad" ni autoriza a desconocer los "puntos ciegos" que separan la experiencia vivida de lo que los entrevistados recuerdan y pueden narrar.

Sin embargo, y aun teniendo en cuenta lo anterior, consideramos que la fuente oral brinda claves interpretativas que permiten no solo reconstruir ciertos procesos sino también, en nuestro caso, identificar modalidades de construcción político-sindical y acercarnos a la comprensión de la experiencia de los militantes y de la recepción de los obreros con los que compartieron sus luchas.

\section{La elección de los casos}

A los fines de la investigación fueron seleccionadas dos fábricas: Mercedes Benz Argentina (Gonzales Catán) y TENSA (Vicente López y Pablo Nogués) en el período 1973 y 1976. La elección de estos casos respondió a múltiples factores, entre los cuales figuran: 1- Un criterio básico: la presencia de militancia perretista en las fábricas durante el período abordado. 2- Un criterio instrumental: se cuenta con fuentes documentales y orales para realizar el estudio. 3- Un criterio teórico y analítico: se eligen fábricas de dos de las ramas industriales más importantes de la industria 
argentina de los años setenta (automotriz y metalúrgica) a los cuales el PRT-ERP consideró "fundamentales" para su trabajo político. A ello corresponde agregar que se trata de fábricas que, por sus niveles de productividad, tuvieron un peso gravitante en los distritos del Gran Buenos Aires donde se hallaron instaladas; y que en ellas la experiencia de la militancia fabril perretista mostró rasgos diferenciales, lo cual permite iluminar y contrastar diferentes formas de traducción de la línea sindical de la organización según la particularidad de cada planta.

En relación a este último punto es necesario realizar algunas precisiones:

Los casos seleccionados adquieren relevancia ya que, como se dijo, el PRT-ERP caracterizaba a las ramas metalúrgica y automotriz como el lugar fundamental donde realizar trabajo político y sindical. En ese sentido, la elección de TENSA y MBA nos brinda la posibilidad de analizar experiencias en fábricas de ambas ramas industriales que, además, fueron importantes tanto por sus niveles de producción como por la cantidad de trabajadores que empleaban. TENSA, metalúrgica dedicada a la producción de autopartes fue dentro de su rubro, junto a Bendix S.A., la fábrica más grande del partido de Vicente López: empleaba alrededor de 1250 operarios, abastecía a varias de las principales automotrices del país (Fiat, Ford y Peugeot) y exportaba a distintos países de América Latina. Por su parte, MBA formaba parte de las siete empresas automotrices con mayor facturación del país (Rodríguez, 2010; Casco Peeble, 2016) y, durante los años setenta, llegó a emplear alrededor de 4000 operarios, siendo la terminal más importante de La Matanza y de toda la zona Oeste.

Además, la elección también demuestra su pertinencia, ya que en el caso TENSA el PRT-ERP contó con activistas en el Cuerpo de Delegados (CD) y la Comisión Interna de Reclamos (CIR), participó de una agrupación sindical junto a otras organizaciones de la nueva izquierda y desarrolló una intensa actividad militar ligada a la conflictividad de la fábrica. En cuanto a MBA, si bien la organización también contó con presencia en los organismos de representación sindical junto a otras fuerzas, allí sus militantes tendieron a desarrollar criterios propios para intervenir sindicalmente que son interesantes de analizar por su creatividad y sus niveles de autonomía respecto de las prescripciones partidarias.

Por último también resulta un elemento significativo el hecho de que ambas fábricas se hallaban ubicadas en el área metropolitana del Gran Buenos Aires, territorio que concentraba el mayor desarrollo industrial de la Argentina y, por ende, el movimiento obrero más nutrido del país. Compuesto por tres grandes zonas (Norte, Oeste y Sur) que 
abarcan los 19 distritos que rodean a la Capital Federal, el Gran Buenos Aires producía para la década de 1960 un 45\% del producto bruto del país y para 1974 concentraba un total de 30.033 establecimientos industriales que empleaban a 499.552 trabajadores. Particularmente nuestros casos se hallan situados en dos distritos de la Zona Oeste y la Zona Norte: La Matanza y Vicente López ${ }^{5}$.

Además, en el Gran Buenos Aires se hallaba el poder central de las cúpulas sindicales predominantemente peronistas y, a su vez, fue el lugar donde se desarrolló una de las regionales más importantes del PRT-ERP (junto a Córdoba y Rosario) por su cantidad de militantes y el nivel de inserción en el movimiento obrero. Por otro lado, fue específicamente durante nuestro período (1973-1976) que la conflictividad obrera de aquella región adquirió características de radicalización similares a las que venían sucediéndose en el interior del país desde 1969. En ese sentido estudiar la experiencia en fábricas de estas zonas nos permitirá conocer cuáles fueron los desafíos que tuvo que enfrentar la militancia perretista en unas de las zonas de mayor concentración obrera del país, de mayor peso de las estructuras sindicales y de una fuerte influencia de la identidad peronista entre los trabajadores.

Tal como señala la bibliografía, los estudios de caso buscan realizar un análisis "denso" de una experiencia con la intención de comprenderla en su especificidad aunque, también mediante ellos, pueden desentrañarse sentidos generales expresados a través de múltiples marcas en la unicidad del caso. Como indica Nélida Archenti, "el estudio de caso se basa en un diseño de investigación orientado al análisis de las relaciones entre muchas propiedades concentradas en una sola unidad" (Marradi, Archenti y Piovani, 2007:277). En síntesis el interés por el estudio de casos radica en que los mismos son "un modo de captar el funcionamiento real de mecanismos que, en un nivel 'macro', dejan demasiadas cosas sin explicar" (Levi, 2003:283).

Según Robert Stake (en Marradi, Archenti y Piovani, 2007) existen, en rasgos generales, tres tipos de Estudios de Caso (EC): intrínseco, instrumental y colectivo. El EC intrínseco es aquel se orienta a realizar una descripción densa que relata la especificidad del caso y no se interesa por nada que trascienda la preocupación por el

\footnotetext{
5 La Matanza para aquel momento contaba con 659.193 habitantes de los cuales 64.661 estaban empleados en 3.792 establecimientos industriales, mientras que Vicente López tenía una población de 285.178 habitantes y contaba con 2.312 establecimientos industriales que empleaban a 46.407 personas (Datos extraídos del Censo Nacional Poblacional y Censo Nacional Económico presentados en: Schneider, 2015)
} 
caso en sí mismo; el EC instrumental, en cambio, es aquel en el que el caso cumple el rol de mediación para la comprensión de un fenómeno que lo trasciende, es decir que el caso es utilizado como instrumento para evidenciar características de un fenómeno general; y el EC colectivo consiste en aquella investigación comparativa de varios casos, donde los casos son comprendidos en su especificidad para luego proceder a la comparación entre ellos buscando regularidades y también diferencias.

Ateniéndonos a dicha tipología, podemos decir que en nuestra investigación el estudio de los casos no puede encuadrarse de manera exclusiva en alguno de esos tres tipos, ya que contiene elementos de cada uno de ellos. El doble registro que ordena esta tesis, evidentemente, le otorga al estudio de nuestros "casos" rasgos del EC instrumental, en tanto a través de ellos buscamos analizar cómo la militancia fabril perretista tradujo en la práctica concreta y en un ámbito específico -la fábrica- una línea política y sindical general. Sin embargo nuestra búsqueda no se agota en el rol de "mediación" que ofrece el caso, sino que nos interesa la experiencia militante en sí misma, su densidad y la vivencia de los actores que la encarnaron, sus relaciones y particularidades (objetivos que encuadrarían en el tipo de EC intrínseco). Por último, al estudiar dos casos con características diferentes, aunque de manera incipiente, esbozaremos un intento comparativo con el fin de identificar diferentes estilos de construcción en cada fábrica.

Creemos que el estudio de nuestros dos casos (TENSA y MBA), en tanto experiencias "situadas", nos permitirá observar en una realidad acotada tanto las determinaciones específicas que le dan una relevancia teórica en sí misma a aquellas experiencias como iluminar aspectos más generales de la línea político-sindical del PRT-ERP. En ese sentido el valor heurístico del estudio de los casos consiste para nosotros en que posibilita un abordaje en profundidad de las múltiples variables que configuran la experiencia militante perretista, y permite analizar en detalle el modo particular en que esta organización intentó articular lo gremial y lo político en la acción de la clase obrera, los límites y los alcances de su propuesta, así como los problemas y tensiones que debieron enfrentar sus militantes a la hora de traducir en las fábricas la política diseñada por la organización.

En consonancia con lo anterior destacamos que esta investigación no pretende formular generalizaciones a partir de los casos estudiados sino, más bien, busca generar nueva base empírica que permita preciar ciertas conceptualizaciones y eventualmente refinarlas, construir perfiles de militantes, identificar modalidades de construcción 
político-sindical, iluminar tensiones, paradojas y problemas e iniciar algunas comparaciones que allanen el camino a nuevas investigaciones.

El juego permanente entre el trazado de líneas generales y el específico análisis de los "casos" ha resultado un camino adecuado para avanzar en el conocimiento de fenómenos complejos como los que aquí se investigan.

\section{Estructura de la tesis}

La tesis se divide en dos partes en función de las dos dimensiones de análisis que guían y estructuran la investigación. Así contamos con una primera parte, denominada “Construir el partido en las fábricas. La política sindical perretista (1973-1976)”, compuesta por los primeros cuatro capítulos, que se concentra en la reconstrucción de la línea sindical del PRT-ERP, así como de las diferentes orientaciones, iniciativas y herramientas que la organización desarrolló durante el período 1973-1976; y una segunda parte, denominada "Perros en las fábricas: los casos de TENSA y Mercedes Benz Argentina”, compuesta por dos capítulos, que está dedicada al análisis de la experiencia militante en las fábricas TENSA y MBA.

La primera parte inicia con un capítulo (“Orígenes y definiciones fundamentales de la línea político sindical perretista, 1965-1973”) dedicado a reconstruir los orígenes y la evolución de las concepciones que el PRT tuvo sobre la clase obrera, la actividad sindical y su estrategia revolucionaria, que nos servirá como base para comprender las características de su intervención en el período que nos interesa. Para ello realizamos un sucinto análisis de las polémicas que lo atravesaron desde su fundación y hasta su ruptura (1965-1968) para luego concentrarnos en la manera en que el PRT-El Combatiente reelaboró dichas nociones y fue conformando una nueva concepción sobre la lucha sindical a la luz de ciertos acontecimientos (CGT de los Argentinos, puebladas y la experiencia del clasismo cordobés) que precedieron al año 1973.

El segundo capítulo (“Definiciones ante la encrucijada democrática, 1973”), dedicado al análisis del año 1973, se propone indagar sobre la forma en que la organización se posicionó tras la apertura democrática y el retorno del peronismo al gobierno, prestando especial atención al lugar que le asignó a la lucha sindical en ese marco. De este modo examinamos de qué manera analizó y enfrentó dos políticas centrales del gobierno peronista como fueron el Pacto Social y la Ley de Asociaciones Profesionales. Por último, hacia el final, le dedicamos un importante espacio a analizar la forma en que se propuso fortalecer su trabajo en el movimiento obrero, estudiando las herramientas 
organizativas que se planteó construir al interior de las fábricas (células, comité fabril, boletín fabril y agrupaciones sindicales).

El tercer capítulo ("El Movimiento Sindical de Base y la Tendencia Obrera Revolucionaria 22 de Agosto ¿dos propuestas complementarias?, 1973-1975”), realiza un análisis de las dos organizaciones sindicales que impulsó el PRT-ERP durante el período abordado: el MSB y la TOR 22-8. Con el objetivo de estudiarlas en profundidad, en este capítulo optamos por suspender la lógica cronológica que ordena a esta parte de la tesis, analizando el derrotero de estas propuestas desde su fundación hasta su ocaso. Es de destacar que la experiencia del MSB ocupa un lugar central en el capítulo por ser el organismo que mayor desarrollo e importancia tuvo en la práctica y en la política perretista.

El cuarto y último capítulo de esta primera parte (“Años de luchas decisivas, 19741975”) aborda la intervención político-sindical de la organización durante los años 1974-1975. Por un lado analizamos la manera en que el "nuevo enfoque estratégico" adoptado para la lucha armada impactó en su intervención sindical y, por el otro, indagamos sobre la búsqueda por construir un frente nacional sindical que centralizara las luchas gremiales y el papel que jugó en la lucha contra el "Plan Rodrigo" y en la conformación de las Coordinadoras Interfabriles del año 1975.

La segunda parte de la tesis, está compuesta por el capítulo 5 (“Tensa 'globo de ensayo' del ERP) y el capítulo 6 (Perros en "La Mercedes"). La experiencia de TENSA aparece en el primero de los dos capítulos ya que se trató de uno de los primeros conflictos sindicales del año 1973, que condensó y anticipó muchos de los elementos que caracterizaran a la conflictividad del período. Allí nos concentramos en la intervención sindical y militar de la organización debido a la importante participación que tuvieron sus militantes en la vida gremial de la fábrica y a la cantidad de acciones guerrilleras que desarrolló la organización sobre el establecimiento. Por su parte para el caso de MBA, nos concentramos sobre todo en el análisis de las formas organizativas que plantearon sus militantes para intervenir sindicalmente, el papel que jugaron en la conflictividad de la planta, sobre todo en la huelga de 22 días de octubre de 1975, y en la forma en que abordaron el advenimiento de la dictadura.

Por último las conclusiones de la tesis buscan recuperar los elementos centrales que se desprenden del desarrollo de la investigación en función de las dos dimensiones de análisis propuestas. Así, por un lado sintetizamos las principales líneas y orientaciones sindicales que la organización planteó en el período mostrando el lugar que ocupó 
efectivamente la lucha sindical en la estrategia perretista, recuperando las tensiones desarrolladas en su vínculo tanto con la lucha política como con la lucha armada. Por otro lado y en dialogo directo con esto último hacemos una reflexión comparativa entre ambos casos enfatizando en las distintas formas en que los militantes buscaron traducir la línea sindical perretista en sus realidades concretas. 


\section{PRIMERA PARTE}

“Construir el partido en las fábricas. La política sindical perretista (1973-1976)" 


\section{CAPÍtulo 1}

Orígenes y definiciones fundamentales de la línea político sindical perretista (19651973)

\section{Introducción}

El presente capítulo tiene por objetivo reconstruir los orígenes y la evolución de las concepciones y definiciones que el PRT-ERP tuvo sobre la clase obrera, la actividad sindical y su papel en la estrategia revolucionaria, desde la ruptura que le dio vida en 1968 hasta el año 1973. Como señalamos, existen numerosos trabajos que se dedican al estudio de la organización, y en ellos se avanza, en mayor o menor medida, en la reconstrucción de sus orígenes. Sin embargo, la mayoría se dedican a rastrear los debates teóricos en torno a la lucha armada como estrategia o al tipo de organización política a construir, y no profundizan sobre la evolución de las definiciones que investigamos en este capítulo.

Entendemos que el estudio de la etapa formativa de la organización, en especial de los años inmediatamente previos y posteriores a la ruptura de 1968, es fundamental para entender tanto la línea sindical perretista, como los rasgos y el sentido que asumió la práctica militante al interior de las fábricas durante el período abordado. Sobre todo si partimos del hecho de que el tipo de intervención en el movimiento obrero y, en especial, las características que debía tomar el trabajo político-sindical, estuvieron en el centro del debate.

En ese sentido hacemos un sucinto resumen del derrotero del PRT, desde su fundación hasta 1968, para concentrarnos en la ruptura, ya que ubicamos allí el momento en el que se forman los pilares sobre los que, posteriormente, se forjó la concepción políticosindical del PRT-ERP. En ese sentido haremos hincapié en la manera en que la nueva organización reelaboró las nociones de sujeto revolucionario y "vanguardia” obrera bajo la nueva estrategia adoptada.

A partir de allí analizamos cómo se fue conformando una nueva concepción sobre la lucha sindical en base a los balances que la organización realizó de las principales luchas obreras: su posición ante el surgimiento de la CGT de los Argentinos, el balance que hizo sobre las gestas populares de mayo de 1969 (Rosariazo-Cordobazo-Rosariazo) y sobre su participación en la experiencia clasista de los sindicatos SITRAC-SITRAM. 
Asimismo indagamos sobre la forma en que la organización analizó la estrategia del Gran Acuerdo Nacional pergeñada por la dictadura militar y la manera en que se dispuso enfrentarla. Además, en ese marco, analizamos las polémicas que los perretistas sostuvieron con las organizaciones de la tendencia revolucionaria del peronismo ya que aquellas fueron interlocutoras directas del PRT-ERP tanto a nivel político como sindical.

Finalmente, presentamos brevemente algunos elementos que definieron el estilo de la intervención sindical del PRT-ERP, que se forjaron durante aquellos años pero que pervivieron a lo largo del período que aquí estudiamos. Específicamente prestamos atención a los métodos de que dispuso la organización para ingresar en las fábricas y la forma en que concibió la "inserción” y la "dirección política” al interior de las mismas.

\subsection{Debates de origen que dejaron huella}

El 25 de mayo de 1965 se fundó, en el barrio de Once de la Capital Federal, el Partido Revolucionario de los Trabajadores (PRT). El mismo era el resultado de la fusión de dos organizaciones que provenían de tradiciones políticas muy diferentes: Palabra Obrera (PO) y el Frente Revolucionario Indoamericanista Popular (FRIP).

PO era una organización de filiación trotskista. Fundada en 1959, fue el resultado del derrotero político de un núcleo de militantes dirigidos por Nahuel Moreno cuyo objetivo principal estaba puesto en penetrar en el movimiento obrero ${ }^{6}$. Para ello pusieron en el centro de su actividad a la lucha sindical, diseñando y practicando distintas tácticas para ingresar en las fábricas e influenciar a los trabajadores, entre las que se destacaron: la proletarización de sus militantes no obreros, la publicación de boletines sindicales, el apoyo logístico y económico a los obreros en huelga y el entrismo al interior de las 62 Organizaciones Peronistas (Gonzales, 1996; Coggiola, 2006; Pereyra, 2014; Mangiantini, 2016 y 2018).

Mientras tanto el FRIP, fundado en Santiago del Estero en 1961 por los hermanos Santucho, era una organización que, alejada del lenguaje del comunismo internacional, se definía como un "movimiento de campesinos, obreros, estudiantes e intelectuales"

\footnotetext{
${ }^{6}$ El grupo comenzó su trayectoria como Grupo Obrero Marxista (GOM), desde el cual, en 1944, impulsó el Grupo Sindical Marxista. En 1948, luego de que Moreno asistiera como delegado al II congreso de la IV Internacional, la organización se redefinió como Partido Obrero Revolucionario (POR). Seis años más tarde, la organización decide incorporarse al Partido Socialista de la Revolución Nacional (PSRN) y tan solo un año después, luego de romper con dicho partido, paso a denominarse Socialismo Revolucionario Trotskista. Desde éste último impulsaron el Movimiento de Agrupaciones Obreras (MAO) desde donde publicaron el periódico Palabra Obrera, nombre que pasó a identificar al grupo desde allí hasta la fundación del PRT. (Gonzales, 1996; Coggiola, 2006; Pereyra, 2014).
} 
del "pueblo del interior"7 . En sus lecturas aparecían el "dilema Buenos Aires-Interior", el antiimperialismo y el indoamericanismo como las claves para entender los problemas de la dominación, la opresión y la revolución a nivel local, nacional y regional. Además, se reconocían en la experiencia del APRA peruano de Víctor Haya de la Torre ${ }^{8}$ y manifestaban expresas simpatías por la Revolución Cubana (Pozzi, 2004; Seoane, 2009;

Carnovale, 2011; Volonté, 2016)

La confluencia entre ambas corrientes se forjó en la militancia común en los ingenios azucareros de Tucumán e hizo pie en cuatro consensos básicos: la búsqueda por construir un partido; la importancia asignada al trabajo político entre los obreros; la adhesión a la lucha armada como vía necesaria para la toma del poder; y la oposición frontal a los comunistas vernáculos 9 .

Sin embargo, desde los inicios de esta confluencia y durante todo el período en que el PRT se mantuvo unificado, se desarrollaron distintas polémicas que fueron delineando las fracciones que protagonizaron la ruptura de 1968. Aquí identificamos cuatro que, a nuestro juicio, resultan centrales ya que estuvieron en los cimientos de la línea políticosindical del PRT-ERP: 1- el debate en torno al entrismo; 2- la consigna "CGT partido político de la clase obrera"; 3- las condiciones para iniciar la lucha armada ligada al movimiento obrero; y 4- el papel de los organismos de participación obrera ${ }^{10}$.

Las dos primeras se dieron en momentos distintos pero compartieron, en el fondo, una misma matriz: la discusión sobre la independencia política del partido revolucionario en relación a los organismos gremiales de la clase obrera.

El entrismo fue una táctica sostenida por PO, que consistía en la penetración de militantes trotskistas en las organizaciones sindicales peronistas, con el objetivo de traccionar a los obreros a posiciones de izquierda. Para ello, se presentaban como peronistas revolucionarios ante los trabajadores buscando acercarles ideas revolucionarias. El rechazo a esta táctica vino de parte de la militancia del FRIP, la cual planteaba que un partido revolucionario debía estar basado en el principio de la

\footnotetext{
7"Algo sobre el FRIP”, Boletín Mensual del FRIP, Nro. 1, octubre 1961

${ }^{8}$ La Alianza Popular Revolucionaria Americana es un movimiento político fundado en Perú hacia 1924 por Víctor Haya de la Torre. El origen de esta organización está relacionado a la Reforma Universitaria de 1918 iniciado en la provincia argentina de Córdoba. Dicho acontecimiento, que estremeció al conjunto de los estudiantes e intelectuales latinoamericanos, inspiró a un sector del movimiento estudiantil que se propusieron superar los márgenes universitarios y fundar un "frente único de trabajadores manuales e intelectuales" (Sessa, 2011). Las bases originales del APRA estaban atravesadas por un programa antiimperialista con fuerte contenido panamericano a través del cual se fomentaba la solidaridad internacional y el nacionalismo económico como principios fundamentales.

${ }_{9}^{9}$ Para un análisis más exhaustivo de las mismas ver Anexo 1

${ }^{10}$ Para un análisis más exhaustivo de las mismas ver Anexo 2
} 
independencia política y en la afirmación de su identidad, por lo que se oponían a camuflarse como peronistas para conectar con el movimiento obrero ${ }^{11}$ (Carnovale, 2011: 57-58).

En cuanto a la consigna "CGT partido político de la clase obrera" fue una política defendida por Nahuel Moreno en el I y II congreso del PRT, de 1965 y 1966 respectivamente. Aquella resultaba del diagnóstico de que el peronismo estaba viviendo una crisis terminal y que con ello la clase obrera estaba perdiendo la unidad a la hora de expresarse electoral y políticamente. El problema entonces era que se abría un vacío político que podía llevar a la dispersión general de los trabajadores si no era llenado por un nuevo partido de masas. En ese sentido el dirigente trotskista postulaba que la CGT era la única organización que podía cumplir ese papel y que por ello debía transformarse en partido político. ${ }^{12}$ Mario Roberto Santucho fue el principal detractor de esta propuesta ya que, según aquel, significaba "capitular al sindicalismo"13. Para el dirigente santiagueño debía ser el partido revolucionario quien llenara el vacío político y no la central sindical. En esta posición, como dijimos, subyacían las mismas críticas que el FRIP había sostenido contra el entrismo: el problema de "esconder" al partido revolucionario detrás de organizaciones de masas reformistas que no aportaban a una política independiente de la clase obrera ni al avance de su conciencia política.

Por otra parte, la tercera y cuarta polémica también pueden ser entendidas a través de un denominador común: la discusión sobre el papel de la lucha armada y su vínculo con el movimiento obrero.

La primera de las querellas germinó en la previa al golpe de estado de 1966 y se radicalizó con la consumación de este último. Básicamente comenzó con la caracterización de Santucho y la militancia tucumana de que, en aquella provincia, se estaba viviendo una situación prerrevolucionaria motivada por la lucha de los obreros azucareros, que planteaba la necesidad de comenzar con la actividad guerrillera en la

\footnotetext{
${ }^{11}$ Es destacar aquel desacuerdo no impidió la confluencia, ya que PO había comenzado a abandonar dicha táctica en el momento en que comenzaban los acuerdos con el FRIP. Sin embargo, su importancia reside en el hecho de que, en la ruptura, será tomado por el PRT-ERP como uno de los contrapuntos centrales sobre los cuales contorneó su nueva concepción político-sindical. En una reunión del Comité Central de PO fechada en noviembre de 1964, se informaba que la única diferencia que se podía vislumbrar con la militancia del FRIP era relativa a la interpretación del trotskismo (“Acta reunión día 17/11/64", Palabra Obrera, AA.3164, Fundación Pluma)

${ }^{12}$ Además argumentaba que con ello se resolvía el problema histórico de la dirección burguesa del peronismo, ya que ahora sería la central obrera la que estaría a la cabeza de dicho movimiento ("Documento Nacional", número 2, mayo de 1965, I Congreso del Partido Unificado FRIP-PO, 11-2. Fundación Pluma.)

13 “Actas del primer Congreso del Partido Revolucionario de los Trabajadores", AA 1.65, Fundación Pluma.
} 
zona. Ante la instauración del gobierno militar, se aceleró el proceso de diferenciación al interior de la organización: Moreno, que había rechazado la caracterización de Santucho, insistía en que para evitar la derrota total de la clase obrera debía emprenderse una lucha más defensiva basada en métodos de piquetes y huelgas prolongadas fuera de fábrica ${ }^{14}$. Mientras tanto, en la militancia tucumana comenzó a prevalecer la orientación de organizar organismos de autodefensa armada para enfrentar la represión (Weiz, 2006: 51). A partir de allí el sector liderado por Santucho comenzó a plantear, con mayor insistencia, la necesidad de iniciar la lucha armada.

Por último, la cuarta polémica tuvo como centro del debate el rol que debían jugar los organismos de base de las fábricas, centralmente los Cuerpos de Delegados (CD), las Comisiones Internas de Reclamo (CIR) y los comité de resistencia fabriles. En esa oportunidad quienes protagonizaron la polémica fueron Moreno y Candela ${ }^{15}$. La discusión se vinculaba directamente con el debate anterior ya que, si bien versaba sobre qué hacer con los organismos sindicales tradicionales, allí se ponía en juego el papel y la importancia que cada sector le empezaba a asignar a la actividad armada en general y en el movimiento obrero en particular. En resumidas cuentas, para Moreno la única posibilidad de luchar por la "recuperación del movimiento sindical" y de resistir a la ofensiva del gobierno militar era a través de los organismos tradicionales, principalmente las CIR y los $\mathrm{CD}^{16}$; mientras que para Candela, el dominio que tenía la "burocracia sindical" sobre aquellos organismos los volvía muy difícil de recuperar inmediatamente, por lo que proponía la formación de grupos de resistencia que actuaran clandestinamente y que, mediante métodos de lucha armada, respondieran a los golpes de la patronal y se trasformaran paulatinamente en la dirección de facto de las fábricas ${ }^{17}$.

Como se deja ver, detrás de todas estas polémicas subyacían debates políticoconceptuales de fondo que se fueron acumulando al punto de forjar dos polos irreconciliables $^{18}$. Lo que estaba en juego allí era la forma de entender las mediaciones entre el partido y la clase obrera, el estatus de la lucha sindical y el vínculo entre violencia y lucha de clases.

\footnotetext{
14“"La lucha recién comienza”, Nahuel Moreno, septiembre de 1966, 1.11, Fundación Pluma.

${ }^{15}$ Seudónimo del dirigente Helios Prieto quien hacia el IV Congreso formó parte de la fracción liderada por Santucho

16 “Documentos Internos” III Congreso del PRT, 1967, 2-1, Fundación Pluma.

17 Ídem.

${ }^{18}$ Es de destacar que no en todas las polémicas se alinearon de igual manera los actores que constituyeron las fracciones que rompieron en 1968. No obstante sí puede encontrarse dos polos definidos en torno a las figuras de Moreno y Santucho.
} 
Entendemos que aquellas polémicas devinieron en huellas de origen de la fracción liderada por Santucho, que pervivieron e influyeron en y sobre sus concepciones a lo largo de toda su historia. Como veremos, en la interpretación fundacional del nuevo grupo, estas controversias aparecen como elementos forjadores de una nueva noción de vanguardia, y como justificadoras del nuevo lugar que pasaba a ocupar la lucha sindical en el nuevo marco estratégico.

\subsection{La ruptura como cimiento de la línea sindical perretista.}

La constitución de dos fracciones bien definidas se transformó en un hecho durante el año 1967. Efectivamente iniciar o no la lucha armada fue el eje principal de la disputa. Alrededor del mismo se alinearon por un lado Moreno y sus seguidores, que reunían a 9 miembros del Comité Central, y por el otro las regionales norte y litoral encabezadas por Santucho y Luis Pujals en alianza con un sector del aparato partidario dirigido por Oscar Demetrio Prada (“Sergio Domecq"), Félix Helio Prieto (“Candela”) y Alejandro Dabat ("Bernardo"), que contaban con 16 miembros en el órgano directivo.

Es necesario destacar que el debate sobre la lucha armada se desarrolló en el marco de la adhesión del PRT a la Organización Latinoamericana de Solidaridad (OLAS), organismo impulsado en agosto de 1967 por la Revolución Cubana para la expansión de la revolución a nivel continental ${ }^{19}$. En esos momentos, Moreno no se mostraba como detractor de la lucha armada; por el contrario, la consideraba como un "arma decisiva para desequilibrar el orden burgués e imperialista" ${ }^{20}$. La diferencia clave estaba en cómo, en qué momento y en qué lugar implementarla.

Según Moreno, en Argentina no estaban dadas ningunas de las condiciones básicas de una situación pre-revolucionaria ${ }^{21}$ Por tal motivo, la tarea señalada como urgente era la defensa de la organización sindical (especialmente de las CIR y CD). Es de destacar que en esta nueva coyuntura Moreno aceptaba la formación de comités de resistencia

\footnotetext{
${ }^{19}$ Hay que tener en cuenta que el PRT desde su fundación adhirió a la IV Internacional trotskista que, para aquel entonces, estaba bajo el mando de la tendencia dirigida por el belga Ernest Mandel quien había apoyado a la Revolución Cubana desde sus comienzos, respaldaba los debates del Che Guevara con la URSS y afirmaba la estrategia armada para América Latina. Debido a ello luego de la ruptura de 1968, el PRT-El Combatiente será la fracción reconocida por aquella internacional como sección oficial en Argentina.

20"La Revolución Latinoamericana, Argentina y nuestras tareas" [Firmado por Nahuel Moreno], IV Congreso Nacional del PRT, 1968, AA 1.68, Fundación Pluma [Documento interno del PRT, noviembre de 1967]

${ }^{21}$ Las condiciones básicas de una situación prerrevolucionaria eran definidas como: la existencia de una crisis de la burguesía, la izquierdización masiva de la pequeña burguesía y la disposición para disputar el poder de sectores importantes del movimiento obrero.
} 
clandestinos aunque como organismos de apoyo a las organizaciones sindicales y, respecto a la lucha armada, contemplaba como posibilidad la formación de un equipo técnico en Tucumán que sirviera de soporte circunstancial a la guerrilla boliviana ${ }^{22}$.

Por su parte Santucho insistía en que sí estaban dadas las condiciones para iniciar la lucha armada. Según el líder santiagueño, debajo de la aparente y relativa estabilidad, comenzaban a engendrarse nuevos enfrentamientos. Éstos debían ser impulsados y motorizados por la acción de un partido que dinamizara la lucha de las masas e incidiera en su desarrollo (Seoane, 2009; Carnovale, 2011). Desde su visión, el "reflujo político" solo podía ser superado a partir del inicio de la guerra revolucionaria. Santucho planteaba una idea de "vanguardia" que abrevaba directamente de la concepción guevarista: el partido no debía moverse "detrás de las masas" ni esperar que las masas se movilicen para comenzar a actuar, sino que debía ir delante de las mismas, marcando el camino.

Durante meses la lucha fraccional fue muy dura y se materializó en el Comité Central de enero de 1968, reunión de la que Santucho salió victorioso, por obtener el apoyo de Prieto y Prada. Finalmente la ruptura se dio con motivo de la realización del IV Congreso convocado para febrero, en el que ninguna de las fracciones se puso de acuerdo en cómo contabilizar los militantes de las regionales y ambas se adjudicaron la mayoría $^{23}$. De este modo, cada una realizó su propio IV Congreso, naciendo con ello dos organizaciones diferenciadas: el PRT-El Combatiente (PRT-EC), dirigido por Santucho, y el PRT-La Verdad, dirigido por Moreno, que años después pasó a llamarse Partido Socialista de los Trabajadores (PST) ${ }^{24}$.

Durante los días 25 y 26 de febrero de 1968, en una iglesia del barrio porteño de La Boca, 50 militantes encabezados por Santucho, Prieto y Prada, realizaron el congreso. En él se eligió la dirección y se debatió y aprobó un extenso documento escrito por esos mismos dirigentes que luego fue editado bajo el título El único camino hasta el poder

\footnotetext{
${ }^{22}$ La propuesta de Moreno contemplaba la construcción de "un aparato técnico rígidamente disciplinado a la OLAS para las tareas técnicas que la OLAS ordene", entendiendo que todos los esfuerzos armados debían concentrarse en la solidaridad con el proceso abierto en Bolivia, donde sí estaba bien planteada la estrategia guerrillera

${ }^{23}$ Ernesto Gonzales (1999) insiste en que Moreno tenía una mayoría de 31 a 23 congresales, y que dicho numero terminó siendo fraguado por la otra fracción, mientras que la mayoría de los militantes e historiadores del PRT-ERP insisten que Moreno quedó en clara minoría y fue quien decidió desconocer los órganos partidarios y romper la organización.

${ }^{24}$ En 1972 el PRT-LV se fusionó con una pequeña corriente del Partido Socialista Argentino conocida como Secretaría Coral, en alusión al dirigente socialista Juan Carlos Coral quien dirigía dicha fracción., dándole vida al Partido Socialista de los Trabajadores. Para el estudio de los derroteros de estas organizaciones ver Mangiantini, 2018.
} 
obrero y el socialismo, llamado coloquialmente por sus militantes como el "librito rojo" ${ }^{, 25}$. El documento giraba en torno "al problema del poder y la lucha armada" y buscaba sentar las bases para una estrategia revolucionaria que, para los autores, ni el PRT ni el resto de la izquierda argentina tenían.

En términos generales, "el librito rojo" caracterizó la etapa de la revolución mundial, latinoamericana y argentina como "final en la lucha contra el imperialismo"; definió que la revolución en Argentina tenía un carácter "obrero y popular, socialista y antiimperialista" y que era, a la vez, un momento táctico de la revolución continental; planteó la estrategia de la guerra popular y prolongada como vía para la toma del poder $\mathrm{y}$, en ese sentido, el inicio de la lucha armada y la construcción de un ejército revolucionario con base en el campo, como tareas inmediatas a emprender ${ }^{26}$.

En términos particulares y en referencia a la concepción sindical perretista, el documento fundacional ofrece pistas analíticas que deben examinarse: el lugar de la lucha sindical en la estrategia revolucionaria, la concepción de "vanguardia" y la línea de acción sindical, fueron forjando los pilares desde los cuales la organización construyó su "línea" sindical. Como advertencia diremos que, desde nuestro punto de vista, el documento está atravesado por un espíritu "antisindical” que pudo haber estado motivado por las recientes polémicas con Moreno. En efecto, algunas definiciones de este período (como la de calificar al trabajo sindical como actividad inferior y secundaria), fueron matizadas en documentos posteriores y contradichas en la práctica de la militancia fabril perretista.

El manuscrito giró en torno a la crítica de la estrategia insurreccionalista de poder sostenida por la organización hasta ese congreso y al supuesto "economismo" y "oportunismo" que, afirmaban, había caracterizado a la línea partidaria. Si bien los autores inician el planteo en tono de "autocrítica", Nahuel Moreno aparece como el principal y único responsable de tales "errores". De este modo, el morenísimo se presentaba como la corriente que reunía todos los atributos y "desviaciones" de las que el partido debía deshacerse. En la versión de Santucho, Prada y Prieto, eso se veía

\footnotetext{
${ }^{25}$ La apuesta teórica principal del documento consiste en la "síntesis" a través del castrismo de los aportes de distintos autores como Lenin, Trostky y Mao Tse Tung. Lo interesante es que dicha "síntesis" se hacía en nombre de un "retorno pleno al leninismo", de modo que el castrismo/guevarismo aparecía como "creación heroica" en el sentido mariateguiano, al mismo tiempo que como una muestra acabada de "marxismo ortodoxo" en el sentido lukacseano, es decir como continuación, ampliación y profundización del marxismo revolucionario en el sentido de sus fundadores. Creemos que en este "sincretismo", que para algunos autores resulta forzado, se encuentra el ardid creativo que configura el quiebre con la izquierda tradicional y que ubica al PRT-ERP en el campo de la nueva izquierda.

26“El único camino hasta el poder obrero y el socialismo” En: De Santis, 2004:141-233
} 
reflejado en las posiciones oscilantes que había asumido la organización, al pasar de una reivindicación cerrada y "abstracta" de la lucha armada, a su rechazo en post de una concepción insurreccionalista que centraba sus esfuerzos en la lucha sindical.

A la vez, el "economismo" aparecía vinculado a un supuesto "desprecio" hacia la actividad política y una sobreestimación de la lucha sindical, que traía aparejada la confusión entre las tareas partidarias y gremiales y una subestimación del papel concientizador que el leninismo le había asignado al partido.

Según los dirigentes del PRT-EC, el morenismo dejaba en segundo plano las acciones de propaganda y la agitación partidaria ${ }^{27}$, y por ende un elemento que realzaban clave: la "educación" de la clase obrera en las ideas del socialismo y la revolución. En cambio, alentaba a caracterizaciones "falsas", como la idea de que las CIR y CD eran la vanguardia natural de la clase obrera y que un triunfo en ese plano era un paso firme en el camino de la revolución. Además se apuntaba que esa "absolutización" de la lucha sindical había llevado a los militantes a jugarse "el todo por el todo" en cada conflicto gremial creyendo que allí se dirimía el futuro de la revolución:

'No es extraño, si creemos 'que el triunfo de una interna' puede provocar el reanimamiento 'de toda la clase' y ese reanimamiento llevar a la huelga general insurreccional que derrocará al gobierno en cuatro días, si teníamos en mente esa caricatura sindicalista del marxismo, que nuestros cuadros quisieran convertir a cada fábrica, a cada conflicto, en un pequeño Vietnam, apareciendo como marcianos ante los obreros y convirtiéndose frecuentemente en los 'mariscales de la derrota' del movimiento obrero (...) lo que determina que, lugar donde nuestro Partido dirigió un conflicto en los últimos años, sea el lugar donde los activistas siguieron el camino del despido" ${ }^{28}$.

A lo largo del documento se insiste en esta crítica así como en la idea de que la lucha sindical debía ser entendía como un aspecto "inferior" y subordinado a la lucha política. De este modo, para los autores, la lucha económica tenía que cambiar de significado: pasar de ser un fin en sí mismo a ser considerada como un medio desde el cual ligarse a la mayoría de los trabajadores para "hacerlos avanzar" hacia la lucha política.

Coincidimos con Scopetta y Torres (2014) en que estas afirmaciones no dejaban demasiado margen teórico a la posibilidad de que las luchas sindicales se transformasen en una forma cotidiana de construcción de poder, ya que a priori eran consideradas como "pre-políticas". Como consecuencia se corría el riesgo de que todo trabajo o

\footnotetext{
${ }^{27}$ El PRT-EC definía con Lenin: "agitación" como el arte de explicar una cantidad reducida de ideas políticas a un grupo numeroso de personas, al contrario de la "propaganda" que sería el arte de explicar una gran cantidad de ideas políticas a un número reducido de personas.

28،"El único camino hasta el poder obrero y el socialismo” En: De Santis, 2004: 180-181
} 
actividad sindical que no redundase en una acumulación directa para el partido fuera calificada de "economicista".

El escrito se distanciaba de la idea de vanguardia obrera que venía sosteniendo el partido hasta ese momento: específicamente criticaba el término de vanguardia sindical acuñado por la organización, considerándolo como un subproducto de las concepciones "sindicalistas". Hasta el momento el PRT había utilizado dos acepciones diferenciadas de vanguardia: una para nominar a aquellos trabajadores que estaban al frente de las reivindicaciones sindicales (vanguardia sindical) y otra para aquellos que se planteaban el problema político del poder (vanguardia política). Según los autores del "librito rojo", aquella distinción era una artimaña política para orientar el trabajo del partido casi exclusivamente a las actividades sindicales:
"Así, durante años, nuestros cuadros y militantes consideraron que la vanguardia en una fábrica o un gremio estaba constituida por los activistas sindicales que se planteaban luchar por reivindicaciones mínimas o contra la burocracia (aunque a veces ni se exigía ese requisito), con prescindencia de su conciencia política. Un obrero podía ser gorila, vandorista, anticomunista furibundo, estar a favor de los yanquis en Vietnam, pero si era capaz de movilizar una sección para exigir papel higiénico en el baño, ese era un obrero de vanguardia" 29

En contraste con ello se planteaba la necesidad de "retomar el sentido marxista de la expresión vanguardia" ${ }^{30}$, lo que en su interpretación refería a aquellos obreros conscientes de la necesidad de luchar políticamente para derrocar al gobierno de la burguesía, aun cuando los mismos no vieran la importancia de las luchas sindicales. En esos últimos casos, a lo sumo, debía inculcárseles la necesidad de prestar atención a todas las formas de lucha. En contraste, los activistas sindicales no eran necesariamente considerados de vanguardia: "A los activistas sindicales que aún no se ha elevado a una concepción política de la lucha de clases, deberemos acompañarlos en sus luchas económicas, pero siendo bien conscientes de que no son obreros de vanguardia, sin hacer la menor concesión a sus concepciones reformistas"31.

Por otro lado, el documento continuaba definiendo a la clase obrera industrial como la clase más revolucionaria del país y al proletariado fabril, especialmente el de las ramas y fábricas más concentradas (metalúrgicas, carne, textil, azucarera y automotrices), como el lugar fundamental de trabajo. En ese marco planteaba dos criterios clave para priorizar la inserción en el movimiento obrero: los niveles de explotación obrera (debía

\footnotetext{
${ }^{29}$ Ibídem, p. 218

${ }^{30}$ Ídem.

${ }^{31}$ Ídem.
} 
priorizarse a los sectores obreros más explotados) y los niveles de conciencia (debía volcarse las fuerzas allí donde surgieran "elementos" de vanguardia). Además, destacaba como región fundamental al noroeste y en ella al proletariado rural y el campesinado pobre como sujetos principales ${ }^{32}$.

En el marco de esas definiciones planteaba como objetivo central "penetrar en profundidad en la clase obrera", que según su propia explicación suponía "formar equipos político partidarios en las fábricas, hacer que esos equipos sean reconocidos como real dirección política y económica en su sector de trabajo "33. Esto se lograría con la actividad política, sindical y militar, aunque fundamentalmente haciendo eje en la primera y la tercera.

No obstante, el documento le brinda un espacio considerable a las definiciones de la línea sindical. Aún hechas todas las advertencias sobre sus límites, se llamaba a no subestimar las "consignas mínimas" y prestarle atención a "los mínimos problemas fabriles y a las múltiples consignas que estos imponen". En ese sentido se planteaba: la defensa y reorganización de las comisiones internas, defensa y recuperación de sindicatos, la organización de oposiciones clasistas a la "burocracia sindical", organización de comisiones de resistencia y destacamentos armados y comités de base del OLAS. Allí el dato distintivo era la insistencia en la organización de las comisiones de resistencia fabriles y destacamentos armados, consignas que, como vimos, habían sido debatidas en el III Congreso partidario y posteriormente desestimadas por el Comité Central. Éstas eran presentadas como consignas organizativas de transición de lo sindical a lo político, como "un escalón intermedio entre las organizaciones sindicales de la clase obrera y la forma más elevada de la misma: el Partido Revolucionario" 34 . El objetivo era incorporar a la lucha sindical métodos clandestinos y armados para elevar los niveles de confrontación contra la patronal y la dictadura. Se buscaba ayudar a la clase obrera a "superar el pasado reformista", fogueándola en la violencia revolucionaria y captar a los trabajadores más "entusiastas" y "conscientes" para la política del partido. Como veremos esta será una consigna que durante el

\footnotetext{
${ }^{32}$ Esta caracterización se remontaba a los análisis que había hecho el FRIP en su documento "El Proletariado rural: detonante de la Revolución Argentina", donde afirmaba que el proletariado rural del noroeste argentino, específicamente el azucarero de Tucumán, jugaría un papel de "detonante" y de "vanguardia" del proceso revolucionario por sus niveles de concentración, politización y explotación, y por contar en aquellas zonas con una burocracia sindical y un aparato represivo del estado débiles en relación al resto del país. (Secretaría ideológica del FRIP. "El proletariado rural detonante de la revolución argentina. Tesis del FRIP”, Junio de 1964.)

33،"El único camino hasta el poder obrero y el socialismo" En: De Santis, 2004

${ }^{34}$ Ibídem, En: De Santis, 2004: 229
} 
período 1973-1976 se plasmó en la propuesta de la Tendencia Obrera Revolucionaria22 de Agosto, que estudiaremos en el cuarto capítulo.

Esta orientación estaba directamente relacionada con lo que la organización definía como una de las tareas fundamentales: "preparar e iniciar la lucha armada bajo la forma de lucha armada parcial ligada al movimiento obrero en todo el país (...)"35. La articulación entre la lucha armada y las luchas obreras, entonces, era un tema central en la estrategia perretista, ya que aparecía, junto a la agitación y la propaganda, como un elemento clave para transformar las luchas sindicales en "lucha de clases políticorevolucionaria", es decir, para dar el salto de lo reivindicativo a lo político. Si bien esa relación adquirirá contornos más definidos en la práctica concreta, ya en este documento quedaba planteada la idea de que la lucha político-militar era inseparable de la lucha de clases, y que si bien no debía depender del alza y la baja de las movilizaciones obreras, debía estar profundamente vinculado a ellas. Se partía de la idea de que el surgimiento de una dirección revolucionaria que iniciase la lucha armada reanimaría las luchas económicas de la clase obrera haciéndola salir del profundo retroceso en el que se encontraba. Bajo esa idea subyacía la concepción guevarista de la lucha armada como motor impulsor de la movilización, generador de la conciencia revolucionaria y de entusiasmo combativo (Guevara, 1965).

Es menester remarcar también que la confianza en los efectos que pudiera generar el inicio de las acciones militares estaba atravesada por el convencimiento, arrastrado desde antes de la ruptura, de que la clase obrera estaba viviendo un proceso de "revolución ideológica" caracterizado por la crisis del peronismo como identidad política, la "pérdida de confianza" en la burocracia sindical y una suerte de permeabilidad de las ideas socialistas y revolucionarias. Si por un lado esta idea lograba captar elementos de la realidad (que poco tiempo después se confirmaría con el surgimiento de la CGT de los Argentinos, el crecimiento de las corrientes clasistas y los estallidos semi-insurreccionales de 1969), por el otro, como veremos, era parte del optimismo crónico que registraban los análisis de la organización, derivada de la idea de que la clase obrera era portadora de un "inmanentismo revolucionario" (Pozzi, 2004; Scoppeta y Torres, 2014).

En síntesis, la línea sindical perretista se forjaba sobre una nueva definición: la lucha sindical era una tarea "inferior" subordinada a la lucha política y a la militar. Partiendo

\footnotetext{
${ }^{35}$ Ibídem, En: De Santis, 2004: 224
} 
de esa certeza los conflictos sindicales debían ser tomados como una oportunidad para ligarse a los sectores más "atrasados" de la clase obrera y desarrollar propaganda y agitación socialista, mas no podían ser considerados como "batallas decisivas" en las que el partido apostase todas sus fuerzas. Teniendo aquello en claro la intervención sindical de sus militantes debía organizarse en torno a la "recuperación" de los organismos sindicales, la organización de oposiciones clasistas y el desarrollo de comités de resistencia.

\subsection{Los fuegos del "Cordobazo": La CGT-A y los “Azos" en el balance perretista.}

En esta sección buscaremos averiguar en qué medida la línea sindical del PRT-EC se fue moldeando al compás de la praxis política y de los avatares de la lucha de clases de aquellos años que, en poco tiempo, estremecieron el escenario político argentino. Así, a tan solo un mes de realizado el IV Congreso, apareció en la cartografía sindical la CGT de los Argentinos (CGT-A), primera manifestación significativa de la crisis de la cúpula sindical peronista. La misma había nacido del Congreso Normalizador de la CGT “Amado Olmos" convocado entre los días 28 y 30 de marzo. Al poco tiempo la CGT-A se trasformó en un polo de oposición sindical y política, con un programa combativo de neto corte antidictatorial y antiimperialista, en el que confluyeron varios sectores en conflicto y militancias opositoras al gobierno militar (James, 1990; Schneider, 2005; Dawyd 2008; Bozza, 2009). Esas características la transformaron en un espacio de politización que, al decir de James Brennan, habilito una suerte de "reconciliación" entre la clase obrera y la izquierda y la clase obrera y el movimiento estudiantil (1996: 164).

Resulta interesante, entonces, analizar la forma en que la organización se posicionó ante la central para ver cómo fue ajustando su línea en función de los acontecimientos.

Tan sólo unos días antes del surgimiento de la nueva central, el 28 de marzo, el PRT-EC denunciaba a los participantes del Congreso Normalizador por dejar afuera a los gremios intervenidos e ilegalizados por la dictadura (como ferroviarios, químicos, portuarios, azucareros y telefónicos). A su vez hacía un llamado a los dirigentes, sindicatos y agrupaciones sindicales opositores a convocar a una reunión nacional al margen de los "colaboracionistas" para dotar al movimiento obrero de una "dirección 
combativa" que levantase un programa de reivindicaciones básicas ${ }^{36}$, que se organizase desde la clandestinidad y que se preparase para la lucha armada ${ }^{37}$.

Con este marco de definiciones, la ruptura de la CGT en dos centrales diferenciadas fue interpretada como una división entre los dirigentes y no como un reflejo de las diferencias e inquietudes de las bases obreras. En sus primeras caracterizaciones, el partido apuntó que los gremios y dirigentes que conformaban la CGT-A eran "burócratas" que se habían visto obligados a adoptar una posición opositora sólo para garantizar su supervivencia. Desde su punto de vista se trataba de una fracción de la "burocracia sindical" que no había encontrado sectores "progresistas" de la burguesía para negociar y que se había visto arrastrada a la oposición, por la "terquedad" de la dictadura $^{38}$. Estas definiciones tempranas eran similares a la que realizaba el PRT-LV, que caracterizaba a la división cegetista como resultado de las fracciones de una misma burocracia sindical (Mangiantini, 2018). Sin embargo y a pesar de aquello, el partido liderado por Santucho preveía que la nueva dirección sindical no iba a tener otra alternativa que la de enfrentar, de algún modo, al gobierno y que se iban a ver empujados a desarrollar un proceso de resistencia a nivel de bases que podía llegar a ser "altamente explosivo" y difícilmente controlable ${ }^{39}$. A su vez podía significar el surgimiento de un polo de atracción para las bases de los gremios "entreguistas" y de un terreno favorable para la acción de la izquierda. Por ello la ruptura era leída como un "hecho necesario y progresivo". Sin embargo, para que efectivamente eso sucediera los activistas y agrupaciones antipatronales y antiburocráticas debían intentar volcar sus gremios a la CGT-A, impulsar instancias de democracia obrera (asambleas de sección, fábrica y gremio) y dar comienzo a la organización de Comisiones de Resistencia ${ }^{40}$. Ese sería el único reaseguro para que la nueva CGT no terminara capitulando ante el gobierno. Durante el año 1968 las potencialidades de la nueva central se fueron

\footnotetext{
${ }^{36}$ Aumento salarial del 40\%; reincorporación de todos los despedidos, levantamiento de todas las intervenciones, derogación de la legislación represiva y el llamado a un congreso de bases de la CGT que elija una dirección antiimperialista y combativa.

37“Pacto CGT-Onganía: contra una CGT colaboracionista! Por una CGT combativa” El Combatiente Nro. 3, 22 de marzo de 1968

38“"Es una dirección que empieza por 'pedir disculpas' al régimen, antes de atreverse a levantar la voz. Es una dirección que se viste con el ropaje de la ideología de las clases explotadoras porque no ha llegado a la dirección representando el espíritu de lucha de la clase obrera, sino la política de colaboración de clases de los patrones 'progresistas', es -para su desgracia- una dirección que se hace opositora porque no ha encontrado patrones progresistas para negociar (...) es una dirección, en fin, para quien la oposición es un impuesto a las actividades lucrativas. Pero es una dirección obligada a reabrir las compuertas de la lucha de clases en el país" En: "Ideología para burócratas" El Combatiente Nro. 622 de abril de 1968.

39"“Congreso de la CGT; ¡Fracasó la entrega!” El Combatiente Nro. 4, 8 de abril de 1968; "Reorganizar al movimiento obrero y preparar la lucha" El Combatiente Nro. 5, 15 de abril de 1968.

${ }^{40}$ Ídem.
} 
confirmando $\mathrm{y}$, de a poco, la desconfianza inicial se fue transformando en reivindicación directa:

"La CGT-A ha cobrado el carácter inevitable que debía cobrar: más que la organización sindical de masas, ha asumido el papel de expresión política de los sectores más conscientes y combativos de la clase, levantando un programa de reivindicaciones clasistas, nacionales y antiimperialista, tras el que se nuclean y nuclearán crecientemente las auténticas agrupaciones gremiales antiburocráticas. Por la situación del régimen, éstas agrupaciones no podrán tener otro programa y otro método de lucha que el que los revolucionarios planteamos para enfrentar a la dictadura. En ese papel, la actual existencia de la CGT es una conquista política, y como tal debe ser defendida y garantizada por la acción permanente de las agrupaciones en el seno de la clase" ${ }^{, 41}$

Este cambio en la lectura perretista tenía distintos motivos: los niveles de definición que había asumido la central sindical, plasmados en la declaración del $1^{\circ}$ de mayo ${ }^{42}$; el papel movilizador que empezó a jugar en el movimiento obrero ${ }^{43}$; el rol de articuladororganizador de la oposición social a la dictadura (sobre todo durante el año 1969); y el protagonismo que comenzaron a tener las organizaciones de izquierda en su seno.

La nueva central obrera se transformó en un espacio aglutinador para los activistas y grupos del peronismo revolucionario quienes desplegaron, desde allí, su política de masas (Bozza, 2001, 2009). Finalmente, la CGT-A también hizo converger a agrupaciones políticas de distinta índole como el PC Comité de Recuperación Revolucionaria (ruptura del PCA que posteriormente pasará a conocerse como Partido Comunista Revolucionario -PCR-) ${ }^{44}$, el Partido Socialista de la Izquierda Nacional ${ }^{45}$, el Movimiento de Liberación Nacional ${ }^{46}$, entre otros.

\footnotetext{
41، 1968 un año de avance en la preparación de la guerra revolucionaria” El Combatiente Nro. 23, 31 de diciembre de 1968.

${ }^{42}$ El PRT-EC reivindicaba que la nueva central levantase "un programa para la clase esencialmente correcto, antiimperialista, que plantea el problema de la aplicación de la violencia y la salida independiente de la burguesía" ("Por qué somos parte de la CGT de los Argentinos" El Combatiente Nro. 34, 26 de agosto de 1969)

${ }^{43} \mathrm{~A}$ mediados de mayo de 1968 la CGT-A había publicado un documento titulado "Unirse desde abajo, Organizarse combatiendo", donde llama a la lucha frontal contra el gobierno y a la organización más allá de la legalidad de los sindicatos (Anzorena, 1998: 41)

${ }^{44}$ El PCR nació el 6 de enero de 1968 como fruto de una ruptura PCA. Aquella ruptura debe entenderse en el marco de los debates que generó la Revolución Cubana al interior de aquel partido. Ésta puso en tela de juicio algunos de los pilares fundamentales de la estrategia y concepción de los comunistas, principalmente el "etapismo" y la "vía pacífica" al socialismo. Así, a mediados de los sesentas un sector importante del partido, con base en su organización juvenil (Federación Juvenil Comunista -FJC-), comenzó una polémica con la dirección que los condujo a la ruptura en 1967. En sus primeros meses de vida, el PCR desarrolló un debate sobre la estrategia revolucionaria que lo llevó a descartar la vía guerrillera y volcarse a la vía insurreccional. En paralelo comenzó un acercamiento ideológico al maoísmo hasta que finalmente en 1974 oficializó su adhesión a dicha corriente. En ese marco caracterizó a la Unión Sovietica como una fuerza social imperialista, y desde allí interpretó la coyuntura argentina y latinoamericana bajo el prisma de la disputa interimperialista (Lissandrello, 2013; Califa, 2015; Rupar, 2016; Cisilino, 2016).
} 
Por su amplitud e independencia, la CGT-A era un modelo de central sindical que entusiasmaba al PRT-EC. De lo que se trataba era de luchar por estructurar una fuerte dirección revolucionaria que lograse superar las tendencias reformistas que habitaban en su seno:

"Nos reclamamos parte integrante de la CGT de los Argentinos, no porque ella sea una organización revolucionaria; no porque ella sea, con todas las garantías, la organización sindical independiente del Estado. Nos reclamamos parte de ella porque creemos que están dadas allí todas las posibilidades para construir esa verdadera organización sindical independiente. (...) No queremos que la CGT se convierta en el partido revolucionario -o en una sucursal del mismo-, porque le haríamos perder el carácter que realmente debe tener de organización de masas. Queremos que sea la central obrera que nuclee a los trabajadores que luchan contra la estatización, contra la dictadura y contra el imperialismo y que su dirección sea consciente que dentro de las estructuras burguesas no haya salida para los trabajadores" ${ }^{, 47}$

Aquí aparecía nuevamente la polémica con el morenismo, el cual consideraba que la CGT-A era una variante de "izquierda" de la burocracia sindical puesta al servicio de la oposición burguesa $^{48}$. Para el PRT-LV el apoyo de los santuchistas a la CGT-A aportaba a generar confianzas en una dirección traidora y reformista, mientras que para el PRT-EC ese planteo era una muestra más de la línea morenísta que llevaba a querer aplicar el "programa para la toma del poder" a las organizaciones de masas y, como consecuencia, a buscar organizaciones puras, bien definidas para poder trabajar sindicalmente ${ }^{49}$.

\footnotetext{
${ }^{45}$ El Partido Socialista de la Izquierda Nacional (PSIN) fue fundado en mayo de 1962 por Abelardo Ramos y Jorge Enea Spilimbergo. Aquella organización, expresión partidaria de la denominada "Izquierda Nacional", buscó la combinación del marxismo y el peronismo y, en ese plan, impugnaba a la izquierda tradicional por considerarla una "izquierda cipaya"("La izquierda nacional ya tiene su partido" Izquierda Nacional Nro.1).

Sin abandonar estas ideas, en 1971, aquella organización transformó en el Frente de Izquierda Popular (FIP) desde el cual apoyó las candidaturas del Frente Justicialista de Liberación (FREJULI) con listas propias en las dos elecciones de 1973.

${ }^{46}$ El MLN o "Malena" se fundó en el año 1961 en base a un grupo de activistas y militantes que venían de la experiencia editorial de la revista Contorno, con Ismael Viñas y Susana Fiorito como sus principales dirigentes. Decepcionados con el gobierno de Frondizi aquellos militantes forjaron el MLN bajo la idea de construir un nacionalismo popular y revolucionario. En ese objetivo, rechazaron la estrategia "etapista" del PCA y tejieron puentes entre socialismo y peronismo. A fines de 1969 la organización se disolvió formalmente y muchos de sus militantes pasaron a engrosar las filas de las organizaciones de la nueva izquierda. (Julieta Pacheco, 2013.)

47،"Por qué somos parte de la CGT de los Argentinos" El Combatiente Nro. 34, 26 de agosto de 1969

${ }^{48}$ Es de destacar que ambas organizaciones habían tenido una posición similar antes e inmediatamente después de la ruptura, ya que el PRT-LV había denunciado a todas las fracciones participantes del congreso, había reclamado un Congreso de las Bases de donde surgiera una dirección combativa con un programa reivindicativo contra la racionalización, los despidos y suspensiones, y había asumido una posición cautelosa ente el surgimiento de la CGT-A ya que si bien barajaban la posibilidad de que el quiebre burocrático posibilitase una salida favorable eso aún estaba por demostrarse (Gonzales, 1999: 262).

49،"Por qué somos parte de la CGT de los Argentinos" El Combatiente Nro. 34, 26 de agosto de 1969
} 
Estos debates dieron otro giro durante el año 1969. Las jornadas de mayo de ese año, conocidas como Rosariazo-Cordobazo-Rosariazo generaron la renuncia del ministro de economía Krieger Vasena y la fractura de la unidad militar. Como remarcara Juan Carlos Torre (1971), aquella insurrección fue un acontecimiento abierto que pario a una nueva oposición social que fue adquiriendo un perfil definido al calor de la movilización obrera que le sucedió. En ese sentido, las luchas proletarias posteriores a 1969 iban a constituir uno de los fenómenos más novedosos que dejaba por herencia el gobierno de la llamada "Revolución Argentina".

Aquellas jornadas pusieron a la orden del día las discusiones teóricas al interior de las organizaciones de la izquierda marxista y peronista. Como señala Brennan (1996) cada una de ellas leyó las manifestaciones bajo su propio marco conceptual e ideológico confirmando sus preceptos y desechando otros. Así, por ejemplo, para un sector de la izquierda marxista se había confirmado la eficacia de la huelga general revolucionaria y de la insurrección como el camino más seguro hacia el socialismo. Dentro de este grupo se encontraban las corrientes maoístas y trotskistas. En relación a los primeros, el PCR terminó volcando su opción por la vía insurreccional, calificando a la vía guerrillera como la opción de la "pequeña burguesía" y desprendiéndose de los sectores que adscribían a la vía militar (Lissandrello, 2013; Rupar, 2016; Cisilino, 2016). Por su parte, Vanguardia Comunista (VC) ${ }^{50}$ abandonó la línea de "guerra prolongada" protagonizada por el campesinado y adoptó el modelo insurreccional centrado en las luchas de la clase obrera industrial (Celentano, 2012, 2014; Sabaj, 2013). En el campo del trotskismo, el PRT-LV afirmó que se habría una nueva etapa prerrevolucionaria marcada por el paso a la ofensiva de la clase obrera y la intensificación de las disputas inter burguesas, y Política Obrera argüía el agotamiento final de las masas con el peronismo y polemizaba con el PRT-EC planteando que el principal límite del Cordobazo no había sido la ausencia del armamento obrero, sino el aislamiento del proletariado cordobés del resto del país (Mangiantini, 2018:15).

Por su parte, la izquierda peronista afirmó que los estallidos confirmaban la esencia revolucionaria del peronismo, el papel retardatario y traidor que jugaba la "burocracia sindical" al interior del movimiento y la posibilidad cierta que se abría para el retorno

\footnotetext{
${ }^{50}$ Vanguardia Comunista fue fundada oficialmente en 1965 por una confluencia de varias organizaciones entre las cuales el Partido Socialista Argentino de Vanguardia fue la más importante. Se trató de la primera organización reconocida por el Partido Comunista de China como representante del maoísmo en Argentina. Si bien en un primero momento adscribió a la estrategia de Guerra Popular y Prolongada, en 1968 "rectifico" su línea por considerarla "izquierdista y militarista" y terminó volcándose hacia la opción insurreccional basada en los centros urbanos (Celentano, 2012, 2014; Sabaj, 2013; Rupar 2017).
} 
del viejo líder (Brennan, 1996). Para las Fuerzas Armadas Peronistas (FAP), que venían actuando desde 1968, el Cordobazo ratificaba su línea de lucha armada, planteando la necesidad de incorporar a las luchas reivindicativas "métodos similares a los de la guerra revolucionaria" (Raimundo, 2004). En efecto, tras los fuegos del cordobazo, importantes sectores del peronismo revolucionario confluyeron en su segundo congreso, reunido en Córdoba en Enero de 1969. Allí surgió por primera vez, el nombre de "Tendencia Revolucionaria del Peronismo" (TRP) para definir a aquellos actores que estaban a favor de la lucha armada como método para enfrentar a la dictadura y crear, al mismo tiempo, las condiciones de conciencia y organización del pueblo peronista (Tocho, 2015).

Las Fuerzas Armadas Revolucionarias (FAR) -organización guevarista que pronto iniciarían un proceso de peronización- interpretaron aquellos sucesos como la "máxima demostración" de la "necesidad histórica" de la construcción de un ejército del pueblo y como un "mandato popular e impostergable" que legitimaba la opción de las armas (Gonzales Canosa, 2012).

Por su parte para la izquierda guevarista, entre la que se encontraban las Fuerzas de Armadas de Liberación $(\mathrm{FAL})^{51}$ y el PRT-EC, aquello también era la demostración práctica de que todo intento insurreccional de las masas fracasaría sin la existencia de un ejército revolucionario que pudiera enfrentarse al poder de los aparatos represivos del Estado ${ }^{52}$.

En los balances del PRT-EC, el Cordobazo debía servir como lección política tanto contra las "ilusiones insurreccionalistas" como contra el "escapismo" que, en nombre de la lucha armada, ignoraba o subestimaba las movilizaciones de masas planteando la construcción del ejército revolucionario como algo independiente y separado de las $\operatorname{mismas}^{5354}$. Por otro lado, la capacidad y el potencial que había mostrado la clase obrera

\footnotetext{
${ }^{51}$ Las Fuerzas Argentinas de Liberación o Fuerzas Armadas de Liberación (FAL) fue una organización político-militar que remonta sus orígenes a principio de la década de 1960. La "célula madre" fue un desprendimiento del "Grupo Praxis" de Silvio Frondizi. A partir de 1973 se conformó como un frente que reunía bajo la misma sigla a grupos de tendencia guevarista como a otros de mayor apertura al peronismo radicalizado. Así surgieron diferentes columnas armadas que llevaban su propia denominación: FAL-Che Guevara, FAL-22 de Agosto, FAL-América en Armas, FAL-Inti Peredo, FAL-Brigada Masetti. Como tal se terminó disolviendo en 1975 y algunas de sus columnas se incorporaron a diferentes organizaciones, como por ejemplo la columna Che Guevara que se unirá al PRT-ERP o las FAL América en Armas a la Organización Comunista Poder Obrero (Grenat, 2004; Hendler 2010)

52“"Por qué se derrumba el gobierno de Onganía” El Combatiente Nro. 31, 9 de julio de 1969

53، ¡Resistencia activa a la dictadura de los monopolios!” El Combatiente Nro. 30, 11 de junio de 1969.

${ }^{54}$ Estimamos que esta última crítica estaba dirigida a las FAL, debido a que las mismas se conformaron como un grupo militar hermético con escaso trabajo político entre los trabajadores. Como indica Stella Grenat: "La renuncia al trabajo político con las masas concuerda con su programa: ellos no buscaban
} 
para dirigir al resto de los sectores de la sociedad, para actuar por fuera de los esquemas corporativistas del peronismo e incorporar la violencia como método de lucha era, para el PRT-EC, una evidencia inconfundible de aquel proceso de "revolución ideológica" que, según sus análisis del IV Congreso, vivían los trabajadores:

"El aparente letargo en que durante tantos años pareció sumida nuestra clase obrera, no fue otra cosa que la cortina de humo que ocultaba el lento proceso de revolución ideológica que inexorablemente se desarrollaba en el seno de gruesos sectores de activistas, y por fin la bancarrota irreversible en el que cayó la burocracia negociadora, entreguista y traidora fue el punto de partida de una nueva etapa de la lucha de clases con la cual la molotov y las agrupaciones clasistas, el repudio a la patronal y al régimen y la violencia y la organización por abajo, está a la orden del día." ${ }^{, 55}$

La política de la organización en los meses posteriores, ante la intervención de la CGTA y el encarcelamiento de sus principales dirigentes, giró en torno a la propuesta de reorganizar la central en la clandestinidad incorporando a las agrupaciones de base, a las agrupaciones estudiantiles y a los partidos políticos revolucionarios y organizar un "argentinazo" impulsando comandos armados y luchando contra los intentos de “estatización sindical".

Un año después, en 1970, Santucho criticó tanto esta orientación como el hecho de que la organización se hubiera declarado parte de la CGT-A, depositado tanta expectativa en ella. La crítica no estaba dirigida a la caracterización general que se había realizado de dicha experiencia, sino al hecho de que el partido, como tal, formara parte de una central sindical, dándole un rol político preponderante. Para el dirigente santiagueño, allí se manifestaba una rémora del morenismo, que llevaba a subordinar la política al sindicalismo.

No es casual que esta suerte de rectificación o "autocrítica" se haya dado en el marco de la nueva ruptura que sufrió la organización en vísperas de su V Congreso. Nuevamente el "virus" morenísta, esta vez en su forma residual, aparecía como una amenaza al inicio de la lucha armada. Es que el Cordobazo había significado un nuevo punto de inflexión también al interior del PRT-EC, donde las conclusiones políticas no fueron homogéneas. Si bien todos compartían la caracterización de que se había abierto una

concientizar a la clase obrera, ni alejarlas de su ideología peronista, ellos se concentraban en el reclutamiento de individuos potencialmente eficaces en tareas de carácter militar." (Grenat, 2004)

55“CGT de los Argentinos. Reorganizarse en la clandestinidad” El Combatiente Nro. 32, 23 de julio de 1969.

56، Organicemos los comandos armados del pueblo" El Combatiente Nro. 31, 9 de julio de 1969; "CGT de los Argentinos..." op. cit., "Contra la estatización sindical. Sindicatos y agrupaciones clandestinas para enfrentar a la dictadura" El Combatiente Nro. 33, 6 de agosto de 1969; "Desde el plenario de Córdoba... Organizar el argentinazo" El Combatiente Nro. 37, 8 de octubre de 1969. 
nueva etapa signada por la incorporación masiva del pueblo a la oposición militante contra la dictadura, las diferencias residían en la orientación que debía dársele, en el nuevo contexto, a la lucha armada y a la forma que debía adquirir el vínculo con el movimiento obrero. La discusión principal versaba en si se había iniciado la guerra revolucionaria; las alternativas se dirimían entre la construcción del Ejército Revolucionario o acciones armadas de carácter defensivo basadas en la propaganda y el acompañamiento de la movilización obrera.

La lucha interna explotó en noviembre de 1969, como consecuencia de la muerte de un militante y la "caída" de otros siete militantes y cuatro simpatizantes, cuando se preparaba el inicio de la lucha armada en el norte, hecho que paso a denominarse como “desastre de Tucumán”. Para ese entonces ya se habían definido tres tendencias internas al interior del partido, dos de las cuales se enfrentaban con la decisión de Santucho de lanzarse a construir un ejército revolucionario ${ }^{57}$. En ese marco, este último, que había caído preso luego del "desastre de Tucumán", mandató a los miembros de su tendencia a convocar lo antes posible el V Congreso para resolver la disputa interna. Así, tan solo unos meses más tarde, los días 28, 29 y 30 de julio, el cónclave partidario se realizó en el Delta del Paraná, compuesto casi exclusivamente por los seguidores del santiagueño. El V Congreso fue contundente al respecto y cerró la disputa interna calificándola como una "lucha de clases en el seno del partido" en la que había triunfado el punto de vista "proletario". 58

En términos generales las definiciones del mismo giraron en torno al lanzamiento de la lucha armada y la creación del Ejército Revolucionario del Pueblo. El documento realizaba un balance y un análisis de cómo había evolucionado el planteo de la lucha armada al interior de la organización, intentando demostrar que no había sido fruto de la decisión voluntarista de un grupo de estudiantes o intelectuales, sino el resultado directo

\footnotetext{
${ }^{57}$ Las tendencias se dividían en: Tendencia Proletaria (minoritaria) encabezada por Sergio Domecq y Hugo Gonzales; la Tendencia Comunista, integrada por cuadros medios y de dirección como Daniel Pereyra, Alejandro Dabat, Eduardo Urretavizcaya y Helios Prieto; y la Tendencia Leninista dirigida por Mario Roberto Santucho, Domingo Menna y Luis Pujals. La primera de ellas, posteriormente calificada como la "derecha" por el V Congreso, era la que más diferencias sostenía con la línea de la lucha armada y decidió abandonar el partido antes de dar el debate. Por el contrario la Tendencia Comunista presento un documento titulado "Proyecto de resolución del C.C. de autocrítica y convocatoria al V Congreso" en el que planteaban, entre otras cosas, que de octubre de 1968 a octubre de 1969 la dirección había sufrido una desviación foquista impulsada por Santucho que había llevado al partido a quedar desarmado ante las movilizaciones de mayo, careciendo de un programa y de consignas que guiaran a las masas en la calle. Además se remarcaba que se había paralizado la penetración en la clase obrera y que se había relegado la acción militar independiente en las ciudades por concentrarse en la preparación de frentes guerrilleros rurales. ("Proyecto de resolución del C.C. de autocrítica y convocatoria al V Congreso" Disponible en: www.eltopoblindado.com)

58 "Resoluciones del V Congreso" En: De Santis, 2004
} 
de la experiencia de las masas y de la propia base obrera partidaria. Luego de varios años de "lucha pacífica, predominantemente sindical" habían experimentado en carne propia la necesidad de utilizar la violencia revolucionaria:

"El planteo de la lucha armada irrumpe en el PRT (...) surge de la experiencia directa de las masas obreras argentinas y es incorporada al Partido por su vanguardia, que ha recorrido previamente el camino de la lucha pacífica, que ha comenzado por las huelgas corrientes, por la participación en elecciones, que ha pasado a la ocupación de fábricas con rehenes, a las manifestaciones callejeras violentas, hasta que, cerradas todas las posibilidades legales con la asunción de Onganía, se orienta correctamente hacia la guerra revolucionaria" $\$$.

El planteo hacía pie en la lucha de los obreros azucareros durante 1967, experiencia que había contado con la participación del PRT y en la que, según lo relatado, los trabajadores habían planteado la necesidad de armarse para enfrentar la represión. Con la anécdota se intentaba demostrar que las condiciones objetivas para iniciar la lucha armada se reflejaban también en el avance de las condiciones subjetivas de un sector de los trabajadores, que la organización calificaba como la vanguardia revolucionaria $\operatorname{argentina}^{60}$.

En otro orden de cosas, se afirmaba que la actividad militar debía orientarse con un punto de vista de masas, impulsando tareas militares en todos los espacios de influencia: “quien no pelea no existe”. Ahora bien, ¿Cómo afectaba esa afirmación en la política del PRT-ERP dentro de las fábricas? ¿Cómo se conjugaba aquello con la línea sindical del partido? Algo ya se había deslizado en el IV Congreso, cuando afirmaron que para "penetrar en profundidad" en la clase obrera, debían desarrollar la actividad política, sindical y militar, haciendo eje, fundamentalmente, con la primera y la tercera. En el V Congreso, sin embargo, no avanzaron en precisiones respecto de la articulación entre lucha armada y trabajo sindical. En lo que respecta a este último, propusieron concentrarse en reivindicaciones urgentes como: 1- la caída del nivel de vida de los trabajadores; 2-, la lucha contra la superexplotación del trabajo impuestas por la racionalización productiva; 3- el intento de "estatizar el movimiento sindical" (la dictadura había intervenido la CGT Azopardo poniendo al frente a un delegado normalizador que respondía a sus intereses); y 4. la represión policial. Se definía la

\footnotetext{
59“"Resoluciones del V Congreso” En: De Santis, 2004: 292

${ }^{60}$ Para Pozzi (2001) y Carnovale (2011) se trata de una "anécdota notable" o a lo sumo el reflejo del estado de ánimo de los trabajadores de una zona, pero de ningún modo un argumento suficiente para justificar el inicio de la lucha armada. Sin embargo es preciso tener en cuenta que para los perretistas esto último no dependía de los factores subjetivos sino de la madurez de las condiciones objetivas que, según las conclusiones del IV Congreso, ya estaban dadas. Además, como dijimos, para la organización no se trataban de simples "trabajadores de una zona" sino del sector más avanzado de la clase obrera argentina.
} 
construcción de agrupaciones clasistas, sindicatos y comisiones de fábrica "lo más amplias y menos clandestinas posibles" como una "necesidad estratégica" para reforzar la influencia de la organización entre los sectores más "atrasados" de la clase obrera, y se planteaba el impulso de comisiones de resistencia clandestinas allí donde hubiera condiciones.

En ese sentido se afirmaba la necesidad de luchar por lograr la dirección del movimiento sindical antidictatorial, pero se aclaraba que dicha tarea debía estar estrechamente vinculada al desarrollo del partido en las fábricas y que no podía afectar la actividad política del mismo. Además resaltaban que si bien se debía pelear por la defensa de la legalidad de los sindicatos y por su recuperación, ese era un objetivo segundario para la etapa.

Bajo la consigna "todo el partido al combate" se cerraba el V Congreso, y con él todas las postergaciones que había sufrido el inicio de la lucha armada. Comenzaría así un período de intensa actividad militar en el marco de una agudización general de la lucha de clases que permitió a la organización duplicar la cantidad de militantes e insertarse en la clase obrera, especialmente en Córdoba (Pozzi, 2004: 25). Sin embargo el énfasis exclusivo en la lucha armada fue prefigurando un período que la propia organización calificó como de "desviación militarista" (1971-1972), en que la actividad militar tomó una centralidad casi unidimensional, frenando la inserción en el movimiento obrero e invirtiendo los términos de la ecuación perretista de que "la política guía al fusil". Esto intentó ser revertido durante el período que aquí estudiamos bajo la consigna "ir hacia las masas", orientación que, como veremos en los próximos capítulos, intento ser llevada adelante por la organización y sus militantes, no sin tensiones y contradicciones.

\subsection{EI Gran Acuerdo Nacional y la polémica con el peronismo revolucionario.}

1970 fue un año en el que reverberaron y resonaron los ecos del Cordobazo. El 29 de mayo, en el primer aniversario de aquella gesta (y dos meses antes del V Congreso), Montoneros se presentaba a sociedad con el secuestro del general Aramburu, figura emblemática del golpe "gorila" de 1955 y el ideólogo de una transición negociada con los dirigentes peronistas más "conciliadores" y con el resto de los partidos políticos (Lanusse, 2005; Gillespie, 2008). Tan solo diez días después, el 8 de junio, Onganía era relevado de su cargo y reemplazado por Roberto Marcelo Levingston, ex jefe del Servicio de Información del Ejército, quien se propuso prolongar el proyecto de la "Revolución Argentina". Sin embargo, la imposibilidad de frenar las protestas, el 
crecimiento de las organizaciones político-militares y la dificultad del gobierno de resolver la disputa al interior de la clase dominante entre la gran burguesía urbana y la burguesía pampeana derivo en la profundización de la crisis dictatorial (Portantiero, 1973; O’Donell, 1977).

El punto más álgido de esta crisis se dio en marzo de 1971, nuevamente en la ciudad de Córdoba, con los hechos conocidos como el "Segundo Cordobazo" o "Viborazo" 61. Con diferencias cualitativas respecto del Cordobazo, esta nueva insurrección tuvo un carácter menos espontáneo, contó con la presencia de las organizaciones de la nueva izquierda (con destacada participación del PRT-ERP) y tuvo rasgos más estrictamente proletarios (Brennan, 1996; Pozzi y Schneirder, 2000).

El resultado inmediato de aquella gesta se produjo a fines de marzo, cuando Levingston fue destituido y relevado por Alejandro Lanusse, Comandante en Jefe del Ejército. Este último asumió con el objetivo de buscar una salida política que le permitiera absorber el descontento generalizado. La base de su estrategia se resumió en la consigna "unir a los adversarios y aislar a los enemigos"; en base a ella, lanzó el Gran Acuerdo Nacional (GAN), política que proyectaba la reinserción del peronismo al sistema político con el objetivo de devolverle legitimidad a la acción estatal y encauzar la conflictividad en el marco de la democracia parlamentaria, frustrando la confluencia entre la izquierda social y la izquierda política (Tortti, 1999).

Perón aparecía como el único capaz de detener el proceso de radicalización política. Más allá de la disputa entre el viejo líder y la cúpula militar, estos coincidían en un diagnóstico común acerca de la naturaleza de la crisis en la sociedad argentina y compartían un mismo objetivo: la institucionalización de la lucha de clases y la represión de los sectores revolucionarios (De Riz, 2000).

Como vimos, el PRT-ERP caracterizaba que la clase obrera estaba viviendo una “intensa revolución ideológica”, encarnada sobre todo, en las nuevas generaciones que habían protagonizado los cordobazos, los rosariazos, y las demás gestas antidictatoriales y antiburocráticas. Sin embargo no dejaba de reconocer que existían extensos sectores de la clase obrera que seguían identificándose peronistas, y por ello evaluaban que, para la burguesía, el peronismo, y más específicamente Perón, podía transformarse en el último y más efectivo recurso para defender al sistema capitalista argentino ante la

\footnotetext{
${ }^{61}$ El nombre de "Viborazo" se debió a los dichos del entonces interventor de la provincia de Córdoba Camilo Uriburu quien declaró que en aquella provincia anidaba "una venenosa serpiente cuya cabeza pido a Dios me depare el honor histórico de cortar de un solo tajo".
} 
avanzada de las organizaciones revolucionarias ${ }^{62}$. De este modo, ya en 1971, PRT-ERP vaticinaba que el retorno del viejo líder sería la última de las cartas que tendrían las clases dominantes para frenar la lucha revolucionaria. El rol contrarrevolucionario que la organización preveía, iba a jugar Perón en su retorno, acrecentaba la necesidad de profundizar el debate con las corrientes que le otorgaban a este último el papel de líder revolucionario, despertando falsas esperanzas entre la vanguardia obrera: "Las organizaciones armadas peronistas participan en la guerra del pueblo planteando el retorno de Perón. Y Perón teje el Gran Acuerdo Nacional con Lanusse, instrumento que éste ha elaborado precisamente para frenar la guerra revolucionaria" ${ }^{63}$.

Es necesario destacar que la organización distinguía dos tipos de peronismo: uno revolucionario, combativo y progresista, que expresaba a los peronistas obreros, campesinos pobres, pobres de la ciudad, pequeños burgueses y sectores progresistas de la burguesía media; y otro burgués y burocrático, expresión de la gran burguesía y de la burguesía media reaccionaria. El problema residía en que ambos peronismos estaban formalmente unidos por el liderazgo de Perón, y Perón, para los perretistas, era el jefe del "peronismo burgués" 64 .

Lejos de la interpretación perretista, el peronismo revolucionario -nucleado ya en la TRP- interpretó de manera heterogénea la salida electoral del GAN. Si en un primer momento, casi todos sus sectores caracterizaron a las elecciones como una "trampa", cuando Perón comenzó a negociar con el régimen, transformaron sus posicionamientos

\footnotetext{
${ }^{62}$ El análisis teórico más acabado que el PRT-ERP hizo sobre el peronismo se dio justamente en aquel contexto en una serie de notas publicadas en el periódico El Combatiente del año 1971. Allí, Luis Ortolani (y con él el PRT-ERP) se propone realizar un análisis marxista sobre el peronismo, caracterizándolo como un "movimiento histórico que intentó un proyecto de desarrollo capitalista independiente, a través de un gobierno bonapartista que controlara a la clase obrera para apoyarse en ella". Esta interpretación abrevaba de la que había hecho el morenismo, específicamente de la realizada por Milcíades Peña en su obra "Historia del Pueblo Argentino". Así es que analizaba al peronismo como fruto de una coyuntura histórica signada por la decadencia del imperio inglés y atravesado por la guerra, que habría hecho posible y necesario el desarrollo de un capitalismo independiente en Argentina. Este último, por no haber contado con una burguesía nacional fuerte, habría tenido que ser impulsado por el sector más lúcido de las fuerzas armadas, que encontró en la clase obrera el único sostén para ese desarrollo. Para eso necesitó ganarse su apoyo y al mismo tiempo controlarla. Esto explicaba a la vez el carácter contradictorio que llevaba al peronismo a un callejón sin salida: para garantizar la expansión industrial, tarde o temprano, iba a tener que garantizar la superexplotación de los trabajadores arriesgando el respaldo masivo que le brindaba la clase obrera, y haciendo inviable la alianza policlasista. Es por ello que aunque desde el punto de vista político el peronismo era un fenómeno vivo y actuante, el PRT-ERP lo entendía como un fenómeno "histórica e ideológicamente agotado". Por otro lado, el documento analizaba al peronismo como la primera etapa en la formación de la conciencia de la clase obrera argentina, es decir, como el momento en que los trabajadores comenzaron a reconocerse como clase, aunque no por ello dejaba de entenderlo como una traba objetiva para el desarrollo de la conciencia revolucionaria. (Ortolani, Luis, "El Peronismo" En: De Santis, 2006.)

${ }^{63}$ Ortolani Luis “El Peronismo" En: De Santis, 2006: 155

${ }^{64}$ Ídem
} 
al respecto. Montoneros pasó a interpretar a las elecciones como una táctica más, dentro de una estrategia integral y revolucionaria liderada por Perón. Por su parte, las FAR se propusieron convertir la coyuntura electoral en un "elemento concientizador" y utilizar los comicios como una táctica en el camino de construir el ejército revolucionario (Gonzales Canosa, 2012). Por otro lado, los sectores vinculados a FAP fueron más reticentes a este tipo de definiciones. Para 1971, esa organización había lanzado la Alternativa Independiente, dando lugar a la corriente alternativista que fundamentalmente llamaba a construir una organización independiente de y para la clase obrera. Aun así la posición hegemónica de Montoneros funcionó como una fuerza centrífuga y logró homogeneizar superficialmente a la TRP en torno a la campaña electoral.

Para ese entonces la polémica entre el PRT-ERP y las organizaciones del peronismo revolucionario ya había comenzado. Entre abril y noviembre de 1971 la organización había desarrollado un intenso debate con las FAR, motivado por la publicación de un reportaje realizado a esta última organización en la revista Cristianismo y Revolución $^{65}$. En esta entrevista al líder de las FAR, Carlos Olmedo, definía a su organización en el marco de una estrategia de "nacionalismo revolucionario", lo que implicaba una valoración positiva del peronismo, calificándolo como una experiencia fundamental para el pueblo argentino, y asumiéndolo plenamente como la identidad de la organización. Para el dirigente guerrillero, el peronismo y el antiperonismo era la forma en que se manifestaba la lucha de clases en Argentina (Campos, 2013: 287), por lo que el socialismo solo podía lograrse con la victoria del pueblo peronista.

Esta larga entrevista motivó la respuesta casi inmediata de un grupo de militantes perretistas, encabezados por el dirigente Domingo Menna, que estaban bajo prisión en la Cárcel Encausados de Córdoba. En el breve documento titulado "Responde el ERP”, de alguna forma, se resume la concepción teórica que tenía la organización sobre el peronismo y la clase obrera. El concepto fundamental de la respuesta estaba en la idea de que no era "científicamente posible" una tercera ideología entre la burguesa (capitalista) y la proletaria (socialista), y que por ello el peronismo podía albergar en su seno las figuras más retrogradas y contrarrevolucionarias sin ser inconsecuente. Como indica Gonzales Canosa (2012), los perretistas cuestionaban varios de los tópicos centrales de los argumentos de las FAR partiendo de dos ideas fuerza: la idea de que

\footnotetext{
65“"Los de Garín”; Cristianismo y Revolución; Nro. 28 (abril de 1971); pp. 56-70
} 
toda ideología siempre respondía a los intereses de una clase social y que la clase obrera, sin un partido marxista-leninista, no podía llegar a su conciencia de clase. Bajo esos preceptos discutían: que el peronismo constituyera la expresión política de los trabajadores, cuando su líder seguía sustentando una ideología burguesa y que la antinomia peronismo-antiperonismo fuera la forma en que se manifestaba la lucha de clases $^{66}(2012: 175-176)$.

El PRT-ERP analizaba que el peronismo se estaba transformando en una "cuña" en las organizaciones armadas que dividía al campo de los revolucionarios y fortalecía en cambio el poderío del enemigo, por lo que su deber era intensificar el debate con estas corrientes. De esta caracterización, la organización concluía que los revolucionarios debían tomar dos actitudes frente al peronismo: por un lado fomentar la unidad en la acción fundamentalmente con las organizaciones armadas y las corrientes combativas del peronismo en el movimiento obrero y, por otro lado, al mismo tiempo, dar una profunda lucha ideológica "sin cuartel" contra las propuestas burguesas y contrarrevolucionarias del peronismo, denunciando el GAN, la salida negociada de la dictadura, y combatiendo a la conducción política y sindical del peronismo. La militancia perretista debía ayudar a agudizar las contradicciones entre las aspiraciones revolucionarias de los sectores combativos y las tácticas conciliadoras de la dirección oficial del movimiento, al tiempo que traccionar o neutralizar a los sectores de la mediana o pequeña burguesía peronista.

\subsection{El clasismo en el PRT-ERP}

La radicalización de un sector importante de la clase obrera se experimentaba tanto en los métodos de enfrentamiento con la patronal y la dictadura como en el contenido político de las acciones. Los paros activos con abandono de lugares de trabajo, las

\footnotetext{
${ }^{66}$ Es de destacar que pese al debate, ambas organizaciones realizaron acciones conjuntas a lo largo del año 1972, como la ejecución del General Juan Carlos Sánchez (Comandante del II Cuerpo de Ejército de Rosario acusado de instalar en la zona el "más bárbaro régimen de tortura contra los combatientes populares de que se tenga noticia”) y la fuga, de dirigentes y militantes de ambas organizaciones, del penal de Rawson. Sin embargo, esta coordinación generó cierto desconcierto y molestias entre las organizaciones de la Tendencia Revolucionaria del peronismo, fundamentalmente en Montoneros, lo que empujó a las FAR a diferenciarse cada vez más del PRT-ERP y priorizar los vínculos con las organizaciones peronistas (Gonzales Canosa, 2012). Finalmente, el alejamiento cada vez más notorio entre ambas organizaciones fue acelerándose hacia el año 1973 ante la inminente apertura democrática y retorno de Perón a la Argentina. En consecuencia, en enero de ese año el PRT-ERP envió una carta a las FAR advirtiéndoles de lo que la organización entendía como un profundo error. En la misiva se criticaba la decisión de las FAR de suspender todo tipo de coordinación y de acción conjunta y sobre todo de participar de la maniobra electoral pactada entre Perón y la dictadura militar, ya que de esa manera estarían minando los avances hacia la unidad de los revolucionarios.
} 
manifestaciones en las calles, las asambleas autoconvocadas, las ocupaciones fabriles con rehenes, el descontento y relevo de las cúpulas gremiales fueron sus principales expresiones, que se cristalizaron en una nueva corriente sindical: el clasismo (Brennan, 1996; Schneider, 2005).

El punto más alto de la experiencia clasista tuvo centro en los sindicatos SITRACSITRAM de las fábricas cordobesas de la automotriz Fiat. Sus trabajadores fueron protagonistas de un proceso de radicalización que comprendió consecutivamente la toma de las plantas con rehenes, el desplazamiento de las direcciones burocráticas, la implementación de una democracia obrera radical al interior de los establecimientos, la creciente influencia de las organizaciones de la nueva izquierda y el levantamiento de un programa revolucionario condensado en la consigna “ ¡Ni golpe ni elección: revolución!”. Esto lo transformó en un ejemplo para un conjunto de fábricas y sindicatos cordobeses, y posteriormente para una parte de la vanguardia obrera del cordón de la ribera del Paraná y el Gran Buenos Aires. La participación y el protagonismo del PRT-ERP en la lucha de SITRAC-SITRAM resultan significativos dado que, entendemos, se tornaron en un punto de inflexión para la línea sindical de la organización.

La presencia del PRT-ERP en las columnas de SITRAC-SITRAM durante el Viborazo era un indicador del crecimiento de la organización en las fábricas cordobesas, que se plasmó en la incorporación posterior de importantes dirigentes y activistas obreros como Gregorio Flores (dirigente de SITRAC), Domingo Bizzi (Secretario Adjunto de SITRAC), Eduardo Castello (Materfer), Julio Oropel (Concord) y Juan Eliseo Ledesma (Concord). Como señala Bizzi, en aquel momento se incorporaron muchos obreros y delegados de Fiat a la organización, lo que le permitió adquirir un protagonismo importante en aquellos conflictos ${ }^{67}$. Además en aquellas fábricas comenzó a ensayarse más decididamente la articulación entre lucha armada y sindical: comenzó a registrarse la presencia de pequeñas unidades del ERP en las movilizaciones y a realizarse acciones de propaganda armada en la puerta de los establecimientos, donde se desarmaban a los guardias, se realizaban actos agitativos y se distribuían materiales de propaganda a los obreros de las fábricas (Bohoslavsky, 2015. 24-25)

SITRAC-SITRAM se transformó rápidamente en un laboratorio político para las distintas organizaciones que actuaron en su seno. Allí se pusieron en juego sus distintas

\footnotetext{
${ }^{67}$ Entrevista a Domingo Bizzi por el autor, Córdoba, Agosto de 2018.
} 
concepciones, análisis, caracterizaciones y estrategias y se evidenciaron sus diferencias a través de disputas, polémicas y acusaciones cruzadas. El papel que cada uno les asignaba a los organismos sindicales, a la clase obrera, al partido revolucionario y a la lucha armada se tradujeron en diferencias concretas sobre los niveles de definición programática que debían tener los sindicatos clasistas, el marco de alianzas que debían construir, si debían participar o no de la central sindical, etc.

Los planteos de SITRAC-SITRAM se transformaron en una muestra cabal del nivel de conciencia al que podía llegar la vanguardia obrera, por también de los límites que tendría el clasismo para confluir en un movimiento más amplio que abarcara al conjunto de los sectores antiburocráticos. De hecho cerraron los canales de diálogo con el resto de los actores sindicales que conformaban dicho espectro, al punto de negarse a integrar la CGT local dirigida por Agustín Tosco y los sectores "legalistas", acusándolos de "querer frenar a la clase trabajadora y su lucha por la liberación nacional y la construcción del socialismo" (Gordillo, 2008: 72; Carrera, Grau y Martí, 2014: 213). Incluso llegaron a convocar a un congreso en oposición al Plenario de Gremios Combativos impulsado por el dirigente lucifuercista ${ }^{68}$. El resultado de esta política fue un asilamiento progresivo que los condujo a un rápido final: en octubre de 1971 la Gendarmería ocupó las plantas de Fiat, intervino los sindicatos y descabezó al movimiento con despidos masivos.

Este desenlace produjo diversos balances entre las organizaciones. Así por ejemplo para los maoístas de VC los obreros de FIAT debían transformarse en el "núcleo de una nueva dirección sindical revolucionaria para todo el movimiento obrero argentino, en la base de la construcción de una fuerza política revolucionaria"; línea que se sintetizaba en la consigna "que crezcan uno, dos, tres, muchos SITRAC". A su vez criticaban al

\footnotetext{
${ }^{68} \mathrm{El}$ "Congreso Nacional de sindicatos combativos, agrupaciones clasistas y obreros revolucionarios", que se realizó el 28 de agosto. En él participaron la mayoría de las tendencias de la izquierda clasista, y se aprobó una declaración en la que se vertieron las principales definiciones del programa de SITRACSITRAM, como la lucha por un sindicalismo "antipatronal, antiburocrática, antidictatorial y antiimperialista", se planteaba como objetivo "la destrucción definitiva del capitalismo, y por ende de su fase superior, el imperialismo, y por la construcción del socialismo", y se levantaba la consigna "Ni golpe ni elección, revolución". En el balance que hacía el PRT-ERP sobre esta reunión se pueden observar las críticas que posteriormente formaran parte del balance general de la experiencia: "Este congreso ha dado un gran paso (...) siendo el germen del futuro movimiento clasista a nivel nacional que coordine la lucha contra la burocracia, la dictadura y el imperialismo, que sea capaz de organizar, con una posición independiente y amplia, a todos los obreros combativos y revolucionarios que estén dispuestos a la lucha. (...) Si bien ha sido positivo este congreso hemos visto poca asistencia de obreros; esto permitió las tradicionales discusiones sectarias de la pequeña burguesía: discusiones fraccionales, disputas partidistas, ataques personales y un falso purismo ideológico (...) Esto los llevó a una actitud sectaria y provocadora frente al peronismo revolucionario, tratando de aislarlo, combatirlo, con un falso purismo ideológico, que en el fondo no es más que "un gorilísmo de izquierda"" ("Hacia un sindicalismo clasista" El Combatiente Nro. 61, 21 de septiembre de 1971)
} 
PRT-ERP de sostener posiciones "reflujistas", de no confiar en el poder de la clase obrera y de descansar solamente en las acciones armadas de "grupos especializados"69. Una posición similar adoptaron los militantes del grupo El Obrero quienes compartían la consigna planteada por $\mathrm{VC}$, haciendo eje en la necesidad de multiplicar la experiencia sindical de Fiat, denunciando la ubicación política de los "independientes" liderados por Tosco como de centro-derecha y criticando a los perretistas por "desviaciones populistas" que tendían a "reafirmar la ideología nacionalista burguesa dentro de la clase $^{, 70}$. El PCR, uno de los grupos más influyentes en la automotriz, endilgaba la derrota a la influencia "pequeño burguesa" tanto de VC como del PRT-ERP y las Fuerzas Armadas de Liberación ${ }^{71}$.

Por su parte el PRT-ERP hacía un balance complemente opuesto. En distintas notas críticas publicadas en el periódico El Combatiente, queda claro que para los perretistas el error del clasismo de FIAT, había sido confundir el rol del sindicato con el del partido revolucionario. En ese sentido les achacaba a las demás organizaciones, fundamentalmente a las maoístas, el ser las responsables de buscar "hacer del sindicato el partido de la revolución", "haciendo discutir y debatir en su seno las consignas y estrategias de poder de los partidos", "perdiendo su carácter de organismo de masas" y como consecuencia "perdiendo el apoyo de grandes sectores de la población y del resto de los sindicatos combativos de Córdoba e incluso de sus propias bases"72. En cuanto a su propia responsabilidad planteaban que si bien el partido había "advertido sobre el peligro del sectarismo" en la práctica los militantes habían abonado al mismo ${ }^{73}$.

Esto se ve reflejado también en el balance de Gregorio Flores, uno de los dirigentes perretistas más destacados de Fiat, quien remarca que el problema estuvo en las "actitudes sectarias" que los llevaron a no participar de la CGT local o no buscar alianzas con otros sectores antiburocráticos ${ }^{74}$.

\footnotetext{
69"'Sitrac y Sitram viven en las masas" No Transar Nro. 105, 9 de noviembre de 1971

70“'Lo que ya ha dejado Sitrac-Sitram" Grupo "El Obrero", 26 de octubre de 1971

${ }^{71}$ A Vanguardia Comunista le criticaba su posición dubitativa "cuyas tesis del reflujo y de la exclusividad lo llevaron a centrear entre el clasismo revolucionario y el comandismo pequeño burgués", mientras que a las fuerzas guevaristas les achacaban que "desconfiaban de la potencialidad revolucionaria de la clase obrera", impidiendo la discusión política en los órganos directivos e imponiendo "economismo para la clase y política de hechos a través de los grupos selectos" ("Hacer de la derrota un triunfo" Nueva Hora Nro. 79, 1ra quincena de noviembre)

72،"Balance del movimiento clasista” El Combatiente Nro. 65, 19 de diciembre de 1971; "Algo más sobre el sindicalismo clasista” El Combatiente Nro. 66, 30 de enero de 1972.

73، Algo más...", op. cit.

74 "Le dimos demasiada cabida a la alianza con sectores pequeño-burgueses y tuvimos actitudes sectarias, como no aceptar nuestra participación en la CGT o buscar alianzas con peronistas honestos y combativos. Eso nos aisló y facilitó la represión. (...) Al mismo tiempo, la conclusión más importante es otra: los
} 
De este modo, había lecciones importantes para el PRT-ERP. Con SITRAC-SITRAM se confirmaban los riesgos de la "sobreidologización" y la traslación de debates estratégicos al interior de las organizaciones sindicales, al mismo tiempo que el carácter amplio que merecían este tipo de ámbitos (Scoppetta y Torres, 2014: 91). Con estas certezas, proponían una definición del clasismo diferente al sostenido por las demás organizaciones: debía ser entendido como una corriente sindical con definiciones amplias. Entre ellas, las principales eran la construcción de organizaciones obreras independientes y democráticas, creadas de abajo hacia arriba, con protagonismo de los organismos de base (comisiones internas, cuerpos de delegados, comisiones de resistencia, etc.) y renuentes a la conciliación, los métodos y las formas burocráticas de dirección. Las mismas debían ayudar a elevar "progresivamente" el grado de conciencia de los trabajadores, concentrándose en las luchas reivindicativas. Además debían adoptar una política de alianzas amplia con las diferentes expresiones combativas del movimiento obrero, evitando el sectarismo y todo tipo de definiciones que confundieran "los verdaderos objetivos de los movimientos de masas" "75. En síntesis, el clasismo debía ser un movimiento sindical antiburocrático que se propusiese "recuperar" los organismos sindicales para "que cumplan exitosamente su tarea de intransigente defensa de los intereses del proletariado en el plano de la lucha económica contra la patronal burguesa-imperialista" ${ }^{76}$.

Para reforzar estas ideas la organización decidió republicar un artículo del dirigente Luis Pujals, titulado "El papel de los sindicatos", que, por su sistematicidad y sus definiciones, se transformó en un documento clave. Entre otras cosas, en él se advierte que los organismos sindicales debían ser lo más amplios posible ya que su misión era defender los intereses económicos de los trabajadores en su lucha contra los patrones y que no podía pretenderse que cumplieran el papel de organismo político para la "toma del poder", ni siquiera en los casos en que existieran direcciones clasistas ${ }^{77}$.

A la luz de los debates internos y de la experiencia de Fiat, esta afirmación se transformó en una prescripción partidaria para todo militante fabril perretista que encarara el trabajo sindical. En base a esta concepción la organización fue contorneando con mayor precisión lo qué entendía por un "sindicalista revolucionario", hasta llegar a

trabajadores no deben limitar su intervención al mundo sindical, deben hacer política. Deben organizar su propio partido político. Yo así lo comprendí y por eso entré a formar parte del Partido Revolucionario de los Trabajadores" (Flores, 2013:115)

${ }^{75}$ Ídem.

76 "Córdoba: un nuevo triunfo del sindicalismo clasista", El Combatiente Nro. 69, mayo de 1972

${ }^{77}$ Luis Pujals: "El papel de los sindicatos" En: Daniel De Santis, 2004: 89 
definirlo como aquel militante con la capacidad de mantener el punto de vista del partido pero respetando los límites propios de los sindicatos, es decir, no cayendo ni en el "ultraizquierdismo" ni en el "reformismo economicista",

Esta forma de entender al clasismo encontró eco, posteriormente, en la experiencia del Sindicato de Mecánicos y Afines del Transporte Automotor (SMATA) de Córdoba. Allí el PRT-ERP participó de la Lista Marrón que ganó las elecciones de abril de 1972. Encabezada por René Salamanca, dirigente sindical y militante del PCR, aquella lista además estuvo compuesta por militantes del PB, Política Obrera ${ }^{79}$, VC y el PCA. Las posibilidades de conformar una lista de esas características se debía al acuerdo generalizado de no forzar definiciones que fueran por delante del proceso de las bases (Brennan, 1996; Laufer, 2018:132).

En ese sentido, el PRT-ERP valoró la victoria en el SMATA como una confirmación de la vigencia del clasismo luego de la derrota de Fiat, pero también como el triunfo de una nueva manera de concebirlo. Esa importancia se vio reflejada en la decisión, sugerida por el propio Santucho, de volcar los "mejores cuadros sindicales" de la regional cordobesa a militar en el SMATA y, sobre todo, de cuidar celosamente la amplitud lograda, combatiendo cualquier tipo de "desviación” que desvirtuara lo alcanzado:

"La amplitud de la lista triunfante exigirá que atendamos seriamente este aspecto y sepamos mantener la unidad en la lucha reivindicativa y antidictatorial al mismo tiempo que marcaremos claramente la diferencia entre nuestra línea con el reformismo, el populsimo y el ultraizquierdismo sindicalista (PCR, etc.). Con esas corrientes debemos actuar pacientemente, fraternalmente, poniendo por delante la unidad frente a la dictadura, estableciendo lazos y evitando resquemores, al mismo tiempo que debatimos con firmeza las posiciones políticas y atacamos con energía (pero también con prudencia), las desviaciones derechistas y ultraizquierdistas, que llevan a errores y derrotas y confunden políticamente a la gente" ${ }^{" 80}$

Como vemos, para el dirigente perretista los riesgos de que el SMATA se transformase en un nuevo SITRAC-SITRAM corrían por cuenta del resto de las corrientes políticas.

\footnotetext{
78 "El sindicalista revolucionario es el compañero que es capaz de desarrollar combinados todos los aspectos de la lucha sindical, ubicándose siempre en la óptica revolucionaria. Es decir que subordina toda la actividad sindical a los intereses de la revolución guiado por el Partido. Esto es un verdadero arte, ya que se trata de mantener una postura dentro de lo que es el sindicato, sus limitaciones, no cayendo en el ultraizquierdismo ni en el reformismo economisista, pero desde el punto de vista de las necesidades de la guerra revolucionaria. El arte de combinar dialécticamente todas las formas de lucha, trasladando con habilidad de una forma a otra, elevando constantemente la conciencia de las masas, ampliando el panorama de las actividades colectivas, teniendo claro que cada acción puede, en determinado momento, estar a la ofensiva o a la defensiva pero que combinadas marchen hacia el objetivo común represente un peldaño más en la experiencia revolucionaria de las masas." ("Los revolucionarios y la actividad sindical" El Combatiente Nro. 120, miércoles 5 de junio de 1974)

79 Política Obrera fue una organización trotskista fundada en 1964 por un desprendimiento de la organización MIR-Praxis, dirigido por Jorge Altamira (Coggiola, 2006)

${ }^{80}$ Boletín Interno Nro. 25, En: Mattini, 2007: 116
} 
Otro elemento que influyó en la concepción clasista del PRT-ERP fue el vínculo con Agustín Tosco, secretario general de Luz y Fuerza de Córdoba y dirigente de la CGT de esa provincia. Aquella relación tuvo un capítulo importante en la cárcel de Rawson donde el dirigente cordobés compartió discusiones e intercambios políticos con el propio Santucho. Aunque también el contacto e intercambio cotidiano se dio en la Empresa Provincial de Energía de Córdoba (EPEC), lugar en el que trabajaba el sindicalista, y donde el PRT-ERP logró una importante inserción, al punto de contar con militantes en la dirección del sindicato ${ }^{81}$. Si bien Tosco formaba parte del Movimiento Nacional Intersindical, impulsado por el PCA, la relación con los guevaristas se fue profundizando a lo largo de los años, llegando a construir una fuerte proximidad política que se materializó con su participación, en calidad de invitado y principal orador, en numerosos actos impulsados por aquella organización (Iñigo Carrera [et. al.], 2006).

La amplitud de su línea sindical y sus definiciones antiburocráticas y antiimperialistas lo transformaron en un modelo de dirigente sindical muy atrayente para el PRT-ERP. Según Bohoslavsky, la regional cordobesa de la organización se identificaba tanto con la línea sindical de aquel que, el resto de las fuerzas políticas, los llamaban "tosquistas" $"$. En ese sentido, resulta significativa la cantidad de ex militantes que hemos entrevistado que han remarcado la influencia que tenía aquel dirigente en sus concepciones político-sindicales. De este modo, nos arriesgamos a considerar que la forma de concebir el clasismo para el PRT-ERP tuvo más puntos de contacto con el "sindicalismo de liberación" de Tosco que con el clasismo propugnado por el resto de las corrientes de izquierda.

\subsection{Algunas notas sobre la línea político-sindical perretista}

Como hemos visto a lo largo del capítulo, la línea sindical del PRT-ERP se fue forjando al calor de los debates internos y de las experiencias concretas en las que intervino el partido. Ahora bien, en esta última sección, antes de iniciar con el análisis de nuestro período, nos proponemos rastrear algunos de los usos y significados que los perretistas le asignaron a ciertos conceptos y analizar algunos aspectos de la política sindical de la organización que se configuraron en los años que repasamos, que estuvieron implícitos

\footnotetext{
${ }^{81}$ El PRT-ERP llegó a formar cuatro células y un comité de fábrica al interior de la EPEC. A su vez contó con dirigentes en el Consejo Directivo de Luz y Fuerza como el "Negro" Bazan, asesinado por la Triple A en septiembre de 1974. (Samojedny, 2016)

${ }^{82}$ Testimonio de Abel Boholavsky en el documental "Clase. La política sindical del PRT-ERP” Grupo Mascaró, 2006.
} 
en el análisis anterior y que pervivieron como rasgos distintivos en su concepción y su práctica. Específicamente examinaremos cuáles fueron las formas y métodos con los que intentó vincularse a los trabajadores. Además buscaremos aclarar a qué se refieren los actores cuando hablan de "penetración”, "inserción” y “dirección política” al interior de las fábricas. Si bien en la práctica estas nociones se presentaron de manera entrelazada, distinguirlos analíticamente nos permitirá comprender mejor las distintas dimensiones de la política y de la concepción de la organización.

\section{6.a. Los métodos de "penetración"}

Cuando hablamos de "penetración" hacemos referencia al ingreso de una organización, a través de sus militantes, al interior de las fábricas. Para conseguirlo existieron distintos métodos y técnicas, muchos de los cuales fueron compartidos por la mayoría de las organizaciones de izquierda. Por su parte, el PRT-ERP recomendaba realizar un trabajo “constante, prolongado y sistemático" sobre los establecimientos, tanto en aquellos que estaban en conflicto como en los que no lo estaban. En los primeros casos, que resultaban los más propicios para una actividad proselitista, se debía lograr a través de la solidaridad y de los distintos medios de agitación y propaganda (como periódicos, folletos, volantes y militantes agitadores); en el segundo caso, la "penetración" debía buscarse fundamentalmente a través de la proletarización de sus militantes y, como vía subordinada, a través de la "peinada". Este último método consistía en entablar un contacto, una relación personal y un diálogo con trabajadores de una fábrica sobre los problemas cotidianos propios del ámbito laboral para, paulatinamente, ir construyendo un vínculo político: entrevistarse directamente con delegados, interiorizarse sobre sus reivindicaciones, realizar una caracterización de la situación de una fábrica y elegir el mejor espacio para insertar a la militancia (Mangiantini, 2014: 38-39).

Para los perretistas la "peinada" era el método predilecto de penetración del morenísmo. Era criticado por tratarse de un trabajo "sobre" el movimiento obrero, es decir, externo, que generaba un contacto "superficial", no exigía "intensidad" y además, en la mayoría de los casos, no trascendía las meras charlas sindicales. En ese sentido se lo reconocía como útil solamente "para vincular a algunos obreros concientes aislados a nuestro Partido y para extender el trabajo en un gremio a partir de la consolidación de un equipo y una corriente fuertes en alguna fábrica importante" ${ }^{83}$. De este modo, la "peinada" se la

\footnotetext{
83“"El único camino al poder obrero y el socialismo” En: De Santis, 2004: 226
} 
equiparaba con otras "formas tácticas" de vinculación al mundo obrero, como convivir en barrios obreros, asistir a los lugares de reunión y diversión de los trabajadores u organizar la defensa de una villa atacada por la policía, por lo que no debía elevárselo "al carácter de rito religioso" 84 .

Los métodos fundamentales para lograr la penetración en las fábricas, en cambio, eran la proletarización y la propaganda armada.

En cuanto a la proletarización debemos decir que fue una práctica común que adoptaron muchas de las organizaciones que formaban parte de la nueva izquierda (Celentano, 2009; Aguila y Viano, 2009), y que tenía ya una amplia tradición en el campo de la izquierda tradicional y el anarquismo. Se trataba de una política desde la cual se buscaba ingresar en las fábricas enviando a militantes a trabajar en ellas para intervenir "desde adentro", transformarlos en referentes del movimiento obrero, aumentar constantemente la porción de obreros a las filas revolucionarias y garantizar la unidad entre la teoría y la práctica.

En el caso del PRT-ERP dicha política se arrastraba desde tiempos de unidad con el morenísimo. Ya en el II Congreso se había planteado que la proletarización era una forma efectiva para la "profesionalización" de los militantes y sobre todo para
"entrar en la fábrica para adquirir los métodos y la disciplina de la clase, para mejor conocer la realidad del movimiento obrero, para hacerse dirigente de los trabajadores. Es decir, entrar en fábrica no para ser un obrero más. No, porque el objetivo del Partido al decidir la entrada en fábrica de un compañero, no es para convertirlo en obrero sino en profesional de la revolución. (...) Para nosotros proletarizarse quiere decir ir donde el partido los necesita, esa necesidad, hoy, los reclama en la fábrica." ${ }^{85}$

Por su parte, el III Congreso había balanceado como sumamente exitosa dicha política instituyéndola como método central del partido. ${ }^{86}$ Luego de la ruptura, el PRT-ERP conservó esa definición y esos objetivos; sobre esa base la profundizó no sólo como herramienta para penetrar en las fábricas sino también para la construcción de una "nueva moral” y "ética socialista". De este modo la proletarización era dividida en dos aspectos: el moral y el organizativo.

\footnotetext{
${ }^{84}$ Ídem

85“"Informe de Actividades II Congreso", 1.3, Fundación Pluma.

${ }^{86}$ "En líneas generales las proletarizaciones han sido un éxito, como es el caso de O. de Baracas que se está convirtiendo en dirigente de una gran fábrica; o N. de Morón, que a pesar de estar en una de las peores fábricas, empieza a intervenir como dirección por abajo muy lentamente; J. de Norte, que le permitió cumplir el rol de dirigente de la oposición en las elecciones metalúrgicas; el $\mathrm{Ch}$. de Berisso, de hecho uno de los puntales de nuestro trabajo en la carne. Todos estos buenos ejemplos del último año (H. en la carne de R...), se dieron también junto a algunas defecciones o desgracias por despidos. Pero el balance es alentador, ha fortificado mucho nuestros frentes y ha consolidado verdaderos dirigentes de la clase y el partido." ("Informe de Actividades III Congreso", 2-2, Fundación Pluma.")
} 
El problema de la nueva moral aparecía como un elemento clave para la construcción de un militante "entregado de cuerpo y alma a la revolución", que estuviera dispuesto a vivir y morir por ella resignando todos los aspectos de su vida individual o ajustándolos a lo que el partido exigiera. Construir la "hegemonía proletaria", suponía prefigurar la sociedad socialista no sólo a través de un programa cargado de medidas políticas y económicas, sino a través de una nueva concepción del mundo. Y allí aparecía la necesidad de realizar una "verdadera revolución en nosotros mismos" bajo lo que la organización consideraba las "auténticas virtudes proletarias": humildad, sencillez, paciencia, espíritu de sacrificio, amplitud de criterios, decisión, tenacidad, deseos de aprender, generosidad, amor al prójimo ${ }^{87}$.

Estas características no eran tanto "virtudes proletarias", como se las consideraba, sino, más bien, valores asociados al modelo de hombre nuevo guevarista, que debía "purificar lo mejor del hombre por medio del trabajo, del estudio, del ejercicio de la solidaridad continuada con el pueblo y con todos los pueblos del mundo" (Guevara, 1965).

El hecho de que esas características fueran concebidas como "virtudes proletarias" tenía más que ver con la idealización de la clase obrera de la que hablamos anteriormente. Sin embargo esa asociación era justificada desde una pretendida visión marxista: la práctica colectiva del trabajo sumada al sentimiento de injusticia también colectivo, que aunaba a la clase obrera, aparecían como elementos generadores de una tendencia contraria al individualismo. Si bien no se negaba que los obreros, individualmente, pudieran tener una conciencia burguesa, se planteaba que, "objetivamente" (por el carácter de su papel en la producción) llevaban consigo los elementos necesarios para superar el individualismo ${ }^{88}$. De este modo, sólo formando parte de la clase, podían transformarse los "vicios burgueses", así como comprender de mejor manera las necesidades de los trabajadores. La proletarización aparecía como la condición básica para “establecer la hegemonía proletaria en la sociedad". ${ }^{89}$

Según Pablo Pozzi (2004), esta política generó un "estilo partidario" que permitió a los militantes conectar rápidamente con los trabajadores y sirvió como una herramienta de cohesión y homogeneización dentro de la organización. Sin embargo, el mismo autor y otros trabajos (Pozzi, 2004; Ciriza y Rodríguez Agüero, 2004-2005; Oberti, 2004-2005; Carnovale, 2006 y 2011) resaltan el papel disciplinador, normativo y prescriptivo que

\footnotetext{
${ }^{87}$ Ortolani Luis “Moral y Proletarización” En: De Santis, 2006: 92-115

${ }^{88}$ Ídem

${ }^{89}$ Ídem.
} 
jugó entre sus militantes ${ }^{90}$. De este modo, pueden encontrarse casos de "proletarizaciones fallidas", en las que los militantes no estaban preparados para dicha experiencia o casos en los que fue exitosa y los militantes lograron transformarse en referentes de sus compañeros de trabajo o, simplemente, vivieron el proceso de manera satisfactoria $^{91}$.

En lo que respecta al aspecto organizativo, la proletarización tenía el objetivo de estructurar el partido al interior de las fábricas. En ese sentido si bien arrojó resultados diversos en diferentes experiencias, varios autores coinciden en que, en términos generales, permitió un acercamiento efectivo con los trabajadores, convirtiendo a la organización en un actor central del sindicalismo de izquierda o clasista (Pozzi, 2004; De Santis, 2010; Scopetta y Torres, 2014; Stavale, 2014; Stavale y De Santis, 2016). Por otro lado, como señalamos en la presentación de la tesis, la proletarización configuró dos tipos de militantes al interior de las fábricas: el militante obrero y el obrero militante (Löbbe, 2006) que, como veremos, influyó en las características del trabajo político al interior de las fábricas.

El segundo método de penetración utilizado fue la propaganda armada. Con ella, el PRT-ERP buscaba producir un fuerte impacto entre los trabajadores, propagandizando la sigla del ejército, mostrando su poderío militar, demostrando la fragilidad del "enemigo" e insuflando espíritu de lucha entre los obreros.

\footnotetext{
${ }^{90}$ Una manifestación clara de ello se resumía en la idea de que aquellos militantes que se resistían a proletarizarse pasaban a cumplir el rol de agentes de las "clases enemigas", "trasmisores de sus presiones de clase, de sus ideas y de sus características negativas" (Luis Ortolani "Pequeña burguesía y revolución" En: De Santis, 2006). Sin embargo es necesario matizar el impacto que tenía este tipo de afirmaciones en la vida interna de la organización. Según De Santis (2010) esta no era la "postura oficial" de la organización, y si bien muchos militantes leyeron y estudiaron estos trabajos, en la práctica la aplicación era bastante más flexible. En ese sentido Pozzi (2004) afirma que la internalización de estas posturas dependía de múltiples factores como por ejemplo las características regionales (para el autor era diferente a como lo internalizaba un militante tucumano que un militante cordobés).

${ }^{91}$ Un ejemplo claro del primer caso es el de "Tito", militante y dirigente de la organización que renunció rápidamente al trabajo en un frigorífico al que había ingresado: "Me empecé a imaginar esa vida tan cruel de explotación y de bajos salarios que no te alcanzaba para nada viste... y me fui a la mierda. Me fui de la fábrica y por supuesto que eso traía la consecuente sanción del partido. Me acuerdo que el "Buzón" Cervato me dijo: 'bueno te vamos a suspender del partido por un año, te damos una suspensión de un año' [y] le digo: 'mira 'Buzón' si vos querés... si ustedes quieren darme un año métanle, si quieren darme diez métanle lo mismo, no hay ningún problema viste' Después eso sirvió en parte para cuestionar esa política de proletarizaciones forzadas ite das cuenta?" (Entrevista con Tito por el autor, Salta, 2017). Por su parte entre los casos de experiencias exitosas se destaca el de Daniel De Santis quien logró transformarse en uno de los principales dirigentes de Propulsora Siderúrgica. Pero también existen casos como el de Jorge Winter, militante perretista, que si bien no dieron esos resultados políticos, evalúan positivamente la vivencia: "cuando me incorporo viene el trabajo, hay que ir a la fábrica viste, la línea de la proletarización, que la mejor virtud que tenía eso era formarnos pudiendo analizar la realidad desde el punto de vista de la clase" (Entrevista con el autor, Buenos Aires, 2014).
} 
La propaganda armada era considerada como un elemento central ya desde la constitución del ERP: en el V Congreso se resaltaba como una de las herramientas fundamentales para el trabajo de masas y sindical y como tarea especial de las células militares, que también debían construirse al interior de las fábricas, para lograr la movilización de las masas:

"Las células básicas del Partido tendrán como preocupación fundamental en el terreno militar la aplicación de una línea de masas por el Ejército Revolucionario del Pueblo y contribuirán a ella mediante un estrecho contacto con dicha organización, aportando informes y transmitiendo la opinión y estado de ánimo de las masas a fin de lograr su movilización con operaciones de propaganda armada" ${ }^{92}$

Como resalta Leandro Inchauspe (2007), la política de propaganda armada era inspirada en la experiencia de guerra de guerrillas vietnamita. Siguiendo a Ernesto "Che" Guevara, la misma tenía el objetivo de mostrar el "poderío" y la "imbatibilidad" del ejército revolucionario que sumido en "el gran mar del pueblo como pez en el agua (...) catalizaba las masas con su presencia" (Guevara, 1964).

Para Héctor Löbbe, "los guerrilleros eran percibidos como militantes decididos y las organizaciones podían capitalizar a posteriori de sus acciones esas simpatías (...)"; según su relevamiento, "las bases obreras de las fábricas no expresaban críticas por este tipo de acciones ante las posibles represalias que podían provocar” (2006:57).

Si bien el PRT-ERP realizaba varios tipos de estas acciones, que iban desde la captura de radioemisoras hasta la ocupación transitoria de pueblos y ciudades, aquí nos interesan aquellas específicamente realizadas sobre las fábricas. Éstas, generalmente, estaban ligadas a conflictos sindicales o a reivindicaciones obreras de distinta índole, dirigidas a los establecimientos en los que se tenía trabajo político o en las que el partido quería ingresar. Comprendían desde atentados a fábricas o a sus dueños (quema de automóviles, quema de stock, atentados con explosivos, etc.), secuestros de gerentes o dueños de empresas (apuntados a resolver algún conflicto o a satisfacer demandas de los trabajadores), intimidaciones y advertencias a capataces, jefes de seguridad o burócratas delatores, "alcahuetes" o hostigadores de obreros, hasta intervenciones directas en asambleas, tomas de guardias para repartir volantes o prensas, tomas de colectivos o trenes cargados de trabajadores, tomas de fábricas y "repartos" (secuestros de camiones con ropa o alimentos para distribuirlos en poblaciones aledañas). Con ellas los perretistas buscaban poner en práctica, a pequeña escala, una muestra del poder dual

\footnotetext{
92،"Resolución de fundación del Ejército Revolucionario del Pueblo” En: De Santis, 2004:325
} 
que revirtiera por un momento la autoridad dentro de la fábrica, infundiera miedo entre los capitalistas e inspirara confianza en los trabajadores quienes, en muchos casos, lo recibían como un acto de justicia y venganza ante una cotidianeidad hostil de explotación, vigilancia y disciplinamiento. (Scoppetta y Torres, 2014: 138).

Acciones de este tipo ayudaron a prestigiar a la organización y en muchos casos permitieron iniciar un trabajo político allí donde aún no lo había, ya que le permitía tomar contacto y acercar a los trabajadores que simpatizaban con la lucha armada o tenían las posiciones cercanas al partido. Ese fue el caso por ejemplo del emblemático secuestro de Stanley Sylvester, cónsul británico y gerente de la planta Swift de Rosario. La acción se dio en el marco de una política patronal de despidos masivos, cierres temporarios de la planta, etc., y tuvo como objetivo lograr cumplir muchas de las exigencias, necesidades y demandas históricas de los trabajadores de la fábrica. No sólo la acción fue exitosa sino que significó un antes y un después para la organización en la zona, ya que generó profunda simpatía entre los trabajadores de la fábrica y la población de la zona sur de Rosario y permitió que la organización potencie su trabajo político y sindical generando contactos e incorporaciones de nuevos trabajadores a sus filas (Pozzi, 2004: 253).

Sin embargo no siempre ese tipo de acciones surtían el mismo efecto. En algunos casos podían llegar a hacer retroceder el trabajo sindical que se estaba desarrollando, como en el caso de la usina de Villa Revol en Córdoba. Allí una acción del ERP en la puerta de la fábrica (un comando guerrillero atacó a un patrullero), dispersó a los obreros congregados a movilizarse luego de una asamblea en la que se había votado una medida de lucha ${ }^{93}$. Esto generó desconcierto entre los trabajadores y un costo político para la militancia perretista dentro de la fábrica (Pozzi, 2004: 184).

Estas acciones conllevaban un alto riesgo si en ellas no imperaba el "criterio político", no se respetaban los tiempos del trabajo sindical y no se trabajaba de manera coordinada y consultiva con la militancia fabril perretista. Así en algunas fábricas, como veremos en nuestros estudios de casos, generaban discusiones al interior de la propia organización.

\footnotetext{
${ }^{93}$ El responsable de la acción fue Juan Manuel Murúa, conocido como el Flaco Caña, militante partidario y destacado combatiente del ERP. Murúa fue compañero de trabajo de Agustín Tosco, quién lo definió en una de sus cartas como "pollo de su gallinero" y quien no habría reparado en críticas ante dicha acción: "Al otro día, Tosco lo llamó al Caña y le hizo una durísima crítica, más que eso fue un reto a uno de los suyos que se había mandado ‘un cagadón', para decirlo en tono cordobés.” (De Santis, 2010:378)
} 


\section{6.b. "Inserción" y "dirección política"}

Definido el concepto de "penetración" y sus métodos, es preciso clarificar los significados y sentidos que la organización le asignaba a la "inserción" y la "dirección política" al interior de una fábrica. Es posible inferir a partir de los documentos y de los testimonios que cuando el PRT-ERP hablaba de "inserción" no solamente hacía referencia a la cantidad de militantes obreros que había logrado organizar y de la cantidad de fábricas en la que había logrado penetrar, sino también al nivel de "influencia" que habían logrado construir sus militantes entre los trabajadores. En ese sentido consideramos que la definición que construye Pablo Pozzi, logra captar estos sentidos cuando la define como "la capacidad que tiene una organización para representar demandas populares, para desarrollarse entre las masas, ser referente y poder orientarlas". En esa dirección una "inserción" exitosa no solo tenía como resultado "la captación de nuevos militantes sino principalmente aumentar su prestigio entre la población, generar simpatía y apoyo" (2004:169-170).

De modo que, la cantidad de militantes no marcaba, en lo fundamental, el nivel de inserción para el PRT-ERP, ya que los criterios con los que la organización evaluaba el ingreso o no ingreso de un militante a la misma, estaban atravesados por las cualidades políticas y humanas del aspirante. De este modo, con la actividad de una célula o incluso con la presencia de un cuadro político de la organización en el seno de una agrupación, sindicato o comisión directiva se debía poder lograr su dirección: "Para dirigir un organismo de masas el problema no es cuantitativo. Un cuadro puede dirigir decenas de trabajadores y llevar firmemente la dirección del organismo de masas en el que se está inserto."94

Así, "lo importante no era cuantos militantes tenía el PRT-ERP en Propulsora Siderúrgica sino su ubicación socio-política, el cómo lo percibían los trabajadores, y el desarrollo y penetración de la prensa y propaganda partidaria" (Pozzi, 2004:172), entendiendo por "ubicación socio política", el peso político y social que podía tener un militante dentro del lugar de trabajo. Esta concepción estaba atravesada por una forma determinada de entender el papel que jugaba la organización en la dirección de los procesos políticos en los que intervenía:

“(...) ¿qué quiere decir que dirigíamos la política de masas en la FOTIA? Quiere decir que si las propuestas del PRT-ERP se imponían y se hacían carne en la gente, es porque

\footnotetext{
94“"Preparar al PRT para dirigir a las masas” El Combatiente Nro. 158, miércoles 12 de marzo de 1975.
} 
los trabajadores se sentían expresados por estas propuestas, las hacían suyas y las llevaban adelante, con sindicatos que fueran o no del PRT-ERP. El concepto de la dirigencia política tiene un sentido cualitativo, no cuantitativo. Yo no dirijo a las masas porque tengo [tal o cual sindicato], se dirige a las masas cuando las masas son capaces de hacer suyas las posiciones de una organización política." (Ledesma, en De Santis, 2010: 60)

De esta manera, estar insertos y dirigir políticamente una fábrica, para los perretistas no significaba necesariamente contar con la dirección formal de un sindicato, sino influenciar a través de posicionamientos políticos y ganar las posiciones en la base. En consecuencia, aunque lo buscaban, no aparecía como estrictamente necesario que los militantes perretistas ejercieran un papel de liderazgo para lograr que sus posiciones sean adoptadas por la mayoría de los obreros. Eso debía garantizarse con la amplitud en las propuestas, la ligazón de los militantes partidarios a los dirigentes o referentes de la fábrica y la agitación y la propaganda a través de volantes y/o boletines fabriles, que a su vez podían ser complementadas con acciones de apoyo o propaganda armada de comandos del ERP.

De este modo la militancia perretista no debía dirigir "administrativamente" los espacios de organización de la clase obrera (como las CIR, los CD o los sindicatos). Por eso no consideraban necesario que la mayoría de los delegados sean de la agrupación o de la organización (aunque se trabajara para ello), ya que la influencia generada por los militantes debía ayudar para que sus propuestas al menos sean escuchadas y tenidas en cuenta por los trabajadores. Lo que allí ponían en juego era el carácter cualitativo del militante que debía desarrollar una política efectiva y sentida por sus compañeros de trabajo al interior de la fábrica.

En síntesis, la inserción dependía de tres elementos indispensables: la ubicación sociopolítica de los militantes, el prestigio y la construcción de una buena imagen del partido entre los trabajadores, a la par del desarrollo de la prensa y propaganda partidaria. Los militantes debían ser bien conceptuados por sus compañeros de trabajo y tener llegada al activismo en la fábrica, ya que la influencia política debía lograrse fundamentalmente en el sector independiente. De este modo, la presencia de algunas células sindicales dentro de los establecimientos o de alguna agrupación sindical debía bastar para el desarrollo de la política gremial del PRT-ERP.

Como veremos en los próximos capítulos esta concepción tuvo un especial desarrollo a partir de 1973 cuando el partido impulsó su política de "construir el Partido en las fábricas" 


\section{Conclusión}

Como vimos a lo largo del capítulo, en sus orígenes, la organización construyó una primera concepción sobre lo sindical que estuvo marcada por la polémica con el morenismo. En ese sentido, la definición de la lucha sindical como un aspecto "inferior" formó parte de un momento de autoafirmación en la estrategia de "guerra revolucionaria". Aun así desde un inicio planteó algunas líneas que orientaron su actividad sindical a lo largo de su existencia y que en rasgos generales se centraron en la lucha por la "recuperación" de los organismos sindicales, la organización de oposiciones clasistas a nivel fabril, la promoción de espacios frentistas, y la construcción del vínculo entre la lucha gremial y lucha armada. Además, a medida que fue interviniendo en la coyuntura política elaboró una forma específica de concebir el clasismo, haciendo eje en la lucha antiburocrática, en la democracia sindical y en la independencia del movimiento obrero, y rechazando toda tendencia a sobreideologizar la lucha reivindicativa. Como veremos en el próximo capítulo, todos estos elementos fueron la base desde la cual el PRT-ERP desarrolló su política durante el período 19731976. 


\section{CAPÍtulo 2}

\section{Definiciones ante la encrucijada democrática (1973)}

\section{Introducción.}

En el presente capítulo abordamos las principales definiciones que tomó el PRT-ERP en el año 1973 ante la apertura electoral y que marcaron, en líneas generales, a sus orientaciones políticas de todo el período estudiado. En un primer momento indagamos sobre la posición que asumió ante las elecciones de marzo, los costos políticos que supuso en su interior y la caracterización que realizó del nuevo gobierno peronista para después analizar cómo resolvió posicionarse ante la coyuntura democrática. En ese marco prestamos especial atención al lugar que le asignó a la lucha sindical en su estrategia. En una segunda parte pasamos a estudiar la forma en que la organización analizó y se enfrentó a dos de las políticas más importantes del gobierno peronista, que tuvieron impacto directo en su política sindical: el "Pacto Social" y el fortalecimiento de las dirigencias sindicales a través de una nueva Ley de Asociaciones Profesionales. En ese análisis le prestamos especial atención al lugar que le dio a la lucha salarial y, en especial, a la antiburocrática y, además, a las polémicas que sostuvo con diferentes corrientes políticas, sobre todo con Montoneros y su corriente sindical, la Juventud Trabajadora Peronista (JTP).

Por último, le damos un importante espacio al análisis de la reorientación que se propuso la organización para fortalecer su trabajo en el movimiento obrero, sintetizada en las consignas de "ir hacia las masas" y "construir el partido en las fábricas", estudiando las herramientas organizativas que se desprendieron de ello.

\subsection{Un partido armado ante el dilema de las elecciones}

El PRT-ERP inició el año 1973 con la certeza de que las elecciones eran inevitables ${ }^{95}$.

Desde fines del año anterior, ante este escenario, barajaba dos alternativas políticas opuestas: el boicot o la participación ${ }^{96}$. Ello era una manifestación evidente de las

\footnotetext{
95 En el Comité Central de diciembre de 1972 la organización afirmaba: "las previsiones de nuestro Partido siguen vigentes y a grandes rasgos debemos basarnos en que las elecciones se concretaran (...)" (Resoluciones del Comité Central de Diciembre de 1972 En: De Santis, 2006: 277)

${ }^{96} \mathrm{La}$ opción del boicot debía ser asumida si la elección se daba en un contexto de auge de las movilizaciones, con importantes niveles de combatividad y una desconfianza generalizada en el camino eleccionario, mientras que la participación debía ser una alternativa si la primera táctica no podía apoyarse en una movilización masiva de la clase obrera y el pueblo. Sobre ésta última posibilidad, en una
} 
tensiones que la apertura electoral producía en la militancia perretista (Pozzi, 2004:303). La encrucijada en la que se hallaba la organización indicaba la efectividad lograda por la política instrumentada por la dictadura militar. Las expectativas que habían generado los comicios en gran parte de la clase obrera eran una muestra del cambio en las condiciones políticas que comenzaban a operarse y que a la organización le costaba aceptar. En sus análisis, los trabajadores y el pueblo aparecían sin esperanzas de cambio $\mathrm{y}$ sin interés en las elecciones ${ }^{97}$. Sus valoraciones estaban atravesadas por un contexto de auge de la movilización obrera en la que las corrientes clasistas crecían en distintas zonas y gremios y grandes sectores de la población demostraban amplia simpatía hacia las organizaciones armadas ${ }^{98}$. Pablo Pozzi analiza que en ese marco el PRT-ERP tendió a equiparar combatividad con "conciencia de clase" (2004:95). Coincidiendo con ello, podemos agregar que además existía una tendencia a generalizar la experiencia de clase de un sector de los trabajadores, aquellos que adscribían al clasismo y construían su referencia política con la nueva izquierda, al conjunto de la clase obrera. Detrás de aquella equiparación subyacía la idea de que los niveles de movilización y combatividad eran parte de la "revolución ideológica" que, como vimos, consideraban que estaban viviendo los trabajadores.

Sin embargo la realidad demostraba otra cosa y, por ejemplo, ya a fines de 1972 la organización debía aceptar que era improbable la opción del boicot porque no existían condiciones políticas para ello ${ }^{99}$. En cuanto a la opción de participar con candidaturas propias, las imposibilidades pasaban por otro lado: la mayoría de sus militantes desconfiaba absolutamente del terreno electoral y mostraban profundas reticencias ${ }^{100}$. De manera que, si bien desde el Comité Central se impulsó la conformación de una

suerte de profecía auto-cumplida, la dirigencia advertía sobre los riesgos de que la organización cayera en una "desviación ultraizquierdista" que la negara de principio (Comité Ejecutivo de Abril de 1971 En: De Santis, 2006: 165-171)

97 "La toma del batallón y las elecciones" El Combatiente Nro. 75, primera quincena de marzo de 1973.

${ }^{98}$ Esta aceptación se ve reflejada por los resultados de una encuesta realizada por IPSA en noviembre de 1971, que daban cuenta de que el $45 \%$ de la población bonaerense justificaba la violencia guerrillera, mientras que en Rosario el porcentaje era del 51\% y en Córdoba alcanzaba al 53\%. (O’Donell, 1982: 464)

99 "Resoluciones del Comité Central de diciembre de 1972” En: De Santis, 2006:277-286.

100 Esto se hizo evidente cuando desde el Comité Ejecutivo se propuso publicar un volante en la que se aclarara ante el pueblo que el ERP no era enemigo de la institucionalización y democratización del país, sino que por el contrario luchaba por la ampliación de las libertades democráticas. La iniciativa motivó duras respuestas de regionales como Córdoba y Tucumán que denunciaron respectivamente en un boletín interno "el abandono de la línea política estratégica fijada en el V Congreso" y la "vacilación de la pequeña burguesía a la guerra y el socialismo" (Mattini, 2007:110-112; De Santis, 2010: 241-243). 
Mesa Nacional Legal para concretar los tramites que requería la participación ${ }^{101}$, y se llamó a la militancia a apuntalar la construcción de comités de base para construir las candidaturas $^{102}$, no hubo margen para esa política. De este modo se terminó llamando a la abstención ${ }^{103}$, descartando incluso la opción del voto en blanco por considerar que sería una opción marginal que, además, dejaría expuesto a quienes lo militasen como un sector minoritario y consolidaría la idea de que amplios sectores del pueblo avalaban los mecanismos de la democracia parlamentaria ${ }^{104}$.

Así como el PRT-ERP, otras organizaciones también quedaron al margen de las elecciones. Política Obrera, VC y el PCR tuvieron una política similar llamando a votar en blanco. Los argumentos que estas organizaciones esgrimían no variaban demasiado del de los perretistas ${ }^{105}$. El PST y el PCA fueron las únicas organizaciones de la izquierda marxista que participaron, con candidaturas propias, por fuera del FREJULI: la organización morenista lo hizo a través de la fórmula presidencial de Juan Carlos Coral-Nora Ciapponi (Mangiantini, 2018:76); mientras que los comunistas participaron

\footnotetext{
${ }^{101}$ La Mesa Nacional Legal tenía la tarea de conseguir personerías electorales, abrir locales públicos, etc. En esta dirección se desarrollaron diferentes experiencias en distintas zonas del país. El mayor ejemplo del cambio en la orientación fue la conformación del Frente Antiimperialista Antidictatorial (FAA), el 3 de diciembre de 1972, presidido por Silvio Frondizi, y preludio de lo que será el Frente Antiimperialista por el Socialismo (FAS) fundado meses después. Por otro lado en la Regional Norte-Norte se intentó construir un partido legal llamado Movimiento Provincial de Trabajadores (MPT), en Córdoba se conformó el Movimiento Popular de Córdoba (MPC), en la ciudad de Rafaela, provincia de Santa Fe, se dio vida al Partido Popular Santafesino, en el norte del país se formó la Coordinadora de Comités de Base del Nordeste, y en Capital Federal, especialmente en la zona sur, se abrieron locales en La Boca, Dock Sud, Isla Maciel y Bajo Flores (Silva Mariños, 2017: 65).

${ }^{102}$ Los comités de base fueron pensados como organismos de masas que la organización dispuso construir para dar respuesta a la coyuntura electoral. Estos comités debían nuclear a distintos sectores del pueblo, contactos, simpatizantes, fuerzas políticas aliadas, etc., organizando el boicot, si esa era finalmente la táctica decidida, o levantando un programa con candidaturas populares si se definían por la intervención. ${ }^{103}$ El partido reconocía, empero, esa posición no era la más atinada sino "la opción [a la que la] organización se vio obligada por el déficit en el trabajo legal que impidió [que] se lograra la activa línea intervencionista que hubiera sido más eficiente para dificultar las maniobras del enemigo y lograr el máximo aprovechamiento de los resquicios legales" ("Resoluciones del Comité Central del Partido Revolucionario de los trabajadores" El Combatiente Nro. 76, segunda quincena de marzo de 1973.)

104 "Nuestra abstención ante el acto electoral" El Combatiente Nro. 75, primera quincena de marzo de 1973

${ }^{105}$ Política Obrera vaticinaba que el Frente Justicialista de Liberación (FREJULI) fracasaría rápidamente como canal de expresión de las aspiraciones obreras ya que consideraban que para llevar adelante un programa nacionalista consecuente debían enfrentarse al imperialismo más allá de sus definiciones y porque la clase obrera estaba viviendo un proceso de radicalización tendiente a la "independencia de clase". Por otro lado el PCR planteó que optar por una u otra opción era claudicar ante una dictadura débil, y confió en que el voto en blanco tendría eco entre los sectores más radicalizados (Campione, 2007). Finalmente, Vanguardia Comunista consideraba que las elecciones no despertaban demasiadas expectativas en la clase obrera y que la convocatoria a votar en blanco constituía, en sí misma, un llamado a la unidad clasista. ("Conferencia Nacional del Frente Único Clasista. Voto en blanco: ¡Por la independencia obrera!" Política Obrera Nro. 144, 26 de febrero de 1973; "Votar en blanco. Por el Partido Obrero Revolucionario" Política Obrera Nro. 145, 7 de marzo de 1973; "La lucha del pueblo derrota al plan Lanusse", Comité Central de Vanguardia Comunista, 15 de mayo de 1971; No Transar Nro. 126, 11 de septiembre de 1973)
} 
de una frente denominado Alianza Popular Revolucionaria (APR) ${ }^{106}$ que llevó a Oscar Alende y Horacio Sueldo como candidatos (Campione, 2007; Casola, 2015).

Sin embargo, la atención general estuvo centrada en el FREJULI y en la participación y protagonismo de la Tendencia Revolucionaria del Peronismo (TRP) en la campaña. En general la mayoría de los actores y sectores de la TRP consideraban que un triunfo electoral del FREJULI sería el primer momento de una "doble batalla" cuyo objetivo final era la "toma del poder" ${ }^{107}$. Desde esta concepción, aquel frente político era la expresión de la alianza de clases necesaria para enfrentar al imperialismo y sus expresiones vernáculas, tarea constitutiva de la primera etapa del proceso de liberación nacional. Si bien en general la TRP tiñó de expectativas revolucionarias el regreso de Perón, dentro de ella existían diferencias en torno a la forma de interpretar el programa y a las perspectivas asociadas a la alianza electoral: organizaciones como FARMontoneros y la JP planteaban a la liberación nacional como una primera etapa en un proceso de largo aliento hacia el "Socialismo Nacional" y consideraban al FREJULI como la base del Frente de Liberación ${ }^{108}$; mientras que el sector "alternativista", conformado por las FAP Comando Nacional, el PB y el Frente Revolucionario Peronista (FRP), entre otras, planteaban a la liberación nacional y a la revolución social como instancias indivisibles y consideraban que si bien el triunfo les podía dar un lugar en el gobierno, la presencia de la "burocracia sindical y política" era mayoritaria dentro de la alianza frejulista (Raimundo, 2004; Stavale M., 2018).

Finalmente el 11 de marzo la formula peronista encabezada por Héctor J. Cámpora y Vicente Solano Lima se impuso cómodamente con más del $49 \%$ de los votos en el marco de una importante algarabía popular. Evidentemente el triunfo de Cámpora, el retorno del peronismo al gobierno y la restauración del régimen democrático significaban un desafío múltiple para una organización como el PRT-ERP, que cuestionaba la identidad peronista, se había forjado en la lucha armada contra la dictadura y se proponía la revolución socialista como meta. La nueva coyuntura, caracterizada por un cambio rotundo en las condiciones en que se venía desenvolviendo la lucha política, social y sindical obligaba a la organización a tomar al menos cuatro definiciones: 1- su posición ante un gobierno que surgía con amplio apoyo y expectativa

\footnotetext{
${ }^{106}$ Aquel frente estaba compuesto por el Partido Intransigente, el Partido Revolucionario Cristiano y la Unión del Pueblo Argentino.

${ }^{107}$ Envido. Revista de política y Ciencias Sociales Nro. 8, marzo de 1973; Envido. Revista de política y Ciencias Sociales Nro. 9, mayo 1973.

108 “Construir el poder popular” El Descamisado Nro. 4, 12 de junio de 1973
} 
popular; 2- la continuación o interrupción de la actividad militar; 3- el posicionamiento ante el nuevo contexto democrático-legal; y 4- en relación directa con este último punto, la reorientación de su trabajo en el movimiento obrero.

La manera en que el PRT-ERP resolvió estos cuatro puntos estuvo atravesada por una máxima que marcó las orientaciones políticas de todo el período: aprovechar al máximo los intersticios legales sin abandonar la lucha armada ${ }^{109}$. Esta definición partía de tres ideas fuerza: 1- que el gobierno que había surgido de las elecciones tenía el único objetivo de salvar al capitalismo de su crisis; 2- que las fuerzas armadas se habían replegado para preparar una nueva embestida, por lo que había que continuar combatiéndolas para no permitirles retomar la iniciativa; 3- que la actividad guerrillera apuntalaba y estimulaba la movilización de las masas y era la garantía del proceso de democratización ${ }^{110}$.

Los primeros dos puntos respondían a una misma caracterización: el PRT-ERP seguía convencido de que el gobierno surgido de las elecciones era parte de una maniobra "contrarrevolucionaria", que buscaría "detener el proceso revolucionario en curso, engañar a las masas, aislar a la vanguardia sindical clasista y a la guerrilla" ${ }^{\text {111 }}$. Aun así, reconocía la presencia de sectores progresistas y revolucionarios en su seno y planteaba que debían ser apoyados y alentados en sus propuestas para lograr que impusieran "la realización de un programa avanzado" ${ }^{\# 12}$. No obstante, seguía afirmando la necesidad de preservar su independencia política, no abandonar la iniciativa, ni generar expectativas en el gobierno ya que consideraba que tarde o temprano apelaría a la represión o sería reemplazado por una nueva dictadura militar. A partir de estas caracterizaciones la organización fijó su posición ante el gobierno en una carta, aparecida en abril, dirigida al presidente Cámpora en respuesta al pedido de tregua que éste último había lanzado. En ella manifestaba su decisión de no atacar al nuevo gobierno, al que reconocía surgido de la voluntad popular, en tanto este no atacara al pueblo y a la guerrilla. Sin embargo, al mismo tiempo, no aceptaba suspender el

\footnotetext{
109 "Resoluciones del Comité Ejecutivo de enero de 1972" En: De Santis, 2006:194

${ }^{110}$ El ejemplo más evidente que ilustraba ese punto de vista fue el del ataque al regimiento 141 de Córdoba que había realizado el ERP en febrero de 1973. La acción tenía como objetivo presionar y advertir a la dictadura militar de lo que sucedería si no respetaba el llamado a elecciones. En ese sentido "cuanto más fuertes fueran los golpes del pueblo y la guerrilla, tanto más se vería obligada la dictadura a recostarse en la tramposa salida electoral" ("La unidad y el desarrollo de la guerrilla" Estrella Roja Nro. 30, 11 de febrero de 1974)

111 "El triunfo electoral peronista y las tareas de los revolucionarios" El Combatiente Nro. 76. Segunda quincena de Marzo de 1973

112 "Resoluciones del Comité Ejecutivo del PRT" El Combatiente Nro. 77, primera quincena de abril de 1973.
} 
enfrentamiento militar contra las fuerzas armadas y las empresas monopólicas, por tratarse de un "enemigo" pertrechado y a la espera de la oportunidad para retornar al $\operatorname{poder}^{113}$.

Si bien dejaban en claro que continuarían con la lucha armada, dado el nuevo marco democrático-legal, se proponían encontrar una complementariedad y un equilibrio entre aquella y la lucha política. El objetivo era revertir la "desviación militarista", es decir el desarrollo unilateral del frente militar, y darle impulso a la intervención política y a la participación en las "luchas legales y semi-legales"114. La manifestación más evidente de esta nueva búsqueda fue la combinación del desarrollo de importantes herramientas políticas legales ${ }^{115}$, de las cuales el Frente Antiimperialista por el Socialismo (FAS) ${ }^{116}$ fue su máxima expresión, con un salto cualitativo en la operatividad militar, que pasó de pequeñas acciones a operaciones de gran envergadura.

Por su parte las orientaciones para el trabajo en el movimiento obrero, como veremos, también estuvieron atravesadas por la búsqueda de equilibrios complementarios. Ya desde el año anterior la organización evaluaba que la extensión de las posibilidades legales y semilegales permitiría generalizar la lucha reivindicativa, y que ello se expresaría fundamentalmente en una tendencia a "recuperar" sindicatos. En ese sentido, preveían que la instauración de un gobierno peronista, si bien en un principio generaría

\footnotetext{
113 “Porqué el ERP no dejará de combatir. Respuesta al Presidente Cámpora” Estrella Roja Nro. 20, 14 de mayo de 1973

114 Boletín Interno Nro. 23, 23 de abril de 1972.

${ }^{115}$ Una de las manifestaciones más importantes de esta política legal fue el impulso de herramientas de propaganda de distinta índole. Así el PRT-ERP compró el diario vespertino de difusión masiva El Mundo y la revista político cultural Nuevo Hombre, a la vez que impulsó revistas regionales como Posición y Patria Nueva. Aquellos eran proyectos editoriales que no se presentaban como herramientas perretistas sino que la organización utilizaba para "enmascarar" su política, difundiendo solapadamente su línea a través de plataformas de difusión masiva y amplia, así como para consolidar y trabajar sus alianzas políticas (Maggio, 2012; Santana, 2015)

116 El FAS fue pergeñado por el PRT-ERP en julio de 1972 con el objetivo de fundar un amplio movimiento democrático y antiimperialista dirigido por la clase obrera que fuese el germen del Frente de Liberación Nacional y Social, herramienta que la organización consideraba uno de los pilares centrales en su estrategia revolucionaria. El frente contó con seis congresos, tres de los cuales forman parte de su período de formación (período pre-FAS) y otros tres que se realizaron formalmente como FAS en el período que aquí estudiamos (18/08/73 en Tucumán, 23/11/73 en Chaco, y el 16/06/74 en Rosario). Estos últimos tres congresos reunieron 5000, 12000 y 25000 personas respectivamente, y entre reunión y reunión se fundaron al menos 6 regionales (Tucumán, Mendoza, Córdoba, Santiago del Estero, Santa Fe y Buenos Aires). El programa del FAS estaba compuesto por un conjunto de medidas que intentaban dar respuesta a los principales problemas del pueblo trabajador entre las que figuraban la educación, la salud, la vivienda y el trabajo. A su vez daba un lugar muy importante a la lucha antirrepresiva y se asentaba en definiciones ideológicas tales como la independencia de clase, la hegemonía obrera y la lucha antiimperialista, anticapitalista y socialista. De él participaron y adhirieron organizaciones y personalidades políticas como el Frente Revolucionario Peronista, MIR-Grupo El Obrero-ORPO, Agustín Tosco, Alicia Eguren, Ortega Peña, Manuel Gaggero, etc. (Payo Esper, 2011; Silva Mariño, 2017;)
} 
desorientación en la clase obrera y el pueblo, alentaría la lucha por las reivindicaciones inmediatas $^{117}$.

En función de ello calculaban que el desencadenamiento de las movilizaciones partiría, fundamentalmente, del reclamo por aumentos salariales, por lo que "lograr buenos puntos de apoyo en el movimiento sindical a nivel local y nacional" resultaba una tarea de primer orden:

"Todo lo que avancemos para ganar influencia sindical a nivel fabril (delegados) y sindical (sindicatos), todos nuestros avances en la construcción de nuestra corriente clasista por la guerra y el socialismo, todos nuestros avances en el frente antiburocrático, serán decisivos, para influir directamente en las movilizaciones como para darnos una estrategia realista de lucha contra la burocracia"118

Consideramos que en estas orientaciones se hallan los fundamentos que llevaron a que la lucha sindical se trasformase, junto a la lucha armada y la lucha democrática, en uno de los tres pilares de la política perretista durante el período que estudiamos.

Si bien en los años previos la lucha sindical había quedado en un segundo plano, en esta nueva etapa aparecía como una actividad fundamental para lograr la inserción en las principales fábricas y darle un cauce revolucionario a las lucha obreras que se desatarían. Ahora bien, ello no significó que la organización abandonara sus prejuicios sobre la actividad sindical. De hecho, así como planteaban la necesidad de impulsar "enérgicamente" las luchas y movilizaciones en torno a las reivindicaciones económicas de los trabajadores, al mismo tiempo advertía a la militancia sobre el riesgo de caer en un "aventurerismo sindical", es decir en sobredimensionar el papel de esas luchas como consecuencia de la intensidad que adquirirían. Por ello reforzaban la idea de que la actividad gremial debía estar en vínculo constante con la actividad clandestina: la "amplitud" y "eficacia" que se lograse en el plano sindical debía estimular el desarrollo del partido y el ejército al interior de las fábricas ${ }^{119}$. Como se verá en el próximo capítulo, esa política de equilibrios complementarios se expresó en el impulso dos herramientas: la Tendencia Obrera Revolucionaria 22 de Agosto (TOR “22-8”), organismo sindical clandestino armado, y el Movimiento Sindical de Base (MSB), herramienta sindical legal antiburocrática.

\footnotetext{
117 "Roto el dique de contención de la Dictadura, las masas se lanzarán decididamente por la brecha abierta a recuperar sus conquistas, a mejorar su nivel de vida. Pero la situación económica impedirá concesiones importantes y el choque violento entre las masas y el nuevo gobierno parlamentario será inmediato, los políticos burgueses deberán recurrir a corto plazo a la represión, a la intervención de los militares." ("Nuestra posición ante la situación política actual” El Combatiente Nro. 70, julio de 1972)

118 "Resoluciones del Comité Central de diciembre de 1972" En: De Santis, 2006: 280

${ }^{119}$ Boletín Interno Nro. 35, 16 de enero de 1973
} 
Los “coletazos" de una definición: La regional Buenos Aires.

Estas discusiones y definiciones no se dieron sin sobresaltos al interior de la organización. Por el contrario durante el período 1971-1973 en la regional Buenos Aires $^{120}$ se habían dado fuertes debates internos que derivaron, para inicios de ese último año, en dos rupturas: el PRT-Fracción Roja y el ERP-22 de Agosto (Weiz, 2006; Cormick, 2012).

La primera, anclada en el Sur de Buenos Aires con centro en La Plata, se produjo luego de que la regional recibiera a una comitiva de militantes brasileños y franceses de la Cuarta Internacional -a la que PRT-ERP adhería desde sus orígenes. La Internacional venía realizando críticas al "militarismo" de la organización desde 1971, introduciendo un debate al interior del partido ${ }^{121}$. El eje principal de la polémica fue la caracterización de la etapa y el papel que debía jugar la lucha armada en el nuevo contexto de apertura democrática. La internacional trotskista y gran parte de los militantes de dicha regional caracterizaban que en el país había una guerra civil embrionaria, y no una guerra revolucionaria abierta, como creía el PRT-ERP, por lo que consideraban que la lucha sindical y política debía tener prioridad por sobre la lucha armada.

Por su parte, el ERP 22 de Agosto tuvo epicentro en la Regional Capital Federal. Esta ruptura giró en torno a la posición que había asumido la organización ante el proceso de apertura democrática y el retorno de Perón. La fracción disidente, en este caso, cuestionaba la idea de que la clase obrera estuviera rompiendo con el peronismo y caracterizaban que el retorno de Perón era vivido como un triunfo por las masas y como una preocupación para las clases dominantes. En ese sentido planteaban la necesidad de

\footnotetext{
${ }^{120}$ Hasta ese entonces la organización partidaria en la provincia de Buenos Aires estaba dividida en tres regionales con sus respectivas direcciones: Regional Buenos Aires, que comprendía Zona Oeste (desde Ciudadela hasta Moreno), Zona Norte (desde Vicente López hasta Pacheco) y Zona Capital Federal; Regional Sur (de Avellaneda hasta La Plata con el anexo de Mar del Plata) que, tras las rupturas mencionadas, se incorporó como otra zona de la Regional Buenos Aires; Regional Norte-Norte (posteriormente llamada Riberas del Paraná) que iba desde la localidad de Campana hasta San Nicolás, llegando al sur de Santa Fe; y la Regional Bahía Blanca (Mattini, 2007; Yofre, 2010).

${ }^{121}$ La Cuarta Internacional comenzó a realizar críticas al PRT-ERP sobre su supuesto "militarismo" a mitad del año 1971. La diferencia fundamental estribaba en que para el PRT-ERP se había abierto la guerra revolucionaria, mientras que para la internacional trotskista lo que había era una embrionaria guerra civil, por lo que la lucha armada debía subordinarse a la lucha sindical y política. La crisis terminó por estallar cuando miembros del Partido Obrero Comunista brasilero (POC) y militantes de la Liga Comunista Francesa, en representación de la internacional se afincaron en la Regional Sur de Buenos Aires iniciando un trabajo fraccional que fue abortado con la expulsión de los militantes brasileros, la conformación formal de una fracción y su posterior ruptura en enero de 1973. (Cormick, 2012)
} 
acompañar la experiencia del FREJULI en las elecciones, capitalizando políticamente para el campo revolucionario el proceso de masas que se había abierto ${ }^{122}$.

Estas dos rupturas significaron costos importantes para el partido en el Gran Buenos Aires $^{123}$ en materia de inserción fabril, que se sumaron a las deficiencias que venía arrastrando desde el período de "desviación militarista". Hay que tener en cuenta que, por ejemplo, el PRT "Fracción Roja" se constituyó con cerca de un centenar de militantes, la mayoría de la Regional Sur (Cormick, 2012).

Según "Títo", uno de los responsables de la Regional Buenos Aires en aquel momento, el trabajo de reconstrucción partidaria tuvo al menos tres aristas: la consolidación de los militantes que aún no habían definido con claridad su continuidad en la organización; la reorganización de la estructura partidaria, fundamentalmente de aquellas zonas que habían perdido la mayoría de sus militantes; y la reorientación de los esfuerzos hacia las fábricas $^{124}$.

Esta última disposición se desprendía de la idea de que las rupturas, en parte, se explicaban por la "composición de clase" de la regional. Desde esta perspectiva la causa principal de todos los problemas era que no se habían concentrado los esfuerzos de construcción partidaria en los principales centros fabriles y que, por ende, el partido había tendido a crecer entre los sectores medios e intelectuales, algo que para los perretistas permeaba al partido de concepciones "pequeño burguesas" 125 .

122 Según Eduardo Weiz (2006) en la conformación de esta fracción confluyeron dos procesos independientes: por un lado el debate sobre el peronismo y el trabajo de masas sostenido por "Cacho" Ventricci y por el otro una discusión sobre los métodos de la dirección, y sobre la preparación de los operativos militares, que preocupaba centralmente al Comité Militar de la regional, dirigido por el Gallego Fernández Palmero y Jorge Belomo. El "ERP-22 de Agosto" (ERP-22) salió a la luz el 8 de marzo de 1973 con una solicitada en el diario Crónica (conseguida tras el secuestro de su dueño) en la que llamaba a votar por la formula Cámpora-Solano Lima. Esta nueva organización criticaba al PRT-ERP por su posición abstencionista aduciendo que esa línea de intervención los dejaría ajenos al proceso de movilizaciones de masas antes y después del triunfo electoral peronista. Estos consideraba que el FreJuLi era la herramienta, imperfecta pero real, que el pueblo había forjado para derrotar a la dictadura, y que su triunfo era la culminación de la primera etapa de un proceso que debería terminar en una verdadera revolución. (Liberación Nro. 1, 16 de Marzo de 1973; Liberación Nro. 4, 22 de Mayo de 1973)

${ }^{123}$ Según Luis Mattini el trabajo de reorganización de las regionales Sur y Buenos Aires, luego de las rupturas, se asimiló al de "la reconstrucción de un país después de la guerra" (2007: 177). Por su parte "Tito", responsable de la Regional Buenos Aires, subraya que luego de las fracciones y las sucesivas "caídas" de militantes, el partido había quedado muy debilitado y con "compañeros que dudaban" sobre su continuidad militante. Ricardo Mónaco, obrero y militante perretista de la Regional Sur, también recuerda los niveles de desorganización que, por ejemplo, llevaron a que él y su equipo quedaran desconectados durante más de un mes (Entrevista a "Tito" por el autor, Cafayate 2017; Entrevista a Ricardo Mónaco por el autor, España, 2015).

${ }^{124}$ Entrevista a "Tito" por el autor, Cafayate 2017.

125 "Se coincidió en que la causa fundamental de todos estos déficits, era que no se había centrado el eje de construcción del Partido en el proletariado fabril, que las direcciones no se habían puesto su principal empeño en construir las células fabriles, principalmente en las grandes fábricas y desde allí garantizar un desarrollo y construcción sana del Partido y todas sus tareas. La ausencia de esta preocupación central, 
Como veremos esta situación intentó ser revertida bajo la consigna "ir hacia las masas", que se tradujo en enviar a los militantes a insertarse en fábricas o, de no ser posible, a realizar trabajo político en barrios obreros ${ }^{126}$.

Efectivamente para ese momento la inserción fabril era incipiente y si bien existían trabajos políticos en algunas fábricas, que provenían de años previos, el desarrollo entre el proletariado fabril comenzó a adquirir relevancia a partir de las nuevas orientaciones con que el partido encaró el período de apertura democrática.

Si bien no existen fuentes que nos permitan construir un mapa de la inserción perretista para 1973 en el Gran Buenos Aires, a partir de los testimonios y de relevamientos personales, hemos podido determinar que durante aquel año la organización ya tenía presencia, al menos, en las siguientes fábricas: Rigolleau (Berazategui), Peugeot (Berazategui), Propulsora Siderúrgica (Ensenada), YPF (Ensenada), Astilleros Rio Santiago (Ensenada), Saiar (Quilmes), Kolynos (Quilmes), Cervecería y Maltería Quilmes, Massuh (Quilmes), Alpargatas (Florencio Varela), Duperial, Eaton (Jose C. Paz), Mercedes Benz (Gonzales Catán), la Cantábrica (Morón) y Tensa (Vicente Lopez y Pablo Nogués).

No obstante, si bien en algunos de esos casos la inserción databa de años anteriores, en la mayoría de ellos era incipiente. Evidentemente el año 1973 se trató de un año de transición para el PRT-ERP, especialmente para la regional Buenos Aires, en dicha materia. Como veremos, será a partir del redireccionamiento de sus esfuerzos hacia las fábricas que comenzará a crecer su presencia en el movimiento obrero bonaerense y con ello su participación en sus principales conflictos.

\subsection{La "oleada" de conflictos y las definiciones perretistas: del triunfo de Cámpora al retorno de Perón}

Las estimaciones sobre el impulso que adquirirían las luchas obreras se confirmaron inmediatamente. Así, tan sólo desde el 11 de marzo hasta el 25 de mayo, día en que asumió Héctor Cámpora a la presidencia, se contabilizan 320 conflictos obreros en todo el país (Izaguirre y Aristizábal, 2002). La fórmula peronista llegaba al gobierno en un

hizo que se cayera en desviaciones y que se pusiera en peligro la dirección del partido de caer en manos de la pequeña burguesía" ("Hacia el VI Congreso. Informe y balance de actividades del Comité Central", 1974)

126 Aproximadamente hasta septiembre de 1973 el encargado de dirigir dicho proceso fue Enrique Gorriarán Merlo, que posteriormente pasó a la Regional Córdoba. A partir de allí "Tito" será designado como responsable político: "entonces lo que había que hacer era ir a consolidar, hacer que se reúnan, hacer que salgan a volantear, que repartan el diario, que busquen la inserción en fábrica" (Entrevista a “Tito" por el autor, Cafayate 2017.) 
clima de intensa movilización. De hecho, el mismo 25 de mayo, en la localidad de Tigre, los trabajadores del astillero ASTARSA ocupaban el establecimiento en demanda de mejores condiciones laborales, anticipando la ola de tomas de fábricas y establecimientos públicos que se dieron durante el breve interregno camporista ${ }^{127}$.

La proliferación de los conflictos obreros tornaba evidente que la existencia de un gobierno consagrado por el voto de los trabajadores había tenido por consecuencia la creación de un nuevo espacio político para transformar el descontento en protesta (Torre, 2004). La nueva atmósfera política no ayudaba a congelar la conflictividad, sino que por el contrario la extendió rápidamente. La movilización traía consigo una fuente adicional de radicalización, que llevaba a trascender las reivindicaciones sindicales y a cuestionar las relaciones de autoridad en la fábrica. Como remarca Torre (2004) las fábricas vivirían durante esos años en un estado de rebeldía. Ahora bien, estas primeras luchas no tenían un contenido antigubernamental. Como indica Fabián Nievas en la mayoría de éstas se planteaba un apoyo explícito al gobierno o, como mínimo, se aclaraba que no se actuaba contra el mismo (1999: 358).

El PRT-ERP se hizo eco de estas luchas en su prensa, sobre todo, a través de la revista Nuevo Hombre ${ }^{128}$, espacio desde el cual buscó amplificar su política legal, democrática y antiburocrática, aunque era consciente de que estas primeras refriegas y movilizaciones obreras no se dirigirían hacia el gobierno sino que tendrían un contenido solamente antipatronal ${ }^{129}$.

En ese marco definió como tareas fundamentales, entre otras, luchar por las reivindicaciones inmediatas de las masas, específicamente por aumentos de jornales, contra el alza del costo de vida, contra la desocupación, los despidos, la

\footnotetext{
${ }^{127}$ Como indica Fabián Nievas (1999) durante todo el gobierno de Cámpora se llevaron a cabo más 600 ocupaciones que comprendieron desde fábricas, hasta colegios, organismos oficiales, hospitales, universidades, diarios, etc.

${ }^{128}$ En marzo la revista Nuevo Hombre inauguró una sección denominada "Por la base" dedicada a repasar los principales conflictos sindicales de todo el país, a través de notas o entrevistas a delegados y activistas. Así, en este interregno, se destacan los triunfos sindicales del clasismo en Perkins, Fiat, Sanidad, Construcción y Luz y Fuerza y la lucha contra la intervención del Smata en Córdoba; la "recuperación" del sindicato de Aceiteros en Reconquísta y de la CGT salteña; los conflictos por despidos y condiciones de trabajo en Jabón Federal, Clarín, la metalúrgica SIAT, astillero ASTARSA, las editoriales Scholnik y Codex en la provincia de Buenos Aires; y las luchas de transportistas, estatales, municipales y docentes y no docentes universitarios de todo el país. (Sección "Por la base", Nuevo Hombre, Nro. 37, 1era quincena de marzo 1973; Nro. 38, 1era quincena de abril 1973; Nro. 39, 2da quincena de abril 1973; Nro. 40, 1era quincena de mayo 1973; Nro. 42, 1era quincena de junio 1973; Nro. 44, 1era quincena de julio 1973)

${ }_{129}$ "El triunfo electoral y las tareas de los revolucionarios" El Combatiente Nro. 76, segunda quincena de marzo de 1973.
} 
superexplotación y contra la "burocracia sindical" "130. Además planteaba la necesidad de promover y desarrollar "la total independencia de la clase obrera respecto a todo intento burgués de integración y conciliación de clases"131. Todas estas definiciones estuvieron condensadas en las resoluciones que el Comité Ejecutivo perretista había aprobado en abril:

"1- Luchar por la independencia del movimiento sindical frente al gobierno parlamentario Campora-Solano Lima y su Ministerio de Trabajo.

2- Impulsar y apoyar enérgicamente la lucha y movilización de los trabajadores por sus reivindicaciones inmediatas.

3- Hacer frente con firmeza e inteligencia a la ofensiva ideológica y propagandística de la burocracia, cuyo carácter maccarthista, anticomunista, debe ser enfrentada con la más amplia y eficiente propaganda socialista.

4- Promover un amplio frente antiburocrático legal, que aproveche al máximo las posibilidades legales y ofrezca nacionalmente, firme resistencia a la ofensiva burocrática y gubernamental contra el clasismo.

5- Mantener y continuar desarrollando, en frente con otras corrientes afines, la Tendencia Obrera Revolucionaria, de carácter clandestino con un programa por la guerra y el socialismo, a nivel fabril, local, provincial y nacional." ${ }^{\text {132 }}$

Dichas orientaciones respondían a una caracterización de lo que la organización entendía que serían los pasos a seguir por el gobierno en materia sindical. En ese análisis el vínculo entre éste último y las cúpulas sindicales aparecían como uno de los aspectos claves a través del cual se buscaría conciliar al capital y al trabajo:

“¿qué pasará una vez que asuma el nuevo gobierno el próximo 25 de mayo? Tanto a nivel nacional como provincial, el aparato político del FREJULI pretenderá peronizar y estatizar a las centrales obreras. Por su lado la burocracia "ruchista" buscará golpear al mismo peronismo combativo y a la izquierda marxista." 133

Los perretistas, además, consideraban que el gobierno combinaría concesiones con represión y buscaría canalizar y resolver todos los conflictos vía el Ministerio de Trabajo, presidido por el dirigente sindical Ricardo Otero ${ }^{134}$ :

${ }^{130}$ En el marco de esas definiciones, la revista Nuevo Hombre lanzaba consignas alentando a la movilización por reivindicaciones sindicales y por la democracia sindical, como las siguientes: "Defender el salario y la carestía de vida"; "La burocracia y la patronal son las dos caras de una misma moneda. Sólo es posible luchar contra ambas y derrotarlas desarrollando desde las bases la democracia sindical"; "No a la traición y la entrega de los burócratas. Estrechemos filas en torno al activismo sindical"; "Enfrentar el macartismo. Movilizarse por la democracia sindical". (Sección "Por la base", Nuevo Hombre, Nro. 37, 1era quincena de marzo 1973; Nro. 38, 1era quincena de abril 1973; Nro. 39, 2da quincena de abril 1973; Nro. 40, 1era quincena de mayo 1973; Nro. 42, 1era quincena de junio 1973; Nro. 44, 1era quincena de julio 1973)

131““Porqué el ERP no dejará de combatir. Respuesta al Presidente Cámpora” Estrella Roja Nro. 20, 14 de mayo de 1973

132 "Resoluciones del Comité Ejecutivo del PRT" El Combatiente Nro. 77, primera quincena de abril de 1973

133 “Panorama político sindical en Córdoba” El Combatiente Nro. 77, primera quincena de abril de 1973.

134 "Resoluciones del Comité Ejecutivo del PRT", op. cit. 
"Sin duda por esta movilización popular que los días van acrecentando, se trata desde el gobierno -con suma celeridad- de levantar ocupaciones solucionando problemas que en definitiva no son de fondo (en el caso de ASTARSA se ve con claridad). Lo importante es quitar del medio factores irritantes, verdaderos ejemplos que en caso de extenderse demasiado pueden hacer peligrar la propia esencia de la concertación del pacto llamado social" ${ }^{\prime 135}$.

Estas caracterizaciones fueron agudizándose en el trascurso del primer mes de gobierno. La firma del Pacto Social, el fortalecimiento del ala derechista demostrado el 20 de junio en la llamada "masacre de Ezeiza"136, y la disposición del Ministerio del Interior que condenaba como "delito de usurpación" a las tomas de establecimientos públicos y privados ${ }^{137}$, eran signos que los perretistas consideraban suficientes para aseverar que el gobierno de Cámpora había "traicionado" la voluntad popular ${ }^{138}$.

Por su parte, del lado de la ortodoxia peronista y del propio Perón existía una preocupación por las concesiones que el presidente había realizado a los sectores progresistas y revolucionarios del movimiento. Es que el retorno del viejo caudillo venía de la mano de un proyecto de reconstrucción política, basado en un discurso de conciliación y "orden social", que era contradictorio con el clima político y social que reinaba desde el triunfo electoral y con el estilo fuertemente movilizador que la composición del nuevo gobierno le imponía a este último (De Riz, 1987:89; Torre, 2004). Por ello, para iniciar el proceso de "reconstrucción nacional" era necesario terminar con las ambigüedades que confundían el verdadero sentido del triunfo peronista. Así, a pesar del intento por apaciguar el estado de movilización social, Héctor Cámpora fue víctima de una ofensiva reaccionaria que lo llevó a renunciar a la presidencia el 13 de julio, a sólo 49 días de iniciado el gobierno.

Con el regreso de Perón y el desplazamiento del presidente comenzaban a ponerse en marcha los objetivos trazados en el GAN: la institucionalización de conflictividad social y política y el aislamiento y la represión de los sectores combativos del movimiento

\footnotetext{
135 "Quincena política" Nuevo Hombre Nro. 42, primera quincena de junio de 1973

${ }^{136}$ La imponente concentración política de masas que se organizó para recibir a Perón en esa localidad, quien regresaba al país tras 18 años de exilio, terminó en una masacre propiciada por las organizaciones de la derecha peronista que, encargadas de la seguridad de los palcos oficiales, abrieron fuego contra las columnas de los militantes de la izquierda peronista que se acercaron al lugar. Tan sólo unas horas después el viejo líder llamaba a volver "de casa al trabajo y del trabajo a casa" y a combatir a todos aquellos que se enfrentaran a la legalidad y a la "pacificación".

${ }^{137}$ En un comunicado del Ministerio del Interior del 25 de junio se comunicaba que se había dado la orden a las fuerzas de seguridad a que procedan a desalojar todos los establecimientos públicos y privados que hayan sido ocupados y a poner a disposición de la justicia a aquellas personas que estuvieran implicadas en los mismos. (Nievas, 1999: 407)

138 "Unidad obrera y popular contra el imperialismo y sus agentes" El Combatiente Nro. 81, lunes 16 de julio de 1973
} 
obrero y las organizaciones revolucionarias. Tras el desplazamiento, la presidencia fue ocupada interinamente por Raúl Lastiri, presidente de la Cámara de Diputados, quien se concentró en dos objetivos: garantizar la convocatoria a elecciones rápidamente y comenzar con la depuración interna en el estado ${ }^{139}$ y en el movimiento peronista (Franco, 2012).

Para el PRT-ERP estos hechos confirmaban sus previsiones. En su lógica se había tratado de un "autogolpe contrarrevolucionario" en respuesta directa a las movilizaciones de masas que habían roto en la práctica el intento de lograr la estabilización de la situación política. En este contexto la organización decidió romper con la tregua militar ${ }^{140}$ y a la vez intentó participar en las elecciones -convocadas para septiembre- a través del FAS y las candidaturas de Agustín Tosco y Armando Jaime ${ }^{141}$. Sin embargo la negativa del primero, quien no quería transformarse en un polo antiperonista a nivel electoral, frustró la táctica perretista y nuevamente la organización asistió a las elecciones repitiendo la política de la abstención electoral.

El 23 de septiembre de 1973 se consagraba triunfante con el 61\% de los votos la fórmula que llevaba a la presidencia nuevamente al general Perón. El triunfo de éste último y la asunción del mando por manos propias, paradójicamente, significaban un alivio para las clases dominantes argentinas. El proyecto del viejo líder expresaba la posibilidad de la "paz social" y de la unidad de las distintas fracciones de la clase capitalista. La clave del mismo residía en la alianza básica que le daba sustento: la "santísima trinidad" conformada por el gobierno, los empresarios y la dirigencia sindical, núcleo de lo que el PRT-ERP denominaba "peronismo burgués y burocrático". Esta alianza se sintetizó en dos ejes centrales: el Pacto Social, estrategia económica que ya se había iniciado bajo el gobierno de Cámpora y que suponía el congelamiento de la libre negociación colectiva de trabajo; y la Ley de Asociaciones Profesionales que favorecía el fortalecimiento de las cúpulas sindicales.

\footnotetext{
${ }^{139}$ En este último sentido unos de sus primeros actos de gobierno fue sustituir a los ministros del Interior, Righi, y de Relaciones Exteriores, Puig, todos ellos funcionarios ligados a la Tendencia Revolucionaria peronista, por Llambí y Vignes respectivamente.

${ }^{140}$ El 6 de septiembre llevó a cabo el copamiento del Comando de Sanidad del Ejército ubicado en el barrio Parque Patricios de la Capital Federal. Frustrada, la acción tuvo como resultado 14 combatientes detenidos y la firma de un decreto con el que se ilegalizaba al ERP como "grupo subversivo".

${ }^{141}$ Esta propuesta venía acompañada por el crecimiento del Encuentro Nacional Pro-Formación del Frente Antiimperialista y por el Socialismo que en agosto realizaría su cuarta reunión y que contaba ya con la mayoría de las organizaciones que luego conformarán la base del FAS. El PRT-ERP buscaba que ese espacio tuviera una intervención propia en las elecciones convocadas para septiembre y que llevase en su fórmula a aquellos dirigentes sindicales. (Silva Mariño, 2017: 83)
} 
Como veremos estos dos pilares marcaron profundamente la conflictividad obrera durante el período, y por ello, a la intervención político-sindical del PRT-ERP.

\section{2.a. La lucha contra el "Pacto Social"}

El Acta de Compromiso Nacional para la Reconstrucción, la Liberación Nacional y la Justicia Social, conocida popularmente como "Pacto Social", fue sin dudas el alma del proyecto de poder de Perón. El mismo fue firmado el 6 de junio bajo el gobierno camporista y fue diseñado por el ministro de economía José Ber Gelbard, empresario nacional que había sido fundador y presidente de la CGE. Se trató de un acuerdo entre esta última institución y la CGT, homologado por el gobierno, que suponía el congelamiento de los salarios al monto vigente y un aumento salarial fijo de 20.000 pesos, que representó aproximadamente un 20\% para las categorías más bajas, contemplando reajustes en junio de 1974 y junio de 1975. Además suponía un aumento de un $40 \%$ de las asignaciones familiares y la suspensión de las negociaciones colectivas por dos años (solo podían ser convocadas para discutir todo aquello que no fuera salarios). En contrapartida se establecían controles sobre los precios y, en particular, el congelamiento en algunos artículos que formaban parte de la canasta familiar. Para garantizar los términos del acuerdo se constituyeron órganos de consulta y vigilancia encargados de seguir la evolución de los acuerdos, compuestos por miembros de ambas entidades y del gobierno.

Como destaca Liliana De Riz (1987), el "Pacto Social" no era sólo una política económica sino fundamentalmente un pacto político, el pilar del proyecto peronista con el que se buscó disciplinar los conflictos entre el capital y el trabajo y restaurar el orden institucional. Con esta medida se buscaba asegurar el gobierno de la economía a través del gobierno político de las clases, a la vez que poner a raya a los sectores antiburocráticos y combativos del movimiento obrero y a las organizaciones revolucionarias.

Las interpretaciones del Pacto no fueron homogéneas entre las organizaciones de la nueva izquierda. El PRT-ERP fue una de las primeras organizaciones en denunciarlo como un "pacto de hambre" para los trabajadores. La organización entendía que dicha política estaba en el centro del proyecto "contrarrevolucionario" que venía a implantar Perón, y por ende la lucha contra el mismo fue un eje importante de su política. A lo largo del año 1973 y 1974 desarrolló un análisis pormenorizado de sus distintos aspectos y dimensiones a través de múltiples notas y artículos periodísticos en sus 
prensas, volantes y boletines de fábrica. La preocupación central de la organización estaba puesta en desenmascarar el supuesto carácter "nacional" y "antiimperialista" del proyecto encabezado por Perón y Gelbard, y denunciar los que consideraban como sus objetivos "verdaderos": "adormecer la lucha de clases" para "renegociar la dependencia", y congelar el nivel de vida de los trabajadores aumentando su explotación vía aumento de la productividad ${ }^{142}$. Para el PRT-ERP el objetivo estaba claro: "el famoso 'Pacto Social' no es más que un intento de las clases dominantes de mantener el actual sistema de explotación en la Argentina en base al sacrificio de los trabajadores." 143 A su vez denunciaban su carácter antidemocrático, ya que había sido firmado sin el consentimiento ni la participación de las bases obreras ${ }^{144}$.

Como indica Guido Lissandrello (2012), para los perretistas, el "Pacto Social" era la expresión de un capitalismo dependiente con una base estructural profundamente debilitada, en el que la burguesía nacional no jugaba ningún papel progresivo y en el que, por ende, no habría ninguna posibilidad de intentar una salida reformista por vía de la conciliación de clases. En ese sentido la sentencia era clara: "o se ataca decididamente a los patrones, especialmente a los monopolios imperialistas o se ataca decididamente a los obreros. No hay término medio que aguante."145

En lo que respecta al resto de las organizaciones políticas, del lado de la izquierda la mayoría de las organizaciones rechazó el acuerdo desde el primer momento. Así, el PST, Política Obrera y el PCR esgrimieron argumentos idénticos a los del PRT-ERP, planteando que el Pacto Social era el mismo plan económico que había intentado aplicar

\footnotetext{
${ }^{142}$ En un análisis más profundo, el PRT-ERP ubicaba al Pacto Social como una medida característica que tomaban las clases dominantes en los momentos recesivos de los ciclos del capitalismo dependiente argentino. Así, según esta lectura, la economía argentina se hallaba desde 1971 en la fase de caída del ciclo, caracterizada por el descenso de las divisas en el Banco Central, la reducción de las importaciones y del mercado interno, la desocupación y una espiral inflacionaria que, junto al primer elemento, comenzaban a lesionar los intereses de los propios monopolios. La única forma de "sanear la economía", entonces, era mediante el congelamiento de los salarios para controlar la inflación mediante la recesión, hasta tanto la economía esté nuevamente en condiciones de iniciar otra fase de acenso del ciclo. Además, según esta lectura, el pacto beneficiaba al capital monopolista ya que este no dependía del mercado interno sino que basaba su crecimiento en la colocación de productos de elevada tecnología en el mercado mundial y en un sector del mercado interno que no se veía afectado por la caída salarial. Además se beneficiaban con la absorción de empresas nacionales que no lograrían sortear el momento recesivo. Otro de los elementos que fundamentaba el carácter pro-monopolista del Pacto Social era que éste basaba todo su andamiaje en la elevación de la productividad por lo que la pequeña y mediana industria, que no tendría condiciones de bajar los costos aumentando la productividad, se veía sumamente desfavorecida para competir en el mercado ("La mentira de la reconstrucción" El Combatiente Nro. 92, Viernes 28 de septiembre de 1973; "Algo más sobre la 'Reconstrucción Nacional”" El Combatiente Nro. 95, Viernes 26 de octubre de 1973; "El Pacto Social institucionaliza la dependencia" El Combatiente Nro. 106 miércoles 6 de febrero de 1974.)

143 “iQué es el pacto social?” Estrella Roja Nro. 22, 12 de julio de 1973.

144 “El 'Pacto Social' es el hambre para las masas" El Combatiente Nro. 81, miércoles 16 de julio de 1973 ${ }^{145}$ Ídem
} 
Krieger Vassena, que era una "burla" para los trabajadores, que se trataba de un "pacto de hambre", etc ${ }^{146}$. Por otro lado el PCA, criticó la medida a pesar de que Gelbard era un hombre de sus filas, ya que consideró que cargaba los "sacrificios" sobre las espaldas de la clase obrera ${ }^{147}$.

Por el lado de la TRP, el panorama fue diferente. Aquí nuevamente existieron matices y diferencias entre el sector alineado a FAR-Montoneros y la JP y las organizaciones "alternativistas". Estas últimas denunciaron el acuerdo desde un inicio, declarando que era una "alianza con el enemigo" que buscaba "no hacerles problemas a los monopolios y sus ganancias", frenar las luchas obreras, hacerles pagar los "platos rotos" a los trabajadores y continuar con el ciclo de dependencia ${ }^{148}$. En cambio las primeras lo aceptaron, aunque con desconfianza. De hecho, en las páginas de El Descamisado, periódico montonero, se instaba a controlar el cumplimiento del acuerdo de precios dispuesto por el ejecutivo y, por otro lado, definía:

"Estas medidas surgieron de la negociación y el acuerdo entre la Confederación General del Trabajo y los empresarios. Para que éstos cumplan con sus compromisos (congelación de precios) la movilización popular y el aparato penal del gobierno popular se encargan de garantizarlo.

Estas medidas constituyen un primer paso en las tareas que ha fijado el gobierno popular. Al lado de las medidas que benefician a los empresarios nacionales, se han dictado otras que permitirán controlar y reprimir cualquier intento de estas fuerzas por desviase de la línea asumida por el gobierno y los trabajadores". ${ }^{149}$

No obstante, no pasó mucho tiempo para que aparecieran las diferencias. En el mes de agosto, el principal dirigente montonero, Mario Firmenich, criticó el acuerdo por haber sido negociado por una CGT "burocrática" que no representaba a los trabajadores. Aun así sostenía la necesidad del Pacto Social, ya que lo consideraban como un acuerdo que

\footnotetext{
${ }^{146}$ El PST planteaba la convocatoria a un Congreso de bases y un plan de lucha de la CGT, mientras que Política Obrera planteaba asambleas de fábrica para rechazar el pacto y un programa basado en la exigencia de un $50 \%$ de aumentos, por la defensa de las paritarias, la incorporación de los despedidos y la destitución de las cúpulas sindicales. Por su parte el PCR convocaba a luchar contra la "tregua" fortaleciendo las Ligas Agrarias y los cuerpos de delegados en las fábricas ("Asambleas de fábrica contra el "hambre social"” Política Obrera Nro. 157, 8 de junio de 1973; "Contra el 'Plan Krieger: plan obrero de reconstrucción"” Política Obrera Nro. 158, 15 de junio de 1973; "Tregua o lucha" Nueva Hora, Nro. 117 25 de mayo de 1973; “¡Tregua No, Liberación Sí!” Nueva Hora Nro. 119, 2da quincena de junio de 1973).

147 "El PC asumirá frente al nuevo gobierno una actitud positiva" Nuestra Palabra, 20 de marzo de 1973;"Un mes de gobierno" Nuestra Palabra, 26 de junio de 1973; "La clase obrera anulará el Pacto" Nuestra Palabra, 26 de septiembre de 1973

${ }_{148}$ Militancia Peronista para la Liberación Nro. 2, 21 de junio de 1973; "FAP Comando Nacional. Ante la coyuntura y distintas acciones" En: Duhalde y Pérez: 2003.

149 "Acuerdo social y control de los trabajadores" El Descamisado Nro. 5, 19 de junio de 1973; "El Gobierno del Pueblo rebajó los precios. El pueblo debe exigir su cumplimiento" El Descamisado Nro. 5, 19 de junio de 1973.
} 
"formalizaba" la alianza de clases expresada en el FREJULI, aunque declaraba que "éste no refleja los intereses de los trabajadores y por lo tanto deberá ser modificado." Como vemos, aunque hubo diferencias entre las organizaciones marxistas y peronistas respecto a las posiciones ante el acuerdo, ninguna de ellas realizó una defensa cerrada del mismo. Sin embargo el PRT-ERP cuestionó la posición de FAR-Montoneros y de la JP por "vacilantes", ya que consideraba que en los hechos, al continuar apostando a un acuerdo con sectores de la burguesía, sus posiciones ayudaban a la consolidación del "Frente burgués". Por otro lado, en esa misma dirección, criticó al PCA porque, a pesar de sus críticas al proyecto económico, continuó apoyando al gobierno ${ }^{151}$.

Los perretistas proponían enfrentar el "Pacto Social" oponiéndole un programa para la "liberación nacional y social", en el que figuraban medidas como la estatización del comercio exterior y de la banca, la reapertura de todas las fábricas cerradas y expropiación sin pago de todas las grandes empresas y su funcionamiento con administración obrero-estatal, aumento masivo de 60.000 pesos y congelación de precios, entre otros. Al mismo tiempo, como plan de acción proponían:

"la necesidad de realizar asambleas democráticas en cada fábrica, sindicato, barrio, lote o finca, facultad y escuela, oficina, etc, donde se analice y repudie el 'Pacto Social'; con la participación de los verdaderos interesados, los trabajadores. Discutiendo en esas mismas asambleas medidas a tomar para desarrollar una movilización independiente de las masas en defensa de su nivel de vida, del patrimonio nacional y de la verdadera liberación de nuestra patria y nuestro pueblo." 152

La organización pensaba que enfrentar al "Pacto Social" era enfrentar el intento de "salvar al capitalismo" que venía a jugar el gobierno de Perón: si se lograba articular las demandas de los trabajadores en torno a su rechazo sería posible acelerar el proceso de ruptura definitiva entre la clase obrera y el peronismo que, según los perretistas, más tarde o más temprano se produciría.

Esta expectativa se apoyaba en el hecho de que el "Pacto Social" no había logrado congelar la lucha de clases, sino que, por el contrario, los conflictos obreros continuaban generalizándose $^{153}$. Como ha sido señalado por Daniel James, si bien el prestigio de

\footnotetext{
${ }^{150}$ El Descamisado Nro. 15, 21 de agosto de 1973

151 "La burguesía penetra el campo popular" El Combatiente Nro.90, viernes 14 de septiembre de 1973.

152 “El 'Pacto Social' es el hambre para las masas", en El Combatiente Nro. 81, lunes 16 de julio de 1973.

${ }^{153}$ Una clara muestra de ello es que sólo en el interregno que fue desde la firma del acuerdo al triunfo electoral de Perón, se registran más de 120 conflictos obreros, y en el plazo de un año, de junio de 1973 a junio de 1974, se registran más de 400 conflictos, de los cuales el $31 \%$ fueron con ocupaciones de fábrica o de lugar de trabajo. Es de destacar que debido a no poder negociar directamente salarios, dicha demanda mutó en otras nuevas: los trabajadores buscaban obtener el aumento salarial de manera indirecta mediante la reinterpretación de los contratos de trabajo, la reclasificación de las tareas, la equiparación de los
} 
Perón permitió contener en un primer momento las demandas por aumentos salariales, los trabajadores encontraron diferentes maneras de trasladarlas en las luchas por mejores condiciones de trabajo, por lo que a despecho de la política oficial de consenso y conciliación en el plano político, en términos sociales hubo una intensificación del conflicto de clases (2005:323-324).

En este contexto el PRT-ERP buscó difundir todos los conflictos que demostraran los niveles de descontento y de movilización de la clase obrera y el pueblo ante aquella política. En consecuencia los conflictos sindicales por aumento de salarios y contra el alza del costo de vida cobraron nueva importancia en la política fabril perretista. Ejemplo de ello fueron: el paro de tres mil trabajadores del frigorífico Swift de Rosario por aumentos salariales; el conflicto en el Ingenio Ledesma de Jujuy, por el reconocimiento del triunfo electoral de una lista combativa que se proponía romper el techo salarial impuesto por la empresa; la conquista de aumentos de sueldo y el pago de doble aguinaldo por parte de los gráficos del diario "La Capital" en Rosario; las luchas por aumentos y despidos de Petroquímica Mosconi y Sasson y Cía; etc. Además, en cada una de estas luchas, la organización denunciaba el papel que jugaba la dirigencia sindical en la defensa del pacto ${ }^{154}$.

Ahora bien, los conflictos que más interesaron a los perretistas fueron aquellos que rebasaron los muros de la fábrica, como los casos de las puebladas en San Francisco (Córdoba) y Villa Carmela (Tucumán), ya que comprometieron a toda la población y se transformaron en una manifestación política con medidas de acción directa ${ }^{155}$. En ese sentido aquellos estallidos fueron vistos como ejemplos a seguir: "El pueblo movilizado en las calles dio su respuesta contundente a los llamados de 'pacificación nacional' que

estatutos, el cálculo de las primas de productividad, etc. También los conflictos estuvieron motivados por la reincorporación de despedidos por razones gremiales o políticas y por el pago de salarios atrasados. (Jelin, 1978)

154 "En síntesis: burócratas de uno y otro gremio coinciden en acusar a la clase obrera por derrotar el pacto social por medio de movilizaciones combativas, jaqueando a la burguesía. Estos agentes del imperialismo traidores a los trabajadores, son despreciables pero no tontos: saben que atacar al pacto es atacar a Perón y a su proyecto de conciliación de clases del que ellos son sirvientes y a la vez ejecutores directos" ("Burócratas al desnudo" El Combatiente Nro. 96, miércoles 7 de Noviembre de 1973.)

${ }^{155}$ En San Francisco, los obreros de la empresa fideera Tampieri tomaron la fábrica ante el atraso en el pago de salarios y la inestabilidad laboral, y lograron extender su conflicto al conjunto del pueblo al punto de concretar una movilización de más de 9.000 personas que terminó con una toma del pueblo y duros enfrentamientos con las fuerzas represivas. Por su parte, en Villa Carmela, los pobladores interrumpieron las vías del ferrocarril, tomaron el tren, desarmaron a la policía ferroviaria, incendiaron ómnibus y cerraron con barricadas las entradas de la ciudad, por reivindicaciones múltiples entre las que se encontraban: mejoramiento del transporte público, distribución de alimentos y remedios para la población, etc. ("San Francisco: El pueblo responde al 'Pacto Social"' en El Combatiente Nro. 85 del viernes 10 de Agosto de 1973; "Villa Carmela. Ejemplo de organización popular" El Combatiente Nro. 86 , viernes 17 de agosto de 1973) 
expresan los reconocidos explotadores Gelbard, López Rega y compañía. La continuidad de la pelea del pueblo por la senda abierta en el Cordobazo, es la respuesta a la política antiobrera del 'Pacto Social'"156.

Sin embargo, como es sabido, esa modalidad de protesta no fue la que predominó en el período y, por otra parte, más allá de la conflictividad señalada, el "Pacto Social" logró, inicialmente, un éxito parcial en sus objetivos de corto plazo. De hecho, en los primeros meses, el gobierno logró disminuir la inflación en tasas muy elevadas (en un 2,8\% en el mes de junio), así como también aumentar en un 65\% el nivel de exportaciones y reducir en términos relativos el alza del costo de vida. Estos argumentos fueron los que llevaron, en noviembre, al ministro Gelbard a anunciar que, al no haber aumento de precios, no habría aumentos de salarios. Por su parte el PRT-ERP reconocía parcialmente esta situación, pero sin embargo advertía que la "semi-contención" que se había logrado fracasaría en un lapso muy breve debido al incumplimiento de los empresarios, al crecimiento del mercado negro y al aumento de los precios de insumos importados ${ }^{157}$.

Efectivamente aquellos éxitos parciales tenían bases frágiles, y las condiciones de posibilidad del pacto comenzaron a desmoronarse tras el impacto de la nueva coyuntura internacional marcada por un alza inflacionaria generalizada. De este modo, la resistencia al pacto dejó de ser exclusiva de los trabajadores y comenzó a ser asumida también por los empresarios que no estaban dispuestos a absorber los mayores costos de producción sin poder trasladarlos a los precios. El deterioro del poder adquisitivo era cada vez más notorio, y hacía fines de 1973 existía ya la certeza de que habría algún reajuste del "Pacto Social". En ese contexto las demandas salariales comenzaron a ganar terreno en los conflictos obreros ${ }^{158}$, al mismo tiempo que cobraban cada vez más vigor las luchas por mejoras en las condiciones de trabajo y por la reincorporación de trabajadores despedidos y suspendidos.

Muchas de estas luchas fueron emprendidas por delegados o activistas combativos que formaban parte del sindicalismo "antiburocrático". Es que las dirigencias sindicales estaban comprometidas en la defensa del "Pacto Social", lo que significaba que, en muchos casos, las demandas obreras tuvieran que ser organizadas por fuera las

\footnotetext{
156 "San Francisco: El pueblo responde al 'Pacto Social"” en El Combatiente Nro. 85 del viernes 10 de Agosto de 1973

157 "Salario real y Renta nacional" en El Combatiente Nro. 97 del miércoles 14 de noviembre de 1973

${ }^{158}$ Según el relevamiento realizado por Elizabeth Jelin, mientras que entre junio y septiembre la cuestión salarial fue mencionada explícitamente en el 5\% de los conflictos, entre octubre de 1973 y febrero de 1974 apareció en un 21\% (1978: 434)
} 
estructuras sindicales. Esto, a su vez, alentaba el crecimiento de las organizaciones revolucionarias en las fábricas. De este modo la persecución a estos sectores asumía dos motivaciones para la "burocracia sindical": garantizar el pacto y contener la "rebelión de las bases" que amenazaban su existencia.

2.2.b. Luchar contra la "burocracia sindical" en momentos de contraofensiva gubernamental: Definiciones y polémicas fundamentales.

La CGT había apoyado desde un inicio el "Pacto Social", aún frente a la evidencia de que era una decisión onerosa. Con aquel acuerdo había comprometido todo su poder institucional: al acordar la suspensión de las negociaciones colectivas anulaban el único poder institucionalmente reconocido que poseían, mientras que, por su parte, los empresarios contaban con la facultad de decidir si invertir o no, si incrementar la producción o reducirla, etc. Sin lugar a dudas Perón había jugado plenamente su autoridad política presionándolos para que se sumasen al acuerdo (Torre, 2004:35) y éstos, más allá de los costos, eran conscientes de que, con ello, recobrarían su espacio perdido en el movimiento. Además tendrían argumentos legales para liquidar la oposición política y sindical que venía creciendo en las fábricas.

Ahora bien el espíritu antiburocrático fue una de las características más destacadas de la conflictividad laboral de la época. El repudio al "Pacto Social", que comenzó a generalizarse entre los trabajadores, redundaba en el desprestigio de las cúpulas sindicales que aparecían como cómplices del deterioro del nivel de vida de las masas. Las bases fabriles, en muchos casos, comenzaron a realizar protestas y reclamos al margen de los sindicatos, de las CIR y los CD dominados por el oficialismo sindical. El descontento se comenzó a canalizar a través de asambleas y reuniones en las plantas donde se exigía a los delegados que asumieran las demandas obreras o en su defecto renunciaran. En muchos casos estos reclamos conducían a medidas de lucha concretas como paros o tomas de establecimientos exigiendo elecciones sindicales libres. Como indica Jelin, durante el período junio-septiembre se registran al menos veinte casos de conflictos en los que los trabajadores cuestionaron la legitimidad de sus representantes sindicales a nivel de planta o sindicato local (1978: 431). Lo novedoso estaba en que este proceso de impugnación a las cúpulas, que hasta el momento tenía peso en el interior del país, fundamentalmente en Córdoba, ahora empezaba a extenderse a las fábricas de Buenos Aires. 
Esta situación de movilización de las bases obreras favoreció y se vio retroalimentada por el crecimiento de las organizaciones de la nueva izquierda al interior de las fábricas.

Coincidimos con Héctor Löbbe en que este proceso prosperó principalmente:

“ $1^{\circ}$ ) debido al acercamiento a esas organizaciones de los nuevos activistas fabriles, que sentían la necesidad de encontrar un encuadramiento político que respondiera a las nuevas condiciones de combatividad obrera y al creciente abandono de su rol de conducción por parte de las direcciones peronistas "ortodoxas"; $2^{\circ}$ ) por el replanteo de la definición político-ideológica que estaban llevando a cabo dirigentes y activistas de cierta trayectoria dentro de las filas obreras y $3^{\circ}$ ) por la orientación hacia las fábricas o proletarización de sus cuadros que impulsaban con distinta fuerza y éxito las distintas organizaciones de izquierda, en especial las marxistas." (Löbbe, 2009: 38)

Fue en el marco de ese proceso que el PRT-ERP logró, en poco tiempo, importantes resultados en su inserción fabril. De hecho, como veremos, para julio de 1973 reunió a más de mil asistentes, entre los que se encontraban varias agrupaciones, delegados y representantes sindicales, en el acto de fundación del MSB.

Como vimos, la lucha contra la "ofensiva maccartista de la burocracia sindical" estuvo entre sus definiciones principales de inicio de año ${ }^{159}$. De este modo, tempranamente, los perretistas denunciaron la creación de la Juventud Sindical Peronista (JSP) ${ }^{160}$, como un "engendro fascista" fundado por Rucci y Lorenzo Miguel para enfrentar en la cotidianeidad de las fábricas a las "corrientes combativas y clasistas". A su vez advirtieron sobre las maniobras estatutarias a las que aquellos dirigentes recurrirían para “castrar" a las direcciones regionales no oficialistas ${ }^{161}$.

En ese marco, el PRT-ERP planteó una orientación que, con matices, sostuvo durante todo el período: la necesidad de hacer converger todas las luchas y expresiones antiburocráticas hacia la "centralización organizativa y programática"162 . En ese sentido la lucha antiburocrática se transformó en un punto de contacto con la mayoría de las corrientes políticas de la izquierda marxistas y peronistas con las que, a pesar de sus profundas diferencias, tendió a confluir en listas sindicales, cuerpos de delegados u otras instancias organizativas al interior de las fábricas. Es de destacar que entre estas fuerzas

\footnotetext{
159 "Resoluciones del Comité Ejecutivo del PRT" El Combatiente Nro. 77, primera quincena de abril de 1973

${ }^{160}$ Esta agrupación apareció públicamente durante las primeras semanas del gobierno de Cámpora. Fundada por José Ignacio Rucci, nació con el objetivo de combatir a la JTP y al resto de las corrientes de izquierda, peronistas y marxistas, del movimiento obrero. En poco tiempo se transformó en la rama juvenil de las 62 Organizaciones, lo que le permitió una rápida y extensa inserción en el mundo gremial y en diferentes fábricas. La misma contaba con grupos de choque que, en connivencia con el Comando de Organización y la policía bonaerense, se encargaron de la represión ilegal de los activistas combativos de las fábricas (Zicolillo, 2013; Schneider, 2015).

161 "Organicemos la lucha contra la burocracia” El Combatiente Nro. 81, lunes 16 de julio de 1973.

${ }^{162}$ Ídem
} 
el FRP y el PB fueron los aliados "naturales" del PRT-ERP ${ }^{163}$. A grandes rasgos estas organizaciones apuntaban a construir una organización política "de y para la clase obrera" que se estableciera por fuera de las estructuras del Movimiento Peronista, y en este sentido, a nivel sindical replicaban esta apuesta buscando trabajar con las bases obreras para que éstas produjeran sus propios líderes y formaran un sindicalismo "antiburocrático", "combativo" e "independiente". Por eso para los perretistas se trataban de los sectores "más lúcidos" de la TRP ${ }^{164}$. Además estas organizaciones, a diferencia de los partidos trotskistas o maoístas, no rechazaban la lucha armada e incluso la practicaban.

Con la Juventud Trabajadora Peronista (JTP), corriente sindical impulsada por Montoneros en abril de ese mismo año ${ }^{165}$, la relación era más conflictiva ya que partían de una concepción y una estrategia distinta para la lucha sindical. A diferencia del PRTERP, Montoneros no buscaba construir una oposición clasista independiente, sino que su disputa pasaba por dentro del movimiento peronista, y más específicamente, al interior de las 62 Organizaciones. Sin embargo los perretistas hacían una diferenciación en la caracterización de la JTP, respecto al resto de los frentes de masas montoneros, ya que consideraba que su componente obrero la llevaba a tener una actitud distinta, aceptando frecuentemente la unidad en la lucha contra la patronal y la "burocracia"166. Además ambas corrientes coincidían en que los burócratas eran "traidores" que actuaban a favor de las patronales y de sus propios intereses y, por ende, eran enemigos a los que debían enfrentar en unidad.

No obstante, es de destacar que el PRT-ERP y Montoneros partían de una explicación distinta sobre el origen y el carácter de la "burocracia". Para los primeros la "burocracia sindical" era una "formación parasitaria" surgida de la clase obrera. Su nacimiento era explicado como el fruto de la "hegemonía burguesa" de la sociedad capitalista que

\footnotetext{
${ }^{163}$ Esto es confirmado por los testimonios de Luis Mattini, responsable sindical nacional del PRT-ERP y Armando Jaime máximo dirigente del FRP. Así el primero afirma que las mejores relaciones y los vínculos más fuertes eran con el PB. Por su parte Jaime plantea que las definiciones del FRP sobre las imposibilidades del proyecto policlasista de Perón los acerco al PRT-ERP al punto de ser sus principales "socios y aliados". (Entrevista a Luis Mattini por el autor, Buenos Aires, 2017; Entrevista a Armando Jaime por el autor, Salta, 2016).

164 "Gobierno: no hay soluciones para el pueblo" El Combatiente Nro. 96, miércoles 7 de noviembre de 1973

${ }^{165}$ El acto de fundación se realizó el 28 de abril en la Federación Argentina de Box con la participación de más de 10.000 trabajadores. Organizada en 8 regionales, la JTP llego a reunir cerca de 200 agrupaciones sindicales y se transformó en una de las fuerzas con mayor peso en los organismos de base fabriles como las comisiones internas y cuerpo de delegados (Vittor, 2011; Pacheco y Lissandrello, 2013; Pacheco, 2014)

166 "Movimentismo y Liberación” El Combatiente Nro. 102., miércoles 26 de diciembre de 1973
} 
imponía normas de vida basadas en el consumo, los lujos y el "prestigio personal", y que afectaba especialmente a aquellos dirigentes que, sin haber adquirido una sólida conciencia de clase, eran "tentados" y "comprados" por los patrones. De este modo, "traicionaban" a su clase transformándose en "agentes de la burguesía"; el sindicato pasaba a ser "el instrumento para ayudar a los patrones a explotar a los obreros y obtener así jugosas ventajas",167.

Ahora bien, la burocratización de los dirigentes era entendida como un fenómeno social necesario del capitalismo, de modo que no importaba quien ocupara esa función en un momento determinado ya que el sistema tenía la capacidad de reemplazarlo rápidamente. Su "liquidación", entonces, era un problema político e ideológico que la propia clase debía resolver mediante la "lucha política" y no a través de la eliminación "física" de aquellos dirigentes:

"Será en la práctica de la lucha económica y política que las bases irán construyendo nuevas direcciones, combativas y clasistas, que vayan reemplazando las direcciones burocráticas. El amplio desarrollo de este movimiento, la unidad de todas las fuerzas clasistas y combativas, verdaderamente antipatronales, antiimperialistas y antiburocráticas, será la única garantía de la desaparición de esta nefasta capa parasitaria." 168

Por su parte Montoneros tenía una explicación más endógena de la "burocracia", al analizarla como fruto de la vida política, económica y social del país con el advenimiento y la caída del peronismo ${ }^{169}$. Ubicaban su origen en el propio gobierno de Perón, más específicamente a partir de 1951, cuando los sindicatos comenzaron a actuar como meras "dependencias administrativas" conducidas por dirigentes que preferían "la tranquilidad de sus cargos y no los riesgos de una profundización política $\mathrm{y}$ organizativa" ${ }^{\prime 170}$. La definían como una "capa social" que a lo largo de los años se había ido sometiendo a los intereses del imperialismo. Según este análisis, luego del derrocamiento de Perón, la "debilidad ideológica" de los dirigentes fue haciendo que priorizaran el mantenimiento de la legalidad de los sindicatos en detrimento de "la lucha por reconquistar el poder". Por ende, eso habría producido una tendencia a negociar e integrarse con el sistema, traicionando al movimiento peronista e introduciendo los intereses del imperialismo en su seno. De modo que la "burocracia sindical" pasaba a

\footnotetext{
167 "La burocracia sindical. Instrumento burgués" El Combatiente Nro. 102., miércoles 26 de octubre de 1973

168 Ídem

169 "Vandorismo: la política del imperialismo para los trabajadores peronistas." La Causa Peronista Nro. 9, Suplemento Especial, 3 de septiembre de 1974 (En: Beschetti, 1999: 154-177)

${ }_{170}$ Ídem
} 
ser un enemigo principal, un elemento infiltrado, en el movimiento obrero y en el movimiento peronista que debía ser liquidado. En ese objetivo consideraban legítimo y un método necesario el "ajusticiamiento" de sus máximos exponentes (Farace y Jäkel, 2016). Esta también era una forma de dirimir las disputas al interior del peronismo. Ello quedó claro con el "ajusticiamiento" de Juan Ignacio Rucci, Secretario General de la CGT y hombre de confianza de Perón, el 25 de septiembre ${ }^{171}$. La acción, realizada pero no asumida por Montoneros, fue el capítulo más álgido de esta lógica política y de la negociación in extremis que la organización tuvo con Perón.

Como dijimos, el PRT-ERP no comulgaba con esta metodología aunque, sin embargo, tampoco la condenaba ya que, aunque "deformada", la consideraban como una expresión del sentimiento de las masas. Además, como veremos, en algunos casos la organización terminó recurriendo a dicha metodología en el marco de la disputa interna de las fábricas. De este modo, las divergencias no significaron una traba para la unidad en la lucha antiburocrática, siendo éste el eje que permitió mayor articulación y coordinación entre ambos sectores, que, como vimos, encontraban mucha mayor distancia en lo relativo a la política nacional.

\section{La ley de Asociaciones Profesionales: el rechazo y la polémica con la JTP}

La confluencia antiburocrática que se fue dando por la base al interior de las fábricas entre los militantes y activistas de las distintas corrientes, no pasó desapercibido ni para la cúpula sindical ni para el gobierno, quienes ensayaron como respuesta una nueva Ley de Asociaciones Profesionales. Los esfuerzos estuvieron concentrados en contar con un instrumento legal que ayudase a imponer el "Pacto Social" y, fundamentalmente, a impedir el proceso de democratización en la conducción de los sindicatos. Ambos objetivos, necesariamente, debían partir de ahogar la organización y el crecimiento de estas corrientes en los lugares de trabajo y desplegar un control más estricto sobre las bases obreras.

A grandes rasgos el proyecto, que había sido presentado el 25 de julio bajo el interinato de Lastiri, buscaba eliminar las dobles personerías y sindicatos por empresa y le

\footnotetext{
${ }^{171}$ Es de destacar que en un primer momento la acción fue adjudicada al PRT-ERP quien debió salir a despegarse de la misma: "Nuestra organización no ha ejecutado a ningún burócrata sindical. Consideramos que la ejecución de algunos de estos traidores sólo debería realizarse en casos extremos muy especiales. Por eso no habríamos encarado acciones como la que dio fin a la carrera de traidor de José Ignacio Rucci. Pero tampoco condenamos esa acción porque la consideramos una expresión aunque deformada del sentimiento de las masas" (El Combatiente Nro. 92. Viernes 28 de Septiembre de 1973.)
} 
otorgaba la facultad a las federaciones de asumir el carácter de asociaciones de primer grado en aquellas zonas o empresas donde no hubiera organizaciones de ese tipo, además de poder intervenir seccionales de grado inferior. Por otro lado el proyecto permitía a las conducciones sindicales intervenir y terminar mandatos de CIR y extendía los mandatos de estas últimas, de dos a cuatro años ${ }^{172}$.

En el mes de agosto el PRT-ERP publicó una nota titulada “Asociaciones Profesionales: la burocracia se defiende" en la que caracterizaba a las modificaciones propuestas por la cúpula cegetista como un intento de "defender sus sillones contra el avance del movimiento clasista y descabezar las direcciones del movimiento obrero; a la par que jugar todo el peso del aparato sindical, ya en forma abierta y 'legal' a favor del peronismo burgués"173. Bajo esta definición general se ocupaban de desmenuzar y analizar los artículos más controversiales de la ley. Es de destacar que en muchos casos cuestionaban artículos que formaban parte del espíritu del modelo sindical peronista y que no eran novedosos respecto a ley original de 1945.

Una de las cosas que objetaban era el hecho de que se extendiera el plazo a la convocatoria de asambleas generales de afiliados, al mismo tiempo que se restringía la autoconvocatoria de asambleas. Según el PRT-ERP esto apuntaba a ilegalizar al movimiento obrero combativo y antiburocrático. Por otro lado advertían sobre el artículo 15, que permitía a las asociaciones profesionales fijar posición política y apoyar a candidatos y partidos en las elecciones. Para el partido, en este caso, la cláusula sólo respondía a una necesidad coyuntural para legalizar el apoyo a la candidatura de Perón. Por otro lado se discutían los artículos que otorgaban al Ministerio de Trabajo el derecho a conceder y retirar la personería gremial a los sindicatos en función de su representatividad; para los perretistas eso significaba que las organizaciones obreras quedaran a merced de las decisiones del gobierno de turno. A su vez, cuestionaban que, bajo aquel criterio de "representatividad", algunos sindicatos pudieran solicitar que se le quitaran la personería gremial a otra asociación en beneficio suyo. Los perretistas afirmaban que esa cláusula estaba pensada para quitarle la representatividad a sindicatos que estuvieran dirigidos por corrientes clasistas. Se ponía el ejemplo del SMATA

\footnotetext{
${ }^{172}$ La "burocracia" no escondía sus intenciones, al punto tal que Otto Calace, secretario general de la Federación de Asociaciones de Trabajadores de la Sanidad Argentina (FATSA), defendía el proyecto como una herramienta que evitaría la "pluración (sic) sindical", mientras que el ministro de trabajo Ricardo Otero señalaba que "la eliminación de los sindicatitos, evitará el daño que éstos actualmente producen al movimiento obrero" (Lissandrello, 2016).

173 "Asociaciones Profesionales: la burocracia se defiende" El Combatiente Nro.88, viernes 31 de agosto de 1973
} 
Córdoba que, con este artículo, podía ser desplazado por la Unión Obrera Metalúrgica (UOM) local que tenía "suficientes" afiliados como para exigirlo. Por último se alertaba sobre el derecho que adquiría la cúpula cegetista al poder imponerse sobre cualquier organismo gremial que no fuera de primer grado.

En función de estas críticas el PRT-ERP llamaba a organizarse de manera inmediata para rechazar la ley exigiendo un proceso de discusión en asambleas de fábrica en la que participasen todos los trabajadores. Al mismo tiempo se planteaba la necesidad de organizar una movilización para exigirle al parlamento que diera publicidad al proyecto presentado y se hacía un llamado a "los legisladores progresistas" a que lo denuncien públicamente $^{174}$.

Todas las organizaciones de la nueva izquierda repudiaron la iniciativa burocrática; sin embargo nos interesa destacar la posición de la JTP por dos motivos: por la importante ascendencia que tenía entre los trabajadores, y por la ambigüedad con la que se posicionaron frente a la nueva ley, que le valió una fuerte crítica por parte del PRTERP.

Si bien, en un primer momento, la JTP calificó al proyecto de ley como un "zarpazo contra la democracia sindical y la reconstrucción nacional" y afirmó que el proyecto era una muestra cabal de los intereses de la burocracia sindical; también destacó "aspectos positivos", fundamentalmente los que aportaban al fortalecimiento del movimiento obrero organizado ${ }^{175}$. Por ello plantearon una contrapropuesta que modificaba los postulados que fortalecían a las cúpulas cegetistas. ${ }^{176}$ Con este proyecto en ciernes la JTP incrementó la publicación de documentos, lanzó volantes y folletos y llevó adelante una importante campaña de difusión que culminó en el "Plenario Sindical Peronista por la Reforma del proyecto de Ley de Asociaciones Profesionales", un acto multitudinario realizado en el mítico Luna Park que reunió a más de 20.000 trabajadores con consignas de claro rechazo al proyecto de la burocracia.

Sin embargo los diputados ligados a Montoneros y a la JP terminaron votando la ley por "razones de disciplina" "177; y la dirección de la JTP justificó la decisión aduciendo que se subordinaba a la voluntad de Perón, quien apoyaba la iniciativa (Löbbe, 2013: 15).

Ante esta actitud el PRT-ERP no escatimó críticas. Unos días antes de la sesión parlamentaria había elogiado la actitud montonera ante el proyecto de ley por

\footnotetext{
174 Ídem

175 "Ley de asociaciones profesionales” Boletín de la JTP

176 "La trampa del 'yerno' no debe pasar", El Descamisado Nro. 22, 16 de octubre de 1973

${ }^{177}$ Diario Noticias, 1 de Diciembre de 1973, p. 9.
} 
considerarla un avance muy importante hacia una política de "independencia de

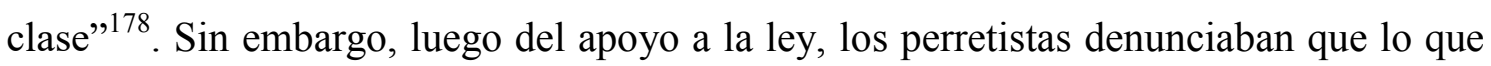
se había transformado en un importante acto de independencia política había culminado con una "nueva concesión", en nombre de la "verticalidad", al peronismo burgués y burocrático $^{179}$.

Los compromisos adquiridos con las políticas del gobierno por las organizaciones de la TRP que, en mayor o menor grado, sostenían posiciones "movimentistas" "180, llevaron al PRT-ERP a chocar con aquellas en algunos espacios de base, sobre todo durante el año 1973, y a denunciar desde El Combatiente las supuestas actitudes "desmovilizadoras", "sectarias" o "vaciladoras" de la JTP. Las críticas más fuertes estuvieron centradas en la posición ante el Pacto Social como en la decisión de apoyar la Ley de Asociaciones Profesionales, cuestiones que repercutían en el plano sindical. Por otro lado también le criticaban cierta falta de predisposición para la unidad antiburocrática más allá de las fábricas. Un ejemplo ilustrativo de ello fue el acto convocado por la CGT cordobesa en diciembre de 1973 contra la escalada represiva y los despidos en la empresa estatal IME. En su balance, los perretistas reprochaban a los militantes de la JP y la JTP el hecho de haber participado del acto con una actitud "anti-unitaria", buscando imprimirle un "carácter peronista" a través de consignas que no reflejaban la amplitud del mismo. En esa dirección los convocaban a abandonar aquella práctica que, a su juicio, atentaba contra la unidad ${ }^{181}$. Por su parte, los Montoneros no acusaban recibo de aquellas críticas, ya que estaban más preocupados por la consolidación y la acumulación de

\footnotetext{
178 "La crisis del peronismo" El Combatiente No. 97 miércoles 14 de noviembre de 1973

179 "La única movilización independiente, la de la Ley de Asociaciones Profesionales, resultó a la postre, una nueva concesión. Primero se organizó la lucha contra la Ley, que culminó en el multitudinario acto en el Luna Park, con la participación de los diputados de la JP. Pero luego se puso en juego la "verticalidad". Otero señaló que "quien está contra la Ley está contra Perón" y los diputados la votaron disciplinadamente. (...) La impresión que las bases de la JTP sacaron de esta solicitada de sus dirigentes, expresada por centenares de compañeros en fábricas y barrios, la resumió gráficamente uno de ellos en carta al director de una revista popular: "Entonces para que mierda nos movilizamos 20.000 tipos al Luna Park?" ("Movimentismo y Liberación" El Combatiente No. 102. Miércoles 26 de diciembre de 1973)

${ }^{180}$ Se denominaba "movimientista" al sector del peronismo revolucionario que sostenía la idea de que el peronismo en su conjunto era revolucionario, incluido el propio Perón, y que la dinámica de la lucha depuraría al movimiento de sus "traidores". Esta posición fue asumida con matices, sobre todo durante 1973, por Montoneros (unificados con las FAR), la Juventud Peronista y sus organizaciones afines: Juventud Universitaria Peronista, Unión de Estudiantes Secundarios y Juventud Trabajadora Peronista. No obstante, consideramos sugerente la distinción analítica que incorpora Lucas Lanusse quien apela a la categoría de "tendencista" para definir la posición de estas organizaciones. La diferencia estaba en que esta última posición, a diferencia de la "movimentista", sí planteaba que existían diferencias irreconciliables al interior del movimiento y llamaban a dar el combate en su interior. Además asumían que su Perón no era genuinamente revolucionario, al menos estaba dispuesto a volcarse a aquella definición (2005:255-256).

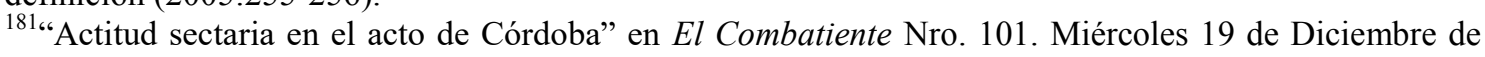
1973
} 
fuerzas propias en la batalla interna del peronismo, que en la construcción de espacios o instancias de unidad antiburocrática con las corrientes de izquierda.

La insistencia del PRT-ERP en su polémica con la JTP respondía al innegable peso que había adquirido esta última en las fábricas. Aquel fenómeno representaba un problema y un desafío para la organización ya que, por un lado, consideraba a la JTP como un aliado fundamental en la lucha antiburocrática y, por el otro, como una influencia ideológica negativa para la clase obrera. Desde la perspectiva perretista el peronismo de izquierda, sobre todo el profesado por Montoneros, estaba atravesado, en última instancia, por la ideología de la "conciliación de clases" y es por eso que, al igual que el "espontaneísmo" o el "reformismo", era considerado como una "enfermedad ideológica" que debían ser combatida en el seno del movimiento obrero. De este modo, el partido llamaba a sus militantes fabriles a no descuidar la "atención" de los obreros que continuaran bajo la influencia de aquellas corrientes y "recuperarlos para la causa revolucionaria" 182 .

Así, los desafíos en las fábricas se multiplicaban para el PRT-ERP: el mayor fortalecimiento de las cúpulas sindicales, habilitado por la nueva Ley de Asociaciones Profesionales, le exigía aumentar los niveles de unidad de acción y de coordinación con aquellas corrientes dentro y fuera de los establecimientos pero, a su vez, el crecimiento de la JTP, le planteaba un límite a su influencia. Para afrontar esa situación necesitaba construir una organización sólida en cada uno de los centros fabriles y en ese sentido se lanzó a construir "el partido en las fábricas".

\subsection{Construir "el partido en la fábrica".}

La búsqueda por consolidar el trabajo político y sindical en los grandes centros productivos fue una constante en el PRT-ERP. Como ha señalado Pablo Pozzi (2004), si bien siempre tuvo como objetivo penetrar en el movimiento obrero, fue a partir de fines de 1972 que la organización comenzó a revertir los efectos de la "desviación militarista" y, bajo la consigna "ir hacia las masas", intensificó su labor entre los trabajadores. Sin embargo, las primeras huellas de esta reorientación pueden hallarse en una serie de recomendaciones e instrucciones redactadas por Mario Roberto Santucho desde la cárcel y publicada en el BI Nro. 25 de la organización con motivo del triunfo de la Lista Marrón en SMATA Córdoba, en abril de 1972. A nuestro entender ésta fue una

\footnotetext{
${ }^{182}$ El Combatiente Nro. 134. Miércoles 11 de Septiembre de 1974.
} 
anticipación de (o más bien la transición a) lo que consideramos la etapa madura de la línea sindical perretista que se consolido en el período 1973-1975.

El escrito desmenuzaba cada una de los aspectos, tareas e iniciativas que no podían faltar en el desarrollo de ningún frente fabril ${ }^{183}$. Los objetivos apuntaban a: "la construcción del Partido, la formación de células, estrecha ligazón con las masas, aumento constante de nuestra influencia, lucha por la dirección del movimiento en su conjunto, fortalecimiento y crecimiento del ERP, amplia difusión de nuestra línea, nuestras consignas, el nombre de nuestra organización y nuestra bandera"184 . Para ello la militancia fabril perretista debía partir de la lucha reivindicativa y concentrarse en influenciar al personal activo, es decir, a la base obrera.

La lucha sindical era el primer aspecto que desarrollaba el documento. Según Santucho los militantes dedicados a esta tarea debían conocer "al dedillo" los problemas de la fábrica, así como la situación de cada una de sus secciones, para intervenir en todas las luchas reivindicativas que surgieran. Ahora bien, al mismo tiempo debían cuidarse de no "sacar línea sindical de la galera", es decir, evitar imponer medidas u orientaciones que no surgieran de la experiencia de los obreros. Aquí el arte pasaba por encontrar la justa medida entre la indecisión y el "aventurerismo". Además instaba a consolidar y desarrollar una “corriente clasista, con el programa 'por la guerra y el socialismo' como eje de un amplio frente sindical antiburocrático, antidictatorial y antipatronal, que se proponga lograr la dirección del movimiento obrero". Como vemos en esta última disposición aún convivían de manera confusa y mezclada los aspectos legales e ilegales de la tarea sindical.

Otro de los temas que trabaja el documento es el de la "propaganda y agitación". En este punto insistía en la difusión de folletos y de la línea partidaria, y en el desarrollo de la propaganda armada ligada a las luchas reivindicativas de las fábricas. Por otro lado reclamaba regularizar la publicación de un boletín fabril con un intervalo semanal, mientras que en el aspecto organizativo instaba a construir distintos tipos de organismos al interior de los establecimientos:

"Como sabemos debemos construir: a) Células partidarias de militantes profesionales e incorporar a ellas a los mejores, los más destacados obreros de las distintas fábricas. b) Grupos o círculos de simpatizantes o colaboradores, atendidos por militantes, e incorporar a todos los obreros que estén de acuerdo con la línea del Partido a colaborar

${ }^{183}$ El PRT-ERP denominaba frente fabril a una fábrica grande o a un grupo de fábricas de la misma industria ubicadas en una misma zona que por algunas circunstancias se hacía necesario tomarlas de conjunto. (Boletín Interno Nro. 63, julio de 1974)

${ }^{184}$ Boletín Interno Nro. 25 En: Mattini, 2007:113 
mínimamente. d) Células del ERP destinando a ellas a todos los compañeros decididos a combatir y que por sus características o por la distribución de fuerzas puedan ser prescindibles en la actividad reivindicativa. e) Una agrupación sindical por la guerra y entre la gente que esté en condiciones de enfrentar eficazmente una eventualidad de pasar a ser la dirección clandestina de la lucha reivindicativa, d) Comandos de apoyo al ERP". ${ }^{185}$

Por ese entonces, dentro de la organización ya existía la Mesa Nacional Sindical, organismo que reunía a todos los responsables sindicales de las distintas regionales en las cuales, a su vez, contaban con sus propias mesas en sus jurisdicciones. Estos órganos, que tenían el objetivo de coordinar e impulsar las tareas y la línea sindical ${ }^{186}$ a nivel nacional y regional, recién alcanzaron un funcionamiento regular hacia 1973, según Mattini ${ }^{187}$.

Creemos que ésta fue la base desde la cual la organización perfeccionó su estructura organizativa cuando, en tiempos democráticos, se lanzó a construir "el partido en la fábrica". Como plantean Scoppetta y Torres (2014) ésta fue una de las líneas fundamentales de la política sindical de la organización en el período post-electoral, con el que se buscaba reconstruir el partido luego de recorrer la experiencia del militarismo, fortaleciéndolo y multiplicándolo en base a la clase obrera como piedra angular de su estrategia de poder. El crecimiento de la conflictividad obrera, que llegaba con fuerza al cinturón industrial de Buenos Aires, era interpretado como una oportunidad inigualable para terminar con las expectativas electorales, lo cual, a la vez, comenzaría a minar la relación del movimiento obrero con el peronismo gobernante (Scoppetta y Torres, 2014: 106-107). Por otro lado afirmaban:

"El resultado del presente auge de masas dependerá de quien logre asumir finalmente la dirección, dependerá de si el peronismo burgués logra imponerse y controlar o si por el contrario, el proletariado revolucionario, organizado en el partido marxista-leninista, es capaz de librarse del canto del cisne de la burguesía, de sus engaños, desarrollar una política independiente de clase y acaudillar, movilizar tras de sí a las amplias capas populares, al campesinado pobre, los pobres de la ciudad y la pequeño-burguesía urbana. La clave para lograr que la clase obrera se coloque a la cabeza de la lucha revolucionaria, conquistando la dirección del proceso, es la influencia, madurez y consistencia de su Partido Revolucionario. Esto se logra básicamente centrando el esfuerzo en la construcción en las fábricas (...)",188

185 Ídem

${ }^{186}$ La Mesa Nacional Sindical eventualmente editaba materiales de formación partidaria donde compilaba documentos o artículos de El Combatiente u otras publicaciones que sirvieran para la instrucción de los militantes del frente.

${ }^{187}$ Según indica Luis Mattini los responsables nacionales de dicho organismo eran él y Antonio del Carmen "Negrito" Fernández. Además agrega que la Mesa Nacional Sindical funcionaba como un "reloj" de manera semanal, teniendo como sede predilecta la ciudad de Córdoba (Entrevista a Luis Mattini por el autor, Buenos Aires, 2017)

188 "Los obreros y la lucha revolucionaria" El Combatiente Nro. 88, viernes 31 de agosto de 1973 
Esto implicaba multiplicar las tareas en "la batalla por la consolidación y desarrollo" de la organización en los centros fabriles. A continuación intentaremos reconstruir cuales fueron los pilares de esta política con la que los perretistas buscaron construir el partido al interior de cada uno de los establecimientos, creando una estructura organizacional basada las células partidarias y los comités fabriles, dotándose de herramientas de propaganda, cuya expresión más creativa fueron los boletines fabriles, e impulsando agrupaciones sindicales.

\section{3.a. Las células: el esqueleto (el modelo ideal)}

Las células eran el organismo básico del partido, la instancia donde se organizaban los militantes, en la que discutían la línea política de la organización y establecían las líneas de acción en un frente de masas determinado. De modo que la existencia de una éstas era el primer requisito para comenzar a edificar el partido en una fábrica y la construcción de otras nuevas (y especializadas en distintas tareas) el paso siguiente.

El partido planteó un modelo ideal de cómo debía desarrollarse la estructura organizativa y sus respectivos organismos en los establecimientos. No obstante es preciso advertir que en la práctica no logró garantizarlo en todos los casos ya que la militancia fabril perretista tendió a ajustar la estructura organizativa en función de los límites y las posibilidades que brindaba la realidad de cada fábrica. Ahora bien, en última instancia, aquel era presentado como un horizonte al que se debía aspirar aún en los casos en que hubiera dificultades. En tal sentido, estudiar el modelo organizativo que proponía el PRT-ERP en sus términos ideales permite comprender cuál era el espíritu que animaba su propuesta y, al mismo tiempo, analizar sus alcances y limitaciones en la experiencia militante.

La apuesta principal estaba en la "especialización" de la militancia en las distintas tareas partidarias (principalmente la sindical, la militar y la política), ya que se partía de la idea de que un mismo grupo de militantes no podía desarrollar cada una de ellas con la profundidad que merecían. Desde la perspectiva perretista dedicar una célula a cada tarea era pasar de "métodos artesanales" a "métodos profesionales" de trabajo.

En febrero de 1973 el partido intentaba solidificar los criterios que había vertido Santucho hacía casi un año. En el BI Nro. 37 el Buró Político perretista "reiteraba conceptos" acerca de cómo organizarse en los frentes de masas, haciendo énfasis nuevamente en el frente fabril, para lograr un desarrollo "armónico" de la organización. 
Para ello la militancia debía esforzarse por construir de manera integral distintos tipos de células: células de masas, células militares, células de propaganda y eventualmente células de trabajo legal. El desarrollo de estos tres organismos debía ser la garantía para evitar caer en el "sindicalismo", el "militarismo" o en desarrollo "superficial de la organización".

La célula de masas era aquella que se ocupaba de todo lo referido a la lucha reivindicativa, al desarrollo de agrupaciones sindicales y de las herramientas que dispusiera la organización para esta tarea, por lo que según el BI debía ocupar el $80 \%$ de su tiempo en todas las cuestiones políticas y reivindicativas relacionadas con las fábricas, mientras que el 20\% restante debía ocuparse colaborando y coordinando con las otras células del frente. Podemos decir que ésta era la "célula madre" del PRT-ERP, ya que era la que debían construir los militantes partidarios allí donde iniciasen de cero un trabajo político, condensando todas las tareas del frente. En ese sentido su primera tarea consistía en construir los otros dos tipos de células en base a la incorporación de obreros de la fábrica sobre la que se estuviera trabajando. Por su parte la célula militar, una vez construida, debía ocupar el $80 \%$ de su tiempo en la realización de acciones ligadas a la fábrica y a sus barrios lindantes aunque también debía destinar un $20 \%$ a la colaboración activa con tareas de propaganda. Fundamentalmente se le exigía que ayudara operativamente al ingreso de periódicos, boletines, volantes y todos los materiales que dispusiera la célula de propaganda. Esta última, a su vez, debía encargarse de la distribución de todos los materiales de propaganda del partido, y se debía encargar de redactar e imprimir, en estrecha colaboración y relación con la célula de masas, los boletines fabriles del partido. Por último la célula de trabajo legal debía establecerse allí donde se pudiera organizar a obreros interesados en el trabajo político amplio y barrial, dedicándose a construir los Comités de Base (que luego serían organismos del Frente Antiimperialista por el Socialismo -FAS-) en los barrios lindantes a las fábricas y, en ese sentido, abracar más de un establecimiento, así como también organizando a las esposas de los trabajadores, las ollas populares y la solidaridad de personalidades políticas y otras organizaciones legales en el marco de los conflictos sindicales $^{189}$.

\footnotetext{
${ }^{189}$ Como se verá, la importancia que fue adquiriendo la tarea sindical en el desarrollo del partido llevó a que en el año 1975 el Buró Político autorizara la construcción de células sindicales diferenciadas de las células de masas.
} 
Desde la concepción de la organización el desarrollo desparejo o parcial de estas células podía llevar a la exacerbación de un aspecto en detrimento de otro, rompiendo el equilibro complementario que se buscaba para esta nueva etapa:

"Si en un frente tenemos sólo células de masas, el desarrollo se frustrará, no avanzaremos sólidamente, las células serán débiles y los militantes formados unilateralmente, probablemente influidos por el sindicalismo. Si sólo tenemos unidades de combate, la organización será muy conocida y querida pero no se concretará en avances organizativos ni en influencia real entre las masas. Las células se cocinarán en su propia salsa, se frustrará el desarrollo y se tenderá hacia el militarismo. Si sólo tenemos células o actividad de propaganda y agitación, la organización y su línea será conocida superficialmente (...) Se hará un trabajo propagandístico amplio, sin resultados en el terreno de la organización."

Estas orientaciones comenzaron a sistematizarse hacia fines de 1973 y principios de 1974. Así en agosto de 1973 la organización exhortaba a sus militantes a "formar centenares de células fabriles" reafirmando la idea de que la lucha por la dirección del proceso revolucionario pasaba por las fábricas ${ }^{191}$. Bajo esta orientación, en septiembre de 1974, como parte de las resoluciones del Comité Central partidario se publicó un documento titulado "Las tareas centrales del Partido" en el que se proponían siete recomendaciones para la "construcción del partido en las fábricas". En él se repasaban cuestiones organizacionales como la distribución de cuadros en las zonas y regionales, la realización de cursos de formación, la necesidad de promover reuniones periódicas zonales y nacionales para intercambiar experiencias y el mejoramiento de la propaganda partidaria. En cuanto a la estructura partidaria al interior de los establecimientos insistía nuevamente en la necesidad de construir las células estructurales (de masas, militar, de propaganda y legal) y proponía, en la medida de lo posible, organizar otro tipo de células y "subequipos de masas" que tomaran nuevas tareas, o tareas más específicas:

"Una célula o subequipo se ocupará por ejemplo en tareas políticas y educativas con los delegados combativos, distribuir entre ellos la propaganda escrita, hacer cursos, llevar adelante la lucha ideológica, en una palabra hacer todo lo posible por ganar la mayor cantidad posible de delegados para las ideas revolucionarias y para el partido.

Una célula o subequipo se ocupará de los jóvenes obreros desarrollando con ellos intensa actividad política e ideológica. Otra célula o subequipo puede tomar una villa, barrio o población situada en la zona de influencia de la fábrica, etc.

Para la incorporación orgánica de la periferia, para la captación e incorporación de nuevos compañeros, es necesario apelar a toda una gama flexible de formas

\footnotetext{
${ }^{190}$ Boletín Interno Nro. 37. 5 de febrero de 1973

191 "Los obreros y la lucha revolucionaria" El Combatiente Nro. 88, viernes 31 de agosto de 1973
} 
orgánicas: equipos de simpatizantes, círculos de lectores, grupos de estudio, comandos de apoyo al ERP, equipos de agitación y propaganda, etc." 192

Esta masa de organismos y actividades posibles surgían de la idea de que la clase obrera poseía energías inagotables, y que para aprovecharlas era necesario que estén dirigidas por un fuerte partido proletario que las organice. En la concepción del PRT-ERP la práctica debía ser audaz y arrolladora, de lo contrario se perdía un tiempo muy valioso en el camino vertiginoso hacia la revolución. En ese sentido la ecuación era sencilla: "el partido es como una dínamo, las tareas son comparables a las lámparas. Si el dínamo es suficientemente poderoso, las lámparas se encienden"193.

Alrededor de las células a su vez debía organizarse el "radio de influencia" del partido, es decir el conjunto de personas a las que los militantes "atendían” y les hacían llegar la línea de la organización. Estas personas podían cumplir algunas tareas, dependiendo del nivel de compromiso que estaban dispuestas a asumir, por lo que las células las organizaban y jerarquizaban como "simpatizantes", "contactos" o "lectores" 194. Los simpatizantes eran aquellos que por algún motivo no podían ser militantes pero que eran considerados como "parte del partido". Estos cotizaban dinero mensualmente, recibían El Combatiente y debían vender al menos un ejemplar del mismo, por lo que permitían multiplicar la influencia de la organización. Por su parte el "contacto" era alguien que también recibía una atención específica, también funcionaba como correa de trasmisión de la línea del partido pero que no tenía un vínculo tan formal y regulado como el simpatizante. Y por último aparecía el "lector" que era todo aquel que recibía "religiosamente" la prensa partidaria y coincidía con las posiciones de la organización. Éste era la "antena fundamental entre las masas" que completaba el "edificio del partido" al interior de las fábricas (y en todo frente de masas) ${ }^{195}$.

\footnotetext{
192 "Las tareas centrales del Partido" El Combatiente Nro. 134, miércoles 11 de septiembre de 1974

${ }^{193}$ Boletín Interno Nro. 63, julio de 1974

194 Auge de masas y construcción del partido" El Combatiente Nro. 194, miércoles 3 de diciembre de 1975.

${ }^{195}$ En julio de 1975 el Comité Central modificó los estatutos y reorganizó a las células por tríos, un número que permitiría garantizar una mejor coordinación y ejecución de las tareas. El trio reemplazaba a las células organizadas con cuatro, cinco o seis militantes y buscaba reforzar la especialización y profesionalización de los militantes: "Al disponer la construcción de los tríos, nuestro Partido precisó que cada uno de los miembros que lo integran (militantes y aspirantes) debe contar, por lo menos, con una periferia formada por cuatro simpatizantes (cotizan, reciben periódico y aseguran la distribución de otro, como mínimo) y otros tantos contactos o lectores, [que] en conjunto, atienda y se apoye, obligatoriamente en un mínimo de 24 hombres y mujeres del pueblo. Ese es el camino por el que el trio se liga con las masas, resuelve sus problemas de funcionamiento, extiende el radio de influencia política, gana nuevos miembros para el Partido, difunde la prensa y la propaganda revolucionaria, lleva la línea partidaria al
} 
Como vemos la idea de construir el "partido en las fábricas" suponía replicar la estructura partidaria a escala fabril desarrollando todas las dimensiones, tareas y organismos expuestos anteriormente, por lo que para completarla era necesario una dirección al interior de los establecimientos: el Comité Fabril. En el organigrama perretista éste debía funcionar como un órgano dirigente que reuniera a los responsables de cada una de las células para coordinar las tareas y la línea de intervención de la organización en todos sus aspectos, además de ser un enlace con las direcciones regionales y nacionales del partido. El Comité Fabril debía elaborar un plan de funcionamiento del conjunto de las células, adecuado a la situación concreta de la fábrica. A su vez era el encargado bregar por la "armonización" de las distintas tareas, velando por una buena distribución de los recursos militantes. Así, por ejemplo, si en una fábrica había tres células de propaganda, una militar y ninguna sindical, desde el comité se debía redistribuir las fuerzas para que se encarara la actividad sindical, destinando a esa tarea a militantes de las células de propaganda, donde habría una fuerza desproporcionada en relación a las otras ${ }^{196}$.

El Comité Fabril además tenía la responsabilidad de atender los problemas de fábricas aledañas donde no se tuviera trabajo político (o éste fuera débil) así como de los barrios de la zona. Es que las fábricas eran concebidas como el punto de partida desde donde construir la hegemonía de la clase obrera, organizando no sólo a ésta última, sino a toda la comunidad que las rodeaban. En ese sentido el vínculo del Comité Fabril con los barrios podía tener múltiples objetivos: en muchos casos se utilizaba como una estrategia de penetración (ya que se incorporaban trabajadores a partir de dicha actividad), además de que permitía seguir el trabajo político con obreros despedidos, y fundamentalmente evitar el aislamiento en momentos de conflictos. Desde la concepción perretista esto era fundamental, ya que le daba mayor respaldo, apoyo y legitimidad a las luchas sindicales, al mismo tiempo que posibilitaba la relación entre la clase obrera y otros sectores de la población que para la organización eran parte de la “alianza básica" de la revolución. De este modo, garantizar el trabajo político entre los comerciantes de la zona fabril y entre los vecinos de los barrios aledaños era una tarea directamente ligada al trabajo en las fábricas.

pueblo" ("Las células: el motor del partido" El Combatiente Nro. 181, miércoles 3 de septiembre de 1975)

196 "Preparar al PRT para dirigir a las masas" El Combatiente Nro. 158, miércoles 12 de marzo de 1975. 
Según Luis Mattini, los Comité Fabriles debían ser la "columna vertebral” del partido en la fábrica y como la autoridad máxima en ese ámbito "perseguía el objetivo de que cada especialidad estuviera convenientemente 'balanceada' para la combinación de las tareas y efectivizara el conocido postulado "combinar todas las formas de lucha" (Mattini, 2007: 242). Pero tampoco debía forzarse su construcción si no era el resultado de un desarrollo genuino y necesario. De hecho el propio Santucho advertía sobre los riesgos de asumir la orientación de manera formal y esquemática:

"Es un caso repetido el del militante que encara una tarea esquemáticamente, que por ejemplo en conocimiento de la resolución partidaria de formar agrupaciones legales o semilegales y tendencias clandestinas en lo sindical, acude a un frente fabril a plantear de entrada esa línea sin conocer la situación real del frente, o el compañero que ante la resolución de los Comité Fabriles resuelve la situación cambiando el nombre de la célula existente"197

Los Comités Fabriles funcionaron como una meta y una orientación a seguir para la militancia fabril perretista. El hecho de que se tratara de modelo difícilmente alcanzable, por el nivel de desarrollo y especialización y por la cantidad de militantes que requería, apuntaba a que la militancia fabril no perdiera la iniciativa ni se conformara con algunos logros alcanzados.

\section{Los boletines fabriles}

La propaganda política fue un pilar central y una prioridad del PRT-ERP en todos los frentes, pero la fábrica debía ser el lugar prioritario donde "bombardear" sistemática y planificadamente con las ideas del partido. De este modo, además de la utilización de los volantes, las "mariposas", el periódico nacional, la organización desarrolló los boletines fabriles. Se trataba de una herramienta que buscaba ligar los problemas cotidianos de la fábrica con las apuestas políticas e ideológicas de la organización. En él se veía reflejada la conjugación de las múltiples dimensiones que, se suponía, debía tener el trabajo fabril del PRT-ERP. Como se señala en una nota de El Combatiente:

"El Boletín Fabril debe ser un reflejo y a la vez un orientador de la vida política del frente, que impulsa las distintas luchas de cada fábrica, denunciando las injusticias diarias que se cometen y estableciendo las conexiones del Partido con las masas más amplias, llevando hasta ellos la línea partidaria y las ideas de la Revolución.

En el Boletín Fabril deben encontrar cabida todos los problemas que se presenten en la fábrica, ya sea con la patronal o la burocracia, o con ambas; todas las inquietudes políticas tanto referidas al país, como a otros países vistos desde una óptica de clase, desde un enfoque proletario y leninista. También se explicaran en él los aspectos

197 “Método y política” El Combatiente Nro. 167, lunes 12 de mayo de 1975 
centrales del marxismo leninismo (...) Es decir que el Boletín Fabril debe cubrir tres aspectos; el reivindicativo, el político y el ideológico" ${ }^{198}$.

En ese sentido no era ni el periódico partidario ni un volante netamente sindical, sino la síntesis de ambos. Para ello debían prevenir dos errores o déficits a la hora de redactarlos: no podía tomar sólo los problemas reivindicativos y dar solamente respuestas sindicales ya que de esa manera se lo estaría confundiendo y equiparando a un boletín sindical de una agrupación, perdiendo su función de material partidario, pero al mismo tiempo debían evitar bajo todo punto de vista que se transforme en un pasquín ideológico y político general y no refiriera a la situación particular de las fábricas ${ }^{199}$. De este modo debía complementar tanto a los periódicos partidarios como a los volantes meramente sindicales, ayudando a consolidar la influencia de la organización entre los trabajadores y a avanzar desde lo reivindicativo a lo político.

El antecedente más inmediato de este tipo de herramienta eran los boletines sindicales que había publicado el PRT en tiempos de unidad con el morenísmo. Durante los tres años en que la organización se mantuvo unificada publicó numerosos boletines sindicales $^{200}$ junto a otro tipo de publicaciones ocasionales (como boletines de huelga o volantes específicos para un conflicto). Estos sin embargo eran estrictamente sindicales e iban dirigidos y abarcaban las problemáticas de toda una rama industrial por lo que no eran específicos por establecimiento, más allá de algunas excepciones (Mangiantini, 2018).

Contemporáneamente al PRT-ERP también existían organizaciones que producían materiales similares: tal es el caso del PST que producía boletines informativos o boletines de huelga allí donde tenía trabajo partidario, o de organizaciones peronistas como el PB y la propia JTP que también producían boletines aunque en su mayoría sindicales. Sin embargo, los boletines fabriles perretistas se acercaban más a los clásicos periódicos de fábrica comunistas ${ }^{201}$, en tanto se asemejaban más al periódico nacional que a un material sindical, buscando cumplir objetivos propagandísticos, organizativos

\footnotetext{
198 "El boletín fabril: una herramienta de lucha" El Combatiente Nro. 205, 26 de febrero de 1976.

199 "La propaganda de masas: los boletines fabriles" El Combatiente Nro. 155, 17 de febrero de 1975.

${ }^{200}$ El activista de la carne; El activista textil, El Activista Metalúrgico, El Activista Azucarero del Norte, el Boletín Sindical Gráfico, El Activista Ferroviario, etc

${ }^{201}$ Este tipo de materiales tenía una larga tradición en la cultura comunista y que en argentina había sido introducido fundamentalmente por el Partido Comunista (PCA) como parte del proceso de "bolchevización" que impulso dicha organización durante los años veinte: en ese marco los periódicos comunistas por fábrica o empresa fueron parte de los repertorios organizacionales adoptó el PCA en su adecuación a los cánones del Comitern. Estos eran elaborados y repartidos por las distintas células partidarias que tenían un carácter similar (clandestinos y de base) y los mismos criterios de periodicidad, que tuvieron los boletines fabriles perretistas (Camarero, 2007).
} 
$\mathrm{y}$ cohesionadores en una realidad $\mathrm{y}$ en un espacio acotado y dirigido a un sector específico de trabajadores.

Así, a partir de la combinación de artículos nacionales, muchas veces extractados de $E l$ Combatiente, y de análisis específicos de la realidad fabril, los boletines se transformaban en pequeños periódicos perretistas que dinamizaban la actividad política de la organización al interior de los establecimientos. Según Luis Mattini:

"Era lo que expresaba la política del partido adentro de la fábrica. El boletín fabril era clandestino, el equipo que lo redactaba era clandestino, expresaba toda la acción que nosotros nos interesaba, por supuesto gran parte de la acción sindical, aunque teníamos que tener cuidado para no deschabarse. Si nosotros teníamos muy fuerte [...] alguna agrupación, el boletín fabril tenías que manejarlo con cierta discreción. Pero el boletín fabril expresaba por ejemplo las acciones que hacía el ERP... era una especie de... nosotros teníamos obsesión con la prensa escrita, y era una especie de periódico de fábrica, pero nosotros le decíamos boletín fabril."202

La particularidad de estos boletines estaba en que combinaban criterios de "propaganda" y de "agitación" en un mismo material. De este modo, la estructura básica consistía en una nota editorial, que trataba de vincular la situación política general con la de la fábrica o la localidad en la que se hallaba esta última, una nota ideológica donde se podían leer textos o pasajes cortos de clásicos del marxismo que ayudaran a entender teóricamente los problemas específicos que vivían los trabajadores en los establecimientos, definiciones sencillas sobre el capitalismo, el imperialismo y el socialismo y una serie de notas sindicales específicas de la fábrica. Al mismo tiempo esta estructura era completada con gráficos y dibujos que explicaban de manera sencilla el contenido de las notas, así como ilustraciones y frases que oficiaban de separadores entre algunos de los artículos. Frases de Lenin, Guevara, Ho Chi Minh se combinaban con llamados a incorporarse y fortalecer ERP, anuncios de los periódicos partidarios, etc., que lo hacían mucho más atractivo y accesible.

Al ser un órgano partidario la simbología perretista era una marca registrada y las imágenes alusivas a la guerra revolucionaria no escaseaban. En ese sentido aparecían recurrentemente dibujos de fusiles, combatientes, estrellas de cinco puntas, etc. Se hacía evidente que el boletín fabril era una herramienta que buscaba hacer empalmar la lucha sindical con la lucha armada. De este modo se podían encontrar notas en las que se enseñaba a los lectores a preparar y utilizar bombas molotv $\mathrm{u}$ otras instando a formar comandos de apoyo al ERP al interior de la fábrica. También funcionaba como difusor

\footnotetext{
${ }^{202}$ Entrevista a Mattini por el autor, Buenos Aires, 2017.
} 
de las acciones que realizaban los comandos o escuadras de la fábrica, en caso de que la hubiera, o de aquellas que actuaban desde afuera.

Los boletines eran, como las células, clandestinos tanto en su elaboración como en su distribución. Las notas no aparecían firmadas, y se tenía que tener especial cuidado en no "quemar" a ningún militante que fuera referente o miembro de alguna agrupación sindical. Por otro lado su ingreso a la fábrica, como vimos, muchas veces lo garantizaban las células militares, distribuyéndolos en tomas de guardia o piqueteos en la puerta de la fábrica.

Otra cuestión central que buscaba cubrir era "la participación activa de los trabajadores; en ese sentido, el Partido planteaba que 'para lograr esto es necesario que los compañeros del frente sientan el boletín como suyo. Que lo redacten, que sugieran los temas que ha de tratar. Es decir, que tiene que ser un periódico abierto para ellos, a sus inquietudes, a sus problemas, a sus preocupaciones"” (Scopetta y Torres, 2014: 108). En ese sentido se insistía en que los mismos debían ser redactados por militantes de las fábricas ya que esa era la única garantía de que se trataran los problemas en profundidad. Si bien la organización aceptaba que en los inicios de un trabajo político en fábricas importantes se apuntalara y reforzara con militantes de otros frentes, esto debía ser estrictamente temporal.

Para septiembre de 1974, el Comité Central informaba sobre la existencia de 32 Boletines Fabriles, ascendiendo a principios de 1975 a más de 40 ejemplares, entre ellos: "17 de abril” (Fiat), "Máximo Menna”, “El Combatiente Telefónico”, "El Obrero Petrolero" (YPF de La Plata), "El Combatiente Metalúrgico” (Dálmine - Siderca), "Boletín Fabril Metalúrgico" (TENSA), "Boletín Fabril de los obreros del PRT" (SOMISA), "Luis Norberto Blanco" (Metalúrgicos de Rosario), "El Zafrero" (Ingenio Ledesma), "José Luis Castrogiovanni" (Eaton), "Luis Pujals" (Ford), "Marcelo Dameri"(General Motors), "Boletín Fabril de los Obreros de la Carne” (Swift), "Héroes de Trelew" (Obreros del Pescado), "Héctor Antelo" (Del Carlo), etc.

Una de las principales dificultades que presentaba la publicación de estos materiales era la regularidad. Este aspecto era fundamental si se quería lograr que el boletín formase parte de la politización de los obreros de una fábrica. La sistematicidad de una publicación era un requisito indispensable en momentos en que circulaban cientos de volantes y materiales de otras organizaciones. De este modo en la mayoría de los documentos, minutas o informes en que se hace alusión a los boletines siempre se remarca la necesidad de regularizarse, planteándose como ideal a cumplir la publicación 
semanal: "El aspecto de la regularidad, que es fundamental para la penetración de las ideas revolucionarias en las masas, aún no ha sido comprendido cabalmente en el Partido como lo indica el hecho de que editamos cerca de 40 boletines y ninguno de ellos es aún semanal”203.

El boletín fabril se producía allí donde había una importante inserción del partido, de hecho para PRT-ERP se trataba del "arma político-ideológica clave para el afianzamiento, consolidación de los comités de fábricas". Era la muestra cabal de que se había logrado estructurar el partido en sus múltiples dimensiones al interior de un establecimiento. Esto queda claro en el testimonio de Luis Mattini:

Entrevistador: Claro... ¿y en todas las fábricas donde estaban había un boletín fabril?

Mattini: Bueno esa es una buena pregunta... en realidad era al revés, si estaba había boletín fabril era porque estaba el partido en serio... es decir el símbolo de que estábamos en esa fábrica era que estaba el boletín fabril. Si no había boletín fabril mmm..."204

En esa misma dirección apunta el testimonio de "Tito" quien remarca que el boletín jugaba un papel importante debido a que ayudaban mucho a organizar el "radio de influencia", y que el hecho de que existieran en una fábrica era un claro indicador del desarrollo ya que para sostenerlo periódicamente se necesitaba una gran capacidad organizativa además de una inserción considerable ya que "se aspiraba a que el boletín fuera hecho por los propios obreros"205.

Como marcan los testimonios, el boletín era un "símbolo" del trabajo fabril del PRTERP y al mismo tiempo un dato objetivo con el que contaba la dirección partidaria para saber a ciencia cierta que niveles de organización se habían logrado en la fábrica, ya que la edición y producción de este tipo de material requería de una estructura y de un desarrollo previo difícil de garantizar allí donde no había demasiada construcción.

\section{3.b. Las agrupaciones sindicales.}

La agrupación sindical era definida por la organización como la herramienta "casi imprescindible en la lucha sindical" ${ }^{\text {206 }}$. Ya desde 1969 caracterizaba que se trataban de herramientas "enormemente útiles" para garantizar el "vínculo entre el Partido, la

\footnotetext{
203 "Las tareas centrales del Partido" El Combatiente Nro. 134, miércoles 11 de septiembre de 1974

${ }^{204}$ Entrevista a Luis Mattini por el autor, Buenos Aires, 2017.

${ }^{205}$ Entrevista a "Tito" por el autor, Cafayate, 2018

206 "Carácter político de la lucha sindical” El Combatiente Nro. 155, 17 de febrero de 1975.
} 
vanguardia y sectores de las masas constituyendo una excelente correa de transmisión de las posiciones partidarias" 207 .

Teóricamente la agrupación era el espacio donde se unificaba la vanguardia obrera con "lo mejor de las masas" de una fábrica, es decir, con trabajadores dispuestos a organizarse para luchar por mejores condiciones de vida, contra la burocracia, por la democracia sindical y la independencia del estado, de modo que debía ocuparse de dinamizar la actividad de los organismos gremiales allí donde se los haya conquistado al mismo tiempo que incorporar a aquellos trabajadores dispuestos a asumir mayores compromisos y definiciones. De este modo era necesario seguir construyéndolas aun cuando se ganase un sindicato o un espacio gremial, ya que su tarea debía ser la de ir elevando paulatinamente el programa reivindicativo una vez que se fueran cumpliendo las principales exigencias con las que se habían ganado la confianza de sus compañeros. No obstante debían hacerse todos los esfuerzos por evitar que la agrupación reemplazara al sindicato o comisión interna para no estrechar las tareas propias de la agrupación y fundamentalmente para no obturar la posibilidad de que el conjunto de los trabajadores asumiesen nuevas tareas y participasen de la actividad gremial.

Para los perretistas en Argentina la lucha por las reivindicaciones económicas estaba estrechamente ligada a la lucha contra la burocracia por lo que la lucha antipatronal aparecía en el mismo plano que la lucha antiburocrática. En ese sentido la construcción de las agrupaciones eran concebidas como una necesidad en tanto las mismas debían desarrollar las reivindicaciones que no eran defendidas por la burocracia al mismo tiempo que luchar por la "recuperación" de los organismos de representación obrera. De este modo estas herramientas organizativas debían proponerse como tarea central la conquista de CD, CIR y sindicatos.

Por último se insistía en la necesidad de formar instancias federativas de organización, tanto provinciales como nacionales, que nuclearan a todas las agrupaciones de dicha tendencia clasista, combativa y antiburocrática. Ese fue el sentido que la organización le dio, como se verá, al MSB.

En el marco de las advertencias constantes que la organización hacía a sus militantes sobre los "riesgos" del trabajo sindical, la sectarización de las agrupaciones aparecía como un error posible y frecuente. El PRT-ERP remarcaba constantemente a sus militantes el carácter "eminentemente económico" que tenían las agrupaciones e instaba

\footnotetext{
207 "Resoluciones sobre táctica y organización aprobadas por el Comité Central del PRT en su reunión de Marzo de 1969" En: http://eltopoblindado.com/
} 
a que no se forzaran sus definiciones más allá de "la conciencia política de las masas". En esta prescripción partidaria reverberaba nuevamente, como en toda definición sindical perretista, el fantasma morenista que podía llevar a los militantes a confundir las tareas del sindicato o de las agrupaciones con las del partido revolucionario:

"El planteo de 'carácter político' a la agrupación, generalmente tiene su origen en el miedo a caer en el economicismo y en el reformismo como crimen mayor de los revolucionarios y da una solución mecánica no dialéctica a la contradicción, lucha económica, lucha política. (...) De manera que a la postre, se reemplaza la lucha política revolucionaria y la construcción del partido por la lucha sindical, cayendo inevitablemente en el tan discutido concepto de 'partido único a partir de los sindicatos'.,"208

En ese sentido los militantes fabriles no debían introducir discusiones interminables que estuvieran al margen de las necesidades concretas de los trabajadores de la fábrica ni crear agrupaciones definidas "a priori” porque las mismas tendían a ser estrechas y sectarias. Por el contrario una agrupación clasista debía tomar las necesidades de la fábrica como los problemas salariales, de sanidad, luchar contra los intentos de racionalización productiva y movilizar a las bases tanto por grandes problemáticas como por las más sencillas y cotidianas. La politización debía darse "al calor de esas movilizaciones" ya que de lo contrario la burocracia podía recuperar posiciones con tan solo "presentar un paquete de reivindicaciones conseguibles", negociándolas con la patronal y mostrándose como los únicos preocupados por resolver los problemas de los trabajadores. $^{209}$

Como veremos en los casos estudiados la aplicación de las prescripciones partidarias no se dio de manera lineal, sino que dependía de la realidad de la fábrica, el nivel de desarrollo que tuviera la organización en ella y, fundamentalmente, de las posibilidades, tareas, prioridades y herramientas que los militantes fabriles se plantearan y creyeran necesarias construir para desarrollar el trabajo político. De este modo no siempre se eligió o se pudo desarrollar una agrupación sindical y en muchos casos se intervino desde listas sindicales más amplias o incluso se trabajó desde instancias tales como los CD, las CIR o los comités de lucha.

\section{Dos Ejemplos paradigmáticos: Eaton Fundiciones y Propulsora Siderúrgica.}

A modo de ejemplo, reseñamos brevemente las características que asumió la construcción del PRT-ERP en dos fábricas del Gran Buenos Aires: Eaton Fundiciones

${ }^{208}$ Ídem. 
(José C. Paz) y Propulsora Siderúrgica (Ensenada). Los casos resultan ilustrativos en cuanto a las diferentes formas y estrategias con las que la organización intervino sindicalmente en los establecimientos.

Eaton Fundiciones era una fábrica de capitales norteamericanos que había sido instalada en el año 1962 en la localidad de José C. Paz, al norte del Gran Buenos Aires. Dedicada a la producción de ejes, diferenciales y otros materiales para la industria automotriz, la empresa contaba con dos plantas (Eaton Ejes y Eaton Fundiciones) ubicadas en el mismo terreno ${ }^{210}$. Los trabajadores estaban encuadrados bajo el SMATA aunque cada planta tenía una CIR y un CD diferente, por lo que las reivindicaciones y la representación gremial eran distintas. Por su parte, Eaton Fundiciones contaba con 300 obreros y se dedicaba a la fundición de metales, por lo que sus principales reclamos pasaban por las condiciones de insalubridad a la que estaban expuestos ${ }^{211}$. Su caso es paradigmático por los niveles de influencia que logró el PRT-ERP en poco tiempo.

La presencia de la organización en aquella planta se remonta al año 1972, momento en que Marcelo Luis “el Flaco” Panizza se incorporó a la organización ${ }^{212}$. Aquel, que había ingresado a la fábrica a fines de 1971, rápidamente se transformó en un referente entre sus compañeros de trabajo quienes lo eligieron como miembro de la CIR y delegado general de la planta ${ }^{213}$. Alrededor suyo el PRT-ERP construyó una célula que, compuesta por militantes extrafabriles, apuntaló su trabajo como delegado realizando acciones de propaganda sobre la fábrica ${ }^{214}$. En 1973 se dio el mayor crecimiento del trabajo político-sindical perretista: a partir de la referencia de Panizza, durante la

\footnotetext{
${ }^{210}$ Además la empresa contaba con otra planta de fundiciones ubicada en la localidad de Tortuguitas llamada Eaton Metalúrgica.

${ }^{211}$ Fundamentalmente los vapores, el polvillo y las emanaciones propias de las fundiciones de metales hacían que en la mayoría de las secciones (Hornos, Noyería, Fusión, Rebajado y Desmoldeo) se produjera un ambiente insalubre cuyo riesgo principal era el saturnismo.

${ }^{212}$ El contacto con el PRT-ERP no se dio al interior de la fábrica sino en Devoto, barrio donde vivía Panizza. Un amigo suyo que militaba en la organización tal enterarse de su incorporación a Eaton, y teniendo en cuenta sus inquietudes políticas, le propuso comenzar la militancia en el PRT-ERP (Comunicación telefónica con Liliana Battistoti, esposa y compañera de Panizza; Comunicación telefónica con Gustavo José Panizza, 2018).

${ }^{213} \mathrm{Su}$ papel destacado como dirigente es resaltado por Raúl Coria, obrero de la Eaton Ejes que se contacta con el PRT-ERP a partir de su militancia. Por otro lado, Misael Aron Pajon, obrero que ingresa a Eaton Fundiciones en 1975, cuando Panizza ya no trabajaba más en la planta, recuerda que todos sus compañeros de fábrica destacaban a éste último como el principal dirigente de la fábrica: "el capo gremial que manejaba los hilos de Eaton" (Entrevista a Raúl Coria con el autor, Buenos Aires, 2017; Entrevista a Misael Aron Pajon con el autor, José C. Paz, 2018.)

${ }^{214}$ Fundamentalmente se realizaban volanteadas en la puerta de la fábrica, pero también desarrollaron actividades de propaganda armada como la toma de colectivos de la Línea 57 que transportaba a los trabajadores, donde arengaban, repartían volantes y vendían periódicos y volanteadas en los barrios aledaños. (Entrevista a Alberto Elizalde con el autor, comunicación telefónica, 2018; DIPBA, Mesa Ds, Varios, Leg. 1309)
} 
primera mitad del año, se conformó una célula de masas con dos obreros más ${ }^{215} \mathrm{y}$, a su vez, se realizó un trabajo de militancia en las distintas secciones de la planta que permitió, en el mes de junio, lanzar la agrupación sindical "Omar Dugetti"216.

La agrupación, que se constituyó en la base político-sindical de la CIR, adhirió e integró el MSB, del cual el "Flaco" Panizza, como se verá en el próximo capítulo, fue uno de sus principales dirigentes. Aquella fue la protagonista del principal conflicto sindical que vivió la planta: desatado por el aumento del precio del ticket del comedor, a principio del mes de julio, los trabajadores decidieron exigirle a la empresa un pliego de 13 reivindicaciones entre los que se encontraba la declaración del trabajo insalubre en algunas secciones. El conflicto duró 20 días y comprendió quites de colaboración, asambleas masivas y $\operatorname{paros}^{217}$. Además, contó con la intervención del ERP que decidió copar el establecimiento para fortalecer la demanda de los obreros y el trabajo político que venía desarrollando el partido ${ }^{218}$. Aquella acción comprendió la toma de la guardia y la organización de una asamblea en la fábrica en la que participó casi la mayoría del personal y donde los combatientes arengaron consignas contra la patronal y repartieron volantes. Según los testimonios y el informe de la DIPBA la acción habría recogido la simpatía y las vivas de gran parte de los obreros ${ }^{219}$. Efectivamente a partir de aquel hecho se consolidó la influencia de la organización, al punto tal que al día siguiente una gran parte de los obreros de la planta decidió dibujarse en los cascos de protección una estrella de cinco puntas en alusión al emblema del ERP ${ }^{220}$.

\footnotetext{
${ }^{215}$ En total la célula estaba compuesta por tres trabajadores de Eaton Fundiciones y tres militantes extrafabriles que, haciendo centro esta fábrica, a su vez atendían el trabajo político de otras fábricas de la zona (Entrevista a Alberto Elizalde con el autor, comunicación telefónica, 2018.)

${ }^{216}$ Omar Dugetti fue un obrero de la fábrica que había muerto en un accidente de trabajo, y que por ello, se transformó en un símbolo de la lucha contra las condiciones de trabajo.

${ }^{217}$ Declarar el trabajo como insalubre significaba pasar de una jornada de $8.30 \mathrm{hs}$ a una de 6hs. Además exigían que se mejore la ventilación de la planta y se garanticen mejores condiciones de trabajo en términos generales ("Eaton 300 obreros contra la patronal" Nuevo Hombre Nro. 46, Segunda quincena de agosto de 1973.)

${ }^{218}$ La toma se realizó el 5 de agosto en medio de un quite de colaboración y el conflicto se resolvió cuatro días después cuando la patronal decidió concederle los 13 puntos planteados por los trabajadores ("Eaton. Ejemplo de unidad" Nuevo Hombre Nro. 53, segunda quincena de diciembre de 1973)

${ }^{219}$ Según un informe de la DIPBA luego de retirado el grupo comando un delegado de la fábrica (que no era Panizza) tomo la palabra y dijo: "Ya el movimiento obrero cuenta con un Ejército Popular que es el ERP, quien los apoya en la lucha contra la burocracia y la patronal" y pidió a los obreros que estrecharan filas y apoyasen a aquel ejército. Por otro lado otro activista de la planta habría manifestado a viva voz con respecto a los obreros que se habían mostrado remisos a participar de la asamblea que "a estos alcahuetes habría que fusilarlos" (DIPBA, Mesa Ds, Varios, Leg. 1309)

${ }^{220}$ Este suceso fue recordado por tres testimonios distintos: Alberto Elizalde, miembro de la célula que trabajaba sobre Eaton, Gustavo José Panizza, y Misael Aron Pajón quien destaca que aquel hecho fue un hito recordado por los trabajadores de la fábrica. (Entrevistas con el autor).
} 
A partir de allí la agrupación creció notablemente y con ello la influencia del PRT-ERP. La organización logró organizar una cantidad importante de simpatizantes y colaboradores y, a través de la agrupación, logró movilizar a una delegación de obreros al V Congreso del FAS realizado en la ciudad de Sáenz Peña, Chaco ${ }^{221}$. Además comenzó a editar el Boletín Fabril "José Luis Castrogiovani”, el cual logró regularidad y constancia ${ }^{222}$. De este modo, en esta experiencia, la influencia perretista se dio a través de la mayoría de las herramientas que el partido planteaba para el trabajo fabril. Sus límites estuvieron directamente relacionados a la abrupta y temprana irrupción de la represión patronal, policial y burocrática que, en menos de un año, descabezó el movimiento de base ${ }^{223}$.

Diferente fue el caso de Propulsora Siderúrgica, fábrica metalúrgica de alrededor de 1300 trabajadores, ubicada en la localidad de Ensenada ${ }^{224}$. Allí la penetración del PRTERP se dio en agosto de 1973 con el ingreso de Daniel De Santis, militante estudiantil perretista que, por motivación propia, decidió proletarizarse e iniciar un trabajo político en el movimiento obrero de la zona. En este caso, el proceso de construcción política al interior de la planta estuvo fuertemente determinado por los tiempos de la proletarización. Al ingresar a la fábrica, De Santis necesito de un período de adaptación para ganarse la confianza de sus compañeros y comenzar con la actividad política, de modo que los primeros materiales de la organización comenzaron a circular aproximadamente un año después de que aquel ingresara a la fábrica. Es que la proletarización no consistía solamente en ingresar a trabajar a un establecimiento sino, fundamentalmente, en adoptar los modos de vida de la clase obrera y compartir sus

\footnotetext{
221 "Eaton. Ejemplo de unidad" Nuevo Hombre Nro. 53, segunda quincena de diciembre de 1973

${ }^{222}$ De julio de 1973 a mayo de 1974 salieron 5 números del boletín que, además, continuó saliendo hasta el golpe de 1976 ("Eaton. Una experiencia valiosa" El Combatiente Nro. 117 Miércoles 15 de mayo de 1974; Entrevista a Misael Aron Pajon con el autor, José C. Paz, 2018)

${ }^{223}$ Aquello llevó a que la patronal y la "burocracia sindical" llevaran adelante una campaña feroz de amedrentamiento, represión y persecución contra el movimiento de base que incluyó: la incorporación de policías infiltrados en el personal, el matonaje de miembros del Comando de Organización, la "compra" de uno de los delegados de CIR que decidió pasar a colaborar con el SMATA y el secuestro de Panizza por un comando no identificado de la policía durante el mes de enero, que terminó con su liberación gracias a la movilización de los 600 obreros de ambas plantas. Finalmente a un mes de este último suceso el SMATA decidió retirarle los fueros de delegado a Panizza y la empresa decidió despedirlo, junto a otros dos activistas. Pese a diversos intentos de resistencia, la represión y la persecución descabezó al movimiento de base que recién en 1975 volvió a reactivar las luchas. ("Denuncian represión en Eaton Fundiciones" El Mundo, 25 de enero de 1974; "Secuestro: Panizza, delegado de la Eaton" El Mundo, 26 de enero de 1974; "Fue liberado Panizza, delegado de Eaton, luego de ser raptado. Asamblea solidaria" El Mundo, 28 de enero de 1974; "Delegado Secuestrado" Noticias Nro. 65, 27 de enero de 1974; "Eaton: Represión a obreros" Noticias Nro. 104, 8 de marzo de 1974; "Eaton. Una experiencia valiosa" El Combatiente Nro. 117 Miércoles 15 de mayo de 1974).

${ }^{224}$ Propulsora Siderúrgica era una fábrica del grupo Techint, fue fundada en 1969 y se dedicaba a la producción de laminados en frío. Sus trabajadores estaban encuadrados en la UOM.
} 
espacios de socialización para poder construir un vínculo de confianza con los trabajadores y, al mismo tiempo, no ser detectado fácilmente por la empresa.

La primera intervención político-sindical de De Santis, y a través suyo del PRT-ERP. se dio en un conflicto sindical que se abrió en mayo de 1974 y culmino en el mes de septiembre de ese mismo año. Motivados por la demanda de aumentos salariales los trabajadores encabezaron una lucha que, luego de diferentes etapas, culminó con el triunfo obrero. Entre otras reivindicaciones, los trabajadores consiguieron el reconocimiento de una CIR y un CD que habían sido elegidos en el proceso de la huelga. Allí, De Santis fue elegido como uno de los cinco miembros de la $\mathrm{CIR}^{225}$, y se transformó rápidamente en uno de los principales dirigentes de la fábrica ${ }^{226227}$.

Según este último, fue recién en el marco de aquel conflicto que el PRT-ERP comenzó a desarrollar actividad propagandística y a sumar a otros trabajadores. En aquel proceso habría logrado formar una célula de aspirantes al partido que, rápidamente, se transformó en una célula de masas ${ }^{228}$, cuya actividad estuvo centrada, fundamentalmente, en la actividad sindical ${ }^{229}$ y propagandística, además de atender a los contactos y simpatizantes que iban surgiendo en cada sección ${ }^{230}$. Es de destacar que en este caso la organización no desarrolló actividad militar al interior de la planta más allá de la aparición de algunos volantes intimidadores ${ }^{231}$.

${ }^{225}$ Aquella CIR elegida en asamblea estuvo compuesta por Omar "Turco" Cherry y Roberto Lopresti (JTP), Luis "Pato" Rave (PB) y Salvador "Pampa" De Laturi (en ese momento militante del PCA).

${ }^{226}$ Esto se evidencia en múltiples fuentes: en un volante repartido masivamente por la "burocracia sindical" donde denunciaban un acuerdo "zurdo-patronal" entre la empresa y la CIR ubicaban a Agustín Rocca (presidente de la compañía) como "capitán" y a De Santis como "sub-capitán" del acuerdo. Por otro lado, en un informe de inteligencia de la policía bonaerense lo describían como "individuo considerado el número uno entre los activistas". A su vez el PST en un boletín interno en el que balanceaba el conflicto lo reconocía como "la figura indudablemente más reconocida" de la fábrica. Por último Jorge Orellano, obrero de Propulsora y simpatizante de la JTP lo reconoce como el principal dirigente de la planta (DIPBA, Mesa B, Factor gremial, Huelgas y Conflictos, Leg. 65; Stavale y De Santis, 2016:194; "Sindical. Minuta sobre Propulsora", BI PST, 30 de abril de 1975, .10, Fundación Pluma.; Entrevista a Jorge Orellano con el autor, La Plata, 2016)

${ }^{227}$ De Santis debió abandonar la fábrica en abril de 1975 por recomendación del PRT-ERP por amenazas de muerte que había recibido de organizaciones paramilitares. No obstante, siguió en contacto con los trabajadores desde afuera y participó con ellos de las jornadas de junio y julio de 1975 (Stavale y De Santis, 2016: 193)

${ }^{228}$ Según el testimonio de De Santis la célula llegó a tener 7 miembros. (Entrevista a Daniel De Santis, La Plata, 2014)

${ }^{229}$ Es de destacar que el PRT-ERP no solo contó con De Santis entre los principales activistas de la fábrica: además de tener varios delegados, posteriormente, contó con la militancia de "el Rifle" Passini (quien se incorporó a la CIR en 1975) y Salvador De Laturi (quien en 1975 se incorporó a la organización luego de abandonar su militancia en el PCA).

${ }^{230}$ Las secciones de mayor influencia partidaria habrían sido las secciones productivas como Tendem (donde se realizaba el laminado plano), Temper (donde se le daba maleabilidad a la chapa) y Decapado (donde se desoxidaban las chapas)

${ }^{231}$ En 1975 la organización paramilitar Triple A amenazaron de muerte a dos miembros de la CIR, que debieron abandonar la fábrica, ante lo cual la compañía "Héroes de Trelew" del ERP repartió una carta 
La diferencia con el caso de Eaton Fundiciones estuvo en la modalidad que adquirió el trabajo político-sindical. En Propulsora la participación se dio a través de una lista pluripartidaria, la Lista Blanca, en la que participaban activistas de la JTP (principal fuerza) el PB, el PCA y el PST $^{232}$ y, posteriormente, a través de la CIR y el CD. Según De Santis nunca pudieron construir una agrupación sindical ya que desde su punto de vista se hacía "superflua" e innecesaria debido a que el CD funcionaba con amplios niveles de consenso y participación, motivado por el profundo acuerdo político que existía con las corrientes que lo componían y por la participación del activismo independiente en el mismo. De este modo aquel organismo sindical (y la lista Blanca) habría ocupado el papel que en otras experiencias tenía asignada la agrupación sindical $^{233}$.

Como se ve en estos ejemplos, las estrategias de intervención sindical fueron diferentes según las condiciones políticas de cada fábrica: en casos como Eaton Fundiciones, en los que no había una presencia importante de otras fuerzas políticas, existieron posibilidades de desarrollar agrupaciones que se planteasen dirigir sindicalmente un establecimiento; mientras que en los casos como Propulsora, donde había presencia de múltiples corrientes, que incluso tenían mayor peso que el PRT-ERP, las posibilidades se reducían y hubo una tendencia a intervenir a través de espacios pre-existentes (ej. Lista Blanca) y/o a través de los organismos de base.

\section{Conclusión}

La organización enfrentó la apertura democrática de 1973 bajo la máxima de aprovechar al máximo los intersticios legales sin abandonar la lucha armada. Desde allí diseño un criterio político, que nosotros denominamos de equilibrios complementarios, desde el cual toda actividad debía combinar el aspecto legal y el clandestino.

dirigida a los directivos de Propulsora en el que advertían que si un obrero era asesinado sería respondido con medidas "tan o más graves" que las que se les aplicase a cualquier obrero ("Del ERP a los directivos de Propulsora", DIPBA, Mesa Ds, Varios, Leg.2512, F. 438)

${ }^{232}$ La Lista Blanca había surgido a fines de 1973 ante las elecciones de CD y CIR. Aquella lista se conformó en oposición a la Lista Azul Rosendo García y fue impulsada fundamentalmente por militantes de la JTP, el PB y el PCA. La Lista Blanca surgió cuando, en la búsqueda de acuerdos por construir una lista única para las elecciones, los miembros de la Lista Azul decidieron proscribir a Salvador Delaturi, por ser militante comunista (Palma, 2008; Rodríguez, 2010; Ducid, 2014)

${ }^{233}$ Es de destacar que esto fue una así para todas las fuerzas políticas que componían la Lista Blanca, exceptuando el caso de la JTP que participaba a través de su agrupación sindical Felipe Vallese. Pero como indica "Pato" Rave, militante del PB y miembro de la CIR: "no había agrupaciones, había organizaciones" (Ducid, 2014:141-142) 
En ese marco de definiciones, a diferencia del período previo, la lucha sindical pasó a ocupar un papel preponderante en las prioridades perretistas. Es que la organización previó que la salida democrática estimularía fundamentalmente las luchas gremiales y, en ese sentido, se planteó lograr "apoyos firmes" en ese plano. Desde esa perspectiva enfrentó la política del gobierno haciendo eje en la lucha contra el Pacto Social y la burocracia sindical, y apuntó a profundizar su inserción en el movimiento obrero a través de la política de "construir el partido en la fábrica". Como vimos, esta orientación suponía la decisión de penetrar en los principales centros industriales y desarrollar una compleja estructura de organismos partidarios al interior de las plantas que abordara todos los aspectos de la política partidaria (sindical, militar, propaganda, etc.). Además, en lo específicamente sindical, lanzó dos herramientas -el MSB y la TOR 22-8- que, como veremos en el próximo capítulo, buscaron aprovechar las condiciones de legalidad y al mismo tiempo preparar la resistencia desde la clandestinidad. 


\section{Capítulo 3}

\section{EI Movimiento Sindical de Base y la Tendencia Obrera Revolucionaria 22-de Agosto, ¿dos propuestas complementarias? (1973-1975)}

\section{Introducción}

En el presente capítulo estudiamos las dos iniciativas más importantes que impulsó la organización para el trabajo sindical: la Tendencia Obrera Revolucionaria- 22 de Agosto (TOR "22-8”) y el Movimiento Sindical de Base (MSB). Como vimos en el capítulo anterior, en el escenario de apertura democrática el PRT-ERP había planteado que la clase obrera y sus organizaciones debían valerse de los espacios legales abiertos y de las contradicciones que poseía el propio gobierno, por lo que había resuelto luchar por la independencia del movimiento sindical del gobierno peronista, impulsar y apoyar enérgicamente la lucha y la movilización de los trabajadores por sus reivindicaciones inmediatas y hacer frente a la "ofensiva ideológica y propagandística de la burocracia". Para ello promovió dos tipos de herramientas: por un lado un amplio frente antiburocrático legal, que aprovechara al máximo las posibilidades legales y ofreciera nacionalmente resistencia desde lo sindical a la ofensiva burocrática y gubernamental contra el clasismo, y por el otro una tendencia obrera pensada para dirigir desde la clandestinidad a los sindicatos y al movimiento obrero cuando sobreviniese la “fascistización" del gobierno y la consecuente ilegalización de los organismos gremiales que preveía.

Sus características y objetivos tenían un sentido pretendidamente complementario. Se inscribían en la política de contrapesos entre la lucha legal y la lucha armada que el PRT-ERP diseñó para la etapa, y que por momentos alcanzó un equilibrio productivo, potenciando el crecimiento de la organización, pero que en otros condujo a una política contradictoria que dificultó el desarrollo de las propuestas o llevó a que una prevaleciese sobre la otra. A nuestro entender esto último fue lo que sucedió entre las experiencias de la TOR "22-8” y el MSB, siendo ésta última la herramienta que más trascendió y que mayor desarrollo e importancia tuvo en la política sindical perretista. Por otro lado, el estudio de ambas experiencias nos permite analizar la forma en que la organización concebía a las herramientas frentistas, las dificultades y los debates que las 
atravesaron, los esfuerzos que realizó para construir espacios amplios que expresaran orgánicamente la unidad de acción y la apuesta de construir una alternativa a nivel nacional que disputara la conducción del movimiento obrero.

La inclusión de un capítulo específico para el análisis de estas experiencias resulta fundamental para los objetivos de este trabajo, ya que fueron las herramientas que el PRT-ERP ideó para intervenir sindicalmente durante el período abordado. En ese sentido optamos por suspender momentáneamente la lógica cronológica que ordena la primera parte de la tesis y analizar en sí mismo el derrotero de estas propuestas desde su fundación hasta su ocaso, para luego, en el siguiente capítulo, retomar el análisis diacrónico propuesto.

\subsection{La TOR “22-8”, una experiencia trunca}

La iniciativa perretista de construir una tendencia sindical clandestina "por la guerra y el socialismo" respondía a diferentes objetivos y argumentos. Por un lado aparecía como una respuesta para enfrentar a la represión en las fábricas y al mismo tiempo como una instancia organizativa que permitiera contener a los trabajadores que simpatizaran con la lucha armada y con el socialismo pero que no necesariamente estuvieran dispuestos a organizarse en el PRT-ERP. En ese sentido se apuntaba a organizar a los que el partido consideraba como "obreros de vanguardia", por su simpatía con la lucha armada, construyendo un escalón organizativo más avanzado que permitiera reunir a "los mejores elementos" dentro del amplio campo de la lucha gremial, y que a la vez se constituyera en una "cantera de militantes" para el partido. En términos estratégicos, era pensada como la forma de ligar la lucha por las reivindicaciones económicas básicas con la guerra por el socialismo ${ }^{234}$. Asimismo en lo que respecta a los objetivos netamente sindicales se erigía como el organismo que, al interior de las fábricas, se preparaba para dirigir al movimiento obrero en tiempos de represión agudizada, proscripción e ilegalización de las organizaciones legales y persecución o detención de los dirigentes de superficie.

Según Luis Mattini la orientación de construir una tendencia de este tipo habría sido rechazada por los sindicalistas del PRT-ERP por resultarles "casi insólita", debido a su carácter "ultraizquierdista" y "sectario" y porque producía confusión entre el activismo sindical simpatizante (Mattini, 2007:185). Sin embargo esto no era algo nuevo en la

234 “El partido en la fábrica. Hacia el VI Congreso" En: Stavale y De Santis, 2016: 97-114 
organización sino que por el contrario hundía sus raíces en los orígenes de la misma. Como se vio en el capítulo 1, en el III Congreso del PRT, realizado a mediados del año 1967, el debate sobre los límites de los organismos sindicales legales fue una de las controversias más importantes entre los sectores que luego encabezaron el quiebre de la organización. En ese momento la propuesta sostenida por el sector santuchista era la de organizar oposiciones clasistas clandestinas que podían tomar la forma de comités de resistencia, comisiones de defensa, etc., a través de las cuales llevar adelante acciones armadas y de propaganda buscando responder a los intentos de despidos, suspensiones, racionalización productiva, etc. Organizados en forma de "estrella", con pequeños grupos "tabicados" 235 conectados por un centro, estos organismos debían erigirse en la dirección política y sindical de la fábrica y coordinar con los delegados o miembros de comisiones internas del partido, allí donde los tuviera. Esta misma política fue incluida en las definiciones del IV Congreso partidario de 1968. Allí, como se ha visto, además se defendía la organización de comisiones de resistencia, agrupaciones gremiales revolucionarias y destacamentos armados como consignas organizativas de transición, como escalón intermedio entre lo sindical y lo político ${ }^{236}$. En esa misma dirección, un año después, el $\mathrm{V}$ Congreso partidario prefiguró la línea de intervención que la organización se daría a inicios del año 1973. En él se resolvía combinar la construcción de organizaciones de masas lo más amplias y menos clandestinas posibles con la organización de comisiones de resistencias fabriles clandestinas o semi-clandestinas allí donde hubiera condiciones. Si bien, como remarca Pozzi, esta línea fue parcialmente abandonada durante los años 1971 y 1972, años en que la organización resumió la intervención sindical al desarrollo y la presencia del partido con la acción armada del ERP dentro de la fábrica (2004:181), fue retomada de manera más ambiciosa ante la apertura democrática al promover la construcción simultánea del MSB y de la TOR "22-8".

\footnotetext{
${ }^{235}$ El "tabicamiento" era una medida de seguridad que adoptaban las organizaciones clandestinas para no ser desarticuladas si alguno de sus miembros caía en manos del "enemigo". Consistía en un método de compartimentación de la organización en la que cada miembro solo conocía a sus compañeros de equipo, célula o grupo de base y se conectaba con la organización solamente a través de un responsable. Con ello se garantizaba que la información del conjunto de la organización y sus miembros este resguardada ante eventuales detenciones, infiltraciones, etc.

236 "Para nosotros las comisiones de resistencia y los destacamentos armados, son un escalón intermedio entre las organizaciones sindicales de la clase obrera y la forma organizativa más elevada de la misma: el Partido Revolucionario." ("El único camino para el poder obrero y el socialismo" En: De Santis, 2004: 229)
} 
Esta última fue fundada en Córdoba a pocos días de comenzado el mes de enero de $1973^{237}$. Según el informe de la reunión incluido en el BI Nro. 36 del 24 de enero, la misma contó con alrededor de 50 activistas y giró en torno al debate sobre el carácter que debía asumir la tendencia. La discusión se ordenó entre aquellos que sostenían que debía ser la fracción sindical del partido y aquellos que planteaban que debía tener un carácter más amplio buscando organizar a todos los sectores y trabajadores independientes que estén de acuerdo con la propuesta. Finalmente, según el informe, la reunión adoptó por unanimidad este último punto de vista. De modo que la tendencia se proponía "la incorporación de todos los obreros revolucionarios independientemente de sus concepciones ideológicas, marxistas, cristianos, peronistas, etc., tomando como eje el apoyo de la guerra por el socialismo"238. Es por ello que la mayoría de los documentos recurrentemente buscan aclarar la diferencia entre de la tendencia y el partido. La homologación de ambos organismos era considerado como un problema grave ya que, por un lado, llevaba a limitar y sectarizar a la TOR "22-8” y por el otro a esconder la actividad del partido, limitando su actividad propagandística y agitativa ${ }^{239}$. Además porque a diferencia este último, la tendencia debía condicionar su programa y sus consignas al "grado de conciencia inmediato de las masas y su estado de ánimo"240. No obstante, estos criterios de amplitud eran muy similares a los del ERP ${ }^{241}$, algo que volvía un tanto confusa la diferencia entre una y otra herramienta, sobre todo si se tiene en cuenta que este último también intervenía en las fábricas, buscando reclutar obreros para construir "comandos de apoyo" que actuaran "en defensa de los intereses y

\footnotetext{
${ }^{237}$ Boletín Interno Nro. 35. 16 de enero de 1973

238 "Los revolucionarios y la actividad sindical" El Combatiente Nro. 120, miércoles 5 de junio de 1974.

${ }^{239}$ Sin embargo ello no estuvo claro en todos los casos. Esto puede verse, por ejemplo, en las palabras del militante perretista Ramón Pablo "Yeyo" Videla cuando rememora su experiencia en el frigorífico Swift de Rosario: "Desde la entrada misma de los materiales a la fábrica había que protegerse para no ser descubiertos. Formábamos grupos de autodefensa y de apoyo, para garantizar la actividad. Así fueron surgiendo comisiones barriales y agrupaciones de bases en las fábricas. Para garantizar la actividad política clandestina del PRT, se formó la Tendencia Obrera Revolucionaria (TOR). La TOR colaboraba con la agrupación elaborando el boletín La Chaira, del Frigorífico Swift de Rosario. En poco tiempo, se alcanzó una participación activa en la lucha gremial y política (...) A partir de las experiencias de los obreros cordobeses, tratábamos de no confundir las actividades del sindicato con las del partido. De ahí nuestra insistencia en no confundir la actividad de la agrupación con la de la tendencia. Una desarrollaba la actividad legal, fundamentalmente reivindicativa gremial amplia, con otras fuerzas sindicales, para el caso de las agrupaciones. En cambio la TOR, debía garantizar la actividad política y el rol del Partido Revolucionario en la fábrica a través de un trabajo semilegal.” (Videla, 2006: 108-116) Aquí la tendencia aparecía como una herramienta para-partidaria y no como el organismo amplio que se había resuelto construir.

240 "Los revolucionarios y la actividad sindical” El Combatiente Nro. 120, miércoles 5 de junio de 1974.

241 “PPuede ser un peronista o un católico miembro o colaborador del ERP?” Estrella Roja Nro. 19, 3 de abril de 1973; "Todo patriota puede ser un colaborador del Ejército Revolucionario del Pueblo" Estrella Roja Nro. 23, 15 de agosto de 1973
} 
reivindicaciones del sector", en las luchas contra las patronales y la "burocracia sindical". De este modo, el ERP apuntaba a organizar al mismo tipo de obreros que la TOR "22-8", con objetivos relativamente homologables. Ahora bien, la TOR "22-8" era una organización específicamente sindical, por lo que, a diferencia del ERP, su actividad debía partir de los problemas concretos de la fábrica. Así, por ejemplo, en aquellos lugares en que se había consolidado la agrupación legal e incluso "recuperado" algún organismo gremial, la tendencia debía encargarse de organizar la "violencia de las masas" en el marco de las luchas sindicales:

"Las tareas prácticas que toma la tendencia en el caso que nos ocupa, será la preparación y organización de la violencia de masas, es decir, la práctica de la autodefensa, ora en la represión a los elementos agentes de la patronal, carneros, capataces, capangas, jefes, etc., ora organizando el sabotaje sistemático a la producción, ya sea organizando la toma de la fábrica, corte de vías de acceso y rutas o bien preparando los piquetes de huelga (...)

Todo esto que las masas hacen y han hecho casi siempre en forma bastante espontánea, la tendencia lo debe prever y preparar lo más organizadamente posible para lograr un máximo de aprovechamiento de las energías del movimiento.

Una forma práctica, a título de ejemplo, es que cada hombre de la tendencia tome la dirección de un grupo entrenándolo y educándolo en los métodos clandestinos de trabajo." 242

Ahora bien, la ampliación de la posibilidades legales que supuso el retorno democrático reordenó las prioridades y en la práctica el trabajo en los sindicatos, en las CIR y CD fue el que mayores demandas y esfuerzos requirió, al mismo tiempo que el que mayores resultados dio. De esto fue consciente el PRT-ERP y por ello es que la construcción de la tendencia fue presentada como algo estratégicamente necesario pero al mismo tiempo de carácter preparatorio, ya que su sentido principal estaba reservado para un contexto de mayor represión. De esa manera la construcción de esta herramienta no sólo no podía, bajo ningún punto de vista, impedir u obstaculizar el aprovechamiento de la actividad legal, sino que debía apuntalarla. La TOR “22-8” también debía impulsar la creación de las agrupaciones sindicales, así como motivar el desarrollo del frente antiburocrático nacional $^{243}$.

En ese trabajo sin embargo debía primar un criterio de preservación de fuerzas y evitar que todos los miembros de la tendencia perdieran la protección que le brindaba la clandestinidad en la actividad abierta y legal. Por otro lado, allí donde hubiese un alto

\footnotetext{
242 "Las tareas de la Tendencia Sindical” El Combatiente Nro. 159, 19 de Marzo de 1975

243 "El trabajo de masas de la tendencia, en el caso que estamos viendo, lo desarrolla en el seno de la agrupación, y sindicato o cuerpo de delegados, impulsando todas las tareas, controlando la línea, llevando paulatinamente sus métodos y capacidad de combate, constituyéndose de hecho en la dirección de la agrupación y acercando los elementos más radicalizados y decididos a la tendencia.”(Ídem)
} 
control de la burocracia sindical en los organismos de base de una fábrica y todo intento de oposición y de construcción de agrupaciones amplias fuese "descabezado", debía organizarse la tendencia con el objetivo de ir conformando una "fuerza de base" que en el momento apropiado se lanzase como agrupación sindical legal. Este criterio se sostuvo aún en los momentos de mayor represión al interior de las fábricas, por ejemplo, durante todo 1975, cuando arreciaron las intervenciones de numerosos sindicatos y las detenciones de dirigentes y activistas clasistas. Por entonces el PRTERP pensaba que seguían existiendo posibilidades legales para la lucha sindical y que era obligación aprovecharlas allí donde se dieran, sin que la construcción de la tendencia lo impidiera u obstaculizara ${ }^{244}$.

Sin embargo la "TOR 22-8" parece no haber tenido un gran desarrollo. De hecho, según Luis Mattini, prácticamente luego de su plenario de fundación no tuvo existencia efectiva:

"Poco a poco se fue diluyendo porque no era una cosa muy clara, no terminaba de entenderse si la tendencia obrera revolucionaria... los propios compañeros de la fábrica no tenían muy en claro que era eso... captar a un compañero para una tendencia de ese tipo... era más fácil captarlo para militante del partido (...) nunca funcionó muy bien, en realidad quedo diluida por falta de práctica... nadie le dio bola, jel MSB arrasó con todo eso! Nosotros íbamos como MSB para todos lados. ${ }^{, 45}$

Lo llamativo es que, aun así, la organización haya insistido hasta último momento en la necesidad de impulsarla, algo que puede verse en la cantidad de ocasiones en que aparece teorizada y mencionada en diferentes notas y boletines internos del PRT-ERP. Es probable que detrás de aquella insistencia se escondiera la desconfianza al sindicalismo que los perretistas arrastraban desde sus orígenes. Así, la TOR "22-8” aparecía como una respuesta revolucionaria ante el crecimiento general de las luchas reivindicativas y, sobre todo, ante el lugar cada vez más preponderante que empezaba a ocupar la intervención gremial en la política de la organización.

Las referencias concretas sobre la presencia de la tendencia en las regionales de Buenos Aires son casi nulas. La única experiencia de intervención y desarrollo efectivo que pudimos corroborar fue en la localidad bonaerense de Campana, más específicamente

\footnotetext{
244 "Importancia de la Tendencia Sindical Clandestina" El Combatiente Nro. 169, lunes 26 de mayo de 1975.

${ }^{245}$ Entrevista a Luis Mattini por el autor, Buenos Aires, 2017
} 
en la empresa Dalmine-Siderca ${ }^{246}$. Allí el PRT-ERP contaba con una importante inserción:

"Del PRT-ERP provendrían las principales acciones armadas en la fábrica, incursiones no necesariamente protagonizadas por obreros. Pintadas, volanteadas, "piqueteadas", inmovilización de los agentes de seguridad privada se incluían en el repertorio de estos avances fugaces en la fábrica. Según algunos militantes que participaron entonces, durante las volanteadas los obreros donaban dinero para la organización. Los principales obreros activistas de esta organización eran Jorge "Oso" Gómez y Juan José Lópes, ambos delegados y el último, como indicamos, miembro de la comisión interna. También se encontraban Alfredo Arias y Antonio Villaverde, Lorenzo Malvicino, Edgardo Eladio Martínez, Rubén Matildo Frutos, Nillo Agnolli, José Alberto Multrazzi, Guillermo Hietala, Raúl Bustos, Luis Ángel Casalone, mientras que Alberto Bedia simpatizaba con la organización (...)" (AA.VV.; 2015:284)

Esta actividad de la organización sobre la fábrica se evidencia en la cantidad de acciones que desarrolló el ERP a lo largo de los años 1973-1976. Así, sólo tomando el primero de esos años, se registran al menos 9 acciones ligadas al establecimiento entre las que se encuentran amedrentamiento a directivos de la empresa ${ }^{247}$, copamiento de la planta, repartos del periódico Estrella Roja, acciones sobre el ferrocarril frente al establecimiento, etc. ${ }^{248}$ Por su parte a nivel sindical había logrado construir la TOR "22-8”, y a través de ella había impulsado y formado, junto a activistas independientes, la Agrupación de Metalúrgicos Independiente (AMI). La tendencia realizaba una asidua e importante actividad de propaganda al interior de la fábrica y era una de las organizaciones más importante del establecimiento (AA.VV, 2015) ${ }^{249}$. Ahora bien, como puede verse en el siguiente volante, la actividad de la tendencia y sus objetivos se confundían prácticamente con la de una agrupación sindical legal:

"Los compañeros metalúrgicos que integramos la Tendencia Obrera Revolucionaria 22 de Agosto propulsamos esta tendencia en base a desarrollar la organización de las luchas

\footnotetext{
${ }^{246}$ En el fondo documental de la DIPBA hallamos un volante de junio de 1973 firmado por la TOR 22-8 dirigida a los obreros de la metalúrgica Camix, también ubicada en la zona de Zarate -Campana (DIPBA, Mesa DS, Varios, legajo 945). Por su parte "Yeyo" Videla recuerda que cuando militaba en la Zona Sur del GBA se "realizaban tareas semilegales como las de la TOR", pero no especifica donde ni si se logró constituir la tendencia como tal (Videla, 2006:133).

${ }^{247}$ El 15/6 un comando del ERP ametralla y punta el frente de la casa del jefe de relaciones laborales y el 15/7 colocaron dos bombas en los domicilios de Dante López y Federico Ranieri, ejecutivo y contratista de la empresa.

${ }^{248}$ Ver sección "Crónica de la guerra revolucionaria" en el periódico Estrella Roja del período 1973-1976

${ }^{249}$ Un informe de inteligencia de la ex-DIPBA refleja los niveles de influencia y desarrollo que logró tanto el PRT-ERP, como la tendencia y la agrupación AMI, cuando las menciona como las organizaciones que principalmente tenían "jaqueadas" a la empresa con el "accionar subversivo" y agregaba que "las bases en gran mayoría aceptaban el accionar subversivo, algunos por temores y otros por propia voluntad" ("Principales establecimientos fabriles industriales de la provincia de Buenos Aires que han sufrido estados conflictivos y posible infiltración subversiva", DIPBA, mesa B, carpeta varios, legajo 133.)
} 
sindicales en defensa de todos los derechos de la clase trabajadora, impulsando la unidad de todos los sectores del Movimiento Obrero, tras un programa antiburocrático, antipatronal y antidictatorial en vistas a la recuperación sindical”,250

Si bien los materiales de propaganda de la tendencia también incluían llamados a organizar la autodefensa y reivindicaciones abiertas al socialismo y a la lucha $\operatorname{armada}^{251}$, según la información disponible, las acciones militares de la zona y sobre la fábrica generalmente fueron realizadas por el ERP, y no por la TOR “22-8”, por lo que, en la práctica, pareciera que esta última habría operado más como una agrupación sindical y no tanto como organizadora de la "violencia de masas".

Por otro lado la única referencia a la tendencia en la revista Nuevo Hombre $e^{252}$ también es de corte sindical-legal. Se trata de una entrevista a uno de sus referentes con motivo de las vísperas a las elecciones de la UOM de Campana. Allí se manifiesta la posición de la organización en las elecciones, llamando a la abstención y a enfrentar a las dos listas de la burocracia (Lista Rosa y Lista Naranja), al mismo tiempo que denunciando al "Estatuto Trampa" que no le habría permitido formar una lista propia. En el mismo número también se publicó un comunicado del grupo en el que se justificaba la posición electoral y se proponía un programa sindical de doce consignas, todas ellas de carácter gremial, que no distaba en ningún punto del programa de una agrupación legal aunque de manera un tanto forzada incorporaba la consigna "ipor el socialismo!"253.

Más allá de esta experiencia concreta, no hemos encontrado referencias sobre la presencia o desarrollo de la TOR “22-8” en otras fábricas, y además la mayoría de los entrevistados no recuerda la existencia de la tendencia ${ }^{254}$, lo que confirmaría que no tuvo un desarrollo significativo. A nuestro entender se trató más bien de una iniciativa que buscó construir, de manera un tanto forzada, el equilibrio complementario entre la actividad legal y la clandestina en el plano sindical. Creemos que el fracaso de esta experiencia se debió por un lado a que chocó con la dinámica de la lucha legal

\footnotetext{
250 “TOR '22 de Agosto””, DIPBA, Mesa DS, Varios, legajo 791, p 9.

${ }^{251}$ Por ejemplo, los volantes de la tendencia en Dálmine Siderca finalizaban con consignas tales como: "Por la unidad del movimiento obrero. Contra la patronal explotadora. Contra la burocracia sindical. Contra el alza del costo de vida y la inflación. Por el Socialismo. Por el sindicalismo clasista. Por el apoyo a las organizaciones armadas del pueblo" (DIPBA, Mesa DS, Varios, legajo 791)

252 "Campana: obreros contra burócratas. La TOR-22 repudia las elecciones trampa de la UOM" Nuevo Hombre Nro. 58, primera quincena de marzo de 1974; "La Tendencia Obrera Revolucionaria '22 de Agosto', a los compañeros trabajadores", Nuevo Hombre Nro. 58, primera quincena de marzo de 1974

${ }^{253}$ También se registra la participación de la "TOR '22-8' Campana” en el acto de abril de 1974 del MSB, figurando su firma entre las organizaciones adherentes.

${ }^{254}$ Dos ejemplos claros son los de Rafael Peralta, miembro de la Mesa Nacional Sindical del partido, y "Tito", responsable político de la regional Buenos Aires desde mediados de 1973 hasta mediados de 1974, quienes no tienen recuerdos de que haya existido tal iniciativa. (Entrevista a Rafael Peralta por el autor, Rosario, 2017; Entrevista a "Tito" por el autor, Cafayate, 2018)
} 
antiburocrática, que arrasó con cualquier otra iniciativa en ese plano y, por el otro, debido a que intentó ocupar un espacio intermedio entre la agrupación sindical y el ERP que no necesariamente existía.

Presumiblemente, como remarca Mattini, era más simple y "lógico" que quien simpatizara por la lucha armada se incorporara directamente al ejército, sobre todo teniendo en cuenta que éste último también tenía un planteo amplio que apuntaba a incorporar a obreros de diversas procedencias políticas e ideológicas ${ }^{255}$.

\subsection{EI MSB, organizador del trabajo sindical.}

Entre las definiciones principales del PRT-ERP figuraba la defensa y el aprovechamiento de la actividad legal de los sindicatos y, en ese sentido, planteó como una necesidad estratégica la construcción de agrupaciones clasistas que llevaran adelante una línea de lucha por la democracia y en contra de las burocracias, al mismo tiempo que apostó a construir espacios federativos que nuclearan a todas las expresiones clasistas y combativas ${ }^{256}$. Bajo esa orientación, en tiempos dictatoriales, participó de múltiples plenarios y encuentros sindicales que apostaban a construir una coordinación nacional de las diferentes experiencias sindicales combativas. De este modo, por ejemplo, participó activamente del Congreso de Sindicatos Combativos, Agrupaciones Clasistas y Obreros Revolucionarias, convocados el 28 y 29 de agosto de 1971, del Plenario Clasista y el Movimiento de Recuperación Sindical (MRS) organizado en Córdoba hacia fines de 1971, entre otros.

En esa dirección la construcción de un Movimiento Sindical Legal fue parte de la respuesta que la organización ensayó para el período de apertura democrática con el objetivo de articular a todas las experiencias combativas que se venían gestando desde 1969, y con la misión de disputar la dirección del movimiento obrero argentino. Este

\footnotetext{
${ }^{255}$ Con la instauración de la dictadura de 1976, la organización planteará como línea principal para las fábricas la organización de Comités de Resistencia clandestinos en las fábricas. Esta nueva orientación tomaba como base la idea de la TOR " $22-8$ " pero, a diferencia de esta, se planteaban como organismos frentistas que reunieran a todas las tendencias y corrientes políticas que tuvieran presencia en las fábricas. Las tareas planteadas para estos comités también eran similares a las que inspiraron a la TOR " $22-8$ ": impulsar la lucha reivindicativa y por la recuperación de los sindicatos, dinamizando o formando con ese fin agrupaciones, listas o comisiones legales y semilegales; realizar propaganda política escrita sistemática de resistencia antidictatorial; organizar el sabotaje planificado de la producción; apoyar la solidaridad activa con los presos políticos y sociales; organizar actos relámpago, manifestaciones, y otras acciones de agitación y lucha; fomentar y propiciar con el ejemplo la unidad obrero popular ("La clase obrera: columna vertebral de la resistencia" El Combatiente Nro. 213, miércoles 14 de abril de 1976).

256 "Resoluciones sobre el trabajo dentro del movimiento de masas y sindical", Resoluciones del V Congreso y de los Comité Central y Comité Ejecutivos posteriores, Ediciones El Combatiente, Junio de 1973
} 
nuevo escenario de legalidad, del que fue hijo el MSB (como también la JTP), permitió la expansión de las experiencias antiburocráticas y facilitó una articulación mayor con el surgimiento de corrientes sindicales de envergadura.

En este sentido, en el MSB se condensaron y confluyeron distintas experiencias con trayectorias previas. Dirigentes sindicales que habían sido fundamentales en la experiencia de SITRAC-SITRAM como Gregorio Flores, Domingo Bizzi, Eduardo Castello, entre otros, así como agrupaciones, delegados y CIR clasistas de fábricas y sindicatos de distintos puntos del país que venían construyéndose a la luz de la lucha antiburocrática, se encontraron en el MSB articulados en gran parte por la influencia que fue logrando el PRT-ERP a nivel fabril a lo largo del país.

\section{2.a. El MSB: génesis, definiciones y estructura.}

El MSB nació el 8 de julio de 1973 en el marco del "Primer Plenario Nacional por la Defensa y la Recuperación Sindical". Sin embargo tuvo como antecedente inmediato un acto clasista realizado en la Federación de Box de Buenos Aires el 14 de junio, organizado por el Instituto de Capacitación Obrera (ICO) $)^{257}$. La participación y la influencia del PRT-ERP en dicho encuentro y en la experiencia del ICO estuvieron motorizadas por la estrecha relación que la organización sostenía con Cerruti Costa, uno de sus fundadores, quien tenía comunicación directa con el Buró Político perretista. El acto se llevó adelante con aproximadamente 3.000 asistentes, y sus oradores principales fueron Antonio del Carmen Fernández, dirigente perretista y del ingenio tucumano San José, Jorge Álvarez Pardo del Sindicato de la Marina Mercante y Agustín Tosco. El primero de ellos hizo hincapié en desarrollar la democracia sindical desde las bases, mientras que el dirigente lucifuercista se ocupó de recuperar la experiencia de la CGT de los Argentinos, denunciar al Pacto Social y llamar a la unidad de todos los sectores revolucionarios, marxistas y peronistas.

\footnotetext{
${ }^{257}$ Este último había sido fundado en las postrimerías de 1972 por los abogados laboralistas Luis Cerrutti Costa y Felix Granovsky, con el objetivo de capacitar a dirigentes y delegados obreros de diversos gremios y de contribuir a la formación de una corriente sindical clasista independiente (Vazeilles, 2006). Luis Cerruti Costa tenía una trayectoria política de larga data: de orígenes nacionalistas y católicos, aunque también obreristas, llegó a ser Ministro de Trabajo del dictador Leonardi, asesor y abogado de múltiples sindicatos (Federación Gráfica Bonaerense, FOTIA, etc.) y formó parte del Comité de Abogados de la CGT de los Argentinos, junto a Manuel Gaggero, Rodolfo Ortega Peña, Eduardo Luis Duhalde, Alfredo Curuchet, Silvio Frondizi, entre otros. Con pasado de director del semanario Revolución Nacional durante los períodos 1946-1950 y 1955-1957, se transformó en director del diario $E l$ Mundo, vespertino adquirido por el PRT-ERP, en agosto de 1973, y fue un colaborador asiduo de la revista Nuevo Hombre. Por su parte Felix Gronovsky, amigo personal y colega de Cerruti Costa, había sido militante del PCA y fue parte de la experiencia editorial de El Mundo. (Maggio, 2012)
} 
Esta reunión fue la manifestación de un proceso organizativo que se venía gestando desde principios del año y que se cristalizó, como dijimos, en el plenario de julio. De éste último, realizado en el salón de actos del sindicato Luz y Fuerza de Córdoba, participaron mil quinientos delegados en representación de 200 organizaciones de trabajadores de todo el país, entre las que se hallaban sindicatos, CIR, comités de lucha y agrupaciones sindicales de Córdoba, de Gran Buenos Aires, Capital Federal, Tucumán, Salta, Jujuy, La Rioja, Santa Fe, Rosario, Paraná, etc. ${ }^{258}$ Entre los más destacados se encontraban los sindicatos de Luz y Fuerza y de Perkins, y el Movimiento de Recuperación Sindical de Córdoba, el Movimiento de Recuperación Sindical de SMATA Capital Federal, el Sindicato San José de Tucumán y la CGT de Salta. En el estrado, como parte de la Comisión Organizadora provisoria que presidía el encuentro, estaban Gregorio Flores, dirigente de FIAT y SITRAC y miembro del PRT-ERP; Leandro Fote miembro del Sindicato San José de Tucumán, también militante perretista; Roberto Campbell del sindicato de viajantes de Córdoba; Pérez del sindicato cordobés de Mercantiles; y López de Grandes Motores Diesel también de la ciudad mediterránea.

La reunión había sido convocada en un clima de alta tensión debido a la amenaza que había realizado la cúpula cegetista, encabezada por Rucci, de caducar el mandato de las

\footnotetext{
258 "Entre las delegaciones y adhesiones podemos citar: Sindicato Luz y Fuerza de Córdoba (delegación fraternal); obreros viales de Buenos Aires; Ferroviarios de Santiago del Estero; Activistas de la Construcción de Córdoba; Metalúrgicos de La Matanza; Agrupación Libertario Ferrari de Gas del Estado de Bs. As.; Comisión Interna de Grandes Motores Diesel (SMATA Córdoba); Movimiento de Recuperación Sindical de Córdoba; Comisión Directiva Provisoria Trabajadores de Sanidad de Córdoba; Agrupación Bancaria de Córdoba; Agrupación Mercantil de Córdoba; Obreros Viales de La Rioja: Municipales de Concepción (Tucumán); Agrupación 27 de Septiembre de Obras Sanitarias de Cba.; S. Fe: Agrupación de fideeros, judiciales, docentes, Personal Civil de la Nación, trasporte, ferroviarios, despedidos de Empleados Públicos, Comisión Interna y Comisión Directiva de Gráficos; de Paraná: Agrupación de Correos y Agrupación de la Unión Obrera de la Construcción; Juventud Trabajadora Peronista de Metalúrgicos de Avellaneda; Agrupación de Despedidos 2 de Marzo de SOMISA; Agrupación Empleados del Caucho de la Provincia de Bs. As.; Movimiento Sindical de San Pedro, Avanzada Telefónica de Cap. Fed.; Movimiento de Recuperación Sindical del SMATA de Capital Federal; Metalúrgica Tortone de Córdoba; Tendencia Obrera Revolucionaria de Metalúrgicos de San Nicolás; Instituto de Capacitación Obrera; Comisión Provisoria de Materfer y de Concord; Activistas Clasistas del SMATA, Córdoba; Sindicato San José, Tucumán; Sindicato del Fósforo de Córdoba; despedidos municipales de Córdoba, Unión de Educadores de Córdoba (Comisión Directiva); Frente de Trabajadores de Prensa, de Capital Federal; Agrupación 16 de Enero de Metalúrgicos de Nougés (Bs. As.); Frente de Trabajadores Combativos de Villa María; Comité de Lucha de Ferroductil (Florencio Varela); Cerveceros de Paraná; Comité Obrero de Giacomelli; despedidos de DINFIA, Córdoba (ex agrupación Felipe Vallese); Sindicato Perkins, Córdoba; Comisión Interna y Agrupación 29 de Mayo de Transax, Cba.; Lista Nueva de Luz y Fuerza de Mercedes; Lista Marrón de Metalúrgicos de Cap. Fed.; Agrupación de la Carne Rosario; Fábrica de Heraldo Euesch, Plásticos de Córdoba; Asociación Docentes de Arquitectura de Córdoba; Lista Gris del Frigorífico Swift de Berisso; Revista Nuevo Hombre; Delegación fraternal de la CGT Reg. Salta; adhesiones del Frente Revolucionario Peronista de Salta y de la Juventud Trabajadora de al Construcción y papeleros de Jujuy." (El Combatiente Nro. 82, viernes 19 de julio de 1973.)
} 
CGT regionales a partir del 1 de julio, apuntando directamente a la central cordobesa ${ }^{259}$. Esto se vio reflejado en la convocatoria al plenario en la que se denunciaba un plan organizado por "los sectores más reaccionarios de las 62 Organizaciones y grupos fascistas" que pretendía intervenir al gobierno cordobés y luego a todos los sindicatos $\operatorname{combativos}^{260}$. El repudio a las amenazas cegetistas formó parte de la mayoría de los discursos y tuvo un lugar en el temario de la reunión, el cual giró en torno a cinco puntos: "1. Caducidad del mandato de las CGT regionales y unidad del movimiento obrero; 2. Por la plena vigencia de las comisiones paritarias; 3. Por la reincorporación de los despedidos por causas gremiales o políticas; 4. Por un salario vital, mínimo y móvil; 5. Tareas de organización"261.

Gregorio Flores fue quien dio inició a la actividad plenaria remarcando la necesidad de que se respetara el carácter sindical del plenario y exhortando a los presentes a evitar transformarlo en un "deliberativo político" dominado por riñas entre las diferentes corrientes políticas que participaban del mismo. Como vimos esta advertencia respondía a la línea perretista de evitar sectarizar los espacios gremiales confundiendo su papel, y en ese sentido el plenario debía saber contener en su seno sin dificultades a "peronistas, radicales, socialistas, comunistas, marxistas y cristianos" que estuviesen de acuerdo con formar una alternativa combativa y antiburocrática al oficialismo cegetista. La participación en el plenario del Frente Revolucionario Peronista, a través de la CGT Salta, y de algunos sectores de la JTP (Salta, Jujuy y Avellaneda), como de otras organizaciones, era una muestra de que la apuesta frentista del PRT-ERP podía concretarse.

El plenario estuvo cargado de manifestaciones antipactistas, de denuncias a la "maniobra intervencionista" de la CGT nacional, de rechazo a la caducidad de la ley de convenios colectivos de trabajo y demás consignas antiburocráticas. Nuevamente el orador principal fue Agustín Tosco, como lo será en todos los actos públicos del MSB. En su discurso arremetió contra el Pacto Social y contra los intentos de intervención de los sindicatos combativos, e hizo un llamado a la unidad de todos los sectores antiburocráticos con permanentes alusiones a la necesidad de construir una "Patria Socialista" en Argentina para resolver los problemas de los trabajadores y el pueblo.

\footnotetext{
259 "Córdoba: plenario de las bases" Nuevo Hombre Nro. 44, jueves 12 de julio de 1973

${ }^{260}$ Es de destacar que el 15 de julio de 1973 el local de la CGT cordobesa fue copado por un grupo de la derecha denominado "Comando Resistencia" y fueron baleados los edificios de Luz y Fuerza y SMATA. Las hostilidades hacia los sindicatos y activistas "antiburocráticos" fueron in crecendo a lo largo de todo el año.

261 "Córdoba: Plenario de las bases" Nuevo Hombre Nro. 44, jueves 12 de julio de 1973.
} 
Según las actas publicadas en Nuevo Hombre, Tosco habría sido elegido como miembro de la Mesa Provisora del MSB, constituida en el plenario, junto a Rivera (Construcción), Russo (Banco Cooperativo de Caseros), Pose (Metalúrgico), Roda (Gas del Estado, Capital), Flores (SITRAC), Fote (FOTIA), Pérez (Mercantiles- Córdoba), López (SMATA) y Barraza (Gráficos), Bolenein y Soria (San José, Tucumán) ${ }^{262}$. Como indican muchos autores (Pozzi, 2004; Iñigo Carrera [et. al.], 2006; De Santis, 2010; Flores, 2013) la relación entre el PRT-ERP y el dirigente cordobés fue muy prolífica, sin embargo la mayoría indica que no habría participado formalmente ni del MSB ni del FAS. Nos arriesgamos a decir que probablemente se haya incorporado a la Mesa Provisora en una especie de "apadrinamiento" del espacio, papel que cumplirá efectivamente.

El plenario resolvió, además de denunciar al Pacto Social y la lucha por la plena vigencia de las paritarias, la construcción del MSB, con la tarea de editar un periódico y convocar a un nuevo plenario. El MSB pretendía ser una alternativa sindical democrática y antipatronal que, en oposición a la denominada "burocracia sindical", disputara la conducción de los sindicatos y de la CGT, sosteniendo los principios de unidad para el movimiento sindical. En ese sentido sostenía la necesidad de una CGT única y no se proponía fomentar la formación de un sindicalismo paralelo (Mattini, 2007: 184).

Como lo sugiere su nombre, para el MSB los organismos de base -agrupaciones, listas, CD y CIR- asumían un papel fundamental en su concepción de democracia sindical. Según los documentos, las bases obreras debían ser las que establecieran las normas que ajustaran el funcionamiento de los sindicatos y en ese sentido los espacios de base aparecían como los organismos a fortalecer debido a que eran considerados como los más propicios para garantizar la participación directa de los trabajadores en las decisiones, y también para controlar las "manipulaciones burocráticas". En ese sentido una de las garantías de la democracia sindical era la lucha contra el "dirigentismo", es decir, contra la tendencia a reducir la actividad sindical a las negociaciones con las patronales, sin promover la participación, organización y la movilización de las bases ${ }^{263}$. En ese marco el delegado de fábrica asumía un papel fundamental ya que era quien tenía menos posibilidades de despegarse de las bases, dependía del reconocimiento directo de sus compañeros de trabajo y podía ser controlado y revocado fácilmente por

\footnotetext{
262 Ídem.

263 "Plenario Sindical en La Matanza" Nuevo Hombre Nro. 54 primera quincena de enero.
} 
estos. Esta perspectiva queda clara en un documento titulado "Qué importancia tiene y cómo debe ser un delegado clasista" publicado por la Mesa Regional de la Zona Sur del MSB. En él se resalta el lugar clave que ocupaba el delegado en tanto representante de secciones de fábrica -espacio donde la contradicción entre la patronal y la clase obrera se hacían evidentes-. Asimismo se exponen las características ideales que, para el MSB, deberían tener estos representantes, entre los que se destacan: estar unidos constantemente con sus compañeros de trabajo, reflejando sus necesidades y llevando adelante sus derechos a pesar de cualquier dificultad que se presente; no perseguir nunca objetivos personales y rechazar todo intento de persuasión por parte de la patronal; sostener una posición antipatronal y antiimperialista y defender la democracia sindical haciéndola respetar consultando permanentemente a las bases. ${ }^{264}$

Detrás de la idea de delegado clasista se resumían los núcleos centrales del modelo sindical que propugnaba el MSB y, a través de él, el PRT-ERP. En oposición al "modelo burocrático", el cual era asociado a la "manipulación", la "corrupción", el "beneficio personal", "las negociaciones a espaldas de los trabajadores", etc., el delegado y el sindicato clasista debía caracterizarse por la "honestidad", la "representatividad", la "solidaridad de clase", "el respeto a la decisión de las bases", la “disposición a la lucha”, etc. Desde esta visión ningún delegado, aún surgido de la lucha antiburocrática, estaba exento de una posible "burocratización”, y la única garantía de evitarlo era con la participación directa de las bases en la toma de decisiones:

"La lucha contra la burocracia sirviente de los patrones no termina con reemplazar a sus personeros en la dirección del sindicato, y menos todavía cuando sólo se consigue hacerlo en la comisión interna de la fábrica. Sin la participación activa del conjunto de los compañeros, en pleno ejercicio de la democracia sindical, en la discusión de todos los problemas, y de todas las alternativas de lucha que se encare por las reivindicaciones generales y propias de cada lugar de trabajo, no está asegurado el triunfo. Si esto no se da, si los nuevos delegados y las nuevas internas, donde se consiguió desplazar a la burocracia, se reducen a las negociaciones a puertas cerradas con las patronales sin promover la participación, organización y movilización de las bases, se transformarán inevitablemente en una nueva burocracia."

En ese sentido, siguiendo a Farace y Jäkel, podemos decir que desde esta concepción, que con matices atravesaban a todas las vertientes de la nueva izquierda, la "democracia sindical" y la "lucha" eran dos conceptos inseparables y en ellos subyacía el supuesto de que la "verdadera" representación de "los intereses" de los trabajadores conllevaba la

\footnotetext{
264 "Qué importancia tiene y cómo debe ser un delegado clasista" Nuevo Hombre Nro. 58, primera quincena de marzo de 1974

265 "Plenario Sindical en La Matanza" Nuevo Hombre Nro. 54 primera quincena de enero.
} 
confrontación directa con la patronal, la burocracia o el Estado (2016: 166). De esta manera, los delegados aparecían como el arma de los clasistas desde la cual construir las fuerzas necesarias para ganar los sindicatos, ya que aquellos, supuestamente, eran más difícilmente controlables por la "burocracia" y por ende su eslabón más débil.

Por su parte, el programa del MSB contenía denuncias, reivindicaciones permanentes y un plan de lucha que intentaba contener las reivindicaciones inmediatas. Lo primero que denunciaba era el Pacto Social y desde allí se criticaba fuertemente a la Ley de Asociaciones Profesionales y de Prescindibilidad -que facilitaba los despidos masivos- a la vez que hacía foco en las reformas al Código Penal. En la lista de reivindicaciones permanentes se exigía la derogación de la legislación represiva, el mejoramiento de las condiciones de vida y de trabajo (en las que figuraba principalmente el reclamo por vivienda digna, fuentes de trabajo, salud gratuita y derechos cívicos) y el ejercicio de la democracia sindical (este último se erigía como punto central). Por último, se incorporaban las exigencias del control obrero de la producción, la libertad a los presos políticos, la convocatoria de las comisiones paritarias nacionales para la discusión de los convenios colectivos, el aumento de los salarios y el retiro de las fuerzas policiales de los lugares de trabajo.

De acuerdo con sus estatutos el MSB podía estar integrado tanto por personas físicas en calidad de trabajadores en relación de dependencia, así como colectivamente a través de agrupaciones gremiales o sindicales de obreros o empleados. El mismo estaba conformado en base a una estructura federativa nacional integrada por regionales, provinciales o zonales, delimitadas y diferenciadas por el número de sus adherentes o características socio-económicas. La dirección nacional consistía de una Mesa Nacional compuesta por un número no menor de 5 y no mayor de 15 miembros que representaban a las diversas regionales; a su vez cada regional, en tanto dirección intermedia, elegía su Mesa Regional a propuesta de los plenarios de cada una de ellas ${ }^{266}$.

De este modo a lo largo de 1973 se fueron desarrollando los distintos plenarios regionales en los que se conformaron las direcciones locales y se definieron los ejes básicos de organización y de lucha. Así por ejemplo, hacia septiembre de ese mismo año en la ciudad de Metán, se llevó adelante la fundación del MSB salteño y jujeño, en la que participaron representantes de la Agrupación 14 de julio del Tabaco, del Sindicato de Obreros del Ladrillo, Municipales, Sindicato Único de Obreros del

\footnotetext{
${ }^{266}$ MSB. Cuadernos de formación popular nro 1. Buenos Aires, Editora Popular Americana, abril-mayo 1974
} 
Vestido, Sindicato de la Construcción, Sindicato de Obreros Gráficos, Obreros temporarios del tabaco, Sindicatos de Canillitas y Judiciales, entre otros. En él se definió la dirección de la zona, y se planteó como prioridad fundamental "rescatar la central [CGT Salta] a cualquier precio" 267.

Por su parte el 22 de diciembre del mismo año en villa Las Antenas, la Matanza, Provincia de Buenos Aires, se realizó un plenario convocado por las regionales Capital Federal y Buenos Aires con el objetivo de lograr una coordinación conjunta y resolver una misma política para la zona, avanzando en la estructura orgánica, con la creación de una coordinadora interzonal. Al mismo concurrieron cerca de 200 activistas, y se discutió sobre la situación de las principales industrias de la zona, las principales luchas que se venían desarrollando en las distintas empresas y se repudió a la Ley de Asociaciones Profesionales y a la Ley de Prescindibilidad ${ }^{268}$. En su convocatoria se resaltaban las luchas de la zona de los telegrafistas de la Seccional Sur, Yelmo, Vialidad, General Motors, empleados de Acindar, Zapeba, Peñaflor, Blindex, Cristaluz, Alpargatas, Wobron, Terrabusi, Squibb, Del Carlo, Philips, Oxigena San Justo y Santa Rosa, entre otras, en muchas de las cuales el PRT-ERP tenía un trabajo político, así como también lo empezaba a tener el movimiento como tal.

El MSB tuvo un crecimiento desigual aunque sostenido en las distintas regionales y zonas, dándose las formas organizativas más propicias en relación a los niveles de desarrollo de cada regional. Por ejemplo en Salta, donde la CGT clasista estaba integrada al MSB, logró niveles de movilización muy importantes durante esos años, pudiendo coordinar medidas de lucha con varios sindicatos. En Tucumán se conformó una Mesa Regional desde la cual se impulsó una activa participación en diversas luchas obreras entre las que se destacaron el conflicto azucarero ${ }^{269}$ y el de la planta citrícola "San Miguel"270 del año 1974, así como también participó de distintos actos contra el

\footnotetext{
267“Salta: se forma el Movimiento Sindical de Base” El Combatiente Nro. 89, 7 septiembre de 1973

${ }^{268}$ Nuevo Hombre, Nro. 54. 1era quincena de enero de 1974.

${ }^{269}$ La lucha de los obreros azucareros fue paradigmática en tanto significó un enfrentamiento directo al Pacto Social ya que la reivindicación central eran aumentos salariales de más del $50 \%$. El conflicto motivó el desarrollo de asambleas zonales en distintos ingenios, la convocatoria a un Congreso Nacional Azucarero, movilizaciones y paros, y la posterior intervención del sindicato por parte del gobierno nacional. Allí el MSB, que intervenía a través de la Agrupación Obrera Azucarera de Base en la que participaban los dirigentes José Amador y Leandro Fote (parte de la Comisión de Movilización de la FOTIA), no solo participó activamente de todas las reuniones y asambleas realizadas sino que logró organizar una asamblea propia de delegados y activistas en la que diseñó una propuesta de plan de lucha. Es de destacar que también editaba un boletín informativo llamado "El trabajador azucarero". (Nuevo Hombre Nro. 68, segunda quincena de agosto de 1974)

${ }^{270}$ La planta "San Miguel" fue tomada por sus trabajadores para reclamar el pago de salarios y asignaciones familiares, el cumplimiento de los horarios y el pago de las horas extras. Luego de tres días
} 
avance represivo. Por otro lado se hallan referencias menores sobre la actividad del MSB en Mendoza (donde realizó de un acto en conmemoración con el 1 de Mayo junto al Peronismo de Base que concentró cerca 600 personas), Misiones y Bahía Blanca ${ }^{271}$. La Regional Buenos Aires, como vimos, se organizaba a través de una mesa interzonal para trabajar en conjunto los conflictos de las zonas, y por ejemplo la Zona Capital, pequeña en relación a las otras, impulsaba una mesa coordinadora provisoria desde la cual apoyaba y participaba en varios conflictos. Esta forma organizativa mutó hacia 1974, año en que la Zona Capital, Zona Norte, Zona Oeste y Zona Sur llevaron adelante sus respectivos plenarios y eligieron sus propias mesas zonales. Por su parte en Córdoba, fue donde tuvo mayor desarrollo ${ }^{272}$. Como indica Gregorio Flores: "El Movimiento Sindical de Base tuvo en Córdoba un crecimiento importante en gráficos, en Perkins Fiat-Concord, Materfer, Renault, en sindicatos como el caucho, lecheros, el calzado, en Luz y Fuerza" (Flores, 2013:123). Su influencia se extendía a ramas como: automotrices, sanitarios, lácteos, docentes, viales, gráficos, viajantes, estatales nacionales y provinciales, construcción, caucho, metalúrgicos, municipales, lucifuercistas, hospitalarios, gremios profesionales, etc., (Bohoslavsky, 2016:59). De este modo se transformó en un pilar del movimiento obrero cordobés en casi todas las fábricas y conflictos gremiales e integró (y fue un actor clave en su formación) el Movimiento Sindical Combativo (MSC) junto a Agustín Tosco y René Salamanca (Pozzi, 2001). Este último era un frente intergremial organizado fundamentalmente por los sindicatos Luz y Fuerza, SMATA y Perkins al cual se sumaron numerosos gremios como Obras Sanitarias, Caucho, Prensa, Gráficos, Viajantes, Lecheros, docentes, entre otros, y CIR y agrupaciones de casi todo el ámbito laboral cordobés. El MSC actuaba como una corriente dentro de la CGT cordobesa, abarcaba a todo el sindicalismo que no estaba alineado a las dos ramas de las 62 Organizaciones, y desde ese lugar fue el que

de toma la fábrica fue desalojada por la policía provincial. Uno de los dirigentes de la fábrica fue el "Negro Miguel" quien a su vez era integrante de la mesa regional del MSB. (Nuevo Hombre Nro. 69, primera quincena de septiembre de 1974)

271 Dichas referencias fueron encontradas en la sección "Crónicas de la Guerra Revolucionaria" del periódico Estrella Roja del año 1974.

${ }^{272}$ El 19 de enero de 1974 el MSB de Córdoba realizó su propio plenario en el que participaron las siguientes agrupaciones: Movimiento Clasista de Perkins; Agrupación de Base Obreros de la Carne; Democracia Obrera de SanCor, Agrupación Activistas de IME; Movimiento de Base de G.M.D; Agrupación Emilio Jáuregui (Prensa); Agrupación 22 de Noviembre de Municipales; Agrupación Activistas Independientes de la Construcción; Agrupación de Base de Bancarios; Agrupación Combativa Mercantil; Agrupación Activistas de Luz y Fuerza; Agrupación Combativa de A.T.S.A; Agrupación Los Decididos de CONCORD; Agrupación Obreros del Vidrio; MSB "San Francisco". Activistas de: Kaiser, Thompson Ramco y de Obras Sanitarias, Metalúrgicos de Córdoba, Docentes y No Docentes, Graficos, Caucho. Despedidos de: Fiat, Perkins y Kaiser. ("Llama a plenario el MSB de Córdoba" El Mundo, jueves 24 de enero de 1974). 
encabezó la resistencia ante la avanzada derechista en la provincia durante 1974 y el que protagonizó la coordinadora de gremios en lucha durante el año 1975.

\section{2.b. El II Plenario Nacional y la intervención de la Regional Buenos Aires.}

Los últimos meses de 1973 y el comienzo de 1974 estuvieron marcados por una clara ofensiva de los sectores del sindicalismo ortodoxo quienes se dispusieron a avanzar desde el gobierno y los sindicatos contra todas las expresiones combativas y antiburocráticas del movimiento obrero. Entre noviembre y diciembre, con la Ley de Asociaciones Profesionales y con la consolidación de Ricardo Otero en la cartera de trabajo, se afirmaba la importancia de la "burocracia sindical" en el esquema del gobierno, algo que se vio reflejado en el poder que fue adquiriendo la figura de Lorenzo Miguel desde la UOM y las 62 Organizaciones. Esto además iba acompañado con el recrudecimiento de la represión legal e ilegal, la persecución y el asesinato de militantes y activistas gremiales ${ }^{273}$ y las amenazas, atentados y allanamientos que sufrieron publicaciones como el diario El Mundo y las revistas Militancia y el Descamisado ${ }^{274}$.

Como parte de esta escalada, la conducción nacional de Luz y Fuerza suspendió la afiliación de la delegación cordobesa liderada por Tosco y el gremio SMATA hizo lo propio con la filial liderada por Salamanca. Esto motivó la realización de un acto convocado por la CGT local el 14 de diciembre, en repudio al avance del "fascismo" en la provincia cordobesa. Del mismo participó el $\mathrm{MSB}^{275}$ que, en la versión perretista, había sido junto al PB y los sindicatos combativos quienes habían tenido la iniciativa y habían logrado imponérselo prácticamente a la CGT regional que no estaba convencida

\footnotetext{
${ }^{273}$ Un ejemplo de ello, entre otros, fue la denuncia realizada en conferencia de prensa por el MSB Regional Campana por la desaparición de Pedro Amaranto, militante de la organización, y del secuestro y la tortura de Luis Marcelo Panizza, delegado de la empresa EATON. (Nuevo Hombre Nro. 62, primera quincena de mayo de 1974)

${ }^{274}$ El vínculo del MSB con estas publicaciones no sólo estaba dado por su afinidad política, centralmente con El Mundo y Militancia, sino a través de la Agrupación de Bases de Prensa, la cual denunció recurrentemente estos ataques: “(...) El gremio de prensa ha sido uno de los sectores más castigados, por expresar algunos periódicos las denuncias y las luchas de la clase trabajadora en su conjunto. Así lo manifiestan los ataques a 'Militancia' y 'El Descamisado', el secuestro de Roberto Reyna, la arbitraria detención de Cazes Camarero, Oscar Gonzales en Santiago del Estero, la de Olguín herido en Rosario, la bomba de COGTAL y la anterior clausura y luego ataque a balazos contra 'El Mundo', dejando en la calle a 300 familias de trabajadores. Con todo esto, queda bien claro que el objetivo de los fascistas es la PRENSA POPULAR (...) ¡Por la apertura de la fuente de trabajo! ¡Por la unidad del gremio contra el fascismo! ¡Coordinemos la lucha antifascista! Agrupación de Bases de Prensa (adherida al Movimiento Sindical de Base)" (Nuevo Hombre Nro. 59 Segunda quincena de marzo de 1974).

${ }^{275}$ El MSB también adhirió y participó del acto realizado el 24 de enero de 1974 frente al Congreso de la Nación para repudiar el intento de modificación del Código Penal. En aquel acto además la organización denunciaba la Ley de Presindibilidad y arbitraje obligatorio y la ley de asociaciones profesionales como parte de un "plan anti obrero y pro-imperialista" ("El MSB en el acto del 24 en el Congreso" El Mundo, miércoles 23 de enero de 1974)
} 
de convocarlo ${ }^{276}$. Pocos meses después, el 28 de febrero de 1974 finalmente la burocracia sindical dio el golpe de gracia sobre la CGT cordobesa. En el marco del "Navarrazo" (golpe de estado policial encabezado por el jefe de la policía provincial Antonio Navarro, que destituyó al gobernador Ricardo Obregón Cano y al vice gobernador Atilio López), se llevó adelante un congreso normalizador que sesionó bajo el principio de que la central obrera debía ser conducida por la ortodoxia justicialista. La presencia del ministro de trabajo de la nación y del secretario adjunto de la CGT nacional, Raúl Ravitti, tuvo el objetivo de legitimar ese proceso (Di Palma, 2014; Iñigo Carrera [et. al.], 2006).

En este contexto, la regional Buenos Aires del MSB publicó una declaración donde denunciaba esta escalada represiva y donde reconocía como única autoridad representativa de la CGT regional a Tosco y a Roberto Tapia (Secretario General) y al mismo tiempo hacía un llamado a la unidad de las bases para la luchar por aumentos salariales, mejores condiciones de salubridad, seguridad laboral, contra los topes de producción y por el retiro de la gendarmería de las fábricas ${ }^{277}$. Esta declaración, a su vez, estuvo acompañada por la participación masiva del movimiento en el acto convocado por el MSC el 25 de marzo, para repudiar la intervención provincial y la “usurpación” de la CGT. Allí el MSB tuvo a Gregorio Flores como uno de los oradores centrales del acto.

Unos días después, el 13 abril, se realizó el Segundo Plenario Nacional del MSB ${ }^{278}$. Reunidos en el Córdoba Sport, ubicado en la capital mediterránea, participaron cerca de cinco mil trabajadores en representación de ciento veinte agrupaciones sindicales, sindicatos y CIR. En él se eligieron los miembros de la Mesa Nacional quedando integrada por quince miembros ${ }^{279}$, siendo designado Eduardo Castello (miembro del

\footnotetext{
${ }^{276}$ De este plenario también participaron la JP y la JTP quienes fueron denunciadas por el PRT-ERP en su periódico El Combatiente por tener una supuesta actitud antiunitaria y "manijera"' por haber intentado copar el acto e imponiendo sus propias consignas (Actitud sectaria en el acto de Córdoba" en $E l$ Combatiente Nro. 101. Miércoles 19 de Diciembre de 1973)

${ }^{277}$ Solicitada aparecida en Nuevo Hombre Nro. 59 Segunda quincena de marzo de 1974

${ }^{278} \mathrm{El}$ mismo había sido definido desde principios de marzo en la reunión de la Mesa Nacional del MSB en la que además se hizo un balance del primer plenario y se paso revista de la constitución de las diferentes zonas. ("Reunión nacional del MSB" El Combatiente Nro. 110, 13 de marzo de 1974)

279 "Otros sindicalistas conocidos que participaron del plenario fueron: Gregorio Flores, Domingo Bizzi y Julio Oropel (SITRAC), Leandro Fote (FOTIA), Melitón Vázques (Ingenio Ledesma), Daniel De Santis (Propulsora Siderúrgica), Miguel Ángel Bazán (Luz y Fuerza de Córdoba), Abelardo Correa (FOESYT Córdoba), Ramón Rojas (Carne de Rosario), Luis Segovia, Zenón Sánchez y Ángel Porcu (UOM- Villa Constitución). La mesa del MSB quedo integrada por Castelo, Oropel, Bizzi, Escobar, Panizza (EATONBuenos Aires), Gonzales (SOETAP), Elías (Paraná), Carnas (Rosario), además de tres tucumanos no identificados, un trabajador rural de Chaco, Luz y Fuerza de Campana, Agrupación Avanzada Telefónica de Capital Federal y la Agrupación 3 de abril del Banco Nación (Capital Federal)" (Pozzi; 2001: 325)
} 
PRT-ERP) como su Secretario General. Además se aprobaron oficialmente los estatutos y el programa. Por otro lado, considerando que existía una ofensiva general de sectores fascistas y burgueses dentro y fuera del Gobierno, así como también de la "burocracia sindical", y una dispersión de los sectores combativos del movimiento obrero, se resolvió hacer un llamado a todas las corrientes de éste último a convocar de manera conjunta un "Gran Plenario Combativo" para definir un plan de lucha y una movilización nacional para derrotar fundamentalmente el Pacto Social.

Entre las distintas regionales que participaron, la Regional Buenos Aires contó con una cantidad considerable de asistentes, entre los que se encontraban agrupaciones de los establecimientos Rigolleau (Berazategui), SIAP, Fiat (Palomar-Caseros), A.T.E, Imperial Crod, Cildañez (Lugano), EATON (José C. Paz), Polimene (Ezpeleta), Terrabusi, Metalúrgica Karen, General Motors, Peugeot, TAMET, Kapeluz, Kodak, Miluz, Lamidesc, Matarazzo (Avellaneda), WINCO, INSUD, FATE, Santa Rosa, entre otras, así como también CIR y delegados de distintos lugares de trabajo ${ }^{280}$. Como muestran los informes de inteligencia de la ex DIPBA, hubo una activa organización del MSB en el Gran Buenos Aires, del cual salieron colectivos desde distintos puntos geográficos: Zona Norte, Zona Sur, Zona Oeste del Gran Buenos Aires y de Zona Capital Federal. ${ }^{281}$

Por lo que puede verse los años 1973 y 1974 fueron los de mayor actividad y desarrollo del MSB Regional Buenos Aires y del MSB a nivel Nacional, llevándose adelante los plenarios nacionales anteriormente mencionados así como también instancias de plenarios zonales y regionales. En la Regional Buenos Aires durante estos años tuvo

\footnotetext{
${ }^{280}$ Agrupación Unidad Obrera- Lista Naranja de la Fábrica Rigolleau, Movimiento gremial TelefónicoAvanzada-Lista Rosa, Agrupación "3 de Febrero" del Sindicato de Plomeros, Agrupación de Base de Municipales, Resistencia Obrera (SIAP), Agrupación de Base de Prensa, Agrupación Sindical 5 de Marzo de Gas del Estado, Agrupación de Base de Correos y Telecomunicaciones, Frente Trabajadores de Prensa, Agrupación Obrera de Fiat (Palomar-Caseros), Delegado de Turno-FAE-Avellaneda, Agrupación Compañeros de Base de A.T.E, Agrupación de Base Imperial Cord., Agrupación de Base CildañezLugano, Agrupación Omar Rigletti de EATON (Fundaciones), Agrupación 3 de Abril de Banco Nación, Comisión Interna del Banco Cooperativo de Caseros, Agrupación de Base del Banco Alemán Transatlántico, Agrupación 30 de Noviembre (Terrabusi), Agrupación de Base de Ezpeleta- Fábrica Polimene, Agrupación Metalúrgica de Karen, General Motors-Lista Marrón-SMATA, Agrupación Juan Lachoski de Peugeot, Agrupación TAMET, Comisión Interna de Kapeluz, Navales-Agrupación Celeste y Blanca-Verde Nilo, Kodak. Agrupación de Base Miluz, Lamidesc- Delegado de Fábrica, Comisión Interna de A. Levin e Hijos, Comisión Interna de UDEN-INTI, Agrupación de Base de Matarazzo, Agrupación de Base 20 de Junio de FATE, Agrupación de Plástico (INDUPLAST), Movimiento de Base de WINCO, Comisión Interna de INSUD, Agrupación de Ferro Ductil, Agrupación de Base de Sandol, Comisión Directiva de Mono-For, Comisión Interna de Papelera Berazategui, Agrupación de BasePlásticos FAT, Agrupación de Base de MONSIL, Delegado Agrupación Paraguaya, Agrupación Docente Universitaria (APUBA), Frente de Recuperación Sindical (Vease MSB. Cuadernos de formación popular Nro 1. Buenos Aires, Editora Popular Americana, abril-mayo 1974)

${ }^{281}$ DIPPBA, Mesa “B”, Carpeta 128. Legajo 16. Localidades Varias
} 
presencia destacada en distintos conflictos. Así por ejemplo participó del conflicto de la fábrica INSUD, productora de plomo, ubicada en la ciudad de San Justo. En esta fábrica los trabajadores reclamaban por el pago de salarios adeudados y por mejores condiciones de salubridad. El pico máximo de este conflicto, que se venía arrastrando desde 1973, fue en marzo 1974 cuando en respuesta a la negativa de la patronal a pagar salarios y ante la muerte de dos trabajadores afectados por saturnismo (enfermedad producida por la reiterada exposición al plomo en el ambiente de trabajo) se llevó adelante una huelga con movilizaciones y ollas populares (Ríos, 2017). La lucha fue cubierta por la mayoría de los medios populares ${ }^{282}$ y fue levantada y defendida en el parlamento por Rodolfo Ortega Peña, por ese entonces diputado nacional, a través del cual se logró declarar insalubre la actividad en la planta. La resolución final del conflicto, sin embargo, se precipitó gracias al secuestro del gerente de la empresa por parte del ERP el 25 de marzo. Es de destacar que el PRT-ERP tenía un intenso trabajo en dicha planta y gracias a ello el MSB intervenía directamente a través de la CIR, la cual participó y adhirió al plenario de abril.

Otra de las luchas destacadas fue la de la fideera Matarazzo. Allí desde diciembre de 1973 se venía desarrollando un conflicto ligado al despido de activistas y trabajadores y por el pedido de aumentos salariales, que culminó con la toma del establecimiento con toma de rehenes en mayo de $1974 .{ }^{283} \mathrm{El} \mathrm{MSB}$, principalmente junto a la JTP, intervino activamente a través de la "Agrupación de Base de Matarazzo" y también externamente con reiterados apoyos y muestras de solidaridad en la puerta de la fábrica.

Por otro lado participó de la lucha de los trabajadores de fábrica de electrodomésticos Winco, ubicada en la localidad de Ciudadela en Zona Oeste del Gran Buenos Aires. El 10 de julio los obreros de la planta habían decidido en una asamblea de 1500 operarios entrar en huelga por salarios adeudados y por la reincorporación de noventa despedidos. Allí la intervención se daba a través del "Movimiento de Base de Winco"284.

\footnotetext{
282 Por ejemplo el colectivo Cine de la Base, dirigido por Raymundo Glayzer y ligados al PRT-ERP, realizó un documental sobre la lucha de los trabajadores de INSUD titulado "Me matan si no trabajo y si trabajo me matan", así como también el conflicto tuvo una amplia cobertura de la revista Nuevo Hombre y el diario El Mundo.

283 "La lucha en Matarazzo muestra para qué sirve el Pacto Social" en Nuevo Hombre Nro. 63 de la segunda quincena de mayo de 1974

${ }^{284}$ Allí mediante un volante titulado "Viva la huelga de los obreros de Winco" la agrupación adherida al MSB exhortaba a los trabajadores a darse una nueva dirección en la fábrica ante la actitud "traidora de la 'comisión interna' y de algunos 'seudo delegados", y a tomar a la asamblea general como el único lugar de decisión. Por último proponía la formación de un Comité de Huelga para dirigir el conflicto y de múltiples comisiones (de solidaridad, de tareas, de finanzas y de autodefensa) con las que organizar la difusión y defensa de la huelga. (Nuevo Hombre Nro. 66, segunda quincena de julio de 1974.)
} 
El MSB también participó, entre otras luchas, en la de los obreros gráficos de IVISA a través de la "Agrupación Gráfica de Base", en la lucha de los trabajadores de prensa con la "Agrupación de Base de Prensa", y en la lucha de los obreros de Bagley, ubicada en Capital Federal, desde la coordinadora zonal.

En el marco de estos conflictos la Regional Buenos Aires convocó a un plenario para el 8 de junio a realizarse a las $14 \mathrm{hs}$ nuevamente en villa Las Antenas. Sin embargo el mismo fue intervenido por la policía y clausurado, acusando que los organizadores no habían pedido el permiso correspondiente a las autoridades necesarias. Ante la imposibilidad de realizarlo, los asistentes, cerca de 600, resolvieron movilizarse hacia la Universidad Tecnológica de Buenos Aires donde estaba sesionando el congreso de la Liga de los Derechos del Hombre para denunciar la proscripción y la represión. Allí además ensayaron una reunión donde se reafirmó la voluntad de realizar el plenario ${ }^{285}$. Pocos días después, el 15 de junio, el MSB tuvo una destacada participación en el VI Congreso del FAS realizado en Rosario como organización adherente al acto y a través de varias de sus agrupaciones de base como por ejemplo la Agrupación de Trabajadores de Prensa y Avanzada Telefónica ${ }^{286}$. En nombre de esta última, y como representante del MSB, un dirigente telefónico brindo una entrevista a la revista Nuevo Hombre en la que planteó la necesidad de un Frente Antiburocrático y remarcaron la importancia de la participación de los obreros en el FAS ${ }^{287}$.

La actividad pública del MSB fue mermando hacia fines del año 1974 e inicios del año 1975. Tal es así que durante ese último año no se registran nuevos plenarios regionales o reuniones publicas, y tampoco se realizó el III Plenario Nacional, algo significativo ya que los plazos estipulados estatutariamente marcaban una periodicidad de Plenarios Nacionales anuales y Plenarios Regionales cada tres meses. Consideramos que esto se debió al menos a dos factores: por un lado al aumento del clima represivo que hizo difícil el desarrollo normal de una organización que se proponía desenvolverse "en el marco de los derechos y garantías emergentes de la Constitución Nacional"; y por otra parte, como se verá en el próximo apartado, a que las aspiraciones de constituirse en un amplio movimiento gremial chocaron con el control "administrativo" y el excesivo "hegemonismo" del PRT-ERP que lo llevó, sobre todo en este último año, a una parálisis de sus estructuras.

\footnotetext{
${ }^{285}$ Nuevo Hombre Nro.65 segunda quincena de junio de 1974.

286 "El VI Congreso del FAS" El Combatiente Nro. 122, miércoles 19 de julio de 1974

287 "El FAS según dirigentes políticos y sindicales" Nuevo Hombre Nro. 65 segunda quincena de junio de 1974.
} 
Sin embargo durante el año 1975 el MSB logró tener distintos niveles de presencia en las luchas obreras y en las coordinadoras interfabriles, sobre todo en la Mesa Previsora de Gremios en Lucha de Córdoba, desde donde a través del MSC se impulsaron y condujeron las grandes movilizaciones de las automotrices Perkins, Transax, Grandes Motores Diesel y Thompson Ramco. En cuanto a las coordinadoras interfabriles del Gran Buenos Aires su intervención es difícil de rastrear ya que no existen demasiadas fuentes que demuestren su participación efectiva, más allá de algunas referencias (Löbbe, 2006), aunque sí podemos afirmar que fue débil ya que hacia agosto de ese mismo año el propio PRT-ERP hacía un llamado a su militancia fabril a "revitalizarlo"288, por lo que es probable que en esos momentos la intervención del MSB se haya reducido casi exclusivamente a la intervención de dicho partido, situación que se extenderá hasta su extinción definitiva.

\section{2.c. El MSB deviene en brazo sindical del PRT-ERP}

El MSB fue pensado por el PRT-ERP como la forma más acabada de llevar adelante una política de democracia sindical clasista, lo que significaba que la amplitud debía ser el rasgo fundamental del movimiento. Esto se refleja en sus estatutos, en los que queda en claro que el MSB no pretendía ser la herramienta de una corriente política, sino una alternativa de organización y combate para las más amplias masas obreras, con sus distintas tendencias políticas.

En el plano de las fuerzas sindicales, el PRT-ERP tenía una caracterización acabada de cada uno de los espacios que formaban parte del amplio abanico de corrientes antiburocráticas. En ese sentido la organización definía seis nucleamientos principales: 1-el "reformismo", en el que ubicaba al Movimiento Nacional Intersindical, corriente impulsada por el PCA, que era caracterizada como una fuerza sindical que agrupaba un sector de la clase obrera dispuesto a la lucha reivindicativa pero cuya determinación y definición netamente combativa variaba según el avance de la lucha de masas; 2- los “espontaneístas", calificativo con el que identificaban a las corrientes dirigidas por las organizaciones trotskistas y que, a los ojos perretistas, se caracterizaban por su marcado sectarismo; 3- la corriente liderada por Agustín Tosco, quien era definido como uno de los dirigentes más destacados del país y uno de los responsables de la experiencias del MSC; 4- las agrupaciones lideradas por el PB, que eran vistas como el sector más

${ }^{288}$ Boletín Interno Nro. 85, 29 de agosto de 1975 
avanzado del peronismo revolucionario por dar muestras efectivas de independencia de clase; 5- la JTP, analizada como la corriente sindical más reticente a romper "definitivamente con la conducción burguesa del movimiento obrero y avanzar hacia el frente contra la burocracia"; y por último 6- el MSB. ${ }^{289}$

Éstos, según Luis Mattini, excepto los trotskistas, eran los aliados considerados principales para la actividad sindical perretista, y por ende los principales aliados para la política del MSB (Mattini, 2007: 184). No obstante, el MSB solo logró nuclear algunos agrupamientos políticos de izquierda como el Grupo Obrero Revolucionario (GOR) ${ }^{290}$, Orientación Socialista ${ }^{291}$, Liga Espartaco, el Partido Comunista Marxista Leninista $(\mathrm{PCML})^{292}$ y si bien contó con la participación y adhesión en sus actos del FRP, las FAL (Columna Lescano-Polti-Taborda, Columna América en Armas y Columna Che Guevara), la Juventud Radical Revolucionaria y la sección tucumana del PB, estos grupos nunca terminaron de incorporarse formalmente. El hecho de que no lograra incorporar a fuerzas políticas como el PB o incluso de formalizar la participación del FRP, que en la práctica eran los principales aliados, fue una clara muestra de las deficiencias políticas que tuvo la experiencia. En la práctica, y a contrapelo de sus objetivos y definiciones, el MSB se transformó en el brazo sindical del PRT-ERP. Como indica el testimonio de Luis Mattini:

“en el MSB se juntaba la gente que no era perro pero movía la cola, o sea que no se identificaba como PRT por las razones que fueran pero bueno, simpatizaban, estaban tan cerca que... bueno algunos grupos que tendría que acordarme, este... OCPO... a veces hemos tenido tareas común con el PST, pero era muy difícil, depende donde... en general era agrupar todo lo que estuviera contra la burocracia sindical. Y bueno el MSB, claro, tuvo el desarrollo donde había gente del PRT (...)",293

La amplitud se transformó así en la dimensión más problemática para la organización, lo que la llevó en muchos casos a transformar al MSB en un sinónimo del PRT-ERP, desviando el sentido original por el cual el partido había impulsado dicha herramienta. Los problemas principales estaban en los criterios con los que la organización tendió a

\footnotetext{
289 "Los revolucionarios y la actividad sindical” El Combatiente Nro. 120, miércoles 5 de junio de 1974

${ }^{290}$ El Grupo Obrero Revolucionario (GOR) se fundó en 1971 en base a una de las fracciones del PRT-El Combatiente que se desprendió de la organización en el V Congreso partidario (ver Capítulo 2).

${ }^{291}$ Orientación Socialista fue el resultado de una fracción interna del grupo El Obrero.

292 El PCML fue una organización de orientación maoísta fundada en 1969 en base a un grupo de militantes de la ciudad de La Plata que había sido expulsado del PCA en 1963 por haber exigido poner en debate la polémica chino-soviética y la Revolución Cubana. Lugo de debates iniciales, aquella organización rechazó el "foquismo", basó su estrategia en la penetración fabril y la intervención clandestina de sus miembros en los sindicatos y se distanció del resto de las corrientes maoístas tanto en su estrategia como en su interpretación del peronismo. Su influencia se concentró en La Plata, Berisso y Ensenada, aunque contó con grupo de militantes en otras zonas del país. (Celentano, 2005)

${ }^{293}$ Entrevista a Luis Mattini por el autor, Buenos Aires, 2017.
} 
construir los espacios frentistas que afectaron la relación con las demás fuerzas políticas. Esto puede verse en el testimonio de Armando Jaime, líder de la CGT Clasista y dirigente del FRP:

“(...) teníamos muchas discusiones con ellos... cuestiones que yo a veces les planteo a los compañeros cuando hacíamos política de alianzas. Había muchas discusiones con ellos en torno más que todo a la metodología, al respeto mutuo entre las organizaciones, todo eso, que a veces a nivel de la dirección de ellos, ellos lo comprendían y lo manifestaban y daban directivas, pero muchas veces en la base, en la militancia común se comenten errores ¿no? De atropello...

En ese sentido, Gregorio Flores reconstruye las prácticas militantes que llevaron, en varios casos, a que algunas fuerzas se sintieran "atropelladas" por el PRT-ERP al interior de los espacios frentistas:

\begin{abstract}
"En el MSB existía el mismo criterio que en la conformación del FAS. La orientación general la daba el PRT; luego en las reuniones con los distintos frentes se informaba lo que sucedía en cada fábrica, obra, talleres, etc. y ahí se sacaban las tareas a realizar (volantes, piquetes, etc). El PRT era, por lejos, la organización que movilizaba la mayor cantidad de militantes, y simpatizantes y también la más conocida y respetada por su conducta militante. En una oportunidad los compañeros de El Obrero me plantearon lo siguiente: nosotros no estamos de acuerdo con que el FAS funcione como un apéndice del PRT. Naturalmente, llevé esta inquietud a la dirección del PRT y el Negro Mauro me respondió lo siguiente: 'El PRT pone el $80 \%$ de los militantes, el $80 \%$ de los locales y el $80 \%$ de la guita. Entonces, con todo derecho tiene que poner el $80 \%$ de la política.' Cuando le conté esto a los compañeros de El Obrero, ellos me dijeron: 'Sí está bien, pero así no se construye un frente.'. Poco tiempo después El Obrero se fue del FAS." (Flores, 2013:125)
\end{abstract}

Aquí se evidencia una forma esquemática de entender la dirección de un espacio político que parece haber obstruido también la incorporación de nuevos aliados al MSB. Creemos que fue ese mismo criterio el que llevó al PRT-ERP, por ejemplo, a hegemonizar la Mesa Nacional, siendo parte de ella con doce de sus quince miembros, y negándose a elevar su número de integrantes para que participasen cuatro agrupaciones que habían pedido formar parte (De Santis, 2010:377). Por otro lado también se rechazó la participación del PRT-Fracción Roja reciente desprendimiento partidario (Flores, 2013:73), algo que probablemente no hubiese sucedido si no hubiera existido un control político absoluto de los perretistas.

Esta forma de dirigir el espacio no coincidía con los criterios que la misma organización planteaba en sus documentos, sino que más bien parecían ser los opuestos. El MSB debía ser la instancia organizativa desde la cual invitar y organizar a la mayor cantidad de organizaciones y dirigentes sindicales que coincidieran con las bases del programa

\footnotetext{
${ }^{294}$ Entrevista a Armando Jaime por el autor, Salta, 2016.
} 
antiburocrático, incluso aquellos que a sus ojos poseían "desviaciones sindicalistas" o "reformistas" buscando canalizar todos los aportes positivos que pudieran realizar, y hasta ofreciéndoles espacios de dirección en caso de que sean representativos. Según los documentos, la militancia perretista debía guiarse por una profunda flexibilidad táctica en materia de alianzas que le permitiera extender, ampliar y organizar a la mayor cantidad de tendencias obreras y trabajadores posibles. El desafío que estos militantes debían enfrentar pasaba por promover la incorporación de las más diversas corrientes clasistas, sin perder la dirección política del movimiento y sin caer en prácticas burocráticas para lograrlo. La dirección partidaria advertía este riesgo cuando sostenía:

"Muchos compañeros plantean la necesidad de garantizar una esfera de influencia. Muchos compañeros plantean la necesidad de garantizar la dirección de este movimiento. Desde luego que se debe hacer, pero no por el método administrativo ni llevándolos a que se separen, sino en base a la aplicación de nuestra línea, en base a la presentación a los organismos de dirección del movimiento, de propuestas y planes correctamente preparados, que es la mejor forma de evitar el "fantasma" de que estos grupos nos lleven a discusiones estériles, imponiendo razonablemente los verdaderos ejes de trabajo, y distribuyendo los esfuerzos entre todas las organizaciones que participan, convenciéndolos de la necesidad de encarar seriamente el trabajo práctico, de manera que la dirección del movimiento se ejerza políticamente."295

En la diferencia entre dirigir políticamente y dirigir administrativamente se jugaba la capacidad que tenía la organización para construir un espacio frentista. Si el PRT-ERP pretendía transformarse en el articulador de una herramienta que se erigiera como una alternativa nacional del sindicalismo combativo, lo cual suponía incorporar necesariamente fuerzas políticas que pudieran disputarle la política del espacio, debía procurar y saber construir consensos, cediendo espacios de poder al interior del movimiento. En tal sentido, a mediados de 1974, la dirección sostenía:

"La pertenencia de tal o cual partido político peronista, o de izquierda, no podía ser un obstáculo para la incorporación de compañeros, muy por el contrario se debía tratar de unificar a aquellos que con estrategias distintas, pero con coincidencias en el terreno sindical estuvieran dispuestos a participar. De esto se desprende claramente el carácter amplio del movimiento, su funcionamiento legal, su iniciativa unificadora. Pero la práctica, si bien demuestra un crecimiento óptimo, ha llevado al Partido, fundamentalmente por responsabilidad de la dirección, a desvirtuar los motivos iniciales, y sectarizar al mismo."296

La persistencia de prácticas sectarias llevó a hipotecar la amplitud y la "política de influencia" que el partido entendía como fundamental para ampliar su política y transformarse en la dirección del movimiento obrero clasista y combativo. De este

\footnotetext{
${ }^{295}$ Boletín Interno Nro. 61 primera quincena de junio de 1974

296 Ídem
} 
modo las prácticas "hegemonistas" del PRT-ERP fueron transformando al MSB en un organismo "parapartidario", al punto de generar una identificación casi mecánica entre ambos espacios. Esto queda claro en los siguientes testimonios que reflejan cómo se construía en la práctica esa mimetización que distorsionaba los objetivos originales del espacio:

"Por ejemplo, en un club en Córdoba se hace el encuentro del MSB... todo el estadio lleno, ¡todo el mundo con banderas del ERP! Y gritando ¡por el ERP y la Revolución! (...) ¡Mal hecho! ¡Equivocado! Porque ese es un congreso del MSB no del ERP, así seamos todos militantes del ERP, ¿te das cuenta donde está la confusión? (...) Yo tenía una agrupación gráfica aca en Rosario, éramos setecientos compañeros y yo era el que lo lideraba (incluso le saque la adhesión al MSB) entonces fuimos a Córdoba, y cuando los compañeros que no eran del ERP vieron eso me dicen '¿flaco donde nos trajiste?, ¿estás loco vos? Yo me voy' ite das cuenta? (...) Porque no hay nada peor para un hombre que sentirse usado, por más que esté de acuerdo con las acciones que haga el ERP y todo...porque escuchame "yo vine a un congreso sindical, yo estoy en contra de la burocracia sindical, estoy en contra de la mafia sindical, estoy a favor de Tosco, estoy a favor de Ongaro, ipero no quiero agarrar los fierros!” Es suficiente con que esté en un acto del MSB. Para lo otro hay tiempo, si total la revolución no se hace en dos días, la toma del poder es lo más difícil que hay. Entonces vos no lo vas a convencer de que tome el poder en dos días, ¡dejalo! Lo quiere a Tosco, lo quiere a Ongaro, lo quiere a Peralta, lo quiere al MSB... itiempo al tiempo!"297

En el mismo sentido otro testimonio apunta: "Yo leía lo que eran las resoluciones, lo que era y para qué era el Movimiento Sindical de Base, era una cosa distinta a lo que después era. Porque si terminaba cantando la marchita del ERP, era una cagada." (Pozzi, 2012:212).

Un repaso por algunas de las consignas coreadas durante el plenario de 1974, y registradas por la revista del MSB "Cuadernos de información popular", confirma el claro contenido perretista que tuvo aquel acto: “Salta, obrera, clasista y guerrillera!”, “¡Libertad, libertad, para los compañeros que tomaron Sanidad!”, “iA la lata, al latero, mi mamá tiene un hijo guerrillero!”, “¡Revolución o muerte, Tucumán presente!”, “¡Al socialismo, una vía, lucha armada contra la burguesía!”, “¡Cinco por uno, no va a quedar ninguno, tenemos los fusiles del 141!" (De Santis, 2000:209).

Advertido del rumbo que había tomado el MSB, el Comité Ejecutivo de junio de 1974 resolvía "dar una dura batalla interna contra la desviación de origen pequeño burgués del sectarismo, por entrañar un grave peligro a la aplicación de la política de alianzas del Partido y a la educación de nuestros militantes" ${ }^{298}$. No obstante esas directivas no alcanzaron para revertir la situación, ya que el MSB no tendió a incorporar a nuevas

\footnotetext{
${ }^{297}$ Entrevista a Rafael Peralta, trabajador gráfico, militante y miembro de la Mesa Sindical Nacional del PRT-ERP. Entrevista realizada por el autor, Rosario, 2017.

${ }^{298}$ Boletín Interno Nro. 61, primera quincena de junio de 1974
} 
fuerzas políticas y sindicales. Ahora bien, si nos concentramos en el primer testimonio, se ve que allí el problema de la mimetización entre el MSB y el PRT-ERP no sólo afectaba la relación o la incorporación de fuerzas aliadas, sino a los propios trabajos de base. Como vimos, la línea sindical de la organización suponía que la intervención en este plano se debía dar a través de las agrupaciones o a través de espacios más amplios (como CIR, CD, etc.), en los que no necesariamente fuera conocida la pertenencia partidaria del militante perretista. De esta forma no todos los trabajadores que participaban de las agrupaciones impulsadas por la organización, o que se identificaban con tal o cual referente sindical, adscribían a la política del partido. Si el objetivo era poder organizar a la mayor cantidad de trabajadores, estuviesen de acuerdo o no con la lucha armada, sean o no peronistas, se identificasen o no con la política del PRT-ERP, un plenario sindical no podía adquirir un tono partidario. Esto resulta significativo si se tiene en cuenta que había sido la propia organización la que, a través de Gregorio Flores, se había encargado de aclarar y advertir en la apertura del plenario de fundación que no se aceptarían actitudes y discusiones que desvirtuaran y confundieran los objetivos del movimiento con los de los partidos que intervenían en ella.

Ahora bien la dificultad de disociar los espacios residía también en el hecho de que gran parte del desarrollo, de las tareas y de la militancia del MSB eran garantizadas por los militantes perretistas que por momentos vivían la contradicción hasta en pequeños hechos de su militancia cotidiana:

"Era difícil, y salir a pintar... que se yo... vamos a una campaña de pintada del MSB, salíamos a pintar por el MSB, pero ya que está pintamos PRT, (risas) pintamos viva este, viva... Que se yo, era lo normal, te dabas cuenta con un mismo aerosol pintabas MSB, PRT, ERP, las consignas del MSB, por ahí pintabas alguna consigna del PRT. Era medio imposible deslindarlo, para nosotros, separar una cosa de la otra., 299

Estas prácticas fueron confundiendo de a poco el carácter del MSB. Sin embargo es necesario remarcar que la capacidad de nuclear expresiones diversas que hicieran del MSB algo más que una agrupación impulsada por el PRT-ERP varió dependiendo las zonas. Córdoba, en ese sentido, fue el caso más exitoso ya que permitió organizar a un conjunto importante de agrupaciones, CIR y sindicatos que escapaban del control directo de los perretistas, permitiéndole adquirir una dinámica propia y participar, con un rol protagónico, en el MSC y de las coordinadoras de gremios en lucha que surgieron durante año 1975. Pero en el resto de las regionales las características del MSB fueron

\footnotetext{
299 Entrevista a Raúl Castro, militante del PRT-ERP y trabajador de Galizia y Bargut, realizada por
} Andres Carminatti, Rosario, 2008. 
diferentes. En zonas como Rosario, Tucumán y Chaco su inserción no fue mayor a la que poseía el PRT-ERP. En el caso del Gran Buenos Aires la situación no fue muy diferente. Como remarca el siguiente testimonio, en la Zona Sur del Gran Buenos Aires el MSB era activo, pero al mismo tiempo no se dejaba ver demasiada diferencia entre el partido y el movimiento:

"Yeyo: [...] bueno yo entre a trabajar clandestino en una fábrica de bulones en Lanús. Desde allí atendíamos distintas fábricas, una de ellas SASETRU, la otra Rigolleau (allí recuperamos el gremio con la lista Naranja), también atendía SAIC, Collino, Duperial, Oslon, Alpargatas, Peugeot ${ }^{300}$. En Peugeot formamos la agrupación "Juan Lachowski", teníamos muchos compañeros nuestros del PRT. Después atendíamos los barrios: Florencio Varela, el barrio Lucchetti, Berazategui, Quilmes, Ezpeleta. En todos ellos tuvimos mucha actividad...

Entrevistador:- ¿Todo eso era de mucha influencia del PRT?

Yeyo:- De mucha influencia del PRT. Logramos que Racing nos prestara las instalaciones de la avenida Mitre y ahí hicimos un congreso del MSB. ¡Era impresionante la cantidad de compañeros que teníamos y como trabajábamos! Ahí en Rigolleau, como te digo, recuperamos el gremio del vidrio, estaba al frente el compañero Aníbal (Luis Angellini) y ahí también desarrollábamos actividad militar. Estaba el "Gordo" Sánchez, el "Petizo" Esteban. Por esa zona pasaron muchos compañeros que forjaron el PRT [...] Teníamos mucho prestigio en todas las fábricas. También estaba la cartonera Masshu, ahí en camino General Belgrano, donde trabajaba "Panchito" Carrara, compañero del partido, y también teníamos muchos contactos y mucha actividad sindical del PRT a través del MSB en esa fábrica... ${ }^{301}$

Por su parte la Zona Capital Federal del MSB, participó a través de la mesa coordinadora construida hacia fines de 1973, por ejemplo, en los conflictos de Citoplast, Sapeba, metalúrgica Santa Rosa y el Banco Mercanti1 ${ }^{302}$, pero sin embargo era una agrupación más y con estrecho control del PRT-ERP.

Por otro lado en La Plata, según Pablo Pozzi, el MSB nunca paso de ser un embrión de organismo gremial basado, sobre todo, en los militantes del PCML (Pozzi, 2001:326). Esto se ve reflejado en el testimonio de Daniel De Santis quien remarca que no era la herramienta desde la cual se intervenía como perretistas: “Acá no llego el MSB, donde funcionaba era en Córdoba. Acá fue incipiente, no es que hubo una mesa del Movimiento Sindical de Base en La Plata, eso no hubo...”303

Esta dinámica fue llevando a la paralización de las estructuras de dirección del MSB, tanto la nacional, como las regionales y zonales, ya que, de facto, por su composición,

\footnotetext{
${ }^{300}$ En los archivos de la ex DIPBA se halla un volante del Movimiento Sindical de Base ligado al conflicto sindical de la fábrica Peugeot, lo que demuestra que se intervenía como tal en dicha zona. (Mesa "B", Factor Gremial, Berazategui, Carpeta 18 bis, Leg. 14.)

${ }^{301}$ Entrevista a "Yeyo" Videla realizada por el autor, Buenos Aires, 2012

${ }^{302}$ Nuevo Hombre, Nro. 54. 1era quincena de enero de 1974.

${ }^{303}$ Entrevista a Daniel De Santis con el autor, Buenos Aires, Junio de 2012
} 
se habían transformado en reuniones del PRT-ERP y la exigencia de sus militantes en tareas del partido llevaba muchas veces a que estas instancias no sean garantizadas.

Por esta razón el Comité Ejecutivo de junio de 1974 había instado a la reorganización de las reuniones con "compañeros no partidarios", pero la directiva parece no haber surtido efecto, ya que hacia agosto de 1975 el partido llamaba a la "revitalización" del espacio (Leiva Flores, 2007):

\begin{abstract}
“Al mismo tiempo es necesario actuar rápidamente en la revitalización del MSB, dado el prestigio que este conserva en el seno de las masas y la vanguardia, para ello lo principal es su presencia en todas las fábricas, no olvidemos que la presencia de la actividad del Partido en lo específicamente sindical la hacemos a través del MSB o de las agrupaciones en las cuales trabajamos. Por eso tenemos que tomar con decisión la tarea de que todo volante de carácter sindical firme el MSB o las agrupaciones. Paralelamente hablar seriamente con los aliados viejos y nuevos, para darle un buen impulso en la superestructura. Tener profundas charlas con ellos entusiasmándolos ante la perspectiva de apertura democrática que permitirá actos masivos del MSB. Ser honestamente autocríticos en nuestras actitudes anteriores pero firmes en la discusión de los principios políticos" ${ }^{304}$.
\end{abstract}

Ahora bien, la realidad era que la intervención sindical del PRT-ERP no se daba necesariamente a través del MSB. En la práctica no era la única forma a través de la cual daba la disputa sindical en la fábrica. Como vimos, en aquellos casos en que no se había logrado construir o no se había impulsado una agrupación sindical propia o del MSB, los militantes perretistas intervenían directamente en los CD, CIR o comités de lucha o bien en listas sindicales amplias que, por su composición, no podían asumirse parte del MSB y tampoco constituirse en agrupaciones. Llegar a desarrollar una agrupación propia o del MSB dependía de las condiciones políticas de la zona y las fábricas donde se actuaba, y estas variaban según múltiples razones: el nivel de desarrollo político alcanzado en esas fábricas ${ }^{305}$, o las posibilidades de coordinación que pudieran lograr con las otras organizaciones.

Un caso ejemplar en ese sentido fue el de Villa Constitución durante 1974, que repasaremos brevemente en el próximo capítulo. En el marco del llamado "Villazo", el MSB organizó la solidaridad de múltiples agrupaciones y fábricas de distintos puntos del país que mostraron su apoyo a la lucha de los obreros metalúrgicos de la

\footnotetext{
${ }^{304}$ Boletín Interno Nro. 85, 29 de agosto de 1975

305 Cuando hablamos de "niveles de desarrollo" en una fábrica nos referimos a diversos factores, como por ejemplo, la cantidad de militantes y simpatizantes con que se contaba, el tipo de actividad que se había logrado desarrollar (sindical, militar, de propaganda y agitación), la referencia política construida entre los obreros, la existencia de agrupaciones independientes previas en la fábrica, la incorporación de dirigentes o activistas fabriles independientes a las filas del partido, etc.
} 
localidad $^{306}$. De hecho la Regional Buenos Aires y la Regional San Nicolás del MSB participaron con importantes delegaciones del Plenario Nacional Antiburocrático convocado el 20 de abril con ese mismo objetivo. Sin embargo, durante el conflicto, en Villa Constitución habría existido una discusión entre militantes perretistas alrededor de cuál debía ser la herramienta sindical que debía desarrollarse entre los obreros de la localidad. Así Ángel Porcu, responsable del PRT-ERP en la ciudad, habría recibido la directiva de impulsar el MSB como agrupación sindical a la par de que se estaba desarrollando la lista Marrón, lista amplia en la que participaban múltiples sectores, entre ellos peronistas ${ }^{307}$. Esta directiva, de hecho, atentaba contra la experiencia de "la Marrón”, ya que, en la práctica, las tareas que podía y debía asumir el MSB estaban siendo desarrolladas por aquella; y, además, porque la lista, debido a su heterogénea composición, no podía encuadrarse bajo la estructura del $\mathrm{MSB}^{308}$. En consecuencia la directiva no fue aceptada por la militancia perretista, ya que se trataba de una línea que no se ajustaba a las necesidades y la realidad concreta, más allá de ser una de las tareas que imponía el partido, de modo que el PRT-ERP continuó interviniendo sindicalmente sólo desde "la Marrón” (Winter, 2010: 75-76).

Este episodio parece mostrar que más allá de discusiones y exigencias partidarias, las formas de intervención estaban dadas por la particularidad de cada uno de los espacios de trabajo y, si en muchos casos no se podía implementar las propuestas del partido, los militantes hacían lo que podían en el marco de posibilidades que ofrecía el lugar de trabajo en que se desempeñaban. Mientras que para algunos el MSB podía ser la herramienta adecuada para ampliar el trabajo y la influencia del partido, para otros podía no ser necesario utilizarla o, más aún, podía transformarse en un obstáculo para su desarrollo.

\footnotetext{
306 "Villa Constitución: Plenario Antiburocrático", El Combatiente Nro. 115 Miércoles 24 de abril de 1974

${ }^{307}$ La lista Marrón había nacido como fruto del Movimiento de Recuperación Sindical (MRS) que había sido creado entre 1971 y 1972 por un nucleo de activistas de la planta metalúrgica de Acindar. De la Lista Marrón participaron militantes de diferentes organizaciones: Vanguardia Comunista, el PRT-ERP, el PB, Organización Comunista Poder Obrero (OCPO), el PST, Socialismo Revolucionario y JTP. Entre sus principales dirigentes se hallaban Alberto Piccinini (cercano a OCPO y, posteriormente, Secretario General de la UOM) y Luis Ángel Segovia (militante perretista y, posteriormente, principal dirigente del Comité de Lucha) (Santella y Andujar, 2007)

${ }^{308}$ Según Ángel Porcu algo similar le ocurría a los militantes de Montoneros quienes eran instados por su dirección a formar la Agrupación Sindical Peronista "Felipe Vallese". Según Porcu, él y Raúl Horton, delegado de Acindar y dirigente sindical montonero, habrían acordado preservar la lista Marrón y no impulsar ni el MSB ni la "Felipe Vallese" para evitar la división de la lista en múltiples tendencias (Winter, 2010:76)
} 
Lo anterior puede contribuir a explicar los desiguales niveles de desarrollo alcanzados por el MSB entre los años 1973 y 1974, a la vez que expone las dificultades que el PRTERP tuvo para revitalizarlo en 1975.

Si bien la debilidad del MSB no dificultó la inserción fabril y la participación protagónica del PRT-ERP en los principales conflictos obreros, ya que, como se dijo, la organización intervino en ellos de diferentes formas, sí debilitó la posibilidad de forjar un espacio más amplio de coordinación nacional. De hecho, como se analizará en el próximo capítulo, una de las búsquedas principales de los perretistas durante los años 1974 y 1975, fue la de conformar un Frente Nacional Antiburocrático donde reunir y organizar a las corrientes político-gremiales más influyentes, tarea para la que en un principio había sido pensado el MSB.

\section{Conclusión}

La TOR 22-8 y el MSB fueron parte de la política de equilibrios complementarios entre la política legal y la clandestina aplicado al ámbito sindical. Como vimos, la TOR 22-8, herramienta pensada para organizar sindicalmente la violencia de masas y la resistencia a la represión al interior de las fábricas, intentó cumplir un papel que, de distintas maneras, cumplieron el MSB por un lado y el ERP por el otro. En ese sentido se trató de una política forzada con la que los perretistas intentaron blindarse de los riegos que veían en el sindicalismo. Distinto fue el caso del MSB que creció ampliamente y permitió a la organización reunir a gran parte del activismo y de las agrupaciones sindicales impulsadas por los perretistas. Ahora bien, la manera esquemática, "administrativa" y hegemonista de dirigirlo, transformó a dicho movimiento en una herramienta "parapartidaria" del PRT-ERP, dificultando la incorporación de otras fuerzas políticas y, por ende, hipotecando la amplitud con la que, desde sus orígenes, los perretistas la habían pensado. Sin embargo, conciente de ello -como veremos en el próximo capítulo-, la organización insistió en la formación de un Frente Nacional Antiburocrático más amplio que contuviera al MSB y al resto de las corrientes antiburocráticas. 


\section{Capítulo 4}

Años de luchas decisivas (1974-1975)

\section{Introducción}

En el presente capítulo nos dedicamos a analizar el desarrollo de la política sindical perretista durante los años 1974 y 1975. En un primer momento reponemos las principales definiciones adoptadas por la organización en el año 1974 con las que buscó dar un salto cualitativo en la lucha sindical, democrática y guerrillera. En ese sentido indagamos el impacto que tuvo el "nuevo enfoque estratégico" adoptado en lo militar y sus implicancias en las otras dos dimensiones. Nos concentramos particularmente en el análisis de su intervención sindical mostrando cómo fue configurándose en un aspecto central de su política; y, en ese marco, mostramos que una de sus principales preocupaciones radicó en el intento de construir un frente nacional que centralizara las luchas gremiales.

En un segundo momento, analizamos el estado de la regional Buenos Aires para finales del año 1974 y principios de 1975, haciendo eje en el balance que la propia organización hacía de su participación en las principales luchas obreras y, sobre todo, construyendo el mapa de su inserción fabril en el Gran Buenos Aires, donde se ubican los casos que veremos en los próximos capítulos.

Luego nos adentramos en el año 1975 e indagamos sobre su participación en la lucha por la apertura de las paritarias, en las "jornadas de junio y julio" contra el "Plan Rodrigo" y en el surgimiento de las Coordinadoras de Gremios en Lucha del Gran Buenos Aires. Finalmente, analizamos las luchas obreras previas al golpe de estado de 1976 y las orientaciones con que la organización intentó enfrentarlo en las fábricas.

\subsection{Los bandos se definen (1974).}

4.1.a. Hacia un "nuevo enfoque estratégico".

1974 fue un año clave para la política argentina, y en consecuencia para la del PRTERP. Decimos clave porque se trató de un año en el que el gobierno peronista y las fuerzas revolucionarias, en especial el PRT-ERP, midieron sus fuerzas. El desplazamiento definitivo de los sectores progresistas del gobierno, la consolidación del ala lopezreguista y la creciente influencia de la dirección cegetista aceleraron el proceso 
de "derechización" que venía viviendo el peronismo gobernante desde la renuncia de Cámpora, abandonando con ello la moderación política que había caracterizado al gobierno de éste último, para pasar a un enfrentamiento directo con las fuerzas revolucionarias. Ya hacia fines de 1973 el gobierno había comenzado a pertrecharse con recursos legales e ilegales para enfrentar el conflicto obrero y social que venía amenazando su proyecto político y económico. A la aprobación de la Ley de Asociaciones Profesionales y la Ley de Prescindibilidad en noviembre, se le sumó la aprobación parcial de la reforma al Código Penal por parte del senado (ley que luego será aprobada definitivamente en enero de 1974) y la suspensión de las paritarias hasta 1975 por decreto del Poder Ejecutivo. En paralelo, inspirada por el "Documento Reservado del Consejo Superior Peronista"309 , había hecho su aparición la organización para-militar Alianza Anticomunista Argentina (Triple A) ${ }^{310}$, a la par que aumentaba significativamente la actividad de las organizaciones de la "derecha peronista" y el "matonaje sindical" a nivel de fábrica (Franco, 2012; Schneider, 2015).

A inicios de año, el PRT-ERP consideraba que el proyecto del gobierno había fracasado y que, con ello, se había abierto una crisis dentro del "campo de la burguesía" manifestada en el enfrentamiento entre dos fracciones: por un lado "el ala fascista" representada por López Rega, y por el otro las FFAA ${ }^{311}$. Para los guevaristas, esto era una cabal demostración de la debilidad del gobierno que en lo político había perdido la

\footnotetext{
${ }^{309}$ El $1^{\text {o }}$ de Octubre de 1973, luego de una reunión encabezada por Perón junto a autoridades nacionales y del Partido Justicialista, el líder del movimiento firmó un documento interno que convocaba a la lucha contra el marxismo, el "terrorismo" y la "subversión". En el marco de lo que definía como un "estado de guerra", el escrito llamaba a luchar contra la infiltración marxista al interior del Movimiento Nacional Peronista, no solo a través de la "defensa" sino también "atacando al enemigo en todos sus frentes". Entre otras cosas llamaba a reafirmar los "principios doctrinarios del Movimiento", obligaba a todos aquellos que se reclamaran parte del mismo a definirse públicamente en guerra contra los grupos marxistas, planteaba utilizar todos los medios de lucha que se considerasen eficientes e instaba a respetar a rajatabla las decisiones de Perón. Lejos de ser secreto, el mismo fue publicado el 2 de octubre por el diario $L a$ Opinión y la edición vespertina del diario Crónica. (Franco, 2012)

${ }^{310}$ A fines de 1973, dicha organización publicó una «lista negra» en el que se enumeraba una serie de personalidades políticas y sindicales a las que se amenazaba con ejecutarlas inmediatamente donde se las encuentre. En esta lista se encontraban: Mario Roberto Santucho, Armando Jaime, Raimundo Ongaro, René Salamanca y Agustín Tosco; Homero Cristali, alias J. Posadas y Nahuel Moreno; los abogados Silvio Frondizi, Mario Hernández, Gustavo Roca y Manuel Gaggero (director interino del diario El Mundo); el profesor Rodolfo Puiggrós (ex-rector interventor de la Universidad de Buenos Aires); Ernesto Giudice, miembro renunciante del Partido Comunista; Roberto Quieto, dirigente de Montoneros y Julio Troxler, ex-subjefe de Policía de la Provincia de Buenos Aires, cercano al Peronismo de Base. La nómina se completaba con los coroneles Luis César Perlinger y Juan Jaime Cesio, el obispo de La Rioja, monseñor Enrique Angelelli y el senador nacional Luis Carnevale. (Bufano, 2005)

${ }^{311}$ Uno de los episodios que marcaban ese enfrentamiento fue la salida de Jorge Carcagno de la Comandancia General y la reorganización de los mandos del Ejército. El PRT-ERP analizaba que el Ejército había aceptado la salida de Carcagno "sacrificándolo momentáneamente" para imponerle al gobierno una reorganización favorable a lo que la organización calificaba como "Partido Militar", posicionando a este último en mejores posiciones para enfrentamientos futuros. ("Reunión del Comité Central de nuestro Partido" El Combatiente Nro. 105, Miércoles 30 de enero de 1974)
} 
iniciativa y se hallaba cada vez más a merced de los militares, mientras que en lo económico no lograba ni lograría revertir la tendencia general al agravamiento de la crisis $^{312}$. En ese cuadro se analizaba que no tendrían otra forma de "consolidar al capitalismo" que pasando a la ofensiva a través de la legislación represiva y las bandas fascistas. En cuanto al "campo del pueblo" evaluaban que se vivía una acumulación importante de fuerzas, basado en los avances de las luchas fabriles y en el fortalecimiento del propio PRT-ERP. Según esta lectura la "vanguardia obrera y popular" estaba rompiendo más claramente con el gobierno peronista y el partido se hallaba "al borde de pasar a ser una organización de primera magnitud en la lucha de clases" $^{, 313}$.

De este modo el PRT-ERP se consideraba con la posibilidad de intervenir decisivamente en el desarrollo de los acontecimientos. Hay que tener en cuenta que para el inicio de 1974 la organización se encontraba alejada de las vicisitudes internas que había atravesado durante el año anterior, contaba con organizaciones de masas en pleno desarrollo -como el MSB y el FAS- y, como veremos en el próximo apartado, empezaba a obtener resultados en la penetración en los cordones industriales de el Gran Buenos Aires, la ribera del Paraná, Córdoba y Rosario principalmente. Aun así, consideraba necesario dar un "salto cualitativo" en el plano sindical y legal, impulsando la lucha reivindicativa y anti represiva. Pero la novedad mayor aparecía en el terreno militar: allí se planteaba adoptar un "nuevo enfoque estratégico" consistente en "mostrar a las masas" que estaba entablada la lucha por el poder y que, en esa lucha, la clase obrera y el pueblo podían triunfar"314. En ese sentido, la propaganda armada debía tomar características de ofensiva y demostrar la capacidad de la guerrilla para "infligir duras derrotas a las mejores fuerzas del enemigo" 315 .

Este nuevo enfoque tuvo un importante impacto para la organización, no sólo en lo relativo a la operatividad militar ${ }^{316}$ sino también a nivel político. Profundizar el accionar

\footnotetext{
${ }^{312}$ Sin embargo se reconocía que el gobierno había logrado paliar la crisis en algunas industrias como la automotriz a través de las exportaciones, aunque sin perspectivas de futuro. (Ídem)

313 Ídem.

314 Ídem.

315 "Después de Azul: balance y perspectivas”, El Combatiente Nro. 105, Miércoles 30 de enero de 1974

${ }^{316}$ Bajo esta perspectiva se realizaron acciones de gran envergadura durante el año: en enero el intento de copamiento de la Guarnición Militar de Azul, en mayo la apertura de un foco rural en Tucumán (la compañía de monte "Ramón Rosa Jiménez") y en agosto las tomas de la Fábrica Militar de Villa María y el Regimiento de Infantería de Catamarca (Este último intento terminó con el fusilamiento de catorce combatientes del PRT-ERP, entre ellos Antonio del Carmen Fernández, uno de los máximos dirigentes de la organización.). Es de destacar también que el año 1974 fue el de mayor proporción de "ajusticiamientos" debido a la campaña de represalias indiscriminadas contra integrantes de las FFAA
} 
armado en los marcos democráticos, agudizando el enfrentamiento con las FFAA y contra el gobierno de Perón, era una decisión que aumentaba la tensión no sólo con las “fuerzas enemigas", sino con las organizaciones del peronismo revolucionario y de la izquierda que seguían caracterizando al gobierno peronista como un gobierno popular o apostaban a las vías institucionales para la transformación política. De modo que esa decisión podía llegar a afectar seriamente las posibilidades de unidad y coordinación sindical o política con otras fuerzas, algo que el propio PRT-ERP planteaba como prioridad para ese año.

El copamiento de la Guarnición Militar de $\mathrm{Azul}^{317}$ en el mes de enero, fue un claro ejemplo en ese sentido: la acción fue repudiada o criticada por distintos actores y organizaciones políticas y sindicales no solo del "campo burgués" 318 sino también del "campo popular, progresista y revolucionario"319, significándole un alto costo para su política de alianzas. Por ejemplo, según Luis Mattini, el vínculo con el PCA se interrumpió casi totalmente, aún en el frente sindical donde tenían acuerdos (2007: 198). Por su parte con Montoneros se suspendió por un buen tiempo el débil vínculo que había construido, mientras que con organizaciones como el $\mathrm{PB}$, si bien no se

(Izzaeta, 2015; Carnovale, 2016). Además, en paralelo se continuaron desarrollando las acciones ligadas a conflictos fabriles. Así por ejemplo, un repaso por la sección Crónica de la Guerra Revolucionaria del periódico Estrella Roja del año 1974, arroja, sólo en el Gran Buenos Aires, aproximadamente 13 acciones armadas del ERP ligadas a las fábricas.

${ }^{317}$ La decisión fue tomada por el Buró Político a propuesta de Santucho con un doble objetivo: 1- hacerse de una gran cantidad de armamentos y municiones (entre seis y ocho toneladas); 2- asestar un "golpe fuerte" a las FFAA en uno de sus principales cuarteles para evitar su reorganización y aletargar la posibilidades de un golpe de estado. Militarmente la acción fracasó: no se logró "recuperar" el armamento y sólo se logró secuestrar al Coronel Jorge Irazabal (quien fue apresado por diez meses y luego ejecutado por el ERP en un traslado que terminó en enfrentamiento policial) mientras que el Coronel Camilo Gay fue abatido en combate. Por otro lado, resultaron tres combatientes muertos, dos desaparecidos y doce militantes detenidos. (Luna, 2016: 21-22)

${ }^{318}$ Al repudio generalizado del gobierno, entre los que se hallaron las declaraciones del ministro de Economía Gelbard y los gobernadores "progresistas” como Ricardo Obregón Cano, se sumaron los máximos exponentes del radicalismo y sus distintas vertientes, como Ricardo Balbín, Raúl Alfonsin, el líder del MID y ex presidente Arturo Frondizi así como Oscar Alende, líder del Partido Intransigente además de distintas figuras políticas parlamentarias.

${ }^{319}$ Así por ejemplo, Montoneros, desde la revista El Descamisado, era contundente a la hora de definir al ERP como un "grupo minoritario", "extraños al pueblo", alejados de la realidad política y a los que debía tratárselos como un problema policial si no entraban en razones. Para esta organización el PRT-ERP no distinguía las profundas diferencias que había entre "un gobierno popular con contradicciones internas" y la dictadura militar. En esa misma dirección, pero con declaraciones más contundentes, diputados de la JP calificaban al ERP como "provocadores de ultraizquierda" que respondían a los intereses de la oligarquía y del imperialismo (La Opinión, 31 de enero de 1974). Por su parte desde las páginas de la revista Militancia Peronista para la Liberación, el ala "alternativista" de la TPR definía a la acción como "inexplicable" en el marco de la lucha contra la legislación represiva que venían llevando adelante los sectores populares (Stavale, M., 2018). No obstante, hubieron organizaciones más pequeñas aliadas al PRT-ERP como Movimiento de Izquierda Revolucionaria que si bien expresaron sus diferencias (no coincidían de que fuera el momento de golpear militarmente a las FFAA con acciones que buscaran su debilitamiento) rechazaban todas las manifestaciones que se "confundían" con las críticas ensañadas de la derecha y reconocía a dicha organización como expresión de las mejores luchas de la clase obrera. 
interrumpió la coordinación o la unidad a nivel de base o de fábrica, sí se obstaculizaron acuerdos superestructurales más profundos como vimos para el caso del $\mathrm{MSB}^{320}$. Otros aliados importantes a nivel sindical y político como Agustín Tosco, Ortega Peña o el FRP si bien criticaron la acción no rompieron ni abandonaron las relaciones que venían construyendo con la organización guevarista.

Los hechos de Azul aceleraron los planes represivos que, como dijimos, el gobierno venía insinuando e incluso aplicando desde mediados de 1973. Así, tan sólo cinco días después, el gobierno aprobó la reforma al Código Penal que endurecía las penas contra el "delito" de subversión y "asociación ilícita", es decir contra la guerrilla y las huelgas "ilegales". A ello le sucedió la renuncia y expulsión de ocho diputados de la JP que se negaron a apoyar la ley y la renuncia del gobernador bonaerense Oscar Bidegain que, por su cercanía al peronismo revolucionario, fue presionado por Perón y hostigado por el entonces vicegobernador y dirigente de la UOM, Victorio Calabró quien quedó a cargo de la provincia ${ }^{321}$.

Ante este escenario, atravesado por un aumento significativo de la represión ${ }^{322}$, la lucha por las libertades democráticas se transformó en un elemento central de la política del PRT-ERP, ya que consideraba que un avance en ese sentido ayudaría a intensificar las luchas obreras y a generar un terreno favorable para el "enraizamiento" de la guerrilla. Detrás de esta orientación seguía operando la idea de que existía una relación virtuosa, un equilibrio complementario, entre la lucha legal e ilegal que se traducía en el

\footnotetext{
${ }^{320}$ Guillermo Caviasca (2009) aporta un ejemplo de ello reconstruyendo una reunión entre Santucho y Raimundo Villaflor, dirigente del Peronismo de Base, en la cual supuestamente el dirigente peronista le plantea que la condición para incorporarse al FAS era poder discutir las operaciones militares del ERP, algo que el dirigente perretista rechazó de plano.

${ }^{321}$ El caso de la Provincia de Buenos Aires no fue el único. Lejos de ello el "ciclo de quiebres de las instituciones provinciales" había comenzado poco antes, en noviembre de 1973, con la intervención de los tres poderes de Formosa, y luego de la renuncia de Bidegain le sucedieron la renuncia por presiones políticas de Martínez Baca gobernador de Mendoza en marzo, junto a la destitución del gobernador de Santa Cruz Jorge Cepernic y la destitución del gobernador de Salta Miguel Ragone en octubre. (Franco, 2012: 77-78). Además en marzo fue intervenida la provincia de Córdoba: el 27 de febrero una sublevación policial al mando de Antonio Navarro (denominada "Navarrazo"), apoyada por las 62 Organizaciones, la Juventud Sindical Peronista y el propio gobierno (el cual consideraba a dicha provincia como un "foco de infección") culminó con la intervención y la destitución del gobernador Obregón Cano (Servetto, 2010; Franco, 2012; Luna, 2016). Como indica Marina Franco (2012) el "Navarrazo" venía poner freno a la avanzada del movimiento sindical y obrero combativo que se venía forjando desde el Cordobazo y que venía desafiando a la conducción nacional de la CGT, legitimando su desplazamiento en nombre de la intervención.

${ }^{322}$ Se produjeron importantes cambios en la Policía Federal y la Policía Bonaerense, siendo los más significativos la designación de los comisarios Jorge Villar y Luis Margaride, destacados exponentes de la política represiva y "antiguerrillera", como Subjefe de la Policía Federal y Superintendente de la Seguridad Federal respectivamente. A partir de allí la escalada represiva aumentó mes a mes de manera sistemática: tan sólo el 26 de enero se registraron diecisiete atentados contra sedes de la JP y otras organizaciones revolucionarias o combativas (Franco, 2012)
} 
complejo triángulo accionar guerrillero-movilización-democratización. En ese sentido planteaba "tres ejes" que debían ordenar su política: 1- el accionar armado; 2- la lucha reivindicativa y antiburocrática; y 3 - la lucha democrática ${ }^{323}$.

En cuanto a estos dos últimos ejes, los esfuerzos debían estar dedicados a ampliar los marcos de alianza. De este modo, buscó ampliar el FAS e intentó confluir con mayores sectores del peronismo revolucionario para replicar el "frente de hecho con el que el pueblo en su conjunto enfrentó y derrotó a la Dictadura Militar"324. Fue así que a mitad del año lanzó la propuesta de transformar dicho espacio en un Frente Antiimperialista Democrático y Patriótico que incorporara a sectores políticos progresistas y democráticos $^{325}$. Con ello se tomaba la decisión de pasar a un segundo plano la definición "por el socialismo" como elemento aglutinador del frente, para organizar a todos los sectores de la sociedad que se sintieran convocados en la lucha democrática y antiimperialista $^{326}$. Es que en sus análisis avizoraba una nueva etapa marcada por el fracaso del populismo y la instauración de un gobierno pro-imperialista, antipopular y

\footnotetext{
${ }^{323}$ Es necesario destacar que estos ejes de lucha estaban directamente relacionados con lo que el PRTERP consideraba los "cuatro pilares" para el triunfo de la guerra revolucionaria: el partido, el ejército, el frente de liberación nacional y social y la solidaridad internacional ("Hacia un nuevo y desesperado intento de la burguesía" El Combatiente Nro. 113 Miércoles 10 de abril de 1974; "La burguesía busca apoyo para sus planes de conciliación de clase" El Combatiente Nro. 115 Miércoles 24 de abril de 1974). 324 "Hacia el Frente Antiimperialista Democrático y Patriótico" El Combatiente Nro. 138 Miércoles 9 de octubre de 1974

${ }^{325}$ En paralelo el PRT-ERP agudizó la polémica con Montoneros y la JP así como también con el PC, al PCR y a VC, organizaciones que, según los perretistas, se habían sumado a la defensa del gobierno apoyando a una $\mathrm{u}$ otra ala en disputa representadas por Gelbard y López Rega respectivamente. Los perretistas analizaban que la táctica de estas organizaciones las habían llevado a abandonar las consignas socialistas y poco a poco también las más básicas reivindicaciones democráticas. Por eso las llamaban a romper con dicha política "vacilante" para formar urgentemente un frente que se opusiera al gobierno y luchara contra su legislación represiva y por las libertades democráticas. ("Eliminar trabas a la movilización popular" El Combatiente Nro. 109 Miércoles 27 de febrero de 1974; "Dos tácticas en la lucha de clases" El Combatiente Nro. 114 Miércoles 17 de abril de 1974; "Hacia el Frente Antiimperialista Democrático y Patriótico" El Combatiente Nro. 138 Miércoles 9 de octubre de 1974)

326 En disidencia con esta orientación varias organizaciones integrantes del FAS (Organización Revolucionaria Comunista "El Obrero", el Movimiento de Izquierda Revolucionaria y Organización Revolucionaria "Poder Obrero") decidieron abandonar el espacio. Presentaron un documento de cara al VI Congreso, realizado el 15 de junio en la ciudad de Rosario, titulado "Frente Revolucionario o Frente Popular" donde si bien aceptaban la necesidad de la unidad de acción con sectores reformistas o con alternativas burguesas y pequeñoburguesas "democráticas, antiimperialistas y progresistas" rechazaban la propuesta de construir un frente político estable y orgánico con estos sectores. (Silva Mariño, 2017: 201202).

Ese mismo año, aquellas organizaciones que venían funcionando prácticamente unidas desde 1973, se fusionaron formando la "Organización Revolucionaria Poder Obrero" (ORPO), la cual en septiembre de 1975, pasará a llamarse Organización Comunista Poder Obrero (OCPO). Sus influencias ideológicas abrevaban de Lenin, Trotsky, Rosa Luxemburgo, Gramsci, el Che Guevara, Mao Tse Tung y Ho Chi Minh, entre otros. La OCPO definió a la lucha armada como un aspecto fundamental de la estrategia revolucionaria y, en ese marco, impulso los "Piquetes Obreros Armados" y, posteriormente, una organización militar específica llamada "Brigadas Rojas". Su práctica militar estuvo centrada en la autodefensa de masas, y en la ligazón con el movimiento obrero. En ese marco desarrolló vínculos con el PRT-ERP y con Montoneros (Cormick, 2015).
} 
de corte fascistoide que se enfrentaría abiertamente a las organizaciones populares y también a algunas corrientes burguesas. Desde este punto de vista, el FAS se había convertido en una herramienta estrecha e insuficiente para alcanzar el tipo de unidad que requerían estas nuevas condiciones (Silva Mariños, 2017:231).

A nivel sindical, aunque como se vio en el capítulo anterior 1974 fue el de mayor desarrollo del MSB, se insistió en la necesidad de un frente nacional sindical más amplio que coordinase las luchas obreras de todo el país y que contuviese a las expresiones "más representativas" del movimiento sindical antiburocrático (la organización era consciente de las limitaciones del MSB). Sin embargo, no fue fácil encontrar un equilibrio entre el "nuevo enfoque estratégico" en lo militar y la construcción de frentes políticos y sindicales más amplios (Silva Mariños, 2017:172).

\section{1.b En búsqueda del Frente Nacional Antiburocrático.}

Durante el período de octubre de 1973 a febrero de 1974 la conflictividad obrera no había disminuido en intensidad y frecuencia lo cual atacaba directamente el corazón del Pacto Social (Jelin, 1978: 434). Más allá de todos los recursos a los que el gobierno echaba mano para seguir sosteniendo la política de concertación de ingresos, lo cierto es que nada era suficiente para frenar las presiones de las bases que se hacían sentir en las espaldas de las cúpulas sindicales. De este modo, al iniciar el año 1974 éstas últimas buscaron, con éxito, adelantar la fecha de la renegociación del acuerdo que estaba prevista para junio, y el 20 de febrero Perón anunció la convocatoria a la CGT y la CGE para comenzar a estudiar los reajustes. El adelanto respondía tanto a las presiones de los trabajadores como a la de los propios empresarios, que descontentos con la política de precios comenzaban a desabastecer de bienes el mercado y a expandir el mercado negro $^{327}$. Al decir de los perretistas, el pacto estaba naufragando a "dos puntas": "la lucha de clases no se resigna, en ninguno de sus dos bandos, a ser metida en el chaleco de fuerza arbitrado por el peronismo burgués." ${ }^{328}$

Finalmente, cuando en marzo se convocó a la Gran Paritaria Nacional, no se pudo llegar a un acuerdo, por lo que el propio Perón, por decreto, el 27 de ese mes anunció un aumento promedio del $13 \%$ en el salario básico con vigencia hasta junio de $1975^{329}$.

\footnotetext{
${ }^{327}$ El aumento de la inflación mundial chocaba con la política interna de congelamiento de precios, por lo que los empresarios buscaban colocar sus productos en los mercados de los países vecinos.

328 "El naufragio del Pacto Social" El Combatiente Nro. 109 del miércoles 27 de febrero de 1974

329 El aumento del 13\% se descomponía de la siguiente manera: "9\% por el deterioro del poder adquisitivo; $2,5 \%$ por el aumento de la productividad de la economía; $1,5 \%$ para cumplir la meta de
} 
Como indican Rougier y Fiszbein (2006), el adelantamiento de la Gran Paritaria implicaba de hecho un incumplimiento del Pacto Social, y ni siquiera logró promover una tregua temporaria en la puja entre trabajadores y empresarios ${ }^{330}$.

Para el PRT-ERP el fracaso de la Gran Paritaria Nacional era la muestra más cabal de la ruptura y "muerte del Pacto Social"331 y de que las luchas reivindicativas se habían transformado en el terreno en el que las masas movilizadas comenzaban a enfrentarse de manera frontal con los planes del propio Perón ${ }^{332}$. En ese marco, lograr la convocatoria a nuevas paritarias y conseguir aumentos salariales por fábrica pasaron a ser objetivos de primer orden para la política de la organización. La posibilidad de un ámbito de discusión como lo eran las paritarias, en ese contexto, prometía un escenario favorable para disputarle la base a una "burocracia sindical" fuertemente presionada $\mathrm{y}$ comprometida con y por el gobierno, del mismo modo que una oportunidad inmejorable para lograr una amplia movilización obrera que consiguiera importantes concesiones económicas. En tal sentido, cada lucha parcial que se daba a nivel de fábrica, era considerada una grieta en el Pacto Social, en la "burocracia sindical" y en el gobierno, y una demostración de los niveles de conciencia que iba adquiriendo el movimiento obrero.

En ese contexto, concretar un Frente Antiburocrático Nacional que centralizase las luchas se constituyó en un objetivo principal para la organización ${ }^{333}$. Si bien reconocía las dificultades que existían a la hora de concretar un movimiento unitario, debido a las diferencias ideológicas y metodológicas existentes entre las distintas organizaciones,

mejora en la distribución funcional del ingreso." A su vez se elevaba un 30\% del salario mínimo, al igual que las asignaciones familiares, mientras que el nivel general de las tarifas públicas se elevó más del 50\%. Por su parte los empresarios quedaban autorizados a aumentar sus precios de acuerdo con los montos establecidos por el Ministerio de Economía (Rougier y Fiszbein, 2006:120)

${ }^{330}$ Según el PRT-ERP esta compensación se diluía prácticamente al instante ante los aumentos de precios en combustibles, transportes, alumbrado y barrido y vestimenta ("La política económica del enemigo" y "La lucha contra el costo de vida", El Combatiente Nro. 115, miércoles 24 de abril de 1974.)

331 "La muerte del Pacto Social y la ofensiva económica", El Combatiente Nro. 113, miércoles 10 de abril de 1973.

332 "Las características profundamente antiobreras del 'pacto social', defendido por Perón contra viento y marea, quedan día a día expuestas con más claridad ante la continuación de las luchas proletarias. Las leyes represivas dictadas para imponer el pacto, eje de toda la política económica del gobierno burgués, comienzan a aplicarse sistemáticamente. Toda movilización, toda lucha reivindicativa aparece así como un ataque directo a Perón y a su programa y como tal es repudiado a coro por la burocracia sindical y por la burguesía." ("Las armas de la burguesía” El Combatiente Nro. 106 Miércoles 6 de febrero de 1974.)

333 "No a la congelación del salario. No a la legislación represiva." El Combatiente Nro. 103, miércoles 2 de enero de 1974. Como vimos en el capítulo anterior, en las resoluciones principales del II Plenario Nacional del MSB de abril, figuró la propuesta de realizar un plenario nacional de las distintas corrientes combativas y antiburocráticas. 
sostenía que el "sentimiento antiburocrático" era un punto de contacto que, aunque mínimo, era suficiente como punto de partida para lograrlo ${ }^{334}$.

En ese sentido la experiencia del Movimiento Sindical Combativo (MSC) ${ }^{335}$ de Córdoba aparecía ante los ojos del PRT-ERP como la mejor expresión de lo que debía construirse a nivel nacional. Por su papel destacado en la organización y coordinación de las luchas provinciales contra el Pacto Social y contra el Navarrazo, aquel movimiento construido en base al liderazgo de Agustín Tosco, marcaba el camino no sólo a nivel sindical sino también a nivel de la lucha democrática. Por tal razón la organización apoyó, promovió y participó de todos los plenarios y llamamientos que realizo dicho espacio buscando transformarlo en el eje articulador de la unidad antiburocrática. Los perretistas eran conscientes del papel que jugaba Tosco para la unidad del movimiento obrero: el dirigente lucifuercista contaba con una estrecha relación con el PCA a través de su participación en el Movimiento Nacional Intersindical, y tenía muy buenas relaciones con el PB, entre otras organizaciones. Por su parte, con el PRT-ERP venía construyendo un estrecho vínculo desde 1972. Esto lo transformaba en una pieza clave para lograr aquello que los perretistas por su propia cuenta no podían lograr ${ }^{336}$. Es que, como vimos, el frente sindical que éstos últimos apostaban construir incluía principalmente al PCA, al PB y a la JTP, por lo que cualquier propuesta que no contuviera a estas fuerzas era considerada insuficiente y no merecía ser respaldada.

Ello se manifestó en el "Plenario de la Democracia Sindical" desarrollado en Villa Constitución, realizado en apoyo a la lucha que estaban protagonizando los obreros

\footnotetext{
334 "Los revolucionarios y la actividad sindical" El Combatiente Nro. 120, miércoles 5 de junio de 1974

${ }^{335} \mathrm{La}$ organización apoyó explícitamente la fundación del Movimiento Sindical Combativo (MSC) de Córdoba lanzado el 5 de enero y fundado como un frente antiburocrático compuesto por 42 sindicatos y agrupaciones con el objetivo de centralizar las luchas de la provincia. A su vez, hacía propio el programa del MSC que planteaba centralmente un rechazo expreso al Pacto Social, exigía un aumento de 200.000 pesos "viejos" de salario mínimo y 60.000 de aumento general inmediato entre otras reivindicaciones y consignas; rechazo a la ley de prescindibilidad; defensa de la democracia sindical; pleno respeto al derecho de huelga; enérgica condena a la legislación represiva, etc. ("Para centralizar la lucha contra la burocracia y los patrones. En Córdoba se lanza el FRENTE ANTIBUROCRÁTICO” Nuevo Hombre Nro. 56. Primera quincena de febrero de 1974.; "Momentos decisivos y de gran responsabilidad." $E l$ Combatiente Nro. 107, miércoles 13 de febrero de 1974; "Unidad antiburocrática contra el Pacto" El Combatiente Nro. 107, miércoles 13 de febrero de 1974.)

${ }^{336}$ Aquella necesidad respondía los niveles de conflictividad obrera que se estaba viviendo que, para el primer semestre de 1974, alcanzaron a su punto más alto no sólo en cantidad sino también en extensión geográfica: entre marzo y junio, el promedio mensual de conflictos fue el más elevado de los tres años del gobierno peronista, agravado por el hecho de que el porcentaje mayor de los mismos perseguían mejoras salariales (Torre, 2004:80)
} 
metalúrgicos de aquella localidad ${ }^{337}$. Aquel plenario, convocado para el 20 de abril, contó con la concurrencia masiva de las organizaciones políticas y sindicales (aunque con la notoria ausencia de la JTP) y de los principales dirigentes combativos y antiburocráticos -entre los que se destacaron René Salamanca (SMATA-Córdoba), Agustín Tosco (Luz y Fuerza-Córdoba), Alfredo Ferraresi (Farmacia) y Alberto Piccinini (principal dirigente de Acindar y de los metalúrgicos de Villa Constitución) ${ }^{338}$. La reunión dejó expuestas las posiciones y diferencias que existían entre las distintas corrientes: la polémica principal giró en torno a la propuesta de formar una Coordinadora Nacional de Gremios en Lucha presentada por el PST. La moción, que no había sido discutida con anterioridad, viró en la polémica principal del encuentro al ser rechazada desde el estrado por Piccinini ${ }^{339}$ y por la mayoría de los participantes, incluido el PRT-ERP, por considerarla "forzada" y sin base real ${ }^{340}$. El rechazo del PRTERP era justificado, entre otras cosas, por la falta de condiciones objetivas para formar un frente representativo ${ }^{341}$. En los hechos la consideraban inviable debido a que el PCA se oponía y la JTP había estado ausente ${ }^{342}$.

\footnotetext{
${ }^{337}$ Conocido como "Villazo", la lucha de los obreros metalúrgicos estuvo motivada por la intervención de la CIR de la fábrica Acindar y la suspensión de las elecciones de la seccional villense de la UOM. Por ello, el 8 de marzo estalló un conflicto que rápidamente se extendió a todas las fábricas de la localidad y pueblos aledaños (Marathon, Metcon, Villiber, Varassi, Lago, entre otros talleres de la zona) generando un movimiento de solidaridad que excedió a las bases obreras e incorporó prácticamente a toda la comunidad. Combinando múltiples formas de acción y de protesta (la huelga, la ocupación, la asamblea masiva y permanente, la organización de un "comité de lucha", etc.) el primer capítulo de esta lucha, que tendrá su segundo episodio en marzo de 1975, terminó en un importante triunfo. En él intervinieron, con diferente nivel de incidencia, la mayoría de las corrientes de la nueva izquierda (JTP, el PST, VC) destacándose, por su inserción e influencia, las organizaciones Poder Obrero/OCPO y el PRT-ERP (Caggiano, 1999; Santella y Andujar, 2007; Winter, 2010; Paulon, 2012).

338 Además participaron importantes contingente de delegados, CIR y agrupaciones clasistas de todo el país.

${ }^{339}$ Según la reconstrucción de Agustín Santella, en medio del acto Alberto Piccinini se "calentó" ante los cantitos del PST que decía "Llegó la hora de la coordinadora", y desde el estrado tomo el micrófono para decir: "dejemos que esto se construya, compañeros, no hay que destruir". Esta posición fue secundada por Tosco, Salamanca y Ferraresi, y sostenida por los organizadores principales del acto entre los que se encontraban la Organización Poder Obrero/OCPO, que tenía una influencia directa sobre Piccinini. (2007:32)

${ }^{340}$ Según la reconstrucción de los hechos que hace el PST, ante la propuesta de formar una coordinadora el MSB y el PRT-ERP habría respondido con el cántico: "No rompan más las bolas con la coordinadora" ("Coordinadora: la única garantía es un plenario" Avanzada Socialista Nro.116, 13 de agosto de 1974); Los perretistas, por su parte, en un balance posterior planteaban: "El intento de forzar una Coordinadora responde a un criterio espontaneísta promovido por la concurrencia no proletaria al Acto que con su apresuramiento e impresionismo pretenden resolver los principales problemas de la Revolución en un par de semanas, y también responde al criterio errado de que en un conflicto sindical se debe jugar la vida todo el movimiento obrero, criterio que sólo nos lleva por el camino de la derrota." ("Las luchas obreras y la pequeña burguesía" El Combatiente Nro. 116 Miércoles 8 de mayo de 1974)

341 "En primero lugar un Frente con estas características, para que realmente sea efectivo (...) debe ser hecho con paciencia y no lo construiremos de un día para el otro, y por decreto. (...) En segundo lugar, el Frente debe ser amplio, expresando a las corrientes combativas más importantes y numerosas del movimiento obrero e incorporando a las nuevas direcciones gremiales y combativas que surjan al calor
} 
La JTP no participó expresamente por considerarlo un acto "falto de representatividad" e "ineficaz" y por tratarse de acuerdos "superestructurales" entre las fuerzas políticas de izquierda $^{343}$. Lo cierto es que detrás de esa posición subyacía su política de evitar un enfrentamiento directo con Perón -algo que presumiblemente también explicaba la oposición del PCA-. No obstante a partir del 1 de mayo este escenario comenzó a cambiar cuando Perón rompió públicamente con Montoneros ${ }^{344}$. A partir de allí esta organización fue aumentando sus críticas al gobierno y, a nivel sindical, comenzó a acercar posiciones con las demás fuerzas antiburocráticas ${ }^{345}$. Sin embargo ello se tradujo más bien en mayores niveles de coordinación a nivel fabril que en avances concretos de acuerdos políticos y sindicales superestructurales.

La preocupación del PRT-ERP por las actitudes y las posiciones de Montoneros (así como las del PCA) y sus constantes llamados a que rompieran definitivamente con el gobierno respondían, entre otras cosas, a que consideraban que se vivía un momento clave para la unidad tanto a nivel político como sindical. Ese "momento", para los perretistas, estaba caracterizado por la ligazón entre las luchas sindicales y la lucha política contra el gobierno ${ }^{346}$ y porque consideraban que los logros a nivel de fábrica venían robusteciendo a las corrientes clasistas con perspectivas de disputar nacionalmente la conducción sindical del movimiento obrero ${ }^{347}$. Este optimismo, que se

del combate. El Frente antiburocrático y antipatronal no debe ser, y por eso insistimos en que este camino se siga pacientemente, un frente que reúna un cúmulo de sellos y siglas sin mayor capacidad de convocatoria. (...) No una unidad antiburocrática superestructural e integrada por tendencias sin representatividad en la clase obrera." (Ídem)

${ }^{342}$ El PRT-ERP había criticado la anunciada ausencia de la JTP en la antesala del acto como una negativa a "consolidar en los hechos la unidad del movimiento obrero clasista", caracterizándola como una actitud "vacilante frente al enemigo de clase y sectaria hacia el resto del campo popular" ("Dos tácticas en la lucha de clases" El Combatiente Nro. 114, 17 de abril de 1974.)

343 "La unidad para la lucha fue una meta inalcanzable" La Justa. Órgano de la JTP Nro. 2 Junio de 1974

${ }^{344}$ En el acto oficial convocado en Plaza de Mayo, el propio Perón se encargó de romper con la TRP al tratarlos, entre insultos, como "infiltrados en el movimiento" y al apoyar públicamente a la "burocracia sindical".

${ }^{345}$ Un hecho de peso en este proceso de acercamiento fue el apoyo de la JTP a la lista Marrón de SMATA Córdoba, lista clasista encabezada por el dirigente René Salamanca, que conducía la seccional desde 1972, y que llevaba en su seno a fuerzas como el PCR, VC, PO y el PRT-ERP. Lo destacable del caso es que en dichas elecciones también se había presentado la Lista Anaranjada apoyada e integrada, entre otros, por el Peronismo Descamisado, el PB 17 (fracción del PB) y el PC, y aun así la JTP decidió volcar su apoyo a los clasistas por considerarlos los verdaderos "representantes de los intereses gremiales de los trabajadores" ("Porque apoyamos a la Lista Marrón en las elecciones del SMATA" en El Peronista Nro. 5. Martes 21 de mayo de 1974.). Además el apoyo no sólo se materializó en declaraciones públicas y votos, sino participando con guardias armadas junto a militantes del PRT-ERP que garantizaron la seguridad de la sede de SMATA (Caviasca, 2013: 230).

346 "Salarios y burocracia" El Combatiente Nro. 121 Miércoles 12 de junio de 1974

347 "Unir y movilizar todas las fuerzas del pueblo" El Combatiente Nro. 121 Miércoles 12 de junio de 1974 
respaldaba en los altos niveles de movilización obrera ${ }^{348}$, adquirió un nuevo giro con la muerte de Perón el 1 de julio, ya que con ello se rompía el "dique" con el que, hasta entonces, se habían podido contener la lucha de clases y sostener la política económica. Ante este nuevo escenario la organización analizaba que se asistiría a niveles superiores de conflictividad que llegaría a cuestionar "aspectos parciales del proyecto burgués y proimperialista del peronismo"349, por lo que la unidad adquiría un carácter de urgencia:

"Entre las tareas principales que la vanguardia proletaria debe encarar con resolución y entusiasmo se inscriben la realización de un gran congreso de bases y de un plenario antiburocrático, que permitan alejar el peligro que entraña la localización de los conflictos, el desgaste de energías revolucionarias. ${ }^{350}$

Como se ve, la preocupación estaba en el aislamiento de los conflictos y en la falta de un plan que los unifique ${ }^{351}$. Nuevamente, la interpelación directa era a Montoneros y al PCA que, según los perretistas, continuaban "distrayendo las luchas de sus ejes revolucionarios". A pesar de ello, se entusiasmaban con algunas señales ${ }^{352}$ : Firmenich, el máximo dirigente montonero, participó como orador, junto a René Salamanca y Agustín Tosco, en un acto convocado el 8 de agosto por la conducción del SMATA cordobés, que había sido intervenido, y en su discurso enfatizó el "camino de la unidad" como el único posible para dar el "combate final"353.

Los buenos augurios se confirmaron finalmente cuando Agustín Tosco anunció ${ }^{354}$ la convocatoria a un congreso de bases para mediados de agosto, como respuesta al congreso de la CGT que se realizaría el 10 y 11 de julio ${ }^{355}$. Según lo planteado por

\footnotetext{
${ }^{348}$ De hecho esta situación obligó a Perón a aprobar, el 12 de junio, un aumento salarial en forma de pago anticipado del aguinaldo. En la lógica perretista este era un nuevo intento por recomponer Pacto Social y salvar a las cúpulas sindicales del "desborde" de sus bases("El pago del doble aguinaldo" El Combatiente Nro. 124 del miércoles 3 de julio de 1974)

349 "Crece la lucha proletaria” El Combatiente Nro. 129 Miércoles 7 de agosto de 1974

350 Ídem

351 "La necesidad de un Congreso de bases" El Combatiente Nro.130, miércoles 14 de agosto de 1974

352 "Córdoba: firme respuesta de los mecánicos" El Combatiente Nro.130, miércoles 14 de agosto de 1974

${ }^{353}$ Causa Peronista Nro. 6 Martes 13 de Agosto de 1974; Evita Montonera Nro. 2 Enero-Febrero 1975

${ }^{354}$ El anuncio se hizo en el VI Congreso del FAS, realizado el 15 de junio en la ciudad de Rosario. Aquella reunión hizo centro en las luchas contra el aumento del costo de vida y del Pacto Social, siendo destacada la participación de distintas agrupaciones y referentes sindicales. El acto contó con alrededor de 30 mil personas, y contó con personalidades como la de Agustín Tosco, Alicia Eguren y Rodolfo Ortega Peña. Además se materializó el planteo de ampliar al FAS para transformarlo en un Frente de Liberación Nacional y Social en el que confluyesen distintos sectores del espectro antiimperialista y democrático (Silva Mariños, 2017).

${ }^{355}$ En el congreso de la CGT se enfrentaban dos corrientes internas, una liderada por Adelino Romero y otra por Lorenzo Miguel (líder de las 62 Organizaciones), ambas representantes de las dos alas del gobierno (el ala gelbardiana y el ala lopezreguista). Si bien el congreso terminó con la presentación de una lista única que llevaba a Romero como secretario general, del mismo salió fortalecida la corriente liderada por el dirigente Lorenzo Miguel, y con ello el "ala derecha" del gobierno. De hecho tan solo dos
} 
Tosco el "contracongreso de las bases" había sido acordado en el curso de una reunión entre el MSC, el MSB y la Intersindical y estaba pactado para realizarse en el estadio Luna Park ${ }^{356}$. Posteriormente la Federación Grafica Bonaerense (FGB) y el MSC reiteraron el llamado en diferentes instancias quedando planteada la perspectiva de construir una coordinadora nacional. En esa dirección el Comité Central del PRT-ERP, reunido en septiembre, resolvió, entre otras cosas, apoyar y alentar la formación y consolidación de dicha coordinadora y de todo aquello que favoreciera a la formación del frente antiburocrático ${ }^{357}$.

Finalmente la Coordinadora Nacional de Gremios Combativos y Trabajadores en Lucha se formó en septiembre. La misma se reunió en Tucumán en apoyo a los obreros azucareros que venían desarrollando una huelga por tiempo indeterminado en demanda de mejoras salariales, la reapertura de ingenios cerrados y en contra de la intervención de la FOTIA (Nasiff, 20015:166-167). La reunión se dio en un contexto sumamente represivo: a la intervención del gremio azucarero se le sumaban el de FGB y el SMATA cordobés, todos ellos impulsores del encuentro. Esto, sumado al gran operativo policial que la rodeó, la obligó a sesionar en la clandestinidad sin la totalidad de los miembros previstos $^{358}$. Sin embargo, quienes pudieron reunirse aprobaron un documento en el que daban por constituida la Coordinadora ${ }^{359}$.

días después de culminado el congreso Romero falleció debido a un ataque cardíaco quedando al frente de la central Segundo Palma, dirigente del sindicato de la construcción y hombre de Lorenzo Miguel.

356 "El VI Congreso del FAS" El Combatiente Nro. 122, miércoles 19 de junio de 1974.

357 "Sesionó el Comité Central de nuestro Partido" El Combatiente Nro. 134, miércoles 25 de septiembre de 1974.

${ }^{358}$ El mismo debía realizarse entre el 14 y el 15 de septiembre en la sede de la FOTIA. Se habían establecido distintos puntos de encuentro: en los sindicatos azucareros (incluyendo a los de los ex ingenios), en los Talleres Ferroviarios de Tafí Viejo y en la Quinta Agronómica de la Universidad Nacional de Tucumán. Se anunció además la participación de Atilio Santillán (FOTIA), Agustín Tosco (Luz y Fuerza-Córdoba), Raimundo Ongaro (Gráficos-Buenos Aires), René Salamanca (SMATACórdoba), Alberto Piccinini (Acindar-Villa Constitución), Mario Aguirre (ATE-Rosario), Jorge Di Pasquale (Farmacia-Buenos Aires) y Enrique Tortosa (Periodistas-Buenos Aires). Sin embargo el operativo policial bloqueo la sede de la FOTIA con carros de asalto y detuvo a la delegación de SMATA impidiendo que el plenario se llevara adelante como estaba programado (Nasiff, 2015).

${ }^{359} \mathrm{La}$ declaración aclaraban no tener como meta ser una CGT paralela y declaraban entre sus objetivos básicos: la defensa de salarios justos y plena vigencia de la democracia sindical. Además planteaban un funcionamiento basado en una Mesa Nacional y Mesas Regionales y Zonales. Aunque se aclaraba que faltaban sumar algunas adhesiones, la declaración estaba firmada por las siguientes organizaciones y comisiones sindicales que figuraban como miembros de la coordinadora: Federación Gráfica Bonaerense Federación Obrera Trabajadores de la Industria del Azúcar (FOTIA); SMATA (Córdoba); Asociación de Trabajadores del Estado (Rosario)- Luz y Fuerza (Córdoba)- Sindicato de Farmacia (Capital)- Asociación de Periodistas- Sindicato de Trabajadores Viales Bs As- Sindicato Gráfico de Resistencia- Unión Gráfica de Córdoba- Fraternidad y Ferroviarios de Rosario- Asociación de Trabajadores de la Educación Provincial (Tucumán)- CINTER (Rosario)- Sindicato Petroquímicos San Lorenzo- Propulsora Siderúrgica- Ingenio Ledesma- Ingenio Tabacal- Federación Azucarera Regional (FAR)- Sindicato Empleados Entidades Financieras- Movimiento Nacional Aceitero- Bagley- Martín Amato- TensaObreros Plásticos Zona Norte- Sindicato Plomeros- Sindicato Electricista Capital y Gran Bs As - Perkins- 
El PRT-ERP, satisfecho por el resultado de la reunión, la calificaba como "un hecho auspicioso, un verdadero paso adelante dado por el proletariado argentino. La necesaria tarea de unificar la dirección de los conflictos en curso, en el camino de la formación de un Frente Antiburocrático (...) ${ }^{\$ 30}$. Es de destacar que esta vez la reunión sí había contado con la participación de la JTP. Sin embargo, según la información con la que contamos, la Coordinadora no pudo trascender mucho más allá de su formación. La ola de intervenciones sindicales que se sucedieron entre agosto y octubre de 1974 y la fuerte disposición represiva que puso a jugar el gobierno para sofocar los conflictos en fábricas (el 6 de noviembre decretó el Estado de Sitio), conspiraron contra la continuidad de la misma que no volvió a tener una nueva reunión. Además no hay que descartar que las diferencias políticas entre las organizaciones y los criterios "hegemonistas" que portaban algunas de ellas (como por ejemplo el PRT-ERP) también hayan aportado a su fracaso ${ }^{361}$. Así, aunque en noviembre el PRT-ERP hizo un llamado a fortalecerla, ante lo que consideraban una "brutal embestida represiva", no habría más noticias de dicho organismo ${ }^{362}$.

\footnotetext{
Asociación de Viajantes (Cba)- Construcción (Cba) - Sindicato Vialidad Nacional (Cba) - Sindicato Publicidad (Cba)- Cuero (Primicia)- Delegación Obreros Navales Astarsa- UTA (Intervenida Rosario)Comisión Interna Acindar- Trabajadores Rurales (Sala)- Delegación Mina Aguilar - Unión Gráfica Sanjuanina - AOTA (Rosario)". ("Coordinar las luchas por aumentos salariales y por la democracia sindical" Nuevo Hombre Nro. 70, segunda quincena de septiembre de 1974)

360 "Comunicado de la Coordinadora Nacional de Lucha Sindical" en El Combatiente Nro. 136 del miércoles 25 de septiembre de 1974

${ }^{361}$ A modo de conjetura consideramos que el fracaso parcial de la Coordinadora pudo haber estado condicionado también por las posiciones que adoptaron algunas fuerzas políticas que formaron parte de la fundación de la misma. Así por ejemplo el PCR, que participaba fundamentalmente a través de René Salamanca, figura de peso de la coordinadora, paso a defender activamente al gobierno de Isabel Perón en contra de lo que consideraban una amenaza de golpe militar "pro-soviético". De hecho, en noviembre dicha organización lanzó un volante a nivel nacional que militó activamente en las principales fábricas del país bajo la consigna: "No a otro 55. Contra el golpe pro-yanqui o pro-ruso, junto al pueblo peronista, defender el gobierno de Isabel, en el camino de la Liberación definitiva de nuestra patria". Por su parte el PCA continuaba con su política de apoyo al ala gelbardiana por lo que buscaba evitar cualquier manifestación que debilitara aún más el proyecto económico del todavía ministro de economía.

Además, por otro lado el PST consideraba a la Coordinadora como un acuerdo superestructural entre Tosco, Salamanca, Ongaro, la JP, el ERP y Montoneros, y por ende como un "órgano frente populista", y si bien decidía apoyarla lo hacía con "cautela" manteniendo una batalla contra los acuerdos entre dichas tendencias ("Boletín interno Nro. 103",14/8/ 1974, ab1, Fundación Pluma). Por otro lado esta misma organización denunciaba que las causas del fracaso de la Coordinadora tenían que ver con la "deserción" de Atilio Santillán, dirigente peronista de la FOTIA quien, si bien había participado de la conformación, poco tiempo después habría "despotricado" contra la misma acusando a sus participantes de querer "pintarla de rojo" y declarando que la FOTIA "es y será peronista". Además endilgaba "el fracaso de Tucumán" al método y la política seguida por los dirigentes sindicales que habrían resuelto los pasos a seguir "a puertas cerradas" sin consultar a las bases ("El fracaso de Tucumán" Avanzada Socialista Nro. 121, 17 de septiembre de 1974).

${ }^{362}$ Resulta sorprendente la escasa bibliografía que hace mención a la constitución de dicha Coordinadora y la poca información disponible sobre la misma, teniendo en cuenta que fue impulsada por los referentes más importantes del sindicalismo antiburocrático y clasista de la época y uno de los intentos de unidad
} 


\section{1.c. El "Estado policial” y la "situación revolucionaria"}

Para entonces el gobierno, al mando de Isabel Perón, había decidido liquidar lo poco que quedaba de la política frejulista lanzada en 1973. Con este objetivo, y en connivencia con la burocracia sindical, decidió convocar a una tercera reunión de la Gran Paritaria Nacional ${ }^{363}$, motivando la renuncia de Gelbard el 21 de octubre. Con ello se iniciaba una nueva etapa caracterizada por lo que el PRT-ERP denominó un "Estado Policial"364 y una política económica de ajuste decidida ${ }^{365}$. La lucha gubernamental contra el sindicalismo combativo se intensificó duramente: la aprobación de la Ley de Seguridad para combatir a la guerrilla suministró a las autoridades del Ministerio de Trabajo un arsenal de instrumentos para reprimir las huelgas ilegales y perseguir e intervenir los principales gremios opositores, por lo que el número de conflictos laborales se redujeron de un promedio de 30 a 11,6 conflictos por mes (Torre, 2004:92). En ese contexto la organización vaticinaba el inicio de "grandes choques de clases" y la apertura de una "situación revolucionaria". Bajo esta caracterización, e inspirado en las luchas obreras de Villa Constitución -que había adquirido carácter de pueblada-, Mario

más importantes del período, además de ser, como indica Héctor Löbbe (2009) uno de los antecedentes directos de las Coordinadoras Interfabriles del año 1975.

${ }^{363}$ Como resultado de la nueva convocatoria a la Gran Paritaria el gobierno, en acuerdo con la CGT y los empresarios, otorgaron un aumento del 15\% de aumento. El PRT-ERP denunciaba que los aumentos eran un nuevo "zarpazo" contra el bolsillo de los trabajadores ya que serían aplicados sobre los salarios vigentes al $1^{\circ}$ de abril de ese mismo año, y no sobre salarios actualizados, además del hecho de que los mismos no serían tomados en cuenta para las futuras negociaciones salariales. ("Paritaria: otra burla al pueblo trabajador" El Combatiente Nro. 142, miércoles 6 de noviembre de 1973)

${ }^{364}$ El PRT-ERP diferenciaba el "Estado Policial" del fascismo, aduciendo que este último era un régimen dictatorial producto de un "triunfo contrarrevolucionario" y del consecuente aplastamiento de las luchas populares, cosa que a su entender no sucedía en la argentina. Por el contrario lo que existía era un estado represivo a la defensiva "lleno de fisuras, impotente para dominar la rebeldía popular" ("Sobre el Estado Policial” El Combatiente Nro.140, miércoles 23 de octubre de 1974).

Es de destacar que ante el avance desmedido de la represión y la consolidación de este tipo de gobierno, el 4 de octubre la organización lanzó una propuesta de armisticio con el objetivo de desarticular la "cruzada antiguerrillera y antipopular" que había encarado el gobierno junto a otros sectores de la oposición burguesa. En ese sentido proponía suspender las operaciones militares y liberar a empresarios y militares secuestrados (Teniente Coronel Ibarzábal, Mayor Larrabure y Erich Breuss) a cambio de la liberación inmediata de todos los guerrilleros prisioneros y demás presos políticos y sociales, la derogación de toda la legislación represiva y la derogación del decreto que ilegalizaba al ERP. La propuesta de armisticio fue una maniobra política que buscaba consolidar la lucha por las libertades democráticas, convirtiéndola en una consigna permanente de lucha por la legalidad, al tiempo que demostrarle a los "sectores intermedios" (principalmente a los "políticos honestos") la supuesta flexibilidad del ERP. ("Porque un armisticio" El Combatiente Nro. 138 miércoles 9 de octubre de 1974). Sin embargo, tan sólo un mes después, ante la avanzada represiva legal e ilegal, el Comité Ejecutivo del PRT-ERP decidió lanzar una campaña de represalias indiscriminadas, en la que se respondería a cada asesinato de obreros, activistas sindicales o militantes del "campo revolucionario, popular y progresista" con la ejecución de empresarios, funcionarios de gobierno, burócratas sindicales, oficiales de las fuerzas represivas y jueces.

365 "La renuncia de Gelbard" El Combatiente Nro. 140 Miércoles 23 de octubre de 1974 
Roberto Santucho escribió un extenso documento que se conoció bajo el título Poder Burgués y Poder Revolucionario ${ }^{366}$, en el que avanzó en las definiciones estratégicas y teorizó sobre la forma que debía adquirir la disputa por el poder. Desde su punto de vista, aquello se resolvería a través de la instauración del poder dual, es decir, zonas liberadas -en el campo ${ }^{367}$ y en las ciudades- gobernadas por las fuerzas revolucionarias que disputaran el control del país al "poder burgués”. Según su previsión, un primer momento ello se manifestaría a nivel provincial, municipal o en zonas fabriles, con la creación de distintas formas de poder local surgidas al calor de las luchas reivindicativas, de modo que la lucha sindical adquiría, aunque implícitamente, un estatus estratégico. Así es que cuando un sindicato o una CIR de una fábrica grande iniciara una lucha sindical o antiburocrática y se enfrentara a las fuerzas represivas y al gobierno, luego de movilizar a los trabajadores y ganar un primer conflicto, debían preocuparse por tomar los demás problemas de la población, acercarse a las organizaciones villeras y barriales, a otros sindicatos y CIR y alentar a los activistas a construir organismos de poder local de carácter soviético -que comenzaran paulatinamente a resolver los problemas de salud, educación, seguridad, justicia, vivienda, etc.- $\mathrm{y}$, paralelamente fortalecer al partido, al ejército, $\mathrm{y}$ al frente antiimperialista.

Ante esta posibilidad, estimaba como lo más probable que el gobierno apuntase a un acuerdo con los militares a fines de instaurar una dictadura que arremetiera contra todo vestigio de legalidad ${ }^{368}$. Por ello volvía a insistir en la necesidad de impulsar la TOR-22 para organizar la resistencia obrera desde la clandestinidad, al mismo tiempo que luchar denodadamente por la defensa de la legalidad de las organizaciones sindicales fortaleciendo la lucha democrática ${ }^{369}$. Consciente de la ofensiva represiva, alertaba sobre la posibilidad de que algunas luchas reivindicativas no triunfaran y planteaba la necesidad de preservar fuerzas, dirigiendo con "inteligencia" los esfuerzos en los enfrentamientos, planificándolos minuciosamente y evitando dar luchas aisladas. ${ }^{370}$

Esa prudencia contrastaba, sin embargo, con la decisión de responder a cada asesinato de "obreros revolucionarios", "activistas sindicales" o "luchadores progresistas", con la

\footnotetext{
366 "Poder burgués y poder revolucionario" Ediciones El Combatiente, agosto de 1974

${ }^{367} \mathrm{La}$ apuesta principal a nivel rural fue, como dijimos en la nota al pie Nro. 316, el desarrollo de la compañía de monte "Ramón Rosa Jimenez", foco rural instalado en los montes tucumanos.

368 "Detrás de la escalada represiva asoma la debilidad del gobierno" El Combatiente Nro. 145, miércoles 27 de noviembre de 1974.

369 "Sesionó el Comité Central de nuestro Partido" El Combatiente Nro. 134 Miércoles 25 de septiembre de 1974

370 “Unidad y habilidad frente al enemigo." El Combatiente Nro. 143 Miércoles 20 de noviembre de 1974
} 
ejecución de empresarios, funcionarios de gobierno, "burócratas sindicales", oficiales de las fuerzas represivas o jueces ${ }^{371}$. Esta orientación se justificaba con la premisa de que la única forma de hacer retroceder la represión y forzar a la "democratización" era asestando duros golpes al "enemigo" y demostrando la fortaleza de las fuerzas revolucionarias. En esa línea, en el mes de diciembre, la organización ejecutó a cuatro empresarios como represalia por la represión ${ }^{372}$. El más resonante de ellos fue el caso de dos ejecutivos de la fábrica de pinturas Miluz, ejecutados como respuesta al secuestro y posterior asesinato de Jorge Fischer y Miguel Ángel Bufano, dos dirigentes sindicales de la fábrica y militantes de Política Obrera. La acción abrió una polémica entre esta última organización y el PRT-ERP: mientras la organización trotskista la calificó como una "provocación" que incrementaba el terror en la fábrica e inhibía a la movilización obrera y acusaba a los perretistas de estar al "servicio del enemigo", estos últimos la justificaban como parte de la lucha contra el "Estado Policial" y rechazaban las críticas acusando a Política Obrera de ser una corriente "sindicalista", reacia al "combate" y defensora de la "legalidad" ${ }^{373}$. Estas acusaciones cruzadas sintetizaban la diferencia de métodos y criterios que, de manera cada vez más aguda, se presentaba entre las organizaciones de izquierda al interior de las fábricas.

En este contexto ultra represivo, los perretistas renovaron su optimismo cuando hacia fin de año repuntó la actividad huelguística (Werner y Aguirre, 2007: 120), y además, se produjo el triunfo de la Lista Marrón de Villa Constitución en las elecciones de la seccional local de la UOM (lista encabezada por Alberto Piccinini y conformada por militantes del PRT-ERP, Poder Obrero/OCPO ${ }^{374}$, PST y VC principalmente) ${ }^{375}$. La organización vio en ello un indicio de que en 1975 las fuerzas progresistas y

\footnotetext{
${ }^{371}$ La decisión fue tomada por el Comité Ejecutivo reunido en el mes de noviembre.

${ }^{372}$ Los empresarios ejecutados fueron: Antonio Do Santos Larangueira (empresario pesquero); Ramón Samaniego (jefe de personal de La Cantábrica S.A.) y Alberto Abeigon y Manuel Martínez (gerente general y gerente de personal respectivamente de la firma MILUZ)

${ }^{373}$ Política Obrera además consideraba que la acción había sido un ataque directo a su organización y una expresión de la bancarrota política del PRT-ERP e incluso llegaba a compararla con las acciones de la Triple A, organización responsable de los asesinatos de sus militantes. ("Miluz. Las ejecuciones del ERP al servicio del enemigo" Política Obrera Nro.219, 8 de enero de 1975). Mientras tanto los perretistas, interpretaba la crítica como una "respuesta típica" de las corrientes "sindicalistas" que "en vez de ponerse a organizar a las masas para el combate", ante el primer golpe se preocupaban por las dificultades que se le presentaban para seguir actuando sindicalmente en la legalidad ("Vacilaciones pequeño burguesas" El Combatiente Nro. 158, miércoles 12 de marzo de 1975).

${ }^{374}$ Como vimos en la nota al pie número 327 la Organización Comunista Poder Obrero (OCPO) fue una organización política que nació como resultado de la fusión de varios núcleos políticos que venían funcionando desde 1973 de manera conjunta. Adoptaron como estrategia la lucha armada de tipo ligada al movimiento obrero y sostuvieron un programa basado en el clasismo (Cormick, 2015).

375 "Villa Constitución: triunfo obrero y popular" El Combatiente Nro. 146 Miércoles 4 de diciembre de 1974.
} 
revolucionarias se recuperarían de los golpes recibidos por la represión y sobrevendría una nueva ola de conflictos y de amplias movilizaciones que sacudirían los cimientos del "edificio burgués" "376. Es que por delante se avecinaban las paritarias, instancia que prometía importantes movilizaciones, pero que, a su vez, exigía redoblar los esfuerzos para lograr construir la tan buscada unidad de las corrientes antiburocráticas.

\subsection{La Regional Buenos Aires y su penetración en las fábricas.}

Resulta importante realizar algunas precisiones sobre el saldo organizativo con que el PRT-ERP terminó el año 1974. A su vez, es necesario reconstruir el mapa de las fábricas en las que logró penetrar, para tener así una dimensión aproximada del peso que alcanzaría entre los trabajadores del Gran Buenos Aires en el contexto de la apertura de paritarias y en las jornadas de lucha de junio y julio de 1975.

1974 fue un año muy importante para la Regional Buenos Aires. Según un informe de la dirección regional ${ }^{377}$ la organización habría comenzado el año con una inserción "casi nula" en el movimiento obrero y lo habría terminado con una penetración considerablemente mayor. Promediando el año, el partido habría contado con presencia en "fábricas importantes" y células en la mayoría de ellas. Además, se informaba que en muchos establecimientos existían equipos y subequipos "militares" y "de masas", dirigidos por células partidarias e incluso, en algunos casos, se había logrado construir Comités Fabriles. Por otro lado se remarcaba que aún en donde la represión había provocado caídas y despidos de militantes, el trabajo político no se había perdido.

Ese saldo tan positivo en la penetración fabril se había logrado en virtud de un "golpe de timón", operado por la dirección regional, en la forma de encarar la construcción partidaria. Si durante el año 1973 -luego de la lucha fraccional-, se habían volcado casi todas las energías a reorganizar las estructuras partidarias pensando que primero se debía tener al partido funcionado "como un reloj", para luego participar activamente en las luchas, en 1974 se partió de otro paradigma: el partido debía participar de todos los conflictos y consolidarse al calor de ellos. Gracias ello se habría dado un rápido reanimamiento de la actividad entre los obreros ${ }^{378}$, manifestada en los actos del MSB

\footnotetext{
376 "Crisis de la burguesía y agitación de las masas” El Combatiente Nro. 146 Miércoles 4 de diciembre de 1974

377 "Boletín interno Nro. 3. Regional Buenos Aires ( $1^{\mathrm{a}}$ quincena de enero)" DIPBA, Mesa DS, Carpeta Varios, Legajo nro. 2853, pp. 35-40

${ }^{378}$ En el informe se remarca que gracias a esa orientación se logró intervenir en los conflictos de Ivisa, Insud, Propuslora Siderúrgica, Matarazzo, Tensa y Panam (Idem).
} 
(abril) y del FAS (julio) en los que la regional participó con aproximadamente 400 y 1200 trabajadores respectivamente.

En el marco de este "golpe de timón”, que como vimos en el Capítulo 2 ya estaba insinuado en la orientación partidaria de "construir el Partido en las fábricas", la Regional Buenos Aires pasó a considerar el trabajo fabril como el pilar en el cual se asentaría toda la actividad del partido. Dicha decisión fue reforzada ante las resoluciones y orientaciones que dio el Comité Central de septiembre, en las cuales se planteaba como "decisivo" intensificar el trabajo político en las grandes fábricas y, como objetivo principal, incorporar "centenares y miles" de obreros fabriles al PRTERP. Para ello la dirección nacional exhortaba a las regionales, y fundamentalmente a Buenos Aires, a que garantizasen una distribución de los "cuadros" orientada a la penetración fabril, se esforzaran para organizar células partidarias en aquellos establecimientos donde se contara con militantes o contactos de la organización y formaran Comités Fabriles donde se tuviese más de una célula.

En función de ello, la dirección bonaerense decidió volcar cada uno de sus integrantes a una zona determinada, atendiendo de manera directa algunos trabajos políticos en fábricas importantes. El caso más emblemático en ese sentido fue el de Benito Urteaga, miembro de la dirección nacional y responsable político de la regional, quien se encargó personalmente de la penetración e inserción de la organización en la automotriz Ford ${ }^{379}$. Además, para lograr mejores resultados, proponía reordenar el trabajo de las células dedicadas a los frentes fabriles. Lo que se buscaba era que éstas estén compuestas por obreros y no, como venía sucediendo en varios casos, por un "rejunte" de militantes que realizaran trabajo político "sobre" la fábrica sin estar insertos en ella. En ese sentido el llamado era a construir células "reales" y no "formales", y a ajustar sus formas organizativas a las condiciones concretas de las fábricas y a los recursos militantes con que se contaba ${ }^{380}$. En función de ello, la organización publicó en sus boletines internos y en el periódico distintos ejemplos de cómo se había logrado penetrar exitosamente en algunas fábricas en base a decisiones y criterios flexibles. Así, por ejemplo, en el BI Nro. 63 se describía el caso de una fábrica, en la que el responsable político de la célula había decidido reorganizar a los militantes. Se trataba de una célula compuesta por solo un obrero de la planta y tres militantes de otros frentes, lo que hacía que los problemas

379 Otro caso significativo fue el de Domingo Menna quien paso a atender el trabajo en las metalúrgicas de Villa Constitución (Entrevista a Luis Mattini con el autor, Buenos Aires, 2017; Entrevista con "Tito", Cafayate, 2017).

${ }^{380}$ Boletín Interno Nro. 63, julio de 1974 
de la fábrica no fueran abordados con la atención necesaria y que las tareas desarrolladas fueran de carácter general. Para revertir aquella situación, el responsable resolvió separar al obrero del resto de los militantes y organizar al primero de manera independiente con el objetivo de construir una nueva célula compuesta exclusivamente por trabajadores de la fábrica. Por su parte el resto de los militantes conformaron un equipo de apoyo con el objetivo de apuntalar "desde afuera" aquel trabajo, contribuyendo con volanteadas, pintadas e incluso acciones militares que no podían ser realizadas por los obreros militantes por cuestiones de seguridad ${ }^{381}$.

Lo que se intentaba resaltar con este ejemplo, era la flexibilidad y creatividad que debían tenerse a la hora de desarrollar el partido en las fábricas que, muchas veces, tendía a perderse debido a los criterios "esquemáticos" que generaba la estricta disciplina partidaria. Con ese objetivo, también se inauguró una sección en el periódico El Combatiente dedicada a la "vida y organización partidaria", en la que se disertaba sobre el "estilo de trabajo" que debía inspirar a la militancia y se la exhortaba a combinar dialécticamente el "profesionalismo" con la "creatividad" a la hora de aplicar la línea de la organización ${ }^{382}$. También se insistía en la necesidad de regularizar las herramientas de propaganda, haciendo especial hincapié en los boletines fabriles y se remarcaba la necesidad de la centralización y especialización en las tareas de las células. De hecho, fue en esa búsqueda de "profesionalizar" y "especializar" el trabajo fabril que, en 1975, el Buró Político decidió sumar un nuevo tipo de célula a los estatutos partidarios: la célula sindical. Como vimos en el capítulo 2, hasta el momento la tarea gremial había sido abordada por la célula de masas ${ }^{383}$, no obstante ahora surgía este nuevo organismo con el objetivo de atender estrictamente las cuestiones gremiales de las fábricas:

\footnotetext{
${ }^{381}$ Otro ejemplo en ese mismo sentido se puede ver en una nota de El Combatiente en la que se reproduce el relato de un militante quien cuenta como logró construir una célula en los ingenios azucareros y participar activamente de sus conflictos sin ser obrero del establecimiento y contando, previamente, sólo con un simpatizante entre los trabajadores. La nota busca reflejar las distintas estrategias que había utilizado (acudir a los lugares de reunión de los trabajadores, programar reuniones con contactos del simpatizante, lograr que algún trabajador lo aloje en su casa, etc.) para ganarse la confianza de los obreros y sentar las bases organizativas del partido ("Como nos orienta el partido" El Combatiente Nro. 186, miércoles 8 de octubre de 1975)

382،"La formación multilateral de los cuadros" El Combatiente Nro. 154, lunes 10 de febrero de 1975; “iCrecer y superarse!”, El Combatiente Nro. 156, jueves 24 de febrero de 1975; "Importancia de la propaganda de masas", El Combatiente Nro. 165, lunes 28 de abril de 1975; "La organización, una actividad fundamental", El Combatiente Nro. 171, miércoles 11 de junio de 1975; "Las células, motor del partido", El Combatiente Nro. 181, miércoles 3 de septiembre de 1975; "Auge de masas y construcción del Partido", El Combatiente Nro. 194, miércoles 3 de diciembre de 1975; "Como nos orienta el partido" El Combatiente Nro. 186, miércoles 8 de octubre de 1975.

${ }^{383}$ Como vimos en el capítulo 2, los cuatro tipos de células que formaban el modelo ideal del partido en las fábricas eran: la célula de masas; la célula o escuadra militar, la célula de propaganda y la célula legal.
} 
"Con el desarrollo, con nuevas experiencias del Partido en la dirección del movimiento de masas ha comenzado a hacerse posible la formación de células sindicales que se ocupen específicamente de ese tipo de problemas, es decir que se dediquen de lleno a la lucha sindical, antipatronal y antiburocrática. Se trata entonces de un nuevo tipo de célula que no reemplaza a la célula de masas ni debe confundirse con ella",384

Las células sindicales debían desarrollarse cuando la organización estuviese al frente de un sindicato, de una CIR o de una agrupación importante, ya que esas tareas absorbían una cantidad significativa de tiempo en detrimento del resto de las actividades partidarias. La organización consideraba que, por la dinámica de las luchas sindicales, era muy probable que la inserción del partido en una fábrica se diera por la incorporación de dirigentes gremiales y, por ende, se hiciera necesario iniciar el trabajo partidario a través de la formación de una célula sindical. Ello significaba un paso adelante que reflejaba el crecimiento de la organización, un reconocimiento del papel que estaba jugando la lucha sindical en su política y, por ende, una muestra de que el prejuicio "antisindical" que arrastraba desde sus orígenes comenzaba a abandonarse ${ }^{385}$. Como veremos a continuación, todas estas orientaciones permitieron que el PRT-ERP lograse una importante inserción fabril que la llevó a ser una de las organizaciones de izquierda más importantes en el movimiento obrero del Gran Buenos Aires y del país.

\section{Mapa de inserción fabril}

En base a datos extraídos de entrevistas realizadas y de fuentes consultadas ${ }^{386}$, así como a la información brindada en la bibliografía disponible (Pablo Pozzi, 2001; Werner y Aguirre, 2007; Löbbe, 2009; De Santis, 2010) pudimos construir un cuadro aproximado de la inserción fabril que logró el PRT-ERP en la regional Buenos Aires:

En la zona de La Plata, Berisso y Ensenada contaba con trabajo político en YPF, Astillero Río Santiago, Frigoríficos Swift, Petroquímica Sudamericana y Propulsora Siderúrgica.

\footnotetext{
${ }^{384}$ Boletín Interno Nro. 82, mayo de 1975.

${ }^{385}$ Sin embargo, seguía insistiendo que la célula partidaria "por excelencia" era la célula de masas ya que era el organismo encargado del trabajo político integral, a través del cual se difundían "las ideas revolucionarias, la línea del Partido entre los obreros de la fábrica" garantizando "su hegemonía política e ideológica." De este modo la célula sindical no debía superponerse con esta última sino, por el contrario, fortalecerla al liberarla de dicha tarea y permitirle una labor más eficiente al tener una mayor especialización de las tareas y un "mejor manejo de la actividad específica ("Organización y lucha de masas" El Combatiente Nro. 173, miércoles 2 de julio de 1975)

386 Fuentes como El Combatiente, Estrella Roja, boletines internos del PRT-ERP y de otras organizaciones que intervenían en las fábricas, boletines fabriles, etc.
} 
Con diferentes niveles de desarrollo, en la zona Sur logró insertarse en las fábricas Rigolleau (Berazategui) -donde cobró protagonismo a través de la Lista Naranja ${ }^{387}$-, en Saiar (Quilmes), Kolynos (Quilmes), Cervecería y Maltería Quilmes, Massuh (Quilmes), Alpargatas (Florencio Varela), Ferroductil (Florencio Varela), Peugeot (Berazategui), Tamet (Avellaneda) y Tenaris-SIAT (Avellaneda).

En Zona Oeste consiguió insertarse en las metalúrgicas Martín Amato (Lomas del Mirador), Santa Rosa (La Tablada), la Cantábrica (Morón), Valmarco S.A. (San Miguel), en las fábricas ROURA, Siam, Mancuso y Rossi, Adams, Mercedes Benz Argentina (Gonzales Catán), en Volkswagen, INSUD, Hilos Cadena (San Justo), Mosaístas, Yelmo (La Tablada) y Schcolnik (Villa Tesei).

Por su parte en zona Norte, contaba con militancia en la fábrica de embragues Eaton (José C. Paz), en la automotriz Ford (Pacheco), la autopartista Del Carlo (Beccar), en Fate Electrónica (Victoria), en las metalúrgicas TENSA y EMA (Vicente López), en Miluz y Alcántara (Vicente López), en Terrabusi (General Pacheco) y Matarazzo (Villa Adelina). También tenía trabajo con disímil nivel de inserción en Cerámica Lozadur (San Isidro), PANAM (Munro), Editorial Abril (Vicente Lopez), General Motors (San Martín), MIC (San Martín) y Wobron (General Pacheco) ${ }^{388}$.

El mapa de inserción presentado, da muestras de que la organización logró tener presencia en la mayoría de las fábricas más importantes de la región, lo que le permitió,

\footnotetext{
${ }^{387}$ La Lista Naranja fue un armado sindical compuesto por militantes del PRT-ERP, como núcleo central, el PST y Montoneros, además de varios activistas independientes En noviembre de 1974 ganó las elecciones de CIR y en marzo de 1975 fue intervenida generando un conflicto de importantes magnitudes (Centrurión, 2013)

388 Esta penetración en el Gran Buenos Aires se daba en el marco del desarrollo general de la organización en el movimiento obrero a nivel nacional. En Córdoba era una de las principales fuerzas sindicales y contaba con células en Perkins, Grandes Motores Diesel, Fiat Concord y Materfer, Thompson-Ramco e IKA Renault; un trabajo importante en Luz y Fuerza y en su comisión directiva; codirigía el gremio del calzado; contaba con presencia en los hospitales de la ciudad, en gremios como municipales, alimentación y docentes. También participaba activamente en la Federación de Obreros y Empleados de Correos y Telecomunicaciones (FOECyT), en Bancarios, en Obras Sanitarias, entre los trabajadores lecheros y de la construcción, y en el Sindicato del Caucho, del que participó de su fundación.

En Villa Constitución también se erigía como una de las organizaciones más importantes de la zona, con una presencia mayoritaria en la Comisión Directiva de la UOM y en los cuerpos de delegados de las fábricas Acindar, Metcon, Marathon y Vilber. Por su parte, en Rosario tenía fuerte presencia en la zona frigorífica (con militancia en Swift y Sugarosa), un trabajo muy importante en la fábrica de electrodomésticos Galizia y Bargut y en metalúrgicos (entre los que se destaca el trabajo político en las fábricas de tractores John Deere y Massey Ferguson). En Tucumán también se contaba con una fuerte organización tanto a nivel de ingenios azucareros como a nivel de dirección de la FOTIA, el Sindicato de Obreros y Empleados Vitivinícolas y Afines (SOEVA), y entre los trabajadores citrícolas.

Junto con pequeños y medianos trabajos en el resto de las provincias (fundamentalmente en Santiago del Estero, Jujuy, Mendoza, Neuquén, Salta, Chaco, Formosa, Santa Fe, Corrientes y Misiones), se completaba el mapa de inserción de la organización en el movimiento obrero.
} 
como se verá en la siguiente sección, jugar un papel relevante en las luchas sindicales del año 1975, especialmente en la conformación de las coordinadoras interfabriles ${ }^{389}$.

\subsection{La lucha sindical en el centro de la política perretista (1975)}

4.3.a. Las paritarias: el PRT-ERP ante la batalla por los aumentos

El año 1975 se iniciaba con un agravamiento de la situación económica y política. La crisis del sector externo ${ }^{390}$, la caída de las inversiones, la intensificación del desabastecimiento y la violación sistemática de los precios oficiales se sumaban a los rumores sobre la preparación de un golpe de estado. Ante esta situación el nuevo ministro de economía Gómez Morales había anunciado la aplicación de un programa económico de ajuste, aunque gradual, basado en la flexibilización de la política de precios, la compresión del déficit público, la reducción de la oferta monetaria y la realización de reajustes en la tasa de cambio. Por su parte el gobierno, presionado por las FFAA y la gran burguesía, aumentaba su ferocidad represiva contra las organizaciones revolucionarias y las luchas obreras, al tiempo que se mostraba poco proclive a los compromisos y negociaciones con la CGT, la cual reclamaba una mayor participación en las decisiones.

Durante el mes de enero, las luchas obreras se canalizaron a través de una ola de ausentismo que llegó a un $20 \%$ de la fuerza laboral ${ }^{391}$. El descontento de los trabajadores estaba fuertemente atado a la caída del poder adquisitivo ${ }^{392}$, por lo que las paritarias se transformaron en una instancia clave para recuperar derechos y salarios perdidos.

\footnotetext{
389 Pablo Pozzi (2001) y Héctor Löbbe (2009) coinciden en remarcar que los perretistas tuvieron un desarrollo solamente equiparable, aunque menor, al de las agrupaciones ligadas a Montoneros y el PCA. Por su parte Luis Mattini (2007), elevando la apuesta, indica que el PRT-ERP era la organización de izquierda que poseía mayor presencia orgánica en los sindicatos industriales del país.

${ }^{390}$ La caída de las exportaciones se había visto agravada por la disposición del Mercado Común Europeo de prohibir la importación de carne. Además la sobrevaluación del peso amplificaban los efectos de una coyuntura sumamente desfavorable (Torre, 2004; Werner y Aguirre, 2007)

${ }^{391}$ Esta era una nueva estrategia de lucha ante la legislación represiva y las posibilidades que brindaba la nueva ley de Contratos de Trabajo (sancionada en noviembre de 1974), que aseguraba estabilidad laboral y dificultaba los despidos en el sector privado.

${ }^{392}$ Entre noviembre de 1974 y febrero de 1975 había aumentado el costo de vida en un 26\% (la inflación sólo en el mes de enero había llegado al 8,5 \%) (Jelin, 1977; Torre, 2004). A la autorización de trasladar a los precios el aumento salarial concedido en noviembre se le sumaba un aumento generalizado de las tarifas de los servicios públicos en febrero.
} 
En ese contexto, la CGT se vio obligada a presionar para que el gobierno definiera el inicio de las negociaciones, que finalmente se convocaron para el 1 de marzo ${ }^{393}$.

El PRT-ERP tuvo claro desde principio de año que las paritarias serían una instancia clave para desatar el descontento contenido de los trabajadores. En ese marco volvía nuevamente a insistir en la unidad y coordinación de las diferentes luchas ${ }^{394}$, aunque esta vez, advertido por el fracaso de la Coordinadora Nacional, planteaba la necesidad de partir de un trabajo paciente en las bases y no tanto de los acuerdos entre organismos o dirigentes:

"Sin prisa desesperada, sin pausa, pero al ritmo de la lucha de clases se deberá ir construyendo pacientemente organismo tras organismo, acuerdo tras acuerdo en Frentes, Zonas, en Regionales para ir convergiendo naturalmente hacia un sólido frente antiburocrático capaz de disputar la dirección de la CGT a la burocracia, primero parcialmente luego totalmente. De no ser posible, por la fuerza de aparato de la misma, constituirse de hecho en la dirección del movimiento sindical." ${ }^{395}$

Para la organización las paritarias, a su vez, eran una oportunidad para hacerle sentir a la "burocracia sindical" la bronca e indignación que venían acumulando las masas ${ }^{396}$. En ese sentido los "lemas de trabajo" eran: 1. Mantenerse informados sobre la situación de las empresas y la evolución de la discusión paritaria; 2. Mantener informados a los trabajadores mediante la propaganda; 3. Movilizar constantemente a las bases; 4. Planificar correctamente las propuestas; 5. Acompañar la movilización con actividad agitativa y propagandística del partido y del ejército ${ }^{397}$.

El PRT-ERP pensaba que la cúpula de la CGT no iba a poder elaborar un proyecto homogéneo en todos los sectores fabriles, debido a la presión de las bases, por lo que en

\footnotetext{
393 El plazo para la firma de los nuevos acuerdos era de dos meses. Además, los líderes cegetistas convocaron a una asamblea general de sindicatos exigiendo un aumento salarial de emergencia, consiguiendo que en marzo se otorgue un aumento cercano al $20 \%$.

394 "Movilizarse por aumentos salariales" El Combatiente Nro. 151, miércoles 8 de enero de 1975

395“Acerca del Frente Antiimperialista Democrático y Patriótico" El Combatiente Nro. 151, miércoles 8 de enero de 1975

396 “A cerca de las paritarias” El Combatiente Nro. 152, miércoles 15 de enero de 1975.

397 "1. Informarse y mantenerse informado de todos los aspectos relacionados (planes de la burocracia, situación de las empresas y sus planes, evolución de la discusión paritaria, posibilidades y planes del campo clasista, etc.). En este y otros aspectos jugarán un rol fundamental los paritarios y asesores por lo que se debe estar en estrecho contacto con ellos.; 2. Llevar en forma inmediata toda la información posible a las masas, con volantes, folletos intervenciones orales, etc., para mantenerlas atentas a la evolución de las paritarias. En este sentido imprimir y distribuir masivamente los anteproyectos clasistas, sus puntos fundamentales, etc., etc.; 3. Arrebatar la iniciativa a la burocracia merced a la constante información y movilización de la base -asambleas, congreso de Delegados, manifestaciones, concentraciones, etc. poniendo las medidas activas equilibradamente, con decisión y madurez, con energía y reflexión.; 4. Planificar correctamente nuestras propuestas y planes de lucha para llevar el conflicto a la Victoria.; 5. Acompañar la lucha con una enérgica actividad agitativa y propagandística del Partido y del Ejército (volantes, intervenciones orales, banderas, pintadas, acciones, etc.) a cargo de las células de propaganda, agitación y militares.” Boletín Interno Nro. 78, marzo de 1975
} 
algunas ramas se mostraría dispuesta o interesada en exigir porcentajes "justos", mientras que en otras se subordinaría a las condiciones impuestas por los empresarios. Con esta lectura, exigía a sus militantes fabriles que hicieran un análisis preciso de esas diferencias (ya que ello les podía permitir levantar un pliego con reivindicaciones “ajustadas a la realidad") y que lucharan para que la elección de los delegados paritarios se hiciera en asambleas, garantizando un vínculo constante de ida y vuelta entre aquellos representantes y las bases obreras ${ }^{398}$.

Dejando atrás el prejuicio contra las "desviaciones sindicalistas", ahora se llamaba a "asir con firmeza el timón de la lucha económica, sindical, sin falsos prejuicios ni temores"399. Es que en los análisis del PRT-ERP, las paritarias podían convertirse en una "batalla de gran valor" en el marco de lo que se caracterizaba como la apertura de una "situación revolucionaria". Por eso es que las orientaciones sobre cómo intervenir en esta instancia fueron adquiriendo mayores precisiones y detalles. Su principal preocupación era encontrar un eje unitario que unificase la acción reivindicativa en todo el país sin distinción de gremios, regiones, tipos de trabajo, etc. Y ese eje fue el monto del aumento salarial que, según sus cálculos, debía ser del 100\%. La lucha por el incremento salarial tenía la virtud, a diferencia de la lucha por mejores condiciones de trabajo, que no variaba de fábrica en fábrica o de gremio en gremio. Además, advertían que la "burocracia sindical" llevaría adelante una serie de reivindicaciones de tipo laboral con el objetivo de postergar la discusión salarial, para que el monto lo estableciera por decreto el gobierno una vez vencida la fecha de negociación. En ese sentido poner en el centro la cuestión salarial ayudaba, además, a poner al descubierto la falsedad de la libertad paritaria que el gobierno decía garantizar.

Entre marzo y mayo, meses en los que se llevaron adelante las discusiones paritarias, la conflictividad obrera volvió a aumentar. Particularmente en el Gran Buenos Aires se sucedieron una serie de conflictos, de un espíritu marcadamente antiburocrático, que tuvieron como eje principal la cuestión salarial pero también otras reivindicaciones, como la reincorporación de despedidos y el rechazo a intervenciones de organismos sindicales ${ }^{400}$. Para el PRT-ERP este repunte en la conflictividad fabril eran los "nuevos retoños" que anticipaban una oleada incontenible de movilizaciones.

\footnotetext{
398 "Paritarias, una lucha que nos pertenece" El Combatiente Nro. 158, 12 de marzo de 1975 399 Ídem.

${ }^{400}$ Así, por ejemplo, en zona Sur se dieron conflictos en Rigolleau, Propulsora Siderúrgica, Astillero Rio Santiago, General Motors; en zona oeste en la planta de SanCor, La Cantábrica, Yelmo, Indiel y Noël; y en zona norte se registraron conflictos en las fábricas Lozadur, Cormasa, Del Carlo, La Hidrofila, Bisciu,
} 
En ese marco Villa Constitución volvió a transformarse en el epicentro de las luchas obreras. El 20 de marzo el gobierno dispuso la ocupación y el control de la ciudad por las fuerzas represivas, acusando que allí existía un "complot subersivo" en su contra ${ }^{401}$. Intervenido el sindicato y apresada toda su Comisión Directiva -excepto Luis Segovia, delegado de Marathon y militante perretista-, al día siguiente los obreros declararon la huelga de "brazos caídos" y ocuparon las plantas de las distintas fábricas metalúrgicas. Inmediatamente se conformó un Comité de Lucha -constituido por dos delegados por fábrica y presidido por Segovia- que funcionó como una dirección alternativa durante todo el conflicto ${ }^{402}$. La huelga duro un total de 61 días, en los que los trabajadores desarrollaron múltiples formas de lucha: la ocupación de las fábricas, la realización de actos y movilizaciones en la localidad, la formación de Comités Barriales ${ }^{403}$, etc. Sin embargo los niveles de represión desplegados y las dificultades para sostener una huelga tan prolongada, obligaron a los trabajadores a levantar la medida de fuerza, consumándose con ello una dura derrota para el movimiento clasista en general.

Junto al resto de las fuerzas políticas que formaban parte de la Lista Marrón (OCPO, PST, etc.) y la JTP, el PRT-ERP participó de lleno en el comité y durante todo el conflicto $^{404}$ ya que lo caracterizó como una de las cuatro "trincheras más avanzadas del

OTIS, Editorial Abril, Imperial Cord, Vicciu, Atma, Mic, Fate, Packard, etc. (Werner y Aguirre, 2007; Löbbe, 2009)

${ }^{401}$ Del operativo "Serpiente Roja" participaron fuerzas policiales, efectivos de la gendarmería, y tropas del escuadrón antisubversivo "Los Pumas". El PRT-ERP interpretó dicho movimiento como un golpe dirigido a sus regionales Norte-Norte y Rosario: “Las 'informaciones confidenciales' que el gobierno alega poseer se refieren fundamentalmente al desarrollo constante y armónico de nuestra organización en esas zonas vitales del país" ("Golpes desesperados", El Combatiente Nro. 160 del 26 de Marzo de 1975) Es de destacar que hacía 45 días el gobierno había lanzado el "Operativo Independencia" con el objetivo de aniquilar a la guerrilla rural instalada por la organización en los montes tucumanos en mayo de 1974 (Getselteris, 2015).

${ }^{402}$ Los ejes reivindicatorios que levanto el Comité de Lucha fueron: la liberación de los presos y la restitución del sindicato a los obreros. Al paro se sumaron todos los sindicatos de la localidad, entre ellos el gremio ferroviario, y también se plegaron los comerciantes de la zona. El Comité, además, publicaba varios boletines de huelga desde los cuales informaba a todos los trabajadores sobre la marcha de los acontecimientos, y organizaba equipos dedicados a la solidaridad, la propaganda y las guardias.

${ }^{403}$ Dichos Comités se encargaban de la recolección de víveres, la recaudación del apoyo financiero, la organización de la autodefensa de masas, garantizar la efectividad de los paros y la organización de los obreros, etc. Según Zenón Sanchez, obrero de Acindar y militante perretista, "la organización popular de villa tuvo todos los ingredientes de un Soviet. Con su auto defensa y un auto gobierno paralelo", (Comunicación virtual de Zenón Sanchez con el autor, 2017)

${ }^{404}$ El PRT-ERP contaba con células en la mayoría de las fábricas metalúrgicas de la localidad y contaba con un Comité Fabril en Acindar a través de las células que había logrado construir en las fábricas. Durante el conflicto intervino a través del Comité de Lucha, donde contaba con la figura principal de Luis Segovia -dirigente principal de dicho organismo-, y mediante una intensa actividad de propaganda armada en todo el territorio de Villa Constitución y zonas aledañas. (Entrevista con Zenón Sanchez con el autor, Rosario, 2017; "Villa Constitución: firmeza y determinación en la lucha" El Combatiente Nro. 162, lunes 7 de abril de 1975; “¡Villa Constitución firme en la lucha!” El Combatiente Nro. 163, lunes 14 de abril de 1975; "Villa: firmeza y unidad en la lucha" El Combatiente Nro.165, lunes 28 de abril de 1975; "Nueva victoria del pueblo en armas", Estrella Roja Nro. 51, lunes 31 de marzo de 1975; "En Villa sigue 
combate político-revolucionario" donde se comenzaban a dar "los primeros choques de una lucha por el poder" ${ }^{\natural 05}$. Desde su óptica allí se había comenzado a desarrollar gérmenes de "poder popular local" y, en ese sentido, el balance que hacían, a pesar de la derrota, era sumamente positivo. Es que según sus criterios los conflictos debían ser evaluados conforme al nivel de conciencia política alcanzada por los trabajadores durante la lucha y el rol que había jugado el partido en ello ${ }^{406}$; y en el caso de Villa Constitución consideraban que los obreros y la población habían acumulado una vasta experiencia de lucha y adquirido altos niveles de conciencia (traducidos, por ejemplo, en el surgimiento de nuevos "dirigentes de masas") y el partido había jugado un rol dirigente y sumado a nuevos obreros a sus filas. Además, enmarcado en un análisis más amplio, aquella lucha era una muestra de hasta donde podían llegar las movilizaciones obreras que se avecinarían y de cuál podía ser el rol del partido en ellas.

\section{3.b. E1 Rodrigazo y las Coordinadoras en la política perretista.}

La proliferación de este tipo de conflictos fue agudizando la crisis política y económica del gobierno. Una primera manifestación fue el fracaso de las paritarias y la renuncia del ministro de economía Gómez Morales ${ }^{407}$. En su reemplazo, el 2 de junio, asumió Celestino Rodrigo, quien planteó un plan de ajuste que, entre otras medidas ${ }^{408}$, supuso la paralización de las comisiones que debían discutir la readecuación de las escalas salariales. El gobierno había decidido no homologar las paritarias, y la negociación era reemplazada por la imposición de condiciones ${ }^{409}$.

el combate" Estrella Roja Nro. 52, miércoles 9 de abril de 1975; "El Combate de San Lorenzo" Estrella Roja Nro. 53, lunes 5 de mayo de 1975)

${ }^{405}$ Según la caracterización que hacía el PRT-ERP, las otras tres "trincheras" se ubicaban en el Ingenio Ledesma de Jujuy, en Tucumán y en Córdoba. ("Nítidas luchas político-revolucionarias" El Combatiente Nro. 162, lunes 7 de abril de 1975)

406 "Carácter político de la lucha sindical. La lucha reivindicativa y la lucha política", El Combatiente Nro. 155 del 17 de febrero de 1975.

${ }^{407}$ Durante todo el mes de mayo se sucedieron reuniones para llegar un acuerdo, hasta que se consensuó a una cifra cercana al 38\% de aumento salarial que, sin embargo, nunca se efectivizo porque superaba el techo planteado por el gobierno (de un 25\%) (Colom y Salomone, 1998; Torre, 2004: 108). Esta situación propició la renuncia del ministro el 31 de mayo.

408 Devaluación del $100 \%$, liberalización de las tasas de interés para los plazos fijos, aumento del $150 \%$ de los combustibles, aumentos en alimentos básicos, incremento del $50 \%$ en boletos de colectivos, etc.

409 El PRT-ERP, que ya había calificado como una "farsa" el acuerdo del 38\%, consideraba que con el "Plan Rodrigo" o "Rodrigazo" el gobierno buscaba sortear el "estado catastrófico" de la economía en base a un proyecto basado en la sobreexplotación de la clase obrera, la concentración monopólica y el reforzamiento de la dependencia ("Nuevo Ministro y vieja política reaccionaria" El Combatiente Nro. 171, miércoles 11 de junio de 1975; "Con el sello de la lucha proletaria" El Combatiente Nro. 172, miércoles 18 de junio.) 
Esta nueva situación motivó una intensa agitación en las plantas industriales de todo el país, con especial énfasis en Capital Federal y el Gran Buenos Aires, dando inicio a lo que posteriormente se dio a conocer como las "jornadas de junio y julio". En fábricas como Ford, General Motors, la autopartista Wobron, Eaton, Armetal, Terrabusi, entre otras, los trabajadores detuvieron la producción con paros parciales y asambleas por fábrica y sección, tomas y movilizaciones. Este tipo de medidas fueron impulsadas por distintos organismos de base, por fuera de la voluntad y el control de la cúpula cegetistas. Como indican Cotarelo y Fernandez (1998) y Löbbe (2006), en este primer momento las acciones se dieron por establecimiento y de manera aislada, aunque comenzó a darse una coordinación informal, "por abajo", entre los distintos establecimientos de las zonas. Ante este panorama, que se replicaba con fuerza en Córdoba y Santa Fe, el PRT-ERP planteó la "imperiosa necesidad de unir energías y desplegar esfuerzos organizativos para centralizarlas" a fin de confluir en una jornada de movilización y un paro nacional alrededor de tres puntos reivindicativos: "aumento de emergencia de 200.000 pesos y $100 \%$ de aumento paritario; contra las medidas económicas del gobierno; fuera el estado de sitio; por las libertades democráticas" ${ }^{\text {410 }}$. Nuevamente se destacaba que la ausencia de un organismo nacional que coordinara y organizara esas medidas ponía límites a esas luchas. Sin embargo se planteaba que las organizaciones sindicales existentes -como el Movimiento de Acción Sindical (impulsado por Tosco en Córdoba para esas fechas), el MSB, la JTP y la Intersindical-, sumado a los dirigentes sindicales reconocidos y a los sindicatos y organismos de base dirigidos por corrientes antiburocráticas, tenían las suficientes fuerzas como para impulsar medidas que canalizaran el estado de movilización reinante ${ }^{411}$.

Mientras tanto el Ministerio de Economía hizo una oferta salarial del 45\% que fue rechazada por la CGT, que reclamaba la libertad en las negociaciones (ley 14.250). Luego de una importante presión, el 15 de junio el gobierno resolvió reanudar las paritarias poniendo como fecha límite para los acuerdos el día 19 de ese mes. En esos 4 días las movilizaciones se intensificaron: el 16 de junio una columna de aproximadamente cinco mil trabajadores de la zona Norte, encabezada por los trabajadores de Ford $^{412}$, intentaron llegar a Plaza de Mayo pero fueron interceptados por

\footnotetext{
410 "Hacia una jornada nacional de movilización y lucha" El Combatiente Nro. 171, miércoles 11 de junio de 1975

411 Ídem.

${ }^{412}$ El motivo inmediato de la reacción de los obreros de Ford fue la denuncia de que la mayoría de los delegados paritarios habían recibido prebendas económicas de la patronal para negociar bajo los criterios
} 
la policía. Un día después, algo similar sucedió con los trabajadores de zona Sur quienes fueron frenados en el puente de acceso a la capital ubicado en Avellaneda (Löbbe, 2006:115).

En ese marco, las dirigencias sindicales cerraron acuerdos salariales que triplicaban el techo pretendido por el gobierno (160\% en promedio) quien se negó, nuevamente a homologar los acuerdos. Presionada por las bases, la CGT convocó a un paro y movilización para el 27 de junio: la masiva manifestación a Plaza de Mayo fue recibida por Isabel Perón con un provocativo aumento salarial fijo del 50\% (Torre, 2004: 113).

Desde la mirada perretista, los dirigentes de la CGT se hallaban en un callejón sin salida: para "conservar sus sillones", se veían obligados a rechazar las ofertas del gobierno y a "permitir" las movilizaciones de los trabajadores dando aire a las corrientes revolucionarias y a los trabajadores para que transformasen sus iniciativas en acciones contundentes de repudio contra el gobierno. Para el PRT-ERP estas circunstancias ponían al país en el "umbral de la situación revolucionaria", ya que inauguraban un nuevo período marcado por la oposición frontal de la clase obrera contra el gobierno, y por la "lucha abierta de camarillas" al interior del partido gobernante $^{413}$.

Esta confianza se afianzó al producirse un nuevo acontecimiento: la conformación de las Coordinadoras Interfabriles del Gran Buenos Aires ${ }^{414}$. Estos organismos funcionaron como aglutinadores y articuladores de seccionales de gremios, CIR, CD y Comités de Lucha dirigidos por las corrientes antiburocráticas, y buscaron organizar el descontento de las bases de manera centralizada y coordinada. Su objetivo no era constituirse como una central paralela a la CGT, sino por el contrario disputar su dirección imponiéndole un plan de lucha.

de esta última. La fábrica ya venía en proceso de asamblea permanente desde el 6 de junio en la que se exigían aumentos salariales del $100 \%$. En ellas se sucedieron repudios masivos a la conducción nacional de SMATA, enfrentamientos con "matones" sindicales y exigencias y presiones a los delegados oficialistas de la fábrica. ("Luis Pujals" Boletín Fabril de los obreros de Ford del PRT Nro. 10, 8 de junio de 1975; "Ford Presente! Obrera y Combatiente" El Combatiente Nro. 173, miércoles 3 de julio de 1975). 413 "Con el sello de la lucha proletaria" El Combatiente Nro. 172, miércoles 18 de junio de 1975; "El desenlace se aproxima" El Combatiente Nro.173, miércoles 2 de julio de 1973

${ }^{414}$ En base a una inscripción territorial se organizaban por zonas, por lo que se conformaron las coordinadoras de Capital Federal, Zona Norte, Zona Sur, y Zona Oeste que a su vez constituían la Coordinadora Metropolitana; aunque no formando parte de esta última, se creó también la Coordinadora de La Plata, Berisso y Ensenada, que a la postre tuvo importantes niveles de coordinación con la primera. 
La primera aparición pública de las flamantes Coordinadoras se dio el 28 de junio con su primer plenario ${ }^{415}$. En él se definió un programa que tenía como puntos centrales: realizar asambleas por lugar de trabajo y exigir asambleas generales a los gremios respectivos, un paro general a la CGT, aumentos salariales, defensa de la ley $14.250 \mathrm{y}$ la libertad de los presos políticos, gremiales y estudiantiles ${ }^{416}$.

En aquellos organismos participaron casi todas las corrientes políticas de izquierda, marxistas y peronistas -a excepción del PCA y el $\mathrm{PCR}^{417}$-, lo que le dio un gran poder de convocatoria e importantes niveles de representatividad. Según la bibliografía y los testimonios, la JTP fue la organización con mayor peso e influencia en las Coordinadoras, seguidas por el PRT-ERP y el PST y, en menor medida, el PB, VC, Política Obrera, el Grupo Obrero Revolucionario (GOR) y OCPO. Esta composición motivó sendos debates y polémicas sobre la orientación y características que debían tener aquellos organismos. La mayoría de las críticas apuntaron a Montoneros y, en menor medida, al PRT-ERP: así, por ejemplo, el PST criticaba a ambas organizaciones por imponer como eje de las Coordinadoras la denuncia a la "burocracia sindical", ya que consideraba que aquellas no debían apartarse de las dirigencias sino presionarlas hasta que finalmente se pusieran a la cabeza. Por otro lado el GOR criticaba la hegemonía de la JTP, por considerar que las ponía bajo una estrategia reformista de "unidad nacional". Coincidiendo con ello, Política Obrera denunciaba el carácter "procamporista" que imprimía la JTP y, al igual que el PST, alertaba sobre el riesgo de que quienes dirigían las llevaran al aisalmiento ${ }^{418}$. Por su parte el PRT-ERP, como veremos, identificaba a estos organismos como un paso fundamental en la unificación de las

\footnotetext{
${ }^{415}$ Según el informe de la propia Coordinadora, de su primer plenario participaron las CI de Propulsora, INDIEL, FAT Electrónica, Bonafide, ATE-Ciudadela (Junta Interna), Bancarios (once CI), UTA-Capital (participantes de 40 empresas), UTA-Zona Sur (participantes de 67 empresas), Productx, Propulsora Capital, Seguros, Noel, Molinos Eío de La Plata, SAIAR, ASTARSA, POLIMET, Rigolleau, Sempere y Cohen, Grafa, Plenario de delegados de la Asociación de Periodistas, Comisiones Directivas de Centro de Educadores de Florencio Varela, Educadores de Berazategui, Educadores de Morón. Delegados de Kaiser Aluminio, SIAP, Empleados de Comercio, Squibb, Morón Metales, Instituto de Jubilados, molinos Río de La Plata, Morixe, FOECIT, Jhon Whay, Ostrillón, La Razón(gráficos), Zanella, Milor y Hércules. (Boletín Nro. 2 Coordinadora de Gremios, Comisiones Internas y Cuerpos de Delegados en Lucha de Capital Federal y Gran Buenos Aires.)

416 Ídem.

${ }^{417}$ El PCA participó circunstancialmente de algunos plenarios a través de algunos activistas pero, en la práctica, no participo de las Coordinadoras ya que las consideraba contaminadas de posiciones sectarias y compuestas por tendencias poco representativas. Mientras tanto, el PCR que, como vimos ya estaba decididamente volcado a la defensa de Isabel, se opuso a las huelgas y a las coordinadoras (Löbbe, 2006; Werner y Aguirre, 2007)

${ }^{418}$ ("Un acuerdo, dos diferencias y una pregunta a la ultraizquierda" Avanzada Socialista Nro. 152, 12 de julio de 1975; "2do Plenario de la Coordinadora" Boletín de la Corriente Clasista Nro. 10, agosto 1975; "110 fábricas en el plenario de coordinadoras del Gran Buenos Aires" Política Obrera Nro. 238, viernes 1 de agosto de 1975”)
} 
luchas, mientras que Montoneros, que hacía caso omiso a las críticas, las consideraba como una herramienta clave para su estrategia que, para aquel momento, pasaba por fuera de las estructuras del movimiento peronista ${ }^{419}$.

Una de las primeras acciones importantes de las Coordinadoras fue la movilización del 30 de junio a la puerta de la CGT para reclamarle a la central que asumiera las reivindicaciones de los trabajadores e iniciara un plan de lucha. La concentración fue una muestra del estado de ebullición que vivían los contingentes obreros y las dificultades en las que se hallaba la cúpula sindical para controlar dicho movimiento. Este estado de movilización se mantuvo y encontró su pico el 3 de julio: ese día Lorenzo Miguel y Casildo Herreras, máximos dirigentes de la CGT, se reunieron con Raul Lastiri (presidente de la Cámara de Diputados) y Celestino Rodrigo buscando negociar la homologación de los convenios pactados, mientras que las bases obreras convocadas por las Coordinadoras se dispusieron a movilizar a la Plaza de Mayo.

Los obreros de Ford encabezaron nuevamente la columna de zona Norte junto a los de los astilleros de San Fernando y Tigre y los de las fábricas Terrabusi, Matarazzo, laboratorios Squibb, Alba, Editorial Abril, Fanacoa, Carrocerías El Detalle, IBM, TENSA, etc. Como vimos, el PRT-ERP había logrado una importante inserción entre los trabajadores de la zona y, fundamentalmente, el peso en dicha movilización se lo debió al trabajo político que había logrado desarrollar en Ford. Allí había conseguido “captar" militantes y organizar células, aunque la influencia principal la obtenía gracias al "Petiso" Kremer, militante perretista que, junto con "el Gordo" Nuñez (militante del PCA), era el principal dirigente de la fábrica ${ }^{420}$. Además acompañó la columna con dos escuadras del ERP, que estaban dispuestas a actuar en caso de que fuera necesario

\footnotetext{
${ }^{419}$ El Montonero, 18 de julio de 1975 En: Beschetti, 1999, pp.516 y 517. Para un análisis en profundidad de estas polémicas ver: Löbbe, 2006.

${ }^{420}$ Según Oscar "Topo" Gramajo, ex obrero de Ford incorporado al PRT-ERP por Kremer, para el momento del "Rodrigazo" era el dirigente principal de la fábrica ("Entrevista al 'Topo' Gramajo, a propósito de la toma de la Ford en 1985" Socialismo o Barbarie Nro. 455, 26 de enero de 2018.). Esto, a su vez, es confirmado por Eduardo Oroño, responsable político y sindical de la Regional Noroeste, Daniel de Santis, responsable sindical de la Regional Sur, y Mario Masolini, delegado independiente de las coordinadoras por la fábrica TENSA. Ellos coinciden en señalar que Kremer fue el principal dirigente tanto de Ford como de la Coordinadora de Gremios en Lucha Zona Norte. Por su parte, según Luis Mattini, el "Petiso" era un dirigente que había surgido "producto de las circunstancias" que se vivía en esos meses y que el PRT-ERP había logrado "enganchar" gracias al trabajo sistemático de Benito Urteaga sobre la fábrica (Entrevista a Eduardo Oroño con el autor, Buenos Aires, 2013; Entrevista a Daniel De Santis con el autor, La Plata, 2014; Entrevista a Luis Mattini con el autor, Buenos Aires, 2017; Entrevista a Mario Masolini con el autor, Los Polvorines, 2018.)
} 
(Löbbe, 2006; Werner y Aguirre, 2007). Sin embargo, al ser interceptados por la policía los trabajadores decidieron evitar el enfrentamiento y no continuaron con la marcha ${ }^{421}$. Otro tanto sucedió en las columnas que llegaban desde la zona Oeste y desde la zona Sur. En este último caso la movilización también fue interceptada por la policía en el puente Pueyrredón donde los manifestantes atravesaron los 300 ómnibus con los que viajaban e intentaron cruzar a pie por calles paralelas. Por su parte en La Plata, Berisso y Ensenada la Coordinadora local había convocado a una concentración en la sede regional de la CGT ubicada en el mismo local donde funcionaba la sede de la UOCRA. Los trabajadores encabezados por los obreros de Propulsora Siderúrgica y Astilleros Río Santiago, se movilizaron hasta el punto de encuentro donde se encontraba la conducción regional de la central sindical. El PRT-ERP también contó allí con comandos armados preparados para actuar ante cualquier imprevisto y con uno de los principales dirigentes de la movilización: Daniel De Santis, quien si bien para ese momento era ex obrero de Propulsora Siderúrgica, fue uno de los oradores centrales ${ }^{422}$. En este caso la concentración fue interrumpida por la represión generando importantes combates callejeros $^{423}$.

Luego de estas álgidas jornadas, la CGT nacional, sin demasiadas alternativas, anunció un paro sin movilización de 48 horas para los días 7 y 8 de julio. Finalmente, derrotado por las movilizaciones obreras, el gobierno decidió homologar los convenios y reabrir las negociaciones hasta el 25 de julio para aquellos gremios que todavía no lo habían hecho. A su vez, el 11 de julio renunciaron los ministros del interior y de educación

\footnotetext{
${ }^{421}$ En la versión del PRT-ERP tal decisión había sido fruto de la posición de la JTP y el PC: "Pero no faltaron los populistas y reformistas que mojaron la pólvora, llevando al desánimo y la confusión a la gente, cuando ésta podría haber hecho retroceder la represión por lo menos hasta el centro de la Capital completando una necesaria experiencia callejera." ("Mantener la ofensiva de masas" El Combatiente Nro. 174, miércoles 9 de julio de 1975)

${ }^{422}$ En la concentración, De Santis propuso exigirles a los dirigentes reunidos en la sede cegetista que formaran una comisión única con miembros de la central y delegados de la movilización para resolver un plan de acción (De Santis, 2005; Anguita y Caparros, 2006; Werner y Aguirre, 2009)

${ }^{423}$ Ello se ve en la crónica de los hechos relatada en las páginas de El Combatiente: "Mientras tanto, al sur, acaudillados por los combativos obreros de Propulsora y Astillero, el grueso del proletariado industrial de Ensenada marchó sobre la Capital de la Provincia de Bs. As. donde se les sumó el resto de los trabajadores de La Plata. Luego de varios enfrentamientos exitosos con la represión, se concentraron frente al local de la CGT regional, pidiendo la cabeza de los dirigentes de la misma y declarando la huelga general contra las medidas del gobierno. Sorpresivamente fueron atacados de todos lados con gases lacrimógenos y vomitivos, arrojados incluso de helicópteros. Luego de la natural dispersión, se reagruparon dando muestras de buena organización, produciendo toda una serie de enfrentamientos con la represión que en ese momento empezó a usar armas de fuego. Así el proletariado del sur del Gran Buenos Aires demostró su inquebrantable decisión de lucha enfrentando valientemente al malón policial, acumulando experiencia para nuevos enfrentamientos (...)" ("Mantener la ofensiva de masas" El Combatiente Nro. 174, miércoles 9 de julio de 1975)
} 
Alberto Rocamora y Oscar Ivanissevich, y ocho días después lo harían López Rega y Celestino Rodrigo.

El impacto de la crisis gubernamental, los altos niveles de movilización que había mostrado la clase obrera y la participación que había logrado la militancia fabril perretista en las jornadas, repercutía fuertemente en los análisis de la organización: “Al cierre de esta edición acaba de renunciar el gabinete en pleno, la CGT está totalmente rebasada por las bases; el gobierno se ha aislado. El plan económico de Rodrigo fue hecho trizas por la lucha de las masas (...)"424. Como vimos, el PRT-ERP había logrado una considerable representatividad gracias a los niveles de inserción fabril alcanzados para ese entonces y por haber contado con algunos dirigentes sindicales de establecimientos que fueron claves en las movilizaciones ${ }^{425}$.

\section{3.c. Unir todas las luchas y todos los sectores contra el "enemigo principal"}

Las jornadas de junio y junio significaron una crisis terminal para el gobierno que se hundió en una creciente fragmentación interna, enfrentamientos y frecuentes recambios en su plantel ${ }^{426}$. Por su parte, la CGT, que ganó peso en el gobierno luego de las movilizaciones, llevó como representantes suyos a Antonio Cafiero a la cartera de economía y a Carlos Rucauf a la de trabajo.

En este contexto, el PRT-ERP consideraba que estaban abiertas las posibilidades para luchar por la "democratización”. Desde su óptica se trataba de una situación extraordinaria y transitoria caracterizada por un gobierno sumamente débil y unas FFAA que, desprestigiadas y en estado de deliberación, aun no podían hacerse cargo de la situación: el "desquiciamiento" de la economía ${ }^{427}$, la acefalía política que vivía el país y los altos niveles de movilización, configuraban un momento propicio para "revisar las bases jurídicas" en que se asentaba el sistema político y económico. En respuesta a esa situación el PRT-ERP exigía la realización de una Asamblea Constituyente Libre y

\footnotetext{
424 Ídem

${ }^{425}$ Por ejemplo: Luis Angellini (Rigolleau), "Petiso" Kremer (Ford), Emilio Tomasín (Martín Amato) quien se habría incorporado en esos momentos-, Daniel De Santis (Propulsora Siderúrgica) y Hugo Crosatto (Mercedes Benz).

${ }^{426}$ Así, por ejemplo, en la cartera de economía el reemplazante de Rodrigo, Pedro José Bonanni, no llegó siquiera a formular sus planes (basado en una tregua de precios y salarios) que se vio obligado a presentar la renuncia. Por otro lado, en la cámara de diputados se destituyó a Raul Lastiri de la presidencia y en el senado se bloqueó la ley de acefalía que había presentado el Ejecutivo para permitir la sucesión presidencial a cualquier miembro del gabinete, designándose a Ítalo Luder como presidente de la cámara (De Riz, 1981: 188).

427 Se estaba viviendo una recesión económica cuyas principales manifestaciones eran: un aumento elevado del desempleo y de la inflación y una caída de la producción industrial que llego al 5,6\% en el tercer cuarto del año y al 8,9\% en sus últimos tres meses (Torre, 2004: 120).
} 
Soberana. Desde su mirada, esta era la única "posición proletaria" posible ante la coyuntura, ya que propiciaba la participación directa de la clase obrera y de los sectores populares en la resolución de las crisis ${ }^{428}$. En paralelo, insistía sobre la necesidad de construir el Frente Democrático y Patriótico, ahora basado en el siguiente programa: 1libertad de todos los presos políticos; 2- derogación de la legislación represiva; 3eliminación del terrorismo de derecha y 4- congelamiento del costo de vida y aumentos dignos de salarios establecidos por convenciones paritarias. Con ese plan, consideraba la posibilidad de "alianzas tácticas" con algunos sectores políticos de la burguesía y de la burocracia sindical, debido a que la lucha debía concentrarse contra "el enemigo principal": la burguesía reaccionaria y el imperialismo ${ }^{429}$.

Este criterio, evidentemente, tenía efectos sobre la línea sindical: aunque coyunturalmente, la "burocracia sindical" pasaba a ser considerada como "enemigo secundario frente al enemigo principal" ${ }^{430}$. Es que, según los perretistas, una parte de ella no sólo se estaba viendo obligada a encabezar las luchas reivindicativas para garantizar sus "intereses particulares", sino que el plan de emergencia económica que

\footnotetext{
${ }^{428}$ Las demás organizaciones también ensayaron su propia respuesta: el PCA propuso una coalición cívico-militar (Fernández Hellmund, 2012), mientras que Montoneros exigía la renuncia de Isabel y la convocatoria a elecciones. Por su parte el PST también exigía la renuncia de Isabel pero planteaba la asunción de un gobierno de transición con un presidente de la "rama gremial" del parlamento, es decir de la CGT, que una vez asumido convocara a una Asamblea Constituyente ("La posición del PST" y "Una polémica en la vanguardia obrera", Avanzada Socialista Nro. 174, 8 de agosto de 1975). La OCPO, con una posición similar a la de Montoneros, exigía la renuncia de Isabel y la convocatoria a elecciones en tres meses, planteando que el gobierno quede provisoriamente en el congreso (El Obrero Nro. 13, julio de 1975). El PRT-ERP criticaba a cada una de estas propuestas por considerarlas "liberal-burguesas", ya que buscaban restringir la deliberación a las fuerzas del sistema (partidos políticos legales, burocracia sindical y FFAA). A diferencia de ellas, la Asamblea Constituyente permitiría plantear a las masas obreras y populares la "solución democrática y socialista" a los diferentes problemas del país como la dependencia económica, política, cultural y militar, el estancamiento económico, la desocupación, la falta de vivienda, etc. Sin embargo, más allá de ello, planteaba que debía remarcarse las coincidencias entre todas las propuestas y bregar "sin sectarismos" por la unidad de todos los sectores. ("Ante las posibilidades democráticas: forjar y fortalecer la unidad" El Combatiente Nro. 174, lunes 21 de julio de 1975; "Asamblea constituyente Libre y Soberana"; El Combatiente Nro. 175, miércoles 30 de julio de 1975)

${ }^{429}$ La organización preveía que, ante el derrumbe del gobierno y la falta de condiciones para una intervención golpista, algunos sectores "vacilantes e incluso contrarrevolucionarios" de la burguesía se verían obligados a aceptar una democratización, por lo que se abría la posibilidad de formar un amplio frente democrático dirigido por un frente obrero y popular (del estilo FAS) que se constituyera en su núcleo. A su vez, para darle peso a la propuesta, la organización ofrecía una tregua militar si se derogaba la legislación represiva y se liberaba a los presos políticos. ("Ante las posibilidades democráticas: forjar y fortalecer la unidad" El Combatiente Nro. 174, lunes 21 de julio de 1975; "Movilización democrática y reivindicativa", El Combatiente Nro. 175, miércoles 30 de julio de 1975; "Abrir el camino de la democracia y la libertad" El Combatiente Nro. 177, miércoles 6 de agosto de 1975)

430 "Movilización democrática y reivindicativa", El Combatiente Nro. 175, miércoles 30 de julio de 1975; "Movilización reivindicativa: importancia y características actuales", El Combatiente Nro. 178, miércoles 13 de agosto de 1975
} 
levantaba era de "indiscutible validez" -e incluso debía ser agitado como bandera en cada asamblea, sindicato y organización de masas exigiendo su puesta en marcha ${ }^{431}$. La nueva orientación no era fácil de digerir para la militancia fabril perretista, lo cual se deja entrever en la exhortación de la dirección a los militantes para que se adecuaran a ella:

"Es necesario que todos los compañeros dedicados a la actividad sindical reflexionemos seriamente sobre la situación actual, estudiando profundamente las resoluciones del ultimo C.C y las orientaciones de la Dirección Nacional, ya que podemos observar rasgos de esquematismo cuando se aborda el tema, o cierto grado de duda o escepticismo ante la caracterización que hace el Partido en la coyuntura sobre el carácter secundario de la burocracia como enemigo. Más aún, cuando insistimos que ella, o por lo menos parte de ella, pasa a ser una fuerza a la cual una política justa por nuestra parte la puede obligar a dar pasos que benefician los intereses de los trabajadores, como lo demuestra el reciente plan de la CGT"432

La organización justificaba dicha orientación remarcando que no significaba tirar por la borda la lucha antiburocrática, sino que, por el contrario, esta debía fortalecerse, y que las corrientes combativas debían tener la iniciativa y evitar el reacomodamiento de los "falsos dirigentes traidores y desprestigiados"433. De ese modo se llamaba a la militancia a fortalecer las Coordinadoras Interfabriles y al MSB. Como se vio en el capítulo anterior, durante este período, la organización reclamó a los responsables sindicales que actuasen rápidamente para revitalizar al MSB y, a través de éste, intervenir en las Coordinadoras Interfabriles. Estas últimas eran consideradas como "el eje de la actividad sindical" del momento ya que, mediante ellas, se podía organizar a las bases y disputarle la conducción del movimiento obrero a la cúpula cegetista. Por ello diseño un plan para intervenir en aquellos organismos basado en los siguientes puntos:

“a) Ligarse estrechamente a las zonas y sub-zonas; b) Darles dinamismo y organizar las tareas; c) Levantar el plan de la CGT; d) Plantear la realización de plenarios zonales; e) Trabajado en los mismos para un plenario provincial; f) Plantear y organizar la intervención popular en los problemas de despidos; g) Organizar comisiones de defensa de las fuentes de trabajo y el nivel de vida, que interesen a los demás sectores populares y además tomen los problemas de los mismos (luz, impuestos, etc.)",434

\footnotetext{
431 El plan de la CGT comprendía reivindicaciones como la congelación de precios y de despidos, la reincorporación de cesantes y el reconocimiento de los salarios ganados en las paritarias.

432 Boletín Interno Nro. 85- 29 de Agosto de 1975

433 "Organizar nacionalmente la resistencia a los despidos y la superexplotación”, El Combatiente Nro. 182, miércoles 10 de septiembre de 1975

${ }^{434}$ Boletín Interno Nro. 85- 29 de Agosto de 1975
} 
Al mismo tiempo, debía descartarse todo espíritu o actitud que llevara a una "lucha por la hegemonía ficticia" en las Coordinadoras. A la luz de los errores que se habían cometido en experiencias como las del MSB, insistía que la dirección política del espacio la conseguiría quienes tuviesen "la línea política justa", es decir aquellos que lograsen resultados tangibles medidos en capacidad de movilizar, organizar y hacer participar al pueblo en la lucha ${ }^{435}$. Como vimos, se partía de la idea de que la fábrica (y en este caso a las Coordinadoras) eran centros desde los cuales se debía organizar al resto de la población, impulsando distintos tipos de espacios que las conectasen con diferentes sectores sociales, tales como juntas de vecinos, centros de comercio, centros de educadores, organizaciones estudiantiles, etc. Como se ve, el auge que había adquirido la lucha sindical llevó a que la organización le diera una centralidad de orden estratégico:

"si a veces la relación entre la lucha sindical y la política es conveniente y necesaria debido al 'techo de la lucha económica' en situaciones como éstas se transforma en una NECESIDAD IMPRESCINDIBLE, sin la cual todo intento de resolver los conflictos actuales por suspensiones y despidos estará condenado al fracaso antes de empezar (...) La táctica adecuada: el arte de lo concreto: El eje general de trabajo entonces, es en este momento organizar y movilizar uniendo indisolublemente la lucha sindical con la democrática" ${ }^{336}$

Y es que las luchas reivindicativas, aunque fragmentadas y en muchos casos defensivas, habían continuado desarrollándose luego de las jornadas de junio y julio, siendo el principal factor de movilización (Jelin, 1977). De este modo la organización agudizó sus análisis y propuestas en lo sindical y estableció tres consignas con las cuales los militantes debían organizar y motorizar la movilización al interior de los establecimientos: 1. Defensa de las fuentes de trabajo (contra los despidos); 2. Aumentos salariales de emergencia (por el costo de la vida); y 3. Resistencia a los intentos de superexplotación (contra la intimidación patronal). A su vez, estas consignas debían bajarse a la práctica en líneas de intervención concretas. Así, por ejemplo, en la lucha contra los despidos la respuesta no debía ser la misma en todos los casos: si se trataba de una empresa monopólica, la organización recomendaba hacer girar la movilización en torno a la expropiación sin pago por parte del Estado, estableciendo una administración obrero-estatal; mientras que en los casos de pequeñas y medianas empresas, la defensa de los puestos de trabajo debía garantizarse exigiendo al gobierno

\footnotetext{
435 Ídem.

436 "Organizar nacionalmente la resistencia a los despidos y la superexplotación”, El Combatiente Nro. 182, miércoles 10 de septiembre de 1975
} 
que otorgase créditos y facilidades para reactivar la producción. Además se recomendaba ser cuidadoso a la hora de "agitar masivamente el problema" para no contribuir a acrecentar el miedo de los trabajadores a ser despedido.

Respecto a la lucha contra la superexplotación (contracara de los despidos), la respuesta era un tanto más compleja, ya que, en muchos casos, los trabajadores la aceptaban a través de premios por productividad, horas extras, etc. De este modo, los militantes tenían primero la tarea de explicar y convencer sobre la injusticia que acarreaban esos métodos, y después organizar la resistencia en la práctica. Este último aspecto podía variar según las particularidades de cada fábrica, aunque a grandes rasgos suponía: la formación de comisiones de control para fiscalizar que se trabajase de acuerdo al convenio (para ello proponían la edición masiva de convenios para repartirle a cada uno de los obreros); la organización de la represión contra jefes, capataces, supervisores y "tomatiempos" ("abucheos", "fierrazos contra los cronometristas", etc); quites de colaboración; paros parciales; y la coordinación con otras fábricas para organizar el boicot al aumento de productividad ${ }^{437}$.

No obstante, la política económica impulsada por el Ministro Cafiero (indexación de los salarios y los precios), permitió evitar mayores tensiones y si bien la conflictividad obrera siguió desarrollándose, se fue dando de manera fragmentada (Jelin, 1977; Torre, 2004). Este cuadro fue leído por el PRT-ERP como un "aquietamiento de la lucha reivindicativa", explicado fundamentalmente por el hecho de que las luchas obreras no habían logrado unificarse con la lucha democrática (Asamblea Constituyente). En su lectura ello había generado una "relativa calma para las fuerzas enemigas" y habilitado una nueva escalada represiva ${ }^{438}$. De hecho el gobierno, bajo la idea de combatir la "guerrilla fabril", venía profundizando la intervención "legal" de las fuerzas de seguridad y dando vía libre a la Triple A, la cual intensificó sus ataques hacia el activismo fabril (Franco, 2012). En esta situación la organización continuó planteando que debía apuntalarse la lucha por la actualización de los salarios y por la defensa de los puestos de trabajo y que, a la vez, debían formarse grupos de autodefensa al interior de los establecimientos para responder a posibles ataques. En paralelo, siguió insistiendo

\footnotetext{
437 "La lucha contra la superexplotación. Métodos y Tiempos", El Combatiente Nro.174, miércoles 9 de julio de 1975; "Movilización reivindicativa: importancia y características actuales", El Combatiente Nro. 178, miércoles 13 de agosto de 1975; "Organizar nacionalmente la resistencia a los despidos y la superexplotación", El Combatiente Nro. 182, miércoles 10 de septiembre de 1975; "Resistir la intimidación patronal" El Combatiente Nro. 183, miércoles 17 de septiembre de 1975

438 "Giro represivo del gobierno" El Combatiente Nro. 184, miércoles 24 de septiembre de 1975; "Porque no se ha concretado la democratización”, Boletín Interno Nro. 87, 25 de septiembre de 1975.
} 
con la intensificación del accionar guerrillero para obligar al "enemigo" a ceder concesiones democráticas.

Algunos sucesos de esos meses -posteriores a julio- parecían confirmar el camino de estas orientaciones: en Córdoba la movilización obrera, de la cual era partícipe y dirigente el PRT-ERP, logró hacer retroceder momentáneamente la represión al forzar la renuncia del interventor Raúl Lacabanne el 16 de septiembre y, como indica Pablo Pozzi (2004), un factor decisivo en aquellos hechos había sido el ataque que la Compañía "Decididos de Córdoba" del ERP había realizado a la División de Informaciones de la Policía, alojada en el centro de la ciudad mediterránea. Por su parte, en Buenos Aires, pese a la disminución de las luchas obrera, la organización continuaba confiando en que la movilización volvería a repuntar y extenderse de la mano de los reclamos sindicales ${ }^{439}$. En ese sentido, el estallido de nuevos conflictos en la industria metalúrgica y automotriz a fines de septiembre era un indicio de que se estaban dando las condiciones para una nueva oleada de movilizaciones.

Finalmente en el mes de octubre hubo un pico de conflictos motivados centralmente por la demora de pagos adeudados, nuevas demandas salariales y disputas intersindicales ${ }^{440}$. La lucha en la mina de Sierra Grande (Rio Negro) y en las automotrices FIAT y Mercedes Benz, fueron las más destacadas ya que supusieron ocupaciones de establecimientos y huelgas de larga duración, que activaron nuevamente a las Coordinadoras y terminaron en victoria para los trabajadores. Estas contiendas, junto a otras (Chrysler, General Motors, Ford, etc.), entusiasmaron nuevamente al PRT-ERP que llamaba a emular las movilizaciones de julio:

"La lucha por los aumentos salariales será en las próximas semanas la bandera que agitara y movilizará a las masas. Nuestro Partido vuelca desde ya todos sus esfuerzos poniéndose en primera fila en la justa lucha de la clase obrera y el pueblo por los aumentos salariales. Debemos unir, coordinar y organizar cada lucha. Impulsar asambleas, actos marchas, paros que desnuden las intenciones de los explotadores, que hagan ver la necesidad de unir, organizar y movilizar las fuerzas de los trabajadores, por las justas conquistas, impulsar la solidaridad con las fábricas en lucha, organizar ollas populares, colectas para ayudar a los compañeros como en el caso de Mercedes Benz o Sierra Grande que ya llevan varios días de conflictos. Avanzar en la coordinación de las fábricas en lucha y en la unidad de todas las corrientes combativas, obligar a los dirigentes sindicales que

\footnotetext{
${ }^{439}$ A mediados de septiembre los perretistas vaticinaban que octubre y noviembre serían meses calientes en los que se intensificarían las luchas obreras debido a que preveían otra brusca caída de la actividad económica ("La aventura de los reaccionarios será desbaratada" El Combatiente Nro. 183, miércoles 17 de septiembre de 1975.)

${ }^{440}$ A inicios de mes desde el Ministerio de Economía se había propuesto una "tregua" entre la CGT, la CGE y el gobierno que suponía la congelación de precios y la suspensión de los aumentos y reajustes salariales, y prohibía las huelgas por 180 días. Esto a fin de mes intentó ser formalizado a través de la creación del Instituto Nacional de Remuneraciones, Productividad y Participación que buscaba aplicar una política de indexación de salarios (Torre, 2004)
} 
asuman el papel para el que se los ha elegido, exigiéndoles que renuncien a la concertación y se pongan al frente de la lucha por los salarios, contra el alza del costo de vida y por la defensa de las fuentes de trabajo." ${ }^{441}$

Durante los meses de noviembre y diciembre siguieron desarrollándose los conflictos por cuestiones salariales, aunque comenzaron a predominar las protestas contra el aumento de la represión al activismo ${ }^{442}$. Sin embargo el PRT-ERP consideraba que se estaba viviendo un nuevo auge de las luchas reivindicativas que se extendería a lo largo de los meses (e incluso de los años) producto de la irreversibilidad de la crisis económica $^{443}$. Esto permite pensar que no se advertía que se trataba de conflictos con un claro corte defensivo, sin perspectivas de confluir en movilizaciones de conjunto, sin un eje político que los unificara y sin interpelar al resto de la población.

Una gran parte de la bibliografía ha analizado este fenómeno como expresión del "aislamiento" político, del proceso de "militarización" o de la "lucha de aparatos" en los que se habría hallado inscripto la organización. Sin embargo, como vimos, ni la organización actuaba de manera solitaria ni se trataba de una coyuntura de franca desmovilización, sino que, aunque defensivamente, la movilización obrera continuaba desarrollándose $\mathrm{y}$, además, con amplios sectores politizados y radicalizados. El problema, desde nuestro punto de vista, estaba en que, al igual que en todo el período, la organización tendió analizar la situación política en base a los niveles de conciencia y al "estado de ánimo" de ese último sector, lo que le hizo perder de vista que el resto de la clase obrera aún no se sentía convocada por una salida revolucionaria y que el resto del pueblo no venía acompañando a las movilizaciones obreras.

Como se verá a continuación estos análisis se sostuvieron durante los primeros meses de 1976, incluso una vez consumado el golpe militar, dejándola expuesta a los efectos de la represión.

\subsection{El camino hacia el golpe}

\footnotetext{
441 "Movilicemos contra la nueva trampa del gobierno" El Combatiente Nro. 189, miércoles 29 de octubre de 1975

${ }^{442}$ Como remarca Jelin (1977), para ese momento el 12\% de las protestas fueron contra los secuestros, asesinatos y otros actos de violencia política.

443 "En el curso de los de los últimos meses, las huelgas y paros obreros han alcanzado uno de los picos más altos (...)Mecánicos, portuarios, ferroviarios, metalúrgicos, mineros, petroleros, textiles, para no citar más que a algunos gremios, junto a empleados estatales, mercantiles y otros trabajadores no proletarios, están protagonizando vibrantes combates por la elevación de los salarios, la reincorporación de despidos, la libertad de presos políticos y el mejoramiento de las condiciones laborales." ("Ante un nuevo auge de las luchas obreras y populares" El Combatiente Nro. 195, miércoles 10 de diciembre de 1975)
} 
La amenaza de un golpe de estado fue una constante durante todo el año 1975. La relación entre el gobierno y las FFAA llegó a un punto crítico en agosto, con el intento fallido de designar al coronel Damasco en el Ministerio del Interior. Ante el anuncio, la cúpula castrense, que no tenía la intención de sostener al gobierno en plena crisis, obligó a este último a renunciar. Este episodio profundizaba la crisis del gobierno y aumentaba el poder político de las FFAA y su injerencia en los asuntos internos.

El PRT-ERP, lejos de optar por la defensa del gobierno ante el avance militar, como lo hacía por ejemplo el PCR, insistía en que la mejor forma de enfrentar la amenaza del golpe pasaba por construir una salida política convocando a un Frente Democrático y Patriótico y a la Asamblea Constituyente y, al mismo tiempo, intensificando la lucha guerrillera para hacer retroceder a las FFAA ${ }^{444}$. En esa dirección, el 23 de diciembre de 1975, llevó adelante la acción político-militar más audaz de la guerrilla argentina: el asalto al Batallón de Arsenales 601 de Monte Chingolo. El objetivo militar de la acción era la apropiación de un arsenal cercano a las 20 toneladas de armas y municiones, mientras que el objetivo político era mostrar al ERP como una opción de poder ante el pueblo, retomar la ofensiva ante los golpes que venía recibiendo la guerrilla y poner a los militares a la defensiva retrasando los planes golpistas. Pero, delatada por un infiltrado del ejército en el aparato logístico del ERP, la acción fracasó y se transformó en la derrota política y militar más grave que sufrió la organización ${ }^{445}$.

Al igual que en el caso de Azul, la acción cosechó críticas de gran parte del espectro político. Así, por ejemplo, organizaciones como el PCA o el PST insistieron en sus críticas tradicionales y caracterizaron a la acción como una provocación que alentaba la furia represiva ${ }^{446}$. Montoneros esta vez no criticó la disposición a enfrentar militarmente a las FFAA, pero si cuestionó la concepción táctico-estratégica desde la cual los perretistas pensaron el ataque. Desde su punto de vista, el problema radicaba en la incomprensión de que se estaba en una etapa de "defensiva estratégica", por lo que no se podían arriesgar las fuerzas propias en una "batalla decisiva" contra el conjunto de

\footnotetext{
444 "La situación actual y nuestras tareas" El Combatiente Nro. 193, miércoles 26 de noviembre de 1975; "La barbarie militar será derrotada" El Combatiente Nro. 19, miércoles 10 de diciembre de 1975

${ }^{445} \mathrm{La}$ acción dejó un saldo humano de 53 guerrilleros muertos entre caídos en combate y detenidos desaparecidos. Para un análisis pormenorizado de la acción ver: Plis-Sterenberg, 2006

${ }^{446}$ El PST calificó la acción como una provocación que brindaba pretextos al gobierno y las FFAA para la represión contra el movimiento obrero y popular, comparándolo con la intentona de golpe de estado dirigido por un sector de la Fuerza Aérea ("Morón y Monte Chingolo", Avanzada Socialista Nro. 177, 30 de diciembre de 1975). Mientras tanto el PCA acusó al PRT-ERP de mandar a jóvenes al matadero y acercó su solidaridad al Ejército mediante dos de sus concejales que se acercaron al Batallón (Nuestra Palabra Nro. 128, enero de 1976).
} 
las "fuerzas enemigas". En ese sentido consideraban que la derrota era militar y política en tanto había significado una pérdida importante de militantes y recursos y, sobre todo, había resentido la confianza de las masas en la capacidad de derrotar militarmente a las FFAA.

Por su parte, el PRT-ERP no reconoció la derrota política: insistió en la idea de que la acción había servido como una demostración "nacional e internacional" de que en Argentina había un pueblo en armas, y de la capacidad operativa del ERP para dirigirlo $^{447}$. Siguió sosteniendo que ese tipo de acciones forzarían a las FFAA a retraerse y otorgar concesiones políticas, al mismo tiempo que potenciarían la movilización popular aumentando sus perspectivas de éxito ${ }^{448}$. La obstinada confianza en las fuerzas propias, impedía ver que, en este caso, los efectos no habían sido los buscados.

Sin embargo, al mismo tiempo, el PRT-ERP admitía que los golpes sufridos por las organizaciones revolucionarias en el mes de diciembre ${ }^{449}$ y la ausencia de una "centro" que coordinara y canalizara las distintas manifestaciones parciales que se estaban sucediendo, habían fortalecido las posibilidades golpistas ${ }^{450}$. Pero, aun así, seguían caracterizando que había una situación de ofensiva revolucionaria debido a la proliferación de huelgas y conflictos en todo el país y de que las unidades guerrilleras seguían actuando y desarrollándose pese a la represión ${ }^{451}$. Estas expectativas se renovarían en los días previos al golpe ante una nueva ola de movilizaciones.

A comienzos de 1976 las causas que habían provocado las movilizaciones de 1975 persistían y se agudizaban ${ }^{452}$. En el mes de febrero se sucedieron una serie de recambios

\footnotetext{
${ }^{447}$ Boletín Interno Nro. 98, 27 de diciembre de 1975

448 “La Lucha Armada y la Democratización” El Combatiente Nro. 196, miércoles 7 de enero de 1976

449 En el mes de diciembre, además de la derrota de Monte Chingolo, la organización había sufrido la detención de Juan Eliseo Ledesma, miembro del Buró Político de la organización y Jefe del Estado Mayor del ERP. Además, por su parte, la organización Montoneros también había sufrido la detención de Roberto Quieto, uno de sus principales dirigentes.

${ }^{450}$ Boletín Interno Nro. 106, 27 de febrero de 1976. Un mes después continuaba remarcando la imperiosa necesidad de construir un organismo centralizador y llamaba a re-editar la Coordinadora Nacional impulsada en 1974: "En lo que se refiere a la movilización, cada día es más evidente que las generosas energías que las masas despliegan en su lucha, requiere imperiosamente una centralización a nivel nacional, es decir, un centro que unifique y organice a nivel nacional las luchas que hasta el presente se desarrollan regional o zonalmente. El camino más indicado para lograrlo es reeditar la experiencia realizada en septiembre de 1974 cuando se convocó en Tucumán un plenario nacional de gremios en lucha, formándose una Coordinadora Nacional de Lucha Sindical. (...) un centro coordinador que permitiría aprovechar en todas sus posibilidades las energías desplegadas por las masas canalizándolas hacia la realización de un paro nacional." ("Intensificar la lucha. Centralizar la dirección” El Combatiente Nro. 209, miércoles 24 de marzo de 1976)

451 "1976: un presente de lucha” El Combatiente Nro. 198, miércoles 7 de enero de 1976

${ }^{452} \mathrm{La}$ economía no daba indicios de una posible recuperación sino que por el contrario estaba entrando en un estado de quiebra por causa de la caída de los principales rubros de la producción, una inflación
} 
en ministerios claves (economía, trabajo, justicia y defensa) y el gobierno intentó aplicar un nuevo plan de ajuste económico. En el Ministerio de Economía, Antonio Cafiero fue reemplazado por Emilio Mondelli, quien presentó un severo plan basado en un aumento salarial de emergencia, la liberalización total de los precios, un $80 \%$ de aumento en tarifas de servicios públicos y combustibles, devaluación, privatización de empresas públicas, etc. Ante semejante política la CGT entró en crisis y se dividió en tres sectores: los leales al gobierno (Lorenzo Miguel), los opositores (Casildo Herrera) y los promotores del golpe de estado (Victorio Calabró).

En esta situación fueron las Coordinadoras Interfabriles las que encabezaron la resistencia al Plan Mondelli. Las jornadas de lucha tuvieron su puntapié inicial en Córdoba, motorizadas por la Mesa Provisora de Gremios en Lucha, y se extendieron rápidamente a las fábricas bonaerenses (Löbbe, 2006: 228; Werner y Aguirre, 2007: 181). Huelgas, quite de colaboración, manifestaciones callejeras y marchas a las sedes sindicales fueron impulsadas por estos organismos en Capital Federal y el Gran Buenos Aires, siendo los trabajadores metalúrgicos y mecánicos quienes encabezaron las $\operatorname{protestas}^{453}$. Para el PRT-ERP estos niveles de movilización eran capaces tanto de derrotar el Plan Mondelli como de frenar los intentos golpistas, y en ese sentido llamaba a "impulsar la lucha y prever la resistencia", resguardando a las direcciones sindicales "honestas y combativas" y preparando la resistencia a través de organismos clandestinos $^{454}$.

Para intervenir en las movilizaciones, la organización decretó el "estado de movilización partidaria", lo que significaba concentrar todas las energías en participar activamente de los conflictos e incidir en su dirección. Para eso proponía una división de tareas en todos los frentes, zonas y regionales bajo las siguientes orientaciones: a nivel legal, al interior de las fábricas, los militantes debían ponerse al frente las protestas "haciendo carteles y banderas reivindicativas y democráticas", oponiéndose al golpe y a

desenfrenada, un aumento estrepitoso del déficit fiscal y graves problemas en las cuentas externas ("Economía. Balance de un año y perspectivas" El Combatiente Nro. 198, miércoles 7 de enero de 1976)

${ }^{453}$ Se registran medidas de lucha en fábricas de todas las zonas como Peugeot, General Motors, Mercedes Benz, Chrysler, La Cantábrica, Águila Saint, Molinos Rio de La Plata, Petroquimica Sudamericana, Alpargatas, Indeco, Laboratorios Squibb, Santa Rosa, Yelmo, Indiel, etc. Datos extraídos de: Avanzada Socialista Nro. 181, 15 de marzo de 1976; El Combatiente Nro. 208, miércoles 17 de marzo de 1976; El Combatiente Nro. 209, miércoles 24 de marzo de 1976.

${ }^{454}$ En el sentido de la TOR-22, estos debían tomar la dirección sindical al interior de los lugares de trabajo y organizaran la autodefensa. En El Combatiente se recuperaba la experiencia de los Comandos de Resistencia de la Unidad del Pueblo impulsados por el MIR chileno que operaron como organismos clandestinos paralelos a los sindicatos que organizaban a los trabajadores en tareas de sabotaje, represalias, etc. ("Chile: la lucha sindical en la Resistencia” El Combatiente Nro. 208, miércoles 17 de marzo) 
la política económica, levantando la consigna de Asamblea Constituyente, y preparando a los oradores sindicales para agitar en las movilizaciones. Por otro lado, en el aspecto ilegal, se instaba a "ligar estrechamente al P[artido] y al ERP a la movilización. Con banderas, carteles, piquetes de EC [El Combatiente] y ER [Estrella Roja] y mariposas [volantes] a millones." ${ }^{455}$ A su vez se llamaba a utilizar todas las células y unidades de combate -aun las que no estuvieran en las fábricas- para apoyar las movilizaciones a través de la agitación y propagandización de la línea de la organización en las columnas obreras $^{456}$.

Al mismo tiempo propuso un programa para las Coordinadoras que exigía: la nulidad del plan Mondelli; aumentos salariales de emergencia; paritarias libres; congelamiento y control obrero de los precios. También reclamaba el fin de los crímenes y secuestros, la derogación de las leyes represivas y rechazaba todo intento de golpe ${ }^{457}$. A los ojos del PRT-ERP, las Coordinadoras Interfabriles eran los organismos que debían dirigir la resistencia, garantizando la vinculación entre las distintas zonas fabriles e impulsando movilizaciones, actos, concentraciones, marchas y acciones callejeras ${ }^{458}$.

Ahora bien, tanto estas aspiraciones como la movilización de los trabajadores chocaron abruptamente con el golpe de estado consumado el 24 de marzo. En los días que siguieron al putch militar, el PRT-ERP insistió en "impulsar y multiplicar las coordinadoras gremiales": consideraba que ellas podían ser los organismos que canalizaran "el odio y las necesidades de los trabajadores hacia la lucha por las reivindicaciones económicas", luchas que se transformarían rápidamente en enfrentamiento a la dictadura militar" 459 .

Estos pronósticos partían de la idea de que la dictadura militar era una "aventura condenada al fracaso" debido a que generaría una amplia movilización obrera y un odio en importantes sectores de la población. Si bien no se lo caracterizaba como un régimen provisorio sino como un "tipo de gobierno definitivo" que buscaba aniquilar a las fuerzas revolucionarias, consideraba que desde el comienzo fracasaría en sus objetivos. Con este pronóstico lanzó la consigna Argentinos ;a las armas!, considerando que estaban dadas las condiciones para pasar de la "guerra entre vanguardias" a "la guerra

\footnotetext{
${ }^{455}$ Boletín Interno Nro. 108, 12 de marzo de 1976

456 Ídem.

457 "Impulsar la lucha y prever la movilización” El Combatiente Nro. 208, miércoles 17 de marzo; “Argentinos debemos ganar la calle" El Combatiente Nro. 208, miércoles 17 de marzo

458 "El Pueblo contra el plan del gobierno" El Combatiente Nro. 208, miércoles 17 de marzo de 1976

459 "Impulsar y multiplicar las Coordinadoras gremiales" El Combatiente Nro. 210, miércoles 31 de marzo de 1976.
} 
de masas", ya que según su visión, el pueblo no soportaría un régimen de esas características y saldría a luchar decididamente contra los golpistas ${ }^{460}$.

En esos mismos días, el 28 y 29 de marzo, en la localidad de Moreno, se llevó a cabo una reunión ampliada del Comité Central que, finalmente, fue interrumpida por la acción represiva de las fuerzas armadas ${ }^{461}$. En esa reunión se había presentado un documento titulado "Línea de construcción actual del Partido" 462 en el que se balanceaba la situación de la organización en los principales frentes fabriles y se llegaba a la conclusión de que los avances en la penetración habían sido muy importantes desde septiembre de 1974 hasta esa fecha. En ese sentido, el documento consignaba que se había logrado la "implantación" del partido en casi todas las fábricas en la que se había propuesto insertarse. También señalaba que la organización había logrado destacarse en los conflictos sindicales más importantes, y que incluso había logrado dirigir alguno de ellos. No obstante se remarcaba que existían fábricas en las que todavía no se había logrado penetrar y otras en las que hacía falta consolidar la organización partidaria existente. En esa dirección, planteaba centrar los esfuerzos y el plan de organización en las grandes fábricas debido que la dictadura concentraría allí la fuerza represiva.

En base a esta línea, se precisaba que la columna vertebral de la resistencia estaba compuesta por alrededor de 300.000 obreros fabriles concentrados en unas 250 fábricas grandes de más de 500 obreros cada una, en todo el país. ${ }^{463}$ La fábrica continuaba siendo el núcleo desde donde organizar a la vanguardia obrera y motorizar la resistencia generalizada. La tarea fundamental de los militantes fabriles, además de construir los órganos partidarios, pasaba a ser el impulso de los Comités de Resistencia Clandestinos que, basados en la idea de la TOR-22, se venían insinuando desde principio de 1976.

En esta orientación se anticipaba un reconocimiento del "reflujo" que vivía la clase obrera como consecuencia de la brutal represión en marcha. Sin embargo esta caracterización fue definitivamente hecha recién en el mes de junio cuando la organización dispuso reducir los organismos partidarios y "refugiarse entre las masas" para preservar la organización y prepararse para un nuevo auge de las luchas obreras que, se estimaba, sobrevendría a más tardar en un año. Ante la evidencia de los hechos,

\footnotetext{
460 “Argentinos: ¡a las armas!” El Combatiente Nro. 210, miércoles 31 de marzo de 1976.

${ }^{461}$ Fruto de la represión que interrumpió la reunión la organización perdió a cuatro miembros del Comité Central, el Jefe de Inteligencia del ERP, la responsable de Solidaridad Nacional y seis militantes. (Mattini, 2007:343)

462 "Línea de construcción actual del Partido", Informe al Comité Central del PRT

463 "La clase obrera: columna vertebral de la resistencia" El Combatiente Nro. 121, miércoles 21 de abril de 1976
} 
que demostraban una importante retracción de las luchas, la organización calificó de "error de apreciación táctico" el no haber percibido y señalado que el peso de la represión afectaría a la lucha popular.

Es que, por entonces, la acción represiva ya comenzaba a dañar seriamente la estructura nacional hasta que finalmente llegó a la misma plana mayor de la organización. En julio cayeron, en una emboscada, sus tres máximos dirigentes (Santucho, Menna y Urteaga) y el PRT-ERP entró en su ocaso final. La derrota de la organización se dio casi en paralelo a la derrota de la clase obrera. Como se vio a lo largo del capítulo, las energías del PRT-ERP se habían volcado decisivamente hacia las fábricas, por lo que los esfuerzos combinados de la dictadura por aniquilar a los sectores combativos del movimiento obrero y a las organizaciones revolucionarias, se combinaron trágicamente en su final ${ }^{464}$.

\section{Conclusión}

Los años 1974 y 1975 estuvieron cargados de tensiones y apuestas para el PRT-ERP.

Como vimos, fue en esos años que la lucha sindical adquirió un papel estratégico en su política al ser considerada un factor movilizador fundamental (junto a la lucha democrática y militar) en la pelea contra el gobierno de Isabel Perón. En ese marco buscó extender al máximo su presencia en las fábricas y, aunque infructuosamente, intentó construir espacios frentistas para centralizar nacionalmente los conflictos. Ante el avance de la política represiva se propuso ampliar la lucha democrática y la movilización sindical al mismo tiempo que intensificar su actividad guerrillera, lo que le significó importantes problemas para su política de alianzas.

Bajo el análisis de que se estaba abriendo una "situación revolucionaria" y de que se vivían "momentos decisivos", en 1975 se preparó específicamente para intervenir en las paritarias, fue protagonista en la fundación de las Coordinadoras Interfabriles del Gran Buenos Aires, y participó activamente en las “jornadas de junio y julio". Montado en la masividad de esas movilizaciones y en una confianza desmedida en sus propias fuerzas, no pudo captar la naturaleza defensiva de la conflictividad previa al golpe militar del 24 de marzo así como tampoco los efectos inmediatos de este último.

\footnotetext{
${ }^{464}$ Como confesó el propio Jorge Rafael Videla en el año 2012: "Por su preparación militar e ideológica, el Ejército Revolucionario del Pueblo (ERP) era más enemigo que Montoneros; era algo ajeno, otra cosa." (Fragmento de entrevista citada en "Videla admitió la muerte y desaparición de '7 u 8 mil personas"” en diario La Nación del viernes 13 de abril de 2012)
} 


\section{SEGUNDA PARTE}

"Perros en las fábricas: los casos de TENSA y Mercedes Benz Argentina" 


\section{Capítulo 5}

TENSA "globo de ensayo" del ERP

\section{Introducción}

Este capítulo aborda la experiencia del PRT-ERP en la fábrica metalúrgica Talleres Eléctrometalúrgicos Norte Sociedad Anónima (TENSA), ubicada en la Zona Norte del Gran Buenos Aires. Allí los trabajadores protagonizaron una intensa lucha antiburocrática contra la dirigencia local de la Unión Obrera Metalúrgica (UOM) que tuvo como eje principal la disputa por la CIR. La importancia del caso de TENSA radica en que fue uno de los primeros conflictos del año 1973 que condensó y adelantó gran parte de los elementos que formaron parte del clima político que se vivió en las fábricas durante el período estudiado. En ese sentido, en la experiencia de este establecimiento pueden señalarse como notas distintivas: la formación de un movimiento de bases antiburocrático, el desplazamiento de la CIR oficialista, la participación de un importante abanico de organizaciones de la nueva izquierda en su seno, la intervención guerrillera, la presencia de grupos de choque ligados al oficialismo sindical y la articulación entre el sindicato y la patronal en la represión de los trabajadores.

La pertinencia del análisis de este caso reside en el hecho de que allí el PRT-ERP contó con activistas en el CD y en la CIR y, a su vez, desarrolló una intensa actividad militar ligada a los conflictos sindicales. De esta manera, además de reconstruir el proceso de lucha de los trabajadores, el estudio se enfocara en tres dimensiones: 1- la forma organizativa que adoptó el PRT-ERP; 2- las características que adquirió su trabajo político-sindical; y 3- la actividad militar que desplegó sobre la fábrica.

\subsection{TENSA: estalla el conflicto.}

TENSA era una fábrica dedicada a la producción de autopartes (servofrenos, zapatas y cilindros de freno, columnas de dirección, etc.) que había sido instalada en Argentina en 1961, y que abastecía a varias de las principales automotrices instaladas en el país (Fiat, Ford, Peugeot $)^{465}$. Era una empresa de capital mixto ${ }^{466}$, que contaba con filiales en

\footnotetext{
465 Hacia inicios de 1976 la empresa comenzó a incursionar en la temática militar y a trabajar directamente con el Ejército Argentino, en principio, repotenciando y arreglando camiones blindados. Con vínculos directos con el Secretario de Defensa de los Estados Unidos, la empresa comenzó a
} 
Uruguay, Chile y Colombia y exportaba a Perú, Ecuador y Venezuela, a las que se abastecía con lo producido en Argentina. La fábrica poseía dos plantas: la principal de ellas, ubicaba en la localidad de Munro (Vicente López), estaba dedicada a la producción general y contaba con 1200 trabajadores, mientras que la segunda, ubicaba en Pablo Nogués (General Sarmiento), estaba destinada al depósito, embalaje y el control de calidad para la exportación, y empleaba alrededor de 50 operarios.

La CIR y el $\mathrm{CD}^{467}$ estaban conducidos por miembros de la Juventud Sindical Peronista (JSP), agrupación que adscribía a la Lista Marrón que conducía la UOM Vicente López desde 1965 y que tenía a Victorio Calabró y a Gregorio Minguito como sus principales dirigentes. Aquella seccional era la segunda más grande del sindicato (la primera era la de Capital Federal), contando con alrededor de 18.000 afiliados de importantes fábricas, entre las que TENSA era la más grande ${ }^{468}$. Por su parte, la JSP no sólo contaba con la estructura del sindicato sino también con el apoyo político y financiero del estado municipal $^{469}$, y un vínculo muy estrecho con la policía provincial y federal. Además contaba con un aparato clandestino compuesto por matones, delatores o informantes y grupos entrenados militarmente ${ }^{470}$. En el caso de TENSA mantenían un vínculo de complicidad con la empresa, basado en una cooperación mutua que comprendía la pasividad del sindicato ante la vulneración de derechos y la persecución de cualquier tipo de oposición sindical que pudiera surgir en las plantas ${ }^{471}$.

Allí la producción estaba organizada en tres turnos fijos de lunes a viernes. Los problemas principales pasaban por las malas condiciones de seguridad e higiene y atrasos en los pagos de los salarios, aguinaldos y horas extras. Como relata Carlos "Lito" Gonzales, obrero de la planta Munro y militante de VC, la fábrica no contaba con

desarrollar tecnología militar y a asistir a distintos ejércitos de América Latina. Así, por ejemplo, en 1978, restauró en tiempos records blindados M-7 Priest para el Ejército Argentino y respondió directamente a su demanda durante la Guerra de Malvinas. Ello demuestra los niveles de colaboración que existieron entre la empresa y el ejército en la desaparición de trabajadores (Piñera, 2006; "Commercial visit: MR. Germán Figaredo, President of Firm TENSA", 24/5/1974, Declassified/Released US Department of State EO Systematic Review 30 JUN 2005, WikiLeaks).

${ }^{466}$ El 30\% de la empresa estaba a manos de capital argentino, la mayoría en manos de German Figaredo, mientras que el resto de las acciones eran de origen norteamericano y pertenecían al grupo Lockheed

${ }^{467}$ La CIR estaba compuesto por 5 miembros y el CD por 38 delegados.

${ }^{468}$ La seccional organizaba a trabajadores de Del Carlo, Wobron, Corni, Bendix, Ema, Otis y una parte importante de los obreros de Astilleros Astarsa (Della Savia, 2017).

${ }^{469}$ En 1973 fueron electos López y Pozzi, ambos hombres de la UOM, como intendentes de los municipios de Vicente López y Tigre respectivamente.

${ }^{470}$ La Causa Peronista Nro. 7, 20 de agosto de 1974.

${ }^{471}$ Un ejemplo de ello es relatado por Roberto Mereta (militante perretista y delegado) quien nos cuenta que en la planta de Pablo Nogués el primer y único delegado con que habían contado los trabajadores antes del conflicto había sido desplazado por haber manifestado su disconformidad con los manejos del organismo por una maniobra sindical-patronal. 
medidas de seguridad básica: los obreros no recibían la ropa adecuada y las máquinas no contaban con los dispositivos que permitieran la interrupción automática de su funcionamiento, por lo que proliferaban múltiples accidentes de trabajo. Además en las secciones de mayor peligrosidad, donde se realizaban los baños químicos de las piezas, no contaban con máscaras ni delantales así como tampoco con la ventilación necesaria. A eso se sumaba una atención médica ineficaz y funcional a las exigencias de la empresa $^{472}$.

En este marco, a lo largo del año 1972 fue organizándose un núcleo de jóvenes obreros que habían ingresado a la fábrica el año anterior y que, motivados por las malas condiciones de trabajo y la falta de respuesta sindical, conformaron una agrupación. Aquel agrupamiento, nombrado "7 de julio" en alusión al día de su primera reunión, fue motorizado fundamentalmente por un núcleo de activistas de $\mathrm{VC}^{473}$ y contó con la participación de militantes del PRT-ERP, el PST y la JTP ${ }^{474}$.

A fines de aquel año comenzaron a sucederse algunos conflictos menores en distintas secciones que fueron tensando los ánimos, y fueron allanando el camino para el crecimiento y la intervención de la agrupación. La situación se agravó cuando se conoció que la empresa había acordado con la CIR el atraso en el pago del aguinaldo. Ante el estado generalizado de descontento, la patronal buscó aplacar los ánimos con un bono en forma de adelanto. No obstante a mediados de enero la situación se volvió insostenible cuando comenzó a adeudarse también la segunda quincena de diciembre. En el marco de esta situación, el 16 de enero de 1973, por presión de los trabajadores, los dirigentes gremiales buscaron negociar el adelantamiento de los pagos y se encontraron con la negativa por parte de la gerencia. Inmediatamente los operarios del turno tarde, encabezados por los activistas de la agrupación “7 de julio”, que luego será

\footnotetext{
${ }^{472}$ Entrevista con Carlos "Lito" Gonzales con el autor, Buenos Aires, 2017. "Lito" Gonzales, de familia proletaria, antes de ingresar a TENSA trabajó en una fábrica metalúrgica de alrededor de 500 trabajadores en la localidad de Villa Marteli. Hasta allí, por influencia de sus padres, tenía simpatía por el peronismo. Al ingresar a TENSA en 1971, conmovido por la realidad de la fábrica buscó organizarse y, junto a un compañero de trabajo, se contactaron con un familiar de éste último quien militaba en VC. A partir de allí entró en contacto con "Pipo" Román, trabajador de TENSA y militante de esta última organización.

${ }^{473}$ Uno de los principales dirigentes de VC en la fábrica fue "Pipo" Román, obrero que había sido parte de Sitrac-Sitram y que luego de esa experiencia fue a trabajar al Gran Buenos Aires donde entró a TENSA.

${ }^{474}$ Entrevista a "Lalo" Piñon con el autor, Buenos Aires, 2018. Lalo Piñon, era un joven de familia obrera. Su padre era activista sindical y simpatizante comunista de la fábrica Cantábrica y su hermano mayor militante universitario del PST. Él, como especialista en electrónica, trabajó en talleres chicos y empresas telefónicas. En 1971, con 23 años, ingresó a TENSA donde tomo contacto con "Pipo" Román, militante de VC, quien comenzó a pasarle materiales de la organización hasta que finalmente se incorporó plenamente a la militancia en aquel partido, llegando a ser un militante sindical destacado dentro de la fábrica y en la organización.
} 
rebautizada como "16 de enero", decidieron parar la fábrica y, reunidos en asamblea, reclamaron que se liquidasen inmediatamente lo adeudado y que renunciaran los representantes sindicales por su complicidad con la patronal. La beligerancia y contundencia de la medida llevó a que los delegados en funciones fueran obligados a retirarse de la fábrica en medio de abucheos ${ }^{475}$. Por su parte, la gerencia buscó evitar que los trabajadores del turno noche entraran a la fábrica, lo que suscitó una radicalización de la medida que viró en amenaza de ocupación y condujo a que a la mañana siguiente parasen los 1200 trabajadores ${ }^{476}$. Esta misma situación se replicó en la planta de Pablo Nogués en donde se plegaron a la medida de forma inmediata ${ }^{477}$.

Finalmente, luego de varias instancias de negociación, la empresa se vio obligada a liquidar los salarios en medio del paro y a pagar el 50\% de las horas caídas en razón de la protesta. Además la CIR y el CD debieron renunciar, aunque la UOM decidió intervenir la fábrica con un agente propio hasta tanto se "normalizara" la situación. Mientras tanto, los trabajadores designaron en asamblea un CD provisional ${ }^{478}$ que finalmente fue ratificado en elecciones realizadas el 5 de abril ${ }^{479}$.

En aquel CD estuvieron representadas la mayoría de las fuerzas políticas que actuaban en la fábrica ${ }^{480}$, aunque fundamentalmente la organización con mayoría de

475 "A las 20,00 horas, se realiza un movimiento encabezado por activistas donde explican a sus compañeros que el objetivo de este paro es lograr el cobro del aguinaldo, pero su verdadera motivación es lograr la renuncia del cuerpo de delegados y CI en su totalidad, por entender que estaban entregados a la patronal. Ante el paro concurren al Establecimiento los dirigentes gremiales xxx, acompañados por el cuerpo de delegados, quienes solicitaron una asamblea con el personal a la vez que se vieron obligados a apoyar este movimiento surgido de las bases obreras.

La asamblea realizada entre estos dirigentes y el personal sirvió para detectar la verdadera motivación que llevaba el personal al iniciar el paro, por cuanto en la misma se manifestaba a través de la voz de los obreros, la gran disconformidad existente con los miembros de la CI, juntamente con la exigencia de la renuncia en forma inmediata de los mismos. Se produjo un desorden verbal que llevó a los dirigentes a dar por finalizada la asamblea, continuando los obreros en estado de paro" (DIPBA, Mesa D(s), Carpeta Varios, Legajo 1309)

476 “Tensa: También Calabró pierde la primera vuelta” Política Obrera Nro. 142, 13 de febrero de 1973

477 "En Nogués a nosotros nos llaman por radio y nos dicen que estaba sucediendo eso en la planta grande y nosotros inmediatamente paramos la planta, y quedo todo así en stand by a la espera... no hizo falta correr a nadie porque nos habían dejado sin delegado." (Entrevista a Roberto Mereta por el autor, Marzo de 2018)

${ }^{478}$ El CD incorporó a Roberto Mereta y Juan Carlos Chersanaz, ambos militantes del PRT-ERP, como delegados de la planta de Pablo Nogués.

${ }^{479}$ En los días posteriores a la toma comenzó a circular un petitorio por toda la fábrica exigiendo la inmediata convocatoria a elecciones de CD y CI. Sin embargo la misma fue convocada recién para abril. Mientras tanto los trabajadores siguieron movilizados limitando cualquier maniobra del interventor. De hecho en los primeros días de febrero, este último intentó nombrar a dedo a los "colaboradores" que oficiarían de delegados provisorios, lo que motivó la convocatoria a una asamblea de urgencia el sábado 3 de febrero durante el turno mañana en la que se exigió la renuncia de los "colaboradores" digitados y se eligió democráticamente a cinco activistas ("Tensa. Se eligieron colaboradores en asamblea" Avanzada Socialista Nro. 48, miércoles 7 de febrero de 1973.)

${ }^{480}$ En aquel cuerpo de delegados había representantes de la JTP, el PRT-ERP, el PST y el PC. Ello no pasó desapercibido para la Juventud Sindical Peronista la cual, durante la campaña, intentó evitar 
representantes fue VC que, en consecuencia, fue hegemónica en la conformación de la CIR, contando con tres representantes de los cinco que la componían ${ }^{481}$. No obstante en este último organismo también salió elegido Roberto Mereta ${ }^{482}$, obrero de la planta Pablo Nogués y militante perretista que, como veremos, tendrá un papel destacado en la vida político-sindical de la empresa.

\subsection{Ninguna tregua a TENSA: el ERP en la fábrica}

Si bien no se ha podido determinar en qué año el PRT-ERP logró ingresar a TENSA, a partir de los testimonios se puede afirmar que la organización ya contaba con presencia en las dos plantas durante el año 1972. Según “Tito”, quien fue responsable político de en aquella zona a principios de 1973, TENSA era una de las fábricas en las que había quedado trabajo político luego del período de "desviación militarista" y de las rupturas sucesivas que se dieron en la Regional Buenos Aires y Capital Federal ${ }^{483}$. Por otro lado, Roberto Mereta confirma que en 1971, año de su ingreso a la fábrica, ya había militantes del PRT-ERP en la planta Munro y Pablo Nogués, lo que coincide con el testimonio de "Lalo" Piñon, quien indica que, para aquel entonces, en la sección tornos había militantes perretistas. De hecho, según éste último, aquellos militantes fueron los que motorizaron uno de los conflictos previos al estallido de enero ${ }^{484}$.

El PRT-ERP participó de los hechos de enero y, aunque logró incorporar militantes al $\mathrm{CD}$, no tuvo un rol protagónico en aquel proceso. De hecho el propio Mereta ingresó al PRT-ERP en el momento inmediatamente previo a ser elegido como miembro de la

infructuosamente el triunfo de la lista antiburocrática denunciando a sus activistas como "mercenarios del trapo rojo" y "propagandistas del voto en blanco" y bajo la consigna "Vota por peronistas y no por troskos". ("Liberación o Dependencia. A los compañeros del establecimiento TENSA", colección personal de Roberto Mereta)

${ }^{481}$ Los integrantes de la CIR eran Lalo Piñon (principal dirigente de la fábrica) Nicolas "Pipo" Román y Francisco Mercado (de VC), Roberto Mereta (PRT) y Carlos Luis Baynon (independiente)

${ }^{482}$ Roberto Mereta, para ese momento, era un joven de familia trabajadora, recibido de técnico mecánico. Antes de ingresar a TENSA trabajó en la fábrica Armetal S.A, ubicada en General Pacheco, del cual fue desafectado por reducción de personal. Luego ingresó a TENSA, donde se incorporó a trabajar en la planta Munro, en la sección de Control de Calidad, para después ser trasladado a la planta de Pablo Nogués. Allí fue contactado por “el Maestro” Sánchez, un trabajador y militante perretista quien lo sumó a la organización.

${ }^{483}$ Entrevista a "Tito" con el autor, Cafayate, 2017. (Remitirse al Capítulo 2.)

484 "Paró la sección [tornos] y eso hizo mucho ruido en la fábrica ¡mucho ruido! Y ellos consiguieron que les dieran el calzado. Lograron un primer acuerdo con la empresa, cedió el jefe de personal Marini. Después trataron de tomar represalias, hubo todo una cosa ahí de lucha por reivindicaciones muy sectoriales (...) Eso fue una de las cosas previas al estallido (...) estos compañeros de esta sección tornos yo creo que eran compañeros del PRT, Bulacio no sé, estaba Luis Sportuno, había otros compañeros..." (Entrevista a Lalo Piñon por el autor, Buenos Aires, Julio de 2018.) 
CIR, por lo que no puede considerarse que su participación en aquel organismo haya sido fruto de su militancia en la organización.

Como relata este último, será inmediatamente después de desatada la "rebelión" cuando la organización guevarista logró su mayor nivel de influencia, fundamentalmente a través de su intervención militar en la fábrica. Allí la organización logró formar escuadras militares en ambas plantas, que funcionaban con obreros de la empresa y militantes de fuera de la misma. Entre 1973 y 1975 se relevaron 9 acciones militares de diferente envergadura, que fueron desde tomas de las plantas, hasta el secuestro del subgerente y el asesinato de un delegado de la "burocracia sindical". Ello llevó a que la DIPBA y la empresa de seguridad privada de la fábrica (Vanguard S.A) caracterizaran que el ERP había tomado a TENSA como "planta piloto" para realizar todo tipo de acciones y que había iniciado una "campaña psicológica” contra la empresa ${ }^{485}$.

En las palabras del propio PRT-ERP la combinación de la lucha sindical con la lucha armada surgía en TENSA como fruto de las circunstancias específicas y generales de la fábrica, y con el objetivo de acompañar y consolidar el triunfo obrero de enero:

"Hace aproximadamente ocho meses los trabajadores de Tensa, iniciamos la lucha organizada contra los dirigentes traidores burócratas que dirigían sindicalmente nuestra fábrica (...) En esa lucha nos unimos todos los compañeros sin distinciones políticas: peronistas, socialistas, cristianos y revolucionarios, con el mismo fin. Acabar con las humillaciones y trato policial ejercido por los capataces. Mejorar nuestras condiciones de trabajo, obtener un salario digno para mantener nuestros hogares. Así surgió la necesidad de combinar la lucha sindical con la acción revolucionaria de la guerrilla, ante la represión y las amenazas de los mercenarios a las órdenes de Vanguard y la bronca de la patronal que no podía admitir la derrota de su aliada la 'burocracia"." ${ }^{486}$

A su vez, Roberto Astudillo, obrero perretista miembro de la escuadra militar de Munro, remarca que las acciones en TENSA tenían dos sentidos: 1- "rechazar las propuestas de la burocracia y la patronal" y 2- "dar a conocer la línea del partido". Además, insiste en que las acciones debían surgir como respuesta a "las necesidades de los obreros" llevando adelante lo que aquellos pensaban ${ }^{487}$.

La primera acción registrada se dio el 8 de febrero de 1973 en la planta de Munro, a muy pocos días de estallado el conflicto. A las 6 de la mañana una unidad del ERP

\footnotetext{
${ }^{485}$ DIPBA, Mesa D(s), Carpeta Varios, Legajo 1309

486 "Boletín fabril metalúrgico" DIPBA, Mesa D(s), Carpeta Varios, Legajo 1309 (el subrayado es del original)

${ }^{487}$ Entrevista a Roberto Astudillo por el autor, Italia, Diciembre de 2017. Roberto Astudillo ingresó a TENSA en 1974. Antes de ello trabajó en la fábrica de calzados PANAM donde participó activamente de las luchas sindicales. Militó en el PST desde 1972 hasta 1974 momento en que decidió romper con aquella organización a causa de la "Masacre de Pacheco", hecho en el que la Triple A secuestro y asesino a obreros militantes de aquel partido. A partir de allí, convencido de la necesidad de la lucha armada, al ingresar a TENSA tomó contacto inmediatamente con militantes del PRT-ERP.
} 
autodenominada "Comando Jorge Ulla-Clarisa Lea Place" (comando que realizó muchas de las acciones en TENSA), compuesta por 8 integrantes, intentó copar el establecimiento con el objetivo de arengar a los trabajadores, realizar pintadas y repartir volantes. No obstante, fueron interceptados por agentes de "Vanguard S.A" quienes se resistieron e iniciaron un enfrentamiento. En él calló abatido el Sargento Segovia (retirado de la policía bonaerense), después de lo cual el comando debió huir sin poder realizar las acciones de propaganda planeadas, aunque, según informaciones periodísticas y policiales, lograron quitarle las armas a dos de los integrantes del servicio de vigilancia ${ }^{488}$.

Según un informe de la DIPBA los días posteriores al intento de copamiento habría habido una serie de reuniones $(10 / 2 ; 11 / 2$ y $20 / 2)$ fuera de la fábrica a las que asistieron varios activistas de TENSA y en las que se habrían discutido temas gremiales y, además, algunos asistentes se habrían adjudicado el intento de copamiento de la fábrica. Estos últimos habrían planteado que acciones como esas, aunque no estaban previstas, eran una "advertencia, para que se supiera que actuarían con mano dura", y que podrían repetirse "de ser necesario para la lucha revolucionaria". Asimismo, en otras de las reuniones, se habría discutido la posibilidad de secuestrar al presidente de TENSA, Germán Figaredo. Si bien en ningún momento lo sugiere, por su amplitud y según algunas versiones, las reuniones habrían sido de la agrupación "16 de enero". Sin embargo, como advierte la propia policía, resulta al menos sospechoso que los militantes del PRT-ERP hayan reivindicado abiertamente las acciones e incluso preanunciado acciones como la del secuestro en una reunión de esas características, con trabajadores independientes "de los cuales no se hallan plenamente seguros de su fidelidad" 489 .

A los pocos días, el ERP efectuó finalmente el secuestro del sub-gerente general de la empresa, el ingeniero Alberto Lloveras. A las 8 de la mañana del 16 de marzo un comando integrado por 3 personas interceptó el auto del ingeniero, quien viajaba de su casa a la empresa, y lo trasladaron a un sótano en el cual lo mantuvieron hasta el 23 de

\footnotetext{
${ }^{488}$ Clarín, jueves 8 de febrero de 1973

${ }^{489} \mathrm{El}$ informe es muy confuso ya que tiende a confundir siglas y acciones. Así, por ejemplo, plantea que uno de los miembros que habría dirigido las reuniones se había presentado como parte de las "Fuerzas Revolucionarias Antiacuerdistas" (FRA) y además de llamar a votar en blanco en las elecciones, habría reivindicado la acción del ERP. Ello resulta confuso ya que efectivamente el FRA fue un frente conformado por el PCR y VC por el voto en blanco, pero resulta al menos difícil que miembros de aquellas fuerzas reivindicasen una acción militar de los guevaristas. (DIPBA, Mesa D(s), Carpeta Varios, Legajo 1309)
} 
ese mes, día en que fue liberado posteriormente al pago de 400 millones de pesos ${ }^{490}$. El secuestro, a diferencia de otros casos, no tuvo como objetivo resolver algún conflicto sindical o lograr una reivindicación sentida por los trabajadores, sino financiar a la organización guerrillera. Esto queda claro en el comunicado que repartió el ERP entre los obreros posteriormente:

"El Sr. Alberto Lloveras fue liberado el viernes 23 de marzo recuperándose 400 millones de pesos para la causa del pueblo. Ese dinero es parte de lo que la patronal a través de la explotación, roba a los obreros y el pueblo, su recuperación contribuye a fortalecer el desarrollo de la guerra revolucionaria que nuestra patria ha emprendido por la segunda independencia (...), ${ }^{, 491}$

También informaban que Lloveras había sido interrogado, y que en el interrogatorio había ratificado la existencia de capitales norteamericanos en las acciones de TENSA por un $30 \%$, algo que era negado por la empresa que se presentaba como "netamente argentina" ${ }^{492}$. El escrito además comparaba a TENSA con un "campo de concentración", donde los obreros eran vigilados y sometidos a tratos policiales, y presentaba al secuestro, y a otro tipo de acciones, como un acto de la "justicia popular" en la que los "explotadores" debían rendir cuentas. Finalmente culminaba llamando a hacer "de cada fábrica una fortaleza" y a formar "comandos de apoyo al ERP" 493.

Si bien la acción había tenido como objetivo principal el financiamiento de la organización, al mismo tiempo funcionó como hecho de propaganda armada en tanto fue una demostración de la operatividad guerrillera y se presentó como un acto de "justicia popular", y un desenmascaramiento del carácter "explotador" e "imperialista" de la empresa. Como indica Vera Carnovale los secuestros en sí mismos eran inscriptos en el orden de un imaginario justiciero, ya que "ofrecían la posibilidad de hacer efectiva la reparación -al menos parcial y en alguna medida particularizada- del daño cometido, al tiempo que le permitían a la organización erigirse ante las masas y ante sí misma como autora y referente de pequeños actos de reversión de injusticias" (2011:146-147). La acción, además, le dio al PRT-ERP un protagonismo que no había tenido hasta al momento en la fábrica. De hecho, a los pocos días, German Figaredo, presidente de la compañía, emitió un comunicado que pegó en todas las paredes de las plantas en el que

\footnotetext{
490 Clarín, domingo 25 de marzo de 1973; DIPBA,Mesa D(s), Carpeta Varios, Legajo 707; DIPBA, Mesa D(s), Carpeta Varios, Legajo 1309

${ }_{491}$ "Comunicado del Comando Jorge Ulla-Clarisa Lea Place del ERP" DIPBA, Mesa D(s), Carpeta Varios, Legajo 1309

${ }^{492}$ Clarín, domingo 25 de marzo de 1973

493 "Comunicado del Comando Jorge Ulla-Clarisa Lea Place del ERP" DIPBA, Mesa D(s), Carpeta Varios, Legajo 1309
} 
pedía abiertamente una "tregua"494. Declarándose "peronista, obrero, canillita y compañero", en la misiva relataba los esfuerzos que realizaba la empresa ante la competencia "monopolista", describía supuestos pesares económicos a los que estaba expuesta la empresa y pedía la "tregua" a cambio del compromiso de mejorar las condiciones de trabajo. Por su parte el PRT-ERP, asumiendo ser el destinatario del mensaje, respondió cada uno de los puntos de la carta mediante un comunicado dirigido a los "compañeros de TENSA". En él denunciaban los planes represivos, las malas condiciones de trabajo y rechazaban las lamentaciones de Figaredo arguyendo que lejos de estar en crisis, la empresa tenía planes de expandirse de la mano de capitales extranjeros y que además contaba con cuantiosas ganancias por el hecho de ser una de las líderes del mercado de autopartes ${ }^{495}$.

A partir de allí la organización comenzó a intervenir más sistemáticamente sobre la fábrica a través de volantes y acciones de diverso tipo. De hecho constituyó un "Tribunal Revolucionario Popular" para todo el partido de Vicente López que tuvo a TENSA como centro principal de operaciones ${ }^{496}$. En una de sus actuaciones, por ejemplo, el tribunal realizó una "investigación" sobre los que consideraban como los principales exponentes de "la patronal, subalternos y su aparato represivo (Vanguard S.A.)". El informe final consignaba los nombres de los indagados, su cargo de responsabilidad con una breve descripción sobre sus actitudes y comportamiento y un largo listado de hechos por los cuales se lo acusaba. Entre ellas se pueden leer imputaciones por amenazas, maltratos, intimidación, despidos, suspensiones, delaciones

\footnotetext{
${ }^{494}$ Entrevista a Floreal Avellaneda, Memoria Abierta

495 "La patronal, mediante Figaredo y sus secuaces, llama a la tregua mencionando su compromiso de mejorar las condiciones de trabajo. Poca memoria tienen estos negreros chupasangre, han olvidado a muchos compañeros que enfermaron en la sección galvanotecnia, cuyo trabajo es insalubre por falta de elementos de protección, han olvidado que en fábrica no existe un departamento de seguridad industrial para prever accidentes, han olvidado que murió electrocutado un compañero y no se investigó ni se dio informe de las causas, han olvidado que el mínimo elemento de seguridad que es el casco, brilla por su ausencia y que los botines y guantes nunca se entregaron con regularidad, han olvidado que hemos sido tratados como animales, con los baños y el comedor en malas condiciones, con la clínica dotada de "profesionales" como el asesino Magazú, que debe desaparecer. (...) Vayan sabiendo Figeredo y sus secuaces que, en la lucha de clases entre oprimidos y explotadores, la clase obrera no tiene nada que perder, que los obreros tienen la iniciativa, que todas las reivindicaciones se han conseguido con la lucha en sus diversas formas: sindical, política y militar." (“A los compañeros de Tensa”, DIPBA, Mesa Ds,, Carpeta Varios, Leg. 1309)

${ }^{496}$ El "Tribunal" a su vez operaba en el territorio. Un ejemplo de ello fue la realización de un juicio a la directora y propietaria de una escuela de la localidad que cobraba una mensualidad elevada a sus alumnos y mantenía la escuela en pésimas condiciones. Así, la "sentencia" a la que arribó el organismo fue: obligar a la directora a bajar la cuota mensual, a no cobrar colaboraciones bajo coacción, a realizar reformas edilicias a las instalaciones y a reincorporar a alumnos que habían sido expulsados por no pagar la cuota. Todo ello so pena de ser arrestada en una "cárcel del pueblo". ("Boletín fabril metalúrgico" DIPBA, Mesa D(s), Carpeta Varios, Legajo 1309)
} 
y arbitrariedades varias. En él no sólo se exponía a personal jerárquico sino también a trabajadores que eran considerados "alcahuetes", "traidores" o "infiltrados" y se los ponía a disposición del tribunal:

"Este TRIBUNAL REVOLUCIONARIO POPULAR liberará órdenes de detención y dictará sentencia cuando la Justicia Revolucionaria establezca. Los responsables más inmediatos: Marini, Carmona, Madariaga, deberán afrontar a los graves cargos formulados sin atenuantes" $"$ "

Con este tipo de declaraciones se buscaba intimidar a los directivos de la empresa para que concedieran las reivindicaciones gremiales básicas, así como también para mejorar y alivianar la cotidianeidad de los trabajadores morigerando los maltratos de supervisores y capataces quienes sentían la amenaza de haber sido nombrados y "sentenciados" por el ERP. Esto se complementó, además, con amenazas telefónicas y con las tomas de las plantas en las cuales se los exponía a un interrogatorio in situ frente a los trabajadores, haciéndolos comprometer ante éstos que cesarían con sus actitudes.

Durante el año 1973 y 1974 el PRT-ERP realizó tres tomas que resultaron exitosas: dos en la planta de Pablo Nogués (12/5/73; 4/9/73) y una en la de Munro (24/5/74). En el caso de Pablo Nogués la metodología empleada fue similar: el comando se presentaba intempestivamente en la fábrica a primeras horas de la mañana, reducía a los guardias que estuvieran vigilando, reducían al personal administrativo que considerasen jerárquicos y reunían a los trabajadores en un espacio común de la fábrica (patio, comedor, etc). Ante ellos leían alguna proclama, volante o comunicado y procedían a vender los periódicos Estrella Roja y El Combatiente, además de repartir volantes o el "Boletín Fabril Metalúrgico". En paralelo algunos de los combatientes se disponían a pintar consignas con aerosol en las paredes ${ }^{498}$ y/o colgar la bandera del ERP en algún lugar visible. Además intentaban entablar un diálogo con los trabajadores sobre la situación de la fábrica y la situación política nacional.

Algunos pasajes de la reconstrucción que realizó la DIPBA de una de las tomas resultan ilustrativos tanto de la forma en que se desarrollaban como de la recepción de los trabajadores:

"El de la ametralladora ordena la reunión del personal presente, lo que hacen frente a los vestuarios, siendo reducidos el personal administrativo por dos o tres jóvenes más pertenecientes al grupo comando (...) Uno de los integrantes del comando procede en alta

\footnotetext{
497 “A los compañeros trabajadores de TENSA: Proclama del Tribunal Revolucionario Popular del Partido de Vicente López” DIPBA, Mesa D(s), Carpeta Varios, Legajo 1309

${ }^{498}$ Se pintaron las siguientes consignas durante las tomas: "Ninguna tregua al ejército opresor"; "Ninguna tregua a las empresas explotadoras", "Libertad a los combatientes de la liberación" (DIPBA, Mesa D(s), Carpeta Daños, Legajo 1309)
} 
voz a leer un comunicado (...) En el cambio de palabras suscitado entre los grupos [entre el comando y los obreros], los del comando dijeron que apoyarían su lucha, posiblemente refiriéndose a presuntas reivindicaciones obreras (...) Dijeron que necesitaban la colaboración económica de todos y procedieron a ofertar el periódico ESTRELLA ROJA al precio de cincuenta centavos Ley, periódico éste que adquirieron todos, notándose inclusive que ante la falta de cambio, se quedaban con el vuelto (...) Retirado el comando, sin haber abandonado los terrenos de la planta regresan sus integrantes y uno de ellos se acerca al grupo de obreros y solicita que le indiquen si vieron un cargador de la ametralladora que extravió y olvido en algún lugar de la fábrica.- Todos se afanan en su búsqueda y no aparece el cargador.,"499

Como vemos, según lo relatado, estas tomas de fábrica no fueron repudiadas por los trabajadores. Si bien no se informa que haya habido apoyo explícito o palabras de aliento, sí se destaca el hecho de que la prensa haya sido comprada por la totalidad de los obreros, y que incluso hayan donado su vuelto. Otro dato significativo es que la policía no pudo obtener ningún ejemplar de los periódicos vendidos porque todos los obreros habían manifestado querer guardarlos "como recuerdo" 500.

En opinión de los obreros perretistas entrevistados las intervenciones del ERP no solo no eran repudiadas sino que despertaban amplia simpatía por los trabajadores. Según Roberto Astudillo despertaban "gran admiración” y "respeto" y ayudaban a prestigiar a la organización. Coincidiendo con ello, Roberto Mereta agrega que además ayudaban a robustecer la confianza de sus compañeros:

"Mereta: Fue un momento donde por primera vez los obreros tuvieron una especie de fuerza de represión (...) por primera vez el laburante tuvo una herramienta para poder levantar la cabeza y decir: no me jodas.

Entrevistador: ¿Y eso lo vivían así la mayoría de los trabajadores?

Mereta: ¡Si! Si, si, ¡absolutamente! Se notaba, se notaba que andaban como sacando pecho, porque sentían que ya no era de un solo lado la fuerza, sino que había fuerza del otro lado para responder. Duró poco, pero el sentimiento fue ese. O sea el laburante sentía que había... no todos obviamente porque que siempre ha habido gente con mentalidad de sometido. Pero los que no, sí... y se notaba, o sea peticionaban de otra manera, tenían otra posición frente al patrón. Eso se notó." 501

Esto es ratificado por Blas Obella, obrero independiente de la planta Pablo Nogués.

Según aquel los obreros se sentían respaldados por el ERP, y sus acciones servían para que los supervisores disminuyeran considerablemente el "verdugueo":

"Blas: Ese día que tomaron la gente se escondía, los supervisores decían que no eran supervisores porque tenían miedo. Había supervisores bravos, muy bravos, que nos trataban mal (...)

Entrevistador: ¿Por qué se ponían la ropa de trabajadores?

Blas: Porque tenían miedo

${ }^{499}$ DIPBA,Mesa D(s), Carpeta Daños, Legajo 2421

${ }^{500}$ DIPBA, Mesa D(s), Carpeta Varios, Legajo 994

${ }^{501}$ Entrevista a Roberto Mereta con el autor, Buenos Aires, 2018. 
Entrevistador: ¿Les tenían miedo al ERP?

Blas: ¡Sí! ¡Les tenían un miedo bárbaro! ¡Parecían ovejas! Después te decían que si querías te hacían la comida iy te la hacían ellos! Tenían un miedo bárbaro. Esos cuando venían no venían a joder, cuando te marcaban te marcaban. Al jefe éste, que era de la marina, fueron y le pintaron la casa para que vean que estábamos respaldados.

Entrevistador: ¿Y eso ustedes como lo vivían?

Blas: ¡Y lo vivíamos con euforia! ¡Estábamos contentos! Porque estos sinvergüenzas eran unos verdugos.

Entrevistador: ¿Pero a usted le caía bien las acciones que hacía el ERP?

Blas: ¡Y sí, por supuesto porque luchaban para los pobres! ¡Sí! ¡Por supuesto!

Entrevistador: ¿Y sus compañeros de trabajo también lo veían bien? ¿Cómo se veía en la fábrica?

Blas: Y trabajábamos tranquilos, porque teníamos un respaldo. (...) Hubo muchos traidores, había gente infiltrada que nosotros sabíamos quiénes eran, de donde venían. Cuando los veíamos venir le tirábamos con repuestos de coches, le partíamos la cabeza. Ya uno tenía más fuerza porque sabíamos que estábamos apoyados." ${ }^{\text {"502 }}$

Como se ve, el testimonio resalta la efectividad de las acciones y sus efectos en la vida cotidiana de la planta y da pistas sobre cómo era vivido y recibido por un sector de los trabajadores. La "euforia" y la "alegría" de ver a supervisores y capataces con miedo, expuestos y humillados delante de los obreros que sufrían sus vejámenes, y el hecho de que cambiara por un tiempo la ecuación de poder en la cotidianeidad del trabajo, funcionaba a su vez como un "respaldo" que alentaba a la iniciativa de los propios operarios. A su vez fue una forma en que la organización logró romper, en algunos casos, los prejuicios que los obreros peronistas tenían con las organizaciones de izquierda. De hecho Blas Obella, que se reconocía como peronista, resalta que lo que importaba, en última instancia, era que el PRT-ERP "luchaba por los obreros"

Por su parte "Lalo" Piñon observa que, a pesar de que políticamente él estaba en desacuerdo, las acciones del ERP "eran bien recibidas" por los trabajadores quienes se veían "seducidos por la acción extrema":

"Tantos compañeros negados en sus reivindicaciones, maltratados, menospreciados en todo sentido, cuando alguien hace una acción de ese tipo y mete miedo adentro de la fábrica, le mete miedo a los de arriba, es una cosa que vos te sentís identificado, se siente identificación con eso. Cuando vos la analizas políticamente y tenés un análisis político ahí empezás a poner los bemoles, pero los compañeros en general acordaron. (...)",504

No obstante es de destacar que todos los testimonios indican que existía un sector de los trabajadores que eran indiferentes o no acordaban con aquel tipo de acciones. Es el caso

\footnotetext{
${ }^{502}$ Entrevista a Blas Obella con el autor, San Martín, 2018

${ }^{503}$ Entrevista a Blas Obella con el autor, San Martín, 2018

${ }^{504}$ Entrevista a Lalo Piñon por el autor, Buenos Aires, Julio de 2018
} 
de "Lito" Gonzales y Mario Masolini (obrero de la planta Munro) ${ }^{505}$, quienes consideran que esas acciones eran reprobadas por el conjunto de los obreros. Masollini remarca que no generaban simpatía por el hecho de que la mayoría de los trabajadores, que eran peronistas, veían a aquellas acciones como una afrenta contra el gobierno de Perón. Gonzales, por su parte, agrega que aquellas acciones no respetaban el trabajo político y gremial que venía desarrollando el movimiento de base de la fábrica porque venían desde "afuera"506. Ambos coinciden en que la actividad del ERP, además, le daban argumentos a la "burocracia sindical" para "desprestigiar" al movimiento de base y atraer la represión.

Como se puede observar en los archivos de la DIPBA, la actividad del ERP motivó una atención especial por parte de las fuerzas de seguridad y un robustecimiento de la vigilancia tanto privada como policial de la fábrica ${ }^{507}$. Por su parte, Mereta reconoce que "sin ninguna duda" la actividad guerrillera alimentó la furia represiva ${ }^{508}$. Inclusive la propia organización debió advertir en su boletín fabril que el presidente de la empresa, German Figaredo, utilizaría el accionar del ERP y las supuestas amenazas hacia su persona como excusa para justificar la introducción de "matones de la Juventud Sindical" y el reforzamiento de la guardia, y "recuperar el terreno perdido",509.

Una visión que resulta interesante es la de "Lalo" Piñón quien observa que si bien por un lado las acciones del ERP ponían a TENSA "en el foco de los servicios de inteligencia", al mismo tiempo habrían tenido un efecto "disuasivo" que morigeró o contuvo, por momentos, la acción represiva de la empresa y de la "burocracia sindical" ya que éstos sabían que ante cualquier acción contra el movimiento de base existía una posibilidad latente de una "respuesta armada enfrente" 510.

\footnotetext{
${ }^{505}$ Mario Massolini ingresó a la fábrica en 1973. Si bien mantuvo diálogo con varias corrientes políticas nunca se incorporó a militar partidariamente en ninguna mantuvo su independencia como activista sindical de la fábrica.

506 "Había discusiones con ellos cuando venían a discutir ahí en la puerta de fábrica, le decíamos 'bueno muchachos eso no es política nuestra, ustedes tienen que respetar nuestra situación, ustedes vengan volanteen, distribuyan el periódico que acá nosotros no le vamos a decir nada, pero no se metan en la cuestión que concierne en la dirección del punto de vista gremial y político de la fábrica que lo estamos manejando nosotros'. Nosotros no nos metíamos en otra fábrica donde estaban ellos, para nada, nada que ver... el trabajo era así." Entrevista a Carlos "Lito" Gonzales por el autor, Diciembre de 2017.

${ }^{507}$ Una manifestación de ello fue la persecución a diferentes obreros independientes de la fábrica que, por el solo hecho de ser activistas, fueron catalogados como miembros del ERP, lo que les significó sucesivos allanamientos en sus viviendas e incluso, como en el caso de Carlos Luis Baynon, la detención. (Entrevista a Carlos Luis Baynon con el autor, Buenos Aires, 2018)

${ }^{508}$ Entrevista a Roberto Mereta por el autor, Junio de 2018

509“"Boletín fabril metalúrgico" DIPBA, Mesa D(s), Carpeta Varios, Legajo 1309

${ }^{510}$ Entrevista con Lalo Piñon, Buenos Aires, 2018
} 
Como se verá, es posible considerar que existieron dos etapas en el accionar del ERP sobre la fábrica: una primera, reseñada en el presente apartado, que comprende todo el año 73 y parte del año 1974, en la que los efectos de las acciones militares tendieron a fortalecer al movimiento de base de la fábrica $\mathrm{y}$, como indica Piñon, ayudaron a morigerar la acción represiva de la empresa y de la propia "burocracia sindical"; y una segunda, que comprende la última mitad del año 1974 (momento en que, como se verá, es derrotado el movimiento de base) hasta el golpe de 1976, en la que, a diferencia del período previo, perdieron su contacto con las demandas obreras y alimentaron el recrudecimiento de la respuesta represiva.

\subsection{La política sindical del PRT-ERP}

Respecto a su intervención sindical en TENSA, la participación del PRT-ERP se centró en los organismos de base. En ellos contó con la presencia de Robreto Mereta entre los miembros de la CIR, y con delegados en ambas plantas.

Las características de la intervención perretista variaron en ambas plantas en función de las condiciones políticas que ellas presentaban. En el caso de Munro estuvo condicionada por la cantidad de fuerzas políticas que intervenían en la agrupación "16 de enero". Allí, como se dijo, los perretistas convivían con militantes de VC, el PST y la JTP, de modo que la influencia estaba más repartida e, incluso, con un protagonismo preponderante de los primeros. Si bien la agrupación funcionaba como "eslabón intermedio" o "correa de trasmisión" entre el CD y el conjunto de la fábrica y, tal como indican la mayoría de los testimonios, el vínculo entre las organizaciones era “excelente", su carácter pluripartidario presuponía una disputa política en su interior y un límite a la influencia perretista ${ }^{511}$.

Por su parte en la planta de Pablo Nogués las condiciones eran distintas ya que allí no todas las fuerzas políticas tenían presencia. De hecho todos los testimonios coinciden en que la dirección "indiscutida" estaba en manos del PRT-ERP ${ }^{512}$, aunque existían militantes de base de la JTP. Esta primacía puede verse, por ejemplo, en el hecho de

\footnotetext{
511 Entre los militantes perretistas quienes más se destacaron fueron los hermanos Jesús Lautaro y Gerardo Cesar De La Rosa Aragón, Luis Alberto Sportuno Pérez (sección tornos) y Luis "el Tío" Arce (sección Mecanizado General), quienes, según los testimonios, eran obreros "muy respetados en sus secciones" (Entrevista a "Lalo" Piñon con el autor, Buenos Aires, 2018; Entrevista a Mario Massolini con el autor, Los Polvorines, 2018; Entrevista con Rubén Guerra con el autor, Buenos Aires, 2018).

512 "Lito" Gonzales plantea que en dicha planta la dirección era exclusiva del PRT-ERP y Mario Massolini lo confirma planteando que la influencia del PRT-ERP en aquella planta llegaba incluso hasta el personal administrativo (Entrevista con Carlos "Lito" Gonzales con el autor, Buenos Aires, Diciembre de 2017; Entrevista con Mario Massolini, Los Polvorines, Junio de 2018)
} 
que, de las dos plantas, la "Agrupación 16 de enero de Metalúrgicos de Nogués" fue la única que participó en el primer plenario del MSB, realizado el 8 de julio de 1973. Sin embargo en Pablo Nogués el funcionamiento de la agrupación era diferente al de Munro. Allí los militantes perretistas se reunían cotidianamente junto a los simpatizantes y discutían e impulsaban las propuestas de manera colectiva en reuniones que se organizaban espontáneamente o en función de algún conflicto específico. El funcionamiento era más laxo gracias a las dimensiones del depósito (50 operarios) y a la ausencia de disputa política. Incluso el propio Mereta, líder sindical de la planta, no recuerda que la agrupación se haya constituido como tal ya que en realidad funcionaba "de hecho",513.

Las diferencias en el tipo de intervención sindical que tuvo el PRT-ERP en cada planta también se manifestaron a nivel de funcionamiento partidario: en Munro, al estar más repartida la influencia entre las distintas organizaciones, se hacía necesario un funcionamiento más "tipo relojito"; mientras que en Pablo Nogués la presencia casi exclusiva del PRT-ERP posibilitaba una forma organizativa más "dispersa". Según Mereta ello le habría significado discusiones con sus responsables ya que, si bien mantenía las reuniones partidarias periódicamente, en la práctica tendía a construir en base a criterios propios y en función de lo que demandaba la práctica ${ }^{514}$.

Como indica Héctor Löbbe (2006), este fenómeno tendió a darse en varios casos en que los obreros con referencia política o activismo sindical ingresaban a un partido revolucionario, ya que allí tendían a hallarse en una negociación constante entre las exigencias del partido y la realidad que imponía día a día la fábrica. Así, muchos de ellos, como en el caso de Mereta, tendían a priorizar los tiempos y las necesidades que dictaba la práctica cotidiana y a resguardar la unidad y los acuerdos con los activistas de las otras organizaciones que actuaban en su mismo espacio, aunque ello significara salirse del libreto partidario.

\footnotetext{
513 Ídem

514 “La forma orgánica de funcionar era media dispersa, o sea, yo más que nada. Porque yo como te dije fui no muy orgánico ¿no? Era una cosa que me costaba que dos por tres me cagaran a pedos, pero bueno yo intenté siempre ser fiel a mis principios y si bien el manual sirve, a mí no me manejaba el manual, yo tenía como prioridad primero la necesidad de los compañeros, no solo de mi fábrica sino cuando se presentaban conflictos de otra fábrica ir a apoyar, las reivindicaciones que estaban siempre a la cabeza, y obviamente en todo momento que se pudiera tratar de ir armando línea, pero no era una... no es que tenía un funcionamiento tipo relojito (...) no, yo el funcionamiento periódico lo tenía con los responsables, eso sí era bastante orgánico, pero en lo referente a lo sindical, como yo tenía mucho contacto con todos los otros grupos sindicales, trataba más de mantener vivo eso (...) A mí me parecía más importante mantener vivo el vínculo con los otros sectores que estaban dentro de la fábrica que estar todo el tiempo juntándonos afuera para decidir cosas que después no se pueden hacer adentro viste." (Entrevista a Roberto Mereta con el autor, Buenos Aires, 2018)
} 
Ahora bien, más allá de estas diferencias que existían entre las plantas, los perretistas partían de un mismo criterio a la hora de intervenir sindicalmente. Uno de ellos fue la clandestinidad: en ambas plantas quienes oficiaban de dirigentes sindicales o delegados no eran públicamente reconocidos como militantes perretistas. Ello, por ejemplo, es lo que hace que activistas independientes como Blas Obella ${ }^{515}$ (planta Pablo Nogués) y Carlos Luis Baynon (delegado de la planta Munro) ${ }^{516}$, considerasen que el PRT-ERP no tenía participación de la vida gremial de la fábrica ${ }^{517}$. Esta modalidad se profundizó a medida que la situación represiva fue recrudeciendo. Como indica Roberto Astudillo, la organización intervenía "con personas que no estaban descubiertas" e intercalaban la intervención en las asambleas para evitar que los militantes fueran identificados como tales $^{518}$. Así, a diferencia de los militantes de VC, los perretistas dedicados a la tarea sindical no buscaban referenciarse públicamente con la organización.

El esfuerzo de los sindicalistas del PRT-ERP estaba puesta en intentar que los trabajadores, incluso el resto de las agrupaciones, asumieran las consignas y la línea partidaria sin que esto fuera explícito. Así según Mereta:

“(...) en un principio como digo a mi básicamente lo que me pedían es que mantuviera las consignas junto con los otros compañeros de las otras agrupaciones. Me pedían que tratara de mantener las consignas, de mantener agrupado a nuestro sector, y que las reivindicaciones que levantáramos tuvieran que ver con la línea del partido. Entonces tratábamos de mantener el pedido de reivindicaciones dentro de la línea del partido, pero a veces había que hacer unas concesiones dentro de lo que planteaban los otros sectores y se hacían (...) las primeras reivindicaciones eran de orden salarial, de orden de condiciones de trabajo, pero siempre nosotros tratábamos de bajar línea respecto de cuál era la verdadera condición del obrero, o sea a qué teníamos que aspirar. Siempre subíamos la vara, obviamente no íbamos a pedir el control de los medios de producción, pero si permanentemente tratábamos de hacerle saber a la gente que había formas de producción donde el obrero podía ser el dueño de esos medios de producción (...) o sea tratábamos hacer entender la plusvalía (...) La línea la bajabas bien cuando se tomaba la fábrica, ahí si el discurso era de tipo socialista puro, pero porque se podía... yo como gremialista no podía ir a fondo con esas cosas."

Como se ve, si bien debía buscarse "subir la vara", intentando darle una explicación tácitamente marxista a las vicisitudes de la vida fabril, el militante dedicado al trabajo

\footnotetext{
515 Obella trabajó 9 años en la planta. Obrero independiente, identificado con el peronismo, acompañó al movimiento de base de la fábrica durante todo el período.

${ }^{516}$ Baynon ingresó a la fábrica a principio de los años 1970. Anteriormente había trabajado en la fábrica Deutz Cantábrica, donde trabajó junto a José Sabino Navarro. Activista independiente, fue miembro de la CIR y perseguido por la burocracia sindical y la policía, al punto de ser detenido en su propia casa en 1974.

${ }^{517}$ Entrevista a Carlos "Lito" Gonzales por el autor, Diciembre de 2017; Entrevista a Carlos Luis Baynon por el autor, Junio de 2018

${ }_{518}$ Entrevista a Roberto Astudillo por el autor, Diciembre de 2017.

${ }^{519}$ Entrevista a Roberto Mereta por el autor, Marzo de 2018
} 
gremial debía respetar el papel de sindicalista evitando asumir un discurso "partidario". En ese sentido la "bajada de línea" explícitamente partidaria estaba a cargo de los militantes extrafabriles que participaban en acciones como las tomas de la planta o incluso con los volanteos en las puertas de la fábrica. No obstante, existían espacios y momentos donde los militantes de la fábrica debían y podían profundizar los planteos e "ir más a fondo" con los debates políticos:

“(...) solíamos tener mini reuniones con la gente y ahí se hablaba un poco más a fondo de política (...) habíamos logrado que nos la dieran como oficinita sindical, entonces por ahí a la hora de comer a la hora del desayuno nos juntábamos algún grupito y charlábamos de política, ahí sí, pero porque era más tipo tertulia. Pero cuando íbamos por una reivindicación, bueno ahí uno hacía una alocución y obviamente uno tenía que medir ahí, ahí era la reivindicación, no me podía poner a hacer un discurso político." ${ }^{250}$

En su rol de delegados los militantes perretistas debían apuntar a transformarse en dirigentes modelo, entregados a la causa de los trabajadores, "incorruptibles" y "combativos". Ese debía ser el punto de partida desde el cual construir vínculos de confianza con sus compañeros y lograr forjar una conciencia antipatronal y antiburocrática independientemente de sus filiaciones políticas. Ello se ve claramente en el testimonio de Blas Obella:

"Entrevistador: ¿Y usted sabía que Mereta y Bartolomé Da Silva participaban en el ERP? Blas: ¡No, no! Eso nunca lo supe, eso nunca lo supe... porque se ocultaba todo. Ahora, ¿que fueron luchadores? te puedo decir mil veces que sí, luchaban para los obreros. Había plata de por medio para darles y nunca se quisieron vender. ¿Los delegados? Ninguno, los de TENSA no se quisieron vender. Había otros que sí, pero Mereta, Babuya [y Da Silva] nunca! Mira que había plata eh! Le daban plata para que se vayan! Y no, no dejaron a los obreros. $" 521$

Además esa referencia construida les debía permitir detectar a aquellos obreros que demostraran interés en la política revolucionaria (o demostraran entusiasmo luego de alguna acción del ERP) para sumarlos a la organización u organizarlos en su órbita.

En base a ese trabajo los militantes organizaban el "radio de influencia", es decir el conjunto de personas a las que debían "atender" haciéndoles conocer la línea de la organización, la prensa y los distintos materiales de propaganda con que contaban. Estos trabajadores eran "simpatizantes" o "contactos" que, organizados por las células fabriles, cumplían algunas tareas dependiendo del nivel de compromiso que estaban dispuestos a asumir. Como indica Astudillo se trataba de un "trabajo de hormiga" a través del cual se iba construyendo el partido:

\footnotetext{
520 Ídem

${ }^{521}$ Entrevista a Blas Obella por el autor, Buenos Aires, 2018.
} 
"Al partido hay que hacerlo como las hormigas. Después de haber captado [al obrero] los podes traer con vos, te puede servir. Si va a ser solamente un simpatizante te das cuenta, si va a ser un militante te das cuenta, o si va a ser solamente colaborador ¿no? Y eso sucedía (...) Y así tomas contacto con uno y discutís con el otro para resolver una cosa, para envolverlo. Y después lo empezás a acercar, si es de tu palo lo empezás a acercar y de esa manera, como te decía antes, puede ser un colaborador que te puede ofrecer la casa para hacer las reuniones, que te puede dar una mano pasándote unos mangos, puede hacer mil cosas ¿no?”

Una de las herramientas que facilitó a esa tarea fue el "Boletín Fabril Metalúrgico de los compañeros de TENSA", órgano del PRT-ERP. Creado a mediados del año 1973, en el editorial de su segundo número, fechado el 29 de agosto, se consignaba que el boletín surgía "como necesidad de muchos compañeros" para denunciar y divulgar todo lo que ocurría en la fábrica dándole una interpretación política ${ }^{522}$. A su vez se planteaba como un vehículo para conocer la historia de lucha del movimiento obrero y de sus "mártires" así como las bases del proyecto socialista. Se proponía además dar a conocer semanalmente las acciones de la organización y ser un espacio para la libre discusión ${ }^{523}$. En el mismo se identificaba como "enemigos" a la patronal, encarnada en Germán Figaredo, a los "traidores" y "alcahuetes" y a las fuerzas represivas, tanto a la policía como a la empresa de seguridad "Vanguard S.A". A su vez se planteaba como objetivos sindicales principales "acabar con las humillaciones y el trato policial ejercido por capataces", así como mejorar las condiciones de trabajo y obtener salarios "dignos". En ese marco se advertía sobre los planes "expansivos" de la empresa y su consecuente necesidad de "descabezar" al movimiento combativo de la fábrica. Denunciaba la complicidad entre la empresa, la Juventud Sindical Peronista (JSP) y la UOM y alertaba sobre posibles provocaciones para garantizar "despidos justificados",524.

Según Astudillo, algunos artículos para este tipo de materiales salían de la discusión con los trabajadores y los colaboradores quienes, a través de sus opiniones, ayudaban a construirlos e incluso, en algunos casos, a escribirlos. El boletín fabril se entregaba afuera de la fábrica por equipos de propaganda que, armados, entregaban en mano los materiales $^{525}$. Ello, según Mereta, conspiraba contra la regularidad de su salida ya que la

\footnotetext{
522 "Boletín Fabril Metalúrgico de los compañeros de TENSA” DIPBA, Mesa Ds, Varios, Leg. 1309

${ }^{523}$ En esa dirección el ejemplar incluía distintos tipos de notas que hablaban de las acciones realizadas por la organización de la zona, denunciaban los planes represivos de la empresa, e incluso convocaban a formar comandos de apoyo al ERP y un instructivo sobre como armar bombas "molotov"

${ }^{524}$ DIPBA, Mesa Ds, Varios, Leg. 1309

${ }^{525}$ Un informe de la DIPBA deja en claro la metodología que utilizaban para repartir el boletín fabril: "Realizadas averiguaciones, se establece que el material adjunto, "BOLETIN FABRIL METALÚRGICO” No. 2 editado por el Partido Revolucionario de los Trabajadores, dirigido a los compañeros de Tensa, fechado el 29 de agosto, fue distribuido mano en mano, por un grupo de jóvenes de
} 
posibilidad de realizar los repartos dependía de la situación represiva y el clima de la fábrica.

Según los testimonios, esta forma de militancia política y sindical, junto al accionar del ERP, permitieron generar una influencia considerable entre los trabajadores de ambas plantas, sobre todo en el depósito de Pablo Nogués, donde lograron organizar en células a aproximadamente siete militantes (lo que para un plantel de 50 operarios era un número importante), tener a todos los delegados ${ }^{526}$, y un amplia red de simpatizantes ${ }^{527}$. Ello se habría manifestado incluso fuera de la fábrica, por ejemplo, con la participación de algunos trabajadores de TENSA en el V Congreso del FAS, realizado en la provincia de Chaco en noviembre de 1973, junto a la delegación del PRT-ERP que había viajado con trabajadores de la zona.

En base a este nivel de inserción y esta metodología de intervención el PRT-ERP participó de todas las luchas que emprendió el movimiento de base de la fábrica desde el triunfo de enero hasta el golpe de 1976. A continuación se buscará reconstruir los principales acontecimientos que protagonizaron los trabajadores de TENSA para, a partir de ellos, analizar el derrotero perretista e intentar comprender algunas claves de su experiencia.

\subsection{Tensa "globo de ensayo" de López Rega}

El triunfo de enero y la elección de la CIR y el CD, cambiaron la situación de la fábrica inmediatamente. La primera conquista se dio en el mes de abril, a pocos días del triunfo electoral. Los trabajadores, encabezados por la nueva conducción, construyeron un petitorio que llevaba entre sus puntos principales la mejora en materia de comedor, insalubridad, ropa de seguridad y el reclamo por la reincorporación de tres despedidos. Luego de una semana sin respuesta, el viernes 27 de abril, el turno noche decidió iniciar un quite de colaboración que luego fue acatado por el conjunto de los turnos. El personal, reunido en asamblea, decidió darle tiempo a la empresa hasta el viernes 4 de mayo para que dé una respuesta positiva y, en caso de no recibirla, tomar nuevas medidas de fuerza. Finalmente, el día pautado, consiguieron la reincorporación de uno

ambos sexos, armados con ametralladoras y protegidos por una pick-up como grupo de apoyo, frente a la planta de Munro y siendo las 06,00hs. Entrada y salida del personal de obreros." (Mesa Ds, Carpeta Varios, Legajo 994)

${ }^{526}$ Roberto Mereta, Bartolomé Da Silva y Juan Carlos Chersanaz Burgos, militantes perretistas, fueron los delegados de la planta.

527 Según Mario Massolini la lectura de El Combatiente en Pablo Nogués era tan extendida que hasta los administrativos lo tenían. (Entrevista a Mario Masolini por el autor, Buenos Aires, Julio de 2018) 
de los despedidos (los otros dos optaron por aceptar el despido y cobrar la indemnización) y el compromiso de resolver todos los problemas planteados, en el plazo de un mes ${ }^{528}$. En poco tiempo, la empresa tuvo que equipar a los trabajadores en ropa de trabajo adecuada, mejorar la seguridad de las máquinas, realizar obras de ventilación e incorporar a los representantes obreros en las discusiones sobre productividad y métodos de trabajo ${ }^{529}$.

La puesta en ejercicio de un modelo de "democracia sindical" basado en la acción directa y los métodos asamblearios fue la clave que les permitió a los trabajadores de TENSA conseguir, durante el año 1973, muchas de estas demandas. Básicamente el mecanismo se basaba en las asambleas de sector en las que se organizaban las reivindicaciones específicas y, en base a ello, el CD semanalmente armaba pliegos de demandas que eran discutidas con el jefe de personal o de producción. Finalmente los resultados de aquellas reuniones se publicaban en la vitrina de informes sindicales y se socializaban a través de la recorrida de los miembros de la CIR por las diferentes secciones y turnos. Ese proceso cotidiano, a su vez, era acompañado por asambleas generales de fábrica en las que se realizaban balances o se discutían temas generales.

De este modo, al poco tiempo se fue operando un cambio en la correlación de fuerzas al interior de las plantas: los militantes de Gregorio Minguito debieron replegarse y los supervisores y capataces debieron morigerar sus maltratos para que su despido no esté entre las exigencias de los trabajadores ${ }^{530}$, o, peor aún, para no ser objeto de represalias por parte del ERP. Un claro ejemplo que ilustra este cambio en la situación es relatado por Roberto Mereta:

"Un día nosotros solicitamos que nos construyeran un comedor y, como a todo, te decían que sí. Paso un mes, pasaron dos meses, dos meses y medio y no habían construido el comedor. Entonces un día con Horacio [Babuya], agarramos los platos de comida y nos fuimos a las oficinas, que eran enormes. Entramos, cada uno se fue a un escritorio, y barrimos con las carpetas ¡todo al suelo! Horacio puso el plato arriba y se sentó a comer y yo hice lo mismo. Los supervisores todos parados y callados y nosotros en silencio comiendo. Terminamos de comer, nos paramos y nos fuimos. Creo que en 15 días construyeron el comedor."

\footnotetext{
528 "Tensa: para qué sirve una comisión combativa." Avanzada Socialista Nro. 58, miércoles 9 de mayo de 1973

${ }_{529}$ Entrevista con Lalo Piñon con el autor, Buenos Aires, 2018

${ }^{530}$ En el marco del conflicto abierto el 16 de enero, una de las reivindicaciones que consiguieron los trabajadores fue la expulsión de un Jefe de Personal. (Entrevista a "Lalo" Piñon con el autor, Buenos Aires, 2018 )

${ }^{531}$ Entrevista a Roberto Mereta por el autor, Marzo de 2018
} 
Este nuevo escenario fue fruto de la combinación de un conjunto de hechos que se dieron en un corto tiempo y que ayudaron a consolidar la confianza de los trabajadores en sus propias fuerzas: el triunfo sindical del 16 de enero, el secuestro del gerente y las demás acciones del ERP, la consolidación de la nueva conducción gremial y la satisfacción de demandas históricas. A todo esto, además se le agregaba el hecho de que TENSA era la fábrica más grande de la zona y la primera en derrotar a las fuerzas de Gregorio Minguito en elecciones de CIR, lo que la transformó rápidamente en un ejemplo para el resto de las fábricas y en una articuladora de las demás experiencias antiburocráticas de la zona (como EMA, Corni y Del Carlo).

No obstante, esto mismo fue lo que llevó a que la empresa, las fuerzas represivas y, en particular, la conducción de la UOM Vicente López, dispusieran de todas sus fuerzas para derrotar aquella experiencia. Desde el momento mismo en que se conformó la nueva CIR, la empresa fue fortificando la vigilancia a través de la seguridad privada y la incorporación de "alcahuetes" de la UOM y agentes de policía a trabajar en la fábrica ${ }^{532}$. Por su parte, desde mediados de año, la "burocracia sindical" comenzó con sus ataques sobre los trabajadores. Para entonces, Victorio Calabró ya se había consolidado como vicegobernador de la provincia de Buenos Aires y las bandas parapoliciales, con una importante participación de las "patotas" de la UOM, habían inaugurado su contraofensiva en la "masacre de Ezeiza".

La primera acción resonante de estos grupos se dio el 16 de octubre. Aquel día un grupo de la JSP ingresó a la planta de Munro y a punta de pistola intentó amedrentar a los trabajadores para que se pronunciaran contra la CIR. Sin embargo no lo consiguieron: inmediatamente se convocó una asamblea que repudió a los "matones" y ratificó a los dirigentes del organismo. Como consecuencia, al otro día, un grupo de 5 obreros fueron atacados a balazos y detenidos por la policía mientras realizaban una pintada en las paredes de la fábrica, lo que motivó la movilización de los obreros de ambas plantas encabezados por la CIR a las comisarías de la localidad de Caseros donde pudieron dar con el paradero de los trabajadores implicados ${ }^{533}$. Semanas atrás un grupo no identificado había golpeado a cadenazos a uno de los delegados fuera de la fábrica y, a

\footnotetext{
${ }^{532}$ DIPBA, Mesa D(s), Carpeta Varios, Legajo 1309; DIPBA, Mesa D(s), Carpeta Daños, Legajo 2421

${ }^{533}$ El Mundo, jueves 22 de octubre de 1973; Nuevo Hombre Nro. 50. $1^{\text {a }}$ quincena de noviembre de 1973; "Victoria obrera en Tensa (Munro)" El Combatiente Nro. 97. Miércoles 14 de noviembre de 1973
} 
su vez, varios de los activistas habían recibido amenazas de muerte ${ }^{534}$. No obstante, el golpe final se dará recién a mediados de 1974.

\section{4, el año de la contraofensiva}

Hasta ese momento la CIR siguió encabezando los reclamos obreros y manteniendo la solidaridad con muchos de los conflictos desarrollados en fábricas de la zona (como los de Terrabusi y Del Carlo). De hecho, el trabajo de coordinación y contacto con otras experiencias antiburocráticas fue contribuyendo para que, a principios de 1974, se conformara la Lista Gris, agrupamiento que buscó disputar la conducción de la UOM Vicente López. La conformación de esa lista fue el resultado de una serie de plenarios de delegados de fábricas ${ }^{535}$ y acuerdos entre las principales fuerzas políticas que actuaban en la zona (PST, PO, VC, el PRT-ERP, la JTP y el PCA) ${ }^{536}$. Por su parte, los delegados de TENSA tuvieron una rol protagónico, participando activamente del Congreso de Delegados Seccionales y posteriormente de la mesa de dirección de la Lista Gris, compuesta por delegados de las fábricas Corni, EMA, ASTARSA e IPSA. A su vez fue una de las fábricas candidatas a ocupar la cabeza de la lista, que finalmente fue ocupada por los obreros de la metalúrgica Corni ${ }^{537}$. Sin embargo, la experiencia no llegó a consumarse: la lista fue proscripta por una maniobra de la UOM en la modificación de los estatutos que les prohibió presentarse ${ }^{538}$.

En cuanto al PRT-ERP todo indica que habría tenido una participación segundaria en esta experiencia. Esto se advierte en el hecho de que los plenarios y la conformación de la lista no tuvieron prácticamente repercusión en los medios de prensa de la

\footnotetext{
534 Ídem

${ }^{535}$ Entre las principales fábricas participaron: Corni, Del Carlo, EMA, ASTARSA, BICCIÚ, Buffalo, OTIS, PENSA, METLCOR, CORMASA, Wobron, Kinittax, Shulman, Singer, PENSA, etc. (Avanzada Socialista Nro. 91, semana del 7 al 14 de febrero de 1974; Política Obrera Nro. 185, 2 de febrero de 1974)

${ }^{536}$ Si bien la JTP y el PC participaron de los congresos que dieron vida a la Lista Gris, e incluso impusieron el nombre Felipe Vallese y la consigna "Liberación o Dependencia", terminaron levantándose de la última reunión abandonando el armado por oponerse a que se incluyera entre las reivindicaciones un rechazo al pacto social.

${ }^{537}$ Según "Lito" Gonzales la disputa entre Corni y TENSA en realidad encubría una disputa abierta y encarnizada entre VC y el PST, fuerza que terminó ubicando a militantes propios en lugares de conducción de la lista.

538 "La Lista Gris de oposición de la Seccional Vicente López, Prov. De Bs As, debía reunir 22 delegados entre titulares y suplentes, con cuatro años de afiliados al sindicato, dos años de antigüedad en la empresa y ser o haber sido delegado. La lista debía además contar con el aval de 2.350 firmas de afiliados y del 10 por ciento de delegados de la seccional. Es interesante resaltar que la inmensa mayoría de los trabajadores de la zona están de vacaciones y que se reintegran al trabajo, 'casualmente' en la misma fecha en que comienzan las elecciones." (No Transar Nro. 131 (Nro. 4 nueva edición), 6 de marzo de 1974). Sobre la denuncia a la proscripción también se hallan artículos en las siguientes publicaciones: Avanzada Socialista Nro. 93, última semana de febrero de 1974; Política Obrera Nro. 186, 16 de febrero de 1974;
} 
organización. Además, para el caso de los representantes de TENSA, Mereta, quien podría haber sido la expresión perretista de la lista, indica que fueron los militantes de VC quienes estuvieron al frente de ese proceso ${ }^{539}$.

El fracaso de esta experiencia -Lista Gris- dio impulso a la reacción burocrática en la zona y, especialmente en TENSA. A nivel provincial se había forzado la renuncia del gobernador Oscar Bidegain luego de los "hechos de Azul" y en su reemplazo había asumido el vicegobernador Victorio Calabró, por lo que las condiciones para la contraofensiva en la fábrica se potenciaron. A su vez, en ese contexto, en abril, debían realizarse nuevas elecciones de CIR en las que la agrupación "16 de enero" debería revalidar su mandato.

Es importante remarcar que para ese momento había existido un conflicto al interior de la CIR con uno de los miembros, quien habría aceptado una propuesta de capacitación de la empresa que lo comprometía con la patronal y lo desacreditaba ante sus compañeros, generando rispideces al interior de la agrupación. Este hecho habría sido utilizado por la "burocracia" para desprestigiar a la conducción y se sumaba a la campaña maccartista que venían sosteniendo contra los dirigentes de la fábrica, a los cuales se acusaba de "trotskos", "comunistas" y "traidores" ${ }^{540}$. Es de destacar que estos sectores habían recuperado terreno al interior de la fábrica: como indica "Lalo" Piñon, habían "aprendido" de la derrota y, de poco, fueron recobrando legitimidad a través del trabajo de base que realizaban algunos activistas "inteligentes", como José Chirino, quienes levantaban algunas reivindicaciones sentidas por sus compañeros ${ }^{541}$.

Finalmente, las elecciones se llevaron a cabo y, con denuncias de fraude, la JSP termino haciéndose de la conducción desplazando a la agrupación "16 de enero" "542. Con ello se asestaba un duro golpe al movimiento de base de la fábrica sobre el cual, posteriormente, tanto la "burocracia" como la empresa se iban a montar para terminar de descabezarlo.

\footnotetext{
${ }^{539}$ Entrevista a Mereta con el autor, Buenos Aires, 2018

${ }^{540}$ Entrevista a Lalo Piñon con el autor, Buenos Aires, 2018.

541 Ídem

${ }^{542}$ Existen diferentes versiones sobre como fue llevado adelante el fraude. Según Lalo Piñon la burocrácia habría llenado de votos las urnas; según Floreal Avellaneda, obrero de Munro y militante del PCA, los representantes del sindicato junto a los del ministerio de trabajo habrían realizado el conteo en el turno noche, momento de menor movimiento en la fábrica y habrían decretado el triunfo. Por otro lado según Baynon la UOM separó a la planta de Munro de la de Pablo Nogués inscribiendo a esta última en la seccional San Miguel para evitar que los votos de esta última planta torcieran la elección a favor de la agrupación 16 de enero (Entrevista a Carlos Luis Baynon con el autor, Buenos Aires, 2018; Entrevista a Lalo Piñon con el autor, Buenos Aires, 2018; Entrevista a Floreal Avellaneda, Memoria Abierta.)
} 
En el balance de la derrota que hacía el PRT-ERP, la organización hacía foco no tanto en la maniobra fraudulenta como en errores de la propia conducción combativa:

"Algunos errores cometidos por los compañeros combativos, fundamentalmente el hecho de no haberse sabido dar una política que permitiera la participación activa del conjunto de los compañeros en la lucha cotidiana, aún de los sectores menos concientes y la actitud débil frente a un elemento capitulador de la interna, dieron pie a una serie de maniobras de la patronal y la burocracia, que permitieron que en las elecciones realizadas el corriente año, la interna volviera a manos de la burocracia de la UOM"543

Como se ve, desde su óptica el problema principal no era el fraude, sino las condiciones que lo habían permitido. Desde la concepción perretista la conducción de TENSA había cometido uno de los "errores" clásicos de muchas CIR o sindicatos "recuperados": con el afán de solucionar todas las demandas postergadas y los problemas que se les presentaban cotidianamente (administrativos, de conducción, de negociación, de organización, etc.) las nuevas conducciones tendían a resolver todas las cuestiones consultando a las bases pero sin involucrarlas lo suficientemente como para que el apoyo recibido se transformase en un avance de la conciencia y del compromiso con el proceso de lucha ${ }^{544}$. Algo de esto deja entrever el testimonio de Piñon quien remarca que estar al frente de la CIR era desgastante por la cantidad de tareas y de tiempo que requería y porque, muchas veces, los obreros terminaban descansando en ellos para resolver problemas incluso no estrictamente sindicales ${ }^{545}$.

Por su parte, $\mathrm{VC}$, en su balance, hacía eje exclusivamente en que el triunfo de los leales a Minguito había sido fruto exclusivo de "la trampa y el fraude"

Ahora bien, la derrota electoral no significó el aplastamiento definitivo del movimiento de base. La agrupación "16 de enero" continuó teniendo incidencia entre los

\footnotetext{
543 “TENSA: 'globo' de ensayo de López Rega”, El Combatiente Nro. 129, miércoles 7 de agosto de 1974 544 "Algunas tareas en sindicatos recuperados", El Combatiente Nro. 156 del 24 de febrero de 1975

545 "Estábamos todo el tiempo en la fábrica, había tres turnos y yo muchas veces hacía los tres turnos. Me quedaba a la mañana, a la tarde y a la noche, para ver a los diferentes compañeros. Uno terminaba arreglando todos los problemas, te decían 'no me alcanza la plata' y vos ibas y gestionabas el anticipo, o temas así. Era un poco pesado a veces, porque los compañeros empezaban tener confianza y bueno a veces empiezan a pedir cosas que no tienen que ver con lo específico, pero bueno había una necesidad y tratábamos de responder a la necesidad. Asique eso nos dio mucho prestigio." (Entrevista a Lalo Piñon, Buenos Aires, 2018)

546 "En abril, para que la lista que representa a Minguito en las elecciones de CI triunfe, deben recurrir al fraude. Su lenguaje es claro. Ganan con trampa y fraude. Y si no les alcanza, cosa que les puede suceder cada vez con más frecuencia, golpean, agreden." ("TENSA. El matonaje no pasara" No Transar Nro. 141 (Nro. 14 nueva edición), Buenos Aires, 7 de agosto de 1974)

547 Es de destacar que no hemos encontrado balances públicos o análisis de las demás organizaciones que intervenían en las plantas. El PCA, por ejemplo, solo mencionan en su prensa que la CIR había sido recuperada con fraude por el oficialismo de la UOM pero no realiza un balance de la derrota electoral (Nuestra Palabra Nro. 56 (Segunda época), 1 de agosto de 1974)
} 
trabajadores y fue desarrollándose en enfrentamientos por momentos silenciosos y por momentos abiertos con la empresa y la nueva conducción de la CIR.

En ese nuevo escenario el ERP continuó actuando, aunque con menor intensidad: el 21 de marzo un comando procedió a copar la clínica en la que se atendía al personal de TENSA donde interrogaron a los profesionales médicos "sobre su actividad al servicio de la patronal" 548 ; y el 24 de mayo, nuevamente, se dio un copamiento de la planta Munro, donde repartieron el periódico Estrella Roja y arengaron a los obreros. La acción terminó en un tiroteo con la policía, del cual un agente resulto herido de $\operatorname{gravedad}^{549}$.

Mientras tanto, la situación en la fábrica seguía convulsionada y, a pesar de haber recuperado la CIR, los delegados de la UOM no poseían la representatividad que sí seguían teniendo los miembros de la agrupación. De hecho, según relatan los testimonios, la propia empresa terminaba quejándose ya que los acuerdos a los que arribaban con los nuevos delegados no eran respetados por las bases que, muchas veces, de manera espontánea adoptaban medidas de fuerzas ${ }^{550}$. En este contexto el sindicato decidió terminar definitivamente con el movimiento de base.

El 25 de julio, en el marco de una asamblea que había convocado la agrupación "16 de enero" sin la autorización de la conducción oficial, en la que se exigía que los nuevos delegados rindieran cuentas de sus negociaciones con la empresa, los nuevos miembros de la CIR montaron una provocación diciendo que allí se estaba gestando un organismo paralelo e ilegitimo. Con esa excusa permitieron el ingreso de un grupo de personas del sindicato quienes expulsaron a los activistas a punta de pistola del establecimiento. En los hechos se trató de una toma total de la planta de Munro: los personeros del sindicato intentaron, mediante amenazas, que los trabajadores votaran en una asamblea a favor de la expulsión de los activistas pero, como no lo lograron, terminaron obligándolos a reanudar el trabajo y se apostaron en los techos de la planta custodiando que no regresaran los obreros expulsados. Con el control del establecimiento, el grupo de la UOM, junto a la CIR, se reunió con la empresa y le exigieron el despido de 27 obreros. Mientras tanto estos últimos se trasladaron a la planta de Pablo Nogués en búsqueda de la solidaridad de sus trabajadores, quienes los recibieron para marchar desde allí nuevamente hacia Munro. Al llegar la fábrica ya estaba desalojada, aunque al otro día la

\footnotetext{
548 “Crónica de la guerra revolucionaria” Estrella Roja Nro. 32, lunes, 10 de abril de 1974

549 “Crónica de la guerra revolucionaria” Estrella Roja Nro. 35, 1ro de julio de 1974

${ }^{550}$ Entrevista a Lalo Piñon con el autor, Buenos Aires, 2018; Entrevista a Mario Masolini con el autor, Los Polvorines, 2018.
} 
empresa confirmó los despidos acusando presión del organismo sindical ${ }^{551}$. Entre los despedidos estaban la mayoría de los militantes de VC, y algunos activistas del ex $\mathrm{CD}^{552}$. Por su parte, el PRT-ERP no sufrió bajas significativas ya que Mereta, su principal referente, al ser obrero de Pablo Nogués no fue incluido en los listados.

Inmediatamente los trabajadores, junto a los despedidos, organizaron una huelga por tiempo indefinido hasta tanto reincorporaran a los cesantes. Sin embargo, como veremos, el proceso de resistencia tuvo un límite y la huelga fue finalmente derrotada.

\subsection{La huelga: un punto de inflexión}

La huelga comenzó inmediatamente después de que se conociera la noticia de las cesantías y tuvo una duración de aproximadamente un mes, aunque las primeras dos semanas fueron las de mayor intensidad y acatamiento ${ }^{553}$. La misma estuvo garantizada desde afuera de la fábrica por los trabajadores despedidos y demás activistas quienes impulsaron, entre otras cosas, ollas populares, piquetes de huelga, comisiones de solidaridad, volanteadas en colectivos y en la estación de trenes, etc. Según los periódicos Noticias ${ }^{554}$ y El Combatiente, la medida alcanzó un nivel de acatamiento del $80 \%$ del personal de Munro y de la totalidad de los trabajadores de Pablo Nogués ${ }^{555}$. La violencia fue, desde el principio, un común denominador del conflicto, siendo el sindicato y las fuerzas represivas del estado los principales protagonistas en ese sentido. De hecho, la primera asamblea que dio inicio al plan de lucha fue reprimida por la policía. A su vez, al interior de la fábrica y en alrededores, la actividad de grupos de la JSP se intensificó, y el amedrentamiento (a punta de pistola o con golpizas) de los obreros que entraban a trabajar, o que realizaban alguna actividad en apoyo a la huelga, fue una constante ${ }^{556}$. Ello se complementaba con la persecución interna organizada por

\footnotetext{
${ }^{551}$ Avanzada Socialista Nro. 114, 1 de agosto de 1974

552 Según "Lito" Gonzales, luego de los despidos quedaron solo dos militantes de VC (Entrevista con el autor, Buenos Aires, 2017)

${ }^{553}$ Es de destacar que el caso de TENSA fue asumido por el diputado Rodolfo Ortega Peña, que el día después de haber presentado los pedidos de explicación por los despidos al Poder Ejecutivo fue asesinado por un comando de las Triple A. (Noticias Nro. 245, viernes 2 de agosto de 1974)

${ }^{554}$ El diario Noticias fue una publicación lanzada por Montoneros entre 1973 y 1974, año en que fue clausurado por el gobierno de Isabel Perón. Dirigida por Miguel Bonasso, en total publico 267 números. En ellos escribieron y colaboraron Juan Gelman, Rodolfo Walsh, Horacio Verbistsky, Francisco Urondo y Norberto Habegger.

${ }_{555}$ Noticias Nro. 245, viernes 2 de agosto de 1974; “TENSA: 'globo' de ensayo de López Rega”, El Combatiente Nro. 129, miércoles 7 de agosto de 1974

${ }^{556} \mathrm{Al}$ interior de la fábrica durante toda la huelga persistieron, portando armas, miembros del sindicato ajenos a la empresa en las oficinas de personal. Además los trabajadores que ingresaban a trabajar eran amedrentados y amenazados por los delegados. Por otro lado, autos con gente armada merodeaban constantemente por los lugares de reunión de los huelguistas y, por las noches, atacaban las viviendas de
} 
"Vanguard S.A" que requisaba a todos los trabajadores que ingresaban a trabajar reteniéndoles cualquier material sospechoso de ser "subversivo",557.

Por su parte el PRT-ERP buscó organizar a los trabajadores para responder a estas agresiones. Desde su punto de vista para hacer triunfar la huelga debían garantizarse tres pilares fundamentales: la organización de la autodefensa obrera para responder a los ataques antes descriptos; la organización de la solidaridad de distintos sectores de la sociedad para evitar el aislamiento; y la unificación de las luchas con distintas fábricas de la zona para darle una perspectiva más amplia al conflicto ${ }^{558}$.

En cuanto a la autodefensa el ERP organizó grupos de obreros y militantes armados que actuaron resguardando los piquetes y ollas populares para repeler cualquier ataque. De hecho existieron algunas escaramuzas en distintos lugares e incluso se dio un enfrentamiento: en un piquete de huelga, un grupo de sindicalistas de la UOM, apoyados por la policía, agredieron a tiros la manifestación y se encontraron con la resistencia armada de estos grupos quienes los obligaron a replegarse en la fábrica ${ }^{559}$. Para los perretistas éste y otros ejemplos, eran la demostración "en la práctica" de la importancia del desarrollo de la lucha armada ligada al movimiento obrero en general y para el caso de TENSA en particular ${ }^{560}$.

En cuanto a la solidaridad y la unificación de las luchas con fábricas de la zona, fue un aspecto impulsado por todas las fuerzas políticas intervinientes y tuvo importantes resultados. En las asambleas participaron trabajadores de diferentes establecimientos y sindicatos como FATE Electrónica, quienes además realizaron un paro de 15 minutos en apoyo a TENSA; obreros de Texas Instruments; trabajadores de la UTA, Santard Textil, Warco, Martin Amato, EMA, la FGB, el Sindicato Capital Gas del Estado,

algunos de los despedidos ("Tensa: siguen los matones" Avanzada Socialista Nro. 116, 13 de agosto de 1974)

${ }^{557}$ Noticias Nro. 256, miércoles 14 de agosto de 1974

558، "TENSA: 'globo' de ensayo de López Rega”, El Combatiente Nro. 129, miércoles 7 de agosto de 1974

${ }^{559}$ La acción es relatada en El Combatiente donde se consigna que la burocracia y la policía se vieron obligados a retroceder. Ello es confirmado por Lito Gonzales quien fue testigo presencial y confirma que "no hubo muertos por casualidad". Por su parte "Tito", quien participó directamente de la acción en calidad de responsable de la zona, nos comenta: "yo me acuerdo haber participado en un piquete de huelga que fuimos y llego la burocracia y ahí nos cagamos a tiros... cuando ellos se cruzaron así nosotros desenfundamos y los cagamos a tiros... por supuesto que después de eso nosotros nos fuimos cagando." (Entrevista a Tito por el autor, Cafayate, 2018)

560،"TENSA: 'globo' de ensayo de López Rega”, El Combatiente Nro. 129, miércoles 7 de agosto de 1974 
etc. ${ }^{561}$ Además se formó una comisión integrada por las organizaciones políticas que se solidarizaban o eran parte de la lucha ${ }^{562}$.

Sin embargo, la huelga expuso las diferencias entre las fuerzas políticas intervinientes que hasta el momento no se habían manifestado. Un ejemplo de ello fue la polémica que suscitó una movilización organizada a la delegación zonal del Ministerio de Trabajo ${ }^{563}$. La moción había sido presentada por los perretistas y aprobada en asamblea sólo con el apoyo de la JTP. Desde la óptica del PRT-ERP, organizaciones como VC, el PCA y el PST, "vacilaban" a la hora de enfrentarse al gobierno y, por ello, se negaban a dirigir el reclamo a la cartera de Trabajo. ${ }^{564}$. Por su parte, VC, aunque sin especificar a quien refería, también acusaba a fuerzas que participaban de la huelga como "agoreros" y boicoteadores de la lucha ${ }^{565}$. A ello se sumaban pequeñas rencillas que desgastaban la unidad y la moral de los trabajadores despedidos ${ }^{566}$.

Con el pasar de las semanas, ante la falta de respuesta de la empresa y el desgaste general de los trabajadores, la huelga comenzó a "desinflarse". En palabras de "Lito" Gonzales fueron varios los factores que hicieron que la medida de fuerza "no diera para más”. Por un lado, pesaban las dificultades que significaba sostener una huelga desde afuera de la fábrica: los huelguistas no podían conectarse con todos los trabajadores, la extensión del conflicto volvía cada vez más difícil la situación de los despedidos y los lugares de reunión cambiaban constantemente. Por otro lado, el aumento del aparato burocrático y los niveles de violencia que adquirían los enfrentamientos, tornaban cada vez más difícil sostener actividades de propaganda ${ }^{567}$.

No obstante, como indican "Lalo" Piñon y Floreal Avellaneda (obrero y activista del PCA), el quiebre final se dio en el momento en que algunos de los despedidos decidieron negociar sus indemnizaciones. Durante las negociaciones con los

\footnotetext{
561 “TENSA: El matonaje no pasará”, No Transar Nro. 141 (Nro. 14 nueva edición), 7 de agosto de 1974; Nuestra Palabra Nro. 56 (Segunda época), 1 de agosto de 1974.

${ }^{562}$ De la misma formaron parte el PCA, la JTP, VC, el MSB, el PST y otras organizaciones sociales como la Unión de Mujeres Argentinas, etc.

${ }^{563}$ El viernes 2 de agosto, aproximadamente 200 obreros marcharon a la delegación zonal del Ministerio de Trabajo, quien se declaró incompetente para tratar los reclamos por los despidos y remitió el asunto a la central ministerial ("TENSA: El matonaje no pasará", No Transar Nro. 141 (Nro. 14 nueva edición), 7 de agosto de 1974)

564 “TENSA: 'globo' de ensayo de López Rega”, El Combatiente Nro. 129, miércoles 7 de agosto de 1974 565 “TENSA: El matonaje no pasará", No Transar Nro. 141 (Nro. 14 nueva edición), 7 de agosto de 1974

${ }^{566}$ Un ejemplo claro de esto fue la pelea entre los militantes de la JTP y el PST. Los primeros decidieron dejar de prestar su local para la realización de las reuniones porque los militantes trotskistas usaban el espacio para realizar proselitismo partidario. (Entrevista a Lalo Piñon con el autor, Buenos Aires, 2018)

${ }_{567}$ Lito recuerda que un punto de inflexión, en ese sentido, fue un tiroteo que se dio cuando estaban volanteando en un colectivo en los alrededores de la empresa, que llevó a los huelguistas a "esperar hasta que se apaciguara la situación" (Entrevista a Carlos "Lito" Gonzales por el autor, Diciembre de 2017)
} 
huelguistas, la empresa había ofrecido indemnizaciones elevadas para terminar con el conflicto, pero la respuesta inicial de los obreros había sido exigir la reincorporación como única condición para levantar la medida de fuerza. Sin embargo, en el marco de desgaste antes descripto, un grupo de despedidos decidió sostener una negociación paralela en la que terminaron aceptando lo ofrecido, algo que desmoralizó a los obreros y fue utilizado por los delegados de la UOM para desprestigiar a los huelguistas. A partir de allí muchos trabajadores volvieron al trabajo y a los pocos días se decidió el levantamiento de la medida de fuerza ${ }^{568}$.

Aquella derrota significó un duro golpe para los obreros. Como indican Mereta y Roberto Astudillo, el resultado inmediato fue el fortalecimiento de la "burocracia", la restricción de las libertades para la militancia gremial, la incomunicación entre los trabajadores de ambas plantas y la inseguridad individual de los activistas ${ }^{569}$. Como preveía el PRT-ERP, la derrota de TENSA iba a significar un envalentonamiento de la derecha sindical en sus ataques contra los trabajadores ${ }^{570}$. Efectivamente, según lo que pudimos relevar, el primer efecto fue una merma significativa en la vida gremial de la fábrica. De hecho las últimas referencias del año 1974 se registran entre agosto y septiembre, mes en el que los obreros de TENSA aparecen firmando el acta constitutiva de la Coordinadora Nacional de Lucha Sindical conformada en Tucumán ${ }^{571}$.

Sin embargo no fue el golpe definitivo para el movimiento de base de la fábrica. Aquel vivió una recuperación que se evidenció durante 1975, aunque ahora con una nueva generación de dirigentes. En mayo de aquel año volverán a aparecer movimientos y protestas gremiales, para luego, participar en las movilizaciones generales de junio y julio así como, posteriormente, en las coordinadoras de gremios en lucha.

\subsection{5: la agrupación, las coordinadoras y el golpe final.}

Desde fines del año 1974 el movimiento de base de la fábrica comenzó a recuperarse lentamente. Luego de un primer momento de desarticulación, los activistas que

\footnotetext{
${ }^{568}$ Entrevista a Lalo Piñon por el autor, Buenos Aires, 2018; Entrevista a Floreal Avellaneda, Memoria Abierta.

569 Entrevista a Roberto Astudillo por el autor, Italia, 2017

570 "Evidentemente, el ataque orquestado contra los obreros de TENSA es un verdadero "globo de ensayo" del fascismo y la burocracia, que en caso de lograr éxito se envalentonaría y acentuaría sus ataques contra el movimiento obrero. De allí que desarrollar la solidaridad con los compañeros de TENSA y contribuir a su victoria es una tarea de gran importancia en el conjunto de las luchas que libra y librarán nuestra clase y nuestro pueblo contra la represión desatada." ("TENSA: 'globo' de ensayo de López Rega", El Combatiente Nro. 129, miércoles 7 de agosto de 1974)

571 "Coordinar las luchas por aumentos salariales y por la democracia sindical" Nuevo Hombre Nro. 70, segunda quincena de septiembre de 1974
} 
quedaron en la fábrica, junto a un grupo de obreros que comenzaron a activar a partir de la huelga, comenzaron a reorganizar la agrupación. Según los testimonios, con la derrota de la huelga y la consolidación del control de la CIR por parte de la "burocracia sindical", los delegados oficialistas abandonaron toda aspiración de representación y se dedicaron al "matonaje" y al "lumpenaje" (se emborrachaban, faltaban al trabajo, etc.). Así es que el descontento, aunque contenido por los niveles de represión, continuaba siendo muy alto y era la base para el crecimiento de la agrupación.

El PRT-ERP continuó interviniendo sindicalmente a través de sus militantes, aunque ahora con niveles mucho más estrictos de clandestinidad. En esta nueva etapa uno de sus principales referentes en la planta Munro fue Luis "el Tío" Arce quien, según los testimonios, era uno de los referentes principales de la agrupación y uno de los activistas más reconocidos entre los trabajadores. Según Mario Masolini y Rubén Guerra $^{572}$, Arce era muy querido entre sus compañeros por ser solidario y a través de esa referencia logró organizar a varios simpatizantes alrededor suyo ${ }^{573}$. Mientras tanto en Pablo Nogués, el trabajo político del PRT-ERP continuó casi intacto ya que en aquella planta no había repercutido la derrota, por lo que Roberto Mereta continuaba siendo el principal dirigente.

Por su parte la actividad del ERP mermó luego de la derrota de la huelga del 74. Según Astudillo por esos tiempos se realizaban acciones menores como "volanteadas" en puerta de fábrica, colocación de "bombas de volantes" o cortes de calles aledañas a la fábrica en los que se exhibían banderas de la organización ${ }^{574}$. Sin embargo, el 5 de abril de 1975 el comando "Uriz-Villaverde-Da Silva" llevó adelante la última acción resonante: el "ajusticiamiento" de José Chirino, hombre de la UOM y delegado general de la fábrica. Esta acción fue realizada en represalia a la desaparición de Tomás Sánchez, obrero de la planta Munro y militante perretista. En las declaraciones posteriores la organización justificó la acción por considerar a Chirino como "responsable directo de la bárbara y criminal represión desatada en la zona"575.

Según "Lito" Gonzales la desaparición de Sánchez habría sido consecuencia de una discusión belicosa que había sostenido aquel con Chirino dentro del vestuario ${ }^{576}$. Por su

\footnotetext{
${ }^{572}$ Rubén Guerra ingresó a TENSA aproximadamente en el año 1973. De familia proletaria, fue obrero y estudiante universitario (cursaba la carrera de ingeniería química). Milito en el PST desde 1972 a 1974. Este último año sostuvo contacto con el PRT-ERP, participando en reuniones como simpatizante.

${ }^{573}$ Entrevista a Rubén Guerra, José C. Paz, 2018; Entrevista a Mario Massolini, Los Polvorines, 2018.

${ }^{574}$ Entrevista a Roberto Astudillo por el autor, Italia, 2017.

${ }^{575}$ El Combatiente Nro. 165, lunes 21 de abril de 1975; Estrella Roja Nro. 53, 5 de mayo de 1975

${ }^{576}$ Entrevista a Carlos Lito Gonzales por el autor, Buenos Aires, 2017.
} 
parte Mereta también apunta al sindicato como principal responsable y recuerda que en aquel momento un militante perretista habría escuchado de boca del propio delegado que tenían a Sánchez, lo que habría motivado a la organización a tomar aquella medida ${ }^{577}$.

Según los testimonios aquella acción habría tenido una recepción distinta en el activismo y en el conjunto de los trabajadores. Mientras que entre los primeros habría caído bien, y mucho de los miembros de la agrupación lo habrían festejado, la gran mayoría de los trabajadores no habrían compartido la metodología.

Por otro lado, (como era de esperarse) la acción recibió el repudio de organizaciones como el PST, que la calificó como una "acción descolgada" y sumamente negativa por atraer la represión y generar "pasividad" y "confusión" entre los trabajadores, fomentando una "división” innecesaria entre quienes las apoyaban y quienes las repudiaban ${ }^{578}$. Lo que resulta interesante en este caso es que, como se vio en capítulos anteriores, el PRT-ERP rechazaba las ejecuciones de "burócratas sindicales" ya que consideraban que la "liquidación de la burocracia" no se resolvía con la "liquidación física" de sus representantes sino con la movilización y organización independiente de las bases ${ }^{579}$. En ese sentido, como indica el propio Mereta, lo esperable en ese caso hubiese sido que se respondiera organizando un paro o con alguna acción de ese tipo, como ya había sucedido en el caso de la detención de los militantes a fines del año 1973. De este modo, puede considerarse que, en esta acción, el ERP respondió a una lógica de enfrentamiento entre estructuras, en las que intentó demostrar capacidad de respuesta a la acción represiva de la "burocracia" bajo la lógica de la "ley del talión" 580 . De hecho, como remarcan los testimonios, la acción se transformó en un nuevo punto de inflexión al interior de la fábrica en tanto agudizó el clima de hostilidad y represión dentro de las plantas ${ }^{581}$.

No obstante ello no impidió que los trabajadores volvieran a movilizarse. De hecho el 8 de mayo, impulsados por la agrupación, decidieron en asamblea, y en oposición a los

\footnotetext{
${ }^{577}$ Entrevista a Roberto Mereta por el autor, Buenos Aires, 2018.

578 “TENSA: el caso Chirino", Avanzada Socialista Nro. 142, 12 de abril de 1975.

579 "La burocracia sindical. Instrumento burgués" El Combatiente Nro.95, viernes 26 de Octubre de 1973

${ }^{580}$ Es de destacar, sin embargo, que este no fue el único caso de "ajusticiamiento" de sindicalistas. Un ejemplo de ello fue el de Antonio Magaldi, sindicalista de la empresa SOMISA, quien fue ejecutado el 4 de abril de 1974, acusado por cargos similares a los de Chirino: por ser uno de los "principales responsables del permanente ataque, persecución y vejámenes que sufren los trabajadores" (Carnovale, 2016).

${ }^{581}$ Entrevista a Roberto Mereta con el autor, Buenos Aires, 2018; Entrevista a Rubén Guerra con el autor, Buenos Aires, 2018
} 
delegados, iniciar un paro reclamando un aumento salarial de 500 pesos por hora que logró un importante acatamiento, incluso de algunos supervisores y capataces ${ }^{582}$. El paro organizado por las bases duro 4 días y terminó en triunfo. La empresa se vio obligada a emitir un comunicado en el que informaba que contaba con la autorización del Directorio para otorgar una bonificación horaria excepcional para todo el personal, siempre y cuando se levantara la medida de fuerza ${ }^{583}$.

Otra de las grandes conquistas que habría conseguido la agrupación fue la renovación de los delegados "co-gestores": se trataban de delegados técnicos que habían surgido como fruto de un esquema de "co-gestión" a través del cual los trabajadores formalmente participaban de las ganancias de la empresa (en un $2 \%$ ) y, por otro lado, comercializaban la chatarra y la viruta que sobraba de la producción ${ }^{584}$. Según testimonios, hasta el momento este $\mathrm{CD}$, que era paralelo al gremial, era manejado por los jefes de personal quienes, en connivencia con los delegados de la UOM, se repartían el dinero sin que llegase ni un centavo a los obreros. Ante esta situación la agrupación impulsó y exigió asambleas, a través de las cuales lograron que dicha función la pasasen a cumplir trabajadores cercanos o activistas de la agrupación ${ }^{585}$, lo que permitió, por primera vez, que los obreros de TENSA recibieran el dinero que les correspondía (casi un sueldo completo adicional). Como indica Guerra aquello fue algo que los delegados y supervisores "nunca perdonaron" y que hizo recrudecer la confrontación al interior de la fábrica ${ }^{586}$.

Esta reactivación del movimiento de bases de TENSA se plasmó en las jornadas de lucha de junio y julio contra el "Plan Rodrigo". A mediados de junio los activistas de la fábrica participaron de la fundación de la Coordinadora Interfabril de la Zona Norte junto delegados de ASTARSA, Editorial Abril, Avon, Laboratorios Squibb, etc ${ }^{587}$. En ese marco participaron de las movilizaciones y de las medidas de fuerza que organizó aquel espacio, entre las que se destacó la movilización del 30 de junio a Capital Federal por Avenida Panamericana (Werner y Aguirre, 2007: 564). Según los testimonios en

\footnotetext{
${ }^{582}$ Avanzada Socialista Nro. 146, 10 de mayo de 1975.

${ }^{583}$ Comunicado al personal de la Dirección General de TENSA (Colección personal de Mereta)

${ }^{584}$ El esquema de co-gestión había empezado a discutirse durante el año 1973 aunque, según Lalo Piñon no habría prosperado ya que la empresa no estaba dispuesta a abrirles los libros contables. Según Mario Masolini se había negociado dicha participación en las ganancias a cambio del aumento del ritmo de producción. (Entrevista a Lalo Piñon con el autor, Buenos Aires, 2018; Entrevista a Mario Masolini por el autor, 2018; Entrevista a Rubén Guerra por el autor, 2018)

${ }^{585}$ Se trataba de trabajadores del sector "control de calidad" que, como personal técnico, podían ejercer la función de "co-gestores".

${ }^{586}$ Entrevista a Rubén Guerra con el autor, Buenos Aires, 2018.

${ }^{587}$ Boletín de la Corriente Clasista Nro. 9, julio de 1975
} 
aquella movilización participaron todos los trabajadores de la fábrica, rebasando por completo a la conducción gremial de la UOM y de los delegados ${ }^{588}$.

A partir de allí el activismo de TENSA se abocó a la militancia en la Coordinadora participando de sus distintas iniciativas y en el apoyo a los conflictos de las diferentes fábricas que lo componían. Sin embargo la represión iba a golpear nuevamente: como consecuencia de los llamados "decretos de aniquilamiento" $" 589$, dictados en octubre por el presidente del senado, a cargo del poder ejecutivo, Italo Luder ${ }^{590}$, el 20 de noviembre fueron secuestrados tres obreros, entre ellos Mario Masolini uno de los principales activistas de la fábrica y delegado en la Coordinadora ${ }^{591}$. Ello fue denunciado por este último organismo que incluyo el reclamo por la aparición y la libertad de los obreros de TENSA (junto al caso dos obreros de la fábrica Fate Electrónica) como punto principal de su pliego de reivindicaciones ${ }^{592}$ y motorizó la movilización de los trabajadores de la fábrica gracias a la cual, según Rubén Guerra, Masolini fue "legalizado" a principios de 1976. A partir de allí la represión recrudeció en la planta y la actividad de la agrupación fue cada vez más difícil de sostener.

Por su parte la actividad del PRT-ERP continuó pero con dificultades. Según Mereta luego del secuestro de Chirino la militancia se volvió cada vez más peligrosa y, paradójicamente, los criterios de seguridad de la organización más relajados, lo que llevó a "malos manejos" e incluso sospechas de infiltraciones. Además, por otro lado, algunos militantes abandonaron la fábrica y pasaron a la clandestinidad ${ }^{593}$ por lo que, en palabras del entrevistado, "los contactos se venían a menos", es decir se iba perdiendo el trabajo y la influencia política lograda por los militantes. Por ello Mereta, al igual que Horacio Babuya (militante perretista de Pablo Nogués), decidieron abandonar el partido

\footnotetext{
${ }^{588}$ Entrevista a Roberto Astudillo por el autor, 2018; Entrevista a Mario Masolini por el autor, 2018; Entrevista a Rubén Guerra por el autor, 2018

${ }^{589}$ Se trataron de 3 decretos que, entre otras cosas, dispusieron de la creación de un Consejo de Seguridad Interna (compuesto por miembros del ejecutivo y las FFAA), la asignación da otro ente de tipo operativo (Consejo de Defensa Nacional) la función de establecer convenios con las provincias y colocar bajo su control operacional al personal policial y penitenciario para la "lucha contra la subversión" y la delegación a las FFAA de la ejecución de las operaciones militares y de seguridad para "aniquilar" "elementos subversivos" en todo el país. (Franco, 2012: 151-152)

590 Ítalo Luder, presidente del Senado, se encontraba a cargo del Poder Ejecutivo debido a la licencia médica de la presidente María Estela Martínez.

591 Masolini recuerda que en el interrogatorio del cautiverio quienes lo detuvieron hacían especial hincapié en el PRT-ERP dentro de la fábrica y que, particularmente, "la obsesión" era Ramón "el Tío" Arce. (Entrevista a Mario Masolini por el autor, 2018)

${ }^{592}$ Volante de la Coordinadora de Gremios, Comisiones Internas y Cuerpo de Delegados Combativos, 28/11/75, El Topo Blindado.

${ }^{593}$ El caso más evidente fue el de Luis Alberto Sportuno (saergento "Lucho") quién formó parte del asalto al Batallón de Arsenales 601 "Domingo Viejobueno" de Montechingolo, donde calló en combate. (PlisSterenberg, 2006)
} 
a fines de 1975. Esta situación se radicalizó con el golpe de estado de 1976. A partir de allí la desaparición de trabajadores se transformó en una práctica sistemática: entre marzo y julio de 1976 desaparecieron una cantidad importante de activistas de TENSA $^{594}$, entre ellos varios militantes del PRT-ERP, mientras que otros tantos abandonaron la fábrica. Ya sin gran parte de sus protagonistas se cerraban los tiempos de la agrupación "16 de enero".

Por lo que pudimos reconstruir, hasta ese momento el PRT-ERP continuó con una estructura mínima en la fábrica, aunque no hemos podido precisar cuándo fue que terminó desarticulándose definitivamente ni hallar datos sobre si desarrolló algún tipo de actividad o acción en tiempos dictatoriales.

\section{Conclusión}

Como se vio a lo largo del capítulo, la experiencia perretista en TENSA tuvo resultados significativos: la organización logró una inserción considerable que le permitió construir células en las dos plantas, editar un boletín fabril y organizar una red de simpatizantes y colaboradores que, en el caso de Pablo Nogués, fue bastante amplia. En el marco de ese desarrollo, sus militantes lograron impulsar, junto a otras organizaciones, una agrupación sindical y participar activamente en el CD y en la CIR. Además, como rasgo distintivo, contó con un audaz y significativo despliegue militar que, por momentos, acompañó y fortaleció el auge del movimiento de base y permitió un crecimiento de su influencia entre los trabajadores aunque, por otros, tendió a atraer la represión en la fábrica con consecuencias negativas para el movimiento de base como para la propia organización.

Como se verá en el próximo capítulo, la experiencia perretista en Mercedes Benz Argentina tuvo otras características que le dieron un sello propio y su análisis permitirá comprender las diferentes formas en que la militancia fabril perretista tradujo la línea de la organización al interior de la fábrica.

\footnotetext{
${ }^{594}$ Entre los desaparecidos de TENSA, hasta hoy, han sido identificados: Antonio Alberto Prieto; Miguel Ángel Gallinari Matos; Esteban Abundio Machado; Nicolás Miguel Ángel Román; Juan Carlos Chersanaz Burgos; Horacio Alberto Babuya Capaldi; Esteban Bonifacio Juárez; Bartolomé Da Silva Nuñez; José Luis Ghigo Correa; Manuel Samudio Samudio; Jesús Lautaro De La Rosa Aragón; Gerardo Cesar De La Rosa Aragon; Basilio Laskievich Daniel Alberto Manzi ; Omar Manzi; José Preisz Meztgler; Carlos Alberto Fernández Ferradas; Oscar Adolfo Koudela Cabrera
} 


\section{CApítulo 6}

\section{Perros en "La Mercedes"}

\section{Introducción}

Este capítulo aborda la experiencia perretista en una de las fábricas emblemáticas de la industria moderna: Mercedes Benz Argentina (MBA). Ubicada en el partido de La Matanza, la planta ocupaba aproximadamente a 4.000 operarios, siendo una de las principales terminales automotrices del país y, en consecuencia, un objetivo importante para el PRT-ERP que, como vimos, definía a la industria automotriz como una de las ramas fundamentales para realizar trabajo político. Para la organización aquella rama se había transformado en la "columna vertebral de toda la industria argentina y de la política imperialista", por lo que asumía un carácter específicamente "estratégico" para la lucha revolucionaria ${ }^{595}$.

A lo largo de este capítulo se analiza el desarrollo de la organización, indagando en las características de su labor político-sindical y en la forma en que sus protagonistas buscaron traducir la línea partidaria a la realidad de la fábrica. Para ello se reconstruye la forma organizativa adoptada, las estrategias que se dieron para intervenir sindicalmente, el vínculo que construyeron con el resto de las organizaciones que intervenían en la fábrica y la influencia construida entre sus compañeros de trabajo. Como veremos, a diferencia del caso de TENSA, aquí la militancia fabril perretista tendió a intervenir sindicalmente con mayor autonomía respecto a las prescripciones partidarias, construyendo herramientas y criterios propios que fueron resultado directo de la experiencia militante.

Con estos fines, nos centramos en el conflicto más importante de MBA: una huelga de 22 días iniciada en octubre de 1975 que buscó terminar con la intervención de la CIR sostenida por la conducción nacional del Sindicato de Mecánicos y Afines del Transporte Automotor (SMATA). En su reconstrucción se hace especial hincapié en la intervención que tuvieron los militantes perretistas y en el balance realizado por la organización. Debemos destacar que el conflicto en MBA comenzó pocos meses antes del golpe militar y que éste último encontró al movimiento de base de la fábrica en un

\footnotetext{
595،El clasismo se extiende en mecánicos” El Combatiente Nro. 140 Miércoles 23 de octubre de 1974.
} 
momento de fuerte movilización. Por este motivo, se avanza en el análisis de la resistencia obrera hasta fines del año 1976.

\subsection{Orígenes del PRT-ERP y del movimiento de base en MBA}

\section{1.a. Mercedes Benz, la gigante de la Matanza}

La llegada de la empresa alemana a la Argentina se dio en el año 1951 y se ubicó primeramente en la localidad bonaerense de San Martín. Según la historia oficial, se trataba de la primera fábrica de la firma en instalarse fuera de Alemania ${ }^{596}$. En el año 1953 comenzó a construirse la planta en la localidad de Gonzales Catán (La Matanza) que pasó a ser la única sede productiva a partir de $1956^{597}$. En 1962 se fundó la Escuela Privada de Fábrica Mercedes Benz, que funcionaba en las inmediaciones del establecimiento, formando a los obreros en las actividades calificadas que requería la producción y siendo un puente directo para el ingreso a la firma (Rodríguez, 2011).

A lo largo de los años, la producción fue creciendo exponencialmente, transformándose de una planta ensambladora de piezas a una productora de vehículos. Allí se fabricaban distintos tipos de camiones y autobuses ${ }^{598}$, entre los que se destacaban los Unimog, camiones medianos multipropósito, que eran vendidos a distintos ejércitos de América Latina. Ello supuso un aumento del plantel obrero llegando a los 4.257 en la década de los setenta (Tomuschat, 2003). A su vez, el aumento de la producción y del personal fue llevando a modificar los tiempos de trabajo, pasando de una jornada laboral de un sólo turno (de 7:00 a 16:30) a cuatro turnos: mañana, tarde, noche e intermedio ${ }^{599}$. En ese proceso la planta fue complejizando la producción, organizándola en numerosas secciones $^{600}$ (Casco Peebles, 2016: 95).

MBA era una de las empresas que mayores salarios pagaba, por lo que, como reconocen algunos entrevistados, entrar a la fábrica significaba "tocar el cielo con las manos"601. En ella convivían obreros híper calificados que trabajaban con maquinarias de alta complejidad, con otros de poca formación que atendían las secciones más riesgosas

\footnotetext{
596 "Historia de Mercedes Benz en Argentina", en: www.mercedes-benz.com.ar 597 Ídem

${ }^{598}$ MBA se transformó en la fábrica que controlaba prácticamente la totalidad de la producción de ómnibus, llegando en 1979 a abastecer el mercado en un 92\%. En aquella planta se producían los modelos de camiones L311, L 312 y los colectivos LO 311 y LO 312. (Tomuschat, 2003; Rodríguez, 2011)

${ }^{599}$ Los nuevos turnos se dividían de 5:00 a 14:00, de 14:00 a 22:00, de 22:00 a 6:00 y el intermedio de 7:00 a $16: 30)$

${ }^{600}$ Algunas de las secciones más importantes eran: piezas chicas, tratamiento térmico, quinta etapa, línea de montaje, mantenimiento, chasis, motor, chapistería, control de calidad, estándar, etc.

${ }^{601}$ Dicha expresión pertenece a Hugo Crosatto, aunque ideas similares son vertidas en los testimonios de Héctor Ratto, Ricardo Hoffman y Nestro Rossi (en entrevistas con el autor).
} 
(como la de Tratamientos Térmicos). En ese sentido, Florencia Rodríguez (2011) analiza que la empresa buscaba fracturar la unidad entre los trabajadores en base a la consolidación de una fracción del personal "privilegiado", representado por aquellos obreros calificados que recibían un $37 \%$ más de ingresos salariales que aquellos de menor escalafón. No obstante, como indica Casco Peebles (2016), estas características no significaron la disminución de la solidaridad de clase al interior de la planta ${ }^{602}$. Según el autor, la existencia de trabajadores altamente calificados, sumado al hecho de que se trataba de una empresa estratégica para la producción nacional, lejos de limitar la acción obrera de la planta le dio fortaleza en la disputa capital-trabajo, ya que la negociación se daba desde una correlación de fuerzas más favorable.

Los obreros estuvieron encuadrados en el SMATA desde que se instaló la fábrica. Casi en simultáneo a la fundación de la planta surgieron el CD, compuesto por alrededor de 60 miembros, y la CIR, compuesta por 9 representantes. El primer convenio colectivo que abarcó a los trabajadores de MBA, de 1954, limitaba la autonomía de aquellos organismos en pos de un aumento de la productividad y de un control ideológico que buscaba evitar la presencia de "comunistas" dentro de la fábrica (Basualdo, et. al., 2016: 495). Estos organismos, además, desde un comienzo estuvieron dominados por la Lista Verde, representada a nivel nacional por los dirigentes Dirck Kloosterman (asesinado el 22 de mayo de 1973 por un comando de las FAP) y José Rodríguez.

Desde fines de la década del sesenta se registra la presencia de organizaciones de izquierda al interior de la planta, aunque fue a partir de la década del setenta que se desarrollaron las diferentes organizaciones de la nueva izquierda. Entre ellas se destacaron en un primer plano, por su presencia e influencia, la JTP (principal fuerza política de la planta) y el PRT-ERP que, como veremos, contó con dirigentes importantes y una cantidad considerable de militantes. En un segundo plano de importancia se ubicaron el PCA y del $\mathrm{PST}^{603}$, fuerzas políticas que primeramente se instalaron en MBA; y por último, en un tercer nivel de importancia se hallaban el PB, el PCR y el PRT-Fracción Roja/GOR ${ }^{604}$.

\footnotetext{
${ }^{602}$ Una muestra de ello fue la participación protagónica de Telmo Ferro, el obrero más calificado de la fábrica, en la CIR surgida de la huelga de 1975

${ }^{603}$ Esta última fuerza contaba con la figura de Charles Grossi, delegado obrero con importante ascendencia entre los trabajadores que fue expulsado en 1973

${ }^{604}$ El derrotero del PRT-Fracción Roja marca que a mediados de 1974 aquel grupo adoptó el nombre de Liga Comunista Revolucionaria y en 1975 terminará incorporándose al Grupo Obrero Revolucionario (GOR). (Cormick, 2013)
} 
Como se verá, la militancia de todas estas corrientes fue fundamental en el proceso de politización y de radicalización sindical que se vivió en la planta, sobre todo, desde 1974.

6.1.b. La conflictividad detrás de la aparente calma. Luchas obreras previas a 1975.

Según el Informe Tomuschat ${ }^{605}$ (2003), MBA estuvo exenta de luchas obreras hasta 1975. Sin embargo, desde la década del 60, la planta estuvo atravesada por varios conflictos vinculados a las condiciones de trabajo y el aumento de los ritmos de producción (Rodriguez, 2011). De hecho, el primer intento por conseguir un CD y una CIR alternativos a la Lista Verde data del año 1969. En aquella oportunidad una lista antiburocrática, impulsada por militantes del PCA y el PST, ganó las elecciones sindicales aunque rápidamente la empresa, en complicidad con el SMATA, terminó con dicha experiencia, despidiendo a todos sus miembros y devolviendo los organismos gremiales a los representantes del Secretario General José Rodríguez (Löbbe, 2004). Según Héctor Ratto ${ }^{606}$, Julio D’Alessandro ${ }^{607}$ y Hugo Crosatto ${ }^{608}$, obreros que ingresaron a la fábrica en 1967, 1971 y 1972 respectivamente, aquel fue el primer antecedente que marcó el espíritu antiburocrático de las posteriores luchas y que contribuyó a la politización de la planta ${ }^{609}$. De hecho, D’Alessandro recuerda que al ingresar se encontró con un clima de descontento generalizado por la expulsión de

\footnotetext{
${ }^{605}$ El informe Tomuschat fue elaborado por la propia empresa para desvincularse de sus responsabilidades en la última dictadura militar. El mismo fue impulsado por un grupo de "inversionistas críticos" ante la denuncia de Gabriela Weber, periodista alemana, quien acusó a la multinacional de ser responsable de la desaparición de trabajadores entre los años 1976 y 1977. La importancia del texto reside, fundamentalmente, en que repone un conjunto de fuentes y documentos de la empresa que no son accesibles al público.

${ }^{606}$ Hector Ratto ingresó a MBA en 1967 con 20 años. Hijo de familia trabajadora ingresó a la escuelafábrica de MBA en 1964, gracias a su buen promedio se incorporó a la fábrica en la sección motores. Activista independiente, participo de la militancia gremial de la fábrica y colaboró con el PRT-ERP y el PRT-Fracción Roja/GOR.

${ }^{607}$ Julio D'Allesandro ingresó a MBA en 1970 con 24 años. Hijo de familia obrera, quedó huérfano a los 6 años y trabajó desde los 12 en diferentes fábricas como tornero donde comenzó con sus primeras actividades sindicales (fue delegado en la fábrica Plavinil).

${ }^{608}$ Hugo Crosatto ingresó a MBA a los 21 años. Hijo de un bancario y una ama de casa, se crió en una casa de radicales. De joven tuvo distintos trabajos hasta que, a través de un vecino, que era Subjefe de Personal en MBA, pudo ingresar a la fábrica donde en 1972 entró en contacto con militantes perretistas que lo sumaron a la organización.

${ }^{609}$ Entrevista a Julio D’Alessandro con el autor, Buenos Aires, 2014; Entrevista a Héctor Ratto con el autor, Buenos Aires, 2017; Entrevista a Hugo Crosatto con el autor, Buenos Aires, 2017. Siguiendo a Héctor Ratto: "Y en el [69] hay una gran movilización, hubo un paro, estuvimos unos cuantos días de paro, habían echado a la comisión interna que respondía al PC, al PCR [y al PST]. Ahí interviene casi la totalidad de los trabajadores en defensa de la democracia y de la comisión interna que habían despedido. Inclusive a algunos los encanaron, y bueno después hace pata la burocracia sindical por medio de gente que siempre tuvieron adentro y que trabaja para ellos (...) En ese momento los burócratas sindicales se hacen cargo de la Comisión Interna."
} 
aquellos delegados y un "odio total" contra el SMATA, que era identificado como el responsable de la destitución de la "mejor comisión interna" que habrían tenido los trabajadores de MBA hasta el momento ${ }^{610}$.

A pesar de aquel golpe, la actividad de las bases no se redujo en los años posteriores. De hecho en abril de 1970 los trabajadores se acoplaron al paro nacional contra la política de la dictadura y participaron de las actividades convocadas por el SMATA contra las suspensiones que se venían realizando en la industria automotriz. Además, entre 1971 y 1972, también se registran conflictos de distinta índole: la lucha por la implementación de las paritarias, el enfrentamiento con la gerencia debido a un intento de aumentar las tarifas del comedor, por la calidad de la comida y el menú semanal, la discusión por la re-categorización de 120 trabajadores y por el incremento del ritmo en la sección "bielas", etc (Harari, 2010; Basualdo [et. al], 2016).

Según el periódico del PST, Avanzada Socialista, en el año 1971 se dieron elecciones de CIR en las que la Lista Verde se impuso gracias a la "ayuda" de la empresa y a maniobras fraudulentas como la desafiliación de Charles Grossi, militante morenista que se había transformado en uno de los principales dirigentes clasistas de la fábrica ${ }^{611}$. Todo ello fue generando un estado de tensión que se manifestó en la realización espontánea de interrupciones parciales, huelgas y actos de sabotajes (Tomuschat, 2003). Durante aquellos años puede reconstruirse una línea de conflictos de pequeña magnitud que expresaban el descontento de los trabajadores en materia de condiciones laborales y de representación gremial (Rodríguez, 2011) que estuvieron impulsados por una nueva generación de activistas, muchos de los cuales militaban en organizaciones de la nueva izquierda, entre ellas el PRT-ERP.

Según indican Casco Peebles y María Agustina Lenuda (2016), la actividad de esta última organización en la fábrica había comenzado en 1971, lo que coincide con el testimonio de Julio D’Alessandro quien habría sido, junto a otro trabajador, el primero que se puso en contacto y se sumó a la organización a fines de aquel año. Según el relato de este último, habría sido el "prestigio" que el PRT-ERP había ganado en años de dictadura, lo que lo llevó a buscar el contacto con la organización, el cual se dio debido a la actividad de propaganda que los perretistas desarrollaban en las puertas de la

\footnotetext{
${ }^{610}$ Memoria Abierta, Testimonio de Julio D'Alessandro, Buenos Aires.

${ }^{611}$ Según la nota, los delegados elegidos en aquella oportunidad habrían tenido que renunciar dos meses antes de cumplirse su mandato por "presión de las bases" ("Mercedes Benz. Si les ganamos la fábrica también les podemos ganar el gremio", Avanzada Socialista Nro. 90, del 30 de enero al 6 de febrero de 1974)
} 
fábrica ${ }^{612}$. A partir de allí comenzó la organización del partido al interior de la planta ${ }^{613}$ por lo cual, al poco tiempo, se incorporó Hugo Crosatto quien se transformó en uno de sus principales dirigentes sindicales ${ }^{614}$. Este núcleo de militantes comenzó a activar gremialmente y, en 1974 participó, junto al resto del activismo fabril, de un conflicto que derivó en la ocupación parcial de la planta.

El mismo se desató debido a la falta de refrigeración en la sección de tratamientos térmicos (Tomuschat, 2003:33). Las altas temperaturas (que en verano superaban los 40 grados), la contaminación del aire y las condiciones de hacinamiento que se vivía en aquella sección llevó a los trabajadores a abandonar las tareas y salir al patio donde, asamblea mediante, exigieron una reunión con la empresa para discutir el mejoramiento de las condiciones de trabajo. Ante la ausencia de respuestas, el viernes 4 de enero decidieron ocupar el establecimiento con las autoridades adentro, lo que obligó a la firma a comprometerse a poner ventanas y ventiladores en las secciones. No obstante, transcurrido el fin de semana, el compromiso no se hizo efectivo y el lunes 7 una asamblea resolvió nuevamente la ocupación. Aunque al día siguiente los trabajadores decidieron aceptar la intimación del Ministerio de Trabajo, que exigía el levantamiento de la medida, consiguieron que la empresa se comprometiera a resolver, en un corto plazo, los problemas de salubridad de la planta, que pagara los días caídos y que rescindiera el contrato de la concesionaria que administraba el comedor fabril. Además, como reaseguro, decidieron continuar la protesta con un quite de colaboración hasta tanto se resolvieran los problemas ${ }^{615}$.

Como se dijo, en esta lucha surgió una nueva generación de activistas y referentes sindicales que, en su mayoría, habían ingresado en la fábrica entre 1971 y 1973. Entre

\footnotetext{
612 "Estábamos buscando yo y otro compañero como engancharnos, y cuando logramos engancharnos le dije a uno de los que volanteaban y rajaban que quería hablar con ellos." (Entrevista a Julio D'Alessandro con el autor, Buenos Aires, 2014)

613 "Después de ahí empezamos a hacer la célula, había unas ganas y una movilización impresionante de luchas antiburocráticas y políticas en esos años, entonces fue fácil. Y como no había que tener todo en manos de un compañero, en el caso mío, cuando enganchaba algún compañero lo pasaba al responsable y se hacían otro tipo de célula." (Ídem)

614 "A mí me engancharon ellos adentro de la fábrica. Yo siempre milite en el PRT por la fábrica, no porque venía desde afuera. Ya te digo, en el ' 72 (...) El proceso es por un compañero, que laburaba en el sector que estaba yo, que siempre charlábamos. Estábamos muy distanciados con la máquina pero charlábamos siempre en el comedor. En alguna oportunidad nos juntábamos y charlábamos y ante su pregunta de si yo militaba en algún lado le dije que no, y me dijo: ‘y te gustaría militar?', a lo que le respondo: 'mira, si me decido va a ser por el PRT'. Ante esta posición él se define como del PRT y me dice 'cuando quieras y donde quieras yo te llevo con mi referente y charlamos un rato' ¡Y así empecé! Nos juntamos en la casa de mi abuela, en la casa de él en San Justo y empecé a militar en el PRT" (Entrevista a Hugo Crosatto por el autor, Buenos Aires, 2017)

615 "Una semana pródiga en conflictos sindicales" El Mundo, 14 de enero de 1974; "Mercedes Benz ocupada: la cosa esta caliente" Avanzada Socialista Nro. 88, del 16 al 23 de enero de 1974
} 
ellos se conformó una lista de base que disputó y ganó las elecciones de CIR realizada en el mes de septiembre de 1974, en la cual la JTP fue la fuerza con mayor peso (Casco Peeble, 2016). Según relata Hugo Crosatto, el triunfo sindical fue amplísimo, y había sido una muestra cabal del nivel de combatividad de la base y el nivel de desprestigio de la "burocracia sindical":

"Hugo: (...) cuando le ganamos la comisión interna en el 74, la ganamos porque obligamos al gremio a abrir las urnas en el sector de trabajo. Porque antiguamente se llevaban las urnas y venían al otro día con los resultados, y siempre ganaban ellos. En esa elección le dijimos: ‘`No, las urnas se abren acá!' Y ahí se da un forcejeo, los tipos no querían saber nada (...) se abrieron y le ganamos en todos lados ipor escándalo! Los 60 delegados eran nuestros

Entrevistador: ¿Y esa lista estaba compuesta por activistas de distintas corrientes?

Hugo: Si de todas las corrientes. En esa elección la Comisión Interna era mayoritariamente de la JP. Se la otorgamos porque había venido Perón, pero después terminaron medio... nos dejaron, los compraron o los amenazaron. Muchos se fueron porque la derecha peronista los amenazaba de muerte, entonces nos quedamos sin Comisión Interna, y sin Cuerpo de Delegados obviamente.",616

Efectivamente esa experiencia fue nuevamente desbaratada por la presión del SMATA que, a través de "aprietes" y amenazas, fue logrando que la mayoría de los miembros de la CIR abandonaran la fábrica. Finalmente, en noviembre, aquel organismo fue intervenido “por falta de integrantes” y el propio José Rodríguez designó a Rubén Darío Aguilar y Juan Carlos Selles como interventores. No obstante, ese proceso ayudó a profundizar el sentimiento antiburocrático de los trabajadores. Según Nestor Rossi, quien ingresó a la fábrica a fines de 1974, en ese momento la Lista Verde ya estaba sumamente desprestigiada: “en general había conciencia de que la Lista Verde era entregadora (...) vos decías Lista Verde y era 'caca""617. Esto mismo se ve reflejado en el Informe Tomuschat en el que un miembro de la junta directiva de la empresa reconoce: "Lamentablemente SMATA no tendría la certeza de poder contar con el total apoyo de sus miembros" (2003: 32).

El aumento del desprestigio del oficialismo sindical fue directamente proporcional a la politización general de los trabajadores y al crecimiento de las organizaciones de la nueva izquierda. Según Ricardo Hoffman, obrero perretista, que también ingresa en 1974 a MBA, para aquel momento, los niveles de debate político entre sus compañeros de sección eran muy elevados:

\footnotetext{
${ }^{616}$ Entrevista a Hugo Crosatto por el autor, Buenos Aires, marzo de 2017.

${ }^{617}$ Entrevista a Néstor Rossi con el autor, Ezeiza, junio de 2018. Nestor Rossi ingresó a la fábrica en diciembre de 1974 a los 22 años a la sección Tratamientos Térmicos. Hijo de trabajadores, participaba en la JP de Cañuelas a nivel territorial.
} 
"Yo tuve la ventaja de entrar a una sección que después fue llamada la "sección roja", en la que estaba Crosatto. Era una de las secciones más politizadas. Yo creo que el 80 u 90 por ciento de los 70 que éramos por turno ahí, estaban relacionados políticamente con algo. Montoneros, el PST, radicales, liberales. Montoneros por supuesto, ¡JTP montones! Y era una discusión política permanente, las discusiones sobre la historia era cotidiana, liberales contra rosistas, libros... mucha lectura, mucha lectura de historia. ¡Ese era el ambiente ahí!"618

De hecho, Crosatto recuerda que en aquella sección los trabajadores llegaron a improvisar una especie de "librería" en la que no sólo circulaban materiales de las distintas organizaciones, sino también libros de historia y de política. ${ }^{619}$ Esto es confirmado por Héctor Ratto quien comenta que el nivel de circulación de materiales y de lectura era muy amplio ${ }^{620}$.

Como remarca Casco Peeble (2016) el grado de organización alcanzado por los trabajadores de MBA estuvo íntimamente ligado a los niveles de inserción que lograron aquellas organizaciones en la fábrica. La presencia de los militantes aportó una importante cuota de radicalización al interior de MBA, aunque no fueron las fórmulas o herramientas preestablecidas por los partidos las que rigieron al movimiento de base sino, como se verá a continuación, la experiencia de los obreros, sus prioridades y formas organizativas.

\subsection{EI CROEMBA y la política sindical perretista}

Según recuerda Ricardo Hoffman ${ }^{621}$, para fines del año 1974 el PRT-ERP contaba, aproximadamente, con seis células de tres o cuatro miembros cada una, y una red de simpatizantes bastante más amplia, con presencia en la mayoría de las secciones: "era una organización que abarcaba horizontalmente [la fábrica]. O sea que no solamente estábamos en la parte obrera, también estábamos en la administración y en el servicio médico." $" 622$

Las células estaban compuestas por un responsable de cada tarea (sindical, militar, de propaganda) y un responsable político elegido por sus propios integrantes. Si bien no

\footnotetext{
${ }^{618}$ Entrevista a Ricardo Hoffman con el autor, Buenos Aires, marzo 2017. Ricardo Hoffman ingresó a la fábrica en enero de 1974 con 22 años. Hijo de padres campesinos proletarizados, luego de terminar la primaria, gracias a un tío que trabajaba en MBA, ingresó a la escuela de fábrica lo que le permitió su incorporación al trabajo. Allí tomó contacto con militantes del PRT-ERP.

${ }^{619}$ Entrevista a Hugo Crosatto con el autor, Buenos Aires, 2017

${ }^{620}$ Entrevista a Héctor Ratto con el autor, Buenos Aires, 2017

${ }^{621}$ La incorporación de Ricardo Hoffman se dio a mediados de 1974 y, a diferencia de Crossato y D'Alessandro, su contacto con la organización se dio por la referencia política y personal de uno de sus compañeros de trabajo (Entrevista a Ricardo Hoffman con el autor, Buenos Aires, 2017).

${ }^{622}$ Ídem
} 
existen documentos que den pistas sobre el funcionamiento de las mismas, siguiendo los testimonios, se puede inferir que no habría sido homogéneo ${ }^{623}$. Por otro lado, hacía 1975, se logró organizar una dirección partidaria que habría tenido todas las características de un "Comité Fabril” que, como vimos en el capítulo 2, agrupaba a los responsables de todas las células:
"Ricardo: (...) Había una dirección que se constituía desde las células para arriba, un organismo que funcionaba como dirección de toda la fábrica, donde se definían las orientaciones para toda la fábrica...
Entrevistador: O sea ¿era un organismo de dirección superior para MBA?
Ricardo: Superior para MBA. Ahí se tomaban los aspectos políticos, el problema de la Coordinadora, etc... eran otros niveles de la discusión política que muchas veces abajo se nos pasaba porque estábamos en la vorágine de lo cotidiano ¿entendés?
Entrevistador: ¿Y ahí pensaban la política de conjunto?
Ricardo: Claro, se discutía la política, tomábamos decisiones como qué íbamos a plantear en el Comité de Lucha, en la Coordinadora (...) Mira, particularmente como era una dirección política, era el trazado de los grandes lineamientos para la semana desde un punto de vista político (...)"624

En cuanto a la propaganda y agitación partidaria, se realizaba a través de la edición de volantes y la venta de los periódicos El Combatiente y Estrella Roja. Según los testimonios se llegaron a vender entre 70 y 120 ejemplares, no obstante, todos coinciden en que era muy común que un mismo periódico lo leyeran más de un obrero por lo que el número de ventas no referiría exactamente al número de lectores ${ }^{625}$.

En cuanto a la actividad militar, los perretistas habrían contado con dos escuadras, una que pertenecía a la estructura formal del ERP y respondía a la dirección regional, y otra impulsada por "los pesados de la fábrica", un grupo de trabajadores "dispuestos a combatir" pero no a entrar al partido ${ }^{626}$. Aunque esta escuadra era organizada por una de las células del PRT-ERP, mantenía importantes niveles de independencia e inorganicidad. En palabras de Hoffman ese grupo "era del partido cuando quería", ya que realizaba acciones independientemente de las decisiones partidarias y muchas veces sin un criterio político claro ${ }^{627}$. Como se ha visto, experiencias como estas podrían

\footnotetext{
${ }^{623}$ Según Hoffman todas las células funcionaban y se reunían dentro de la fábrica y "muy rara vez" sesionaban fuera del establecimiento, mientras que Crosatto recuerda que su célula funcionaba todo el tiempo en el exterior con un responsable y con miembros que no eran obreros de MBA. No obstante, el propio Crosatto se encarga de aclarar que su caso era diferente al del resto de los militantes ya que al no vivir en la Matanza, las dificultades de reunirse por aquella localidad lo obligaron a formar parte de una célula de otra zona partidaria. (Entrevista a Ricardo Hoffman con el autor, Buenos Aires, 2017; Memoria Abierta, Hugo Crosatto, Buenos Aires.)

${ }^{624}$ Entrevista a Ricardo Hoffman con el autor, Buenos Aires, 2017

${ }^{625}$ Entrevista a Crosatto con el autor, marzo de 2017, Buenos Aires

${ }^{626}$ Entrevista a Ricardo Hoffman con el autor, Buenos Aires, 2017.

${ }^{627}$ Hoffman recuerda que la escuadra realizó distinto tipos de acciones que fueron desde una emboscada a la comisaría de Cañuelas hasta cortes de ruta y atentados menores contra algún gerente. Sin embargo estas
} 
haber encuadrado en la TOR 22-8, sin embargo no hay registro de que esta experiencia haya sido encuadrada bajo aquella organización.

Por su parte, la escuadra del ERP, realizó actividad de propaganda a través de volantes intimidatorios y de amenazas a gerentes de la empresa (Tomuschat, 2003:36), aunque, a diferencia del caso de TENSA, se limitó a pequeñas acciones.

Finalmente, la intervención sindical adoptó características particulares. Allí los militantes impulsaron, junto a activistas independientes y de otras organizaciones, un volante clandestino firmado como Cuerpo de Representantes Obreros y Empleados de Mercedes Benz Argentina (CROEMBA). En él se fijaban posiciones sobre la situación gremial y los problemas laborales que se vivían en la fábrica. No se trataba de una agrupación sindical sino de una herramienta de propaganda que les permitía coordinar la intervención con el resto de los activistas, representar las principales preocupaciones de los trabajadores y construir una opinión alternativa a la de la Lista Verde.

Su carácter clandestino tenía dos motivaciones: 1- evitar que los militantes fueran detectados por la patronal y la dirigencia sindical; 2- conocer de primera mano la opinión "sin filtro" de los trabajadores y, a partir de ella, representar de manera vívida sus inquietudes y planteos:

"Cuando nosotros hacíamos [CROEMBA] con los problemas de la fábrica no se los dábamos en mano, lo pegábamos en 4 o 5 lugares, entonces en los momentos en que tenían que tomar el colectivo de una planta a otra, leían el volante y se ponían a discutir. Discutiendo y charlando estaban elaborando el volante siguiente, porque lo que poníamos en el volante siguiente era lo que ellos estaban viendo. Nosotros lo encuadrábamos en el clasismo, entonces los tipos se identificaban con ese volante. Se cargaban, decían: "¡uh mira viste que yo te decía! porque acá paso la otra vez..." y te contaban todos los problemas, y entonces nosotros lo llevábamos a la discusión de por qué el Pacto Social, de por qué el Rodrigazo." 628

La agilidad del material y el hecho de que los trabajadores sintieran que sus demandas estuvieran siendo expresadas, fueron construyendo las bases para la gestación de una nueva alternativa gremial.

El CROEMBA, además, fue un medio por el cual se logró la articulación entre las distintas corrientes antiburocráticas de la planta:

“(...) no había política partidaria, ese volante se hizo con el acuerdo de todos en que tenían que ser posiciones públicas, específicamente gremiales, para mejorar la calidad de vida, para tratar de ganar el gremio, [desde una concepción] clasista y democrática. No

acciones no habrían estado dirigidas políticamente y en muchos casos generaron dificultades como la concentración de policías en la zona y la desaparición de algunos de sus miembros durante la dictadura. En el testimonio además se remarca que en la planta habrían armado una "fábrica de armas" donde producían clandestinamente escopetas calibre 32 y 22 (Ídem.)

${ }^{628}$ Entrevista a Julio D’Alessandro con el autor, Buenos Aires, 2014 
importa que partido interviniera, estaba abierta a todos... pero esa era la premisa básica, no hacer política partidaria." ${ }^{229}$

En ese sentido, como indica Casco Peeble (2016), por sus características, el CROEMBA puede ser entendido como un antecedente del Comité de Lucha creado a la luz de la huelga de 22 días, que se analizará en la próxima sección.

Si bien aquel volante no era una herramienta partidaria, el PRT-ERP lo impulsó a través de sus militantes y aportó imprimiendo algunos de los ejemplares en sus imprentas clandestinas. Ahora bien, resulta significativo que en los testimonios de los perretistas, el apoyo del partido al trabajo gremial aparezca como algo externo y la creación del CROEMBA como un mérito propio de los militantes:

Entrevistador: ¿Y el CROEMBA fue una política del PRT?

Hugo: Sí... fue una política de... hasta nos hacían algunos volantes, muchas veces los volantes los hacían ellos... nosotros hacíamos el volante y ellos lo traían impreso...

Entrevistador: ¿Eso se lanzó ya cuando usted estaba en el partido o antes?

Hugo: No, eso lo inventamos nosotros adentro de la fábrica (...) para poder ingresar, entrarle al compañero con nuestras posiciones sin que él se sintiera afectado partidariamente, es decir, que no tuviera que pertenecer al partido, estar de acuerdo con ese volante pero no porque lo hacía partidario; es decir, no como el PST que venía y te hablaba, te hablaba y después te vendía el pasquín, y el flaco decía ‘¡No! Si yo soy peronista' ¡¿entendes?! Entonces ¿Cómo le entras a un tipo así? Le tenes que entrar de una forma independiente..."

Aquí encontramos algunas claves para comprender la manera en que la militancia fabril perretista de MBA entendió la relación entre el partido y la fábrica en ese plano. De éste y otros testimonios se puede inferir que la línea sindical se ordenaba bajo una "premisa básica": al interior de la planta "mandaban" los obreros y no los partidos. Esto se ve claramente en las palabras de Julio D'Alessandro:

"Nosotros trabajábamos en dos niveles. Cuando tocábamos el problema general de los 4000 obreros no dejábamos que entre esa política, pero sí se la hacíamos llegar a todos los que se interesaban y querían ingresar al partido. Los que leían el periódico y todo eso le dábamos la discusión con Montoneros. No era una contradicción, son momentos, si vos sos sindicalista, defendés los intereses de los trabajadores, y los intereses de los trabajadores son que los medios de producción y todo eso sean de los trabajadores... no de un partido." ${ }^{631}$

De este modo pareciera ser que en MBA, la organización actuaba a "dos niveles": si el nivel político era abordado a través de las herramientas partidarias tradicionales (fundamentalmente, las prensas orgánicas), la intervención sindical tenía sus propias

\footnotetext{
${ }^{629}$ Ídem.

${ }^{630}$ Entrevista a Hugo Crosatto con el autor, Buenos Aires, 2017. (Cursivas nuestras)

${ }^{631}$ Entrevista a Julio D’Alessandro con el autor, Buenos Aires, 2014.
} 
reglas, contorneadas y definidas por la experiencia militante. Así, en este último plano, los esfuerzos debían estar puestos en la defensa de los intereses obreros por sobre cualquier interés u objetivo político partidario. En ese horizonte aparecía como un acuerdo básico el cuidar celosamente que no ingresara la "política de los partidos" en los ámbitos gremiales ya que, en opinión de los militantes, atentaba contra la unidad y la organización de los obreros. Además, esa era una forma de evitar trasladar las disputas que el PRT-ERP sostenía con las demás corrientes fuera de la fábrica:

"Como no dejábamos entrar las políticas de los partidos, con los Montoneros no teníamos ningún problema (...) En la clase obrera entre montos y el PRT no había diferencias, la diferencia estaba en el vértice y en la línea política. En los problemas de la fábrica, cuando había que hacer todo eso trabajábamos todos juntos sin ningún problema. El problema se da después del 73 a nivel de la discusión de líneas, pero como nosotros no dejábamos que se discutan las líneas dentro del gremio, porque teníamos que ponernos de acuerdo con las necesidades de los trabajadores y con llevar adelante la [lucha contra la burocracia y] queríamos recuperar el gremio y lo recuperamos nosotros." ${ }^{632}$

Uno de los factores que influyó fuertemente sobre esa perspectiva, entre otros, fue el peso de la identidad peronista de los trabajadores. Como indican todos los entrevistados, en MBA la mayoría de los operarios eran peronistas y eso era un desafío innegable para el desarrollo de las organizaciones marxistas que debían enfrentarse a los "prejuicios macartistas" que circulaban en la planta. Por su parte los militantes perretistas, conscientes de ello, habrían percibido los límites que tenía la sobre-ideologización del trabajo político-sindical:
“QQué pasa? Nosotros veíamos, charlabamos con los compañeros, estaban leyendo un volante de cualquiera, no importa de quien, entonces yo me acercaba y les decía: 'que están leyendo' y me dice 'está bien, las posiciones a mí me gustan, pero son del... del PC (ponele)' y le digo 'pero bueno el tema no es quien lo firma sino el texto lo que dice, si es correcto, si les parece que se puede llevar a cabo', 'Si pero (dice...) yo soy peronista'. Con esto que quiero decir, para el compañero era angustiante reconocer algo que no fuera del peronismo como algo cierto viste... como decir 'este es el camino', pero no está el peronismo involucrado."

Como indica Crosatto, la identidad política aparecía como una traba que obstaculizaba acceder al contenido de los planteos y, por ende, a la construcción de consensos. De modo que no podía permitirse que por cuestiones de siglas políticas se obturase la posibilidad de organizar a los trabajadores. El objetivo estaba puesto en "entrarle al compañero $\sin$ que él se sintiera afectado partidariamente" ${ }^{\$ 4}$. Como indica D'Alessandro, en ese contexto, "llevar el partido a ultranza" podía transformarse en un

\footnotetext{
${ }^{632}$ Entrevista a Julio D’Alessandro, junio 2012, Buenos Aires.

${ }^{633}$ Entrevista a Hugo Crosatto con el autor, Buenos Aires, 2017

${ }^{634}$ Ídem.
} 
problema para lograr la influencia y la inserción buscada. En esta línea, como se dijo, descartaron la posibilidad de construir una agrupación sindical propia y, como consecuencia, no participaron del MSB ${ }^{635}$.

Sostenemos que el hecho de que el PRT-ERP haya penetrado en MBA a través de la incorporación de obreros que ya trabajaban en la fábrica, y no a través de la "proletarización” de sus militantes, le permitió tener un conocimiento más agudo de las aspiraciones, los tiempos y los límites de los trabajadores, lo que le brindó mayor flexibilidad y creatividad a la hora de encarar el trabajo político. En ese sentido retomamos la distinción analítica entre militante obrero y obrero militante (Löbbe, 2006: 173-174). Como hemos dicho, el concepto de militante obrero refiere a aquellos activistas o cuadros de una organización que "bajaban" a la fábrica, es decir que se "proletarizaban"; por su parte el obrero militante refiere a aquel trabajador que se incorporaba por propia voluntad y convicción a una organización política. En ese sentido el obrero militante tendía a reconocer más rápidamente la temperatura política y disposición a luchar de la fracción obrera a la que pertenecía, por lo que no siempre aceptaba incondicionalmente las prescripciones partidarias sino que tendía a priorizar los tiempos de maduración política de la clase por sobre la premura de la organización $^{636}$.

Existen versiones cruzadas entre los entrevistados sobre las consecuencias que ello traía al interior del partido. Según algunos habría habido ásperos debates con el "aparato" partidario que, muchas veces, intentaba imponer verticalmente la línea de la organización. Mientras que, para otros, el partido habría aceptado siempre y sin discusiones las orientaciones decididas por los militantes fabriles. No obstante todos coinciden en que en MBA quienes "mandaban" eran los obreros militantes y no la estructura partidaria.

Consideramos que ello permitió que los perretistas lograran una importante referencia en la planta $\mathrm{y}$, como consecuencia, que la organización incorporara a nuevos trabajadores. Es que el trabajo sindical que se desarrolló desde el CROEMBA abría un espacio para profundizar las discusiones políticas que habilitaba a posibles

\footnotetext{
${ }^{635}$ Ello no es algo que resulte menor si para 1975 la organización consideraba que "la presencia de la actividad del Partido en lo específicamente sindical la hacemos a través del MSB o de las agrupaciones en las cuales trabajamos" (Boletín Interno del PRT-ERP Nro. 85)

${ }^{636}$ Es necesario destacar que esto no siempre fue así, sino que existieron casos de proletarización exitosos en los que los militantes perretistas fueron elegidos como delegados y considerados como pares por el conjunto de los trabajadores en las fábricas. Un caso paradigmático en ese sentido fue el de Daniel De Santis quien se transformó en uno de los principales dirigentes en Propulsora Siderúrgica (Stavale y De Santis, 2016)
} 
incorporaciones. Según D’Alessandro los obreros que iban adquiriendo "coraje y conciencia" en el proceso de activación y organización sindical eran quienes aparecían como potenciales militantes, y era a estos a quienes se les hablaba del PRT-ERP fuera de la fábrica ${ }^{637}$. Además, alrededor de cada militante, se organizaba el "radio de influencia" del partido con aquellos obreros que simpatizaban con la organización, lo cual permitía amplificar la política perretista:

"Pablito era independiente, no militaba, pero era un buen cuadrito, yo lo tenía siempre al lado porque era muy claro para decir las cosas. Y él se pegaba a mí. Nunca me lo dijo pero congeniaba mucho con las ideas del partido, y de esos había muchos. No se animaban a decirlo... yo tenía a Mosquera por ejemplo, uno de los 14 desaparecidos, que era mi sombra, donde iba yo él estaba atrás mío",638

Esta influencia a su vez ayudaba a la circulación de los materiales del PRT-ERP, ya que en base a ella lograban construir una red de distribución con los simpatizantes que le permitía llegar al conjunto de la planta con pocos volantes ${ }^{639}$. Esto se deja ver también en el testimonio de Héctor Ratto quien, si bien construyó un vínculo de mayor cercanía con el PRT-Fracción Roja/GOR, colaboraba lateralmente con los perretistas:

"Entrevistador: ¿Y usted qué tipo de tareas asumía?

Héctor: No, yo colaboraba en todo lo que podía, de llevar gente, de si podía distribuir propaganda, hablar con la gente, qué era lo mejor para los trabajadores para enfrentar a la empresa (...)

Entrevistador: ¿Y usted vendía El Combatiente?

Héctor: No, distribuía, venderlo ya era muy difícil. O sea a menos que alguno tenga ya la ideología y te lo compre viste...

Entrevistador: ¿Y tus compañeros de trabajo tenían simpatía?

Héctor: Bueno sí, siempre lo leíamos, lo comentábamos entre los círculos más chicos, también se podía pegar algún afiche en alguna pared o en algún 'coso' que había ahí para poner los informes internos del gremio, de la empresa y eso (...)" "c640

Esta modalidad del trabajo político, que como vimos también se dio en TENSA, fue la manera en que la militancia fabril perretista buscó influir en los trabajadores y erigirse como la dirección política, en los hechos, al interior de la fábrica.

Ahora bien, no toda la influencia lograda por el PRT-ERP se traducía en una demostración del apoyo de los trabajadores al proyecto revolucionario. En la mayoría de los casos, las lealtades construidas tenían que ver más con la "honestidad" de los militantes que con la línea política que profesaban: “¿Qué veía la gente en aquella militancia? La honestidad y reconocían que no iban a ser traicionados por esos

\footnotetext{
${ }^{637}$ Entrevista a Julio D’Alessandro con el autor, Buenos Aires, 2014

${ }^{638}$ Entrevista a Hugo Crosatto con el autor, Buenos Aires, 2017

${ }^{639}$ Entrevista a Ricardo Hoffman con el autor, Buenos Aires, 2017.

${ }^{640}$ Entrevista a Héctor Ratto con el autor, Buenos Aires, 2017
} 
compañeros, por eso fue que nos acompañaron en una forma tan contundente." ${ }^{641}$ En ese sentido también pueden entenderse las palabras de Ratto quien plantea que el trabajador promedio no diferenciaban a un militante del PRT-ERP del de cualquier otra organización de izquierda ${ }^{642}$.

Este tipo de referencia fue lo que permitió la masividad del apoyo brindado por los trabajadores a los representantes surgidos en la huelga de 1975. De hecho, como vimos, la propia militancia perretista fue consciente de ese fenómeno y por él fue que se propuso intervenir con los niveles de amplitud con que lo hizo a través del CROEMBA. Incluso aquello fue lo que le permitió lograr niveles importantes de protagonismo en la fábrica que se materializaron en la elección de algunos de sus militantes como integrantes de las comisiones paritarias de junio y en la participación desatacada de Hugo Crosatto como uno de los principales dirigentes de la “Comisión de los 9" durante la huelga de octubre.

\subsection{La huelga de 22 días y el papel de los perretistas en el conflicto.}

Si bien hacia fines de 1974 los conflictos sindicales habían disminuido por el recrudecimiento de la política represiva del gobierno, ante la caída del salario real de un $4 \%$, los trabajadores respondieron con nuevas formas de lucha desatando una ola de ausentismo que llegó a un 20\% de la fuerza laboral en todo el país (Torre, 2004: 98). Por su parte, entre julio y octubre de 1974, en las automotrices del Gran Buenos Aires $\left(\mathrm{MBA}^{643}\right.$, Ford, General Motors, Eaton Ejes y Peugeot) se dieron un conjunto de asambleas y conflictos en reclamo de mejoras salariales que alertaron a la conducción del SMATA. Este fenómeno no pasó desapercibido para el PRT-ERP que avizoraba el surgimiento de un movimiento antiburocrático similar al cordobés en las plantas bonaerenses:

"Las movilizaciones realizadas muestran también, claramente, que en el gremio mecánico de Buenos Aires, se desarrolla, en forma lenta pero segura, una corriente clasista y combativa que, a mayor o menor plazo, derrotará a la burocracia como sucedió en Córdoba y arrancará nuevas y nuevas conquistas a la patronal.

Contribuir a su fortalecimiento y consolidación es una de las tareas de masas que permitirá a nuestro Partido edificarse sana y sólidamente en el seno de los combativos trabajadores del automotor, gremio clave del proletariado argentino." ${ }^{644}$

\footnotetext{
${ }^{641}$ Entrevista a Hugo Crosatto con el autor, Buenos Aires, 2017

${ }^{642}$ Entrevista a Héctor Ratto con el autor, Buenos Aires, 2017

${ }^{643}$ Por ejemplo, el 12 de junio de 1974 una asamblea resolvió pedir un aumento de 120.000 pesos, aunque poco después una nueva asamblea convocada por el SMATA logró dar de baja el pedido de los obreros ("Noticiero Sindical" El Combatiente Nro. 126 Miércoles 17 de julio de 1974.)

644 "El clasismo se extiende en mecánicos" El Combatiente Nro. 140, Miércoles 23 de octubre de 1974.
} 
Como marcan la mayoría de los testimonios, el ejemplo del clasismo del SMATA Córdoba era una importante fuente de inspiración del activismo de base de MBA y de muchas otras fábricas de la zona. De hecho, las protestas a las que se hace referencia se respaldaban en la lucha de aquel sindicato que, dirigidos por la Lista Marrón ${ }^{645}$, encabezaba el reclamo por aumentos salariales del $60 \%$ para todo el sector.

En ese sentido, el comienzo del año 1975 estuvo marcado por las expectativas generadas por la convocatoria a negociaciones paritarias que, como vimos, fueron llamadas para el mes de marzo. En la mayoría de las fábricas se llevaron a cabo asambleas para elegir los representantes obreros a dichas comisiones, y MBA no fue la excepción. Como relata Eduardo Fachal, militante del PB y trabajador de la sección Tratamientos Térmicos, en aquellos momentos existían dos tipos de asambleas: las oficiales convocadas por el SMATA, donde "surgían algunas voces de cuestionamiento" y, por otro lado, una asamblea "autoconvocada", un tanto más reducida, que expresaba al movimiento de base de la fábrica ${ }^{646}$. Los activistas que motorizaban estas últimas, muchos de ellos nucleados en el CROEMBA, organizaron un relevamiento sector por sector mediante el cual auditaron las condiciones laborales por puesto de trabajo y elaboraron un pliego de reivindicaciones para encarar la lucha por las paritarias con exigencias diversas. Este proceso de activación gremial condujo a la presentación de una lista propia, opuesta a la de la burocracia, que terminó ganando por amplia mayoría. Como remarcan la totalidad de los entrevistados, fue Julio D’Alessandro quien encabezó aquel proceso. Según su testimonio, él y otros dos militantes perretistas fueron elegidos como delegados para la comisión paritaria, junto algunos trabajadores independientes. Esta era la cristalización de la inserción que había logrado el PRT-ERP hasta ese momento, y del papel que habían jugado sus militantes en la experiencia del CROEMBA. Es de destacar que, poco tiempo antes de la elección, los trabajadores se habían enterado de la pertenencia partidaria de D'Alessandro, ya que en una asamblea general convocada por el SMATA, un representante del gremio lo había acusado públicamente como "subversivo del ERP":

\footnotetext{
${ }^{645}$ Como vimos en el capítulo 4, la la Lista Marrón de SMATA Córdoba era una lista clasista encabezada por el dirigente René Salamanca, que conducía la seccional desde 1972, que había revalidado su conducción en 1974. En su seno llevaba a fuerzas como el PCR, fuerza a la que pertenecía Salamanca, VC, PO y el PRT-ERP.

${ }^{646}$ Entrevista a Eduardo Fachal con el autor, Buenos Aires, 2017. Eduardo Fachal ingresó a MBA en 1974. Hijo de familia de clase media y universitaria, estudió la carrera de sociología donde militó en la Corriente Estudiantil Nacional y Popular y posteriormente ingresó al PB donde, como parte de la política de la organización, decidió proletarizarse.
} 
"Todos sabían que yo era del PRT, porque una vez que voy a hablar... yo nunca quise hablar en las asambleas, pero una vez estaba por decir algo que nadie decía sobre el SMATA Córdoba, y salen unos matones a decir: 'este es del ERP, es del ERP!' y bueno fue ahí que... ¡mira vos la influencia que tenía el partido! Porque yo no le había dicho a nadie que militaba en el partido, sólo a aquellos que estaban interesados en incorporarse, ¡y ahí es cuando me eligen paritario! Así que los burócratas me lo dicen para echarme mierda iy los compañeros me elijen a mí y a otros dos que son del PRT!" ${ }^{647}$

No obstante, la experiencia de los delegados paritarios duró muy poco, ya que las comisiones paritarias quedaron sin efecto a nivel nacional el 31 de mayo al ser suspendidos los Convenios Colectivos de Trabajo y vencerse el plazo para la convocatoria a las reuniones de negociación con el Ministerio de Trabajo. A su vez, los delegados fueron objeto de una campaña de aprietes y amenazas dirigida por grupos de choque del SMATA y del "Comando de Organización"648 que buscaron con ello descabezar el movimiento que se estaba gestando en la planta. En ese marco la empresa, en una reunión con los delegados, les "recomendó" que abandonaran el trabajo para “evitar problemas", dejando entrever que no podían hacerse cargo de su seguridad. Ante esta situación, agravada por las amenazas de muerte recibidas, todos los miembros de la comisión paritaria se vieron obligados a aceptar el despido y la indemnización que les proponía la empresa. Esto habría generado indignación entre los trabajadores, que respondieron con quites de colaboración y algunas medidas de sabotaje a la producción $^{649}$. La situación se agravó cuando el SMATA firmó un convenio colectivo a espaldas de los obreros en el que, entre otras cosas, se establecía la prestación de servicio fuera de los días y horas de trabajo, la prohibición de todo tipo de actividad política en la empresa, e incorporaba un artículo titulado "Aporte extraordinario al fondo de acción social" que reglamentaba la entrega del 1\% de la facturación por ventas de la empresa al sindicato para "la erradicación de todos los factores negativos que puedan perturbar el normal desenvolvimiento de la actividad laboral y empresarial” $\$$. Todos estos hechos fueron aumentando la tensión en MBA hasta que, el 8 de octubre, estalló el conflicto. Es de destacar que en las luchas que se habían dado en el Gran

\footnotetext{
${ }^{647}$ Entrevista a Julio D’Alessandro con el autor, Buenos Aires, 2014.

648 El Comando de Organización (CdeO) nació en 1961 como un desprendimiento de la Juventud Peronista. Dirigido por Antonio Brito Lima, aquella fue una organización de orientación peronista, nacionalista y católica que se organizaba a través de una estructura militar y tenía especial peso en La Matanza, Morón y Mataderos. Durante el período 1973-1976, se volcó al enfrentamiento contra el peronismo revolucionario, especialmente con Montoneros. Defensores del gobierno de Isabel, también funcionaron como grupos de choque de la burocracia sindical en las fábricas. (Denaday, 2016) 649 Ídem.

650 “"Buenos muchachos' (La historia negra de la burocracia del SMATA)”, La Izquierda Diario, 24 de diciembre de 2014.
} 
Buenos Aires los meses anteriores, sobre todo en las jornadas de junio y julio contra el "Plan Rodrigo", la participación de los trabajadores de MBA no había sido masiva debido a que la CIR continuaba intervenida desde 1974. Esto también afectó la participación en la organización de la Coordinadora de Gremios en Lucha de la Matanza ya que los activistas no podían arrogarse formalmente la representación de los trabajadores (Casco Peeble, 2016). Finalmente la gota que rebalsó el vaso fue una disposición resuelta por el SMATA que descontaba un día de trabajo a todos los obreros como aporte a la caja del gremio. Al conocer aquella resolución, una cantidad importante de trabajadores se reunieron en la puerta de la oficina de los interventores sindicales exigiendo la anulación de aquella medida y, además, aumentos salariales indexados a la inflación, el fin de la intervención y el llamado a elecciones de la CIR. Ante la presión de los obreros, uno de los interventores se vio obligado a llamar a una asamblea general en la que, por unanimidad, se resolvió ir a la huelga y se eligió una CIR provisoria compuesta por nueve miembros (que paso a conocerse como "el grupo de los 9") de los cuales dos pertenecían a la JTP (Henestroza y Víctor Hugo Ventura), uno al PRT-ERP (Hugo Crosatto) y el resto eran trabajadores independientes (Telmo Ferro, Alfredo Cano, Pablo Hernández, Eduardo Estivil, Silvio Daniel Portnoy y José Barreiro). Además, también se eligió un cuerpo de delegados provisorio de 60 miembros organizado por sección de trabajo.

Al día siguiente los interventores, acompañados por hombres armados del sindicato, se hicieron presentes en la planta para controlar la situación, y fueron repudiados y echados por los trabajadores que declararon el paro por tiempo indeterminado. Como respuesta a la medida de fuerza el 11 de octubre la huelga fue declarada ilegal por el Ministerio de Trabajo, mientras que la conducción nacional del SMATA quitó el apoyo a los trabajadores luego que estos se movilizasen al local pidiéndole su respaldo ${ }^{651}$.

El conflicto tuvo un nuevo giro cuando, el martes 14, la empresa comunicó 117 despidos, entre los que se incluían la totalidad del "grupo los 9" y el CD, impidiéndoles el ingreso a la fábrica ${ }^{652}$. La respuesta de los trabajadores a esta medida fue contundente: bajo la consigna "los 4.000 adentro o los 4.000 afuera" comenzaron a realizar asambleas en las puertas de la fábrica donde organizaron la huelga. Un volante

\footnotetext{
651 "Reportaje a la Comisión Provisora de Mercedes Benz" Avanzada Socialista Nro. 168, 24 de octubre de 1975

${ }^{652}$ El Cronista Comercial, 14 de octubre de 1975; El Cronista Comercial, 21 de octubre de 1975
} 
firmado por el CROEMBA sintetiza el espíritu y el pliego de reivindicaciones del conflicto:

"Los trabajadores de Mercedes Benz Argentina, en lucha por sus derechos de clase trabajadora, decimos BASTA a toda clase de explotación y traición.

Reclamamos:

1- REINCORPORACIÓN inmediata de 117 compañeros despedidos

2- RECONOCIMIENTO de la Comisión Interna elegida democráticamente por asamblea.

3- REAJUSTE cuatrimestral de salarios.

4- REAJUSTE para los turnos desplazados.

5- Gratificación extraordinaria.

6- Actualización de CATEGORÍAS para los cros. empleados.

Si bien el SMATA nos acusa públicamente de 'asesinos' y 'manijeros' y boicotea nuestra lucha, somos concientes de su traición y que nuestra lucha es la que deben protagonizar todos los trabajadores para lograr juntos nuestra LIBERACIÓN"

El volante culminaba con un llamado a la solidaridad de todos los sectores sociales y comprometía a las autoridades nacionales a buscar una solución a los problemas de la fábrica.

A partir de allí la huelga funcionó en base a tres organismos de deliberación y dirección: el "grupo de los 9", que era la representación sindical visible y el organismo que mantuvo la negociación con la empresa durante todo el conflicto ${ }^{653}$; un Comité de Lucha, que reunía a todo el núcleo de activistas de la fábrica; y las asambleas, que eran el espacio de deliberación colectiva.

Respecto del Comité de Lucha, según el testimonio de Ricardo Hoffman, este era el organismo por donde pasaba la disputa por la dirección política del movimiento de masas en MBA, y por ello el PRT-ERP habría volcado todos sus esfuerzos a dirigir políticamente ese espacio. Ese organismo reunía a militantes de las diferentes corrientes así como al activismo independiente, oficiando de "núcleo duro del activismo huelguista". Desde allí se editaron dos números de un boletín llamado "El Engranaje", que llego a tener una tirada de aproximadamente 700 ejemplares, con el que se mantenía informada a la base; se organizaron fondos de huelga, grupos de autodefensa y comisiones que buscaron la solidaridad tanto de otras fábricas como de la comunidad. Según Fachal, en aquel Comité se nucleaba al activismo más consciente y avanzado de la fábrica que comenzaba a cuestionar al peronismo y a acercarse a posición mayormente de izquierda o críticas:

\footnotetext{
${ }^{653}$ Así, por ejemplo, en la impresión de Nestor Rossi, quienes conducían eran el "grupo de los 9": “A nosotros nos bajaban línea los delegados. Yo creo que uno de los que encabezaba eso era Ferro... Crosatto, era otro compañero.” (Entrevista a Néstor Rossi con el autor, Ezeiza, 2018.)
} 
"Entrevistador: Y vos me dijiste que entraste a la fábrica y viste que había un sector importante de la clase que venía rompiendo del peronismo ¿cómo es eso?

Eduardo: Si, los sectores jóvenes, esos sectores que se aglutinaban en el Comité de Lucha. Muchos que venían de sectores del peronismo que veían, bueno sobre todo después de la muerte de Perón, Isabel, López Rega, en lo que se había convertido el peronismo. Bueno venían participando de las luchas de lo que eran la Coordinadora de Oeste que llego a ser muy fuerte y muy importante. Yo creo que ahí, en torno a eso, se aglutinaba un sector de la clase joven que empezaba a buscar otras alternativas diferentes del peronismo, que algunos podían ser mas de izquierda o menos de izquierda pero que iban en ese sentido" ${ }^{954}$

Por su parte Héctor Ratto destaca que el Comité era el grupo que "militaba" la huelga buscando convencer a los trabajadores, colaborando con distintas iniciativas y apuntalando al "grupo de los 9".

Como indica Casco Peeble, la existencia de 4 organismos gremiales de distinta índole (el "grupo de los 9" -CIR-, el CD, el Comité de Lucha y las asambleas), permite sopesar la fuerte organización sindical que había en la planta de MBA que, en los hechos, eran obstáculos contundentes para los planes de la gerencia (2016:162).

Con este nivel de organización, el conflicto logró trascender los límites de la fábrica. A través de la gestión del Comité de Lucha, se logró que los trabajadores de otras empresas se solidarizaran con la lucha de MBA, como Santa Rosa, Indiel, FAPESA, MAN, Monofort, y Jabón Federal, ubicadas en La Matanza, y de otras zonas como Grafa (Capital Federal), SAFAR-Peugeot (Morón) y Sierra Grande (Rio Negro) ${ }^{655}$. También, organizaron un acto en el centro de Cañuelas, localidad lindante a la planta, de la que participaron, según datos periodísticos, cerca de cuatro mil quinientas personas ${ }^{656}$. La participación de la comunidad en aquel acto fue masiva, consiguiéndose que se apoyara la medida con la suspensión de las actividades comerciales de la localidad $^{657}$. Además contaron con la adhesión del intendente de la localidad y del gobernador bonaerense y dirigente de la UOM Victorio Calabró ${ }^{658}$. Por otro lado,

\footnotetext{
${ }^{654}$ Entrevista a Eduardo Fachal por el autor, Buenos Aires, 2017

655 "Reportaje a la Comisión Provisora de Mercedes Benz" Avanzada Socialista Nro. 168, 24 de octubre de 1975

${ }^{656}$ La Prensa, jueves 23 de octubre de 1975

${ }^{657}$ Un volante sin firma, del 22 de octubre, convocando al paro de comercio en Cañuelas expresaba: "En la reunión a que fuera convocado el comercio de Cañuelas, relacionado con el conflicto existente en la planta de Mercedes Benz Argentina, de Gonzales Catán, la mayoría se expidió en el sentido de efectuar un cierre de medio día, hoy a partir de las $12 \mathrm{hs}$, declarando que el mismo está inspirado en el anhelo de que se llegue a una rápida y feliz solución del conflicto, teniendo en cuenta las importantes derivaciones que ello puede generar en beneficio de la comunidad" (Volante en poder del autor). Por otro lado, según El Cronista Comercial los comerciantes de aquella localidad organizaron colectas, alcancías públicas y fondos de huelga para ayudar a los trabajadores. (El Cronista Comercial, 25 de octubre de 1975).

${ }^{658}$ El gobernador había recibió en su despacho a la CIR donde se comprometió a que la policía provincial no impidiera ni reprimiera las asambleas en la puerta de la fábrica (El Cronista Comercial, 22 de octubre
} 
algunos miembros de la CIR mantuvieron una reunión con Ricardo Balbín, quien había manifestado su apoyo, para que mediara en el conflicto ${ }^{659}$. Además consiguieron el respaldo público de los senadores Afrio Pennisi (hombre de la UOM), Edgardo Murguía (hombre de ATE Santa Cruz) y Luis León (UCR), de los diputados Antonio Troccoli (UCR), Jesús Mira (PCA) y Mariano Lorences y del dirigente Oscar Alende (ambos del Partido Intransigente) ${ }^{660}$.

Este nivel de acatamiento y de apoyo público que recibieron los trabajadores de MBA fue una expresión del estado de movilización y oposición al gobierno que se vivía por esos meses y, al mismo tiempo, el resultado de una política, llevada adelante por el “grupo de los 9" y el Comité de Lucha, que apuntó a evitar el aislamiento del conflicto y, sobre todo, a darle legitimidad social a sus reclamos. Lo destacable en ese sentido, es que los militantes que encabezaron el conflicto, buscando el triunfo y respondiendo a sus bases, no antepusieron pruritos políticos e ideológicos a la hora de recoger adhesiones. Consideramos que ello tuvo que ver con el "acuerdo básico" que reinaba entre los activistas de que en cuestiones gremiales no interfiriera las disputas partidarias. No obstante, la amplitud y diversidad de los apoyos que consiguieron los huelguistas no estaba por fuera de la línea que el PRT-ERP planteaba para los conflictos. En múltiples casos la organización promovió la búsqueda de la solidaridad de distintos sectores políticos así como, principalmente, de los comerciantes y vecinos de los barrios de las zonas fabriles $^{661}$. De hecho, este último aspecto era considerado fundamental en dos sentidos: por un lado, porque ayudaba a cultivar la relación entre la clase obrera y otros

de 1975). Presumiblemente el apoyo de este último haya tenido que ver, como veremos más adelante, tanto con la disputa que tenía con la dirección del SMATA como por el enfrentamiento que, en aquel momento, el gobernador tenía con Isabel Perón. Como vimos en el capítulo 4, luego de las jornadas de junio y julio, y fundamentalmente hacia fines de 1975 y principios de 1976, el gobernador Calabró se ubicó en oposición al gobierno de Isabel, incluso apoyando una salida golpista. El enfrentamiento comenzó cuando Lopez Rega había intentado colocar la red de obras sociales bajo su órbita, se profundizó cuando el gobierno decidió no homologar las paritarias y luego se radicalizó con el Plan Mondelli en 1976.

${ }^{659}$ La Prensa, jueves 23 de octubre de 1975; "Banca y comercio de Cañuelas apoyan a obreros en conflicto" El Cronista Comercial, 24 de octubre de 1975

660 "Reportaje a la Comisión Provisora de Mercedes Benz" Avanzada Socialista Nro. 168, 24 de octubre de 1975; "Cumple 13 días la huelga en Mercedes Benz" El Cronista Comercial, 22 de octubre de 1975

${ }^{661}$ En varios conflictos donde el PRT-ERP tuvo una participación destacada, la organización promovió ese tipo alianzas: ejemplo de ello fueron los conflictos de INSUD, donde realizaron ollas populares con los habitantes de barrios aledaños y recibieron el apoyo de varios diputados y dirigentes políticos; en Villa Constitución donde, como vimos, gran parte de la población de la localidad participo del conflicto y Rigolleau (Berazategui) donde el vínculo con los pobladores de la zona fue un elemento de suma importancia en el conflicto de marzo de 1975. De hecho en este último caso el propio PST, que reconocía la dirección política del PRT-ERP al interior de la fábrica, rescató que en el conflicto los guevaristas habían sido los únicos que habían propuesto unir la lucha a los comerciantes y vecinos de la localidad (Centurion, 2013). 
sectores de la población, promoviendo el papel dirigente de la primera, y, por el otro, porque ayudaba a darle respaldo, apoyo y legitimidad a las luchas sindicales.

Esta trascendencia que tuvo el caso de MBA, motivó al SMATA a publicar una solicitada en el diario Clarín en la que buscaba desprestigiar al "grupo de los 9" acusándolos de ser un "grupo de seudo obreros" que estaban conduciendo a los trabajadores a una lucha "suicida" de características imprevisibles y que además buscaban crear un sindicato por empresa de características "seudo revolucionarias". A la vez, exigían que los dirigentes clarificaran ante los trabajadores cual era el rumbo del conflicto y cuáles las soluciones propuestas ${ }^{662}$. Es evidente que las acusaciones del sindicato estaban basadas en la creciente politización que fue adquiriendo el conflicto y la participación que tuvieron las organizaciones revolucionarias.

Dos días después, el 24 de octubre, se dio un hecho que marcó un punto de inflexión para la huelga ${ }^{663}$ : Montoneros secuestró al gerente de producción y accionista de la empresa Franz Metz. En su comunicado la organización planteaba las exigencias para su liberación: "entre las condiciones para liberar a este chupasangre está la reincorporación de los despedidos y el reconocimiento de la comisión interna de reclamos" ${ }^{\$ 64}$. Es de destacar que no era la primera intervención de una organización guerrillera en el marco del conflicto. El ERP había realizado una campaña de intimidación a través de volantes de "advertencia" que amenazaban con nombre y apellido a varias personas de la gerencia (Tomsuchat, 2003), y en la segunda semana de la huelga había "atentado con explosivos contra la vivienda de un ejecutivo de Mercedes Benz" ${ }^{\prime 65}$. Sin embargo aquellas acciones no tuvieron el impacto que tuvo el secuestro.

A los pocos días, el lunes 27, la empresa decidió reincorporar a algunos trabajadores y abrir las puertas de la fábrica. Ello motivo, al día siguiente, una importante movilización de trabajadores que, encabezados por el "grupo de los 9", se dirigió hasta el Ministerio de Trabajo para exigir la reincorporación de todos los obreros y una resolución efectiva del conflicto ${ }^{666}$. Es de destacar que de los nueve integrantes de la CIR, Hugo Crosatto,

\footnotetext{
${ }^{662}$ Clarín, miércoles 22 de octubre de 1975.

${ }^{663}$ Ese mismo día apareció un volante del CROEMBA donde se ratificaba el rumbo que venía teniendo el conflicto: "Ante este estado de cosas y siendo el día 24.10.75 en asamblea gral. realizada en campo frente a la empresa (sic) (...) los trabajadores de Mercedes Benz Argentina reafirmaron su decisión de seguir firmes en la lucha hasta sus últimas consecuencias, nuestra consigna: los 4.000 adentro o los 4.000 afuera" (Copia digital del volante en poder del autor.)

664 "Mercedes Benz: derrota de patrones y burócratas", Evita Montonera Nro. 9 de Noviembre de 1975.

665 “Crónica de la guerra revolucionaria” en Estrella Roja, 17 de Octubre de 1975.

666 “Operarios de MBA realizan una concentración” El Cronista Comercial, 29 de octubre de 1975
} 
dirigente perretista, fue designado como vocero ante las cámaras de televisión, una muestra de los niveles de representatividad e influencia que había logrado durante el conflicto.

Ante la falta de respuestas del ministerio la movilización se redobló: el miércoles 29, más de tres mil trabajadores se dirigieron a las oficinas de MBA en Capital Federal para obtener una reunión con el directorio. Finalmente, consiguieron una amplia victoria: la empresa se comprometió a dejar sin efecto los despidos producidos desde el 30 de septiembre, conceder el pago de los salarios de los días de huelga, reconocer a la nueva CIR y no tomar represalias contra los participantes del conflicto ${ }^{667}$. Al día siguiente a las 7 de la mañana los obreros decidieron en asamblea retornar al trabajo luego de que los integrantes de la CIR comunicaran que la empresa se avenía a otorgar todos los puntos reclamados ${ }^{668}$. De este modo "cantando y vivando a sus delegados, los 4.000 trabajadores efectuaron una vuelta olímpica alrededor de la planta fabril" ${ }^{\prime 669}$. El viernes 31, en una solicitada, el Directorio de MBA confirmaba y comunicaba lo resuelto ${ }^{670}$.

\section{Balances del conflicto.}

Uno de los aspectos que la mayoría de los testimonios tiende a afirmar es que, en el conflicto, las fuerzas políticas que mayor peso mostraron fueron la JTP y el PRT-ERP, tanto por la cantidad de militantes que poseían como por el rol que jugaron los mismos en los espacios de dirección. Otro de los aspectos en que coinciden es que una de las mayores fortalezas de la huelga radicó en el nivel de unidad logrado entre los trabajadores, sobre todo gracias a que se respetaron los espacios de deliberación

\footnotetext{
${ }^{667}$ En la revista Nuevo Hombre, del 5 de noviembre de 1975, aparece una nota dedicada al análisis de las luchas salariales que se venían dando en los últimos meses y en la que se hace especial referencia a la lucha de Mercedes Benz Argentina, al punto de dedicarle un recuadro especial titulado "Vuelta Olímpica en Mercedes Benz" en la que relatan los pormenores de la resolución del conflicto: "(...)Luego de informar la comisión de reclamos que la empresa se avenía a otorgar todos los puntos reclamados por los obreros, los 117 cesanteados y reincorporados fueron los primeros en ingresar a la planta al calor de una entusiasta gritería del conjunto del personal. Cantando y vivando a sus delegados, los 4.000 trabajadores efectuaron una vuelta olímpica alrededor de la planta fabril. Los manifestantes hicieron un alto frente a la central termoeléctrica, cuyos operarios - 20 en total- trabajaron a lo largo del conflicto por decisión del conjunto de la asamblea. Tal postura se debió a que dicha central abastecía de electricidad a los barrios obreros aledaños a la fábrica. Las expresiones de júbilo se reprodujeron durante varios minutos y como una prueba de buena voluntad del personal, los trabajadores de los 3 turnos trabajaron en forma conjunta a lo largo de esa primera jornada después de las medidas de fuerza. (...)" (Nuevo Hombre, del 5 de noviembre de 1975)

668 "La Mercedes Benz aceptó todas las demandas de sus operarios" El Cronista Comercial, 30 de octubre de 1975

${ }_{669}^{60}$ Nuevo Hombre, del 5 de noviembre de 1975

${ }^{670}$ Clarín, 31 de octubre de 1975.
} 
colectiva $^{671}$. Ahora bien, ello no supuso la ausencia de disputas políticas entre las organizaciones. Si bien los activistas buscaron que aquellas no incidiera en los acuerdos gremiales logrados, cada organización observó la conflictividad desde su prisma político y de sus concepciones ideológicas, lo cual se nota claramente en la interpretación y el balance que realizó cada una de ellas.

Uno de los ejemplos más evidentes de la existencia de diferencias fue el del PCR. Aquel partido, que tuvo una participación marginal en la huelga, miró todo el proceso con desconfianza ya que lo consideró como una jugada contra el gobierno por parte de la cúpula sindical, la empresa y las organizaciones revolucionarias, conjunto al que ellos calificaban de "enjambre prorruso". Es de destacar que en ese momento dicha organización estaba jugada en la defensa del gobierno de Isabel Perón, por lo que tendía a oponerse a todo conflicto que condujera a desestabilizarlo políticamente. Como indica Casco Peeble, la línea de aquella organización durante la huelga fue la de "arribar a una justa solución al problema" lo más rápido posible para no desgastar al gobierno (2016:136).

Por su parte el PST, que caracterizaba al conflicto como el más importante entre todas las luchas fabriles del momento ${ }^{672}$, en su boletín interno sindical realizaba un balance sumamente crítico respecto del "grupo de los 9" por fallar en la dirección del conflicto:

"La dirección -los 9-, nunca le dieron a la gente conciencia real de que estaban en huelga y que era larga. Por el contrario alentaron las esperanzas que terminaría de un día para otro. Nunca trabajaron orgánicamente, fueron la anarquía total. De conjunto, ni los 9 ni los 50 se reunían en otro lugar que no fuera la asamblea. Las asambleas mal preparadas, duraban unos minutos, no se daban tareas, eran meramente informativas y la dirección desaparecía para tocar distintos puntos: Calabró, Balbín, Cañuelas, Parlamento, etc." ${ }^{~}{ }^{\prime 673}$.

\footnotetext{
${ }^{671}$ Esto queda claro, por ejemplo, en el testimonio de Ramón Segovia, militante del PST, quien remarca que si bien a nivel político cada uno planteaba sus posiciones a nivel sindical se coordinaba todo, teniendo a la asamblea como principal especio deliberativo. Esto mismo se deja ver en el testimonio de Ratto quien remarca que las diferencias entre las organizaciones existían pero de la fábrica para afuera ya que adentro se limaban todas las asperezas que podían existir. Ello se ve claramente en la visión de Néstor Rossi quien en la entrevista enfatiza que "desde afuera" se veía un nivel de homogeneidad y unidad absoluto. Por último es de destacar que uno de los aspectos que más remarca Eduardo Fachal es el nivel de diálogo permanente que sostenían los militantes de las diferentes corrientes al interior de la fábrica. (Entrevista a Ramón Segovia con el autor, Buenos Aires, 2016; Entrevista a Héctor Ratto con el autor, Buenos Aires, 2017; Entrevista a Néstor Rossi con el autor, Ezeiza, 2018)

672 "Reportaje a la Comisión Provisora de Mercedes Benz" Avanzada Socialista Nro. 168, 24 de octubre de 1975

${ }^{673}$ PST. Boletín Interno del 4 de noviembre de 1975, Fundación Pluma.
} 
Es de destacar que esta apreciación estaba teñida por la frustración de no haber podido intervenir con mayor fuerza en la huelga debido a la debilidad con que, según el propio informe, habían "entrado al conflicto" 674 .

En el caso del GOR, la huelga era reivindicada por los niveles de unidad de acción alcanzados, aunque, al mismo tiempo, criticaban algunas "debilidades" que se habrían desnudado en el desarrollo del conflicto y que a su criterio podían "torcer el rumbo de la unidad en la lucha"675. Específicamente reprochaban algunas "expresiones de confianza en la burocracia y en sectores políticos de la burguesía", en alusión a los apoyos buscados en la conducción nacional del SMATA y en figuras políticas como Balbín, Alende e incluso el propio Victorio Calabró.

Por su parte, para el PRT-ERP no hubo aspectos criticables. En su balance los niveles de unidad y organización de las bases fueron los elementos más destacados. En una nota titulada "Triunfo obrero en Mercedes Benz", la organización remarcaba: "La capacidad de organización demostrada por los trabajadores a lo largo del conflicto se erigió como una herramienta decisiva para alcanzar la victoria"676. En ese sentido, la solidaridad recogida de la comunidad y de las fábricas de la zona, así como las movilizaciones al Ministerio de Trabajo y a la casa matriz de la empresa, fueron los hechos más reivindicados de la huelga.

A diferencia del resto, Montoneros fue la única fuerza que planteó públicamente que el secuestro del gerente fue el hecho decisivo que permitió el triunfo, ya que, desde su visión, dicha acción había obligado a la empresa a aceptar una negociación directa. En su interpretación, aquel hecho había permitido romper la alianza de "los patrones con la burocracia y el estado" y evitar la intervención militar-policial, como había sucedido en Villa Constitución ${ }^{677}$. En ese sentido, si bien reivindicaban la fortaleza de los trabajadores, era la intervención política montonera la que aparecía como la calve del triunfo.

El secuestro cosechó críticas y beneplácitos, y todas las organizaciones revolucionarias, salvo por el caso del $\mathrm{PCR}^{678}$, coincidieron que la acción había sido recibida con entusiasmo por los trabajadores. Ni siquiera el PST, que condenó la acción por

675 "Mercedes Benz. Después de la vuelta olímpica." Boletín de la Corriente Clasista Nro.12, diciembre de 1975

676 “Triunfo obrero en Mercedes Benz", El Combatiente Nro. 190 del 5 de noviembre de 1975.

677 "Mercedes Benz, derrota de patrones y burócratas" Evita Montonera Nro.9, noviembre de 1975

${ }^{678}$ Desentonando con el resto de las voces, los maoístas en una nota de su periódico Nueva Hora planteaban que algunos trabajadores habían manifestado su repudio al secuestro ya que "el terrorismo pretendía confundir la lucha” (Casco Peeblo, 2016: 138).
} 
"sustituir" la actividad de la clase obrera, pudo desconocer los efectos del secuestro: "no podemos dejar de señalar que también hay algunas acciones guerrilleras que son vistas con simpatía por la vanguardia. Este es el caso, por ejemplo, de los compañeros de Mercedes Benz"679. En esa misma dirección, en su boletín interno afirmaban: "la repercusión que tuvo en la gente fue buena y la vanguardia quedó impactada" ${ }^{\natural 80}$. En lo que respecta al GOR, aunque le daba poco espacio en su balance, hacía referencia al secuestro como la acción que, junto a la movilización de las bases, había "jaqueado" a la empresa obligándola a negociar.

El caso del PRT-ERP es interesante ya que públicamente la organización afirmó que el secuestro había venido a "robustecer y dar nuevas perspectivas al combate proletario" ${ }^{, 681}$, pero los entrevistados, en general, consideran que la acción no ayudó a fortalecer la conciencia de los trabajadores. Tanto Crosatto como Hoffman plantean que se dio en un momento en que el conflicto "estaba prácticamente ganado" y que por ende se les estaba arrebatando el triunfo a los obreros o, al menos, se les estaba dando un "mensaje equivocado":

"Y nos produjo una cierta discusión porque yo les dije: 'la verdad muchachos ustedes nos dejan pegados a esta acción ahora cuando nosotros tenemos casi la huelga ganada', porque eso es a fines de octubre. 'Bueno nosotros lo hicimos en apoyo a ustedes' responden. Está bien, no estoy para nada en desacuerdo. Lo que quiero decir es el momento, estamos en una huelga, porque ¿qué le estamos diciendo a los trabajadores? le estamos dando una idea equivocada después en la lucha, porque vos decís 'yo paro por un aumento de salario, y si no me lo das me llevo a un gerente...' no es así, la idea de la lucha es otra. Pero bueno, la hicieron y ya está." ${ }^{682}$

Incluso Hoffman va más allá y, a diferencia de Crosatto, plantea que el secuestro habría caído muy mal en el Comité de Lucha:

"Entrevistador: ¿Cómo cae en el comité de lucha y en los trabajadores?

Ricardo: ¡Para el orto! ¡Todo el mundo reaccionó para el orto! ¡Porque ese día estábamos por firmar el acuerdo! ¡Se terminaba el conflicto! O sea fue un descuelgue absoluto $(\ldots)^{, 683}$

Si bien las afirmaciones de los testimonios pueden ser resultado de un balance y una reelaboración posterior, sorprende que la crítica se centre en que la acción tendió a "sustituir" a la clase obrera, crítica que otras organizaciones le hacían al PRT-ERP

\footnotetext{
679 "La acción guerrillera en Mercedes Benz", Avanzada Socialista Nro. 170, 8 de noviembre de 1975

${ }^{680}$ PST. Boletín Interno del 4 de noviembre de 1975, Fundación Pluma.

681 "Triunfo obrero en Mercedes Benz" en El Combatiente Nro. 190 del 5 de Noviembre de 1975.

${ }^{682}$ Entrevista a Hugo Crosatto con el autor, Buenos Aires, 2017.

${ }^{683}$ Entrevista a Ricardo Hoffman con el autor, Buenos Aires, 2017.
} 
cuando realizaba acciones similares ${ }^{684}$. Además, como vimos, el ERP había intervenido con "advertencias" e incluso atentando contra la vivienda de un ejecutivo de la empresa, es decir, con acciones que tenían el mismo sentido y espíritu que la realizada por Montoneros.

Por otro lado, Hoffman recuerda que tuvo que rechazar la propuesta del ERP de realizar un secuestro similar al que posteriormente terminó realizando Montoneros:

"Ricardo: Yo tengo que reconocer que esa semana anterior viene un jefe de afuera, no de la escuadra nuestra, del ERP y nos plantean bueno marquen a uno que nosotros lo vamos a hacer. ¡Y nosotros dijimos que no! ¡Olvidate! Acá no tocan nada a nadie....

Entrevistador: $Y$ eso como resulto, ese debate, cuando ustedes dijeron que no...

Ricardo: Hubo una escaramuza ahí con los del ERP, nos apretaron un poco... como son milicos viste... nos apretaron un poco.

Entrevistador: Pero termina primando la opinión de ustedes...

Rircardo: Y si... ¡nosotros mandábamos! Era así, los frentes mandábamos..."685

El testimonio refuerza la idea de que en MBA las decisiones relacionadas a lo sindical eran tomadas por los obreros militantes e incluso cuando existían "aprietes" por parte de la organización, terminaba imponiéndose la decisión de estos últimos.

Por su parte, Crosatto y D'Alessandro afirman que el secuestro, en un principio, había sido coordinado por ambas organizaciones, pero que finalmente Montoneros habría decidido realizarlo por su cuenta ${ }^{686}$.

De este modo, y más allá de los matices, la crítica a la acción montonera que aparece en los testimonios puede interpretarse de dos formas distintas que, lejos de ser contrapuestas, pueden resultar complementarias: por un lado puede considerarse, como se ve en el testimonio anterior, que el desacuerdo con el secuestro respondía a la línea sindical perretista en MBA de no dejar que los partidos interfiriesen en la vida gremial de los trabajadores. Así, puede entenderse el sentimiento de que aquello les "arrebataba" el triunfo a los obreros. Ahora bien, por otro lado, también puede pensarse que las críticas estuvieron motivadas por el factor de la competencia entre organizaciones. Es que con dicha acción Montoneros ganó un protagonismo que, en parte, opacó el papel de dirección que los militantes perretistas venían ocupando durante el conflicto. Esta hipótesis parece ser la más fuerte ya que los entrevistados reconocen que las acciones armadas, lejos de generar rechazo, eran bien recibidas por los trabajadores.

\footnotetext{
${ }^{684}$ Es de destacar que los secuestros a gerentes o personal jerárquico de las empresas fue una de las acciones más frecuentes llevadas a cabo por el ERP, siendo la organización que realizó aproximadamente la mitad de las acciones de este tipo durante todo el período. (Carnovale, 2011).

${ }^{685}$ Entrevista a Ricardo Hoffman con el autor, Buenos Aires, 2017

${ }^{686}$ Entrevistas a Julio D’Alessandro con el autor, Buenos Aires, 2014; Entrevistas a Hugo Crossato con el autor, Buenos Aires, 2017.
} 
Ahora bien, y aun teniendo en cuenta estos balances, coincidimos con Casco Peebles y Lenuda (2016) en que el secuestro fortaleció la posición de los trabajadores durante la contienda, demostrándose en los meses posteriores tanto en el papel asumido por la CIR como en las luchas que encabezó el movimiento de base de la fábrica. En esos meses, como veremos, consiguieron importantes conquistas para los trabajadores y participaron activamente de la lucha contra el Plan Mondelli en los albores de la dictadura, transformándose en una referencia antiburocrática importante en la zona.

\subsection{El "grupo de los 9": entre las conquistas obreras y la lucha contra la "burocracia" por el reconocimiento sindical.}

Luego del triunfo obrero, la planta de MBA vivió unos meses muy intensos en materia de conquistas y conflictos sindicales. La consolidación de la CIR y el CD significó un cambio en la correlación de fuerzas que nunca se había logrado operar debido a las derrotas sucesivas previas a la huelga. Los niveles de democracia participativa logrados en el marco del conflicto fueron tomados como criterio general para la vida cotidiana de la planta. Así, por ejemplo, lejos de disolverse, el Comité de Lucha incorporó a trabajadores de todas las secciones y la asamblea siguió siendo el lugar donde se tomaban las decisiones gremiales.

La inercia del triunfo llevó a que la CIR se lanzara de manera inmediata a conseguir las reivindicaciones históricamente postergadas. Como relata Hugo Crosatto, en poco tiempo, las conquistas fueron de distinta índole:

"Y después del conflicto re-categorizamos a todo el personal, obligamos a la empresa a dar barbijos y leche en las zonas donde había saturnismo, le bajamos a 6 horas de trabajo a tratamientos térmicos, le obligamos a poner un turno más en el departamento médico. Por ley de obras sociales las empresas estaban obligadas a hacer por año un examen médico a los trabajadores, pero ninguna empresa lo hacía. Ese año se lo hicimos cumplir a Mercedes Benz, y vinieron con vehículos con tomógrafos, les hicieron análisis a todos. (...) Pusimos más micros para traer al personal, porque había zonas que los compañeros se tenían que tomar un colectivo para ir hasta el micro, entonces lo hicimos ir hasta la zona en que estaban los compañeros. Es decir una serie de cosas para mejorar la calidad de vida." $\$ 87$

Por otro lado, si bien en el marco del reciente conflicto los trabajadores habían conseguido un aumento salarial del $40 \%$, la lucha continuó para que dicho aumento

\footnotetext{
${ }^{687}$ Entrevista a Hugo Crosatto con el autor, Buenos Aires, 2017.
} 
fuera incorporado al salario básico y se mantuviera un reajuste cuatrimestral en relación con la inflación ${ }^{688}$.

Estas luchas y conquistas se dieron en el marco de una negociación regular entre los trabajadores y la empresa, la cual había decidido ceder a la mayoría de los reclamos para evitar mayores problemas. De hecho, el directorio expresamente planteó, en enero de 1976, que debían "empeñarse en primer lugar en no dejar que surjan conflictos" (Tomuschat, 2003: 51).

Esta negociación cotidiana se puede apreciar en el testimonio de Eduardo Fachal quien comenta cómo se lograron las reivindicaciones de la sección Tratamientos Térmicos:

"Nosotros trabajábamos en condiciones de explotación muy grande, porque había mucho calor, no había las protecciones suficientes. Bueno, se continuó con un quite de colaboración. Se fueron logrando una cantidad de cosas en las que estábamos trabajando nosotros para lograr el trabajo insalubre con un expediente que se había presentado, en ese momento, en el Ministerio de Trabajo. Una vez, aprovechando que el grupo de los 9 había invitado al directorio a hacer una recorrida por la fábrica, nosotros armamos para que pasara el directorio por ahí. Y cuando paso el directorio cargamos los hornos con un poco más del cianuro que hacía falta, entonces cuando ibas a hacer el enfriamiento explotaban las cosas, no teníamos la protección y todo lo demás. Bueno se lograron un montón de mejoras por esa visita y porque veníamos con un quite de colaboración que continuó después de la huelga de los 22 días."

En paralelo, los conflictos con la conducción del SMATA continuaron. El sindicato buscó sabotear a la CIR de distintas maneras a sabiendas de que MBA se estaba transformando en un ejemplo opositor importante en la zona. Una de las estrategias que adoptó fue quitarles la obra social y los beneficios sociales (campo recreativo y hoteles) a todos los trabajadores de la fábrica. Con aquella medida extorsiva desconocían la representación gremial del "grupo de los 9" al mismo tiempo que buscaban deslegitimarlo frente a los trabajadores ${ }^{690}$. A su vez, le negaban sistemáticamente las elecciones para formalizar la representación de la CIR y el CD. Como indican los testimonios, en reuniones que los trabajadores de MBA habrían mantenido con José

\footnotetext{
688 "En Mercedes seguimos luchando por el ajuste de salarios" El Auténtico Nro. 6, 26 de noviembre de 1975.

${ }^{689}$ Entrevista a Eduardo Fachal con el autor, Buenos Aires, 2017.

${ }^{690}$ Ante esta situación los trabajadores publicaron una solicitada en algunos diarios nacionales, dirigida a la presidenta y a la opinión pública, en la que denunciaban el cierre de las clínicas y del campo recreativo y exigiendo el reconocimiento gremial. La nota, además, explicaba los antecedentes y objetivos que había tenido la huelga, en respuesta a la solicitada que había publicado el SMATA, difamando a la nueva CIR. Es de destacar que la medida fue sostenida por la conducción del SMATA hasta la intervención del sindicato por la dictadura militar ("Solicitada. Obreros y Empleados de Mercedes Benz Argentina", Fundación Pluma)
} 
Rodríguez, el mensaje del sindicato era claro: la situación no se arreglaría hasta tanto no renunciasen y dejaran sin efecto a la nueva representación gremial ${ }^{691}$.

Esta disputa tuvo un nuevo capítulo en noviembre de 1975, en el marco de un conflicto entre el SMATA y la UOM. El problema se desató como producto del laudo 29/75 emitido por el Ministerio de Trabajo que establecía, en su artículo primero, que los establecimientos dedicados a la fabricación, montaje y armado de automotores en general quedaban bajo la égida del sindicato de metalúrgicos. Como indica Casco Peebles (2016) aquella medida amenazaba al SMATA con su virtual desaparición debido a que perdería la mayoría de sus afiliados. Ante esta noticia, José Rodríguez convoco a paros totales y progresivos demandando la anulación del laudo, logrando un importante acatamiento en la gran mayoría de las automotrices del Gran Buenos Aires. Además, el plan de lucha de SMATA incluyó una movilización, el 25 de noviembre, en las puertas del Congreso de la Nación y en el local sindical del gremio, así como un multitudinario acto en el estadio Luna Park al día siguiente ${ }^{692}$.

Lo interesante del caso es que los obreros de MBA participaron activamente de la querella a favor del SMATA. La oposición a ser encuadrados en la UOM pasaba fundamentalmente por el riesgo de que la CIR fuera intervenida y descabezada inmediatamente. En ese sentido mantenerse dentro del SMATA significaba conservar lo que se había conseguido hasta el momento y seguir construyendo la alternativa clasista al interior de los mecánicos, que ya tenía al SMATA Córdoba como principal expresión pero que también venía creciendo en algunas fábricas de Gran Buenos Aires (como Ford, General Motors, Peugeot, Chrysler, etc.). En ese sentido, la intervención se dio con una declarada actitud opositora a la conducción nacional del SMATA, expresándose en todas las movilizaciones en las que intervinieron, muchas de las cuales terminaron en enfrentamientos directos con la Lista Verde que, como vimos, respondía a la "burocracia sindical". Hay que tener en cuenta que la CIR de MBA, al igual que la conducción provincial del SMATA Córdoba, seguía sin ser reconocida por las autoridades sindicales, por lo que su participación en el conflicto inter-gremial tenía esa lucha como trasfondo. En ese sentido, estos dos casos aparecían como los símbolos de la oposición a Rodríguez, al punto que el reclamo por el reconocimiento se transformó en una de las consignas emblema levantadas por los clasistas en ambos casos.

\footnotetext{
${ }^{691}$ Entrevista a Hugo Crosatto por el autor, Buenos Aires, 2017.

692 "Mecánicos. La más grande movilización obrera desde el 27 de junio" Avanzada Socialista Nro. 173, 28 de noviembre de 1975.
} 
Héctor Ratto destaca cómo el SMATA buscaba por todos los medios evitar que los obreros de MBA participaran de las manifestaciones, negándoles, por ejemplo, medios de transporte para movilizarse:

"Entonces había grandes movilizaciones. Una de las primeras se hizo en el Luna Park, después fuimos a Morón, y en algunas partes más. Y bueno ahí iba gente de todas las empresas, el sindicato le ponía los micros en la puerta de la fábrica pero [a nosotros] no nos ponía micros. Nosotros nos pagábamos nuestros propios [micros] e íbamos. Estábamos totalmente enfrentados." ${ }^{.693}$

Por su parte, Hoffman y Fachal remarcan que, en algunos casos, los enfrentamientos llegaron a refriegas violentas que incluyeron golpes y exhibición de armas ${ }^{694}$.

Como indica la siguiente crónica del conflicto, la férrea posición de los obreros de MBA y sus niveles de movilización, obligaron al SMATA a reconocerlos como un actor de peso en el conflicto:

"Rodríguez, que había desconocido a la comisión de reclamos de Mercedes Benz, en forma oportunista se comprometió a recibirla. De hecho se trata de un reconocimiento por parte de Rodríguez y una victoria de los mecánicos que por el laudo 29/75 no dejaron de lado su oposición al titular del SMATA" ${ }^{695}$

Finalmente, el 3 de diciembre, el Ministerio de Trabajo dio a conocer una resolución que, si bien no invalidaba el laudo, impedía la anexión de las fábricas que estaban bajo jurisdicción del SMATA. De este modo, la conducción nacional de los mecánicos dio por cerrado el conflicto levantando todas las medidas de fuerza.

Esta disputa inter-sindical generó algunas discusiones sobre qué posición asumir al interior de la izquierda. El problema radicaba en que se trataba de una querella entre Lorenzo Miguel y José Rodríguez, dos "burócratas" indefendibles para aquellas organizaciones. Así, por ejemplo, para el PST había que encolumnarse detrás del SMATA ya que Miguel era el "enemigo principal", debido a que sólo buscaba atacar a los mecánicos que estaban a la cabeza de las luchas. En una nota de su periódico planteaba: "Para nosotros, efectivamente Miguel y Rodríguez son dos burócratas de dos trayectorias igualmente negras. La diferencia la dio la importante movilización de las bases del SMATA. Más de cien mil obreros pararon y se movilizaron detrás de Rodríguez" ${ }^{\text {696,697 }}$. De este modo, para esta organización había solo dos alternativas en el

\footnotetext{
${ }^{693}$ Entrevista con Héctor Ratto por el autor, Buenos Aires, 2017

${ }^{694}$ Entrevista con Ricardo Hoffman por el autor, Buenos Aires, 2017; Entrevista a Eduardo Fachal por el autor, Buenos Aires, 2017

695 "SMATA-UOM y Sierra Grande: dos definiciones para la cúpula del poder" Nuevo Hombre, 4 de diciembre de 1975.

696 "Hubo 'vanguardias esclarecidas' que no supieron escuchar a miles de obreros" Avanzada Socialista Nro. 174, 5 de diciembre de 1975.
} 
marco del conflicto: con el SMATA o contra el SMATA, y en esa línea criticaron la actitud tomada por MBA por considerarla "confusa" 698 , aunque luego reconocieron el hecho de que se plegaran a la lucha ${ }^{699}$. Si bien no hicieron una crítica explícita a Montoneros y al PRT-ERP, es de suponer que, por sus niveles de influencia, el reproche a la posición adoptada por MBA fuera un tiro por elevación a aquellas organizaciones $^{700}$.

Por nuestra parte, no hemos encontrado ninguna declaración de estas últimas organizaciones que, durante el transcurso del conflicto, dejara en claro cuál fue la respectiva posición, aunque sí hallamos breves referencias que dan indicios de que estuvieron en sintonía con la postura asumida por los trabajadores de MBA. Así, por ejemplo, la organización peronista, en un pequeño recuadro de su prensa Evita Montonera, calificaba al laudo como "una avanzada del vandorismo sobre los trabajadores mecánicos" y valoraba que "a pesar de la práctica burocrática y propatronal desarrollada por los dirigentes del SMATA", los trabajadores se hayan movilizado en defensa de su sindicato ${ }^{701}$.

Por su parte los perretistas hacían un balance similar, al destacar los niveles de movilización lograda por los trabajadores mecánicos durante el conflicto:

"Los mecánicos de SMATA acaban de lograr a través de paros, y movilizaciones masivas de claro contenido político y hondo fervor combativo la virtual anulación de la resolución ministerial por la que se pretendía encuadrarlos en la UOM; la batalla adquiere su verdadera significación si se tiene en cuenta que la incorporación al gremio de los metalúrgicos suponía un automático incremento salarial. Pese a esa circunstancia, miles de trabajadores ganaron las calles en defensa de su sindicato y en repudio a Lorenzo Miguel, paralizando la industria automotriz de todo el país."

\footnotetext{
${ }^{697}$ Estas definiciones se reforzaron en un volante nacional: "Nuestra lucha por la defensa de los derechos de los trabajadores mecánicos, nuestro llamado a la unidad de todos, no puede ocultar el hecho de que nosotros (...) mantenemos discrepancias con los dirigentes actuales del SMATA. Pero hoy más que nunca debemos permanecer unidos en torno a la defensa de nuestra organización" (“Abajo el laudo del gobierno y Miguel. Defender el SMATA”, AD 1.3, Fundación Pluma.)

698 "Hubo 'vanguardias esclarecidas'(...)" op. cit.

699 "El laudo de la discordia" Avanzada Socialista Nro. 172, 21 de noviembre de 1975.

${ }^{700}$ La crítica también estaba dirigida al PCA, que se mantuvo al margen del conflicto por considerar que ambos sectores eran pro golpistas; el PCR habría adoptado una actitud de "frenar la lucha" para no fortalecer a la "burocracia" y Política Obrera planteaba que los trabajadores debían decidir en asamblea a que gremio pertenecer. ("Córdoba. Luchar con el gremio" Avanzada Socialista Nro. 173, 28 de noviembre de 1975; "Para defender nuestras conquistas: luchemos por la vigencia del convenio y por el reconocimiento inmediato de Mercedes Benz y Córdoba." Volante Política Obrera. Versión digital en poder del autor.)

701 "Crónicas de la resistencia. La resistencia en las fábricas" Evita Montonera Nro. 10, diciembre de 1975.

702 "Ante un nuevo auge de las luchas obreras y populares" El Combatiente Nro. 195, miércoles 10 de diciembre de 1975
} 
Como vimos en el Capítulo 4, para este momento la organización había resuelto dejar en un segundo plano la disputa con algunos sectores de la "burocracia", sobre todo con aquellos que movilizaran a sus bases por reivindicaciones justas, en pos de concentrar los ataques a los sectores "reaccionarios". No obstante, ello no significaba abandonar la lucha antiburocrática, por lo que presumiblemente la estrategia de los trabajadores de MBA, de participar en el conflicto a favor del SMATA sin renunciar a la disputa interna, significaba una síntesis perfecta de cómo creía que debía intervenirse. Así es que reivindicó y destacó públicamente a MBA como un ejemplo de avanzada en el marco de las luchas desplegadas por esos meses ${ }^{703}$.

Efectivamente la intervención de la CIR en este conflicto reforzó el rol opositor de los trabajadores de MBA al interior del SMATA pese a los importantes niveles de acatamiento y respuesta que consiguió José Rodríguez entre las bases mecánicas. Eso ayudó a consolidar su posición de referencia entre el sindicalismo combativo de la zona que, como veremos, se ratificó pocos meses después en los meses previos al golpe de estado de 1976.

\subsection{MBA y los perretistas ante el Plan Mondelli y los comienzos de la dictadura}

La movilización de los obreros de MBA tuvo un nuevo capítulo en los primeros meses de 1976, en el marco de la lucha contra el Plan Mondelli. Por entonces la CIR había decidido incorporarse a la Coordinadora de Gremios en Lucha y, en ese marco, al igual que los trabajadores de Peugeot, General Motors y Chrysler, impulsó asambleas en la fábrica, y decidieron ir al paro como respuesta a las medidas económicas anunciadas por el gobierno el 5 de marzo (Werner y Aguirre, 2009:158).

El diario La Nación, advertía que estas medidas habían desbordado a las conducciones sindicales y que estaban encabezadas por "delegados de filiación marxista”. De hecho, el propio José Rodríguez debió reconocer públicamente que los paros en las plantas automotrices había sido una reacción espontánea de los trabajadores (Löbbe, 2006:228). Efectivamente MBA puso a jugar el papel de referencia opositora que se venía ganando desde hacía meses. Así es que sus columnas protagonizaron una de las movilizaciones más importantes del plan de lucha diseñado por las Coordinadoras: el 12 de marzo los trabajadores de la Zona Norte y Oeste, organizados en más de cincuenta colectivos y camiones, intentaron ingresar a la Capital Federal buscando reeditar las marchas de

\footnotetext{
703 “Ante la crisis de la burguesía, unidad en la lucha democrática y reivindicativa” El Combatiente Nro. 191, miércoles 12 de noviembre de 1975.
} 
junio y julio del año anterior. Pero fueron detenidos por un importante operativo policial que no les permitió continuar con la movilización. El liderazgo de los obreros de la empresa alemana fue destacado por el PRT-ERP en su periódico:

"El punto culminante de este clima de movilización, revelador del combativo estado de ánimo del proletariado fueron las marchas protagonizadas por obreros mecánicos de Mercedes Benz quienes intentaron marchar sobre la Capital por la autopista Richieri siendo detenidos por la policía que impidió su avance en la General Paz"

Este hecho, alimentaba la preocupación del diario La Nación que destacaba el "problema de los 'bichos colorados' infiltrados en las Comisiones Gremiales Internas" de los mecánicos (Löbbe, 2006:229).

Esta ola de protestas estuvo acompañada al interior de la planta, por paros de dos horas en cada uno de los turnos que duraron varios días. Además 3000 obreros de la fábrica participaron de una movilización, convocada por la Coordinadora Zona Oeste, a la sede de la seccional de la UOM de La Matanza para exigirle un plan de lucha (Casco Peeble, 2016:129). Sin embargo, este proceso se vio interrumpido abruptamente por el golpe militar del 24 de marzo.

La nueva situación represiva que se instaló en el país y en MBA en particular, obligó a una reorganización desde la clandestinidad del movimiento de base. La resistencia se organizó fundamentalmente a través del sabotaje de la producción, por ejemplo, mediante el intercambio de los insumos para las diferentes máquinas, la ruptura de los contactos de los tableros de control, la desaparición de los calibres, etc ${ }^{704}$. Estas expresiones de lucha fueron acompañadas, además, por una nueva edición del volante del CROEMBA, ahora titulado Unión de Obreros y Empleados de Mercedes Benz que se imprimían en una imprenta clandestina que los propios trabajadores habían fabricado al interior de la planta.

También se intentó intervenir legalmente a través de la CIR, que siguió funcionando durante casi todo el año. A través de ella se entregó una carta al interventor del SMATA solicitándole que se restablecieran las prestaciones sociales que habían sido suspendidas por Rodríguez, así como también, en mayo, se elevó un petitorio a la patronal en reclamo de aumentos salariales. Incluso, ante este último pedido la empresa les ofreció premios a la producción, lo que fue rechazado por los obreros con una importante campaña de protesta. El suceso fue relatado en El Combatiente por un trabajador de la empresa en estos términos:

\footnotetext{
${ }^{704}$ Entrevista a Ricardo Hoffman con el autor, Buenos Aires, 2017
} 
“(...) nosotros como respuesta iniciamos una campaña de ruidos con sopletes, los compresores y golpeando con mazas en todo objeto metálico mientras gritábamos: ¡Hambre! Durante dos días y a horarios determinados. El bochinche y nuestra bronca eran tan grandes que toda la patronal se retira "por falta de seguridad en la planta", ${ }^{\prime 705}$.

Los llamativos niveles de protesta logrados en ese contexto se explican por el hecho de que cuando la dictadura militar se instauró, el movimiento de base de MBA estaba en el momento de mayor madurez; sin embargo no deja de sorprender el nivel de movilización logrado en meses de álgida represión. Una demostración de esa combatividad se había dado previamente, en abril, ante el secuestro del obrero Juan José Martín quien fue detenido en la propia fábrica mientras trabajaba ${ }^{706}$. Ante tal situación los obreros se reunieron en asamblea y decidieron marchar hacia el regimiento, donde, aproximadamente mil trabajadores, acamparon hasta que lograron su liberación:

"Después hay un hecho histórico, revolucionario, heroico, que hicimos y que no está difundido como corresponde. ¡Lo que hicimos nosotros en abril del 76 no lo hizo nadie! En plena dictadura se llevaron a un compañero de mi sector, a Martín, y salimos igual. Lo salimos a buscar por todos lados, terminamos en el [Regimiento] III de la Tablada con más de 800 compañeros plantados en el regimiento y lo recuperamos. ¡Mira la conciencia que teníamos que le fuimos a patotear el [Regimiento] III de La Tablada a los milicos! A la semana lo largaron a Martín.,"707

Pero esta firme resistencia de los trabajadores llevó a que, en el mes de julio, los militares intervinieran directamente en la fábrica instando al personal a que normalizara la producción. En ese marco, Hugo Crosatto, principal dirigente sindical perretista, se vio obligado a renunciar: el hecho era una muestra evidente de las dificultades que empezaban a existir para la militancia al interior de las fábricas (Basualdo, 2016: 507). La empresa aumentó la ofensiva y decidió suspender y despedir a dos trabajadores, pero nuevamente se encontró con la reacción de los trabajadores que lograron su reincorporación:

"A principios de agosto la patronal trata de medir fuerzas nuevamente y suspende a un compañero y despide a otro, acusándonos de sabotaje a la producción. Inmediatamente se moviliza toda la planta y en 20 minutos se resuelve parar si no se reincorporaba a los compañeros. A las 13.30 supimos la noticia del despido y a las 14.55 , cinco minutos antes de empezar el paro, son reincorporados los dos compañeros."

\footnotetext{
705 “Mercedes Benz en la resistencia” El Combatiente Nro. 234, miércoles 22 de septiembre de 1976

${ }^{706}$ Martin fue enviado a la comisaría de San Justo donde estuvo detenido durante 19 días. Allí fue torturado por personal del ejército hasta que fue liberado en la puerta de su domicilio (Testimonio de Martin, en "Milagros No Hay" documental de Gaby Weber).

${ }^{707}$ Entrevista con Hugo Crosatto por el autor, Buenos Aires, 2017

708 "Mercedes Benz en la resistencia” El Combatiente Nro. 234, miércoles 22 de septiembre de 1976
} 
La persistencia de la resistencia obrera se expresó en los meses siguientes con quites de colaboración, trabajo a desgano y sabotajes. De hecho, durante septiembre, volvieron a realizar paros parciales por turnos en reclamo por aumentos salariales (Basualdo, 2016). Por su parte, los militantes perretistas intervenían activamente organizando la resistencia clandestina e incluso realizando una campaña partidaria de afichadas y pintadas al interior de la planta:

"Mientras tanto nosotros, los compañeros del PRT de Mercedes Benz, continuábamos con la propagandización de nuestra línea por medio de volantes, distribuyendo $E l$ Combatiente y Estrella Roja y armando a partir de ellos nuestra red interna de organización. Además con pintadas y pegatinas dábamos nuestra propuesta a los compañeros. ${ }^{, 709}$

Como vimos en el capítulo 4, esto era parte de la línea de acción que el PRT-ERP había resuelto para resistir a la dictadura. No obstante, a partir de diciembre de 1976, la situación comenzó a revertirse drásticamente. Las desapariciones forzadas de varios $\operatorname{activistas}^{710}$ ya no pudieron ser respondidas por los trabajadores; al mismo tiempo la empresa quebró uno de las principales reivindicaciones obreras imponiendo los premios por productividad -antes rechazados-. Con la derrota del movimiento de base también se consumó la desarticulación de los perretistas en la planta quienes, para mediados de 1977, ya habían perdido toda la estructura construida en MBA.

\section{Conclusión}

Como vimos a lo largo del capítulo lo distintivo en el caso de MBA radicó en que la intervención sindical de los militantes perretistas alcanzó importantes niveles de autonomía respecto a las prescripciones partidarias. Consideramos que detrás de ello hubo una forma distintiva de entender la relación partido-fábrica basada en la diferenciación de dos niveles: el de "la política", que podía y debía ser abordado por el partido a través de sus herramientas tradicionales; y el gremial, en el cual quienes decidían eran los obreros y no los partidos. Así es como desarrollaron la estructura propiamente partidaria construyendo los organismos tradicionales (células, periódico, etc.), pero a nivel sindical crearon una herramienta original (CROEMBA) que buscó ajustarse a las condiciones y posibilidades políticas que ofrecía la fábrica y que

\footnotetext{
709 Ídem

710 Trabajadores desaparecidos de MBA: Oscar Alberto Alvares Bauman, Alberto Francisco Arenas, Héctor Alberto Belmonte, Carlos Cienciala, Rubén Oscar Caddeo, Fernando Omar Del Contte, Alberto Gigena, Miguel Grieco, Charles del Carmen Grossi, Jorge Alberto Leichner, Diego Eustaquio Nuñez, Juan José Mosquera, Esteban Alfredo Reimer, Víctor Hugo Ventura, José Vizzini.
} 
contempló la unidad de todas las corrientes antiburocráticas. En ese mismo sentido, la actividad militar de la organización estuvo fuertemente mediada por el criterio y la decisión de la militancia fabril perretista, la cual llegó a rechazar y confrontar con propuestas traídas por los responsables del ERP desde fuera de la fábrica. Lo interesante del caso es que bajo este estilo de construcción, el PRT-ERP logró ser una de las principales organizaciones que animó el proceso de radicalización política y sindical de la planta: contó con militantes en la dirección de las luchas, incorporó nuevos militantes a sus filas y organizó a simpatizantes y contactos de distintos perfiles (como fue el caso de la escuadra formada al interior del establecimiento). 


\section{CONCLUSIONeS}

A lo largo de esta tesis nos hemos concentrado en la reconstrucción y el análisis de un aspecto escasamente estudiado en los trabajos que se ocupan del PRT-ERP: su línea político-sindical y la experiencia de sus militantes fabriles. Para ello hemos articulado la investigación en dos dimensiones de análisis que ayudaron a iluminar el objeto desde ángulos distintos pero complementarios: la dimensión político-organizacional, en la que analizamos el lugar que le asignó el PRT-ERP al trabajo político-sindical en su estrategia revolucionaria durante 1973-1976; y una dimensión militante, en la que reconstruimos la experiencia, en esos mismos años, de sus militantes fabriles en dos establecimientos del Gran Buenos Aires.

Como hemos advertido, en su mayoría, los estudios sobre el PRT-ERP se han preocupado por analizar los problemas estratégico-organizativos y de la lucha armada, y si bien en este último tiempo han comenzado a publicarse algunos estudios sobre otras dimensiones de la experiencia perretista (género, política de masas, etc.), son pocos los que se han preocupado por su vínculo con el movimiento obrero y, menos aún, los que han estudiado los modos de su intervención sindical y la experiencias de sus militantes en fábricas. De modo que con esta investigación esperamos ocupar una parte del doble vacío historiográfico que existe en los estudios del PRT-ERP y dejar planteada una ruta para futuros trabajos.

Esta tesis buscó mostrar que el PRT-ERP tuvo una política sindical específica que, durante nuestro período, se profundizó, adquirió nuevas características, logró incidir en las luchas obreras y ocupó un lugar central en su estrategia revolucionaria, articulándose con otras dimensiones de su política (lucha armada y lucha democrática). Además, al ubicar a la organización en el campo de la nueva izquierda, la puso en contexto con las posiciones de otras organizaciones y analizó sus vínculos políticos y sindicales. Y, por último, realizó un avance en el estudio de la experiencia perretista en fábricas, identificando modalidades de construcción político-sindical, tensiones, problemas y perfiles militantes en la práctica concreta. Particularmente en la reconstrucción y análisis de los "casos", la tesis aborda el tema de la difícil relación entre acción gremial y acción política; tarea ardua tanto en el plano de su resolución práctica como en el de su identificación y análisis durante el procesos de investigación. En ese sentido se 
espera que haya contribuido a la construcción de una visión más completa y compleja de la trayectoria del PRT-ERP.

Hemos abordado nuestro tema como parte de un campo problemático más amplio: el del vínculo entre el movimiento obrero y la izquierda, más específicamente entre la política revolucionaria y la lucha sindical. A través de las herramientas que brinda la historia social y desde una perspectiva sociopolítica, hemos indagado en las complejas relaciones entre política y clase social, fábrica y política y lucha armada y lucha sindical, atendiendo tanto a la cosmovisión y al sistema de ideas desde la que partió una organización revolucionaria para intervenir en las fábricas como a la experiencia de la clase obrera de la que formaron parte y a la que se dirigieron sus militantes.

Seriamente afectado por el surgimiento del peronismo a mediados de los años cuarenta, el vínculo entre el movimiento obrero y la izquierda comenzó a restablecerse a lo largo de los sesenta y setenta como resultado de un doble proceso: la transformación de las identidades políticas, marcadas por un nuevo ethos revolucionario -caracterizado por la reinterpretación del peronismo y el convencimiento de que la lucha armada era la única vía al socialismo-, y una experiencia de clase forjada en la resistencia, la clandestinidad y la acción directa que dio nacimiento a una nueva oposición sindical antiburocrática receptiva del discurso izquierdista. Este fue el caldo de cultivo para el crecimiento de las organizaciones de la nueva izquierda en general y en el movimiento obrero en particular. En ese sentido el concepto de nueva izquierda nos permitió encuadrar la experiencia del PRT-ERP en un proceso de activación social más amplio protagonizado por una constelación de nuevos actores (entre los que se destacaron organizaciones revolucionarias, dirigentes sindicales, movimientos de base, etc.) que animaron la vida política de las fábricas durante nuestro período.

El proceso de radicalización política, que a partir de 1969 comenzó a adquirir características antisistémicas, estuvo directamente relacionado al clima altamente represivo instaurado por la "Revolución Argentina" y la desconfianza que despertaban los mecanismos institucionales y democráticos en el conjunto de la sociedad. En ese sentido, la propuesta del GAN, resumida en la apertura democrática y la legalización del peronismo, vino a cambiar dicha racionalidad política devolviéndole legitimidad a la acción estatal, encauzando la conflictividad en el marco de la democracia parlamentaria y buscando aislar a las organizaciones revolucionarias del conjunto de la sociedad. Efectivamente la posibilidad real del retorno del peronismo al gobierno despertó esperanzas en amplios sectores de la población y obturó la unidad de hecho que venía 
forjando la lucha antidictatorial entre las distintas expresiones políticas de la nueva izquierda. Es que el nuevo escenario puso en primer plano las diferencias estratégicas que se escondían detrás de las distintas interpretaciones que cada cual hacía del peronismo. Ello se expresó en la posición que las distintas organizaciones asumieron ante las elecciones de 1973 y el triunfo del FREJULI en las mismas. Si el nuevo contexto democrático-legal era un desafío para quienes habían nacido con el sello de la desconfianza a la "democracia burguesa", lo era aún más para quienes, como el PRTERP, tenían una visión crítica del peronismo y adoptaron una actitud opositora hacia el nuevo gobierno.

Ahora bien, como mostramos en nuestro trabajo, ese período fue el de mayor crecimiento del PRT-ERP en términos generales y, específicamente, de su inserción en el movimiento obrero. Las tesis que recorre nuestra investigación sostiene que este fenómeno, en apariencia paradojal, puede explicarse por la concurrencia de los siguientes factores: 1- Por el hecho de que la apertura democrática coincidió con el momento en que la organización salió del período de "desviación militarista" (19711972) y se planteó aprovechar al máximo los intersticios legales recientemente habilitados para profundizar su política hacia el movimiento obrero -a partir de allí, la intervención sindical asumió un lugar clave en la política de la organización y la acción guerrillera se ligó más fuertemente a las luchas reivindicativas; y 2- porque, en las nuevas condiciones, la clase obrera, lejos de desmovilizarse, se lanzó a conquistar sus reivindicaciones interpretando el triunfo electoral del peronismo como una oportunidad para lograrlas y porque un sector de ella, ante las políticas de austeridad económica (Pacto Social) y represivas asumidas por los sucesivos gobiernos peronistas, comenzó a romper con esa experiencia. En ese marco, el PRT-ERP -como tal vez otras organizaciones de izquierda- se transformó en una referencia política para este último sector que se sintió atraído por su posición antiburocrática y antigubernamental, su intervención decidida en las luchas sindicales y su línea guerrillera. De este modo la organización incorporó a una cantidad importante de obreros a sus filas ${ }^{711} \mathrm{e}$, incluso, se transformó en una fuerza centrífuga para un conjunto de núcleos militantes $\mathrm{u}$ organizaciones pequeñas que terminaron sumándose a su estructura ${ }^{712}$.

\footnotetext{
${ }^{711}$ Según Luis Mattini, para 1975 resultaba más sencillo sumar trabajadores de las fábricas que insertar militantes en los establecimientos (Löbbe, 2006:175).

${ }^{712} \mathrm{Tal}$ es el caso, por ejemplo, de las FAL- Columna Inti Peredo o de un sector de Montoneros Sabino Navarro ("Documento de incorporación al PRT de las FAL Columna Inti Peredo" El Combatiente Nro.173, miércoles 2 de julio de 1975; Seminara, 205).
} 
Como puede verse a lo largo de la investigación, durante el período 1973-1976 las luchas obreras se multiplicaron y el movimiento antiburocrático se expandió a nivel nacional manifestándose en el Gran Buenos Aires con una gravitación que no había tenido en los años previos. Si bien desde un inicio aquellas luchas no tuvieron un carácter antigubernamental, golpearon al corazón del proyecto económico y político peronista tornando inviable el Pacto Social. En ese sentido, una porción importante de la "vanguardia obrera", a la que junto a Cristina Tortti (1999 y 2016) consideramos parte de la "izquierda social", luchó por sus reivindicaciones incluso desoyendo los pedidos explícitos de Perón. Además, en ese camino, se enfrentó al poder de la burocracia dentro y fuera de las fábricas e incluso llegó a construir las Coordinadoras Interfabriles, desde las cuales disputó la dirección efectiva del movimiento obrero a las cúpulas cegetistas entre junio de 1975 y marzo de 1976. En ese proceso las organizaciones de la nueva izquierda, que formaron parte de la "izquierda política", jugaron un rol determinante, tanto por contar con importantes dirigentes obreros en las fábricas y en las Coordinadoras, como por ser las productoras de una narrativa política que inspiró a aquellos trabajadores.

Es en ese sentido que sostenemos que el GAN no logró plenamente su cometido de impedir la confluencia entre la "izquierda social" y la "izquierda política", ya que una parte significativa de esa "izquierda social”, compuesta en gran medida por los sectores antiburocráticos del movimiento obrero, se incorporó a las filas de las organizaciones revolucionarias, peronistas o marxistas -entre ellas el PRT-ERP-, o bien simpatizo, se referenció y/o compartió espacios y luchas con estas, dando lugar a la conformación de una vanguardia político-social. Desde nuestra perspectiva, lo que sí produjo la apertura democrática y el retorno del peronismo fue una fractura entre esa vanguardia políticosocial y el resto de la sociedad argentina (incluidos sectores de la clase obrera), y una profundización de la grieta programática y política en el seno de la nueva izquierda entre quienes, hasta último momento, apostaron al movimiento peronista y quienes, desde un comienzo, buscaron construir una alternativa fuera del mismo.

Consideramos que el primero de los efectos antes reseñado fue lo que el PRT-ERP no pudo identificar: animado por el desarrollo de las movilizaciones obreras, por su participación en ellas y por su crecimiento orgánico, tendió a analizar la situación política generalizando la experiencia de clase del sector de los trabajadores que formaba parte de la vanguardia político-social al conjunto de la clase obrera y del pueblo. Ello 
fue lo que lo llevó a considerar al triunfo revolucionario como algo cercano e inevitable $y$, por ende, lo que lo condujo a lanzarse a la ofensiva político-militar.

Detrás de ese razonamiento, operaban una serie de axiomas de diferente carácter: que la lucha armada jugaba un papel catalizador y concientizador en todo momento -legado del paradigma guevarista-; que el peronismo era un fenómeno "histórica e ideológicamente agotado"; que el proyecto gubernamental peronista estaba condenado al fracaso desde un inicio; y que la clase obrera estaba viviendo un proceso irreversible de "revolución ideológica"- idea derivada de una concepción escencializadora de la clase obrera como portadora de un "inmanentismo revolucionario" (Pozzi, 2004; Scoppeta y Torres, 2014). Dicha idea se había visto reforzada por las insurrecciones populares de 1969 (Rosariazo-Cordobazo-Rosariazo) y el surgimiento del clasismo, y fue la que motivó tanto la ilusión de que el pueblo asistiría a las elecciones de 1973 sin esperanzas de cambio como, posteriormente, la de que el mismo pueblo se alzaría en armas contra la dictadura de 1976.

Ahora bien, como se evidenció en los casos estudiados, algunos de esos axiomas fueron relativizados en los hechos por lo que hemos llamado militancia fabril perretista. Así, por ejemplo, la convicción de que la clase obrera estaba rompiendo irreversiblemente con el peronismo o la idea de que el accionar armado apuntalaba en todo momento la movilización obrera, fueron puestos en cuestión en la experiencia militante en las fábricas. Es que en la práctica los militantes, concientes de la distancia ideológica que los separaba de muchos de sus compañeros de trabajo, desarrollaron herramientas político-sindicales ajustadas a las condiciones y posibilidades de las plantas.

Dicho esto sobre las tesis generales que atravesaron la investigación, a continuación corresponde referirnos de manera más específica a nuestro objeto de estudio en las dos dimensiones de análisis que lo articulan.

\section{I}

En la primera parte de este trabajo nos hemos dedicado a reconstruir la línea políticasindical del PRT-ERP y, sobre todo, las orientaciones con las que intervino en las fábricas durante el período 1973-1976. En ese sentido, la tesis principal sostiene que fue fundamentalmente a partir de 1973 que su intervención sindical adquirió relevancia dentro de su estrategia, manifestándose tanto en la importancia que adquirió en su discurso como en la incidencia que logró en las luchas obreras. 
Como vimos, durante el período previo a la apertura electoral (1968-1973) si bien la organización forjó una línea sindical, ésta estuvo fuertemente atravesada por la polémica con el morenismo y por la crítica incisiva a aquellas corrientes que, rechazando la lucha armada, hacían de la actividad sindical el eje de su estrategia. Por tal razón las definiciones sobre la acción sindical tendieron a ser despectivas y concluyentes: se la definía como una tarea "inferior" en relación a la actividad política (agitación y propaganda socialista) y militar, y sólo como un medio para conectarse con los sectores "más atrasados" de la clase obrera. A nuestro juicio, esta caracterización generó un "espíritu antisindical" que, si bien fue matizándose parcialmente en la práctica, contribuye a explicar la llamada "desviación militarista” del período 19711972. Aun así, ya en el IV Congreso (primero del PRT-EC - del año 1968) se delinearon algunas de las orientaciones básicas que sostuvo durante toda su existencia: luchar por la "recuperación" de los organismos sindicales; organizar oposiciones clasistas a nivel fabril y bregar por la construcción de espacios que las centralicen a nivel nacional; desarrollar organismos clandestinos que articulasen la lucha gremial con la guerrillera.

Fue a partir de estas orientaciones que intervino en la CGT-A, interpretó el Cordobazo y participó de los sindicatos "clasistas" de SITRAC-SITRAM. Consideramos que es fundamentalmente a partir del balance de la derrota de esta última experiencia que la organización construyó la base más acabada de su concepción sobre lo sindical, luego complejizada y profundizada durante nuestro período. Es que SITRAC-SITRAM, a la vez que funcionó como confirmación de sus críticas a quienes les asignaban al sindicalismo un estatus estratégico, motivó una reflexión más profunda sobre el rol y las características que debía asumir la lucha sindical en una estrategia política revolucionaria.

Fue así como, a partir de 1973, la cuestión sindical cobró un rol fundamental en la política y la estrategia perretista: al analizar que la salida democrática estimularía las luchas gremiales, pasó a considerar estratégica la construcción de "apoyos firmes" en ese plano. Si bien, como mostramos en el Capítulo 1, por entonces la organización ya contaba con una definición propia del clasismo, métodos de penetración en las fábricas (la proletarización y la propaganda armada) y una forma de concebir el trabajo político en ellas, aún no se había despojado plenamente de su prejuicio hacia la actividad sindical y seguía afectada por los efectos de la "desviación militarista". En parte como consecuencia de ello sufrió dos rupturas en los albores de 1973: el PRT-Fracción Roja y el ERP 22 de Agosto. En ese marco, el trabajo de reconstrucción partidaria supuso, 
entre otras cosas, una reorientación de los esfuerzos hacia el movimiento obrero, diseñando una política específica y sistemática para penetrar y construir el partido en las fábricas e intervenir en las luchas sindicales.

Esta política estuvo en el marco de definiciones que el PRT-ERP asumió ante la apertura democrática y que se sintetizaron en la fórmula: aprovechar al máximo los intersticios legales sin abandonar la lucha armada. Como analizamos, bajo aquella máxima la organización buscó que todas sus intervenciones articularan complementariamente lo legal y lo clandestino, configurando un criterio político que nosotros llamamos de equilibrios complementarios. Las manifestaciones más evidentes de ello fueron el lanzamiento de un frente político-legal como el FAS (1973) y el salto en la envergadura de las acciones militares. Por su parte, a nivel fabril se plasmó en la política de "construir el partido en las fábricas" lo que supuso, a grandes rasgos, desarrollar una estructura partidaria ideal para el interior de los establecimientos, compuestas por células dedicadas a tareas específicas que, en su conjunto, abordarían todos los aspectos de la política perretista (células de masas, militares, de propaganda y legales).

En esa dirección, hizo de la lucha contra el Pacto Social y contra la "burocracia sindical" los ejes centrales de su política, buscando movilizar al conjunto del pueblo y enfrentar a las principales políticas del gobierno peronista. Vio en las luchas salariales una oportunidad para politizar la conflictividad obrera -y acelerar la ruptura de los trabajadores con el gobierno- y por ello las amplificó desde sus órganos de prensa y las impulsó al interior de las fábricas a través de sus militantes. Asimismo apostó a construir listas o agrupaciones clasistas que disputaran los organismos de base a la "burocracia sindical", además de enfrentar desde un inicio la Ley de Asociaciones Profesionales.

Para ello, y como parte de la política de equilibrios complementarios, en la primera mitad de 1973 lanzó dos herramientas sindicales: la TOR 22-8, tendencia sindical clandestina, y el MSB, herramienta sindical legal. La TOR 22-8 fue pensada como un instrumento específicamente sindical encargado de organizar la violencia de masas y la resistencia a la represión al interior de las fábricas y de apuntalar, desde la clandestinidad, al movimiento sindical legal. No obstante, no tuvo desarrollo en la práctica concreta ya que el lugar que intentó ocupar, de distintas maneras, ya lo 
ocupaban el ERP -en lo militar ${ }^{713}$ - y el MSB -en lo sindical. En ese sentido su creación no fue la respuesta a una necesidad dictada por la realidad política de las fábricas sino, más bien, una forma esquemática de adosarle un "carácter revolucionario" -propia de la lucha armada- a la actividad sindical. Por ello consideramos que se trató de un acto reflejo derivado de los prejuicios "antisindicales" que seguían operando en el inconsciente partidario. Distinto fue el caso del MSB, herramienta que se desarrolló significativamente durante los años 1973-1974. Es que su creación vino a aprovechar el auge de las luchas reivindicativas, reuniendo en un mismo organismo y con un mismo programa a referentes, activistas sindicales y a agrupaciones clasistas con trayectorias previas o en pleno desarrollo. El problema, en este caso, estuvo en la manera esquemática, "administrativa" y hegemonista en que el PRT-ERP lo dirigió, ya que la transformó en una herramienta políticamente estrecha -prácticamente "parapartidaria"cuando en realidad había sido pensada para reunir a diferentes expresiones políticosindicales antiburocráticas.

No obstante, ello no significó que la organización abandonara la búsqueda de un frente sindical (y también político ${ }^{714}$ ) más amplio. De hecho durante todo el período planteó la necesidad de conformar un Frente Nacional Antiburocrático que contuviera al MSB y, principalmente, a la Tendencia Revolucionaria del peronismo -centralmente al PB y la JTP-, al PCA y al sindicalismo independiente dirigido por Agustín Tosco. Como vimos, si bien ese frente tendió a darse en los hechos al interior de las plantas, motorizado por las bases militantes de las distintas organizaciones, a nivel superestructural se transformó en un frente imposible. Desde nuestra lectura, esta imposibilidad estuvo dada fundamentalmente por las diferencias estratégicas entre aquellas organizaciones, manifestada especialmente en el desinterés de Montoneros y el PCA de confluir en frentes políticos o sindicales con organizaciones como el PRT-ERP cuyas definiciones los obligaban a romper con el gobierno. Por su parte, el PRT-ERP tendió a profundizar aquella grieta al sostener una polémica constante con estas organizaciones y, por otro lado, al mantener durante todo el período la ofensiva militar, llevando adelante acciones altamente controversiales que dañaron su política de alianzas (como el copamiento de Azul).

713 El ERP intervenía en las fábricas con propaganda armada (secuestros, copamientos de establecimientos, tomas de guardia, etc.), fomentando la autodefensa obrera y la creación de comités de apoyo formados por obreros.

${ }_{714}$ Recordemos que la organización para ese momento planteo la ampliación del FAS y la conformación de un Frente Democrático, Patriótico y Antiimperialista. 
Aun así ello no limitó el desarrollo de la organización. Por el contrario los años 19741975 fueron los de mayor crecimiento, a pesar del contexto altamente represivo que se empezaba a vivir. Como creemos haber mostrado, la organización dio un salto cuantitativo importante en su inserción fabril, lo cual le permitió jugar un rol protagónico en las luchas obreras, destacándose en las de Villa Constitución y, fundamentalmente, en las de 1975.

Este último año, atravesado por las negociaciones paritarias, encontraron a un PRT-ERP que, en la práctica, comenzaba a otorgarle una centralidad de orden estratégico a la lucha sindical. Partiendo de esa posición, elaboró un plan detallado para intervenir activamente en el escenario paritario y fomentar, junto al resto de las organizaciones antiburocráticas, la movilización de las bases y la presión sobre la cúpula cegetista. Ello le dio protagonismo en las movilizaciones de junio y julio contra el "Rodrigazo" y en la conformación de las Coordinadoras Interfabriles, organismos que la organización llegó a considerar como el eje principal de su actividad sindical.

Lo anterior fortaleció su confianza en el desarrollo del proceso revolucionario, y partiendo de la evaluación del "estado de ánimo" de la fracción más politizada de los trabajadores, comenzó a consolidarse un desfasaje entre sus análisis y la situación política. En base a ello evaluó que se había entrado en una situación revolucionaria, que se vivían "momentos decisivos" en la lucha de clases y que en esas circunstancia las organizaciones revolucionarias y el pueblo se hallaban en condiciones para lograr una democratización o enfrentar una guerra civil. En ese marco respondió con la máxima, audaz y controversial, que guió su política durante todo el período: ampliar la lucha político-democrática -a través del Frente Democrático, Patriótico y Antiimperialista y de la propuesta de Asamblea Constituyente- e intensificar el accionar militar -el copamiento del batallón de arsenales 601 de Montechingolo fue la acción más significativa en ese sentido.

Ahora bien, dicho ofensivismo sumado a la creciente represión, se tradujo en duros golpes para el PRT-ERP, pese a los cuales no evaluó la posibilidad de un "repliegue estratégico" propio ni del activismo obrero. De este modo, las manifestaciones obreras de febrero de 1976 contra el Plan Mondelli, aunque netamente defensivas, renovaron su confianza en el estado de movilización reinante. Confundiendo el carácter y significado de aquellas luchas, la organización no pudo captar los efectos inmediatos del golpe militar del 24 de marzo: en el momento en que la fractura entre la vanguardia social y política y el resto de la sociedad se hizo evidente, la organización consideró que estaban 
dadas las condiciones políticas para pasar de la "guerra entre vanguardias" a la "guerra de masas".

Antes de entrar de lleno analizar los "casos" estudiados, y si bien no ha sido un objetivo específico de nuestra investigación, es necesario referirse a la la Regional Buenos Aires del PRT-ERP, dado que ha sido el "teatro de operaciones" en el cual hemos inscripto nuestro análisis, y donde se hallaron ubicados nuestros casos.

Como hemos visto la Regional Buenos Aires del PRT-ERP fue una de las de mayor desarrollo, junto con Córdoba y Rosario. No obstante su consolidación se dio de manera tardía ya que fue la más afectada por las sucesivas rupturas (en 1968 y en 1973), llevándola a un estado de reconstrucción permanente. Aquellas escisiones tuvieron como consecuencia, entre otras, la perdida de trabajos políticos en algunas fábricas, lo que dejó a la regional con un mapa de inserción fabril bastante pobre para 1973. De hecho, para inicios de 1974, según el informe que hemos hallado, la dirección regional seguía considerándola "prácticamente nula", por lo que volvió a ajustar y reforzar la orientación hacia las fábricas cambiando el paradigma de construcción: el partido debía consolidarse al calor de los conflictos. En base a aquella consigna, la regional logró dar un salto significativo en ese sentido, alcanzando una presencia bastante extendida en las fábricas más importantes de las distintas zonas del Gran Buenos Aires, aunque la rapidez con que se dio aquel crecimiento no dio tiempo suficiente, en todos los casos, para consolidar su trabajo político.

Como hemos dejado planteado en la primera parte de la tesis, a grandes rasgos, la intervención sindical tendió a darse a partir de agrupaciones sindicales impulsadas por la organización y encuadradas en el MSB, tal como lo muestra el caso de EATON Fundiciones -brevemente reconstruido-, o a través de listas sindicales amplias como la Blanca de Propulsora Siderúrgica o la Naranja de Rigolleau -estudiada por Centurión (2013)-. Sin embargo no en todos los casos aquello se dio de manera lineal ya que los estilos de construcción variaron según la especificidad de cada establecimiento y, sobre todo, según haya sido el desarrollo de la experiencia militante. Es que en muchas fábricas de la región los militantes fueron construyendo las herramientas que pudieron, supieron o creyeron necesarias construir y no necesariamente las que el partido planteaba. Hay que tener en cuenta que en muchos casos se trató de experiencias 
intensas pero breves, de 2 o 3 años. Según observamos, ello estuvo atravesado por el hecho de que, muchas veces, la identidad y la experiencia de clase tendió a pesar más que la identidad partidaria en la militancia fabril perretista.

Lo anterior fue abordado en profundidad en la segunda parte de nuestra tesis donde mostramos los resultados del estudio de dos "casos", el de TENSA y MBA. Dicho estudio nos permitió identificar diferentes formas, estilos y perfiles de militancia y militantes, así como los problemas y tensiones surgidos de la práctica concreta. Las fábricas fueron elegidas, entre otros factores, porque en ellas hubo una participación reconocible del PRT-ERP, y porque llegaron al apogeo de sus luchas durante nuestro período, aunque en momentos políticos distintos: el caso de TENSA a inicios de 1973 momento de la apertura democrática- hasta mediados de 1974, y MBA -aunque con episodios de lucha durante todo el período- a fines del año 1975, posteriormente a las movilizaciones contra el Plan Rodrigo.

Según nuestra reconstrucción, en ambas fábricas los militantes perretistas, además de contar con dirigentes sindicales en la CIR y el CD, construyeron la organización de acuerdo con la estructura orgánica básica diseñada por el partido: lograron organizar una estructura compuesta por varias células -en MBA, llegaron a construir una dirección especifica del tipo Comité Fabril-, escuadras militares, así como un radio de influencia alrededor de sus militantes que le permitió amplificar su política entre los trabajadores y difundir sus órganos de prensa. En ambos casos aquella influencia estuvo compuesta por distintos perfiles de trabajadores: lectores de la prensa; contactos que apoyaban las acciones de la organización y/o formaban parte de círculos reducidos de discusión política; simpatizantes o colaboradores que ayudaban a hacer circular los materiales de la organización en las plantas, activaban junto a los referentes sindicales; o, incluso como en MBA- activistas que llegaron a organizarse en una escuadra organizada por militantes perrtistas.

Más allá de estos rasgos comunes, existieron diferencias importantes en la forma en que los militantes perretistas concibieron el vínculo partido-fábrica y en el tipo de intervención político-sindical y militar que desarrollaron. En TENSA, los militantes tendieron a construir en base a las prescripciones partidarias, impulsando y participando de la agrupación sindical "16 de enero" - e incluso, en la planta de Pablo Nogués, adhiriendo al MSB-, creando un boletín fabril y desarrollando una profusa actividad armada ligada al establecimiento. En cambio, en MBA los militantes tendieron a construir con un criterio autónomo en materia político-sindical, evitando que los 
objetivos partidarios interfiriesen en la unidad de los trabajadores y con los diferentes sectores políticos antiburocráticos de la fábrica. De este modo, en el trabajo militante, distinguieron dos niveles: el de "la política", que podía y debía ser abordado por el partido a través de sus herramientas tradicionales (volantes, periódicos, etc.); y el gremial, en el que quienes "mandaban" eran los obreros y no los partidos. Vale decir que la herramienta sindical era ajustada a las necesidades y posibilidades de la fábrica y a la experiencia de los trabajadores. Bajo ese criterio, decidieron no desarrollar una agrupación sindical ni participar del MSB; por el contrario construyeron una herramienta original (el CROEMBA) que, aun no siendo una agrupación, permitió articular a todas las expresiones y corrientes antiburocráticas de la planta, organizar y representar las reivindicaciones de los trabajadores y construir la propia agenda de reclamos. Además, durante el conflicto de 1975 y luego de él, los obreros perretistas concentraron su intervención en la participación en los distintos organismos creados por los trabajadores: el Comité de Lucha y el llamado "grupo de los 9". Consideramos que en la adopción de esta estrategia jugo un papel importante la apreciación del hecho de que la mayoría de los trabajadores conservara su identidad peronista, y que eso, de alguna forma ponía un límite al trabajo político y a la influencia de la militancia fabril perretista. En ese sentido es que planteamos que, la experiencia del CROEMBA por un lado demostró ser sumamente efectiva para representar los intereses de los trabajadores y transformar a varios de los militantes perretistas en referentes sindicales pero también expresó los límites de la influencia política del PRT-ERP en la planta: los militantes tuvieron que ocultar su identidad política para lograr conectar e influenciar al conjunto de los trabajadores y no ser rechazados.

En el aspecto militar también existió una diferencia sustancial entre ambas experiencias. Si bien, como dijimos, en las dos fábricas se formaron escuadras militares, en el caso de TENSA la actividad guerrillera estuvo en el centro de la actividad del PRT-ERP, tanto por la cantidad como por el tipo de acciones que allí desarrolló. Los copamientos a las plantas, el secuestro del sub-gerente, la conformación de un tribunal revolucionario en la zona, hasta el asesinato del delegado, marcaron la dinámica de su intervención polítco-sindical. A diferencia de otros casos, como el de Rigolleau o el de EATON Fundiciones -donde el ERP intervino sólo en el marco de los conflictos $^{715}$-, en TENSA

\footnotetext{
${ }^{715}$ En el caso de Rigolleau la intervención del ERP se dio en el marco de una huelga de 1975, en la que la organización tomó la guardia, quemó el depósito de la fábrica y realizó pintadas en su interior (Centurión,
} 
la actividad guerrillera se trasformó en un factor casi permanente y clave para el crecimiento orgánico y político de la organización. En ese sentido consideramos que el accionar militar explica en buena medida aquella experiencia, tanto por sus efectos potenciadores, que llevaron en un primer momento a fortalecer la organización y el movimiento de base, como los negativos: la desarticulación del partido y, en parte, el haber alimentado la virulencia de la represión sobre la fábrica.

En el caso de MBA, en cambio, la actividad militar fue escasa y estuvo lejos de significar un rasgo sobresaliente o determinante en la experiencia de sus militantes. Son pocas las referencias a acciones sobre la fábrica, siendo la intimidación y el atentado contra la casa de un ejecutivo en medio de la huelga de 22 días, la más importante en ese sentido. Además, según los testimonios, los propios militantes, en sintonía con la autonomía que reclamaban respecto a las directivas partidarias, habrían rechazado la propuesta del ERP de realizar un secuestro y visto con malos ojos el concretado por Montoneros durante la huelga. No obstante, resulta sugestivo que, como indicó uno de los entrevistados, allí se hubiese organizado una escuadra militar con trabajadores independientes que, sin formar parte del partido ni del ERP, se sentían atraídos por la lucha armada y desarrollaran acciones ligadas a la fábrica. Este perfil de activistas, organizados por militantes del partido, reunía todas las características de la franja de trabajadores que el PRT-ERP había intentado organizar en la TOR 22-8 -aunque en el caso de MBA no hemos hallado referencias a la existencia de dicha tendencia. De modo que lo militar no estuvo ausente en esta planta aunque, a diferencia del caso de TENSA, se dio de manera más mediada y significó un elemento mucho menos determinante para la militancia fabril perretista.

Como hemos visto, en ambos casos, la penetración en estas fábricas no se logró a través de la proletarización de militantes -como sí ocurrió, por ejemplo, en el caso de Propulsora Siderúrgica- sino por la incorporación de trabajadores al partido. Aunque no hemos podido determinar cuándo y quién fue el iniciador del trabajo político en TENSA, sí sabemos que los principales referentes/militantes se incorporaron al partido ya siendo trabajadores, es decir que fueron, al igual que en MBA, obreros militantes. Ello nos muestra tanto la llegada que tuvo la propuesta perretista al mundo obrero como la capacidad de la organización para interpelar e incorporar a un sector de los trabajadores. Ahora bien, como resalta Héctor Löbbe, a diferencia del militante obrero - 
es decir el proletarizado-, el obrero militante solía encontrarse más tensionado entre las prescripciones de su organización y la realidad que le imponía la fábrica -niveles de participación y conciencia de sus compañeros de trabajo, composición política del activismo, características de la patronal y de la "burocracia", etc.

Dicha tensión se jugó de diferentes maneras en uno y otro caso: en MBA fue resuelta inclinando la balanza hacia los propios obreros perretistas, quienes decidieron no dejar que "el partido" impusiera sus prescripciones sino ser ellos los que marcaran los tiempos y las reglas de juego al interior del establecimiento, incluso a costa de fuertes discusiones con los responsables políticos. Ello puede verse claramente en ciertos pasajes de algunos testimonios en los cuales el partido aparece como un actor en cierta medida externo que los "apoyaba" en algunas actividades o tareas, por caso imprimir volantes. En cambio en TENSA, la tensión fue tramitada de diferentes maneras: si por un lado en la planta de Pablo Nogués, el principal dirigente sindical tendía a manejarse con un criterio propio - "más relajado"- a la hora de intervenir y organizarse al interior de la planta -incluso discutiendo con sus responsables políticos-; por el otro, en la planta Múnro, la organización tendía a funcionar como un "reoljito", es decir, con importantes niveles de disciplina partidaria y poniendo en pie el conjunto de organismos recomendado por el partido.

Del análisis de ambos casos parece desprenderse que dicha tensión -entre las aspiraciones del partido y la realidad de las fábricas- tendió a ser vivida de manera más conflictiva por aquellos obreros militantes que, a la vez, eran referentes sindicales; ellos se veían forzados a combinar las tareas propiamente partidarias con la representación de los intereses de todos los trabajadores de la planta y, quizás lo más difícil, a lograr la unidad de acción con los militantes de otras corrientes políticas. Nos arriesgamos a decir que fue esto último lo que generó más contradicciones entre la militancia fabril perretista y la estructura partidaria, ya que en pos de lograr la unidad los militantes tendieron a resignar las prescripciones de la organización. Pero creemos que fue esta decidida actitud la que permitió la unidad de acción registrada a nivel de las bases (el "frente de hecho"), y la que marcó una notable diferencia respecto de la imposibilidad de las direcciones de construir acuerdos políticos y sindicales a nivel nacional.

Como hemos visto, en ambos casos la lucha de los trabajadores y la persistencia del movimiento de base, aunque con matices y altibajos, se desarrolló durante todo el período enfrentando incluso, como en el caso de TENSA, duros embates represivos y una derrota que dejó a la agrupación sin sus principales dirigentes. Al igual que en todas 
las fábricas, la instauración de la dictadura militar de 1976 significó un punto de quiebre para los movimientos de base y la militancia fabril perretista de TENSA y MBA aunque, como vimos, en este último caso la capacidad de resistencia se extendió con fuerza durante todo aquel año.

El estudio de estas experiencias nos ha permitido iluminar diferentes modalidades de construcción político-sindical llevadas adelante por la militancia del PRT-ERP, observando sus problemas, tensiones y características, y mostrando la complejidad de una práctica militante que, en muchos casos, queda oscurecida por el discurso homogéneo y prescriptivo de la organización. Sin buscar generalizaciones a partir de los casos, creemos que esta investigación allana el camino para el análisis de otras experiencias fabriles habilitando posibles comparaciones que ayuden a echar luz a nuevos problemas y modalidades de construcción, así como a complejizar la mirada sobre el vínculo entre el PRT-ERP y el movimiento obrero.

\section{IV}

Antonio Gramsci en las Notas sobre Maquiavelo asegura que la historia de un partido no puede ser menos que la historia de un determinado grupo social y que escribirla no significa otra cosa que escribir la historia general de un país desde un punto de vista monográfico (2003:31). La realización de la presente investigación nos lo ha confirmado. Aquí hemos estudiado una parte de la historia del PRT-ERP, específicamente sus concepciones, estrategias y herramientas político-sindicales desde donde buscó vincularse al movimiento obrero argentino. Desde ese recorte hemos visto que la experiencia perretista formó parte de la experiencia de clase de una fracción importante de los trabajadores argentinos que, al fragor de la lucha de clases, construyó un horizonte cargado de expectativas revolucionarias. En ese sentido la investigación cuestiona en sí misma a quienes han explicado a las organizaciones armadas, en especial al PRT-ERP, como una expresión "extraviada” de la época y "externa” a la clase obrera argentina. Consideramos que uno de los problemas fundamentales de estas visiones radica en haber abordado el objeto tomando a esas nociones como punto de partida, lo cual las condujo a explicar el derrotero de esas experiencias exclusivamente a través de la dinámica interna de las organizaciones, sin preocuparse por la experiencia de sus militantes y de quienes los rodearon, y por ello sin poder ver que fueron parte de un proceso de activación social y político más amplio. 
En ese sentido, una de las apuestas centrales de esta tesis fue la articulación de las dos dimensiones de análisis puestas en juego -la de la organización y la de la experiencia de sus militantes fabriles. Ello se tornó en un desafío teórico y metodológico, en tanto ninguna de ellas fue planteada como subsidiaria de la otra sino como dimensiones complementarias: así, ni la reconstrucción de la línea político-sindical perretista fue hecha como soporte para estudiar los casos, ni los casos fueron utilizados como ejemplos o reflejos de la línea político-sindical reconstruida. Es que a la elección de abordar en un mismo trabajo el análisis de ambas dimensiones le subyace la idea gramsciana de que la reconstrucción de la historia de un partido político, en cualquiera de sus dimensiones, nunca puede aspirar a ser completa si no se considera la experiencia de quienes, en distintos niveles, encarnaron e intentaron desarrollar la propuesta política de la organización en la práctica concreta, pero también de sus amigos, adversarios y enemigos. 
ANEXOS 


\section{ANEXO 1 \\ Dos tradiciones, un mismo sujeto: clase obrera y lucha sindical en el FRIP y PO}

En este anexo complementario buscamos profundizar el conocimiento de las dos organizaciones que le dieron vida al PRT en el año 1965 para comprender cómo fue posible un acuerdo entre dos organizaciones de orígenes tan distintos como PO y el FRIP. Si bien existen múltiples dimensiones sobre las cuales abordar el análisis de aquellas organizaciones, aquí haremos especial hincapié en las concepciones que cada una tenían sobre la clase obrera y la lucha sindical.

PO era, de las dos, la que mayor trayectoria política cargaba sobre sus espaldas. Dicha organización debe ser entendida como un momento del desarrollo de una corriente política que giró en torno a la figura de Hugo Miguel Bressano, más conocido por el seudónimo de Nahuel Moreno ${ }^{716}$. Aquel agrupamiento, que contó entre sus filas con militantes como Milcíades Peña, Ángel Bengochea, Ernesto Gonzales y Daniel Pereyra, fue rebautizado varias veces con diferentes denominaciones hasta llegar a constituirse como Palabra Obrera ${ }^{717}$. Como hemos dicho, desde sus inicios, la corriente se caracterizó por dirigir todos sus esfuerzos a insertarse en el movimiento obrero, centralmente del Gran Buenos Aires. Para ello dispuso de la proletarización de sus militantes no obreros como estrategia central para penetrar en las fábricas, pero también editó boletines fabriles e intentó ligarse a los conflictos y huelgas brindándoles apoyo logístico y económico ${ }^{718}$.

Es de destacar que la lucha sindical estuvo en el centro de la actividad de la corriente morenísta y, a nuestro entender, explicó muchos de sus vaivenes tácticos y organizativos. Sin embargo, más allá de esas oscilaciones la organización sostuvo

\footnotetext{
${ }^{716}$ Nahuel Moreno comenzó su trayectoria política en el trotskismo en torno a la figura de Liborio Justo, participando fugazmente de la Liga Obrera Revolucionaria de la cual será expulsado rápidamente, para luego participar de la fundación del Grupo Obrero Marxista (GOM) en 1944.

${ }^{717}$ El grupo comenzó su trayectoria como Grupo Obrero Marxista (GOM), desde el cual, en 1944, impulsó el Grupo Sindical Marxista. En 1948, luego de que Moreno asistiera como delegado al II congreso de la IV Internacional, la organización se redefinió como Partido Obrero Revolucionario (POR). Seis años más tarde, la organización decide incorporarse al Partido Socialista de la Revolución Nacional (PSRN) y tan solo un año después, luego de romper con dicho partido, paso a denominarse Socialismo Revolucionario Trotskista. Desde éste último impulsaron el Movimiento de Agrupaciones Obreras (MAO) desde donde publicaron el periódico Palabra Obrera, nombre que pasó a identificar al grupo desde allí hasta la fundación del PRT. (Gonzales, 1996; Coggiola, 2006; Pereyra, 2014).

${ }^{718}$ Una de las primeras acciones fue el apoyo a la huelga del frigorífico Anglo-Ciabasa de 1945 ubicado en Dock Sud, al cual les brindaron una activa solidaridad con apoyo económico y logístico permitiéndoles incorporar a obreros de la carne.
} 
invariablemente las banderas de la democracia sindical y de la independencia política del movimiento obrero como ejes constantes en sus consignas.

En lo que respecta al peronismo, como el resto de la izquierda tradicional, en sus primeros años lo caracterizó como un movimiento "semifascista". En esa dirección levantó la consigna "Frente Único contra la CGT" y, en 1948, llamó abiertamente a conformar oposiciones sindicales al gobierno ${ }^{719}$ (Coggiola, 2006: 110; Pereyra, 2014:63).

Sin embargo, este antiperonismo sufrió un revés en 1954 cuando sus análisis de la coyuntura nacional e internacional viraron radicalmente. Frente al avance del imperialismo norteamericano, el morenísimo evaluó la necesidad de adherir al peronismo por considerarlo el "frente único anti-yanqui" (Coggiola, 2006:147). En el marco de esa política se incorporó al Partido Socialista de la Revolución Nacional (PSRN), organización que formaba parte del movimiento peronista, y luego, ya por fuera del mismo, practicó el entrismo al interior de las 62 Organizaciones Peronistas. Esta última orientación fue impulsada desde el Movimiento de Agrupaciones Obreras (MAO) en 1957, con el objetivo de ligarse a "los sectores de vanguardia, simpatizantes peronistas del movimiento obrero" ubicados en las ramas tradicionales de la industria (metalúrgica, frigorífica y textil). Como hemos visto, la táctica del entrismo consistió en la penetración de militantes trotskistas en las 62 Organizaciones peronistas. Para ello se presentaban como peronistas revolucionarios e intervenían a través del periódico Palabra Obrera que, asumiéndose "bajo la disciplina del General Perón”, pretendía introducir ideas revolucionarias entre los trabajadores. Según Ernesto Gonzales (1996) con dicha política se buscaba dotar al movimiento obrero de una nueva dirección, clasista y revolucionaria, capaz de preparar y llevar al triunfo la huelga general insurreccional. Para el autor, el entrismo se explicaba como un momento táctico en el marco de un objetivo estratégico más amplio: derrotar los planes del imperialismo yanqui en el país. A su vez respondía al proceso de crecimiento y fortalecimiento de las agrupaciones sindicales peronistas que, mediante las 62 Organizaciones, habían logrado superar la dispersión del movimiento obrero. Dicha táctica tenía el objetivo de "ganar a su vanguardia obrera para la construcción del partido revolucionario" (Gonzales, 1996:17). Esta política permitió que la organización llegase a alcanzar la influencia más

\footnotetext{
${ }^{719}$ En 1952, se propuso construir corrientes de oposición en el seno de sindicatos peronistas llevando adelante una línea antiburocrática, a partir de la cual lograron algunas experiencias de relativo éxito como las listas verdes en la Asociación Obrera Textil y la UOM Seccional Capital y Avellaneda
} 
extendida de la corriente trotskista en Argentina en el terreno sindical (Gonzales, 1996; Mangiantini, 2014: 21-22; Pereyra, 2014: 63-71). Así, Palabra Obrera se transformó rápidamente en el nombre con el que el grupo empezó a ser identificado y poco después se convirtió oficialmente en el nombre de la organización.

Su influencia no solo abarcó a algunas industrias del Gran Buenos Aires sino que logró extenderse hacia la provincia de Tucumán. En 1959, de la mano de militantes como Esteban Rey, Hugo Santilli, Ángel Bengochea y Ernesto Gonzales, la organización logró insertarse en los ingenios azucareros donde tomaron contacto con la militancia del FRIP. Allí desempeñaron un papel importante en las huelgas de aquellos años y lograron organizar a algunos activistas de la FOTIA como Leandro Fote, Juan Manuel Carrizo, Marcelo Lescano y Antonio del Carmen Fernández, muchos de ellos importantes militantes del PRT primero y del PRT-ERP después (Pozzi, 2004; Carnovale 2011).

El abandono del entrismo se dio varios años más tarde, en 1964. El viraje se produjo fundamentalmente por lo que la organización consideró como un cambio en las condiciones políticas tras el triunfo electoral de Arturo Illia en julio de 1963. Aunque el triunfo del radicalismo se había dado bajo la proscripción del peronismo, los índices de abstención no fueron extraordinarios y el voto en blanco tampoco había sido una expresión mayoritaria ni contundente. A los ojos del morenísmo ello había significado una derrota aplastante para la dirección política y sindical peronista. En este nuevo escenario de "democracia formal" se preveía que el peronismo se convertiría en un partido burgués integrado al régimen por momentos aliado al oficialismo, y que sus antiguas agrupaciones sindicales serían aparatos burocráticos. En ese contexto se agotaban las posibilidades de trabajar políticamente al interior del peronismo y la organización volvía a cambiar de táctica. Ahora la tarea inmediata era enfrentar la ofensiva patronal en cada fábrica y en cada sección fortaleciendo las CIR y CD combativos, mientras que a nivel táctico-estratégico los esfuerzos debían estar puestos en construir un "partido único de la revolución argentina". Esta orientación a su vez se sustentaba en la idea de que nuevos sectores del activismo obrero estaban viviendo un proceso de "revolución ideológica" que se expresaba en la búsqueda de nuevos métodos de lucha y en el desprestigio de los dirigentes sindicales (Gonzales; 1996 (b): 17). En el marco de este cambio de táctica se firmó el acuerdo de frente único con el FRIP.

Por su parte, esta última organización había sido fundada el 9 de julio de 1961 en Santiago del Estero, bajo el liderazgo de los hermanos Santucho. Como remarca Pablo 
Pozzi (2004) el FRIP debe ser entendido como la resultante de tres vertientes: la primera y eje central, es la que se organizaba alrededor de la librería "Dimensión" de Francisco René Santucho, que a su vez editaba una revista político-cultural que llevaba el mismo nombre; la segunda provenía de un grupo de estudiantes santiagueños de la Universidad Nacional de Tucumán que, encabezados por Mario Roberto Santucho junto a estudiantes como José Pirró, formaban parte del Movimiento Independiente de Estudiantes en Ciencias Económicas (MIECE); por último un grupo de obreros e intelectuales de la provincia de Salta que habían sido contactados por la actividad política de Asdrubal y Francisco René Santucho.

De estas tres vertientes resulta importante destacar brevemente el itinerario de las dos primeras ya que fueron las que influyeron con sus posiciones y experiencias al FRIP en primera instancia, y también a la militancia del PRT-ERP.

La trayectoria del grupo "Dimensión" (en el que incluimos a quienes transitaron la librería y la revista) resulta una pieza clave para comprender el surgimiento del FRIP, no sólo porque muchos de sus integrantes fueron los fundadores sino porque sus preocupaciones intelectuales, culturales y políticas permiten entender, en parte, los rasgos identitarios y las coordenadas políticas que asumió esa experiencia (Gómez, 2011; Volonté, 2013; Gómez, 2013/2014; Sujatt, 2014; Volonté, 2016).

La revista se publicó en la provincia norteña entre 1956 y $1961^{720}$ y se proponía el objetivo de rescatar una herencia cultural popular en torno a dos temáticas clave: el “dilema Buenos Aires-Interior” como traducción vernácula de la dominación y opresión de occidente; y el indoamericanismo como identidad continental que se afirmaba en la historia de lucha contra el yugo cultural, político y económico de sucesivos dominadores. En ese marco se inspiraban en el APRA peruano de Víctor Haya de la Torre $^{721}$.

\footnotetext{
${ }^{720}$ La revista sólo publicó ocho números. Dimensión se transformó en el núcleo articulador del resto de las actividades que llevaba adelante el grupo como eran las muestras de arte, las conferencias de formación con intelectuales de la talla de Miguel Ángel Asturias y Hernández Arregui, o la realización del Seminario de Investigaciones Sociales, Económicas y Políticas de Santiago del Estero (SEISEPSE) (Gómez, 2011: 6). A su vez funcionaba como aglutinadora de personalidades con diferentes trayectorias artísticas, intelectuales y políticas, entre las que se encontraban nacionalistas de izquierda, católicos, comunistas y liberal-socialistas (Volonté, 2016).

${ }^{721}$ La Alianza Popular Revolucionaria Americana es un movimiento político fundado en Perú hacia 1924 por Víctor Haya de la Torre. El origen de esta organización está relacionado a la Reforma Universitaria de 1918 iniciado en la provincia argentina de Córdoba. Dicho acontecimiento, que estremeció al conjunto de los estudiantes e intelectuales latinoamericanos, inspiró a un sector del movimiento estudiantil que se propusieron superar los márgenes universitarios y fundar un "frente único de trabajadores manuales e intelectuales" (Sessa, 2011). Las bases originales del APRA estaban atravesadas por un programa anti-
} 
Según Juan Carlos "Cacho" Ledesma, militante del FRIP y posteriormente dirigente del PRT-ERP, el grupo Dimensión había logrado acercar a algunos militantes que ya habían comenzado a trabajar, sin organización, en el seno de los hacheros santiagueños y de los obreros del obraje, organizados en la Federación Obrera Santiagueña de la Industria Forestal (FOSIF), donde posteriormente el FRIP conseguirá un cierto nivel de influencia (De Santis, 2010: 45).

La segunda vertiente estuvo centrada en la experiencia del MIECE. La agrupación estudiantil, radicada en la facultad de Economía de la Universidad Nacional de Tucumán, nació en 1959 como el resultado de las luchas conocidas como "laica o libre" de septiembre y octubre de $1958^{722}$. Combinaba un discurso de neto corte clasista con un antiimperialismo radical que la llevó a ser una de las primeras organizaciones estudiantiles defensora, solidaria y difusora de la Revolución Cubana. Una de las principales iniciativas del agrupamiento fue el impulso de la Comisión de Relaciones Obrero Estudiantil, desde la que organizaban charlas, reuniones o asambleas con dirigentes gremiales de la FOTIA como Benito Romano, Simón Campos y Mario Aparicio $^{723}$. El impulso y la búsqueda política e intelectual de los miembros del MIECE y su preocupación temprana por ligarse a la clase obrera fueron elementos de peso para la experiencia del FRIP.

Como dijimos, en julio de 1961 se llevó a cabo la primera reunión del FRIP impulsada por Francisco René ${ }^{724}$. En su primer Boletín el grupo planteaba que se lanzaba a la acción política por la desaparición de las injusticias y por el desarrollo integral de la provincia, y se definían como un "movimiento de campesinos, obreros, estudiantes e intelectuales" ${ }^{\prime 725}$.

imperialista con fuerte contenido panamericano a través del cual se fomentaba la solidaridad internacional y el nacionalismo económico como principios fundamentales.

${ }_{722}$ En su manifiesto liminar la agrupación declaraba: "ni humanismo ni reforma son opciones claras, la verdadera opción es con el pueblo o contra el pueblo, a favor de la clase obrera o contra la clase obrera" (Volonté, 2016).

${ }^{723}$ Además la agrupación organizó conferencias sobre "El ser nacional en América Latina" en la que participaron intelectuales-militantes como Hernández Arregui, Abelardo Ramos y Silvio Frondizi, lo que dejaba entrever la búsqueda del grupo y el tipo de marxismo que comenzaban a transitar

${ }^{724}$ Es necesario remarcar que de esa reunión no participó Mario Roberto, quien desde enero de 1961 se encontraba en un viaje por Latinoamérica con destino final a Cuba. Con una parada en Perú, Santucho logró entrevistarse con el líder del APRA, reunión de la cual sacará una contundente conclusión: "Es notable cómo Haya de la Torre olvidó a Mariátegui, y es muy probable que pronto claudique ante el imperio y termine sus días como un nacionalista de derecha llevándose a la tumba al APRA" (Seoane, 2009: 118). En lo que respecta a su estancia en Cuba, Santucho asistió a la plaza de la revolución donde Fidel Castro declaraba el carácter socialista de la revolución, se integró al trabajo voluntario en la zafra e inició su primer entrenamiento guerrillero junto a otros revolucionarios. El viaje reforzaba su certeza y convicción revolucionaria, así como prefiguraba y moldeaba aún más su marxismo latinoamericano.

725 “Algo sobre el FRIP”, Boletín Mensual del FRIP, Nro. 1, octubre 1961 
Si bien esta organización ha sido caracterizado por la mayoría de los autores como "campesinista" (Pozzi, 2004; Seoane, 2009; Carnovale, 2011), ya desde el primer número de su Boletín pueden encontrarse numerosas alusiones a los trabajadores y el movimiento obrero. Tal es así que en esta primera publicación se pueden encontrar afirmaciones como la siguiente: "El movimiento obrero es la fuerza organizada más patriota del país. La que defiende con mayor resolución los intereses de la nación y el pueblo, la que lucha más decididamente contra la entrega, la injusticia» ${ }^{, 726}$. De hecho, desde un comienzo, el FRIP sostendrá desde su publicación una de sus tesis más conocidas: la del proletariado rural como detonante de la revolución en Argentina ${ }^{727}$.

Por otro lado, la organización descartaba la idea de que existiesen sectores "progresivos" de la burguesía vernácula, ya que las consideraba cómplices (conscientes o no) del juego imperialista. Por el contrario sostenían como única solución para la liberación nacional y latinoamericana la conformación de "Un gobierno de trabajadores"728. De este modo, eran los trabajadores y no el "pueblo argentino" los que aparecían como sujeto de la revolución, como los únicos interesados en resolver el problema de la opresión y el desarrollo:

"¿Y esto por qué? Porque a los patrones les interesa utilizar el gobierno para ganar cada vez más, para robarle al trabajador una parte mayor de lo que produce y porque los patrones son cómplices, amigos, de los imperialistas que sacan sus ganancias del país (...) En cambio los trabajadores quieren que vivamos cada día mejor, que el país crezca, se desarrolle (...)" 729

El FRIP hacía una caracterización minuciosa de aquellos sectores que formaban parte de "los trabajadores del campo y la ciudad": entre los trabajadores del campo ubicaban al hachero, al pequeño agricultor, al pequeño criador, al bracero, a los peones de estancia, obreros caleros, de las salinas y de las minas; mientras que en la ciudad aparecían el asalariado y jornalero (los obreros de la construcción, municipales, enfermeros, efectivos policiales, obreros del taller, etc.) y otros empleados y obreros (ferroviarios,

\footnotetext{
726 “Ante el movimiento obrero" Boletín Mensual del FRIP, Nro. 1, octubre 1961

727 Es en ese sentido que podemos entender la incorporación de ideas centrales y textos simples en quichua en sus boletines. Estos no fueron solamente un gesto reivindicatorio de una lengua estigmatizada o del indigenismo, sino también una herramienta para llegar a aquellos trabajadores que no hablaban español y organizarlos.

${ }^{728}$ La revista apuntaba: "La salvación definitiva, la única salvación que tiene el trabajador, la mayoría del pueblo, y que es al mismo tiempo la salvación de la provincia, del país y de toda América Latina, es que sea el propio trabajador el que gobierne. Mientras los gobernantes sean los patrones, el obrajero, el industrial, el banquero, el comerciante fuerte, el latifundista, sólo se puede esperar que el obrero sea cada vez más explotado, que el país se empobrezca cada vez más" ("Un gobierno de los trabajadores" Boletín Mensual del FRIP, Nro. 2, noviembre 1961)

${ }^{729}$ Ídem.
} 
maestros, correo, teléfono, metalúrgicos, textiles, gastronómicos) ${ }^{730}$. En ese marco la tarea fundamental que se planteaban era organizar a los trabajadores recuperando a los sindicatos en manos de la burocracia, como primera condición para robustecer el espíritu de lucha del movimiento obrero santiagueño ${ }^{731}$. Los trabajadores debían organizarse para controlar a sus dirigentes, expulsar a los "camanduleros políticos" que "utilizan las organizaciones gremiales para acomodarse" y "ponerle el hombro (...) al dirigente sacrificado que está al servicio del gremio",732.

Con estas definiciones la organización siguió muy de cerca las luchas obreras, entre la que se destacó la huelga ferroviaria de 1961 contra el gobierno de Arturo Frondizi, lo que le permitió desarrollar un incipiente trabajo entre los ferroviarios a partir del año siguiente. Por otro lado comenzó a ofrecer una "oficina de consultas para obreros" de forma gratuita y a su vez sus militantes, centralmente Francisco René y Asdrubal, comenzaron a recorrer el interior de Santiago del Estero, Tucumán y Salta para vincularse con sus trabajadores ${ }^{733}$. En Tucumán, Mario Roberto Santucho entabló vínculos con los obreros del azúcar, del surco y de las fábricas, y con algunos dirigentes de la FOTIA (como Antonio del Carmen Fernández -futuro dirigente del PRT-ERP-). Esto lo llevó a involucrarse directamente en los conflictos de los ingenios Santa Ana y San José, donde comenzó el vínculo con militantes de Palabra Obrera (entre ellos con Leandro Fote y Hugo Santilli -ambos militantes de PO-).

Según Seoane (2009) esa relación se intensificó cuando Mario Roberto Santucho comenzó a trabajar como contador del Sindicato San José. Para ese entonces su preocupación fundamental era la construcción de un partido revolucionario ${ }^{734}$. Esa certeza lo hizo avanzar en las relaciones con Nahuel Moreno y en el invierno de 1963, en la capital tucumana, concretaron una reunión que fue el primer antecedente formal de acercamiento entre las organizaciones. Con el dirigente trotskista lo acercaba la

\footnotetext{
730 "El FRIP: Movimiento de campesinos, obreros, estudiantes e intelectuales" Boletín Mensual del FRIP, Nro. 3, diciembre de 1961.

731 "Por la organización de los trabajadores" Boletín Mensual del FRIP, Nro. 3, diciembre de 1961.

732 "Dirigentes gremiales o camanduleros políticos" Boletín Mensual del FRIP, Nro. 4, enero de 1962.

${ }^{733}$ Hacia 1963, FRIP había construido adhesiones entre docentes y estudiantes de Metán (Salta), entre los hacheros y peones de Monte Quemado, Titina, Quimilí, Bandera Bajada, Suncho Corral, Bañada de Figueroa, entre los ferroviarios de La Banda y Clodomira y textiles de la capital santiagueña y en el FOSIF del que participo protagónicamente en su recuperación y su dirección (Pozzi, 2004: 46-48).

${ }^{734}$ Esto se ve claramente en uno de los principales escritos de Mario Roberto: “...Entonces el FRIP debe organizarse como el Estado Mayor de la Revolución Argentina, sobre la base del proletariado rural, especialmente sobre el azucarero; debe dirigir sus esfuerzos a consolidarse organizativamente entre el proletariado rural, fundirse con él y con el resto de la clase obrera, ponerse a la cabeza y señalarle el camino de la lucha, de la toma del poder..." ("La lucha de los pueblos indoamericanos". Folleto del FRIP. Editorial Norte Argentino, Santiago del Estero, 1963)
} 
preocupación por construir el partido, la insistencia en la importancia del trabajo político entre los obreros, la adhesión a la lucha armada como vía necesaria para la toma del poder y su oposición frontal a los comunistas vernáculos.

Es de destacar, como indica Mangiantini (2014), que Moreno, y a través suyo PO, para ese entonces proponía una lectura de la revolución cubana en la clave de la teoría de la revolución permanente trotskista, alimentada por el no alineamiento inicial de la dirección cubana al stalinismo. Además afirmaba que el campesinado y la pequeñaburguesía podían cumplir un papel revolucionario en América Latina y caracterizaba al castrismo como la dirección revolucionaria del continente ${ }^{735}$. Asimismo, si bien polemizaba con las tesis guevaristas ${ }^{736}$, también planteaba a la lucha armada como método decisivo e indiscutible para la toma del poder ${ }^{737}$. Estos marcos de definiciones teórico estratégicas, sumado a la experiencia común que venían sosteniendo ambas organizaciones en los ingenios azucareros fueron el telón de fondo que permitieron este primer acercamiento y los acuerdos posteriores.

\footnotetext{
735 Esta nueva posición hallará su máxima expresión en un documento titulado La Revolución Latinoamericana elaborado por Nahuel Moreno en 1962. Allí afirmaban que la revolución cubana había generado un quiebre político en la coyuntura latinoamericana al haber cambiado la relación de fuerza entre las oligarquías nativas y las masas y contribuido a profundizar la descomposición del imperialismo norteamericano constituyéndose como la vanguardia de la revolución latinoamericana.

${ }^{736}$ En su trabajo Dos métodos sobre la revolución latinoamericana (1964) el líder trotskista criticaba los trabajos de Guevara, considerando que el principal error de éste último era sobreponer un método de lucha (la guerrillera) a la especificidad política de cada realidad nacional, subestimando las grandes organizaciones de masas como los sindicatos y apelando a ideas falsas como la de que el método guerrillero sería método predilecto de las masas campesinas y, al mismo tiempo, la única forma de garantizar el carácter continental de la lucha.

${ }^{737}$ Moreno sostuvo dos debates previos a los sostenidos con Santucho en 1968, sobre la puesta en práctica de la lucha armada: por un lado con Daniel Pereyra entre 1962 y 1964 y por el otro con Ángel "Vasco" Bengochea entre 1963 y 1964. Con Pereyra, militante de PO enviado a Perú a apoyar al POR peruano en el proceso de luchas campesinas, sostuvo una polémica centrada en si existía o no en aquel país condiciones para realizar acciones armadas independientes (Pereyra protagonizó acciones armadas en búsqueda de aprovisionamiento financiero por las que termino preso), o si las mismas debían estar atadas al desarrollo de las luchas campesinas. Por su parte el debate con Bengochea, uno de los principales dirigentes de la organización, terminó con una ruptura de la organización y la fundación porr éste último de las Fuerzas Armadas de la Revolución Nacional (FARN) en agosto de 1963. La discusión se dio luego del viaje de un contingente de militantes de PO a recibir instrucción militar en Cuba, aprobado por el Comité Central de la organización. Como indica Vera Carnovale, quién o quienes tomaron la decisión es materia de debate: "Para quienes después de la ruptura de 1968 se alinearon en la corriente santuchista, la decisión es atribuida a Moreno. Para quienes después de esa ruptura se alinearon con Moreno, este se hallaba preso en Perú al momento de la decisión" (Carnovale, 2011:45). Al margen de eso, lo cierto es que el resultado del viaje fue la incorporación del grupo del "Vasco" a los planes del Che Guevara, lo que suponía la formación de un grupo de apoyo al Ejército Guerrillero del Pueblo (EGP) liderado por Jorge Ricardo Masetti. La oposición frontal a estos planes de Nahuel Moreno, quien consideraba el apoyo a la lucha peruana como la prioridad en materia político-militar significó la inmediata ruptura del grupo del Vasco una vez arribado a la argentina. La breve experiencia de las FARN se vio trágicamente interrumpida el 22 de julio de 1964, cuando en un edificio de la calle Posadas en Capital Federal estalló el arsenal que habían logrado apertrechar, lo que produjo la muerte del dirigente y varios militantes más.
} 
En enero de 1964 el FRIP realizó su último congreso del que Mario Roberto Santucho salió como principal dirigente y autor de sus tesis que posteriormente se editaron bajo el título de Proletariado rural: detonante de la revolución argentina ${ }^{738}$. Este documento fue fundamental para el grupo porque representó un avance en función de los análisis anteriores. En él se incorpora un registro ya definitivamente marxista-leninista y un análisis más acabado de la realidad argentina. Sus conclusiones, además, persistirán una vez fundado el PRT, generando debates en su interior y pervivirán como sello distintivo de la corriente santuchista.

En el documento, el sindicato aparece como un "aparato administrativo que el proletariado debe desarrollar para su lucha económica por sus reivindicaciones gremiales". En ese sentido es concluyente en la necesidad de un partido revolucionario que sea "capaz de someter la lucha económica a una lucha política revolucionaria, capaz de llevar al proletariado a superar las limitaciones de las reivindicaciones puramente económicas". Para el FRIP la ausencia de ese partido revolucionario sumado a la existencia de "sectores privilegiados" dentro de la clase obrera habrían sido dos de los factores más importantes para la formación de una poderosa burocracia sindical que anidaba con fuerza sobre todo en Buenos Aires. Esto último es lo que lleva a la organización a plantear que el movimiento obrero del interior era clave para dar la batalla antiburocrática. Por otro lado se resaltaba el papel de vanguardia que jugaría el proletariado rural tucumano por su nivel de concentración, politización y explotación y por estar ubicado en el norte argentino que era considerado como el "eslabón más débil" del capitalismo vernáculo.

Este salto político también tuvo su reflejo en el campo organizativo: después de ese congreso el FRIP transformó su Boletín en un periódico partidario denominado Norte Revolucionario, y realizó transformaciones en la estructura, tendientes a organizarse como partido revolucionario ${ }^{739}$. Este avance político y organizativo se daba con miras a lo que pocos meses después será el acuerdo con PO.

\footnotetext{
${ }^{738}$ Secretaría ideológica del FRIP. El proletariado rural detonante de la revolución argentina. Norte Argentino, 1964. Según Pozzi el mismo fue escrito sobre la base de un texto de Mario Roberto Santucho titulado Cuatro Tesis sobre el Norte Argentino, producido en 1962 y posteriormente publicado en la revista Estrategia 3ra época Nro. 5, abril de 1966. La misma era la revista política del PRT y estaba dirigida por Nahuel Moreno.

739 Estas transformaciones se basaron en la formación de "comandos" y "unidades", en las que los primeros eran especies de células dedicadas a todas las tareas militantes (prensa, propaganda, obrera, barrial, coordinación, escuela, ideológica) mientras que las segundas estaban dedicadas a tareas prácticas específicas (reuniones sindicales, distribución de boletín, etc.) en las zonas de acción de los "comandos". Además se formó una Secretaría Ideológica desde la cual se producían folletos de la organización ("La importancia de la organización" Norte Revolucionario Nro. 14 Julio de 1964)
} 
El primer capítulo de acercamiento entre las dos organizaciones se dio el 17 de julio de 1964 con la firma de un acuerdo para realizar un trabajo común bajo el formato de Frente Único con el objetivo de "lograr al más corto plazo posible un partido único de la revolución de la argentina", misión que un año después se logrará concretar con la fundación del PRT. 


\section{ANEXO 2}

\section{Debates y polémicas: del I al IV Congreso}

En este anexo nos proponemos ampliar el análisis de las cuatro polémicas que presentamos en la sección 2.1 del capítulo 1: el debate en torno al entrismo; la consigna "CGT partido político de la clase obrera"; las condiciones para iniciar la lucha armada ligada al movimiento obrero; y el papel de los organismos de participación obrera. Como hemos dicho, a nuestro juicio aquellas discusiones resultan centrales para entender la línea sindical del PRT-ERP ya que, implícita o explícitamente, fue en función de las mismas que la organización teorizó sobre el papel que debía jugar la lucha sindical en la estrategia revolucionaria.

En cuanto al debate sobre el entrismo no agregaremos demasiados comentarios. Es que, según los documentos disponibles, todo indica que aquello no habría sido un problema sustancial para la confluencia entre FRIP y PO, ya que este último venía abandonando dicha táctica hacía un tiempo. De hecho, en una reunión de Comité Central de PO fechada en noviembre de 1964, se informaba que la única diferencia que se podía vislumbrar con la militancia del FRIP era relativa a la interpretación del trotskismo ${ }^{740}$. Además, en los primeros momentos del acuerdo, en las páginas del periódico del FRIP se pueden hallar algunas posiciones y caracterizaciones positivas sobre sectores del peronismo e incluso algunas notas que se planteaban expectativas en el retorno de Perón ${ }^{741}$ que indicarían una suerte de acoplamiento de la militancia norteña a la política entrista de PO. No obstante, lo que sí es claro en las posiciones del FRIP es su rechazo el espíritu fundamental del entrismo, es decir, a su travestismo político para conectar con los trabajadores. Esto queda claro en la siguiente declaración:

“(...) mantener respecto al peronismo nuestra táctica actual, independencia completa, trabajo desde fuera del movimiento de los aspectos positivos del peronismo (...). Se resolvió también aceptar y aconsejar la participación individual de nuestros militantes en algunas organizaciones del peronismo como la Juventud y las 62, pero bajo la disciplina de nuestra organización, con conocimiento de nuestros órganos directivos, y sin que los

\footnotetext{
740، “Acta reunión día 17/11/64”, Palabra Obrera, AA.3164, Fundación Pluma.

${ }^{741}$ Por ejemplo, ponderaba de manera positiva el Bloque Revolucionario Peronista de Andres Framini y rescataba como positiva la búsqueda del Movimiento Revolucionario Peronista de conformarse en partido revolucionario. Por otro lado planteaba expectativas en el retorno de Perón: "la vuelta de Perón para bien del pueblo y la clase obrera argentina, sólo puede producirse por la revolución social. Los únicos que pueden garantizar el regreso son los trabajadores" ("Las tendencias peronistas ante la vuelta de Perón" Norte Revolucionario Nro. 15, septiembre de 1964.)
} 
compañeros que trabajen en la juventud o en las 62 nieguen ni oculten su militancia en el FRIP.” (Carnovale, 2011:57-58)

Así, si bien la organización aceptaba trabajar en algunas organizaciones del peronismo, proclamaba la necesidad de una completa independencia política y se negaba a camuflar la pertenencia partidaria bajo la identidad peronista.

La segunda polémica que identificamos, primera reconocida y registrada en los documentos partidarios, giró en torno a la consigna "CGT partido político de la clase obrera" y se desarrolló entre el primer y segundo congreso, realizados en mayo de 1965 y de 1966 respectivamente. La misma resultaba de un documento presentado por Moreno en el I Congreso ${ }^{742}$, en el que analizaba la situación política nacional luego de un año de duros enfrentamientos entre el gobierno radical de Illia y la $\mathrm{CGT}^{743}$. Moreno partía de la idea de que la argentina estaba viviendo una etapa de "equilibrios inestables", caracterizada por un gobierno estable pero envuelto en una crisis general, que posibilitaba el desarrollo de fuerzas revolucionarias. La estabilidad era considerada como una consecuencia de varios factores: 1. La crisis terminal del peronismo como movimiento nacionalista. Para el dirigente trotskista esta crisis estaba dada por la participación electoral del peronismo en marzo de 1965 a partir de la cual entraba a “formar parte del régimen", institucionalizándose como un partido burgués que iniciaba un vuelco definitivo hacia la derecha; 2. El frustrado regreso de Perón al país, que le daba un respiro importante al gobierno; y 3. Lo que consideraban el "fracaso del plan de

\footnotetext{
742،"Documento Nacional”, número 2, mayo de 1965, I Congreso del Partido Unificado FRIP-PO, 11-2, Fundación Pluma.

${ }^{743}$ El primer capítulo del Plan de Lucha de la CGT se desarrolló en mayo de 1963 con la conocida Semana de Protesta contra las políticas económicas del presidente Guido, supuso una semana de marchas, paros sorpresivos parciales, paros simbólicos, actos, manifestaciones, sabotajes, etc., que culminó con una huelga general nacional de 24 horas. El triunfo de Arturo Illia en las elecciones de julio de 1963 con el peronismo proscripto, motivo que a inicios de 1964 la CGT estableciera un calendario para la realización de la segunda etapa del Plan de Lucha que tuvo como punto más álgido las ocupaciones de fábricas entre los meses de mayo y de junio. El plan se cumplió durante cinco semanas y, según la CGT, fueron ocupadas más de 11.000 plantas (Coratelo y Fernández, 1994; James, 2005; Schneider, 2006). Por su parte, para ese entonces PO y el FRIP, que estaban en proceso de fusión, evaluaban que las tomas de fábrica habían ayudado a desarrollar la actividad y la confianza de la vanguardia obrera, la cual había demostrado altos grados de unidad, decisión y combatividad. Por otro lado consideraban que la radicalidad de las medidas había contribuido a evidenciar las contradicciones de la burocracia sindical que ante las presiones de las bases volvían a dividirse entre el sector de Independientes, que habían se habían negado a apoyar el Plan de Lucha, y las 62 Organizaciones y el MUCS que habían tenido que "ceder a regañadientes" y defender la aplicación de las medidas hasta el final. Desde su óptica ello había ayudado a fortalecer a las organizaciones de base habilitando el surgimiento de tendencias combativas y opositoras en su seno. En cuanto a los pasos a seguir plantearon las consignas: "Congresos o Plenarios de las Bases" para la CGT combinada con la de "Asamblea Constituyente" como consigna de poder ("Plan de lucha: balance y perspectivas" documento de Palabra Obrera 9/7/64; "Plan de lucha: intensa movilización obrera" Norte Revolucionario Nro. 14, julio de 1964).
} 
lucha de la CGT" que, como indica la bibliografía, luego de las tomas de fábrica de mayo y junio de 1964, había perdido vigor ${ }^{744}$.

Según Moreno, la supuesta crisis del peronismo podía acabar con lo más positivo que había dejado dicha experiencia: la unidad de la clase obrera a la hora de expresarse electoral y políticamente. Desde esta perspectiva, se abría un vacío político que, de no ser llenado por un nuevo partido de masas, podía llevar a la dispersión general de los trabajadores. Ante este cuadro, el dirigente trotskista postulaba a la CGT como la única candidata a cumplir ese papel, para lo cual debía pasar a conformarse como partido político. Moreno alegaba que dicha posición, además de ser "realista", resolvía al menos tres cuestiones: 1. el problema histórico de la dirección burguesa del peronismo, ya que ahora sería la central obrera la que estuviera a la cabeza; 2. que la clase obrera votara unida; y 3. que habilitaría un diálogo directo con activistas sindicales peronistas y combativos, que percibían la crisis de su movimiento y buscaban una salida política $^{745}$. La crítica principal al documento estuvo a cargo de Mario Roberto Santucho, para quien la propuesta significaba "capitular al sindicalismo". El dirigente santiagueño re rechazó la consigna remarcando que era una rémora del entrismo que arrastraban los militantes de PO. En contraposición planteó que debía ser el partido revolucionario quien llenara el vacío político:
"En esto nosotros estamos capitulando, entregándonos, al plantear que el papel que nosotros como organización revolucionaria debemos asumir, quede en manos de la CGT. (...) la diferencia entre partido y sindicato está totalmente obscura, nosotros hablamos como si no hubiera diferencia entre partido y sindicato, como si los clásicos no estuvieran cansados de plantear las diferencias entre estos y la necesidad absoluta de diferenciarlos, única forma de dirigir a la clase porque si no el partido no existe en la clase... nosotros vamos a hacer la revolución como partido revolucionario, no como sindicatos.",746

Con esta línea, Santucho propuso suprimir la consigna "CGT partido político de la clase obrera" y planteó la necesidad de que fuera el PRT quien ocupara dicho lugar. ${ }^{747}$ En esta crítica, tachada por Moreno como "sectaria y esquemática", radica una de las claves para entender las diferentes concepciones que se fueron fraguando al interior de la organización y que se manifiestan de manera más sistemática a partir de 1968. En la

\footnotetext{
${ }^{744} \mathrm{La}$ tercera y la cuarta etapa del Plan de Lucha se dieron entre agosto y septiembre y noviembre y diciembre respectivamente. En el primer caso la central convocó a Cabildos Abiertos no vinculantes en diferentes ciudades del interior del país que terminaron teniendo muy poca repercusión, y el segundo caso consistió en movilizaciones que culminaron con una huelga general de bajo acatamiento (Grau, Martí y Ianni, 2005;Schneider, 2006)

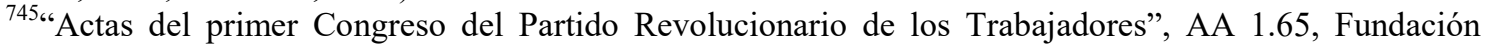
Pluma.

${ }^{746}$ Ídem.

${ }^{747}$ Ídem.
} 
posición de Santucho, subyacían las mismas críticas que el FRIP había sostenido contra el entrismo: el problema de "esconder" al partido revolucionario detrás organizaciones de masas reformistas que no aportaban a una política independiente de la clase obrera ni al avance de su conciencia política. La crítica al "sindicalismo" o a la "política sindicalera" que Santucho ya deslizaba en ésta intervención fue creciendo al correr de los años y traduciéndose en distintas polémicas a lo largo de los congresos.

Finalmente fue la posición de Moreno la que primó en el congreso y la consigna "CGT partido político de la clase trabajadora" se hizo efectiva: en diciembre el Comité Central decidió enviar una carta abierta a las 62 Organizaciones bajo el título “¡No más ordenes de arriba!", planteándoles que debían construir un partido propio rompiendo definitivamente la verticalidad centrada en Perón: "ustedes tienen que seguir avanzando hasta ser los voceros políticos y organizativos de la clase obrera en su conjunto"748. Allí se manifestaba la tensión que se había reflejado en el debate congresal: si la organización tenía en la "burocracia sindical" su principal enemigo dentro de las fábricas, por fuera de las mismas, ésta aparecía como la responsable de darle una respuesta política a los trabajadores. Si bien decían no creer en Vandor al mismo tiempo lo reconocían como aquel que debía llevar adelante dicha orientación, al punto de apoyarlo "condicionalmente" en su cruzada contra Perón.

Lejos de saldarse, el debate continuó un año después, en el II Congreso realizado los días 24 y 25 de mayo de 1966. A pesar de la oposición de Santucho, el partido decidió, por mayoría, continuar con la política hacia la CGT, aunque, ahora, bajo una nueva consigna: "Por una CGT antiimperialista y revolucionaria y por un gobierno de la CGT y los partidos que se reclaman de la clase obrera" ${ }^{\text {749 }}$. Si bien este debate y esta política se vieron suspendidas escasos meses después, debido a la supresión de las elecciones que trajo aparejado el golpe autodenominado "Revolución Argentina", fue parte importante de la grieta que produjo el quiebre.

La tercer polémica que identificamos (las condiciones para iniciar la lucha armada y su ligazón con el movimiento obrero) también germinó en el II Congreso y derivó del debate en torno a la caracterización de la situación política en Tucumán que, desde julio de 1965, venía viviendo un proceso de tomas de ingenios en toda la provincia en reclamo por las paritarias y el convenio colectivo.

\footnotetext{
${ }^{748 “ " C a r t a ~ a b i e r t a ~ a ~ l a s ~} 62$ Organizaciones” La Verdad Nro. 23, 20 de diciembre de 1965, En: Gonzales, 1996 b: 103.

${ }^{749}$ Ídem.
} 
Siguiendo a Eduardo Weisz (2006) -en coincidencia con Julio Santucho, Luis Mattini y Ernesto Gonzales-, observamos que este habría sido el hecho fundamental alrededor del cual se dieron las discusiones que llevaron a la ruptura. Las diferencias sobre el tema ya se habían manifestado por primera vez en una reunión del comité central de marzo de 1966 y tenía nuevamente a Santucho y a Moreno como principales protagonistas. En resumidas cuentas, el debate giraba en torno a dos posiciones contradictorias. Por un lado, la militancia tucumana planteaba que en su provincia se vivía una situación prerrevolucionaria motivada por la lucha de los obreros azucareros, que asumía cada vez más visos de violencia y que, a diferencia de las luchas en el resto del país, eran de ofensiva $^{750}$. Lejos de este análisis, el morenismo sostenía que allí no había una situación cualitativamente distinta a la del resto del país y que quienes planteaban lo contrario lo hacían desde un análisis "estático" y "aislado".

Estas diferencias de caracterización trajeron consigo los debates sobre la necesidad de comenzar o no con la actividad guerrillera en la zona y en el país. Aunque, nuevamente, la posición de Moreno consiguió la mayoría y limitó la iniciativa de la militancia tucumana, la discusión tomó un nuevo giro frente al golpe de estado.

Este último, consumado el 28 de junio, significó una profundización de la ofensiva contra el movimiento obrero y sus organizaciones. Onganía asumía con el objetivo de estabilizar la situación económica y política mediante un proyecto coherente de acumulación de capital que lograra sortear la crisis y el desequilibrio de fuerzas desatadas desde el golpe de 1955; prevenir una posible radicalización de la clase obrera que había demostrado "potencialidades intolerablemente subversivas"; e imponer a la gran burguesía urbana local y trasnacionalizada como fracción dominante y hegemónica del capitalismo argentino (O’Donell, 1977, 1982).

En esta coyuntura, los debates que habían animado a la tercera polémica se potenciaron. El PRT caracterizó a Onganía como un líder bonapartista y a la dictadura como "proimperialista" y "preventiva", es decir con el objetivo de impedir un posible desborde de las masas trabajadoras ${ }^{751}$. En julio Nahuel Moreno escribió un documento aprobado por el Comité Central y publicado en septiembre bajo el título La lucha recién comienza ${ }^{752}$, que agudizó las diferencias en torno a la lucha armada.

\footnotetext{
${ }^{750}$ En marzo los cañeros habían tomado como rehenes a dos funcionarios públicos y la prensa tucumana también agitaba la idea de que existía una situación de tales características. (Gonzales, 1999:112)

${ }^{751}$ La Verdad Nro. 47, 4 de julio de 1966 En: Gonzales, 1999:133

752“"La lucha recién comienza”, Nahuel Moreno, septiembre de 1966, 1.11, Fundación Pluma.
} 
Allí se planteaba que no había perspectivas inmediatas de un nuevo ascenso del movimiento obrero. Para aquel dirigente se abría una etapa en la que la clase obrera sufriría de manera inmediata la superexplotación en las fábricas, los despidos, la desocupación y una brutal carestía de vida, al mismo tiempo que una persecución a los activistas sindicales, militantes de izquierda y a las organizaciones de base. Aun así, insistía que la derrota no era definitiva y que, por ende, la tarea era evitarla. Para ello se debía volver a los viejos métodos de piquetes y huelgas prolongadas fuera de fábrica y evitar la huelga parcial con ocupación y toma de rehenes ya que sería rápidamente aplastada por las FF.AA (Gonzales, 1999: 150-151).

Por su parte, Santucho conservaba la caracterización que había defendido en el II Congreso sobre la situación tucumana, por lo que, como veremos enseguida, propuso una política diferente a la que sostenía el dirigente trotskista.

Coincidimos con Weiz (2006) en que estas definiciones aceleraron el proceso de diferenciación al interior de la organización. Ello quedó claro en las luchas que se desarrollaron entre agosto de 1966 y julio de 1967. Mientras la intervención del PRT en la lucha por los convenios metalúrgicos, textiles y de la carne tuvo la orientación propuesta por Moreno, levantando la consigna "Ni un paso atrás: piquetes de huelga y huelgas gremiales a la antigua"; en la provincia de Tucumán la orientación fue otra. La decisión de Onganía de cerrar once ingenios azucareros (dejando aproximadamente a 40.000 trabajadores sin empleo) fue enfrentada con una resistencia basada en el sabotaje y la violencia organizada. La lucha de los ingenios se transformó en una experiencia fundamental para Santucho, quien participó de manera directa de los enfrentamientos con la policía y los incendios de cañaverales. Si Moreno pregonaba una lucha más defensiva como la que resumimos arriba, en Tucumán comenzó a prevalecer la orientación de organizar organismos de autodefensa armada para enfrentar a la represión (Weiz, 2006:51).

El balance sobre la lucha azucarera y las consecuencias de su derrota significó un quiebre para el sector liderado por Santucho que, a partir de allí, comenzó la insistencia sobre la necesidad de iniciar la lucha armada Este planteo fue presentado por la dirección de Tucumán a la dirección nacional en 1967 a través de un documento que fue rechazado, en el que se planteaba que, en la provincia, estaban dadas las condiciones para iniciar la actividad guerrillera:

"nuestra línea debe ser prepararnos para iniciar lo más pronto posible acciones de tipo guerrillero (...) Nuestra tarea debe ser la de mantener estrechos contactos con el 
proletariado, semiproletariado y campesinado de la zona, eludir los combates frontales, realizar acciones en forma esporádica y hacer eje en la actividad guerrillera la propaganda armada, la penetración, el avance en la población" "753

La corriente santuchista buscó llevar el debate al III Congreso partidario, realizado en junio de 1967. Sin embargo, la discusión se vio obstruida por la lógica congresal que, por cuestiones de seguridad, debió sesionar en tres grupos divididos.

A pesar de estas dificultades, las diferencias continuaron potenciándose. En ese cónclave estalla, finalmente, la cuarta polémica que señalamos en torno al rol del partido hacia los organismos de participación obrera. A decir de Mangiantini (2014, 2018), este debate fue un antecedente inmediato de la ruptura definitiva.

En esa oportunidad quienes protagonizaron la polémica fueron Moreno y Candela ${ }^{754}$. La diatriba giró en torno al rol de los organismos de base, en una etapa caracterizada como "eminentemente defensiva" y de "crisis irreversible" de las direcciones sindicales.

La "Tesis XIII" del documento nacional defendida por Moreno, planteaba que la única posibilidad de luchar por la "recuperación del movimiento sindical" y de resistir a la ofensiva del gobierno y las patronales era a través de los organismos tradicionales, principalmente los CIR y CD. Además, como algo subordinado y segundario, planteaba la incorporación paulatina de métodos de lucha armada ${ }^{755}$.

Por su parte, Candela planteaba que, debido a la correlación de fuerzas desfavorable para la "vanguardia clasista", no habría posibilidades inmediatas de cambiar las direcciones sindicales burocratizadas; para revertir esa situación se imponía el trabajo clandestino por sobre el legal. De este modo proponía impulsar grupos de resistencia que, mediante métodos de lucha armada, respondieran a los golpes de la patronal, ganando prestigio entre los trabajadores y transformándose paulatinamente en la dirección de facto de la fábrica. En ese esquema las CIR y CD debían cumplir un papel segundario de apoyo y fortalecimiento de estos grupos ${ }^{756}$. La discusión develaba tanto el lugar que cada sector les asignaba a los organismos sindicales tradicionales, como el papel y la importancia que le empezaban a asignar a la actividad armada en general y en

\footnotetext{
753،"Documento presentado por Tucumán” al Comité Ejecutivo del PRT, 1967. En: Gonzales, 1999: 195

${ }^{754}$ Seudónimo del dirigente Helios Prieto quien hacia el IV Congreso formó parte de la fracción liderada por Santucho

755 "Documentos Internos” III Congreso del PRT, 1967, 2-1, Fundación Pluma

${ }^{756}$ Estos grupos (Comisiones de Resistencia, Comités de Resistencia, Comisiones de Defensa, Oposición Clandestina Armada, etc.) debían mantenerse en la clandestinidad aun habiendo ganado la dirección de la fábrica, y debían organizarse en forma de "estrella", es decir "donde las puntas no se conozcan y estén articuladas por un centro". La consigna era "convertir la lucha sindical en una lucha guerrillera, en una lucha clandestina con métodos armados". (Ídem)
} 
el movimiento obrero en particular. Como veremos, el planteo de las comisiones o grupos de resistencia clandestinos fue retomado por el ala santuchista luego de la ruptura y durante todo el período que aquí estudiamos.

Es importante remarcar que, en el marco de la cuarta polémica, la corriente morenista volvió a imponerse al interior del partido y consolidó una serie de apreciaciones conceptuales en torno al vínculo lucha sindical-lucha política. De este modo el trabajo en la base fabril pasó a considerarse como "estructural" y compuesto por dos aspectos claves: el sindical, basado en las reivindicaciones de fábrica y los organismos de base (CIR y CD), y el político, que garantizaba la ligazón de los problemas sindicales con los problemas políticos del país. De esta distinción, a su vez, surgían dos nociones diferenciadas de vanguardia que no necesariamente debían coincidir: por un lado la vanguardia sindical (aquellos trabajadores que estaban al frente de las reivindicaciones económicas) y por el otro lado la vanguardia política (aquellos trabajadores que se planteaban el problema político del poder).

Estas distinciones conceptuales, sobre todo la idea de vanguardia sindical, fueron profundamente criticadas por el ala santuchista al producirse la ruptura, funcionando como botón de muestra para impugnar de conjunto las posiciones defendidas por Nahuel Moreno. 


\section{GLOSARIO DE SIGLAS}

APR: Alianza Popular Revolucionaria

APRA: Alianza Popular Revolucionaria Americana

BI: Boletín Interno

CD: Cuerpo de Delegados

CGT-A: Confederación General del Trabajo de los Argentinos

CIR: Comisión Interna de Reclamos

CROEMBA: Comisión de Representantes Obreros y Empleados de Mercedes Benz Argentina.

DIPBA: Dirección de Inteligencia de la Policía de la Provincia de Buenos Aires

FAL: Fuerzas Armadas de Liberación

FAP: Fuerzas Armadas Peronistas

FAR: Fuerzas Armadas Revolucionarias

FAS: Frente Antiimperialista por el Socialismo

FGB: Federación Grafica Bonaerense

FOTIA: Federación Obrera Tucumana de la Industria del Azúcar

FREJULI: Frente Justicialista de Liberación.

FRIP: Frente Revolucionario Indoamericanista Popular

FRP: Frente Revolucionario Peronista

GAN: Gran Acuerdo Nacional

GOR: Grupo Obrero Revolucionario

ICO: Instituto de Capacitación Obrera

JP: Juventud Peronista

JSP: Juventud Sindical Peronista

JTP: Juventud Trabajadora Peronista

MSB: Movimiento Sindical de Base

MSC: Movimiento Sindical Combativo

OCPO: Organización Comunista Poder Obrero

OLAS: Organización Latinoamericana de Solidaridad

PB: Peronismo de Base

PCA: Partido Comunista Argentino

PCR: Partido Comunista Revolucionario

PO: Palabra Obrera 
PRT-ERP: Partido Revolucionario de los Trabajadores-Ejército Revolucionario del Pueblo

PSIN: Partido Socialista de la Izquierda Nacional

PST: Partido Socialista de los Trabajadores

SITRAC-SITRAM: Sindicato de Trabajadores de ConCord-Sindicato de Trabajadores de MaterFer.

SMATA: Sindicato Mecánico y Afines del Transporte Automotor

TOR 22-8: Tendencia Obrera Revolucionaria 22 de Agosto

TRP: Tendencia Revolucionaria Peronista

UCR: Unión Cívica Radical.

UOM: Unión Obrera Metalúrgica

VC: Vanguardia Comunista 


\section{BIBLIOGRAFÍA}

AA. VV (2015): Responsabilidad empresarial en delitos de Lesa Humanidad. Represión a trabajadores durante el terrorismo de Estado, Bs. As., Editorial Ministerio de Justicia y Derechos Humanos de la Nación.

Águila, Gabriela y Viano, Cristina (2009): “De la Universidad a la fábrica: algunos elementos para pensar el mundo de la militancia en los primeros 70 en el Gran Rosario. El Peronismo de Base (PB)” En: Los trabajadores y los días. Revista de la cátedra de Historia Socioeconómica de América Latina y Argentina, Año 1, No 1.

Anguita, Eduardo y Caparrós (2006): La Voluntad. Una historia de la militancia revolucionaria en la Argentina, Tomo I: 1966-1969, Tomo II: 1969-1973, Tomo III: 1973-1974, Tomo IV: 1974-1976, Tomo V 1976-1978, Editorial Planeta, Bs. As.

Aricó, José (1964): “Examen de conciencia”, Pasado y Presente, Año 1 Nro. 4. (2015): Pasado y Presente: edición facsimilar, Biblioteca Nacional, CABA.

Beba Balvé y Beatriz Balvé (1989): El '69. Huelga politica de masas. Bs. As., Ed. Contrapunto, Bs. As.

Beschetti, Roberto (1999): Documentos, 1973-1976, Editorial Campana de Palo, La Plata.

Blixen, Samuel (1987): Conversaciones con Gorriarán Merlo, Editorial Contrapunto, Bs. As.

Bohoslavsky, Abel (2015): Los Cheguevaristas. La Estrella Roja, del Cordobazo a la Revolución Sandinista, Ediciones Imago Mundi, Bs. As.

Bonavena P., Maañon M., Morelli G., Nievas F., Piva R. y Pascual M. (1998): Origenes y Desarrollo de la Guerra Civil en la Argentina. 1966-1976., Eudeba, Bs. As.

Bozza, Alberto (2001): "El Peronismo revolucionario. Itinerario y vertientes de la radicalización, 1959-1969”, Sociohistórica Nro. 9-10, p. 135-169.

(2009): "La voluntad organizada. CGT de los argentinos, una experiencia de radicalización sindical", Anuario del Instituto de Historia Argentina Nro.9, p. 179-208. 
Brennan, James (1996): El Cordobazo: guerras obreras en Córdoba, 1955-1976., Editorial Sudamericana, Bs. As.

y Gordillo, Mónica (2008): Cordobazo, clasismo y movilización social, De la Campana, La Plata.

Brunetto Luis (2007): 14250 o paro nacional. Bases obreras, direcciones sindicales peronismo en la crisis del Rodrigazo: junio y julio de 1975, Estación Finlandia, Bs. As

Bufano, Sergio (2005): "Perón y la Triple A.", En: Revista Lucha Armada en la Argentina Nro. 3.

Caggiano, María Cecilia (1999): “¡Pichi Corazon!” En: Rodriguez, Ernesto y Videla, Oscar R. (Compiladores): El Villazo. La experiencia de una ciudad y su movimiento obrero. Tomo I., Revista Historia Regional Libros, Villa Constitución.

Califa, Juan Sebastián (2015): “Del Partido Comunista al Partido Comunista Comité Nacional de Recuperación Revolucionaria en la Argentina de los años sesenta. Una escisión con marca universitaria.”, En: Revista Izquierdas Nro. 24, IDEAUSACH, pp. 173-204

Camarero, Hernán (2007): A la conquista de la clase obrera. Los comunistas y el mundo del trabajo en la Argentina, 1920-1935, Siglo XXI, Bs. As. , Pozzi Pablo y Schneider Alejandro (2001): "Eppur si muove. De la realidad a la conceptualización en el estudio de la clase obrera argentina"; en Taller. Revista de Sociedad, Cultura y Política, v.6, Nº16, Bs. As.

Campione, Daniel (2007): "El Partido Comunista de la Argentina. Apuntes sobre su trayectoria", en Concheiro, Elvira; Modonesi, Mauro; y Crespo, Horacio (coord.): El comunismo: otras miradas de América Latina, México, Centro de Investigaciones Interdisciplinarias en Ciencias y Humanidades, Universidad Nacional Autónoma de México, pp. 167-210

Campos, Esteban (2003): "La cuestión del peronismo en el debate entre las FAR y el PRT-ERP.”, En: Anuario Nro. 25, Escuela de Historia Revista Digital Nro.4, UNR.

Carnovale, Vera (2011): Los combatientes. Historia del PRT-ERP, editorial Siglo XXI, Bs. As.

(2006): "Postulados, sentidos y tensiones de la proletarización en el PRT-ERP”, Lucha Armada, No 5, Año 2, p. 38. 
(2007): “Aportes y problemas de los testimonios en la reconstrucción del pasado reciente en la Argentina”, En: Franco M, Levin F.: Historia reciente. Perspectivas y desafios para un campo en construcción., Paidós, Bs. As.

Carlos Peebles Mariano (2016): "Radicalización sindical en la industria automotriz argentina 1969-1976. El caso de Mercedes Benz Argentina. Una interpretación marxista" Tesis de Maestria, Guadalajara, Mexico.

y Lenuda María Agustina (2016): “Conflicto obrero y acción guerrillera. La huelga en Mercedes Benz en 1975 y el secuestro de un nazi.” En: Archivos, año V, Nro. 9, pp. 97-116.

, Leunda María A. y Santos Maria. V (2013): “La organización de los trabajadores en la industria automotriz. El caso de Mercedes Benz 19691976”, X Jornadas de Sociología, UBA.

Casola, Natalia (2015): El PC argentino y la dictadura militar. Militancia, estrategia política y represión estatal., Imago Mundi, Bs. As.

Castillo, Cristian y Raimundo, Marcelo (comp.) (2012): El 69 platense: luchas obreras, conflictos estudiantiles y militancia de izquierda en La Plata, Berisso y Ensenada durante la Revolución Argentina., Estudios Sociológicos Editora, Bs. As.

Cavarozzi, M. (1983): Autoritarismo y Democracia., CEAL, Bs. As

Caviasca, Guillermo (2006): Dos caminos. ERP-Montoneros en los setenta. Ediciones del CCC, Bs. As.

Celentano, Adrián (2015): “Cartas desde la prisión a la fábrica. Un análisis de la correspondencia entre los obreros clasistas presos y los intelectuales de la secretaría de prensa del Sitrac", Políticas de la Memoria n 15/, Bs. As.

(2014): "El maoísmo en las iniciativas político-editoriales del grupo pasadopresentista (1963-1976)" En: Prismas - Revista de Historia Intelectual, vol. 18, núm. 2, diciembre, pp. 193-198

(2012): “Las ediciones del maoísmo argentino.”, Primer Coloquio Argentino de Estudios sobre el Libro y la Edición, UNLP-FAHCE (2005): "Maoísmo y lucha armada: el PCML", en Lucha Armada Nro. 4, Bs. As.

(2009): "Unidad obrero estudiantil. La nueva izquierda y las proletarizaciones de corrientes maoistas en Argentina” En: Los trabajadores y los 
días. Revista de la cátedra de Historia Socioeconómica de América Latina y Argentina, Año 1, No 1.

Centurión, Bárbara Noelia (2013). “Cuidado patrones, el ERP vigila. Un acercamiento a los vínculos existentes entre el PRT-ERP y la clase obrera (1974-1975)" En: Trabajadores: Ideología y experiencias en el movimiento obrero, Año III, $\mathrm{N}^{0} 4$, Bs. As.

Ciriza, Alejandra y Rodríguez Agüero, Eva (2005): “Militancia, política y subjetividad. La moral del PRT-ERP”, En: Políticas de la memoria, 5. Bs. As.

Cisilino, Juan (2016): “Izquierda y nueva izquierda en los orígenes del Partido Comunista Revolucionario (1967-1969)", IX Jornadas de Sociología UNLP

Coggiola, Osvaldo (2006): Historia del trotskismo en Argentina y América Latina., Razón y Revolución, Bs. As.

Colom, Yolanda; Salome, Alicia (1997): "Las Coordinadoras interfabriles de Capital Federal y Gran Bs. As.”, En: Razón y Revolución No 4, Bs. As.

Cormick, Federico (2012): Fracción Roja: debate y ruptura en el PRT-ERP., El Topo Blindado, Bs. As.

Cormick, Federico (2015): “Apuntes sobre la Organización Comunista Poder Obrero" En: Revista Cuadernos de Marte Nro. 8, pp. 95-128

Dawyd, Darío (2008): “A 40 años del Programa del $1^{\circ}$ de mayo. La CGT de los argentinos y la ofensiva contra la „Revolución Argentina ${ }^{e e ”, ~ E n: ~ R e v i s t a ~ N u e v o ~}$ Mundo Mundos Nuevos, Paris, CERMA - Ecole des Hautes Etudes en Sciences Sociales.

(ed.) (2017): Si trabajo me matan. Las huelgas metalúrgicas en La Matanza en 1974: Insud, Martín Amato y Santa Rosa, San Justo., Universidad Nacional de La Matanza.

De Riz, Liliana (1981): Retorno y Derrumbe. El último gobierno peronista. México: Editorial Hyspamerica.

De Santis, Daniel (1997): "Testimonio y memoria: la lucha obrera en Propulsora Siderúrgica (1974-1975)". Taller. Revista de Sociedad, Cultura y Política, Nro. 5 (1998): A vencer o morir. PRT-ERP. Documentos, Tomo I, Eudeba, Bs. As. (2000): A vencer o morir. PRT-ERP. Documentos, Tomo II, Eudeba, Bs. As. (2005): Entre Tupas y los Perros, Ediciones RyR, Bs. As. 
(2010): La historia del PRT-ERP por sus protagonistas, A formar filas editora guevarista, Bs. As.

Della Savia, Guillermo (2017): "Las luchas de los trabajadores de Del Carlo" En: La Roca Nro. 4, 2017. (2018): “Las huelgas de Matarazzo (1973-1974)” En: La Roca Nro. 5, 2018.

Denaday, Juan Pedro (2016): “Comando de Organización: un peronismo plebeyo, combativo y nacionalista (1961-1976)" En: Quinto Sol Vol. 20 Nro. 1, Santa Rosa.

Di Palma, Gustavo (2014): "La política en Córdoba en el periodo 1973-1976: un campo de ensayo para la dictadura militar. El Estado violento en vida de Perón.”, En: Revista Escuela de la Historia, Vol.13 Nro.1, Salta.

Diez, Rolo (2010): El mejor y el peor de los tiempos, Nuestra América, Bs. As.

Ducid, Manuel (2014): “Lucha obrera, conflicto sindical y organización armada: El caso de la Juventud Trabajadora Peronista de Propulsora Siderúrgica.”, Tesis de grado, FaHCE-UNLP.

Farace Rafael y Jäkel Gabriela (2016): "Nociones sobre 'democracia obrera' y "burocracia sindical" en la izquierda de los años 70. Una comparación entre la izquierda peronista y la izquierda marxista" En: "Trabajo y sociedad Nro 26, Santiago del Estero.

Fernández Hellmund, Paula Daniela (2012): “Acerca de la convergencia cívico-militar del Partido Comunista de la Argentina (1975-1982)", En: Revista Aletheia, Vol. 2, Nro.4.

Flores, Gregorio (2006): Lecciones de batalla, Ediciones ryr, Bs. As.

Franco, Marina (2012): Un enemigo para la nación. Orden interno, violencia y “subversión”, 1973-1976., Fondo de Cultura Económica, Bs. As.

y Levín Florencia (2007): Historia reciente, perspectivas y desafios para un campo en construcción., Paidós, Bs. As.

Frondizi, Silvio; Justo Gaggero, Manuel (2015): Nuevo Hombre: edición fascimilar, Biblioteca Nacional, CABA.

Galliteli, Bernardo (1999): “La huelga de Villa Constitución” En: Rodríguez, Ernesto y Videla, Oscar R. (Compiladores): El Villazo. La experiencia de una ciudad y su movimiento obrero. Tomo I., Revista Historia Regional Libros, Villa Constitución. 
Getselteris, Gonzalo (2015): Desde el monte: la compañia de Monte vencerá, Nuestra América, Lanus Oeste.

Gillespie, Richard (2008): Los soldados de Perón. Historia crítica sobre Los Montoneros., Ed. Sudamericana, Bs. As.

Gómez, César Daniel (2011): “La estructura Significativa de la Revista Dimensión y su vínculo con el FRIP”, VI Jornadas de Jóvenes Investigadores. Instituto de Investigaciones Gino Germani, UBA, Bs. As.

(2013/2014): "La cultura como incitación. Apuntes sobre la revista, el grupo y la librería Dimensión.” En: Políticas de la Memoria Nro. 14, p. 118-123.

Gonzales, Ernesto (coord.) (1996): El trotskismo obrero e internacionalista en Argentina. Tomo 2: Palabra Obrera y la Resistencia (1955-1959), Editorial Antídoto, Bs. As.

(coord.) (1999): El trotskismo obrero e internacionalista en Argentina.

Tomo 3: Palabra Obrera, el PRT y la Revolución Cubana (1963-1969), Editorial Antídoto, Bs. As.

González Canosa, Mora (2012): “Las Fuerzas Armadas Revolucionarias: Orígenes y desarrollo de una particular conjunción entre marxismo, peronismo y lucha armada (1960-1973)", Tesis de posgrado [en línea]. UNLP. Facultad de Humanidades y Ciencias de la Educación.

Gordillo, Mónica (2003): "Protesta, rebelión y movilización: de la resistencia a la lucha armada, 1955-1973”. En: James, Daniel. Nueva Historia Argentina. Tomo IX: Violencia, proscripción y autoritarismo (1955-1976)., Sudamericana, Bs. As.

Gorriarán Merlo, Enrique (2003): Memorias de Enrique Gorriarán Merlo. De los setenta a La Tablada, Planeta, Bs. As.

Gramsci, Antonio (2009): Antología, Siglo Veintiuno Editores., Bs. As (2003): Notas sobre Maquiavelo, sobre la política y sobre el Estado moderno, Nueva Visión, Bs. As.

Grenat, Stella (2014): "Una espada sin cabeza. Los antecedentes de FAL (1959-1969)", En: Razón y Revolución $\mathrm{N}^{\circ} 13$.

(2004): "Una espada sin cabeza. Los antecedentes de FAL (1959-1969)", en Razón y Revolución, nro. 13, reedición electrónica.

Guevara, Ernesto (1964): Prólogo al libro de Vo Nguyen Giap, Guerra del pueblo, ejército del pueblo, Editora Política, La Habana. 
Harari, Ianina (2010): "La burocracia peronista. El sindicato automotriz argentino ante el auge de la lucha de clases. 1969-1976” En: Revista IZQUIERDAS, año 3, Nro. 8.

Harnecker, Marta (1990): América Latina: Izquierda y crisis actual, Siglo XXI editores, Bs. As.

Hendler, Ariel (2010): Las guerrillas invisibles. Historia de las Fuerzas Armadas de Liberación ( $F A L)$, Javier Vergara Editor, Chile.

Hobsbawm, Eric J. (1987): El mundo del Trabajo. Estudios Históricos sobre la formación y la evolución de la clase obrera, Editorial Crítica, Barcelona

Hoggart, Richard (1990): La cultura obrera en la sociedad de masas, Grijalbo., México

Inchauspe, Leandro Hernán (2007): “'La organización militar del pueblo.' El PRT-ERP, guerra y política en la Córdoba de los setenta.” XI Jornadas Interescuelas Departamento de Historia. Facultad de Filosofía y Letras. Universidad de Tucumán.

Iñigo Carrera N., Grau M.I. y Martí A. (2014): Agustín Tosco. La clase revolucionaria., Ediciones La Llamarada; Editorial Yulca; Amauta Insurgente Ediciones, 2da Edición, Bs. As.

Izaguirre Inés y Aristizábal Zulema (2002): "Perfil social de los asalariados desaparecidos en la Argentina.”, Dossier: CICSO: Marxismo, Historia y Ciencias Sociales en la Argentina, En: Razón y Revolución, Nro. 6, reedición electrónica.

Izzaetta, Marco (2015): "De lo pequeño a lo grande": el PRT-ERP y las acciones armadas consideradas como cualitativamente menores (1971-1976)." En: Contenciosa, Año III, Nro.5.

James, Daniel (1990): Resistencia e Integración. El peronismo y la clase trabajadora argentina 1946-1976. Editorial Sudamericana, Bs. As.

Jellin, Elizabeth (1978): “Conflictos laborales en la Argentina, 1973-1976”, Revista mexicana de sociología, vol. 40, no 2, p. 421-463.

Lanusse, Lucas (2005): Montoneros. El mito de sus doce fundadores., Editorial Vergara, Bs. As.

Laufer, Rodolfo (2018): “Izquierda y clasismo en los 70. Debates frente al Movimiento de Recuperación Sindical - Lista Marrón del SMATA Córdoba" En: Revista Archivos Nro. 12. 
Leiva Flores, Sebastián (2007): “Teoría y práctica del poder popular, los casos del MIR, Chile, 1970-1973 y el PRT-ERP, Argentina, 1973-1976”, Universidad de Santiago de Chile.

Lenci, Maria Laura (1998): “La radicalización de los católicos en la Argentina. Peronismo, cristianismo y revolución, 1966 - 1971”. En: Cuadernos del CISH, La Plata, Año 3, Nro. 4.

Levi, Giovanni (2003): "Un problema de escala", Relaciones. Estudios de historia y sociedad, Vol. XXIV, Nro. 95, México.

Linhart, Robert (1997): De cadenas y de hombres, Siglo XXI, Bs. As.

Lisandrello, Guido (2015): "La discusión estratégica en la izquierda argentina en los años '70. Aproximación al debate entre guerrillerismo e insurreccionalismo en el Partido Comunista Revolucionario (PCR), 1967-197211” Andes vol.26 Nro.1, Salta.

(2013): “El Partido Comunista Revolucionario (PCR) y la discusión estratégica en los setenta (1967-1972)", X Jornadas de Sociología de la Facultad de Ciencias Sociales-UBA, CABA.

(2012): "Montoneros y el Partido Revolucionario de los Trabajadores-Ejército Revolucionario del Pueblo ante el Pacto Social (19731974). Una perspectiva comparada”, En: Revista Izquierdas Nro. 13, pp. 83-108. Löbbe, Héctor (2006): La guerrilla Fabril. Clase obrera e izquierda en la Cooridnadora de Zona Norte del Gran Buennos Aires (1975-1976), Ediciones RyR, Bs. As.

(2004): “Las desmemorias de José Rodríguez” En: El Aromo Nro. 17. (2010): "Defendiendo al Capital: la burocracia sindical argentina en los ‘70” En: Revista Nuevo Topo Nro. 7, pp. 25-39.

(2013): "Entre la clase y Perón: la Juventud Trabajadora Peronista ante la Ley 20.625 de Asociaciones Profesionales" XIV Jornadas Interescuelas de Historia, Mendoza.

Lorenz, Federico (2013): Algo parecido a la felicidad. Una historia de la lucha de la clase trabajadora durante la década del setenta (1973-1978), Edhasa, Bs. As. (2005): “Pensar 'los setenta' desde los trabajadores”, En: Políticas de la Memoria Nro. 5.

Luna, Marcial Enrique (2016): El copamiento de Azul., De la Campana, La Plata. 
Maggio, Marcelo (2012): Diario El Mundo: PRT-ERP: prensa masiva para una política de masas., Editorial Cooperativa El Rio Suena, Bs. As.

Mangiantini, Martín (2018): Itinerarios militantes. Del Partido Revolucionario de los Trabajadores al Partido Socialista de los Trabajadores (1965-1976), Imago Mundi, Bs. As.

(2016): Moreno, Santucho y la ruptura del PRT., Colección Controversias, Bs. As.

Marradi, A.; Archenti N.; Piovani J.I (2007): Metodología de las ciencias sociales, Emecé Editores, Bs. As.

Martínez, Paola (2015): Género, política y revolución en los años setenta. Mujeres del PRT-ERP., Editorial Maipue, Ituzaingó.

Mattini, Luis (2007): Hombres y mujeres del PRT-ERP de Tucumán a la Tablada, De la Campana, La Plata.

Mercedes Benz Argentina (2018): "Historia de Mercedes Benz en Argentina", en: www.mercedes-benz.com.ar

Nassif, Silvia (2015): "Protagonistas olvidados: las luchas obreras en Tucumán en los años '60 y principios de los '70”, Estudios Nro. 34, pp. 159-176.

Nievas, Fabián (1999): “Las tomas durante el gobierno de Cámpora”, Tesis de Maestría, Universidad de Bs. As.

Oberti, Alejandra (2005): “La moral según los revolucionarios” En: Políticas de la memoria, 5. Bs. As

O’Donnell, Guillermo (1982): El Estado Burocrático Autoritario, Ed. De Belgrano., Bs As.

(1977): "Estado y alianzas en la Argentina, 1956-1976", Desarrollo Económico, Vol. 16, Nro. 64, pp. 523-554

Ortolani, Luis (2007): "Del primer al quinto congreso del PRT”, Cátedra Libre "Che" Guevara, La Plata.

Pacheco Julieta (2014): "La izquierda peronista y su inserción en el movimiento obrero", Revista Latino-americana de estudios do trabalho Nro. 19, año 19, 157 184.

y Lissandrello, Guido (2013): "Montoneros y el PRT-ERP: una propuesta comparativa a partir del análisis de sus posiciones frente al movimiento obrero (1973-1976)" En: Amérique Latine Histoire et Mémoire. Les Cahiers ALHIM 26. 
(2015): “Análisis de la militancia sindical de Montoneros: la Juventud Trabajadora Peronista y sus luchas” En: e-1@tina, Vol. 13, num. 50, Bs. As.

(2012): Nacional y Popular. El MALENA y la construcción del programa de liberación nacional 1955-1969., Razón y Revolución, Bs. As.

Palma, Laura (2008): "Estudio de caso: Propulsora Siderúrgica, un conflicto sindical en los años setenta.", V Jornadas de Sociología, UNLP.

Pasquali, Laura (2007): "Memorias y experiencias en las y los militantes de la guerrilla marxista. Un abordaje desde la historia social en el Gran Rosario, 1969-1976”, Tesis doctoral, inédita. Disponible en la biblioteca de la Escuela de Historia, de la Facultad de Humanidades y Artes, Universidad Nacional de Rosario.

Paulon, Victorio (2012): Una larga Huelga. Historia de metalúrgicos, Desde el Subte, Bs. As

Payo Esper, Mariel (2011): “El FAS, más que un «ejército político» impulsado por el PRT-ERP”, En: Revista Questión Nro. 29, Volumen 1, Número 29. Instituto de Investigaciones en Comunicación de la Facultad de Periodismo y Comunicación Social de la Universidad Nacional de La Plata.

Pereyra, Daniel (2014): Memorias de un militante internacionalista., Razón y Revolución, Bs. As.

Pérez Álvarez, Gonzalo (2010): "Retomando un viejo debate: bases, direcciones, sindicatos y estrategias obreras" Revista Nuevo Topo Nro. 7, pp. 55-74.

Piñeiro, Federico Luis (2006): "TENSA. La historia oculta" En: Revista Ares Worldefense \& Security Nro.4.

Plis Sterenberg, Gustavo (2003): Monte Chingolo: la mayor batalla de la guerrilla argentina., Editorial Planeta, Bs. As.

Portantiero, Juan Carlos (1973): “Clases dominantes y crisis política en la argentina actual", Pasado y Presente Año IV, Nro. 1.

(1977): "Economía y política en la crisis argentina", en Revista Mexicana de Sociología, No 12, México.

Pozzi, Pablo (2001): Por las sendas argentinas... El PRT-ERP. La guerrilla Marxista, Eudeba, Bs. As.

(2012): Historia de Perros. Entrevistas a militantes del PRT-ERP, Imago Mundi, Bs. As

y Schneider, Alejandro (2000): Los setentistas. Izquierda y clase obrera: 1969-1976., Eudeba, Bs. As. 
(2011): "Historia oral y estudios de la guerrilla en Argentina",

Testimonios. Revista digital de la Asociación de Historia Oral de la Republica Argentina, Año 2, Nro.2

Pucciarelli, Alfredo (1997): "Dilemas irresueltos en la historia reciente de la sociedad argentina", Revista Taller, No 5, Bs. As.

Raimundo, Marcelo (2010): "Burocracia y democracia sindical: necesidades y herejías" Revista Nuevo Topo $\mathrm{N}^{\mathrm{0}}$ 7, pp. 91-10.

Ríos, Maximiliano (2017): "Metalúrgica INSUD: lucha obrera fabril y sindicalismo de base. La Matanza, marzo de 1974”, En: Dawyd, 2017.

Rodríguez, Florencia (2010): “Conciencia de clase y política. El caso de los obreros de Propulsora Siderúrgica. 1973-1975”, En: PIMSA Documentos y Comunicaciones.

Rougier, Marcelo y Fiszbein, Martín (2006): La frustración de un proyecto económico: El gobierno peronista de 1973-1976., Manantial, 1ª ed., Bs. As.

Rupar, Brenda (2017): "El rol de la revolución cultural china en el maoísmo argentino. Las interpretaciones en las visiones oficiales de Vanguardia Comunista y el Partido Comunista Revolucionario" En: Leste Vermelho Vol.3, Nro. 1.

(2016): "Via pacifica ou via armada: os debates na esquerda revolucionária na década de 1960, através de duas organizações maoístas argentinas", En: Revista Historia, UERJ, Vol. 1, p.6-6

Sabaj, Daniela Aldana (2013): "Vanguardia Comunista (1965-1978) Origen, historia y resistencia.”, XIV Jornadas Interescuelas/Departamentos de Historia de la Facultad de Filosofía y Letras Universidad Nacional de Cuyo.

Samojedny, Carlos J. (2016): Caña. Un guerrillero inolvidable. La vida de Juan Manuel Murúa., Nuestra América, Lanus Oeste

Santanna, Martín (2015): "Nuevo hombre: una revista como síntesis de una época" En: Nuevo Hombre: edición facsimilar, Biblioteca Nacional.

Santella Agustín y Andujar Andrea (2007): El Perón de la fábrica eramos nosotros. Las luchas metalúrgicas de Villa Constitución 1970/1976., Desde el Subte, Bs. As

Santucho, Julio (2004): Los últimos guevaristas, la guerrilla marxista en la Argentina, Vergara, Ciudad Autónoma de Bs. As.

Sartelli, Eduardo; Grenat, Stella; Rodríguez, Rosana López (2009): Trelew, el informe: arte, ciencia y lucha de clases: 1972 y después. Ediciones RYR, Bs. As. 
Schneider, Alejandro (2005): Los compañeros: trabajadores, izquierda y peronismo, 1955-1973. Imago Mundi, Bs. As.

(2015): “Cuando hizo tronar el escarmiento. La política laboral de Juan D. Perón para disciplinar al movimiento obrero" En: Schneider Alejandro y Ghigliani, Pablo (comps): Clase obrera, sindicatos y Estado. Argentina (1955-2010), Imago Mundi, Bs. As.

Scoppetta Laura y Torres Pablo (2014): "La apuesta armada. Notas sobre la política sindical del PRT-ERP en el Gran Rosario (1965-1976)", Mimeo, Rosario. Disponible en la Biblioteca de la Escuela de Historia, Facultad de Humanidades y Artes, Universidad Nacional de Rosario.

(2018): "La política sindical del PRT-ERP: notas sobre una búsqueda (1965-1976)” En: Simonassi, Silvia y Dicósimo, Daniel: Trabajadores y sindicatos en Latinoamerica, Imago Mundi, Bs. As.

Seminara, Luciana (2015): Bajo la sombra del imbú: montoneros Sabino Navarro, historia de una disidencia. Imago Mundi, Bs. As.

Seoane, María (1991): Todo o Nada. La historia secreta y pública de Mario Roberto Santucho, el jefe guerrillero de los años setenta., Sudamericana, Bs. As.

Alicia Servetto (2010): 73/76. El gobierno peronista contra las "provincias montoneras", Siglo XXI editores, Bs. As.

Sessa, Leandro (2011): “'Semillas en tierras estériles': La recepción del APRA en la Argentina de mediados de la década de los treinta", En: Revista Sociohistórica Nro. 28, pp. 131-161

Silva Mariños, Lisandro (2017): FAS Frente Antiimperialista y por el Socialismo. Un ejército político de masas impulsado por el PRT, Ediciones La Llamarada, Bs. As.

Slatman, Melisa; Rodríguez, Florencia y Lascano, Natalia (2009): "Las Coordinadoras Interfabriles de Capital y Gran Bs. As. (1975-1976): Un estado del arte”, En: Revista THEOMAI Nro. 19.

Soul, Julia, (2011): "La estructuración de una estrategia gremial dominante en SOMISA (1960-1976). Los procesos sindicales y las relaciones de hegemonía/subalternidad”, en Dicósimo, Daniel y Simonassi, Silvia (comps.): Trabajadores y empresarios en la Argentina del siglo XX: indagaciones desde la historia social. Prohistoria, Rosario. 
Stavale, Mariela (2018): Las revistas "Militancia Peronista para la Liberación" y "De Frente con las bases peronistas": una propuesta "alternativa" para la identidad política del peronismo revolucionario, 1973-1974., Tesis Doctoral, Mimeo, Fahce-UNLP.

Stavale, Santiago y De Santis, Daniel (2016): Un partido de la clase obrera. La política del PRT-ERP en el movimiento obrero., Ediciones Finlandia, Colección A formar Filas, CABA. (2017): "Entre la lucha ideológica y la unidad de acción en las fábricas. La relación del Partido Revolucionario de los Trabajadores con la Tendencia Revolucionaria del Peronismo en los años 70”, Izquierdas Nro. 36, pp. 78-104

(2014): “¿Amplio frente sindical o brazo sindical perretista? Reconstruyendo la trayectoria del Movimiento Sindical de Base.” VIII Jornadas de Sociología de la UNLP, La Plata.

Stedman Jones, Gareth (1983): Lenguajes de Clase. Estudios sobre la historia de la clase obrera inglesa., Siglo XXI de España Editores, Madrid.

Sujatt, Julio Andrés (2014): “Un aporte al campo temático de la nueva izquierda. Nacimiento de la nueva izquierda en Argentina", VIII Jornadas de Sociología de la UNLP, La Plata.

Svampa, Maristella (2003): “El populismo imposible y sus actores, 1973-1976," En: Daniel James (ed.), Nueva Historia Argentina IX: Violencia, proscripción y autoritarismo (1955-1976), Sudamericano, Bs As.

Tarcus, Horacio (1997): El marxismo olvidado en la Argentina: Silvio Frondizi y Milcíades Peña, Ediciones El Cielo por Asalto, Bs. As

Thompson, Edward. P (1989): La formación de la clase obrera en Inglaterra, Crítica, Barcelona

Tocho, Fernanda (2015): “El desafío institucional: Las prácticas políticas no armadas de la Tendencia Revolucionaria del Peronismo en el Ministerio de Asuntos Agrarios de la provincia de Bs. As. [1973-1974].”, En: Sociohistórica Nro. 35.

Tomuschat, Christian (2003): "Mercedes Benz Argentina durante la dictadura militar (1976-1983)", Informe.

Torre, Juan Carlos (1971): “Una oposición social”, Los Libros Año 3, Nro. 21.

(2004): El gigante invertebrado. Los sindicatos en el gobierno 19731976, Siglo XX1, Bs. As. 
Tortti, María Cristina (2006): “La Nueva Izquierda en la historia reciente de la Argentina", en Cuestiones de Sociología, № 3 .

(1999): "Protesta social y Nueva Izquierda en la Argentina del

Gran Acuerdo Nacional”. En: Pucciarelli, Alfredo. La primacía de la política. Lanusse, Perón y la Nueva izquierda en tiempos del GAN. Bs. As.: Eudeba.

(Directora), Mauricio Chama y Adrián Celentano (co-directores)

(2014): La nueva izquierda argentina (1955-1976): socialismo, peronismo y revolución., Prehistoria Ediciones, Rosario.

Vazeilles, José Gabriel (2006): Memorias de la militancia, Manuel Suárez Editor.

Videla, Pablo Ramón (2006): Un día, una esperanza. Historia de un militante., Nuestra América, Bs. As.

Vittor, Carolina (2011): “La JTP y su papel en las luchas del movimiento obrero (19731975)" En: El Topo Blindado.

Volonté, Fernanda (2016): "Experimentando la política revolucionaria: el FRIP en el Norte Argentino.”, En: IX Jornadas de Sociología de la UNLP.

Weisz, Eduardo (2006): El PRT-ERP. Claves para una interpretación de su singularidad. Marxismo, Internacionalismo y Clasismo. Ediciones del CCC. Bs. As.

Werner Ruth y Aguirre Facundo (2007): Insurgencia obrera en la Argentina. 19691976. Clasismo, coordinadoras interfabriles y estrategias de la izquierda, Ediciones IPS, Bs. As.

Winter, Jorge (2010): La clase trabajadora de Villa Constitución. Subjetividad, estrategias de resistencia y organización sindical., Reunir, Bs. As.

Yofre, Juan B. (2010): El escarmiento: La ofensiva de Perón contra Cámpora y los montoneros, 1973-1974., Ed. Sudamericana, Bs. As.

Zicolillo, Jorge (2013): La era de los culatas. La derecha peronista y el patoterismo sindical., Vergara, Bs. As.

\section{FUENTES}

\section{Volantes y documentos}

- “Abajo el laudo del gobierno y Miguel. Defender el SMATA”, PST, AD 1.3, Fundación Pluma.

- “Acta reunión día 17/11/64”, Palabra Obrera, AA.3164, Fundación Pluma 
- "Actas del primer Congreso del Partido Revolucionario de los Trabajadores", AA 1.65, Fundación Pluma. "La lucha recién comienza", Nahuel Moreno, septiembre de 1966, 1.11, Fundación Pluma.

- “Carta abierta a las 62 Organizaciones" La Verdad Nro. 23, 20 de diciembre de 1965, En: Gonzales, 1996 b: 103.

- “Comité Ejecutivo de Abril de 1971” En: De Santis, 2006: 165-171

- "Commercial visit: MR. Germán Figaredo, President of Firm TENSA", 24/5/1974, Declassified/Released US Department of State EO Systematic Review 30 JUN 2005, WikiLeaks

- "Cuatro Tesis sobre el Norte Argentino", Estrategia 3ra época Nro. 5, abril de 1966.

- "Documento Nacional", número 2, mayo de 1965, I Congreso del Partido Unificado FRIP-PO, 11-2, Fundación Pluma.

- "Documento presentado por Tucumán” al Comité Ejecutivo del PRT, 1967. En: Gonzales, 1999: 195

- “Documentos Internos" III Congreso del PRT, 1967, 2-1, Fundación Pluma.

- "Dos métodos sobre la revolución latinoamericana" Nahuel Moreno, 1964

- "El papel de los sindicatos” En: Daniel De Santis, 2004: 89

- "El partido en la fábrica. Hacia el VI Congreso" En: Stavale y De Santis, 2016: $97-114$

_ “El Peronismo" En: De Santis, 2006: 155

- "El proletariado rural detonante de la revolución argentina. Tesis del FRIP", Secretaría ideológica del FRIP. Junio de 1964.

- "El único camino hasta el poder obrero y el socialismo" En: De Santis, 2004:141-233

- "FAP Comando Nacional. Ante la coyuntura y distintas acciones" En: Duhalde y Pérez: 2003.

- "Hacia el VI Congreso. Informe y balance de actividades del Comité Central", 1974

- “Informe de Actividades II Congreso", 1.3, Fundación Pluma.

- "Informe de Actividades III Congreso", 2-2, Fundación Pluma

- "La lucha de los pueblos indoamericanos". Folleto del FRIP. Editorial Norte Argentino, Santiago del Estero, 1963 
- "La lucha del pueblo derrota al plan Lanusse", Comité Central de Vanguardia Comunista, 15 de mayo de 1971

- "La lucha recién comienza", Nahuel Moreno, septiembre de 1966, 1.11, Fundación Pluma.

- "La Revolución Latinoamericana, Argentina y nuestras tareas" [Firmado por Nahuel Moreno], IV Congreso Nacional del PRT, 1968, AA 1.68, Fundación Pluma [Documento interno del PRT, noviembre de 1967]

- “La Revolución Latinoamericana” Nahuel Moreno, 1962.

- “Ley de asociaciones profesionales” Boletín de la JTP

- "Liberación o Dependencia. A los compañeros del establecimiento TENSA", colección personal de Roberto Mereta

- "Línea de construcción actual del Partido", Informe al Comité Central del PRT

- "Lo que ya ha dejado Sitrac-Sitram" Grupo "El Obrero", 26 de octubre de 1971

- "Luis Pujals" Boletín Fabril de los obreros de Ford del PRT Nro. 10, 8 de junio de 1975

- “Moral y Proletarización” En: De Santis, 2006: 92-115

- "Para defender nuestras conquistas: luchemos por la vigencia del convenio y por el reconocimiento inmediato de Mercedes Benz y Córdoba." Volante Política Obrera. Versión digital en poder del autor.

- “Pequeña burguesía y revolución” En: De Santis, 2006

- "Plan de lucha: balance y perspectivas" documento de Palabra Obrera 9/7/64

- "Preparar al PRT para dirigir a las masas" El Combatiente Nro. 158, miércoles 12 de marzo de 1975.

- "Proyecto de resolución del C.C. de autocrítica y convocatoria al V Congreso" Disponible en: www.eltopoblindado.com

- "Poder burgués y poder revolucionario" Ediciones El Combatiente, agosto 1974, En: De Santis, 2004

- "Resolución de fundación del Ejército Revolucionario del Pueblo" En: De Santis, 2004:325

- “Resoluciones del Comité Central de Diciembre de 1972” En: De Santis, 2006: 277 
- "Resoluciones del Comité Ejecutivo de enero de 1972" En: De Santis, 2006:194

- "Resoluciones del V Congreso" En: De Santis, 2004

- "Resoluciones sobre el trabajo dentro del movimiento de masas y sindical", Resoluciones del V Congreso y de los Comité Central y Comité Ejecutivos posteriores, Ediciones El Combatiente, Junio de 1973

- "Resoluciones sobre táctica y organización aprobadas por el Comité Central del PRT en su reunión de Marzo de 1969” En: http://eltopoblindado.com/

- "Solicitada. Obreros y Empleados de Mercedes Benz Argentina", Fundación Pluma

- Comunicado al personal de la Dirección General de TENSA (Colección personal de Mereta)

- MSB. Cuadernos de formación popular Nro 1. Bs. As., Editora Popular Americana, abril-mayo 1974

- Volante de la Coordinadora de Gremios, Comisiones Internas y Cuerpo de Delegados Combativos, 28/11/75

\section{Boletines Internos}

- Boletín Interno Nro. 23, 23 de abril de 1972.

- Boletín Interno Nro. 25

- Boletín Interno Nro. 35, 16 de enero de 1973

- Boletín Interno Nro. 37, 5 de febrero de 1973

- Boletín Interno Nro. 61, primera quincena de junio de 1974

- Boletín Interno Nro. 63, julio de 1974

- Boletín Interno Nro. 78, marzo de 1975

- Boletín Interno Nro. 82, mayo de 1975.

- Boletín Interno Nro. 85, 29 de agosto de 1975

- Boletín Interno Nro. 87, 25 de septiembre de 1975.

- Boletín Interno Nro. 98, 27 de diciembre de 1975

- Boletín Interno Nro. 106, 27 de febrero de 1976

- Boletín Interno Nro. 108, 12 de marzo de 1976

- Boletín Nro. 2 Coordinadora de Gremios, Comisiones Internas y Cuerpos de Delegados en Lucha de Capital Federal y Gran Bs. As.. 
- PST Boletín interno Nro. 103,14 de agosto de 1974, ab1, Fundación Pluma.

- PST Boletín Interno, 30 de abril de 1975, .10, Fundación Pluma.

- PST. Boletín Interno, 4 de noviembre de 1975, Fundación Pluma.

\section{Prensas partidarias}

- Avanzada Socialista (1973-1976)

- Boletín de la Corriente Clasista (1975)

- Boletín Mensual del FRIP (1961-1962)

- Cristianismo y Revolución (1971)

- El Auténtico (1975)

- El Combatiente (1968-1976)

- El Descamisado (1973)

- El Peronista (1974)

- Envido. Revista de política y Ciencias Sociales (1973)

- Estrella Roja (1973-1976)

- Evita Montonera (1975)

- Izquierda Nacional Nro.1

- La Causa Peronista (1974)

- La Justa. Órgano de la JTP (1974)

- La Verdad (1966)

- Liberación (1973)

- Militancia Peronista para la Liberación (1973)

- No Transar (1971-1974)

- Norte Revolucionario (1964)

- Nuestra Palabra (1973-1976)

- Nueva Hora (1973)

- Nuevo Hombre (1973-1975)

- Política Obrera (1973-1974)

\section{Archivo DIPBA}

- DIPBA, Mesa “B”, Carpeta Varios, Legajo 133

- DIPBA, Mesa “B”, Carpeta 128. Legajo 16. Localidades Varias

- DIPBA, Mesa “B”, Factor Gremial, Berazategui, Carpeta 18 bis, Legajo 14

- DIPBA, Mesa “B”, Factor gremial, Huelgas y Conflictos, Legajo 65 
- DIPBA, Mesa D(s), Carpeta Varios, Legajo 1309

- DIPBA, Mesa D(s), Carpeta Varios, Legajo 707

- DIPBA, Mesa D(s), Carpeta Daños, Legajo 2421

- DIPBA, Mesa D(s), Varios, Legajo 945

- DIPBA, Mesa D(s), Varios, Legajo 791

- DIPBA, Mesa D(s), Varios, legajo 994

- DIPBA, Mesa D(s), Carpeta Varios, Legajo 2853

- DIPBA, Mesa D(s), Varios, Legajo 2512

\section{Entrevistas}

Realizadas por el autor

- Alberto Elizalde, militante del PRT-ERP. Entrevista Telefónica, 2018.

- Armando Jaime, dirigente del FAS y el FRP, Salta, 2016.

- Arnaldo "Lalo" Piñon, dirigente sindical de TENSA y militante de Vanguardia Comunista, CABA, 2018.

- Blas Obella, obrero de TENSA, San Martín, 2018.

- Carlos "Lito Gonzales", obrero de TENSA y militante de Vanguardia Comunista, CABA, 2017.

- Carlos Baynon, obrero de TENSA, San Antonio de Padua, 2018.

- Carlos Vidal, dirigente sindical de Cristalería Rigolleau, Berazategui, 2017.

- "Coco", obrero de EATON Ejes y militante del PRT-ERP, CABA, 2017.

- Daniel De Santis, dirigente de Propulsora Siderúrgica y militante del PRT-ERP, La Plata, 2016.

- Domingo Bizzi, dirigente de Sitrac-Sitram y militante del PRT-ERP, Córdoba, 2018.

- Eduardo Fachal, obrero de Mercedes Benz Argentina y militante del Peronismo de Base, CABA, 2017.

- Eduardo Oroño, obrero de La Cantábrica y militante del PRT-ERP, CABA, 2014 Y 2018.

- Gustavo Panizza, militante del ERP, España, 2018

- Héctor Ratto, obrero de Mercedes Benz Argentina, CABA, 2017.

- Hugo Crosatto, dirigente sindical Mercedes Benz Argentina y militante del PRTERP, CABA, 2017.

- Ignacio Pérez, dirigente sindical de Cristalería Rigolleau, Berazategui, 2017. 
- Jorge Orellano, obrero de Propulsora Siderúrgica y militante JTP, La Plata, 2016.

- Jorge Winter, activista estudiantil y militante del PRT-ERP, La Plata, 2014.

- Juan Manuel Romero, activista del MSB, La Matanza, 2018.

- Julio D’Alessandro, obrero de Mercedes Benz Argentina y militante del PRTERP, CABA, 2015.

- Liliana Battistoti, militante del PRT-ERP y compañera de Panizza, comunicación telefónica, 2018

- Luis Mattini, dirigente del PRT-ERP, CABA, 2017.

- Mario Massolini, obrero de TENSA, Polvorines, 2018.

- Misael Aron Pajon, obrero de EATON Fundiciones, José C Paz, 2018.

- Néstor Rossi, obrero de Mercedes Benz Argentina y activista de la JP, Ezeiza, 2018.

- Pablo Ramón Videla, obrero de Swift y militante del PRT-ERP, CABA, 2014.

- Rafael Peralta, dirigente sindical Diario La Capital y militante del PRT-ERP, Rosario, 2017.

- Ramón Segovia, obrero de Mercedes Benz Argentina y militante del PST, CABA, 2017.

- Ricardo Hoffman, obrero de Mercedes Benz Argentina y militante del PRTERP, CABA, 2017 y 2018.

- Ricardo Mónaco, militante del PRT-ERP, España, 2016.

- "Ricardo", militante del PRT-ERP, La Matanza, 2018.

- Roberto Astudillo, obrero de TENSA (PRT-ERP), Italia, 2017.

- Roberto Meretta, obrero de TENSA y militante del PRT-ERP, CABA, 2017 y 2018.

- Rubén Guerra, obrero de TENSA, José C Paz, 2018.

- “Tito” Ripodas, dirigente del PRT-ERP, Cafayate, 2017 y 2018.

- "Victor", trabajador del Hospital Posadas y militante del PRT-ERP, CABA, 2018.

- Zenón Sánchez, obrero de Acindar y militante del PRT-ERP, comunicación telefónica, 2017

Editas o realizadas por otros: 
- "Entrevista al 'Topo' Gramajo, a propósito de la toma de la Ford en 1985" Socialismo o Barbarie Nro. 455, 26 de enero de 2018

- Entrevista a Raúl Castro, militante del PRT-ERP y trabajador de Galizia y Bargut, realizada por Andres Carminatti, Rosario, 2008.

- Memoria Abierta, Testimonio de Floreal Avellaneda, Bs. As.

- Memoria Abierta, Testimonio de Julio D’Alessandro, Bs. As.

- Testimonio de Abel Boholavsky en: "Clase. La política sindical del PRT-ERP” documental Grupo Mascaró, 2006.

- Testimonio de Martín, en: "Milagros No Hay" documental de Gaby Weber

\section{Archivos consultados:}

El Topo Blindado/ Centro de Documentación e Investigación de la Cultura de Izquierdas (CeDInCI)/ CD "La Historia del PRT-ERP por sus protagonistas"/ Ruinas Digitales/ Fundación Pluma/ Marxit.org/ Archivo de la DIPBA y el Centro de Documentación de la Comisión Provincial por la Memoria/ Centro de Documentación y Archivos de Memoria Abierta/ Hemeroteca de la Biblioteca Nacional/ Hemeroteca de la Legislatura de la Provincia de Buenos Aires/ Hemeroteca de la UNLP/ Colección personal de Roberto Meretta/ Colección personal de Hugo Crosatto/ Colección personal de Gustavo Panizza.

\section{Material Fílmico}

- "Clase. La política sindical del PRT-ERP en Córdoba", Mascaró Cine Americano, 2006

- “Gaviotas Blindadas” Mascaró Cine Americano, 2008

- "Milagros No hay”, Gabriela Weber, 2003 